\title{
Lecturas de la tradición en la poesía argentina de los noventa
}

\author{
Tesis de doctorado
}

Directora: Dra. Ana Porrúa

Codirectora: Dra. Graciela Goldchluk

Doctoranda: Lic. Marina Yuszczuk

Carrera: Doctorado en Letras / Facultad de Humanidades y Ciencias de la Educación / Universidad Nacional de La Plata

Noviembre de 2011 


\section{Índice general}

\section{Introducción}

1. Planteo inicial. pp. 4

2. El campo poético de los noventa. pp. 10

3. Planteo del problema y estado de la cuestión pp. 17

4. Marco teórico general pp. 35

Capítulo I. La conformación de una poética objetivista: de la lectura a la escritura.

1. Planteo inicial. pp. 52

2. El Diario de poesía como formación: la construcción del dispositivo objetivista como tradición selectiva. pp. 56

3. La luna como “cascote gris”: figuras de poeta y usos del lenguaje. pp. 86

4. La forma objetivista: de lo concreto a lo abstracto y de lo descriptivo a lo especulativo. Una mirada dialéctica sobre los objetos. pp. 105

Capítulo II. Del archivo a los repertorios: configuraciones de la biblioteca objetivista.

1. Planteo inicial. pp. 121

2. La puesta a prueba de los objetos: Carlos Battilana y José Villa. pp. 125

3. Procesamientos de la tradición en relación a lo local y cotidiano: Rubio, Ortiz, Díaz, Raimondi. pp. 135

4. Dos variaciones sobre Pound: la escritura ideogramática de Laura Wittner y las recuperaciones clasicistas de Walter Cassara. pp. 181

Capítulo III. Poéticas de ruptura: figuraciones del bárbaro y el analfabeto.

1. Planteo inicial. pp. 199

1. 1. El uso del habla y la construcción de personajes en Ricardo Zelarayán y Leónidas Lamborghini. pp. 205

2. El poema como laboratorio: mezcla de oralidad y registro poético. La puesta al día de la tradición en Segovia. pp. 215

3. Literatura, cultura de masas y usos populares: una idea de cultura ampliada. pp. 231

4. Variaciones de la figura del bárbaro y el analfabeto: Durand, Gambarotta, Llach. pp.

4. 1. La raza y Punctum: el presente como patología del lenguaje. pp. 258 
Capítulo IV. Poéticas performáticas, poéticas pop.

1. Planteo inicial. pp. 269

2. "Como una fiesta en un libro para niños”. pp. 284

3. Muñecas pop. pp. 306

Capítulo V. Poetas malditos e ingenuos: la construcción de autorespersonajes en Washington Cucurto y Belleza y Felicidad.

1. Planteo inicial. pp. 331

2. Analfabeto, marginal y maldito: la construcción de Washington Cucurto. pp. 340

3. Belleza y felicidad: escrituras ingenuas y la poesía como arte de lo efímero. pp. 364

Conclusiones pp. 392

Bibliografía pp. 405 


\section{INTRODUCCION}

\section{1- Planteo inicial}

Este trabajo se propone analizar la tradición que los poetas argentinos de los noventa comienzan a construir desde principios de la década y, a la vez, indagar en los desplazamientos conceptuales del término en el estudio de casos concretos. El corpus que se trabaja en esta tesis corresponde a los años de emergencia y consolidación de la llamada “poesía de los noventa”, que pueden situarse entre 1988 y 2001; ${ }^{1}$ en estos años

\footnotetext{
${ }^{1}$ Corpus:
}

Vanna Andreini, Bruciate / quemadas, Buenos Aires, Siesta, 1998

Carlos Battilana, Unos días, Buenos Aires, Libros del Sicomoro, 1992 -, El fin del verano, Buenos Aires, Siesta, 1999

Gabriela Bejerman, selección de plaquetas editadas por Belleza y Felicidad

Fabián Casas, Tuca, Buenos Aires, Libros de Tierra Firme, 1990 , El salmón, Buenos Aires, Libros de Tierra Firme, 1996

Walter Cassara, Juegos Apolíneos, Buenos Aires, Siesta, 1998

Juan Desiderio, La zanjita, Buenos Aires, Trompa de Falopo, 1992

Washington Cucurto, Zelarayán, Buenos Aires, Ediciones DelDiego, 1998

----------------, La máquina de hacer paraguayitos, Buenos Aires, Siesta, 1999

Marcelo Díaz, Berreta, Buenos Aires, Libros de Tierra Firme, 1998 -, Diesel 6002, Bahía Blanca, Vox, 2001

Daniel Durand, Segovia, Buenos Aires, Trompa de Falopo, 1996 , El estado y él se amaron, Buenos Aires, Mansalva, 2006

Romina Freschi, Redondel, Buenos Aires, Siesta, 1998

Martín Gambarotta, Punctum, Buenos Aires, Libros de Tierra Firme, 1995

Daniel García Helder y Rafael Bielsa, Quince poemas, Rosario, El lagrimal trifulca, 1988

Daniel García Helder, El faro de Guereño, Buenos Aires, Libros de Tierra Firme, 1990 -, El guadal, Buenos Aires, Libros de Tierra Firme, 1994

Roberta Iannamico, Mamushkas, Bahía Blanca, Ediciones Vox, 1999

------------, El collar de fideos, Bahía Blanca, Ediciones Vox, 2001

Fernanda Laguna, selección de plaquetas editadas por Belleza y Felicidad

Santiago Llach, La raza, Buenos Aires, Siesta, 1998

Karina Macció, Pupilas estrelladas, Buenos Aires, Siesta, 1998

Anahí Mallol, Postdata, Buenos Aires, Siesta, 1998

-------, Polaroid, Buenos Aires, Siesta, 2001

Marina Mariasch, Coming attractions, Buenos Aires, Siesta, 1997

XXX, Buenos Aires, Siesta, 2001 
pueden registrarse hitos relevantes de una nueva poética. En 1988 se publican Quince poemas de Rafael Bielsa y Daniel García Helder y Verde y Blanco de Martín Prieto, primeros libros de una línea que se continúa en toda la década y que se dio en llamar “objetivismo”. El 2001, por su parte, fue pensado como el momento en que se estarían resolviendo las líneas o los momentos que la crítica -como veremos en el próximo punto de esta Introducción- considera como características de la poesía de la época. De hecho, Polaroid de Anahí Mallol, ¿existe el amor a los animales? de Cecilia Pavón y $X X X$ de Marina Mariasch, todos publicados en el 2001, pueden considerarse como instancias de consolidación del procesamiento de los materiales provenientes del pop, o de lo que denominaremos luego como poéticas “ingenuas”. Por su parte, Diesel 6002 (2001) de Marcelo Díaz supone un replanteo del tratamiento de lo popular si se lo lee en relación con los libros de la primera mitad de los noventa y Poesía civil (2001) de Sergio Raimondi trabaja con el objetivismo como material que ya puede ser transformado. Lo emergente, entonces, está consolidado en ciertos libros publicados en el 2001, así como también empiezan a visualizarse reformulaciones importantes, que hablarían de los límites de una poética.

Mario Ortiz, Cuadernos de Lengua y Literatura Vol. I, Bahía Blanca, Vox, 2000

------------, Cuadernos de Lengua y Literatura Vol. II, Bahía Blanca, Vox, 2001

Cecilia Pavón, selección de plaquetas editadas por Belleza y Felicidad

---------, ¿existe el amor a los animales?, Buenos Aires, Siesta, 2001

, Caramelos de anís, Buenos Aires, Belleza y Felicidad, 2004

Martín Prieto, Verde y Blanco, Buenos Aires, Libros de Tierra Firme, 1988

-----------, La música antes, Buenos Aires, Libros de Tierra Firme, 1995

--------------, La fragancia de una planta de maíz, Buenos Aires, Libros de Tierra Firme, 1999

Sergio Raimondi, Poesía Civil, Bahía Blanca, Vox, 2001

Alejandro Rubio, Música mala, Bahía Blanca, Vox, 1996

-----------, Metal pesado, Buenos Aires, Siesta, 1999

José Villa, Cornucopia, Buenos Aires, Trompa de Falopo, 1996

--------, ocho poemas, Buenos Aires, Ediciones Deldiego, 1998

Verónica Viola Fisher, Hacer sapito, Buenos Aires, Nusud, 1995

Ana Wajzczuk, Tropico trip, Buenos Aires, DelDiego, 1999

Laura Wittner, El pasillo del tren, Buenos Aires, Trompa de Falopo, 1996

, Las últimas mudanzas, Bahía Blanca, Vox, 2001 
La denominación “poesía de los noventa”, entonces, remite a aquellas poéticas que pueden considerarse como emergentes a partir de la definición de Raymond Williams. Se trata de "los nuevos significados y valores, nuevas prácticas, nuevas relaciones y tipos de relaciones que se crean continuamente” en el marco del proceso cultural, $^{2}$ y que se definen de modo relacional con respecto a los elementos de la cultura dominante.

En ese sentido, la producción que nos ocupa se plantea como emergente en relación a las líneas vigentes hasta fines de la década del ochenta en el subcampo de la poesía (que verdaderamente constituye un espacio separado dentro del campo literario, al menos en su aspecto diacrónico): el neobarroco y el neorromanticismo. El surgimiento del objetivismo, estrechamente vinculado al Diario de poesía que comienza a publicarse en el '86, representa una línea de ruptura que por un lado impugna los valores implícitos en estos movimientos y por otro, da inicio al armado programático de una tradición que funcionará como eje para los diversos posicionamientos de los poetas a lo largo de la década. Al mismo tiempo la diversificación de los formatos de publicación (tanto impresos como en Internet), junto con la proliferación de nuevas editoriales independientes y de lecturas de poesía, conforman una red ampliada en la que conviven una serie de poéticas heterogéneas que se diferencian en el modo de procesar la literatura del pasado y sobre todo en una nueva manera de relacionarse con la cultura de masas.

Por eso el rótulo "poesía de los noventa” no sólo no abarca la totalidad de la producción poética de la década -en tanto designa, como dijimos, a las poéticas emergentes del período-, sino que remite a una zona específica de dicha producción delimitada por las características generales mencionadas. El corpus tampoco intenta dar

\footnotetext{
${ }^{2}$ Raymond Williams, Marxismo y literatura, Barcelona, Península, 1997 (145). Traducción de Pablo di Masso. Todas las citas posteriores están tomadas de la misma edición.
} 
cuenta del panorama de estas poéticas aparecidas sobre fines de la década del '80 y principios de los '90, ya que está pensado como corte crítico y supone, entonces, la elección de algunos textos representativos de los diversos modos de procesar la tradición en este período. Por esta razón tampoco se toma la obra completa de un autor, sino una constelación de autores y textos que escenifican el problema crítico de esta tesis. $^{3}$

Con respecto a la tradición, Adorno considera que la forma en que el pasado continúa en el presente es la del ejercicio crítico sobre la misma a partir del estado actual de las cosas. ${ }^{4}$ En este sentido, nos proponemos revisar cuáles son los clivajes desde los que se lee críticamente el pasado de la literatura argentina, pensando este gesto básicamente en el ejercicio de recorte y en las variables del mismo. Desde esta perspectiva, la idea de Raymond Williams funcionará como un eje teórico fuerte en nuestras indagaciones. Para Williams la tradición es "una versión intencionalmente selectiva de un pasado configurativo y de un presente preconfigurado, que resulta entonces poderosamente operativo dentro del proceso de definición e identificación cultural y social” (Raymond Williams: 1997, 137). La tradición no es, de este modo, lo que se recibe como un bloque autónomo y autosuficiente, sino el ejercicio de lectura

\footnotetext{
${ }^{3}$ La lista de poetas que comienzan a publicar en la década del '90 es extensísima. Bastaría tomar el índice de las dos primeras antologías, Poesía en la fisura (1995), con selección de Daniel Freidemberg y Monstruos (2001), cuya selección estuvo a cargo de Arturo Carrera, para dar cuenta de la cantidad de autores que no forman parte del corpus de esta tesis. O mejor aún, el panorama, el arco completo podría rearmarse recorriendo los catálogos de las editoriales que los publican: para empezar, Libros de Tierra Firme, pero también Bajo la Luna, tsé=tsé, Deldiego, Trompa de Falopo, Siesta y Vox, entre otras. Allí podrán recuperarse poetas como Eduardo Ainbinder, Mario Varela, Darío Rojo, Silvana Franzetti, Mariana Bustelo, Roxana Páez, Marilin Briante, Bárbara Belloc, Selva Dipasquale, Carlos Eliff, Santiago Pintabona, Gabriela Saccone, Oscar Taborda, Andy Nachón, Fernando Molle, Ezequiel Alemian, María Medrano, Damián Ríos, etc. El corpus de esta tesis, como se ha dicho, se articula alrededor de la cuestión de la tradición, de la lectura de las tradiciones y del armado de tradiciones en los noventa. Entonces, se abordan aquellos textos y autores que produjeron movimientos importantes en relación a este problema crítico, aquellos que evidencian ciertos movimientos con respecto al pasado y ciertas innovaciones que pueden pensarse, además, como colectivas.
}

${ }^{4}$ Theodor Adorno, Teoría estética, Madrid, Taurus, 1971 (61). Traducción de Fernando Riaza. 
que los poetas hacen de distintos segmentos de la misma, asociado en este caso -a principios de los noventa- con operaciones claras de identificación cultural, y con estrategias de autopercepción y autofiguración peculiares.

El ejercicio de selección en la poesía de los noventa no se rige, sin embargo, por lógicas conocidas. No hay un gesto de adhesión u oposición más o menos programático a una tradición genérica ya consagrada. Los poetas de los noventa no asumen una crítica sistemática de las líneas poéticas de la tradición. Esto podría pensarse en relación a la “poesía política” de los años sesenta o de las vanguardias que, en la larga duración, deberían remontarse a la década del veinte en Argentina y luego en los cuarentacincuenta con el grupo Surrealista liderado por Aldo Pellegrini y el Invencionismo de Poesía Buenos Aires, liderado por Raúl Gustavo Aguirre.

En uno y otro caso, los poetas de los noventa establecen estrategias puntuales de recuperación o ruptura con los componentes estéticos, ideológicos y culturales. En relación a la línea de “poesía política”, por ejemplo, se produce un ejercicio de ruptura con las constituciones estéticas previas y una variación visible de sus elementos ideológicos, que en algunos casos retoma la poesía de Leónidas Lamborghini (en tanto literatura anti-elegíaca) y en otros la de Osvaldo Lamborghini (que opera otro corrimiento con respecto a "lo políticamente correcto" de la poesía sesentista). Las vanguardias, por su parte, y a partir de una fuerte recuperación del neobarroco (de figuras como Perlongher), se revisitan en términos ideológicos y estéticos y también operan como reducción al procedimiento, transformándose por momentos en cantera de “técnicas” de experimentación controlada con el lenguaje.

Una de las instancias que más incide en el armado de esta tradición como “máquina selectiva” (Williams: 1997) son las instituciones: la escuela, los diarios, etc. Pero no se puede dejar de lado lo que Williams denomina como formaciones culturales 
(los grupos, las tendencias, los movimientos) (Williams: 1997, 139), que suponen filiaciones menos estructuradas. Una mención especial merece el Diario de Poesía que desde sus inicios actuó como repertorio de lecturas para los nuevos poetas y como espacio de promoción de sus textos.

Por otra parte, algunos centros culturales alternativos, los talleres y las nuevas revistas fueron redes de suma importancia en las estrategias de selección y difusión de la poesía argentina de los noventa. Es más, podrían leerse estas formaciones como un posicionamiento ante el mercado y el escaso margen de visibilidad histórica de la nueva poesía. El soporte de Internet, las revistas y las ediciones artesanales son parte de un programa conciente en la década en cuestión y de allí en adelante. Todos estos espacios y operaciones envían también a la idea de “campo literario” analizada por Pierre Bourdieu en Las reglas del arte (1997), como fragmento o sub-campo de lo que antes había teorizado en términos de campo intelectual (Bourdieu: 1967 y 1971). Escritores, artistas, editoriales y crítica, definen este campo como una red compleja con distintos puntos de tensión.

Pero el procesamiento de las tradiciones no debe ser abordado solamente en términos de sociología de la cultura o de crítica cultural, sino también en los más estrictos de la crítica literaria, porque involucra el trabajo sobre ciertas figuraciones y retóricas o estéticas previas. Desde este punto de vista se analizarán las distintas praxis de reescritura que definen filiaciones y rupturas en el campo literario o en el artístico en general. 


\section{2- EL CAMPO POÉTICO DE LOS NOVENTA}

Las líneas poéticas más importantes de la década del ochenta -tan heterogéneas y llenas de matices como cualquier conjunto de textos que pretenda leerse a partir de unos pocos rasgos, a la vez que se soslayan otros- son el neorromanticismo y el neobarroco. El neorromanticismo ocupa en realidad la primera mitad de la década y su surgimiento se remonta a la dictadura, período desde el cual estuvo vinculado a la revista y luego editorial Ultimo Reino, en actividad desde 1979. En la revista, dirigida por Víctor Redondo y Gustavo Margulies, se dio a conocer la producción de quienes aparecerían -provenientes de distintos grupos o publicaciones- como el grupo de poetas de Ultimo Reino: Mónica Tracey, Susana Villalba, Mario Morales, Jorge Zunino y Horacio Zabaljáuregui, entre otros. Si bien publicaron poemas de Arturo Carrera y Emeterio Cerro, no podría asociarse a la revista el neobarroco, porque como dice Víctor Redondo “Ultimo Reino busca un lenguaje donde la belleza no esté confrontada con el sentido". ${ }^{5}$ No obstante, la idea de poesía como último lugar de resistencia frente una situación específica como fue la de la última dictadura militar, inscripta en el título de esta publicación y editorial, se convirtió en residual en el campo modificado de la segunda mitad de los ochentas, luego del afianzamiento de la democracia.

Al mismo tiempo, muy tempranamente en los ochenta se pone a consideración la existencia de una poesía neobarroca en nuestro país, cuyos principios, relacionados con la intertextualidad, el juego con la multiplicidad de sentido y la concepción del poema como superficie lingüística autorreferencial fueron enunciados entre otros por el cubano

\footnotetext{
${ }^{5}$ Tomado de Guillermo Lombardía, "Revista de poesía. Ultimo Reino”, prólogo a Antología Ultimo Reino, Buenos Aires, Libros de Tierra Firme, 1987 (5-6).
} 
Severo Sarduy. ${ }^{6}$ Los principales exponentes de esta tendencia son Héctor Piccoli, Emeterio Cerro, Arturo Carrera y Néstor Perlongher, que se referirá a la versión rioplatense del movimiento como "neobarroso". ${ }^{7}$ El término pone de relieve la voluntad de intervenir desde lo local sobre una tradición que puede remontarse hasta el barroco hispanoamericano pasando por el modernismo y en la poesía argentina, por los usos experimentales del lenguaje de Oliverio Girondo y varias décadas después, Osvaldo Lamborghini.

Ambas líneas fueron sustentadas en su momento por distintas publicaciones que les dieron visibilidad y legibilidad al mismo tiempo. La revista Ultimo Reino comenzó a publicarse como dijimos en el año 1979; un año después aparecería Xul y en 1981, La danza el ratón (que difundió una producción de tipo coloquial). Cada una de ellas sostuvo una línea poética identificable junto con un discurso crítico que desplegó ideológicamente la política editorial de la revista y que le permitió ocupar un lugar reconocible en el campo a partir del cruce del discurso poético con la crítica. Según Carlos Battilana, “la aparición de Ultimo Reino, Xul y La Danza del Ratón fue configurando, con diferentes extensiones y modulaciones, discursos críticos para la

\footnotetext{
${ }^{6}$ Severo Sarduy, "El barroco y el neobarroco", en César Fernández Moreno (comp.), América Latina en su literatura, México, Siglo XXI, 1984 (1972).

${ }^{7}$ Perlongher, Néstor, "Neobarroso y el realismo alucinante”, entrevista de Pablo M. Dreizik, en Tiempo Argentino, Buenos Aires, domingo 3 de agosto de 1986. Ver también, de Perlongher, "Neobarroco y neobarroso", en Caribe transplatino. Poesia neobarroca cubana e rioplatense, San Pablo, Iluminuras, 1991 (19-20), de Tamara Kamenszain. "La nueva poesía argentina: de Lamborghini a Perlongher”, en AAVV, Literatura y crítica. Primer encuentro UNL, Santa Fe, Cuadernos de Extensión Universitaria, 1987, y de Martín Prieto, "La poesía neobarroca. “Cadáveres”, de Néstor Perlongher”, en Breve historia de la literatura argentina, Buenos Aires, Taurus, 2006 (447-452).

Para un análisis más detallado de ambos movimientos, y del campo poético de los ochenta en general, ver Jorge Fondebrider, Prólogo a Una antología de la poesía argentina (1970-2008), Santiago de Chile, Editorial LOM, 2008 (31-49), Daniel Freidemberg, "Para una situación de la poesía argentina”, La Danza del Ratón, № 6, diciembre 1984 (22-27); Javier Cófreces, “Diez años de poesía argentina”, Mascaró, № 4, 1984 (29-32); Jorge Monteleone, "Una mirada corroída. Sobre la poesía argentina de los años 80”, en Roland Spiller (comp.). Culturas del Río de la Plata (1973-1995). Transgresión e intercambio, en Lateinamerika-Studien 29, Universidad Erlangen-Nürnberg, y Ricardo Herrera, “Romanticismo, neorromanticismo”, en La hora epigonal, Buenos Aires, GEL, 1991 (97-99).
} 
poesía efectuados en las propias revistas", y esto fue "la condición de posibilidad para la producción de un discurso crítico que emerge de los propios poetas, apartándose del discurso del periodismo cultural”. ${ }^{8}$ En este sentido habría que pensar a estas revistas como antecedentes del Diario de poesía, que a su vez construye su propio lugar en el campo por oposición a ellas, como veremos.

La revista $X u l$ se vinculó con dos tradiciones en particular: la del neobarroco y la de la poesía concreta brasilera. Por esto, Battilana señala un cierto "hermetismo" presente en los textos publicados por $X u l$ que residía en el gesto de privilegiar el significante por sobre el significado: "La tradición concretista y la tradición barroca permitieron a Xul recuperar y formular una reflexión acerca del significante, la dimensión fónica y la disposición espacial del poema, que cumplieron un rol preponderante en la poética experimental de la revista” (Battilana: 2009, 116). A partir de estos criterios de selección, el linaje establecido por Xul se remonta a Stéphane Mallarmé, pasando por distintas experiencias de la vanguardia europea (Tristan Tzara, Antonin Artaud) y latinoamericana (Vicente Huidobro, Oliverio Girondo) hasta llegar a la poesía concreta de Haroldo y Augusto de Campos y Décio Pignatari, por lo cual no es de extrañar que Xul publicara a Néstor Perlongher en su segundo número. ${ }^{9}$ Sin embargo el neobarroco, centrado en el significante como modo de construir un sentido desviado de la función referencial (Battilana: 2009, 118), será una línea residual en los noventa salvo por recuperaciones puntuales como las de Romina Freschi en Estremezcales (tsé=tsé, 2000) y en menor medida, Gabriela Bejerman en Alga (Siesta,

\footnotetext{
${ }^{8}$ Carlos Battilana, "Formas de lo ilegible. En torno a la revista Xul”, en Celina Manzoni (compiladora), Errancia y escritura en la literatura latinoamericana contemporánea, Alcalá La Real, Alcalá Grupo Editorial, 2009 (113-126) (114).

${ }^{9}$ Xul No 2, septiembre de 1981 (26).
} 
1999) y Crin (Belleza y Felicidad, 2001) mientras que algunos redactores y poetas del Diario de poesía se le opondrán abiertamente. ${ }^{10}$

En este contexto, el Diario de poesía surge como una propuesta novedosa cuyo nombre, diseño y programa suponen una concepción de la poesía diferente. Porque la sola idea de hacer un periódico de formato tabloide que se exhibiera en los puestos de diarios implicaba la búsqueda de una ampliación del público lector de poesía, como señala Battilana, al sacarla del circuito restringido donde se ofrecen la mayoría de las veces las revistas especializadas (librerías, festivales, encuentros y lecturas de poesía). Y de hecho la tirada inicial del Diario, de 5000 ejemplares, superó ampliamente los parámetros habituales para las publicaciones sobre poesía. Esto es lo que Battilana denomina el "gesto de masividad", que intentaba relacionarse de una manera nueva con el público lector. ${ }^{11}$

Este dato está en consonancia con la postura confrontativa de la revista respecto a la poesía concebida en términos defensivos o de repliegue. En palabras de Battilana, el Diario “construyó un espacio nuevo, fundado en relación con la circulación misma de la poesía. También confrontaba con una idea de la poesía concebida como una práctica imbuida de cierta iluminación especial, distinta de cierta destreza material específica que parecía pregonar Diario de poesía” (Batttilana: 2005, 150). Esta idea se opone tanto al "hermetismo" presente en Xul como a la noción de una poesía vinculada a lo trascendente y excepcional sostenida por la línea neorromántica de Ultimo Reino. Además, se trata de una publicación que lleva a cabo una intervención amplia sobre la tradición, no sólo desde sus políticas de traducción que permitieron difundir la obra de

\footnotetext{
${ }^{10}$ Battilana aclara sin embargo que "Cuando Xul deja de aparecer, la revista tsé=tsé dirigida por Reynaldo Jiménez y fundada en 1997 retoma claramente las genealogías concretista y neobarroca.” (Battilana: 2009).

${ }^{11}$ Carlos Battilana, "Diario de poesía: el gesto de la masividad", en Celina Manzoni (compiladora), Violencia y silencio. Literatura latinoamericana contemporánea, Buenos Aires, Corregidor, 2005 (147).
} 
poetas norteamericanos, franceses e italianos poco conocidos, sino porque también se constituyó una zona de crítica dedicada especialmente a la poesía argentina contemporánea que logró la difusión y consagración de jóvenes autores, así como la reconsideración de la obra de poetas marginales u olvidados. En este sentido, los dossiers dedicados a la obra de un autor y conformados por entrevistas, traducciones o publicaciones y artículos críticos fueron centrales en la revisión del “canon”, así como en la recuperación de autores poco leídos hasta el momento (Battilana: 2005, 163, 164).

Otra publicación relevante de los noventa fue la revista 18 Whiskys, que duró sólo dos números. 18 Whiskys tuvo una primera entrega en el número 1/2 de noviembre de 1990 y aunque en buena medida compartió su biblioteca con el Diario de poesía (con el que coincide en la publicación de Ricardo Zelarayán, Alberto Girri, y las traducciones de poetas norteamericanos como William Carlos Williams) algunos de sus integrantes, y sobre todo Daniel Durand, la construyeron retrospectivamente como una instancia de oposición a la hegemonía del Diario (que por otra parte, publicó a todos estos poetas) llevada a cabo por un grupo de poetas más jóvenes. 18 Whiskys fue dirigida por José Villa, y de su redacción formaron parte Daniel Durand, Fabián Casas, Rodolfo Edwards, Teresa Arijón y Darío Rojo, entre otros. El número 3/4 de la revista apareció en marzo de 1993, y si bien ambos números se diferencian del Diario en el diseño y en las actitudes entre paródicas e irreverentes hacia los poetas contemporáneos -a los que hacen alusión como si el público esperado de la revista fueran precisamente los poetas, a diferencia de la búsqueda de un público ampliado del Diario-, las dos revistas tienen en común el interés por la crítica y la recuperación de poetas poco difundidos. En cualquier caso, como veremos en el tercer capítulo, algunos poetas de los noventa 
vinculados a 18 Whiskys delinearon sus poéticas en parte desde la confrontación, menos con la biblioteca armada por el Diario que con su modo de leerla. ${ }^{12}$

Una novedad de los noventa posibilitada por la aparición de nuevas tecnologías la constituye el surgimiento de sitios virtuales especializados en poesía tales como el desaparecido Poesia.com, coordinado por Daniel García Helder, Alejandro Rubio y Martín Gambarotta, La voz del erizo (que complementó el ciclo de lecturas homónimo llevado adelante por Delfina Muschietti en el Centro Cultural Rojas entre 1992 y el 2002) y zapatosrojos.com (1999-2006), realizado por Romina Freschi y Karina Macció. Más tardíamente aparece la Vox Virtual, relacionada con la Editorial Vox (que también publicó una revista de poesía en papel) y con la galería de arte y espacio de lecturas Vox de la ciudad de Bahía Blanca, publicó veinticuatro números entre el 2001 y el 2009, que podían leerse online pero también se enviaban gratuitamente a la casilla de correo electrónico de los suscriptores. La publicación, editada en distintas etapas por Gustavo López, Marcelo Díaz, Sergio Raimondi y Sebastián Morfes, se dedicó sobre todo a la difusión de poemas inéditos de autores contemporáneos, acompañados por lo general de una reseña crítica, y también de entrevistas y textos de reflexión sobre poesía y artes plásticas. Vox virtual continúa la difusión empezada en la revista en papel desde Bahía Blanca en el año 1995, bajo la dirección de Gustavo López. En la versión en papel antes del surgimiento del sello editorial Vox- se publicaban pequeñas plaquetas de poesía, como El zorro gris, el zorro blanco, el zorro colorado de Roberta Iannamico, Putina de Gabriela Bejerman, Historias extraordinarias de Osvaldo Aguirre e Hinchada de metegol de Omar Chauvié, entre otras.

${ }^{12}$ Otras revistas de los noventa, en general de pocas páginas y dedicadas sobre todo a la publicación de poesía contemporánea pero no de crítica, fueron La mineta (1987-1990) y La novia de Tyson (1998-2002), una hoja de poesía y una revista dirigidas por Rodolfo Edwards; Nunca, nunca quisiera irme de casa (1995-2001), dirigida por Gabriela Bejerman y Los amigos de lo ajeno (1998-2006), editada por Luis Chaves. Aquí no abundaremos en estas publicaciones, aunque tuvieron un papel central en la difusión de la poesía de los noventa, puesto que no intervienen en el armado de tradiciones que nos ocupa. 
Poesia.com fue otra publicación virtual, coordinada como dijimos por García Helder, Rubio y Gambarotta, que a partir de 1996 se dedicó a la difusión de la poesía argentina y latinoamericana en una doble vertiente, similar a la del Diario de poesía: por un lado, reprodujo libros fuera de circulación o de difícil acceso y conformó un archivo de texto y en ocasiones audio en el que figuraron poetas como Ricardo Zelarayán, Arturo Carrera y Leónidas Lamborghini, pero también difundió la obra de poetas contemporáneos a través de la publicación de textos inéditos, una práctica que fue compartida por el sitio zapatosrojos.com. Además envió a sus suscriptores un “Poema del día” que podía recibirse en la casilla de correo personal. Este dato es importante porque mientras que algunos poetas pusieron en escena un diálogo crítico con la tradición en sus textos, otros parecieron armar su producción estrictamente en diálogo con los contemporáneos, según veremos en el desarrollo de este trabajo.

Como adelantamos, las editoriales independientes de poesía de los noventa (la mayoría de ellas dedicadas exclusivamente a la poesía contemporánea) se suman a estos nuevos formatos de publicación y junto con ellos cumplen un papel central en la promoción de las nuevas poéticas y como modo de contrarrestar la casi inexistencia de un mercado específicamente poético en un período de crisis económica. Entre estas se encuentran Libros de Tierra Firme, dirigida por José Luis Mangieri -que en realidad funciona como pivote con la producción de décadas anteriores, porque es su catálogo figuran autores como Juan Gelman y Leónidas Lamborghini pero a la vez publica los primeros libros de Martín Prieto, Daniel García Helder, Fabián Casas, Martín Gambarotta y Marcelo Díaz-, Siesta, Ediciones DelDiego, Vox, Trompa de Falopo, Nusud, tsé=tsé, Bajo la Luna Nueva, Belleza y Felicidad, Gog \& Magog y Mansalva. ${ }^{13}$

\footnotetext{
${ }^{13}$ Bajo la Luna Nueva surge en Rosario en 1992, bajo la dirección de Mirta Rosenberg; Nusud, también de principios de los 90, fue una cooperativa editora entre cuyos miembros fundadores estuvo Diana Bellessi; Ediciones Deldiego fue un proyecto llevado adelante por Daniel Durand, José Villa y José Varela, entre 1998 y 2001; Trompa de Falopo, que también fue una revista,
} 
Todas ellas se especializaron en poesía (aunque algunas como Mansalva se ampliaron luego para incluir a la narrativa) y la mayoría trabajó con pequeños formatos de publicación, en ocasiones artesanales, que posibilitaron una circulación ampliada de libros a bajo costo, a la vez que nuclearon líneas de escritura muy diversas. En efecto, la poesía de los noventa es un objeto eminentemente heterogéneo: en los década conviven y son publicadas por las mismas editoriales poéticas que guardan poca relación entre sí con respecto a los materiales y tradiciones que procesan y a las ideologías que suponen, pero que sin embargo se vinculan a partir de la pertenencia a un mismo circuito y porque establecen relaciones de oposición y convergencia por medio de las cuales se determinan unas a otras.

\section{3- Planteo DEL PROBLEMA Y ESTADO DE LA CUESTIÓN}

En el momento de emergencia de las poéticas que trabaja esta tesis, si bien el objetivismo, que como veremos es la línea que más explicita sus recuperaciones de la tradición, no había presentado dificultades para ser leído críticamente y admitido como parte de un discurso legítimamente "poético”, otros textos suscitaron polémicas, discusiones y hasta rechazos en nombre de diversos valores como lo "bien escrito” y lo

estuvo dirigida por Leonardo Gabo y asociada fuertemente a la figura de Juan Desiderio, entre los años 1989 y 1993. Belleza y Felicidad, dirigida por Fernanda Laguna y Cecilia Pavón surge en 1998; Siesta, en cuya constitución son centrales las figuras de Marina Mariasch y Santiago Llach, publica entre los años 1998 y 2007; Vox se inicia como sello editor en 1997, y continúa editando hasta la fecha, bajo la dirección de Gustavo López. Es interesante aclarar que las plaquetas de Belleza y Felicidad continúan saliendo hasta la fecha pero el momento de mayor auge y difusión de una línea poética concreta cierra, como ya veremos en el capítulo $\mathrm{V}$, en el año 2001. Gog \& Magog es un proyecto editorial surgido en el año 2003, bajo la dirección de Julio Sarachu, Miguel Ángel Petrecca y Laura Lobov y Mansalva es aún posterior, fundada en el año 2005 por Francisco Garamona. Ambas se mencionan aquí, sobre todo, porque han reeditado una parte importante de la poesía de los noventa. 
provisto de "contenido" en oposición a lo "mal hecho" y lo banal. Especialmente a partir de la aparición de La zanjita de Juan Desiderio y Segovia de Daniel Durand, publicados en 1992 y 1993 respectivamente, lo propio de los noventa se identificó tempranamente como algo que era nuevo en relación a la tradición (y con la cual, al parecer, a veces ejecutaba un corte abrupto), difícil de asimilar en un primer momento para el público y la crítica, al punto de que requirió ajustar algunas herramientas teóricas para poder ser leído, y que incluía rasgos como el uso del habla coloquial en sus variantes más crudas, la incorrección política y la banalidad a ultranza. ${ }^{14}$

Es importante señalar que cuando decimos "habla coloquial” no nos referimos al coloquialismo de los sesenta, que mimaba sobre todo un tipo de discurso oral que podría caracterizarse como estándar y de clase media, ya ampliamente difundido y asimilado para la década del noventa, sino a la posibilidad de hacer versos como "Meté la mano/ sacá lo hueso de poyo/ de la zanja”, que dan comienzo a La zanjita, ${ }^{15}$ o "Por el ojo del choto/ yo lo veo todo roto", famosa rima de Durand en Segovia. ${ }^{16}$ La incorrección política se lee en versos como éstos: "No teníamos puto en el barrio/ así que hicimos uno:/ "El puto Larba”/ (...) en la casa abandonada el flaco Premá / le rompió el culo” (Durand: 2001, 18) y la banalidad, en un poema de Fernanda Laguna que dice simplemente "Xuxa es hermosa./ Su cabello es hermoso/ y su boca dice cosas

\footnotetext{
${ }^{14}$ Martín Prieto y Daniel García Helder, "Boceto No 2 para un...de la poesía argentina actual”, en Punto de vista No 60, Buenos Aires, abril de 1998 (13-18).

${ }^{15}$ Juan Desiderio, La zanjita, Buenos Aires, Trompa de Falopo, 1992, poema I. La edición no contiene páginas numeradas, por lo tanto se cita el número de poema.

${ }^{16}$ Daniel Durand, Segovia, Buenos Aires, Selecciones de Amadeo Mandarino, 2001 (10) (como explicitamos en el capítulo III al trabajar Segovia, esta es la primera edición completa en libro y por eso es la que citaremos, aunque el texto es muy anterior al 2001. De hecho ya había sido publicado un fragmento en la revista 18 Whiskies $\mathrm{N}^{\circ} 3$ / 4, marzo de 1993, y una versión completa en formato electrónico en Poesía.com No 8 (sin fecha).
} 
hermosas./ Yo creo en su corazón”. ${ }^{17}$ Si bien la obscenidad y la violencia de los versos de Durand ya estaban en textos como "El fiord” y "El niño proletario" de Osvaldo Lamborghini, publicados en 1969 y 1973, es decir, con alrededor de treinta años de anterioridad, y el trabajo con la banalidad y el discurso sentimental podría remontarse a ciertas novelas de Puig, la poesía pareció ser un discurso mucho menos permeable que cualquier forma narrativa al ingreso de este tipo de materiales y registros. ${ }^{18}$ Hay algo de extremo en estas escrituras, al borde del analfabetismo cultural (en Desiderio y Durand) y de la nada (en Laguna) que volvió a plantear el problema del valor y de qué perspectiva de lectura emplear para sancionar esos versos como "poéticos”.

Además, los poetas mismos contribuyeron a esta percepción de un conjunto de escrituras que se estaban constituyendo por fuera de la tradición literaria, en la medida en que plantearon de diversas maneras la idea de escribir sin filiaciones o “paternidades” asumidas sino, por el contrario, a veces en abierta oposición a ellas. Así, Martín Gambarotta hace decir a uno de los personajes de Punctum: "Nunca leí el Quijote./ En todo caso sueño con Alien/ escupiendo los huesos de Don Q. en el basural./ Las tripas de Sancho Panza/ vaciadas en la mandíbula de Alien./ Veo capítulos repetidos de Kojak/ durante el invierno sin chica”, ${ }^{19}$ y Durand hace ostentación de la falta de “pulimento” como rechazo de la ideología que asocia la escritura poética con el trabajo de artesano sobre el verso. A modo de ejemplo, un poema de Durand se presenta como el producto de una escritura que se realiza con el sexo, que se moja en un tintero, y dice: “con trazo grueso van estas magnolias/ rosadas por debajo pero duras./ Para vos va esta

\footnotetext{
${ }^{17}$ Poema de Fernanda Laguna citado por Martín Prieto y Daniel García Helder en "Boceto № 2 para un...de la poesía argentina actual”, en Punto de vista $\mathrm{N}^{\circ}$ 60, Buenos Aires, abril de 1998 (17).

${ }^{18}$ Ver Osvaldo Lamborghini, “El fiord” y “El niño proletario”, en Novelas y cuentos I, Buenos Aires, Sudamericana, 2003.

${ }^{19}$ Martín Gambarotta, Punctum, Buenos Aires, Libros de Tierra Firme, 1996 (56). Todas las citas posteriores están tomadas de la misma edición.
} 
frenada:/ caucho para tus narices/ de provinciana emputecida,/ Y para vos leproso canalla/ no te dejo ni siquiera cuarta raya/ y a la rima no la pulo/ no me importa metétela en el culo” (Durand: 2001, 11). El texto, además de negar el trabajo como valor tradicionalmente asociado a la escritura, exhibe una genealogía “popular” (“mamá es maestra/ papá trabaja en el correo/ Pablo es taxista/ Susana es panadera/ mi abuelo tiene una fábrica de ladrillos”, etc.) que se opone a aquellos que “intentan un texto/ para quedar adentro aunque sea/ en el último puesto/ puesto que tienen metida a toda la familia/ dentro de la biblioteca” (Durand: 2001, 11).

Este rechazo explícito de la "biblioteca” esgrimido por Gambarotta y Durand se complementó con diversas declaraciones de los poetas en cuanto a, por ejemplo, la muerte de la lírica, tal como lo hace Alejandro Rubio en su poética escrita para Monstruos. Antología de la joven poesía argentina, compilada por Arturo Carrera. Allí Rubio comienza por establecer una oposición entre "lírica” (que puede leerse como sinécdoque de la poesía entendida en un sentido tradicional, al menos en el modo en que la plantea Rubio) y los medios de comunicación masivos: “La lírica está muerta. ¿Quién tiene tiempo, habiendo televisión por cable y FM, de escuchar el laúd de un joven herido de amor?”, aunque agrega después que “El cadáver de la lírica, en efecto, puede abonar una tierra baldía”. ${ }^{20}$ Si Rubio decreta el fin de una manera de concebir la poesía pero asume que puede haber material aprovechable para las nuevas escrituras en esa tradición (escrituras que confrontarían con la “televisión por cable” y la radio como los nuevos medios hegemónicos con respecto a los cuales la poesía estaría desplazada), otros poetas son más radicales en el modo de posicionarse y sus artes poéticas, significativamente, no hacen ningún tipo de alusión a la literatura.

${ }^{20}$ Alejandro Rubio, “Ars poética”, en Arturo Carrera (selección y prólogo), Monstruos. Antología de la joven poesía argentina, Buenos Aires, Fondo de Cultura Económica, 2001 (169). 
Fabián Casas de hecho presenta como poética una anécdota que lo tiene mirando un talk show por televisión en una noche de insomnio en Londres (Carrera: 2001, 53), y Marina Mariasch dice: "Yo miro la tele y pienso en cosas como qué se pone una chica para una situación sin palabras (Pero, por favor, ¡hagan callar a esa chica!) o qué palabras se pone para un poema. No voy muy lejos para escribir, camino por el barrio o voy al supermercado” (Carrera: 2001, 88). Su poética concluye citando unas palabras de Charly García a su hijo Miguel, mientras que Martín Prieto nombra tanto a T. S. Eliot como a las canciones de Leonardo Favio entre sus “influencias” (Carrera: 2001, 141) y Santiago Llach alude a la "tradición occidental” pero afirma que lee y copia “a los clásicos: mis contemporáneos” (Carrera: 2001, 80). Por último, Santiago Vega (nombre que hasta ese momento usaba el poeta que después sería más conocido como Washington Cucurto) relata la siguiente historia como origen de su escritura:

La primera alegría de la familia la trajo Cacho, mi hermano mayor. A pesar de tener sólo 5 años, recuerdo aquel día con mucha nitidez. Era pleno domingo de fútbol, jugaba el Club Atlético Quilmes, un clubcito de segunda división y San Lorenzo de Almagro. Esa tarde debutó mi hermano en primera división y convirtió un golazo de cabeza. El barrio se convulsionó: todos venían a vernos. Los vecinos nos traían obsequios tales como empanadas, mermeladas caseras y pastelitos dulces, etc. El barrio tenía un nuevo crack y era mi hermano. Esa tarde, mentalmente, garabateé los primeros versos de mi vida. Mi primer libro inédito aún, Los mellizos del fútbol, lo escribí pensando en mi viejo, vendedor ambulante del Mercado de Frutas de Avellaneda, y en mi hermano, futbolista sin gloria más que la que les conté arriba. (Carrera: 2001, 185).

En los poemas y las artes poéticas citadas hasta aquí se despliegan una serie de variantes que van desde el rechazo de la literatura en nombre de la cultura popular y la cultura de masas, en Durand y Gambarotta, la constatación de estar escribiendo en un tiempo en que la presencia de la televisión puede tanto disputar con el discurso poético como proveerlo de materiales, según las opciones de Rubio y Casas, y en el caso de Llach, la identificación de los contemporáneos con los clásicos, que supone un adelgazamiento del tiempo por el cual la sincronía coincide con lo diacrónico. El comentario de Llach sugiere además cierta idea de la poesía contemporánea como recorte autosuficiente, 
capaz de constituir por sí misma una tradición “sin padres” en la que los poetas se leen y dialogan entre sí, desprendidos de cualquier tipo de “pasado” literario.

Marina Mariasch, por su parte, sustrae la poesía al dominio de la tradición o de las influencias literarias para situarla, una vez más, en la televisión, el barrio y el supermercado, mientras que Santiago Vega hace el gesto de escribir puramente a partir de la experiencia, una experiencia de tipo barrial y popular, en un relato de origen donde se omite por completo cualquier alusión a la literatura. Este tipo de figuraciones y autopercepciones, por persuasivas que puedan resultar como gesto, entran en tensión sin embargo con el hecho de que algunos de estos poetas -especialmente Durand y Gambarotta- despliegan al mismo tiempo un conjunto de saberes sobre poesía y exhiben un conocimiento de segmentos de la tradición (Gambarotta cita y reescribe a Pound, Durand trabaja formas como el soneto y los caligramas de Apollinaire en algunos poemas de Segovia), con lo cual las figuras construidas en los poemas y otras instancias discursivas aparecerían más bien como modo de disputar la definición de la legitimidad literaria y los límites de lo admitido como poético con los poetas consagrados (Bourdieu: 1997, 191).

Sin embargo el gesto fue polémico en los noventa y de hecho, como testimonio del malestar que generaron estos textos queda el carácter “defensivo”, por decirlo de algún modo, de dos de los artículos críticos más tempranos que se escribieron respecto a este corpus. El primero llevó la firma de Daniel García Helder y Martín Prieto, que por entonces eran miembros de la redacción del Diario de poesía. En un artículo publicado en Punto de vista estos poetas y críticos afirman que si bien algunos de los textos de los noventa apuestan por la banalidad, su “grado de participación en lo real y en lo actual”, o “Zeitgeist”, es proporcional al modo en que presentan los hechos y las cosas sin hacer abstracciones ni sacar ninguna conclusión, y que su “carácter ontológico” residiría en la 
afirmación de que “el ser no está más allá de las cosas”. ${ }^{21}$ Al mismo tiempo destacan los “saberes más técnicos” a los que los poetas someten la materia verbal (cortes de verso, rimas, aliteraciones, etc.) como garantía de su "poeticidad" (si bien el término nunca es empleado por los autores, la idea de argumentar a favor de esa cualidad en el corpus que trabajan está implícita en cada una de sus afirmaciones).

En una operación que es consecuente con la que acabamos de describir, García Helder y Prieto intentan encontrar para un corpus de libros editados de manera independiente a lo largo de la década una filiación dentro de la tradición argentina, es decir, de “domar” de alguna manera su revulsividad y convertir esos textos que parecen apartarse de la tradición, lo más pronto posible, en "poesía” con pleno derecho. Por su parte Anahí Mallol, en "Muchachos futboleros, chicas pop y chicas que se hacen las malitas: la ‘poesía joven de los 90’ en la Argentina”, afirma que el riesgo de estas poéticas consiste en que “mimando lo banal, volviéndose poesía marca Tinelli” consiguen, sin embargo, no ser banales ni acríticas sino sobrepasar esa cualidad por el plus del humor y la ironía. ${ }^{22}$ Arturo Carrera también llama la atención sobre el uso de la oralidad y la tendencia a lo trivial en la poesía de los noventa, que no valora negativamente, cuando afirma que "La poesía de los jóvenes parece acercarnos con zoom lo trivial de las hablas; trae el sermo plebeius y lo instala tranquilamente en el poema” (Carrera: 2001, 11). Lo cierto es que la repetición de términos como "banal” e incluso “marca Tinelli” en los primeros artículos críticos sobre poesía de los noventa y la insistencia de los críticos en señalar cierto manejo de la retórica (ironía, saberes técnicos) que permitiría admitirlos como literarios da cuenta de que se puso en juego

\footnotetext{
${ }^{21}$ Martín Prieto y Daniel García Helder, "Boceto $n^{\circ} 2$ para un...de la poesía argentina actual”, en Punto de vista nº 60, Buenos Aires, abril de 1998 (15).

${ }^{22}$ Anahí Mallol, "Muchachos futboleros, chicas pop y chicas que se hacen las malitas: la `poesía joven de los 90" en la Argentina”, en Literatura argentina. Perspectivas de fin de siglo, Buenos Aires, Eudeba, 2001 (458).
} 
como pocas veces el problema de la significación y del valor (o la falta de ellos) y de la pertenencia o no de estos textos al ámbito de la poesía, que pareciera estar asociado aún a un grado importante de sacralización.

En relación a esto, la legitimación de las escrituras por el modo de instalarse en determinada tradición, que en ocasiones se planteaba en oposición a otros valores degradados cifrados en las figuras de la televisión y del mercado, fue parte del debate. Pero estos planteos, junto con la constatación de que existía una tensión entre cierto rechazo de la tradición y su empleo en los poemas, nos llevaron a preguntarnos por los alcances de este tipo de posicionamientos y su funcionamiento efectivo en los textos, dado que lo que en algunos poetas se leía simplemente como gesto, en otros tenía un correlato patente en la ausencia visible de cualquier tipo de reelaboración o inscripción literaria en los poemas. A partir de estas reflexiones se fue delimitando el objeto de esta tesis, la indagación en esta forma aparentemente novedosa en que los poetas de los noventa se vinculan con la tradición literaria; de este modo, abordamos un problema prácticamente ausente en la bibliografía crítica.

En efecto, dentro de los textos críticos que se ocupan de la poesía de los noventa se distinguen dos líneas, una de las cuales los lee en la diacronía y en el alcance de sus poéticas en relación a la realidad y los usos del lenguaje, mientras que otra, mucho menor, se dedica a situarlos en relación a ciertas tradiciones o a constatar, al menos, una reformulación en cuanto a este punto. En el "Boceto $\mathrm{N}^{\circ} 2$ para un...de la poesía argentina actual”, ya mencionado, Daniel García Helder y Martín Prieto ponen el foco en la relación de los poetas con el presente, con la historia literaria y la cultura de masas, planteando que estas relaciones serían "lo nuevo" con respecto a lo anterior. Lo común en estos poetas sería su capacidad para captar los signos de ese presente -entre 
los cuales el habla tomada como material tendría un lugar privilegiado- ${ }^{23}$ y someterlos a una serie de procedimientos específicamente literarios que alejarían a estas poéticas del coloquialismo de los sesenta y del “realismo” sin más (García Helder y Prieto: 1998, 15). Los autores encuentran, como contrapartida a la falta de una relación orgánica con la historia literaria, una nueva relación con la cultura de masas, que estaría ahora en el mismo nivel que la "alta cultura”. A este respecto, Delfina Muschietti fue la primera en observar que lo que se modifica en los noventa es que "no hay división entre la alta cultura y la cultura de masas en el trabajo del poema; pierden su diferencia, su partición”. ${ }^{24}$ Sin embargo Muschietti se refiere sobre todo a las citas que se incorporan al poema, mientras que ninguno de estos textos se ocupa de analizar el modo en que la irrupción de la cultura de masas cambia la concepción del poema como un todo, e incluso el modo de pensar la literatura.

A partir de estos supuestos García Helder y Prieto arman dos líneas distintivas dentro de las cuales se podrían agrupar las poéticas de los noventa: la primera de ellas, que se niegan a llamar “realista”, “objetiva” o "referencial”, tendría como rasgo saliente el dar cuenta de lo real y de lo actual sin “comentarlo” (García Helder y Prieto: 1998, 17). La otra tendría a la puerilidad como característica central, y estaría ligada en principio a poéticas que construyen miniaturas banales cercanas al pop y al neobarroco. ${ }^{25}$ García Helder y Prieto hacen el ejercicio de sugerir un linaje posible para cada una de estas líneas, que serían la “red antipoética satírica urbana antilírica y

\footnotetext{
${ }^{23}$ Algo muy similar plantea Martín Gambarotta con respecto a su propia poética en el artículo "El habla como materia prima”, en Jorge Fondebrider (compilador), Tres décadas de poesía argentina. 1976-2006, Buenos Aires, Libros del Rojas, 2006, que analizaremos en detalles en el tercer capítulo.

${ }^{24}$ Delfina Muschietti, Tecnorama: la poesía de los 90”, en Radar Libros, 18 de octubre de 1998.

${ }^{25}$ Una tercera línea, no tan directamente vinculada a lo emergente, tendría que ver con una reformulación de la lírica.
} 
coloquial” que remontan hasta la gauchesca del siglo XIX, en el caso de la primera, y el kitsch y el neobarroco de los ochenta para la segunda.

Emiliano Bustos, desde una perspectiva casi opuesta, propone el realismo como gesto que define a la generación de los noventa (que García Helder y Prieto se negaban a pensar en términos generacionales), pero delimita a su vez dos líneas dentro de la generación, la primera de las cuales ocupa la primera mitad de la década. ${ }^{26}$ Bustos destaca, como García Helder y Prieto, la relación de estos poetas con la cultura de masas, "lo bajo" y la cultura popular, que podría leerse a partir de la presencia en sus textos del rock y la televisión, el fútbol, la basura y la chatarra, y construye para las poéticas realistas (García Helder, Casas, Prieto) una tradición que remite a la prosa. El segundo gesto que Bustos lee en los noventa, situable en la segunda mitad de la década -y que representaría una continuidad y una ruptura con el gesto realista- es el de lo lúdico, en una serie de poetas a través de los cuales ingresa en la poesía lo que el gesto realista había excluido: “misterio, sueño, estupidez, acción de lo insólito” (Bustos: 2000, 101). La serie que arma Bustos alrededor de esta segunda línea se conforma casi exclusivamente de nombres femeninos (Iannamico, Viola Fisher, Mariasch, Freschi, Macció, Laguna, etc.). En este punto la división de Bustos se cruza con la de García Helder-Prieto, si bien difieren los criterios a partir de los cuales se realiza en cada uno de estos artículos el armado de las líneas ("realismo” y puerilidad en García HelderPrieto, gesto realista y gesto lúdico en Emiliano Bustos).

Por último, Bustos menciona al pasar dos nuevos rasgos de la poesía de la década que no desarrolla: la dificultad para publicar, por un lado, y los nuevos modos de circulación de la poesía, mayormente a través de Internet, problemas que no aborda el resto de los artículos sobre la poesía de los noventa. El tema de los nuevos modos de

\footnotetext{
${ }^{26}$ Emiliano Bustos, “Generación poética del '90, una aproximación”, en Hablar de poesía № 3, Año II, junio de 2000 (98-103).
} 
edición aparecerá en cambio como la problemática central en un texto de aparición más reciente firmado por Ana Mazzoni y Damián Selci, "Poesía actual y cualquierización”, 27 en el que los autores se preguntan de qué modo los nuevos modos de edición y los nuevos soportes funcionarían como principio estructurante de la poesía actual. Cecilia Palmeiro recupera el planteo en torno a los nuevos modos de producción y edición artesanales de libros, especialmente en Belleza y Felicidad y Eloísa Cartonera, en un estudio que aborda también los nuevos modos de construcción de subjetividades modelados por tecnologías recientes, con un énfasis especial en la conformación de subjetividades queer. ${ }^{28}$

Beatriz Vignoli, por su parte, introduce el problema de la autonomía de la obra literaria, ${ }^{29}$ después de leer en el artículo de García Helder-Prieto y en el prólogo de Freidemberg a Poesía en la fisura ${ }^{30}$ la afirmación de dicha autonomía en la poesía de los noventa. A partir de esta idea de obra autónoma, la autora descarta de plano la denominación de “realista” para esta poesía que parece realista "por su constante referencia a la contemporaneidad” pero que en realidad sería fuertemente esteticista. Es por eso que Vignoli, a diferencia de García Helder y Prieto que circunscribían la cercanía al pop solamente a una de las líneas poéticas, amplía la caracterización de pop para aplicarla a toda la poesía de los noventa en su conjunto, ya que es una poesía que “no opina, que no dice y se limita a mostrar” (Vignoli: inédito). Mostrar es también el

\footnotetext{
27 Ana Mazzoni y Damián Selci, “Poesía actual y cualquierización”, en Jorge Fondebrider (compilador), Tres décadas de poesía argentina. 1976-2006, Buenos Aires, Libros del Rojas, 2006.

${ }^{28}$ Cecilia Palmeiro, Desbunde y felicidad. De la cartonera a Perlongher., Buenos Aires, Título, 2011.

${ }^{29}$ Beatriz Vignoli, "Poesía argentina de los noventa: breve bibliografía crítica” (inédito) (Sin fecha).

${ }^{30}$ Daniel Freidemberg (antologador), Poesía en la fisura, Buenos Aires, Ediciones del Dock, 1995.
} 
gesto que postula Daniel Freidemberg ${ }^{31}$ como la operación mayor de la poesía argentina de los últimos años, un gesto que buscaría dar visibilidad a lo absolutamente visible y tendría un efecto de saturación semejante -otra vez- al pop art, a la vez que implicaría cierto esteticismo al presentar lo banal como objeto estético desde una mirada desdramatizada e indiferente. Tamara Kamenszain, en lugar de intervenir en el debate de García Helder-Prieto, Bustos y Vignoli alrededor del término “realismo”, asume una perspectiva teórica diferente para plantear que la operación que caracteriza a los noventa consiste en un trabajo con el lenguaje que tiende a forzar el punto de cese de la lengua (concepto que retoma de Jean Claude Milner) para permitir la irrupción de lo real, sin alusión a la experiencia subjetiva. ${ }^{32}$

Un rasgo que es común a los artículos de García Helder-Prieto, Vignoli y Freidemberg es que todos ellos llaman la atención sobre ciertas corrientes que se alejarían de esta vertiente "pop” y que podrían considerarse como "líricas”, si bien no explicitan lo que se entienden por ese término. Tampoco lo hace Vignoli, quien se limita a afirmar que algunos poetas “'pelan’ un yo lírico que se la juega como sujeto, que se posiciona políticamente” (Vignoli: inédito). Freidemberg por su parte define al

\footnotetext{
${ }^{31}$ Daniel Freidemberg, "Escuchar decir nada (una vieja respuesta nunca enviada y después notas, notas de las notas y algo más)”, en Jorge Fondebrider (compilador), Tres décadas de poesía argentina. 1976-2006, Buenos Aires, Libros del Rojas, 2006.

${ }^{32}$ Tamara Kamenszain, "Testimoniar sin metáfora, narrar sin prosa, escribir sin libro. La joven poesía argentina de los noventa.”, en Jorge Fondebrider (compilador), Tres décadas de poesía argentina. 1976-2006, Buenos Aires, Libros del Rojas, 2006. Estas ideas tienen un desarrollo más amplio en un libro de ensayos posterior de la autora, en el que se toman como punto de partida para leer un recorte de la producción de Martín Gambarotta, Washington Cucurto y Roberta Iannamico. Ver Tamara Kamenszain, La boca del testimonio, Buenos Aires, Norma, 2007.
} 
lirismo como “cierto temblor que impregna las palabras y las magnetiza”, y que tiene que ver con "la capacidad de ser sensible". 33

Otros artículos se centran en la relación entre la nueva poesía y la producción de los ochenta, en particular el neobarroco. Jorge Fondebrider, en Treinta años de poesía argentina, ${ }^{34}$ no hace más que constatar la existencia de las poéticas objetivistas a partir de las afirmaciones de los propios poetas y críticos (Samoilovich, Freidemberg, Aulicino), a la vez que sitúa estas poéticas mayormente como reacción ante el neobarroso y el neorromanticismo. ${ }^{35}$ Alicia Genovese, sin atribuir a las poéticas de los noventa una voluntad de reacción contra las anteriores, construye dos bloques perfectamente delimitados y opuestos: el neobarroco de los años ochenta y las nuevas escrituras de los noventa. ${ }^{36}$ Las últimas comenzarían con el objetivismo para dar paso, más en general, a un "realismo" o incluso "hiperrealismo" que optaría por un uso “coloquial, vulgar, callejero de la lengua” (Genovese: 2006, 95) que no responde a modelos constructivos fuertes y que genera una palabra "liviana, de poco peso" y referencial (Genovese: 2006, 96). La descripción de los noventa que hace Genovese resulta, de esta manera, la más generalizadora de todas las mencionadas, si no fuera por

33 El problema de la voz lírica se pondrá a consideración en el capítulo IV a partir de lo planteado por Käte Hamburger en "El género lírico", en La lógica de la literatura, Madrid, Visor, 1995.

${ }^{34}$ Jorge Fondebrider, “Treina años de poesía argentina”, En Jorge Fondebrider (compilador), Tres décadas de poesía argentina. 1976-2006, Buenos Aires, Libros del Rojas, 2006 (7-43).

${ }^{35}$ Una operación similar es la que realiza Edgardo Dobry en su artículo "Poesía argentina actual: del neo-barroco al objetivismo (y más allá), publicado en Jorge Fondebrider (compilador), Tres décadas de poesía argentina. 1976-2006, Buenos Aires, Libros del Rojas, 2006, en el que atribuye parte de la novedad de la nueva generación poética a su separación con respecto a la retórica neobarroca de los ochenta. De todas formas, el mismo Dobry matiza luega esta separación al alegar que algunos poetas vinculados al neobarroco, o por lo menos pertenecientes a generaciones anteriores, tales como Perlongher, Carrera, Juan L. Ortiz, Saer y Samoilovich, encuentran su resonancia en los poetas de los noventa.

${ }^{36}$ Alicia Genovese, "La escritura poética en los años ochenta y en los noventa: de la sobrecarga a la liquidez", en Jorge Fondebrider (compilador), Tres décadas de poesía argentina. 19762006, Buenos Aires, Libros del Rojas, 2006 (91-99). 
el hecho de que, una vez más, aparece una serie de poéticas que se alejarían del mainstream, todas ellas femeninas (y Genovese es la única que resalta esta adscripción, al mencionarlas explícitamente como “producción de poetas mujeres”), cuyas poéticas constituirían el núcleo “lírico” de la época; García Helder y Prieto, en cambio, remitían las poéticas femeninas a la lírica pero también al pop, mientras que Bustos las ubicaba dentro de lo que denominaba "gesto lúdico”.

A pesar de estas diferencias, las poéticas femeninas aparecen situadas, más o menos explícitamente, como el opuesto del “realismo” de los varones. ${ }^{37}$ Es Anahí Mallol quien relativiza esta dicotomía en El poema y su doble ${ }^{38}$ a partir de la idea de que "todo es político" y de que por lo tanto, si bien la escritura de los varones estaría dando cuenta de lo político de un modo más explícito y en su aspecto social, la escritura de las chicas sería también política en la medida en que cuestiona la separación entre esfera pública y privada y permite leer el nivel de la micropolítica en el ámbito de lo privado.

Existe otro conjunto de textos críticos que trabajan el problema de la subjetividad y la mirada en relación a la poesía de los noventa. Entre éstos, el artículo ya citado de Edgardo Dobry propone el acto de filmar como metáfora posible para pensar la producción de los noventa, en la que habría una mirada que se limita a registrar lo que ve, cercana a la del flaneur, sin tratar de elevar los objetos por medio de un lenguaje “culto” sino por el contrario rebajándolos, y rebajando el lenguaje a la vez. Mario Ortiz se refiere por su parte a la des-subjetivación del poema como forma de oponerse al “yo” lírico de la tradición romántica. La del poeta ya no sería una mirada

\footnotetext{
${ }^{37}$ También Mario Ortiz y Ana Porrúa adhieren a esta división en los siguientes artículos: Mario Ortiz, "Entre la `videncia' y el 'lumpenaje': sujeto(s) / objeto(s) en la poesía argentina del siglo XX (breve aproximación histórica)”, en Cuadernos del Sur. Letras, N ${ }^{\circ}$ 34, Bahía Blanca, EdiUns, año 2004. y Ana Porrúa, "Escenas de los `90: el ejercicio del ojo sobre las superficies” (inédito).

${ }^{38}$ Anahí Mallol, El poema y su doble, Buenos Aires, Simurg, 2003.
} 
privilegiada sino más bien la del lumpen, a la vez que estos textos socavarían la identificación -característica de lo lírico- entre la voz del poema y la del poeta. ${ }^{39}$ Ana Porrúa piensa el problema de la subjetividad y de la relación con lo real a partir de tres líneas diferentes. La primera de ellas propondría una mirada que intenta reponer cierta historicidad en los objetos más que limitarse a constatar su presencia, pero sin llegar a un despojo absoluto de la subjetividad. La segunda pondría el foco en los paisajes del mercado, los objetos de consumo y las nuevas formas de racismo desde una mirada “salvaje” y políticamente incorrecta y con un modo de representación desprovisto de moral. Una tercera línea, que engloba a las poéticas femeninas, sería aquella que trabaja con los interiores y con la miniaturización de los objetos desde la exaltación de lo artificial y la construcción del poema como pura superficie, y que podría leerse como devolución exagerada de la mirada del otro -los varones- sobre las mujeres. ${ }^{40}$

En los artículos citados aparece, en primer lugar, el problema de la delimitación del objeto de análisis, ya que se alude tanto a “poesía argentina actual” (García HelderPrieto) como a "generación de los noventa” (Bustos) y "poesía de los noventa” (Vignoli, Porrúa y Mallol). Fondebrider y Genovese, en cambio, circunscriben sus reflexiones al objetivismo, sin llegar a afirmar que esta categoría pueda ampliarse para incluir en ella toda la producción de los noventa, mientras que Freidemberg cuestiona rótulos como “poesía de los noventa” o “poesía joven” en términos de todo lo que estos encuadres reduccionistas estarían dejando afuera. En nuestro caso hemos optado por la

\footnotetext{
${ }^{39}$ Mario Ortiz, "Entre la 'videncia' y el 'lumpenaje': sujeto(s) / objeto(s) en la poesía argentina del siglo XX (breve aproximación histórica)", en Cuadernos del Sur. Letras, $\mathrm{N}^{\circ}$ 34, Bahía Blanca, EdiUns, año 2004.

${ }^{40}$ Ver, Ana Porrúa, “Esos viejos aires nuevos: poesía argentina de los `90”, en Adriana Bocchino (coordinadora), Puntos de partida, puntos de llegada, Actas III Jornadas de Investigación del Departamento de Letras, Facultad de Humanidades, UNMdP. Mar del Plata: Estanislao Balder, UNMdP, 2003 (209-215), y “Lo nuevo en la Argentina: poesía de los `90”, en Foro Hispánico. Revista Hispánica de Flandes y Holanda. Número especial dedicado a la Literatura argentina de los años `90. Coordinado por la Dra. Ilse Logie y Dra. Fabry Genevieve. No 24, Amsterdam- New York, Fecha de publicación: marzo 2003 (85-96).
} 
denominación “poesía de los noventa” (mayormente consensuada entre la crítica especializada) con la aclaración pertinente de que aquí se emplea para referirse a las poéticas emergentes del período, como dijimos, puesto que “poesía argentina actual” nos resulta demasiado generalizador, mientras que pensar esta producción en términos generaciones o de “poesía joven” parece poco apropiado en función de la variedad etaria de los poetas considerados, además de que se trata de criterios extraliterarios.

En general estos estudios tienden a explicar la poesía de los noventa como reacción contra la producción anterior, especialmente el neobarroco, en un movimiento que supone una visión de la historia literaria como producto de las luchas internas y sucesivas entre distintas tendencias. En otros casos, las escrituras más recientes se leen en su diálogo con poéticas anteriores de la tradición argentina, como ser la poesía coloquialista de los sesenta y las obras de Osvaldo y Leónidas Lamborghini y de Joaquín Giannuzzi. Son excepciones el artículo de Edgardo Dobry y el prólogo a Twenty Poets from Argentine de Daniel Samoilovich. ${ }^{41}$ Dobry remite el objetivismo -que no podría ubicarse sin más como “poesía de los noventa”- a la tradición norteamericana de Pound, William Carlos Williams y T. S. Eliot, mientras que Samoilovich señala a William Carlos Williams y a W. H. Auden como parte de las lecturas fuertes de los ochenta.

Con respecto al problema de la tradición en su aspecto teórico, en general tiende a leerse la relación con la historia literaria en términos de “filiación” y de "influencias” (Mallol, Bustos, Vignoli). Beatriz Vignoli se refiere por ejemplo a la "gran novela familiar neurótica que se sigue dando en llamar historia del arte moderno” (Vignoli: inédito), mientras que en Mallol aparece la idea de la poesía como una serie de diálogos y reescrituras entre poetas y poéticas. En nuestro caso, no estamos de acuerdo con el uso

\footnotetext{
${ }^{41}$ En Jorge Fondebrider (compilador), Tres décadas de poesía argentina. 1976-2006, Buenos Aires, Libros del Rojas, 2006.
} 
del término "influencias” para pensar el modo en que cada poeta se vincula con la tradición porque supone una pasividad de parte de un productor que en realidad reelabora creativamente ciertos materiales disponibles. Pero en todo caso, se trata de modos convencionales y en alguna medida acríticos de referirse al diálogo entre textos de diversas épocas. Solamente en el artículo de García Helder y Prieto aparece la idea de que en los noventa se reformula la relación con la tradición, que ya no sería orgánica sino “corta, intensa, heterodoxa, no predeterminada, esporádica” (García Helder y Prieto: 1998, 14). Ana Porrúa parecería adscribir a esta tesis cuando afirma que "La relación con la tradición es una de las cosas que cambia radicalmente en los 90. No sólo no se puede esgrimir la tradición como fuente, sino que las tradiciones no son lineales. No se retoma, en términos generales, una tradición mayor a la que se adhiere sin más, sino segmentos de distintas tradiciones.” (Porrúa: 2005) y analiza, partiendo de esta hipótesis, las distintas lecturas y apropiaciones de la tradición en tres poetas de los noventa (Marcelo Díaz, Sergio Raimondi y Mario Ortiz). ${ }^{42}$

En un artículo muy posterior al de Punto de vista, Martín Prieto vuelve a analizar, ahora sí más detalladamente, el modo en que se procesan tradiciones en la poesía argentina de los ochenta y noventa, centrándose en cómo los neobarrocos (Carrera, Perlongher, etc.) recuperan una obra que proviene de la narrativa: la de Osvaldo Lamborghini, y construyen una biblioteca simultáneamente nacional y latinoamericana. Luego Prieto pasa revista a la biblioteca objetivista y destaca como el mérito mayor del armado llevado a cabo por el Diario de poesía la incorporación de la obra de Joaquín Giannuzzi, hasta entonces poco conocido y marginal, para señalar finalmente algunas confluencias entre las bibliotecas neobarroca y objetivista, como gesto que repasa y relativiza la disputa entre ambas líneas que tuvo lugar en el marco

\footnotetext{
${ }^{42}$ Ana Porrúa, “Una nueva lectura de los clásicos: poesía argentina del `90”, en Revista del CELEHIS, Mar del Plata, Buenos Aires, UNMdP, N 15, 2003-2004 (157-170).
} 
del Diario de poesía. ${ }^{43}$ Sin embargo, aunque tanto este texto como otros de Fondebrider y Freidemberg citados anteriormente se dedican a explicitar el armado de tradiciones, en ocasiones bajo la forma de una larga lista de nombres y poéticas que se recuperan, no existen estudios específicos que profundicen en el modo en que esos materiales ingresan y se reelaboran en el poema, además de que, como puede verse, estos críticos confinan la idea de tradición estrictamente a la literatura, sin contemplar las diversas y abundantes recuperaciones de la cultura popular y la cultura de masas.

Por eso hemos conformado un corpus de la poesía de los noventa que nos permita avanzar a partir de estas primeras consideraciones, omitiendo las poéticas que pueden considerarse como residuales (especialmente las que se circunscriben a repeticiones del neobarroco o del propio objetivismo, que sí abordaremos). Y sobre todo que nos permita indagar, no sólo en la biblioteca que construye cada poeta o conjunto de poetas sino sobre todo en las modificaciones que suponen esas apropiaciones y el modo de trabajarlas en el poema con respecto a la ideología sobre la literatura, el lenguaje y su relación con la realidad, la historia y el presente.

De esta manera, si bien nuestro análisis toma como base las definiciones de Raymond Williams en torno a la tradición, hemos considerado pertinente ampliar incluso la idea de cultura de Williams con los aportes de Andreas Huyssen y Fredric Jameson, quienes trabajan el nuevo lugar de la cultura en el espacio indiferenciado del capitalismo avanzado, y también de Michel De Certeau, que desplaza el acento de los productores a los receptores concibiéndolos en tanto productores creativos (e invirtiendo a su vez esta idea de “influencias” que señalábamos anteriormente); de Certeau, además, provee una definición de “cultura popular” que es operativa para nuestra investigación,

\footnotetext{
${ }^{43}$ Martín Prieto, "Neobarrocos, objetivistas, epifánicos y realistas: nuevos apuntes para la historia de la nueva poesía argentina”, en Delgado, S., y Premat, J., (eds.), Movimiento y nominación. Notas sobre la poesía argentina contemporánea, Cahiers de LI.RI.CO, $\mathrm{n}^{\circ} 3$, Université de Paris 8 - Université de Bretagne-Sud, Paris, 2007 (23-44).
} 
como explicitaremos en el apartado siguiente. Por último, el problema de la referencialidad, presente en los análisis mencionados, tanto como el de la subjetividad cifrada en nuevos modos de construir el lugar de enunciación en el poema, y las vinculaciones con el arte pop, también serán abordados en el caso de textos puntuales, donde se volverá a poner en consideración esta bibliografía específica.

\section{4- MARCO TEÓRICO GENERAL ${ }^{44}$}

El concepto de tradición en su acepción más corriente, pero también cuando se lo plantea desde el discurso crítico en términos de "influencias", como acabamos de señalar a propósito de algunos artículos críticos sobre los noventa, tiene connotaciones que lo asocian a la idea de "transmisión” y de "herencia”. De hecho el diccionario de la Real Academia Española lo define como “Transmisión de noticias, composiciones literarias, doctrinas, ritos, costumbres, etc., hecha de generación en generación”. ${ }^{45}$ El verbo latino “trado”, que se encuentra en la raíz de la palabra “tradición”, significa literalmente “entregar”, “dar” o “transmitir”. Asimismo el sustantivo latino “traditio”, derivado del verbo "trado", alude a la acción de entregar o transmitir. Por lo tanto “tradición”, en sus primeros usos, sería literalmente “transmisión”, e incluso presenta en

\footnotetext{
44 Los marcos teóricos específicos, como ser los referidos al problema de la mirada en el objetivismo, el modo de enunciación lírico en las escrituras "femeninas" o al arte pop, serán abordados en los capítulos respectivos de esta tesis, por considerar que allí tiene más sentido su desarrollo, dado que no se trata de pautas de lectura generales.

${ }^{45}$ Diccionario de la lengua española de la Real Academia Española, Vigésimo segunda edición, Buenos Aires, Espasa Calpe, 2001.
} 
latín matices que connotan la idea de “enseñanza”. ${ }^{46}$ La acción primaria de "entregar” que implica la palabra supone un agente, aquel que entrega, y un receptor que se figura como pasivo. En todo caso, es de imaginarse que el receptor podría aceptar o rechazar aquello que se le entrega, pero no intervenir en su conformación. En ese caso, la pasividad estaría dada por hacerse beneficiario, o no, de un objeto que ya ha sido hecho por otros.

Raymond Williams historizó el término para la lengua inglesa en Palabras clave, y encontró que el sustantivo latino tenía los sentidos que acabamos de consignar: entrega, transmisión de conocimiento, comunicación de una doctrina, pero también, significativamente, rendición o traición, si bien este último sentido sólo fue usado durante los siglos XV a XVII. Williams señala que los sentidos que más se desarrollaron son los que tienen que ver con la idea de transmitir conocimientos o doctrinas, como puede ser el traspaso de viejas canciones o incluso valores morales de una generación a otra. Pero en el uso circunscrito a las relaciones familiares, el término designa cosas que se transmiten de padres a hijos e implica actitudes como la obediencia y al respeto a los mayores. ${ }^{47}$

Sin embargo, en este brevísimo apartado de Palabras clave Williams encuentra que a veces son suficientes dos generaciones para que algo se constituya en tradición, porque éste es el sentido de tradición como "proceso activo" (Williams: 2000, 320). En esta entrada de apenas dos páginas sobre el término es posible detectar cómo Williams rescata este sentido activo para oponerlo, precisamente, al sentido naturalizado de "legado" o "herencia” entre generaciones que el término había adoptado en lo concerniente a la cultura, con las consecuentes implicaciones de respeto y reverencia. El

\footnotetext{
${ }^{46}$ Diccionario Ilustrado Vox, Latino-Español, Español-Latino, Barcelona, Biblograf, 1998.

${ }^{47}$ Raymond Williams, Palabras clave. Un vocabulario de la cultura y la sociedad., Buenos Aires, Ediciones Nueva Visión, 2000 (319).
} 
desarrollo de esta idea se encuentra en el concepto de “tradición selectiva” que Williams propone posteriormente en sus estudios sobre cultura.

El concepto de tradición selectiva es elaborado por Williams en un contexto muy específico: el del ambiente intelectual de la Gran Bretaña de posguerra, en el que un grupo reducido de pensadores venía elaborando desde la década del '30 una idea restringida de cultura como reacción a los cambios producidos en la sociedad por la difusión de los medios de comunicación de masas. En este contexto, Williams se forma intelectualmente en la Universidad de Cambridge, donde el pensamiento hegemónico está representando por la tendencia crítica de F. R. Leavis (el close reading). ${ }^{48}$ Leavis es parte de una minoría que piensa a la cultura como una esfera ideal en la que se mantienen los valores más importantes de lo humano, y que se opone a la civilización el mundo material- por la que se encuentran amenazados esos mismos valores. Desde esta perspectiva, es tarea de una minoría privilegiada, una élite, preservar esos valores y esa cultura. El “otro” amenazante son los medios de comunicación, como parte de la industria: ni el cine ni la radio y la televisión entran en esa definición restringida de cultura.

Esta definición de cultura como una esfera separada del mundo material, en la que se mantienen los valores humanos que en la civilización se pierden irremediablemente debido al "progreso", sustenta una idea naturalizada de la tradición que en ocasiones se formula en términos de “canon”. Porque es en esa misma esfera autónoma, separada de la vida cotidiana, donde se gestan las grandes obras de la humanidad que se reconocen como "tradición” (Cevasco: 2003, 51). La tradición, en esta perspectiva, no es más que la supervivencia en el presente de aquellos segmentos del pasado que vale la pena conservar, e incluso que han permanecido en la cultura en

\footnotetext{
${ }^{48}$ Maria Elisa Cevasco, Para leer a Raymond Williams, Buenos Aires, Universidad Nacional de Quilmes, 2003 (86).
} 
función de la superioridad de los valores que sostienen. Esta idea de tradición, relacionada a las clases dominantes -algo que se "reconoce" o acepta pero no se “construye”, como si no hubiera agentes involucrados en su constitución, sino sólo una minoría de "buen gusto" que es capaz de identificarla y valorarla- no contempla el papel que cumplen en su trazado las instituciones y formaciones que participan de manera activa en la lucha por la definición de la tradición y la cultura, y decididamente no contempla lo mucho que se deja afuera en su conformación.

Es así como lo señala el propio Williams en una entrevista:

Lo que hace la clase dominante es (...) controlar la tradición, y siempre trabajé sobre eso, porque todo el tiempo somos bombardeados con lo que se llama el pasado de nuestro país, los escritos del pasado y la tradición relevante, y, es claro, siempre es relevante. La maniobra no funcionaría si lo que fuese seleccionado no tuviera valor. Lo que sucede y que siempre acaba descubriéndose si buscamos con cuidado es que otras cosas fueron dejadas de lado, o simplemente excluidas, otras fueron interpretadas de manera de tener otro sentido, (...) y otras fueron sobrevaloradas, porque establecían una conexión cuyo énfasis interesaba a la clase dominante y a sus instituciones educacionales. Este es el proceso que llamé de tradición selectiva (...). No se trata de un proceso necesariamente falso en sí mismo, sino apenas de algo tan incompleto y tan selectivo, tan deliberadamente excluyente (...) que simplemente tiene que ser cuestionado en sus propios términos, para demostrar su ignorancia, sus prejuicios e injusticias. (Cevasco: 2003, 77).

Por eso, en Marxismo y literatura, Williams ofrece su propia definición de “tradición”, a la que llama "tradición selectiva”, justamente para enfatizar el hecho de que en su constitución fue necesario un proceso activo de selección y recorte llevado a cabo por individuos, instituciones y formaciones específicas con intereses también específicos.

Para Williams, entonces, la tradición, al contrario de lo que quieren hacer creer los conservadores, no es un segmento históricamente inerte que las nuevas generaciones reciban pasivamente. Toda tradición es construida según un principio de selección y funciona como un poderoso mecanismo de incorporación, articulando procesos de identificación y definición cultural. Y lo que es aún más importante, funciona como un elemento formador del presente, ideando una versión del pasado que no es natural, ni 
representa al pasado "tal como fue”, sino que es creada deliberadamente para establecer una conexión con el presente y ratificar sus significados y sus valores. De este modo, ofrece los medios para una continuidad pre-dada. La tradición es también algo por lo que se lucha, y como declara María Elisa Cevasco, “dejar todo ese campo a los enemigos de la democracia y de la lucha por una cultura común es algo que Williams no hizo” (Cevasco: 2003, 78).

La primera acepción de tradición que citamos -aquello que sobrevive del pasado por la superioridad de los valores que representa- supone además una concepción continuista y lineal de la historia. Como apunta Cevasco, “desde Dante en adelante, hay una línea de obras que preservan los valores humanos que interesan, y se pretende que por esa misma razón han sobrevivido” (Cevasco: 2003, 94). La tradición sería entonces una prolongación no problemática de Dante a Hardy (en el caso, por supuesto, de la literatura inglesa), que mantiene el “idioma del espíritu”, y es papel de una minoría preservarla y diseminarla. Esta idea esencialista se basa en la noción de que hay un continuum inmutable que une todas las épocas, atravesando incluso fronteras nacionales y lingüísticas. Se trata, como se ve, de una visión no histórica de la historia, en la medida en que no contempla el cambio y las luchas concretas que la producen.

Para Williams en cambio, el tiempo histórico está hecho de cortes, discontinuidades y rupturas, lo que equivale a contemplar que existe el cambio histórico. Esta concepción de la temporalidad se articula con la de Benjamin, para quien el pasado no es un residuo pasivo que sobrevive en el presente sino que es ante todo un hecho de memoria. Benjamin se pronuncia en contra del historicismo que plantea una 
imagen “eterna” y estática del pasado, y afirma que el materialismo histórico toma como objeto a una experiencia con el pasado que es única. ${ }^{49}$

En esta relación benjaminiana con el pasado intervienen tanto la noción de “memoria” como la de "lucha”, porque adueñarse del pasado constituye una acción de la memoria y porque ese adueñarse siempre se hace desde las luchas por la tradición que la configuran en el presente: “Articular históricamente lo pasado no significa conocerlo 'tal y como verdaderamente ha sido'. Significa adueñarse de un recuerdo tal y como relumbra en un instante de peligro”, dice Benjamin en la VI Tesis de filosofía de la historia. "El peligro amenaza tanto al patrimonio de la tradición como a los que lo reciben. En ambos casos es uno y el mismo: prestarse a ser instrumento de la clase dominante. En toda época ha de intentarse arrancar la tradición al respectivo conformismo que está a punto de subyugarla” (Benjamin: 1989, 180).

Los aportes de Benjamin y Williams y la visión de las temporalidades que suponen permiten pensar una idea desnaturalizada de tradición conformada siempre a partir del presente, y al mismo tiempo hacen surgir ese presente como un conjunto de tiempos heterogéneos que se superponen, en ocasiones de manera conflictiva. Georges Didi-Huberman retoma las observaciones de Benjamin para proponer una historia del arte donde se haga explícito que todo objeto artístico está constituido por un montaje de tiempos heterogéneos, impuros, en el que el anacronismo, usualmente excluido del análisis, cumple un papel central. ${ }^{50}$ Esta noción resulta útil para pensar la presencia del "pasado" en los poemas porque en ellos, tanto como en las imágenes a las que se refiere Didi-Huberman, todo el "abanico del tiempo" se despliega en los usos de la tradición.

\footnotetext{
49 Walter Benjamin, "Tesis de filosofía de la historia”, en Discursos interrumpidos I, Buenos Aires, Taurus, 1989 (175-191). También en Georges Didi-Huberman, Ante el tiempo, Buenos Aires, Adriana Hidalgo, 2006 (135), quien recupera a Benjamin para proponer nuevas perspectivas sobre el modo de considerar el tiempo en los objetos por parte de la historia del arte.

${ }^{50}$ Georges Didi-Huberman, Ante el tiempo, Buenos Aires, Adriana Hidalgo, 2006.
} 
Se trata, efectivamente, de objetos “temporalmente impuros” y complejos, como señala el autor (Didi-Huberman: 2006, 22, 26).

Pero esto no sólo puede decirse de los poemas mismos, sino también de la poesía de los noventa en tanto objeto que nos ocupa, uno en el que diversas temporalidades, a veces en lucha, coexisten y se interpelan unas a otras. Porque más todavía que en otros períodos, las poéticas que abarca esta tesis presentan ciertos rasgos que Jameson considera propios de la situación cultural que junto con otros teóricos denomina “posmodernismo" (tenemos reparos en valernos del término, pensado para describir la cultura de las grandes metrópolis del primer mundo en el capitalismo avanzado). Según Jameson, la sociedad actual ya no tiene una ideología configurada por la clase dominante, sino que es "un campo de heterogeneidad discursiva y estilística carente de norma”. ${ }^{51}$ Por eso la literatura reflejaría ahora tanto la ausencia de un proyecto colectivo como la inexistencia de la vieja lengua nacional, diluida en la multiplicación de los códigos. Con las objeciones que acabamos de mencionar, estas observaciones nos resultan sin embargo pertinentes para pensar un corpus de textos en el que coexisten una diversidad de poéticas heterogéneas e incluso contrapuestas, sin que ninguna pueda reclamar para sí la legitimidad impugnando a las otras ni la mayoría de las veces intente hacerlo.

Para resumir, Williams propone el concepto de “tradición selectiva” con el objetivo de oponerlo a una perspectiva sobre la tradición que la naturaliza recuperando el primer sentido del término que consignamos a partir del latín: la idea de transmisión, con el correlato de recepción más o menos pasiva que ello implica. Hay dos sentidos en esta nueva perspectiva sobre la tradición que nos interesa rescatar: primero, el reemplazo de la idea de “transmisión” por el de “construcción” habilita la posibilidad de

\footnotetext{
${ }^{51}$ Fredric Jameson, El posmodernismo o la lógica cultural del capitalismo avanzado, Barcelona, Paidós, 1991 (43).
} 
reflexionar sobre los intereses de los agentes involucrados en el proceso, tanto como las luchas por la definición de lo que es la tradición en las que están inmersos.

En segundo lugar, esta idea de tradición como construcción efectuada desde el presente contempla que la selección de aquello que se recorta del pasado surge a partir de operaciones concretas de lectura. Pero en este caso la lectura, que tiene lugar en un “aquí y ahora”, no debería pensarse a su vez tanto como consumo sino más bien como producción, tal como lo hace Michel de Certeau. En este sentido se tomará en cuenta lo planteado por De Certeau en La invención de lo cotidiano. Puesto a indagar acerca de los modos históricos de pensar las relaciones entre los medios de comunicación de masas y la sociedad como receptora de los mismos, De Certeau encuentra que suele aplicarse a esta relación la misma lógica que regía los procesos de alfabetización y la consecuente reforma de la sociedad que fueron centrales en los proyectos modernizadores desde el siglo XVIII. En estos, la producción se imaginaba a cargo de una élite letrada que debía "informar" -en el doble sentido de formación y de transmisión de saberes y conocimientos- a la población. ${ }^{52}$

Es esta misma lógica la que por mucho tiempo ha estado inscripta en el modo de pensar la recepción dentro de la moderna sociedad de masas y que rige también, podemos agregar, la idea de tradición literaria como "transmisión”: la producción, a cargo de un sector social bien definido y separado de los consumidores, impondría determinados contenidos a una sociedad pasiva. De Certeau, como antes lo hicieron otros teóricos -Barthes y Rifaterre, entre otros- cambia el eje para pensar esta relación desde la perspectiva de los consumidores y de la recepción como una producción activa. En efecto, el punto de vista según el cual "se supone que `asimilar' significa necesariamente `volverse parecido a' lo que se absorbe, y no 'hacerlo semejante' a lo

${ }^{52}$ Michel de Certeau, La invención de lo cotidiano I. Artes de hacer., México, Universidad Iberoamericana, $2000(178,179)$. 
que se es, hacerlo suyo, apropiárselo o reapropiárselo” (De Certeau: 2000, 178) da por sentada la pasividad propia del consumo y el hecho de que no hay creatividad en los consumidores.

No sólo eso, sino que este modelo tiene además su origen en el ámbito de lo sagrado, más concretamente en la práctica de la lectura del catecismo y de las Sagradas Escrituras, en la que escribir es producir el texto y leer es recibirlo sin rehacerlo. En este sentido toda interpretación divergente aparece como "profanación" de una interpretación única y autorizada, por lo tanto sigue estando presente aquí la idea de transmisión de conocimientos que deja intacto el objeto que se transmite. Esta sacralización del texto es importante también para pensar la literatura, puesto que el armado de la tradición, al menos en su versión naturalizada que cuestiona Raymond Williams, adopta muchas veces este sentido de sacralidad laica que se cifra en términos como “consagración” y “canon”, provenientes del ámbito religioso.

En oposición a esto, De Certeau propone sustituir el par conceptual producciónconsumo por el de escritura-lectura (desde el momento en que una sociedad cada vez más escrita y organizada según modelos escriturarios permite ser pensada en términos textuales), y pensar la lectura como producción creativa de sentido. Si hasta el momento el funcionamiento de la cultura contemporánea jerarquiza la escritura por sobre la lectura -con la consecuente sobrevaloración de la figura del autor y de sus “intenciones”, así como también de los intérpretes autorizados, como los críticos y docentes-, es necesario pensar que “toda lectura modifica su objeto” (De Certeau: 2000, 181).

Se trata entonces de pensar el libro y la interpretación del mismo como una construcción del lector, que “inventa en los textos algo distinto de lo que era su ‘intención’” (De Certeau, 2000, 182). El lector, en efecto, separa al texto de lo que era 
su origen (perdido o accesorio), combina sus fragmentos y crea algo nuevo. Es importante destacar el carácter fragmentario de esta operación, que se articula en un nivel microscópico con lo propuesto por Williams a propósito de una tradición selectiva, efectuada también a partir del recorte, la resignificación y la omisión.

Por todo lo expuesto, la indagación en torno a las operaciones que constituyen tradición en la poesía de los noventa se organizará entonces a partir de la idea de tradición selectiva, que para Williams es conformada por las instituciones y formaciones, y el concepto de lectura como producción tal como lo plantea Michel De Certeau, que permite pensar a cualquier productor literario antes que nada como lector. Asimismo se tomarán en cuenta las distintas temporalidades que surgen de los textos, y que pueden vincularse con la idea de tradición que en ellos se plantea.

Nuestro marco teórico se completa con textos que trabajan la cultura popular y la cultura de masas, y que nos permitirán iluminar aquellas zonas de la producción de los noventa que no restringen sus recuperaciones a la tradición literaria. Porque si bien Williams propone, junto con el concepto de "tradición selectiva”, una idea ampliada de cultura, que contempla los modos de vida en general de una sociedad en un momento histórico determinado, hemos visto la necesidad de sumar a nuestras herramientas teóricas los postulados de Andreas Huyssen y Fredric Jameson, a partir de la corroboración en el análisis de los textos de lo señalado por Delfina Muschietti y García Helder-Prieto en cuanto al nuevo modo de relacionarse con la cultura de masas de varios poetas de los noventa. Huyssen llama “Gran división” al discurso que sostiene la dicotomía alta cultura/cultura de masas, distinción que fue cuestionada por las vanguardias históricas pero que sobrevive hasta la actualidad, como veremos incluso en 
algunas poéticas del período que nos ocupa. ${ }^{53}$ Sin embargo, el paradigma posmoderno supone una relación distinta con la cultura de masas que se verifica sobre todo en las artes plásticas de fines de la década del cincuenta y comienzos de los sesenta, pero que en la poesía argentina no se haría patente hasta la década del noventa. Fredric Jameson señala también una transformación en la esfera de la cultura que concuerda con la descrita por Huyssen, y propone como algunos rasgos de la nueva situación cultural una nueva superficialidad, el debilitamiento de la historicidad, un nuevo tipo de sujeto, y las relaciones de todo esto con las nuevas tecnologías, que nos serán útiles sobre todo para leer las poéticas vinculadas al pop.

En cuanto a la “cultura popular”, la definición de Michel De Certeau como una cultura que se formula esencialmente en "artes de hacer", es decir, en consumos combinatorios y utilitarios donde se pone en juego una manera de pensar investida de una manera de actuar, un arte de combinar indisociable de un arte de utilizar (De Certeau: 2000, XLV), resultó indispensable para abordar ciertas poéticas que no sólo ponen en escena estos modos de hacer populares en los textos sino que también construyen figuras de poeta vinculadas a este modo de pensar la cultura. (XLV). Así, mientras en algunos casos la idea de una tradición estrictamente "literaria” se torsiona para situar el poema en relación a la cultura popular, en otros casos se establece una tensión similar con la noción de “experiencia”. Es por eso que haremos uso del término, que convoca una serie de debates que pueden remontarse hasta lo planteado por Theodor Adorno y sobre todo Walter Benjamin en el ensayo "Experiencia y pobreza"54 acerca de la imposibilidad de la experiencia para el hombre moderno.

\footnotetext{
${ }^{53}$ Andreas Huyssen, Después de la gran división, Buenos Aires, Adriana Hidalgo, 2002 (5-11).

${ }^{54}$ Walter Benjamin, “Experiencia y pobreza”, en Discursos interrumpidos I, Madrid, Taurus, 982 [1972].
} 
Esta idea de Benjamin de un mundo modificado constantemente (sobre todo por el desarrollo de la técnica) donde el tiempo se acelera al punto de obliterar la adquisición de experiencias es retomada más recientemente por Giorgio Agamben, que suscribe a lo planteado por Benjamin. Agamben empieza sus ensayos de Infancia $e$ historia con la constatación de que la experiencia ya no es algo realizable (así, lleva incluso un poco más allá la afirmación de Benjamin: donde éste hablaba de "pobreza de experiencia”, Agamben habla sin más de inexistencia, de imposibilidad), ${ }^{55}$ porque las experiencias ahora se dan fuera del hombre, que se limita a contemplarlas. Sin embargo para este autor la condición normal de la poesía moderna desde Baudelaire en adelante es justamente "lo inexperimentable", en la medida en que el discurso poético se dedicaría a captar “lo nuevo”, “lo extraño”, es decir todo aquello con lo que no se puede hacer experiencia (Agamben: 2001).

Es necesario aclarar que tanto Benjamin como Agamben se refieren en este caso a la experiencia en tanto vivencia que se ha procesado y convertido en relato, pasible de ser transmitido incluso entre generaciones (con la connotación de "sabiduría” que se obtiene luego de haber vivido, en el caso de Benjamin), aunque Agamben agrega también el sentido de experiencia perceptual. Raymond Williams en cambio opone la noción de “experiencia” (vinculada a su definición de “estructuras del sentir”) a la de “saber”, por lo cual la primera designaría “lo que se está viviendo” y no es del todo comunicable, o al menos no es recuperable en una totalidad narrativa dotada de sentido (Williams: 1997, 150-155; Williams: 2003, 140). Martin Jay señala al respecto que el término alemán engloba dos sentidos divergentes que se traducen en otros idiomas con la misma palabra. En efecto, “Erlebnis” designa lo que en español se traduciría como “vivencia”, que alude a “experiencia vivida”, más inmediata, irreflexiva y personal,

\footnotetext{
${ }^{55}$ Giorgio Agamben,, Infancia e historia, Buenos Aires, Adriana Hidalgo, 2001.
} 
mientras que "Erfahrung” se refiere a una experiencia que se elabora en un tiempo más amplio, basada en un proceso de aprendizaje y en la integración de “momentos discretos de la experiencia en un todo narrativo o en una aventura”, que puede tener un carácter más bien público y colectivo. ${ }^{56}$

Según Martin Jay, si bien “experiencia” se ha usado repetidamente para designar aquello que excede a los conceptos y al lenguaje mismo, sería más apropiado cuestionar la separación entre experiencia y lenguaje para insistir en cambio en la cualidad productiva del discurso (Jay: 2009, 20), porque “la experiencia (...) se halla en el punto nodal de la intersección entre el lenguaje público y la subjetividad privada, entre los rasgos comunes expresables y el carácter inefable de la interioridad individual” (Jay: 2009, 20). Al abordar la recuperación de la noción de experiencia en el postestructuralismo, Jay destaca que para Roland Barthes la experiencia es inescindible del acto de escritura, dado que el pasaje por la materialidad de la letra es parte de la experiencia misma más que simplemente el intento de construirla retrospectivamente (Jay: 2009, 441). De modo similar, Michel Foucault abogó por la interpenetración entre lenguaje y experiencia (Jay: 2009, 445) y apuntó a esta última como una estructura multiestratificada basada en la correlación entre los discursos del saber y las diferentes formas de la subjetividad (Jay: 2009, 448).

En este sentido, y en vista de su estrecha vinculación con el lenguaje, puede pensarse la experiencia en relación a la tradición en cuanto esta constituye, también, un "lenguaje público" desde el momento en que se trata de un conjunto de retóricas construidas colectivamente a lo largo del tiempo, y disponibles para usos individuales, que ciertas poéticas -sobre todo aquellas centradas en el habla- trastocan en nombre de

\footnotetext{
${ }^{56}$ Ver Martin Jay, Cantos de experiencia. Variaciones modernas sobre un tema universal, Buenos Aires, Paidós, 2009 (27, 28, 384-386).
} 
esta instancia de la experiencia como algo "nuevo" que reclama también nuevo usos del lenguaje para decirse (Jay: 2009, 21).

Por último, y pasando a las herramientas indispensables para el análisis textual, nos valdremos reiteradamente de la noción de "poética", 57 en tanto entramado conceptual que puede abstraerse a partir de un conjunto de textos puntuales y en el que se condensa cierta ideología sobre la literatura, y también de la de "materiales” para designar aquellos elementos de diversa procedencia que ingresan al poema y que dan cuenta, también, de posicionamientos ideológicos en cuanto a los límites de lo que puede ser considerado como “poético”. 58

Estas retóricas particulares que dan lugar a ser pensadas como poéticas inscriben también determinadas figuras de poeta, a las que daremos especial atención por considerar que muchas veces en ellas se cifra la posición que se construye con respecto a la tradición, como señala María Teresa Gramuglio. En efecto, las autoimágenes de escritor, que en ocasiones pueden tomar la forma de contra-imágenes o contra-figuras de sí que tensionan determinada ideología (como veremos en el capítulo III a propósito de lo que denominamos "figuras de analfabeto", o en el armado de figuras de poetas “ingenuos” que abordamos en el capítulo V) son construcciones que remiten no sólo a

\footnotetext{
${ }^{57}$ El término "poética" puede emplearse para designar: 1) toda teoría interna de la literatura, 2) la elección hecha por un autor entre todas las posibilidades (en el orden de la temática, de la composición, del estilo, etc.) literarias: 'la poética de Hugo'; 3) los códigos normativos construidos por una escuela literaria, conjunto de reglas prácticas cuyo empleo se hace obligatorio". Ver Oswald Ducrot y Tzvetan Todorov, "Poética", en Diccionario enciclopédico de las ciencias del lenguaje, México, Siglo XXI, 1986, [1972] (98). En este trabajo utilizaremos la segunda y tercera acepción dadas.

58 Theodor Adorno define "material" del siguiente modo: "Material por el contrario es todo aquello de lo que parten los artistas: todo lo que en palabras, colores, sonidos se les ofrece hasta llegar a las conexiones del tipo que sea, hasta llegar a las formas de proceder más desarrolladas respecto del todo: por eso las formas pueden tornarse en material, como pueden convertirse en todo lo que se les opone y sobre lo que tienen que decidir." Ver Theodor Adorno, Teoría estética, Barcelona, Ediciones Orbis-Hyspamérica, 1983, [1970] (197).
} 
la poética sino también a la historia literaria, y que funcionan como modo de intervenir en ella. ${ }^{59}$

Además, en estas construcciones se reúne, en palabras de Gramuglio, una “constelación de motivos heterogéneos” que permite leer el modo en que el escritor representa su subjetividad en tanto escritor, la posición que imagina respecto a sus pares y sobre todo el modo de plantear la relación entre su propia escritura, la literatura y la sociedad. La pertinencia de leer estas figuras en un estudio sobre la tradición tiene que ver con el hecho de que ese lugar en la literatura que el poeta imagina para sí se define
en relación con sus pares, con los escritores que son sus contemporáneos y aún con los futuros, pero también con la tradición literaria en que se inscribe o que pretende modificar; con los temas y los lenguajes que esa tradición le provee; su relación de amor y de odio con sus modelos y precursores; sus filiaciones, parentescos y genealogías; su actitud frente a los lectores, las instituciones y el mercado. (...) En este sentido, es posible postular que la construcción de la imagen conjuga una ideología literaria y una ética de la escritura (Gramuglio: 1992, 37-39).

Por eso algunos capítulos se centran incluso en las figuras de poetas construidas en los noventa, como lugar en el que se articula la posición que el poeta imagina para sí con el modo específico en que la inscribe en los textos.

Al analizar el corpus a partir de estos criterios, hemos podido distinguir cinco zonas dentro de la producción de los noventa que a nuestro criterio constituyen las posiciones más representativas en cuanto al modo de construir y procesar tradiciones, y permiten leer al mismo tiempo las distintas modulaciones conceptuales del término que se dan en los noventa (al punto de que, como veremos, en parte de la zonas abarcadas por los capítulos IV y V ya no es posible hablar de “tradición” en ciertos casos, aunque sí de “lecturas” y apropiaciones). En consecuencia hemos intentado abordar cada una de estas zonas en un capítulo de esta tesis. Así, el primero se dedica a estudiar la conformación de una tradición y una poética objetivistas en el Diario de poesía -

\footnotetext{
59 María Teresa Gramuglio, "La construcción de la imagen", en Héctor Tizón, Rodolfo Rabanal y María Teresa Gramuglio, La escritura argentina, Santa Fe, Universidad Nacional del Litoral, Ediciones de la Cortada, 1992 (35-64).
} 
entendido como formación cultural (Williams: 1997, 139)- a partir de operaciones concretas de lectura sobre determinados materiales que se recortan. El capítulo analiza primero entonces el armado de tradición llevado a cabo por los poetas vinculados al Diario, en una doble vertiente que contempla a la vez la lectura crítica de la tradición en artículos de esa revista, y en los mismos poemas en tanto ponen en escena, también, operaciones de lectura. Pero estos modos de leer se fusionan, sobre todo en los textos poéticos, con modos de representar el ejercicio de la mirada como experiencia perceptual, y también con temporalidades heterogéneas que se despliegan a partir del acto de mirar. Por eso dedicamos apartados especiales a revisar la bibliografía al respecto y ponerla en relación con los poemas.

El capítulo II recorre aquellas líneas de escritura que se vinculan con el objetivismo ya sea porque trabajan con distintos segmentos de la biblioteca construida por el Diario (por eso nos hemos valido del par conceptual archivo/repertorio, a fin de evidenciar el modo en que cada poeta retoma y combina elementos dispersos de esta biblioteca vuelta disponible por el Diario), o porque tratan los mismos problemas planteados por el objetivismo, especialmente el de la mirada, al que dan diversas resoluciones en los poemas según la tradición a la que apelen. De esta línea surgen ciertas poéticas que incorporan la cultura popular como instancia que se cruza con la tradición literaria en los poemas y a la que a veces tensiona o complementa, según la posición asumida por cada poeta. Estas, como veremos, funcionan como primer movimiento de apertura de la idea de “cultura” y "tradición” establecidas por el Diario de poesía.

El capítulo III se dedica a la lectura de un gesto que hemos llamado de "tabula rasa” y a la construcción de figuras de poetas bárbaros y analfabetos, como instancia ya no sólo de ampliación sino en ciertos casos hasta de ruptura con la ideología poética 
sostenida por el Diario de poesía. Estas figuras condensan una serie de motivos que funcionan en ocasiones como impugnación de una tradición concebida en términos estrictamente literarios, en poéticas que operan al mismo tiempo sobre el habla como material privilegiado y que habilitan el ingreso de materiales de la cultura de masas a un nivel que, en nuestra opinión, constituye un giro definitivo en el modo de pensar la tradición y su lugar jerárquico respecto a la cultura popular y la cultura de masas durante la década.

El capítulo IV se ocupa de aquellas poéticas que, si por un lado pueden considerarse como continuación y profundización del gesto nivelador entre tradición literaria y cultura de masas (de hecho algunas de ellas pueden pensarse en este sentido como poéticas pop, según veremos), por otra parte retoman una tradición de representaciones de lo femenino ausente en el resto de las zonas de escritura de los noventa. Por eso el capítulo aborda el problema del género y de la “enunciación femenina” tal como ha sido planteado por la crítica especializada, y se pregunta por su pertinencia al momento de leer determinadas poéticas que construyen lo femenino, y hasta la misma subjetividad en el poema, como gesto performativo.

Por último dedicamos el capítulo $\mathrm{V}$ al análisis de figuras de poetas que, aunque pueden considerarse como modulaciones de la figura del poeta analfabeto, a nuestro juicio representan un cambio radical en el modo de plantear la relación entre lenguaje, ficción y realidad, en la medida en que se trata de poéticas donde la instancia autoral se funde con la construcción de personajes. El capítulo se organiza en un doble movimiento que va del armado de estas figuras al análisis textual de los poemas, porque sostiene la hipótesis de que en estas imágenes de poetas está cifrado ante todo el modo de intervención de estos poetas sobre la tradición literaria, que al mismo tiempo modifican fuertemente. 


\section{CAPITULO I}

\section{LA CONFORMACIÓN DE UNA POÉTICA OBJETIVISTA: DE LA LECTURA A LA ESCRITURA}

\section{1- Planteo inicial}

La conformación de una poética objetivista -tanto por la publicación de libros que podrían ser leídos bajo ese rótulo como por la enunciación de la misma que llevaron a cabo, en su doble rol de poetas y críticos, ciertos escritores vinculados al Diario de poesía - constituye el primer momento de lo que se llamaría años después “poesía de los noventa”, y en realidad articula dos épocas. No tanto desde una perspectiva histórica, aunque los primeros libros objetivistas aparecieron entre el '88 y el '90, en la inflexión que va del alfonsinismo al menemismo -se sabe que esas inflexiones sólo se construyen como tales retrospectivamente-, sino porque las poéticas que se pondrán a consideración en este capítulo revisan la literatura del pasado y en el mismo movimiento sientan las bases para lo que vendría, es decir, para la emergencia de las poéticas que representan aquello que la crítica denominaría después “poesía de los noventa”.

Esta operación estuvo a cargo del Diario de poesía, que empezó a publicarse en 1986, y que reunió a un grupo de poetas y críticos que pueden considerarse como formación en el sentido williamsiano, tal como se explicita en Marxismo y literatura. Las formaciones son "movimientos y tendencias efectivos, en la vida intelectual y artística, que tienen una influencia significativa y a veces decisiva sobre el desarrollo 
activo de una cultura” (1997: 139), y cumplen un papel importante, junto con las instituciones formales, en el establecimiento de una tradición selectiva. Pero en el caso de la poesía contemporánea, cuya filiación institucional es débil o incluso nula, las formaciones son determinantes y el Diario de poesía no sólo vino a ocupar un lugar que estaba vacante en la cultura sino que además se constituyó con relativa rapidez en una instancia de difusión y consagración de los nuevos poetas. De difusión, porque en cada número se publicaron poemas inéditos de jóvenes escritores, además de que se reseñaron sus libros. Y de consagración, porque a partir del 1994 se instauró el Concurso Hispanoamericano de Poesía, que premió en 1994 a Martín Gambarotta y en 1996 a Santiago Llach y Santiago Vega (seudónimo de Washington Cucurto). Ninguno de ellos tenía nada publicado en formato de libro al momento de ser premiados, si bien habían aparecido textos suyos en algunas revistas y antologías. ${ }^{60}$

El Diario de poesía en tanto formación construyó la tradición selectiva (Williams 1997: 137) más persistente en la década del noventa (y la más productiva, en la medida en que habilitó tanto nuevas poéticas que pueden leerse como continuadoras del objetivismo, como gestos y escrituras que se conformaron por oposición), y lo hizo mediante una serie de operaciones de lectura que trazaron una línea entre determinadas poéticas previas y los primeros libros que el Diario mismo postuló como objetivistas, firmados por Rafael Bielsa, Daniel García Helder, Martín Prieto y Fabián Casas, entre otros. $^{61}$

\footnotetext{
${ }^{60}$ Si bien el Diario de poesía se sigue publicando hasta la fecha, nos referimos a él en tiempo pasado puesto que aquí se trabajará con el período que va desde el surgimiento del Diario en el año 1986 hasta fines de la década del '90, años en que tanto Martín Prieto como Daniel García Helder formaron parte de su staff de redacción, como exponemos a continuación (más precisamente, ambos dejaron la redacción en el año 2002).

${ }^{61}$ Tal como se explicitó en la Introducción, el corpus que aquí se trabaja está formado por aquellos poetas cuyos primeros libros surgen en los noventa, por eso si bien Daniel Samoilovich, Daniel Freidemberg y Jorge Aulicino son parte de la formación que estamos analizando, en cuanto a textos poéticos nos centraremos en los de Martín Prieto y Daniel García
} 
El objetivo de este capítulo es analizar la conformación de una poética objetivista como dispositivo de lectura, ${ }^{62}$ a partir de ciertos artículos clave que se publicaron en el Diario de poesía y de poemas que funcionan a su vez como parte de un dispositivo crítico. Al mismo tiempo, se tratará de dar cuenta de los modos en que las lecturas -especialmente de la poesía argentina y norteamericana- se procesan en la escritura poética. En efecto, tanto en los textos críticos como en los poemas se pone en escena un modo de leer que es precisamente aquello que constituye tradición. Porque si para Williams la tradición es un proceso de selección y recorte, en este caso se trata de textos -sobre todo los artículos del Diario- que explicitan los criterios a partir de los cuales se efectúa la selección. Esta práctica de lectura, a su vez, delinea un corpus en el que coexisten poéticas anteriores con otras contemporáneas; éste, si bien reúne fragmentos dispersos de distintas tradiciones, puede considerarse orgánico en el sentido de que está atravesado por unos pocos criterios concretos de selección que lo sistematizan.

Parte del capítulo estará dedicada entonces al seguimiento de la ideología objetivista, que se construye en el Diario de poesía a partir del ejercicio de la lectura crítica. De modo simultáneo, en un recorrido que va de los textos críticos a los poemas -desde el momento en que, como veremos, la doble función de poetas y críticos es Helder, que a nuestro juicio tienen continuidad en otras líneas de escritura de la década (el primer libro de Aulicino, Vuelo bajo, es de 1974; el de Freidemberg, Blues del que vuelve solo a casa, es de 1973, y la primera publicación de Samoilovich, Párpado, pertenece a ese mismo año).

${ }^{62}$ No usamos la noción de "dispositivo" con las connotaciones de "dispositivo de poder" explicitadas por Michel Foucault, sino más bien como "una especie de ovillo o madeja, un conjunto multilineal” que en este caso nos permite recorrer tanto los artículos críticos como las enunciaciones de poéticas y los poemas mismos. Según Deleuze, un dispositivo "está compuesto de líneas de diferente naturaleza y esas líneas del dispositivo no abarcan ni rodean sistemas cada uno de los cuales sería homogéneo por su cuenta (el objeto, el sujeto, el lenguaje), sino que siguen direcciones diferentes, forman procesos siempre en desequilibrio y esas líneas tanto se acercan como se alejan unas de otras”. Es en este sentido que haremos uso del término, en tanto aparato de lectura, crítica y escritura con distintos puntos de contradicción y confluencia, que atraviesa objetos heterogéneos. Ver Gilles Deleuze, “¿Qué es un dispositivo?”, en AA.VV., Michel Foucault, filósofo, Barcelona, Gedisa, 1990. 
inescindible en algunos de los autores a trabajar-, se pondrá a consideración el procesamiento de esas lecturas en las prácticas de escritura poética de Fabián Casas, Martín Prieto y Daniel García Helder. Porque el dispositivo de lectura objetivista se pone en funcionamiento con diversas inflexiones en una serie de libros que se publicaron aproximadamente durante el mismo período que los artículos del Diario de poesía que analizaremos (1988-1996), y que no pueden pensarse solamente como puesta en práctica de una teoría adquirida previamente. Antes que eso, lo que hay es la constitución de poéticas que suponen una circulación entre lecturas, críticas y escrituras.

Desde esta perspectiva serán abordados El faro de Guereño (Libros de Tierra Firme: 1990) y El guadal (Libros de Tierra Firme: 1994), de Daniel García Helder, Verde y blanco (Libros de Tierra Firme: 1988) y La música antes (Libros de Tierra Firme: 1995) de Martín Prieto, y Tuca (Libros de Tierra Firme: 1990) y El salmón (Libros de Tierra Firme: 1996) de Fabián Casas. ${ }^{63}$

Este análisis tomará como eje, en primer lugar, la construcción de figuras de poeta que se plantean como variantes alrededor de la idea de "hombre común”, "hombre medio" o "standard”. ${ }^{64}$ Estas figuraciones de poeta reúnen una constelación de motivos que pueden leerse ideológicamente, en la medida en que ponen en escena el modo en que el poeta se imagina en relación a sí mismo y a la sociedad, y en tanto tienen su correlato en un modo particular de usar la lengua (Gramuglio: 1992).

\footnotetext{
${ }^{63}$ Si bien Casas no formó parte de la redacción del Diario de poesía, sí tuvo colaboraciones ocasionales. Pero la pertinencia de trabajarlo aquí está dada sobre todo por la recuperación de la poética de Giannuzzi, cuyo rescate es una de las operaciones centrales en la conformación de tradición de la revista.

${ }^{64}$ Para una consideración sobre este carácter de "poeta standard” propuesto por el mismo Giannuzzi, ver el ensayo de Sergio Chejfec, Sobre Giannuzzi, Buenos Aires, Bajo la luna, 2010, donde Chejfec aborda esta voluntad de escribir desde la experiencia cotidiana y propone un Giannuzzi intimista, alejado de la perspectiva más corriente de poeta distanciado y "objetivo" que es la que recuperan los poetas aquí considerados.
} 
Luego se trabajará la relación con los objetos y el uso de la imagen en la apropiación de formas que el Diario de poesía sancionó como objetivistas, así como las distintas inflexiones que les otorga cada poeta, especialmente en cuanto al modo de organizar el poema que consiste en vincular lo descriptivo con lo especulativo. ${ }^{65}$

En relación a esto, se dará especial atención a las nociones de temporalidad que propone cada uno de estos libros como variantes de una concepción histórica que, en palabras de Pound, consiste en pensar un presente a la vez profundamente moderno y profundamente enraizado en la tradición. ${ }^{66}$ Esta concepción se pensará también a partir de la relación entre sujeto y objeto desde la perspectiva de la dialéctica de la mirada planteada por Georges Didi-Huberman en Lo que vemos, lo que nos mira. ${ }^{67}$

\section{2- EL DIARIO DE POESÍA COMO FORMACIÓN: LA CONSTRUCCIÓN DEL DISPOSITIVO OBJETIVISTA COMO TRADICIÓN SELECTIVA}

El Diario de poesía comenzó a publicarse en el invierno de 1986 y a partir de esa fecha mantuvo un ritmo de publicación trimestral hasta la actualidad. Dirigido por Daniel Samoilovich, el Diario contó entre sus redactores a Diana Bellesi, Jorge Fondebrider, Daniel Freidemberg, Martín Prieto, Daniel García Helder y Elvio Gandolfo, todos ellos poetas. Jorge Aulicino se incorporó al Consejo de redacción en 1988 y se mantuvo en él hasta 1994. La secretaría de redacción fue compartida por

\footnotetext{
${ }^{65}$ Martín Prieto, “Giannuzzi, Cantón, Girri, y los otros”, en "Dossier Giannuzzi”, Diario de poesía No 30, Invierno de 1994 (17).

66 “Dossier Pound”, Diario de poesía № 3, Verano de 1986, (13).

${ }^{67}$ Georges Didi-Huberman, Lo que vemos, lo que nos mira, Buenos Aires, Manantial, 1997.
} 
Daniel García Helder y Jorge Fondebrider desde el número 19 (invierno de 1991) hasta el 24 (primavera de 1992), después de lo cual Fondebrider abandonó la revista. García Helder fue secretario de redacción hasta el año 2002, fecha en que tanto él como Martín Prieto dejaron de pertenecer al Diario, a partir de su número $60 .{ }^{68}$

Como se ve, se trata de una publicación donde la crítica era ejercida por poetas, algunos de los cuales estaban escribiendo al mismo tiempo sus primeros libros de poesía, y esa doble función de los redactores del Diario -involucrados a su vez en las luchas internas que definen el campo (Bourdieu: 1997)- determina muchas veces el enfoque sobre los textos que se trabajan. Desde sus primeros números, el Diario revisó la literatura argentina y llevó a cabo un proceso de reordenamiento que dio visibilidad a poetas que estaban olvidados y cuestionó, o simplemente ignoró, a otros consagrados; pero estas omisiones son tan significativas como las inclusiones, desde el momento en que, en la idea de tradición selectiva de Williams, lo que se deja de lado cumple una función configurativa tan importante como aquello que se rescata.

Esta conformación de una tradición selectiva cuyos criterios se explicitaron en las páginas del Diario y que analizaremos a continuación fue verdaderamente, como señala Williams, una versión del pasado que tuvo el objeto de "ratificar el presente y de indicar las direcciones del futuro” (1997: 139), es decir, en este caso, de establecer las condiciones en las que serían leídas las propias poéticas de los integrantes del Diario. La versión que propuso la publicación acerca de la literatura del pasado también proveyó los medios para una continuidad deseada (Williams 1997: 138) en el sentido de que armó una genealogía de la que los propios poetas y críticos nucleados alrededor del Diario serían los continuadores en el presente.

\footnotetext{
${ }^{68}$ Ana Porrúa, “La novedad en las revistas de poesía: relatos de una tensión especular”, en Orbis Tertius, año X, número 11, Universidad Nacional de La Plata, 2005 (57-72).
} 
Esta selección se dio principalmente a través de los dossiers, que en cada número reunieron poemas, entrevistas, cronologías y textos críticos y ensayísticos sobre un poeta en particular. Los poetas a los que se dedicaron dossiers funcionan como un muestrario de la biblioteca que armó el Diario de poesía: Juan L. Ortiz ( $\mathrm{N}^{\circ}$ 1, Invierno de 1986; este número también contenía un reportaje a Allen Ginsberg), Ezra Pound (Nº 3, Verano de 1986; en este número también figura un reportaje a Juan José Saer), W. H. Auden ( $\mathrm{N}^{\circ}$ 9, Invierno de 1988; en este número también hay dos poemas inéditos de Leónidas Lamborghini), Francis Ponge ( $\mathrm{N}^{\circ}$ 16, Primavera de 1990), César Fernández Moreno ( $\mathrm{N}^{\circ}$ 20, Primavera de 1991), Marianne Moore ( $\mathrm{N}^{\circ} 27$, Invierno de 1993), Montale, Laforgue, Ponge, Lezama y Pavese ( $\mathrm{N}^{\circ}$ 26, Otoño de 1993; se trata de un dossier conjunto compuesto por diarios de escritores), Joaquín Giannuzzi ( $\mathrm{N}^{\circ} 30$, Invierno de 1994), Leónidas Lamborghini ( $\mathrm{N}^{0}$ 38, Invierno de 1996) y Juana Bignozzi ( $\mathrm{N}^{\mathrm{o}}$ 46, Invierno de 1998), entre otros.

Es útil comparar esta lista de nombres con la que hasta el momento era la biblioteca obligada para cualquier joven poeta que estaba comenzando a escribir, tal como la describe Jorge Fondebrider, para apreciar la dimensión del reordenamiento propuesto por el Diario. Dice Fondebrider:

En los primeros años de la década del ochenta -con la última dictadura todavía vigente- quienes tímidamente empezábamos a publicar poemas en Buenos Aires estábamos desperdigados y, prácticamente, no había puntos de confluencia salvo las revistas Ultimo Reino, Xul y La Danza del Ratón. Cada cual sabía un poco de algo, pero nadie -o casi nadie- tenía una idea global de lo que era la poesía argentina. ${ }^{69}$

El canon post-dictadura, producto tanto de la selección como del estancamiento en la difusión y circulación de poesía que tuvo lugar durante el proceso, estaba compuesto según Fondebrider por “Girri, Molina, Orozco y Juarroz. Por supuesto, todo el mundo hablaba de Pizarnik. Los libros de Gelman circulaban clandestinamente. En el panteón

\footnotetext{
${ }^{69}$ Jorge Fondebrider, “Una causa personal”, en el “Dossier Giannuzzi”, Diario de poesía № 30, Invierno de 1994 (22).
} 
de los muertos estaban González Tuñón, Girondo y, en menor grado, Marechal. Eso era la poesía argentina para cualquier joven poeta”.

El Diario de poesía vendría entonces a ocupar ese lugar de confluencia que había quedado vacante en el testimonio de Fondebrider, pero quizás la parte más significativa de su declaración resida en la frase "una idea global de lo que era la poesía argentina” en la medida en que la cita pone de manifiesto al sintagma “poesía argentina” como centro de gravedad de la tradición construida por el Diario, al mismo tiempo que lo "global” aparece como valor en un proyecto que intentaría ofrecer una visión de conjunto. Es decir, no se trataba sólo de recuperar autores largamente ignorados o revisar la posición otorgada a autores consagrados, sino también de pensar el lugar de éstos en ese conjunto mayor que sería la poesía argentina. En efecto, como señala Edgardo Dobry:

De las generaciones anteriores los poetas del noventa rescatan a Raúl González Tuñón, Juan L. Ortiz, Manrique Fernández Moreno, Leónidas Lamborghini, Joaquín Giannuzzi y Juana Bignozzi. No casualmente, estos tres últimos han sido objeto de dossiers monográficos en Diario de poesía. Se adivina ahí la postulación de un nuevo canon de la poesía argentina, estructurado en torno de unos poetas a los que hasta entonces no se les había adjudicado un lugar central (130). ${ }^{70}$

Es por eso que la relectura de la tradición comienza con un gesto por demás elocuente: la elección de un poeta argentino pero no porteño, y de ninguna manera central en el sistema poético, como Juan L. Ortiz, al que se le dedica el primer dossier de la flamante publicación. Y ya en el tercer número se presenta un dossier sobre el poeta que puede leerse por varias razones como faro de la ideología poética sustentada por el Diario: Ezra Pound. Se trata de una figura que había sido dejada de lado por

\footnotetext{
${ }^{70}$ Edgardo Dobry, "Poesía argentina actual: del neobarroco al objetivismo (y más allá), publicado en Cuadernos Hispanoamericanos No 588, Madrid, junio de 1999 (45-58). Una versión actualizada de este artículo se encuentra en Jorge Fondebrider (comp.), Tres décadas de poesía argentina. 1976-2006, Buenos Aires, Libros del Rojas, 2006 (117-134). Esta es la versión que aquí citamos.
} 
algunos poetas de los sesentas y setentas -pero no por Juan Gelman, por ejemplo- a causa de su simpatía por el fascismo.

El “Dossier Pound” del Diario de poesía comienza por rescatar la idea de Pound de un presente moderno y fuertemente vinculado a la tradición al mismo tiempo, como dijimos, poniendo de manifiesto el interés del propio Diario en esa doble temporalidad, y consiste en una revisión de Pound desde su repercusión en lo que los críticos del Diario denominan "literatura hispanoamericana”. ${ }^{71}$

Como puede verse tanto en este planteo como en la lista de poetas a los que se dedicaron dossiers y que hemos consignado más arriba, el Diario de poesía organiza su biblioteca en una doble vertiente: por un lado, los poetas modernistas norteamericanos ocupan un lugar central, junto con algunos poetas puntuales que se toman de otras tradiciones, tales como Eugenio Montale y Francis Ponge. Por otro lado, el acceso a esos poetas se da por intermedio de las lecturas de otros poetas argentinos o “hispanoamericanos” -tal es el término empleado por el Diario para designar a la poesía escrita en español, terminó que no será recuperado por los poetas contemporáneos y posteriores al Diario de poesía. ${ }^{72}$

Así, el “Dossier Pound” incluye testimonios a cargo de Juan Carlos Onetti, Mario Vargas Llosa, Jorge Luis Borges, Ernesto Cardenal y Jaime Gil de Biedma, entre otros $(14,15)$. El texto introductorio pertenece a Jorge Fondebrider y en él se aclara que de algunos maestros se aprenden formas concretas de expresión, mientras que de otros -tal sería el caso de Pound- se aprenden “actitudes frente al hecho de escribir, vale decir

\footnotetext{
71 “Dossier Pound”, Diario de poesía N 3, Verano de 1986, (13).

${ }^{72}$ El uso del término "Hispanoamérica” puede pensarse como un intento de incluir a la poesía escrita en español, tanto en América como en Europa, pero sin recurrir al término "Latinoamérica” o "América Latina”, un constructo que designaba en los sesentas/setentas tanto a una entidad geopolítica caracterizada por la dominación y asociada a la idea de "tercer mundo" como un a proyecto político de izquierda, tal como lo señala Claudia Gilman en Entre la pluma y el fusil. Debates y dilemas del escritor revolucionario en América Latina., Buenos Aires, Siglo XXI, 2003 (26, 27).
} 
ideas que rigen la concepción de la literatura” (14): esta segunda modalidad de la herencia poundiana será la adoptada por el Diario, como veremos. En el mismo artículo Fondebrider remonta las influencias de Pound hasta la obra de Ernesto Cardenal, Alberto Girri, Juan Gelman e incluso Alberto Laiseca, poniendo siempre el acento en las repercusiones de su obra en la literatura hispanoamericana (15).

También se enfatiza el hecho de que en Pound la crítica nace junto con su objeto y no lo pierde de vista, es decir que la reflexión sobre poesía va seguida de cerca por la práctica, rasgo que intentarán emular los integrantes del Diario de poesía. ${ }^{73}$ Por eso el Pound que recorta el Diario es sobre todo el de El ABC de la lectura, un pequeño tratado prescriptivo sobre poesía que a su vez revisa la tradición y sugiere lecturas a partir de criterios expuestos en el mismo libro. La idea central de Pound, que separa a la poesía de las concepciones románticas y simbolistas y pone el acento en el trabajo específico sobre la palabra, es que la buena literatura es el idioma cargado de sentido en su grado máximo. ${ }^{74}$

En El ABC de la lectura Pound construye una tradición heterogénea que incluye desde Homero hasta Chaucer y algunos poetas anónimos del siglo XVII pero atravesada por un solo criterio de selección: la intensidad y precisión en el uso del lenguaje. El modelo de precisión para Pound es nada menos que Flaubert; en la adaptación de los esquemas poundianos a la literatura argentina que los integrantes del Diario llevan a

\footnotetext{
${ }^{73}$ Sin embargo, el Diario también se hace cargo de las acusaciones de filo-fascismo que durante mucho tiempo condenaron la obra de Pound a cierto ostracismo mediante la inclusión de una breve columna donde Juan Gelman, a pesar de reconocer las "confusiones políticas e ideológicas" que habría padecido Pound, rescata el "Canto XLV" como el mejor poema anticapitalista jamás escrito. La operación del Diario consiste de esa manera en desplazar los componentes ideológicos de parte de la obra de Pound y rescatar su ideología específicamente poética.

${ }^{74}$ Ezra Pound, El ABC de le lectura, Buenos Aires, Ediciones de la Flor, 1968 (23).
} 
cabo, ese modelo de una prosa pulida y precisa será Juan José Saer, que es entrevistado en el tercer número de la publicación. ${ }^{75}$

El modo en que se delinea la figura de Pound en el Diario debe leerse entonces a partir de estrategias de autopercepción y autofiguración: lo que el Diario de poesía toma de Pound es ante todo la figura de poeta-crítico, que revisa la tradición desde criterios de selección puntuales que pasan ante todo por un modo particular de usar la lengua. Por eso, cuando se habla junto con Pound de un presente moderno y tradicional al mismo tiempo (y no hay nada paradójico en esta idea, según esta perspectiva sobre la tradición), se está planteando nada menos que un programa que el Diario de poesía intentará llevar a cabo en los años siguientes.

Se trata de un enorme proceso de relectura, selección y valoración que se da a partir de un dispositivo de lectura al que los mismos integrantes de la revista se refieren como "objetivista", construido según criterios poundianos como lo demuestra sobre todo la recurrencia de las categorías establecidas por Pound en El ABC de la lectura para ordenar la tradición, según veremos.

Este dispositivo de lectura organiza un doble movimiento, que tiende tanto a caracterizar poéticas contemporáneas como las de Fabián Casas y las de los propios integrantes del Diario (especialmente García Helder, Prieto y Samoilovich) como a construir retrospectivamente una genealogía objetivista que rastrea antecedentes de esta línea poética en las obras de Giannuzzi, Girri, Roque Dalton y por supuesto el propio Pound. El ejemplo más evidente de este dispositivo de lectura se encuentra en el artículo que Martín Prieto escribe para el "Dossier Giannuzzi”, en el que anuncia que la obra de

\footnotetext{
${ }^{75}$ Ver “Juan José Saer: La poesía es el arte literario por excelencia”, en Diario de poesía № 3, Buenos Aires, Invierno de 1986 (3).
} 
ese autor puede leerse como "el programa de una poética objetivista que, por otra parte, nadie formuló”. ${ }^{76}$

La organización del artículo de Prieto es cronológica, de modo que se pone en juego un criterio historicista pero también poundiano, porque Prieto va a pensar en términos de "inventores" y "maestros", que son categorías elaboradas por Pound en El $A B C$ de la lectura. ${ }^{77}$ Prieto empieza por plantear que Giannuzzi pudo ser leído como uno de los poetas del cuarenta, aunque era algo más joven que el resto de la generación, porque trabajó con los retazos del neorromanticismo: “Las especulaciones filosóficas y la presencia de un yo como verterbrador de los poemas, lo siguen colocando a Giannuzzi como un hombre del cuarenta” (Prieto: 1994, 17). Pero de esa generación, como se ve, se dejan de lado el componente lírico y sobre todo las poéticas que plantean una mirada romántica sobre el paisaje, y se rescata únicamente a Giannuzzi y a Alberto Girri, siempre en función de aquellos elementos presentes en sus textos que permiten leerlos como objetivistas: en primer lugar, las mismas cualidades verbales que propone Pound, y en segundo lugar la idea de objetivar la emoción y las reflexiones en poemas cuyo movimiento vaya desde las cosas concretas hacia la interioridad del poeta, como inversión de la premisa romántica de la “expresión” de adentro hacia fuera practicada por la generación del cuarenta.

En el artículo que estamos considerando, la línea precursora de esta poética que traza Prieto pasa por Girri y Giannuzzi, y luego incluye a Darío Cantón cuyo poema “La

\footnotetext{
${ }^{76}$ Martín Prieto, “Giannuzzi, Cantón, Girri, y los otros”, en "Dossier Giannuzzi”, Diario de poesía $\mathrm{N}^{\mathrm{o}}$ 30, Invierno de 1994 (17).

77 Dice Pound: "Cuando se buscan "elementos puros" en la literatura, se descubre que la literatura ha sido creada por las siguientes clases de personas”, y a continuación propone una lista que incluye las siguientes categorías: los inventores, los maestros, los que diluyen, los buenos escritores sin cualidades salientes, los literatos, los iniciadores de manías. Ezra Pound, El ABC de la lectura, Buenos Aires, Ediciones de la Flor, 1968 (32,33). Estas categorías son la que sigue Prieto en su jerarquización de los poetas a los que considera objetivistas en el artículo “Giannuzzi, Cantón, Girri, y los otros”, y también organizan en parte su Breve historia de la literatura argentina, Buenos Aires, Taurus, 2006.
} 
corrupción de la naranja”, publicado en 1968, es leído desde Pound y la anécdota de Agazzis y el pez que está en $E l A B C$ de la lectura para decir que una de las premisas del objetivismo es "mirar hasta que se pudra" como modo de conocimiento del objeto. Porque en la anécdota narrada por Pound, un estudiante recién graduado con honores va a visitar a Agassiz, quien le muestra un pez y le pide que lo describa. El estudiante dice que es sólo un pez luna, pero el maestro insiste en reclamar una descripción. Entonces el estudiante define científicamente al pez, y luego realiza un ensayo de cuatro páginas, pero esto no es suficiente todavía para el maestro, quien demanda que el alumno mire al pez. Finalmente, después de tres semanas “el pescado estaba en avanzado estado de descomposición, pero el estudiante ya sabía algo sobre él” (Pound: 1968, 15).

Como se ve, se trata de poner en escena el conocimiento empírico que parte de la observación en contraste con un tipo de conocimiento erudito e intelectual que se apoya en discursos constituidos previamente, como el científico. Para Pound, la poesía como modo de conocimiento podría llegar a dar cuenta de ciertos aspectos del objeto concreto que no sería posible descubrir a partir de otros saberes y sus retóricas específicas. Este modo de mirar y conocer tiene entonces su correlato en un modo de usar el lenguaje, desde el momento en que la poesía es un medio para condensar y transmitir conocimiento. Por eso en el artículo de Prieto, al texto de Cantón se suma luego el Diario de un libro que Girri publicó en 1972, en el que este poeta habla de otorgar a la poesía las virtudes de la prosa: “desnudez, economía, eficacia” (18). El modelo de una escritura que sostiene estos valores va a ser para Girri y Giannuzzi, como había anticipado Pound, la prosa de Flaubert.

Entonces, en la lectura objetivista de Prieto, Giannuzzi habría sido el inventor de una poética que él mismo no llegó a concretar. Según Prieto, pasarían años hasta que aparecieran en Argentina los primeros poemas “definitivamente objetivistas”, con el 
libro Quince poemas de Rafael Bielsa y Daniel García Helder (19). La particularidad de este libro es que la enunciación está a cargo en los poemas de diversas voces que no pueden confundirse con la voz de los autores (por otra parte, el hecho de que los poemas estén escritos en conjunto echa por tierra de por sí la posibilidad de pensar en una identificación lírica entre el autor y la voz del poema). En uno de ellos, por ejemplo, habla una mujer (que se dice "interpuesta y casi traspasada/ por la reverberación tangible/ del azar”, p. 17) ${ }^{78}$ y en otro un sacerdote que confiesa a un muchacho (23), mientras que en "Mensajero" se da voz a un soldado de Agamenón (39), en un ejercicio que recuerda al realizado por Pound en Cathay. ${ }^{79}$

En todos los casos, incluso cuando se trata del soldado griego, o de otro personaje que describe una peste medieval (45), los poemas recortan escenas cotidianas en las que en ocasiones aparece la muerte $(37,45)$ o la intrascendencia (27) pero que pueden agruparse bajo la premisa enunciada en el primer poema: "No tengo oficio,/ o mi oficio es pensar; aplicando/ palabras sencillas a cuestiones elevadas/ corrijo mi biografía” (13). Como se ve, el tipo de reflexión o pensamiento que se cifra en "palabras sencillas”, postulado también por Giannuzzi, ${ }^{80}$ se activa en el libro incluso como programa, puesto que se anuncia desde los primeros versos.

Pero, para volver al Diario de Poesía, no sólo García Helder y Prieto leen a Giannuzzi desde Eliot y Pound, sino que el mismo Giannuzzi, entrevistado por

\footnotetext{
${ }^{78}$ Daniel García Helder y Rafael Bielsa, Quince poemas, Rosario, El lagrimal trifurca, 1988. Todas las citas posteriores están tomadas de la misma edición.

${ }^{79}$ En este libro Pound reescribe motivos y textos de la poesía de Li Po y hace hablar en los poemas, en ocasiones, a mujeres, como en "The River Merchant' Wife: A letter" ("La esposa del mercader del río: una carta") o en "The Jewel Stairs" Grievance" ("El lamento de la escalera de gemas”). Ver Ezra Pound, Personae. Los poemas breves., Madrid, Hiperión, 2003 (267, 270). Traducción de Jesús Munárriz y Jenaro Talens.

${ }^{80}$ Dice Giannuzzi, entrevistado por Freidemberg en el Diario de poesía: “aspiro a un lenguaje no sé si 'llano', diría 'lineal': significados muy explícitos, nada de hermetismos, ni de oscuridad, que es peor que el hermetismo". En Daniel Freidemberg, "Un poeta standard". Entrevista a Joaquín Giannuzzi., en "Dossier Giannuzzi”, Diario de poesía No 30, Invierno de 1994 (14).
} 
Freidemberg, menciona a Eliot, Pound y William Carlos Williams como referentes para su poesía en tanto introdujeron en el discurso poético lo trivial y cotidiano. ${ }^{81}$

El “Dossier Giannuzzi”, que es de 1994, contiene también un breve artículo de Fabián Casas; si García Helder, Prieto, Freidemberg y Fondebrider se construyen en estas notas discursivamente como críticos, Casas lo hace como lector aficionado, y habla del descubrimiento de Giannuzzi desde su experiencia personal. ${ }^{82}$ Lo significativo es que los primeros libros de García Helder, Prieto y Casas -y todos ellos reconocen el procesamiento de Giannuzzi en sus poéticas- se publicaron entre el año '89 y el '90. Por lo tanto el dossier del Diario de poesía es posterior al procesamiento de Giannuzzi por parte de los poetas del noventa y viene a dar visibilidad a una serie de lecturas previas. Sin embargo este dossier es una pieza central en el proceso de conformación de una poética objetivista que realiza el Diario de poesía, sobre todo con el artículo de Martín Prieto, que intenta construir una modalidad de lectura que ilumine la producción de los poetas integrantes del Diario y al mismo tiempo pueda “apadrinar” a poetas más jóvenes como Fabián Casas.

Otra instancia importante en la tradición que conforma el Diario y que pone de manifiesto a su vez el funcionamiento del dispositivo de lectura objetivista del que hemos hablado es el “Dossier Lamborghini”. Publicado en el № 38 (Invierno de 1996) en un número especial que celebra el décimo aniversario de la revista; el dossier se abre

\footnotetext{
${ }^{81}$ Daniel Freidemberg, “Un poeta standard”, en “Dossier Giannuzzi”, Diario de poesía No 30 , Invierno de 1994 (14).

${ }^{82}$ Casas nombra en su texto a una constelación de poetas que servirían tanto para leer a Giannuzzi como a él mismo: Eliot, Montale, Ponge, Girri. Además, lee en la poética de Giannuzzi “un orden clásico donde cada palabra estaba sustentada por la necesidad” (23), y una poesía conceptual, de ideas, que usa de manera borgeana los adjetivos y que representa "un mapa mental de los terrores y ansiedades del hombre de clase media que habitó Buenos Aires durante buena parte del siglo XX", con un yo lírico que representa al "hombre mass media" de su tiempo. También es importante destacar que Casas señala que llegó a Eliot vía Giannuzzi, porque en ese sentido reproduce el modo de acceso a la poesía norteamericana planteado por los integrantes del Diario de poesía. Ver Fabián Casas, “Como una aguja en la mesa de saldos”, “Dossier Giannuzzi”, Diario de poesía No 30, Invierno de 1994 (23).
} 
con una nota en la que Daniel Freidemberg sitúa a Lamborghini, como ya Prieto lo había hecho con Giannuzzi, como poeta marginal de la generación del cuarenta. ${ }^{83}$

Freidemberg lee en Lamborghini un antecedente muy temprano de las teorías postestructuralistas sobre el lenguaje que pondrían en práctica Osvaldo Lamborghini y el grupo de escritores articulado en torno a la revista Literal (dirigida por Héctor Libertella) en la década del setenta. Pero mientras el crítico atribuye el tratamiento del lenguaje de este grupo al "nuevo consenso en torno a la idea de escritura resultante del impacto en el campo intelectual argentino de la teoría estructuralista y postestructuralista” (14), encuentra la motivación para la poética de Leónidas Lamborghini en una relación directa entre forma y experiencia política, cuando afirma que tal poética sería la "respuesta a una disconformidad que encontró en el peronismo su principal inspiración” (14). También se destaca, en el mismo artículo del “Dossier Lamborghini”, un uso de lo popular que tendría sus raíces en una variante particular (y no intelectual) del peronismo que en Lamborghini se traduce en la liberación de las fuerzas de lo bajo, lo vulgar y despreciado, junto con una suerte de "sentido común popular” y una toma de partido por el “concreto trabajo físico” y el "contacto de la materia”.

Al mismo tiempo Freidemberg encuentra que algunos rasgos en la manera de usar el lenguaje son comunes a la poesía de Lamborghini y la de los neobarrocos, pero separa cuidadosamente el signo ideológico que subyacería en esos usos. Porque en Lamborghini habría, como se dijo, una motivación que hace de la escritura "un gesto de tomar la palabra, derecho cuyo ejercicio inscribe en una lucha por el poder”. De hecho Freidemberg apela a Franz Fanon y su teoría de las estrategias del débil para decir que el gran proceso de reelaboración de la tradición que incluyen los libros de Lamborghini

\footnotetext{
${ }^{83}$ Daniel Freidemberg, “Leónidas Lamborghini”, en “Dossier Lamborghini”, Diario de poesía No 38, Invierno de 1996 (14).
} 
implica un modo de resolver la relación colonizador-colonizado, apropiándose de lo impuesto para hacer de ello un uso desviado que estaría cifrado en la famosa consigna de Lamborghini “Asimilar la distorsión y devolverla multiplicada” (14). ${ }^{84}$

En contraste con esto, Freidemberg no atribuye un sentido específico al uso neobarroco, con lo cual lo que en Lamborghini es un “disfrute chocarrero y materialista de la manipulación de las palabras que algunas teorías del neobarroco propugnarían después” (14), en los neobarrocos aparece, siempre según la lectura de Freidemberg, como un gesto gratuito (lectura que está en consonancia, como veremos, con la apreciación de Daniel García Helder respecto al neobarroco en otro artículo del Diario).

En la entrevista a Lamborghini que figura en el mismo dossier y que los editores titularon con una cita del poeta, "Nada que ver con la belleza”, se destacan a partir de las preguntas de Daniel García Helder algunos aspectos de la obra de Lamborghini que son funcionales al modo de leer la tradición de los propios críticos del Diario. En primer lugar porque Lamborghini, al igual que Giannuzzi, se reconoce como miembro de la generación del cuarenta por fecha de nacimiento pero se separa de esa generación en su rechazo de la lírica y, dentro de la lírica, de lo elegíaco, mediante el uso de voces y personajes que se aceran más al tipo de obra en verso donde un personaje se construye desde la voz, analizada por Eliot en su ensayo "Poesía y drama”. ${ }^{85}$ En segundo lugar,

\footnotetext{
${ }^{84}$ Esta frase fue repetida por Leónidas Lamborghini en casi todos los reportajes que se le hicieron, pero además funciona en los propios prólogos a sus libros y hasta en el interior de sus poemas. Así, en la nota preliminar de Tragedias y parodias I se lee sobre los poetas gauchescos que "Asumieron la Distorsión y, soslayando o compensando el lloriqueo, la devolvieron, de esa manera, multiplicada: conectando el horror y la risa” (Libros de Tierra Firme, 1994). Reaparece también en Risa y tragedia en los poetas gauchescos (Buenos Aires, Emecé, 2008) y está articulando la propia poética en versos de Odiseo confinado (Buenos Aires, Ediciones Van Riel, 1992) y Comedieta (Buenos Aires, Ediciones Estanislao, 1995). La distorsión está asociada a lo bufo pero sobre todo a la parodia. En este sentido puede leerse, tempranamente, "El estro paródico", un texto en prosa que cierra El Riseñor (Buenos Aires, Marano-Barramedi, 1975; p. 49).

${ }^{85}$ En este ensayo, Eliot hace ciertas consideraciones sobre la posibilidad de escribir dramas en verso y sobre el modo en que el verso y el habla pueden ir juntos sin que el resultado sea
} 
porque en lo escrito por las generaciones del cuarenta y del cincuenta hay según Lamborghini un rechazo de lo "bajo”: “Se trataba de una poesía elevada. No ponían el cuerpo" (16). ${ }^{86}$

El modo de concebir la relación del poeta con la tradición que rige estas lecturas debe atribuirse no sólo a Pound, como señalamos, sino también a T. S. Eliot, que en su texto "La tradición y el talento individual" sostiene que el poeta no tiene una “personalidad” que expresar sino un dominio de su medio, y que debe conseguir una objetivación de sus emociones en la medida en que es capaz de separar dentro de él “el hombre que sufre y la mente que crea”, ${ }^{87}$

Al mismo tiempo, Eliot hace una afirmación fundamental sobre la temporalidad cuando sostiene que el poeta, en su asimilación de la tradición, debe vivir no en el presente exactamente, sino en "el momento presente del pasado” (Eliot: 1944, 29). Para Eliot, la relación con la tradición pasaría, no por estar el poeta conciente de lo que está muerto en el pasado, sino de "lo que ya está vivo". Esta es la idea de tradición que

artificial, además de que contribuya a una presentación directa del personaje. Lamborghini comparte con Eliot el interés por pensar la poesía en relación al teatro sobre todo por la capacidad de este último para incluir al habla (aunque Eliot se refiera a Shakespere entre otros, y Lamborghini encuentre cualidades similares en la gauchesca). Ver T. S. Eliot, Poesía y drama, Buenos Aires, Emecé, 1952.

${ }^{86}$ Daniel García Helder, “Nada que ver con la belleza”. Entrevista a Leónidas Lamborghini, en “Dossier Lamborghini”, Diario de poesía No 38, Invierno de 1996 (16, 17).

La poesía de Lamborghini en cambio, según Miguel Dalmaroni, ha sido caracterizada por él mismo como "antilirismo", anti-lagrimita" y "anti-humanismo". "Contra esas humedades" Lamborghini propone "dureza, sequedad”, y reivindica "una continuidad con la línea de los gauchescos, lo grotesco, los saineteros, Arlt, el Olivari de La musa de la mala pata, los letristas del tango, Marechal...”. Ver Miguel Dalmaroni, La palabra justa. Literatura, crítica y memoria en la Argentina, 1960-2002, Mar del Plata, Melusina, 2004 (16). Esa genealogía "popular" -que no se confunde con el populismo porque en Lamborghini las estrategias compositivas provienen de la vanguardia, como señala Dalmaroni- es similar a la que trazan Martín Prieto y Daniel García Helder para gran parte de la poesía del noventa en "Boceto $\mathrm{N}^{\circ} 2$ para un...de la poesía argentina actual”, en Punto de vista $\mathrm{N}^{\circ}$ 60, Buenos Aires, abril de 1998, en el que se refieren a la "red antipoética satírica urbana antilírica y coloquial" (18) que va desde Manrique y Baldomero Fernández Moreno, Carlos de la Púa, Boedo, el tango, Leónidas Lamborghini, Ricardo Zelarayán, hasta el rock nacional y buena parte de la poesía del sesenta.

${ }^{87}$ T. S. Eliot, "La tradición y el talento individual”, en Los poetas metafísicos y otros ensayos sobre teatro y religión, Buenos Aires, Emecé, 1944, Tomo I (11-23). 
Lamborghini rescata en Eliot desde la práctica y que los poetas del Diario de poesía rescatan a su vez en Lamborghini como modelo para su propia conformación de una tradición selectiva.

El interés de Leónidas Lamborghini por apropiarse de y reescribir la tradición, así como la relación entre escritura y experiencia que Freidemberg lee en su obra, son instancias de una ideología poética que Freidemberg usa para descalificar tanto al postestructuralismo de importación (cuando hablaba del “impacto en el campo intelectual argentino de la teoría estructuralista y postestructuralista” (14), no sin un dejo de sospecha por las escrituras nacidas, en su opinión, no de la experiencia sino de las teorías) como al neobarroco. En esa mención al neobarroco, que en el artículo de Freidemberg sobre Lamborghini es lateral, resuena a su vez la tesis central de un texto firmado por Daniel García Helder que el Diario de poesía había publicado casi diez años antes.

El texto se titula “El neobarroco en Argentina” y apareció en el $\mathrm{N}^{\circ} 4$ del Diario de poesía (Otoño de 1987), es decir, en el momento en que la publicación estaba delimitando por primera vez su propia posición dentro del campo literario. Por ese motivo, y por la contundencia de sus postulados, adoptó para algunos valor de manifiesto (valor que deberá ser matizado, y que de hecho lo fue por otros integrantes del Diario). ${ }^{88}$

García Helder, en tono siempre irónico, reconoce la existencia de una tendencia barroca en Argentina durante los últimos años (década del ochenta) en la que pueden incluirse a Héctor Píccoli, Emeterio Cerro, Arturo Carrera, Néstor Perlongher y en alguna medida, el propio Leónidas Lamborghini, pero se ocupa por destacar

\footnotetext{
${ }^{88}$ Daniel García Helder, “El neobarroco en Argentina”, Diario de poesía № 4, Otoño de 1987 $(24,25)$. Para un seguimiento de las derivaciones de este debate en el interior del Diario de poesía, ver Ana Porrúa, "Una polémica a media voz: objetivistas y neo-barrocos en el Diario de Poesía”, Boletín del Centro de Estudios de Teoría y Crítica Literaria, Facultad de Humanidades y Artes, Univ. Nac. De Rosario, Nro. 11, diciembre de 2003 (59-69).
} 
rápidamente que los antecesores de esta tendencia no son argentinos sino cubanos: José Lezama Lima y Severo Sarduy.

En la lectura de García Helder, el neobarroco se caracteriza por "burlar” el vínculo entre un sonido y su significado directo mediante diversos procedimientos que otorgan opacidad a las palabras y hacen que se remitan unas a otras en lugar de subordinarlas a fines comunicativos (24). El tipo de escritura que resulta de estos procedimientos es caracterizada por García Helder como “escritura de superficie”, que desvanece toda ilusión referencial e impide “todo descenso a un fondo semántico” (24). El desprecio de García Helder por este modo de usar el lenguaje puede verse en la siguiente cita, que condice con la suspicacia que Freidemberg expresaba en el "Dossier Lamborghini” a propósito de las teorías importadas de Francia: "Esta voluntad de producir una textura más que un texto, esta intención de perder profundidad para ganar bulto no es posible, a menudo, diferenciarla del automatismo psíquico; los surrealistas del 50 no llegaron a ser tan franceses como los neobarrocos” (24).

En el mismo movimiento García Helder expone su rechazo por cualquier tendencia que parezca afrancesada y descarta por esa razón a la vanguardia surrealista del cincuenta (que no aparece, por supuesto, en el armado de la tradición objetivista que hace el Diario, aunque sí se dedicaron artículos a algunos de sus integrantes y un dossier a “Poesía Buenos Aires”) ${ }^{89}$ y al neobarroco en bloque.

Los argumentos principales que opone García Helder al tratamiento del lenguaje que hace el neobarroco son tres: en primer lugar, se trata de recursos envejecidos, que ya resultaban fastidiosos en el modernismo de Darío y que habían sido recusados por las generaciones subsiguientes de poetas (con lo cual la recuperación que hace el neobarroco de esos recursos sería cuanto menos retrógrada) (24).

\footnotetext{
${ }^{89}$ Ver el dossier “Poesía Buenos Aires”, en Diario de poesía, № 11, Verano 1988-1989 (13-24)
} 
En segundo lugar, García Helder repite la idea de Freidemberg con respecto a la importación de la cultura francesa en Argentina cuando sitúa como antecedente importante del neobarroco latinoamericano contemporáneo el acercamiento de Severo Sarduy al grupo Tel Quel en París, e indica que las repercusiones en Argentina se deberían a que "mucho ayudó la tolerancia del intelectual medio para con la crítica francesa y su ductibilidad, en general, para aprehender los rudimentos de cualquier ciencia y enterarse de lo último” (25). De esta manera, García Helder plantea al neobarroco como moda importada de Francia por una intelectualidad por lo menos frívola, pendiente de "lo último” (aunque García Helder trata de demostrar, como indicamos en el párrafo anterior, que eso “último” en realidad es tan viejo como el modernismo).

Por último, el argumento más fuerte que se esgrime contra el neobarroco pasa por oponerle otra visión de la literatura que supone una ética. García Helder cita la máxima de Pound "La gran literatura es sencillamente idioma cargado de significado hasta el máximo de sus posibilidades” y, a partir de ella, considera que el uso que hacen los neobarrocos del lenguaje es un fraude: "amagar misterio en todo, armar simulacros de revelación donde no se dice nada”. El crítico vuelve a citar a Pound cuando éste dice en El arte de la poesía que la "falsa literatura” provendría de la pretensión de "hablar de lo que no se conoce, o hacer pasar una vaciedad por una plenitud” (25), actitud en la que García Helder encuentra una insinceridad que bloquea toda posibilidad de ofrecer una percepción emotiva del mundo. ${ }^{90}$

García Helder, al igual que Freidemberg en el "Dossier Lamborghini”, vincula forma y experiencia para decir que en el neobarroco las dos instancias se encuentran

\footnotetext{
${ }^{90}$ Para un análisis más detallado de la polémica neobarrocos-objetivistas en el Diario de poesía, ver Ana Porrúa, "Una polémica a media voz: objetivistas y neo-barrocos en el Diario de Poesía”, Boletín del Centro de Estudios de Teoría y Crítica Literaria, Facultad de Humanidades y Artes, Univ. Nac. De Rosario, Nro. 11, diciembre de 2003 (59-69).
} 
separadas. Ambos poetas-críticos señalan que no les interesa una forma poética que no esté motivada por una experiencia, y ambos encuentran en el neobarroco y las vanguardias del cincuenta modalidades atribuibles únicamente a la adaptación de teorías y poéticas francesas por motivos que tienen que ver más con la moda o con hábitos culturales cuestionables que con la necesidad.

Este criterio que conforma tradición se activa en determinados poemas de García Helder que funcionan también como parte de un dispositivo crítico. El faro de Guereño $^{91}$ se abre con un poema, "La pérdida de sangre”, en el que opera desde el discurso poético el modo de procesar lecturas empleado para evaluar el neobarroco. En este texto hay un poeta que está escribiendo mentalmente unos versos neoclásicos donde se plantea un símil sobre la condición humana, pero ese símil es evaluado inmediatamente como un "símbolo de fácil conversión”, y lo que sigue es una situación concreta que cuestiona desde la ironía esos primeros versos. El poeta que estaba pensando mientras manejaba que "Somos el animal que huye herido/ dejando, a su paso, sobre las hojas/ de la hierba, sobre la tierra pelada/ y las piedras, tibias gotas encarnadas/ que el frío a la noche cristaliza/ y el sol de la mañana evapora” (García Helder: 1990, 11) llega a un edificio, sube por la escalera y se hace un tajo en la frente con el batiente de una puerta.

Los versos neoclásicos son puestos a prueba en el poema en dos niveles: en primer lugar, se los presenta como una praxis meramente intelectual que puede compararse al del ingeniero que continúa haciendo cálculos mientras se lava las manos. La comparación de la escritura mental del poeta con los cálculos del ingeniero supone pensar esos versos neoclásicos como un ejercicio abstracto que poco tiene que ver con la vida práctica, y menos todavía con la emoción. En segundo lugar, el poema

\footnotetext{
${ }^{91}$ Daniel García Helder, El faro de Guereño, Buenos Aires, Libros de Tierra Firme, 1990. Todas las citas posteriores están tomadas de la misma edición.
} 
contrapone el contenido de esos versos con la escena "real" en la que el poeta se lastima

la cabeza. En este caso, el lenguaje que se usa para dar cuenta de esa situación "real”

difiere radicalmente de la escritura neoclásica ensayada al comienzo, y hace pensar, a su

vez, en la adecuación o falta de adecuación de ese lenguaje para dar cuenta de una

experiencia concreta. ${ }^{92}$

En "Una alegoría”, del mismo libro, se pone a prueba otra tradición, en este caso

la platónica, al contrastarla nuevamente con una imagen del presente:

Aquello, a medida que el tren avanzaba

describiendo una curva, iba quedando atrás, a medio camino entre las dos ciudades.

Con la puesta de sol, al fondo, terminaba otro día, otra semana

-débil luz de brasa filtrando

los árboles que cierran el paisaje.

Una capa de polvillo hacía aún más denso

el grueso vidrio de la ventanilla,

de modo que veladamente podían verse

aquellas figuras ilusorias, casi,

a un lado del terraplén.

Como arqueólogos, unos

cavando en la tierra con palas y picos,

los torsos desnudos, en la cabeza

pañuelos a modo de barbijos;

encorvados, los otros, empujando

carretillas a través de un matorral

rumbo a los hornos de barro.

Actores de una escena en sí misma anodina,

sin luz propia, pero que,

como los encadenados de la caverna

\footnotetext{
${ }^{92}$ Pero lo que complica la relación entre la escritura y la realidad que se pone en escena es que todo el poema es a su vez una reescritura de Borges, más precisamente de un fragmento de "El sur”, el cuento donde Borges representa, a través del personaje de Juan Dahlmann, el accidente que lo deja ciego. La segunda parte del poema de García Helder, que aparecía como realidad, está por lo tanto tramada por la lectura desde el comienzo. Ver Jorge Luis Borges, Ficciones, Buenos Aires, Emecé, 1989 (177- 185). El poema de García Helder no es una parodia del cuento de Borges aunque sí plantea con ironía la situación del que vive un poco en las nubes por culpa de la literatura, ya que el personaje de Dahlmann, apurado por devorar el ejemplar de Las mil y una noches que acaba de conseguir, no espera el ascensor -igual que el personaje del poema de García Helder- y sube por las escaleras, donde tiene lugar el accidente al que Borges, un poco en broma, se refiere como "destino". García Helder recupera a Borges, entonces, para dejar planteada desde el principio una figura de poeta que no se lleva demasiado bien con el mundo que lo rodea pero que tampoco se toma demasiado en serio. El otro elemento que surge del primer poema de El faro de Guereño es el desfasaje entre un conjunto de versos que no tienen correspondencia con la realidad y una realidad que, aunque más concreta, parece también más espuria.
} 
de Platón, parecían representar

una alegoría de la naturaleza humana. (García Helder: 1990, 42).

Se trata de una escena de trabajo observada a través de la ventanilla de un tren, en la que las figuras se perciben "veladamente" en sentido literal y metafórico. Este efecto ilusorio es reforzado por la calificación de los trabajadores como "actores”, y lo que están representando, pero no del todo, es una alegoría de la condición humana.

En este caso se acude a un símil tomado de la filosofía griega clásica -la alegoría de la caverna de Platón- pero contrariamente a lo que el título promete, el poema no es una alegoría, y de hecho niega la posibilidad de serlo: la palabra que se usa es “parecían”, y ese sólo verbo cuestiona la posibilidad de traducir la escena en términos alegóricos. Además el carácter ilusorio de toda la escena, lo que le quita realidad y habilita la transmutación en el plano ideal, proviene del polvo que cubre las ventanillas de todos los trenes argentinos, es decir que el guiño metafísico se debe más a una alteración de la percepción y a la luz débil del atardecer que a una mirada que cuestione el estatuto de realidad de aquello que se ve.

Por otra parte, el contenido que se desprende del símil es por demás trivial: los hombres que trabajan encorvados parecerían representar a la totalidad de los hombres en función de su condena al trabajo pero en realidad no representan nada; de hecho la escena se califica como “anodina”, insignificante. Lo que se intenta poner en práctica es más bien un modo de leer la alegoría de la caverna que destaque la falta de adecuación entre la escena percibida y el símil, en un texto que está revisando al mismo tiempo la realidad y la validez de una determinada tradición a la hora de interpretarla.

El poema siguiente de El faro de Guereño, “Sobre la corrupción”, es de hecho una reescritura del “Coloquio de los centauros” de Darío, ${ }^{93}$ y por medio del modernismo

\footnotetext{
${ }^{93}$ Más específicamente, García Helder retoma la proposición de Darío de que "toda forma es un gesto, una cifra, un enigma”, es decir, que el mundo sensible sería una superficie donde se hace legible aquello que en realidad lo excede (eso que se designa en el poema como "enigma”, y que
} 
latinoamericano, también de la teoría de las correspondencias y del mundo como "bosque de símbolos" de Baudelaire. ${ }^{94}$ En este texto se rechaza un sistema interpretativo de carácter simbólico debido a que, dice el sujeto, "no me conviene interpretar mensajes en nada” (García Helder: 1990, 43) porque lo que se tiene enfrente es un montón de pescados pudriéndose en mostradores, esperando para ser vendidos. En estos textos la tradición, que aparece en la forma de símiles y analogías que condensan textos previos y también como reescritura directa, no funciona como una lente a través de la cual percibir la realidad, sino que la relación es más compleja y revisa críticamente tanto una como otra.

Porque el conjunto de teorías idealistas que parten de una separación entre la realidad y la esfera de lo ideal es puesto a prueba de distintos modos cuando las lecturas se contrastan con el entorno perceptual en una determinada ciudad y una determinada época, y los poemas toman partido por lo que se ve. El mismo criterio que se usa para evaluar al neobarroco y al postestructuralismo en los artículos críticos es empleado aquí para revisar la teoría platónica, el simbolismo y el modernismo: se trata de medir las

también es "el soplo que hace cantar la lira”), y por extensión discute con la idea de que el dotado para captar esos mensajes sea el "vate", homologado en el poema de Darío al “sacerdote”. Ver Rubén Darío, “Coloquio de los centauros”, Prosas profanas [1986-1906], en Poesía, Caracas, Biblioteca Ayacucho, 1977. Prólogo de Ángel Rama.

${ }^{94}$ Ver Charles Baudelaire, "Correspondencias" en Les fleurs du mal (1857): La Nature est un temple où de vivants piliers/ Laissent parfois sortir de confuses paroles;/ L'homme y passe à travers des forêts de symboles/ Qui l'observent avec des regards familiers.// Comme de longs échos qui de loin se confondent/ Dans une ténébreuse et profonde unité,/ Vaste comme la nuit et comme la clarté,/ Les parfums, les couleurs et les sons se répondent.// Il est des parfums frais comme des chairs d'enfants,/ Doux comme les hautbois, verts comme les prairies,/ - Et d'autres, corrompus, riches et triomphants,// Ayant l'expansion des choses infinies,/ Comme l'ambre, le musc, le benjoin et l'encens,/ Qui chantent les transports de l'esprit et des sens.” La traducción al castellano dice: "La naturaleza es un templo de pilares vivos/ que a veces dejan salir confusas palabras;/ el hombre la recorre entre bosques de símbolos/ que lo miran con ojos familiares.// Como largos ecos que se confunden de lejos/ en una unidad tenebrosa y profunda,/ vasta como la noche y como la claridad,/ perfumes, colores y sonidos se responden.// Hay perfumes frescos como carne de niños,/ dulces como oboes, verdes como praderas/ -y otros, corrompidos, ricos y triunfantes,// que tienen la expansión de las cosas infinitas,/ como el ámbar, el almizcle, el benjuí y el incienso,/ que cantan los transportes del espíritu y los sentidos.” En Charles Baudelaire, Las flores del mal, Buenos Aires, Colihue, 2006. Edición bilingüe. Traducción de Américo Cristófalo (21). 
distintas tradiciones en función de su utilidad para dar cuenta del presente a partir de la experiencia.

Al mismo tiempo los poemas ponen en escena el contraste entre conocimiento empírico y conocimiento erudito que analizamos a propósito de Pound y de la anécdota de Agassiz y el pez. El mismo principio de entender a la poesía como un modo de conocimiento funciona en los textos que acabamos de analizar tanto como en la afirmación descalificadota que hace García Helder sobre el neobarroco al situarlo en la línea que supone "hablar de lo que no se conoce". ${ }^{95}$ Por eso otro problema que se discute en los poemas y artículos de García Helder y Prieto es el de la percepción. El poema de Prieto titulado, precisamente, “De la percepción” dialoga con Saer (al que se dedica el texto) a propósito de la mirada, cuando sostiene: "La vista puede diluir las líneas galvanizadas/ que marcan el límite de la propiedad/ y hacer de este campo yermo/ una barranca quebrada,/ suponer sauce al paraíso/ y río a esa franja de cemento/ donde se suceden autos brillantes,/ haciendo de la percepción un instrumento del deseo/ y no de la verdad”. 96

Al igual que en “Una alegoría” de García Helder, aquí se afirma la preeminencia del mundo exterior por sobre la mirada, que puede cambiar, “diluir”, "suponer”, pero se trata siempre de operaciones que se realizan sobre un objeto concreto cuya existencia puede sustraerse a la mirada. Esto puede verse en “Cerámica Verbano y alrededores” de García Helder, en el que se están mirando los restos de una fábrica de cerámica y de repente ocurre "un trance de pálida gracia" que hace brillar los restos y encontrar belleza entre las ruinas. Pero esa percepción se debe únicamente a una basurita que se mete en el ojo, y es como dice el texto un trance del que "a pedazos de cerámica,

${ }^{95}$ Daniel García Helder, “El neobarroco en Argentina”, Diario de poesía № 4, Otoño de 1987 (25).

${ }^{96}$ Martín Prieto, Verde y Blanco, Buenos Aires, Libros de Tierra Firme, 1988 (39). Todas las citas posteriores están tomadas de la misma edición. 
árboles y chapas/ no le costó nada escabullirse” (García Helder 1994: 20). De la misma manera en el poema de Prieto lo real predomina por sobre lo hipotético, porque el campo yermo sigue siendo un campo yermo aunque la mirada lo modifique para el sujeto.

Esto supone una ideología en la que la realidad no se encuentra en el lenguaje (como en los neobarrocos) sino que tiene una existencia propia independiente de la palabra y del sujeto, y el valor de la palabra se mide entonces, como en Pound, por el grado de adecuación a esa realidad que nombra. Porque en El ABC de la lectura, Pound establece que la palabra es como un cheque cuyo valor dependerá de lo que haya en la cuenta: “Toda afirmación general es como un cheque sobre un banco. Su valor dependerá de lo que haya en caja (...). Lo mismo se aplica a los cheques sobre el conocimiento en general”. Por lo tanto "Una afirmación abstracta o general es BUENA si en último término corresponde a los hechos” (Pound: 1968, 21, 22; las mayúsculas pertenecen a la versión original).

Como se ve, el objetivismo se separa del neobarroco -y lo descalifica, al menos cuando García Helder impugna en este movimiento el hecho de "hablar de lo que no se conoce”, como dijimos- en esta actitud que considera a la poesía como un modo de conocimiento empírico del mundo exterior, mediado por supuesto por la conciencia del sujeto, pero donde la precisión en el lenguaje consiste en encontrar la palabra que se “corresponda" con el objeto o con los hechos, como dice Pound. En El ABC de la lectura esta actitud está cifrada como hemos visto en la anécdota de Agassiz y el pez, pero también en otro momento donde se cuenta que "Las agudas cualidades literarias de Homero son tales que un médico escribió un libro para demostrar que el poeta debía haber sido médico del ejército” (Pound: 1968, 36) (Pound se refiere a aquellos momentos en que Homero describe, por ejemplo, algunos golpes y su efecto, y dice que 
las heridas son tan precisas que su descripción podría figurar en una investigación criminal).

El interés por la precisión referencial se pone de manifiesto en los libros de García Helder, Prieto y Casas por el modo de nombrar abundantemente lugares geográficos reconocibles, lo que le otorga al poema cierto carácter "verificable” que no está por supuesto en el neobarroco pero tampoco con esa precisión en la poesía de Giannuzzi o Leónidas Lamborghini. Así, el poema más conocido de Casas lleva por título "Paso a nivel en Chacarita" 97 y su libro El spleen de Boedo ${ }^{98}$ plantea una geografía específica para los poemas desde los títulos, mientras que los libros de Martín Prieto, y sobre todo los de García Helder, proponen un recorrido espacial por la ciudad de Rosario y sus alrededores para el que los libros podrían funcionar verdaderamente como guías.

Esta es una característica que Pound rescata, nuevamente, en Homero, cuando dice que "la geografía de la Odisea es una geografía correcta, no como podemos descubrirla en un libro de geografía y en un mapa, sino como aparecería en un “periplo”, es decir, tal como la descubriría un marinero que bordeara la costa” (Pound: 1968, 36). Esta vinculación entre poesía y experiencia está indicada también en Prieto, cuando sitúa un poema desde el primer verso en “el puerto de Montevideo” (Prieto: 1988, 19) y otro en la “Barranca David Peña” que funciona como título (Prieto: 1988, 28), al tiempo que la mención repetida a la orilla del río, "la provincia de Entre Ríos” que se ve del otro lado (Prieto: 1988, 37) y las barrancas señala una y otra vez la geografía de Rosario.

\footnotetext{
97 Fabián Casas, Tuca, Buenos Aires, Libros de Tierra Firme, 1990 (17). Todas las citas posteriores están tomadas de la misma edición.

${ }^{98}$ Fabián Casas, El spleen de Boedo, Bahía Blanca, Vox, 2003.
} 
Y García Helder, que también titula un poema "Barranca del este” (García Helder: 1990, 33) y se refiere en otro a la isla La invernada (García Helder: 1990, 44), especifica en un texto que "por Santa Magdalena llegué a este puente/ que pide PRECAUCION/ VELOC. MAX. 5 KM”, nombra en otro al Puente de La Noria y La Matanza (en el Gran Buenos Aires) (García Helder: 1994, 19), las orillas del arroyo Ludueña y el Autódromo, también de la ciudad de Rosario (García Helder: 1994, 22), y al río Carcarañá (García Helder: 1994, 28). La precisión no es sólo espacial sino también temporal, porque el título de un poema consigna "Un barrio periférico de una ciudad más de mil kilómetros al sur de la capital, agosto de 1991” y en el epígrafe de otro donde se visita un cementerio se especifica que la visita ocurrió en el "Cementerio de Disidentes, Rosario, enero de 1994” (García Helder: 1994, 31). Estas referencias, a la vez que sitúan el poema en un tiempo y lugar determinado, funcionarían además como garantía de que el poeta está efectivamente hablando de aquello que conoce de primera mano, por experiencia. ${ }^{99}$

Porque la vinculación entre forma y experiencia que Freidemberg leía en Lamborghini está relacionada con el modo de García Helder de leer la obra de Giannuzzi como representativa de la experiencia del hombre común porteño de una época determinada ${ }^{100}$ y con la idea de Pound de que el poeta debe hablar de lo que conoce. Estas premisas constituyen una ética que para los integrantes del Diario de poesía también es un criterio de armado de la tradición, y se vincula a su vez con un modo de concebir la poesía en relación a la cultura en que se produce que opera tanto en los poemas como en los textos críticos.

\footnotetext{
${ }^{99}$ Sin embargo, como veremos en el último capítulo al analizar la poética de Washington Cucurto, la referencialidad no funciona siempre del mismo modo, porque en el caso de Cucurto se trata de poemas plagados de referencias a lugares concretos de la ciudad de Buenos Aires pero que funcionan como soporte de fantasías donde el criterio de realidad se pierde.

100 Daniel García Helder, “Giannuzzi”, en "Dossier Giannuzzi”, Diario de poesía No 30, Invierno de 1994 (13).
} 
Como señala Edgardo Dobry, en el objetivismo "la palabra recupera su significado directo, denotativo; el poema su referencia a la realidad, el poeta su voluntad de pertenencia a una comunidad (nacional, y por lo tanto lingüística) a la que, al menos en principio, su escritura se dirige” (Dobry: 2006, 121). En esto Dobry encuentra una vinculación con la poesía “coloquialista y ‘comprometida’ de los sesenta y setenta”, y una clara diferenciación con el neobarroco.

Efectivamente, esa noción de pertenencia a una comunidad lingüística y cultural se lee en "El neobarroco en la Argentina” -donde el título ya enuncia que se pondrá en relación la poética con ese constructo nacional- donde García Helder incluso plantea que la intención de su artículo es "hacer generalizaciones que considera útiles para el desarrollo de la poesía de un país” (25). En esta afirmación de García Helder está Pound, por supuesto, tanto como estaba en Freidemberg (ese Pound que afirmaba en El $A B C$ de la lectura que una nación que descuida las percepciones de sus artistas, declina; Pound: 1968, 65). Pero además, García Helder y Freidemberg apelan a otros términos que son variantes de la idea de “nación” y “campo intelectual”. Porque ambos evalúan las distintas poéticas en relación a esa instancia que a veces se denomina positivamente como “Argentina” y “país” (en el artículo de García Helder sobre el neobarroco) como modo de aludir a una cultura que excede los límites del ámbito literario, cuya versión de signo negativo, restringido y “artificial” sería el “campo intelectual argentino” según Freidemberg, ${ }^{101}$ o el “intelectual medio” en palabras de García Helder. ${ }^{102}$

De esta manera, ambos representantes del Diario de poesía apuestan a poéticas que se originen en la experiencia de una época y un lugar determinados -podríamos decir, en un presente situado- y no artificialmente en un campo intelectual en el que

\footnotetext{
${ }^{101}$ Daniel Freidemberg, “Leónidas Lamborghini”, en “Dossier Lamborghini”, Diario de poesía No 38, Invierno de 1996 (14).

${ }^{102}$ Daniel García Helder, “El neobarroco en Argentina”, Diario de poesía № 4, Otoño de 1987 (25).
} 
ingresarían por importación o copia. La alternativa retórica/experiencia rige muchas veces la selección que se hace de la literatura del pasado y la contemporánea, y en nombre de esa dualidad se argumenta el rechazo de ciertas poéticas (como es el caso especialmente del neobarroco). Porque así como García Helder la usaba en los poemas que consideramos para oponer su propia poética a cualquier tipo de ideología dualista que distinga entre materia y espíritu -para optar por el segundo, claro- Daniel Durand la esgrimirá, como veremos en el tercer capítulo, para descartar las poéticas objetivistas por retóricas y oponerles su propia escritura centrada en el habla como la única que puede dar cuenta de la experiencia.

De todos modos en este punto, tanto como en la intención de evaluar los textos en función de esa idea "global” de la poesía argentina de la que hablaba Fondebrider al principio de este apartado, los integrantes del Diario se revelan como lectores y continuadores de Adolfo Prieto, César Fernández Moreno, Francisco Urondo y Noé Jitrik (que también aunaban la escritura literaria con la crítica) quienes en la década del sesenta escribieron textos donde se analizaba el desarrollo de la poesía argentina en relación a la experiencia, el uso de la lengua y la mayor o menor dependencia de estilos importados, entre otros rasgos. ${ }^{103}$

En este sentido el Diario de poesía aparece como una publicación que pivotea entre dos épocas, porque a la vez que toma al presente como objeto privilegiado para sus reflexiones sobre poesía -ese presente profundamente enraizado en la tradición al que se refería Pound-, retoma un modo de ejercer la crítica (y de unirla a la escritura poética como parte de una misma práctica) que no tendrá continuadores en la década del

\footnotetext{
${ }^{103}$ Ver Noé Jitrik, "Poesía argentina entre dos radicalismos”, en Ensayos y estudios de literatura argentina, Buenos Aires, Galerna, 1970 (200-221); Adolfo Prieto, “Los años sesenta”, en Revista Iberoamericana, No 125, octubre-diciembre de 1983 (889-901); Francisco Urondo, Veinte años de poesía argentina. 1940-1960., Buenos Aires, Galerna, 1968; César Fernández Moreno, La realidad y los papeles. Panorama y muestra de la poesía argentina contemporánea., Madrid, Aguilar, 1967.
} 
noventa, cuando nociones como “país”, “poesía argentina” o prácticamente cualquier

instancia que aluda a un colectivo, se vean atomizadas. ${ }^{104}$

A modo de resumen, el dispositivo de lectura objetivista que acabamos de exponer (y que no agota de ningún modo el repertorio de problemas y poéticas abordadas por el Diario de poesía) construye una tradición selectiva a partir de criterios puntuales que remiten sobre todo a una ideología poética de raíz poundiana: precisión en el uso del lenguaje, exactitud referencial, incorporación de la tradición -que es evaluada siempre en función de su utilidad en el presente-, relación entre poesía y experiencia en el marco de una época y un lugar determinados.

${ }^{104}$ Sin embargo es importante señalar que, si bien nuestro análisis se centra en la conformación de una poética y un modo de leer objetivistas en el Diario de poesía, los poetas neobarrocos también tuvieron su lugar en esta publicación que apostó a la pluralidad y el debate, y que construyó al mismo tiempo una relación de "paternidad” con los poetas más jóvenes vinculados a otras revistas como la 18 Whiskys, como señala Ana Porrúa:

"Diario de poesía surgió como una revista hecha por poetas-críticos jóvenes. La novedad, siempre estuvo presente en sus páginas, ya sea mediante la puesta de lo que en los '80 comenzó a surgir como "poesía femenina" y a dividir las aguas generacionales, como mediante la publicación del neo-barroco -Perlongher, Carrera e incluso Emeterio Cerro tuvieron un espacio en el Diario, un espacio para sus textos, para una versión crítica de los mismos o para "hablar de poesía”.

Paralelamente, el Diario... iba construyendo su propia línea poética, la del "objetivismo", término que comenzó a circular internamente y a cubrir una trama de textos y posiciones que se debatían -y esta es una burda simplificación- entre las ideas de Gianuzzi y Williams, o buscaban un recorrido simbolista para los objetos que ingresaban al poema y la mirada que allí se construía. Como grupo cercano, los integrantes de las revistas La Mineta, LaTrompa de Falopo y, básicamente, la 18 whiskies, Villa, Desiderio, Durand, Edwards y Fabián Casas, tenían en el Diario de poesía un lugar importante de visibilidad.

La "nueva poesía", por llamarla de algún modo, no aparece entonces como algo exótico en el Diario... porque tenía una tradición reciente que la respaldaba, una especie de paternidad joven. Pero además, el Diario fue el lugar en el que la novedad no sólo adquirió un lugar sino que fue legitimada. El "I Concurso Hispanoamericano Diario de poesía" fue fundamental en este sentido. El libro premiado sería, nada más ni nada menos que Punctum de Martín Gambarotta. Esa primera muestra, la de los premios y las menciones especiales, armaba una línea de continuidad: el segundo premio era para José Villa, uno de los 18 wiskies. El rol del Diario en relación a lo que se estaba produciendo, a la poesía del presente más inmediato, fue desde ese momento el de la promoción y el de la puesta en común: no hay, prácticamente, un poeta reciente que no haya publicado sus textos allí y todos tuvieron desde ese momento un lugar equivalente al de los poetas ya consagrados, sin distinción de líneas estéticas”.

Ver Ana Porrúa, "La novedad en las revistas de poesía: relatos de una tensión especular”, en Orbis tertius, Revista de Teoría y Crítica Literaria, Nro. 11, Centro de Estudios de Teoría y Crítica Literaria, Facultad de Humanidades y Ciencias de la Educación, UNLP, 2005 (57-72). 
En este sentido, el Diario de poesía funciona como una formación que inventa al objetivismo sobre todo como adaptación de segmentos específicos de la poesía modernista norteamericana a la tradición argentina, y que traza una genealogía a partir de la cual hacer legibles las propias poéticas de los integrantes del Diario (Prieto, García Helder, Samoilovich, Aulicino y Freidemberg).

En el mismo movimiento, la literatura argentina es revisada a partir de los criterios que hemos consignado. Por ese motivo, se descarta a la generación del cuarenta con excepción de los poetas que permanecieron marginales a ella, como Leónidas Lamborghini, Joaquín Giannuzzi y Alberto Girri, y se omiten (en el armado de esta tradición objetivista) los intentos de vanguardia tardíos que fueron el invencionismo de la revista Poesía Buenos Aires y el surrealismo liderado por Aldo Pellegrini de la década del cincuenta. La línea de “poesía política” de la década del sesenta tampoco ocupa un lugar importante en la tradición armada por el Diario, desde el momento en que su modo de plantear la relación entre poesía y sociedad se convierte en residual en el período post-dictadura, mientras que sí se recupera de este período el modo de pensar la poesía y la función del poeta en relación a una comunidad lingüística y nacional, como apuntaba Dobry, rasgo que también está presente en Pound. ${ }^{105}$

Del corpus de poetas consagrados que Jorge Fondebrider nombraba como canónicos para cualquier poeta joven de los ochenta -Girri, Molina, Orozco, Juarroz, Pizarnik, Gelman, González Tuñón y Girondo- el Diario omite las poéticas vinculadas al surrealismo, tales como las de Enrique Molina y Olga Orozco, cuyas obras construidas “en base a largas digresiones metafóricas y a intensas imágenes oníricas, se encuentran en el polo opuesto de la poética del objetivismo”, como señala Dobry

${ }^{105}$ Cabe aclarar nuevamente que, en todos los casos, nos referimos a la tradición objetivista construida por el Diario de poesía, que omite estas poéticas más allá de que en ocasiones se hayan publicado aisladamente en el Diario. De hecho la política de publicación de la revista es altamente inclusiva, pero aquí nos referimos al recorte de lo que los mismos redactores del Diario construyeron como "objetivismo". 
(Dobry: 2006, 131). Por el contrario, se privilegian las escrituras anti-líricas y “realistas” (Girri, González Tuñón), a la vez que se cuestionan las ideologías sobre el lenguaje vinculadas al estructuralismo y postestructuralismo.

En su lugar se levantan poéticas que habían permanecido marginales, como las de Lamborghini y Giannuzzi, así como ciertos poetas norteamericanos o europeos que llegan a los integrantes del Diario por intermedio de poetas argentinos, como Eliot procesado en la escritura de Leónidas Lamborghini (además de la particular lectura de su poética que surge de la entrevista a Lamborghini publicada en el Diario), o Pound en la de Giannuzzi. Esto se debe a que, como se dijo, siempre se hace centro en la poesía argentina porque en el Diario se trata de revisar y proyectar una poesía vinculada a su lugar de origen, escrita según los usos particulares del español rioplatense. Por eso resulta fundamental la idea de Eliot mencionada anteriormente de que el poeta debe tener conciencia de aquello en el pasado que no está muerto sino que “ya está vivo”. 106

Ese es el espacio ideológico desde el cual se construye la tradición en el Diario, y a partir de esos criterios ingresan poetas como Francis Ponge, Marianne Moore y W. H. Auden, junto con buena parte del modernismo norteamericano. Pero la figura que ordena todas estas selecciones es la de Pound, en razón de algunos preceptos específícos sobre la literatura, el lenguaje y la relación del poeta y la sociedad, como hemos visto. Pound condensa asimismo la figura de poetas-críticos y poetas-lectores que algunos integrantes del Diario construyen para sí, en artículos críticos (como señalamos por ejemplo a propósito de Prieto leyendo a Giannuzzi) pero también en sus libros de poesía.

Por último, la conformación de esta tradición selectiva funciona como toma de posición (Bourdieu 1997: 343) en el campo literario en dos sentidos: en primer lugar,

${ }^{106}$ T. S. Eliot, "La tradición y el talento individual”, en Los poetas metafísicos y otros ensayos sobre teatro y religión, Buenos Aires, Emecé, 1944, Tomo I (11-23). 
porque define el lugar del Diario en oposición al neobarroco (pero este debate funciona también como modo de recortar posiciones dentro del Diario, cuyos integrantes discutieron la posibilidad o no de separar objetivismo de neobarroco). Y en segundo lugar, porque permite al Diario de poesía “apadrinar” a los poetas más jóvenes cuya producción también se lee como objetivista, especialmente a Fabián Casas, y ocupar de ese modo un lugar central en el sistema poético de los noventa.

Por último, hay en el Diario y sus integrantes una idea de tradición que es orgánica y además abarcativa, como ponía de manifiesto Fondebrider con el uso del término "global”, porque la tradición consiste en un corpus -y un modo de leerlo- que contempla a la vez el valor histórico de los textos y su utilidad en el presente, su carácter actual, y que se construye a partir de criterios definidos que permiten trazar una genealogía, en este caso objetivista, entre textos heterogéneos. En los siguientes capítulos se establecerá un contraste entre este modo de pensar la tradición y el de otros poetas de los noventa que trabajan con lecturas más aleatorias y microscópicas; en algunos casos, como veremos, ya no se podría hablar de "tradición” sino de "lecturas” porque la apropiación es fragmentaria, nunca se sistematiza y tampoco permite ser pensada en términos de corpus.

\section{3- LA LUNA COMO “CASCOTE GRIS": FIGURAS DE POETA Y USOS DEL LENGUAJE}

Las figuras de poeta que construyen para sí los objetivistas reúnen, como hemos adelantado, "una constelación de motivos heterogéneos que permiten leer un conjunto variado y variable de cuestiones: cómo el escritor representa, en la dimensión 
imaginaria, la constitución de su subjetividad en tanto escritor” pero sobre todo “cuál es el lugar que piensa para sí en la literatura y en la sociedad” (Gramuglio: 1992). Como establecimos en la Introducción, es pertinente considerar estas figuras al analizar la tradición porque en ellas se cifra la posición que un escritor se construye con respecto a esta tradición que continúa o pretende modificar, y sobre todo "con los temas y los lenguajes que esa tradición le provee” (Gramuglio: 1992). Al mismo tiempo, la relación entre figuras de poeta y usos del lenguaje es inescindible porque los usos lingüísticos son en sí mismos la realización de las figuraciones de poeta que se explicitan también en los textos en forma de representaciones y motivos.

El lenguaje tal como lo conciben los objetivistas tiene su sustento teórico, como vimos, en Pound, para el que la condensación es la característica principal del lenguaje literario (y que se opone manifiestamente a la dispersión del sentido propuesta por los neobarrocos). Una derivación importante de esta idea es que el lenguaje literario no se considera como separado completamente de los usos corrientes del idioma, sino que la diferencia entre ambos reside en una cuestión de grado. La palabra es social para Pound, y el lenguaje es ante todo un instrumento de comunicación, puesto que en la visión del poeta considerarlo de otro modo sería precisamente separarlo de la sociedad (Pound: 1968, 24). La consecuencia más importante de esta ideología sobre el lenguaje es la que toca a la función social de los poetas, que sería "exactamente proporcionada a su habilidad como escritores”, según El ABC de la lectura. En efecto, la utilidad de los poetas, y su calidad, se mide por el grado en que "conservan la eficiencia del lenguaje. Es decir, que lo mantienen preciso, claro” (Pound: 1968, 27).

Este modo de pensar el lenguaje no supone un estatuto diferenciado para el poeta, quien se caracteriza no por un conjunto de cualidades excepcionales o el manejo de un lenguaje hermético sino por un trabajo específico sobre la palabra. Esta idea 
encuentra su concreción en la lectura que Prieto hace en el "Dossier Giannuzzi” sobre el libro de García Helder y Bielsa. Las consideraciones en torno a este libro constituyen un momento importante del artículo de Prieto porque en ellas puede verse la construcción de una figura de poeta sobre la que después insistirán el mismo Prieto, Daniel García Helder, Fabián Casas, y todos los poetas de los noventa que son continuadores del objetivismo de distintas maneras. Esa figura también funciona como criterio de selección para el armado de la tradición que realiza el Diario de poesía, y condensa a su vez todo un espectro de cuestiones que van desde la ética del escritor con respecto al lenguaje hasta el modo de pensar su lugar en la sociedad y recortarlo a su vez en relación a sus pares.

Porque cuando Prieto se refiere a ese libro tempranamente objetivista que sería Quince poemas de García Helder y Bielsa, describe el proceso de escritura que llevaron a cabo estos poetas de manera conjunta en estos términos: "un par de tipos, que viven en ciudades distintas, que durante meses se envían, por el correo argentino, unos papeles escritos que luego serán poemas”. ${ }^{107}$ El mismo Prieto recupera esta escena de escritura como un trabajo que se diferencia de la ideología romántica de la inspiración y que supone "escribir poemas como quien talla, en vidrio pesado, un pisapapeles con la forma de un sapo”. El material en bruto a partir del cual se trabaja es "vidrio pesado”, y es importante tanto la alusión a los poetas como "un par de tipos” como el hecho de que se trata de un trabajo que se extiende en el tiempo, “durante meses”, y que consiste en intercambiar textos que sólo después de un trabajo continuado y persistente serán poemas.

La figura de poetas de los propios García Helder y Prieto se construye como modulación de esta idea, y es también desde esta figura que el Diario lee a Giannuzzi.

${ }^{107}$ Martín Prieto, “Dossier Giannuzzi” (19). 
De hecho el título elegido para el reportaje de Daniel Freidemberg a Giannuzzi que aparece en dossier del Diario es “Un poeta standard”. ${ }^{108}$ Este carácter de “standard” se refiere a que para los críticos del Diario la poesía de Giannuzzi es representativa de la experiencia del hombre común porteño de una época determinada. García Helder, en el mismo dossier que hemos considerado, separa a Giannuzzi de sus contemporáneos en función de un criterio muy específico cuando dice que en el contexto de su generación -Alejandra Pizarnik, Hugo Padeletti, Juana Bignozzi, Leónidas Lamborghini, Juan Gelman- la de Giannuzzi es la voz "menos fantasiosa, si se quiere la más pobre, prosaica, y por tanto, tal vez la que mejor manifiesta, sin reflejarla servilmente, ese habla común en ese espacio determinado del que se habló al principio”. ${ }^{109}$ Ese espacio es lo que García Helder denomina "la época”, y al mismo tiempo en esa caracterización resuena la idea poundiana de que los artistas son la "antena de la especie”, que deben cifrar la experiencia contemporánea del modo más sencillo posible (Pound: 1968, 64, $66)$.

Puede decirse que en este sentido hay una continuidad con la figura de poeta más característica de la década del sesenta. Porque según Miguel Dalmaroni,

Entre 1955 y los primeros años de la década del 70 aproximadamente, emergen en la literatura argentina poetas y poemas que intentan aproximar el texto al contexto histórico-social, la poesía a la vida, para crear un imaginario de continuidad e identificación entre la escritura y una manera particular de ver el mundo: la literatura debe mimetizarse con la praxis política, y más específicamente revolucionaria, y con los discursos sociales que comunicarían de manera directa la experiencia vivida inmediata. La poesía debe hablar como la gente, de cosas que le pasan a la gente. ${ }^{110}$

Sin embargo, si bien en los objetivistas está dada la misma relación entre escritura y experiencia que enfatiza Dalmaroni, esa relación se plantea de modo distinto porque la

\footnotetext{
${ }^{108}$ Diario de poesía, “Dossier Giannuzi” (14).

${ }^{109}$ Daniel García Helder, “Giannuzzi”, en “Dossier Giannuzzi”, Diario de poesía No 30, Invierno de 1994 (13).

${ }^{110}$ Miguel Dalmaroni, Juan Gelman. Contra las fabulaciones del mundo., Buenos Aires, Editorial Almagesto, 1993 (10).
} 
oposición entre literatura y “contexto histórico-social” o entre “poesía” y “vida”, apuntada por Dalmaroni, no está presente en la conceptualización del Diario de poesía ni en los poemas, que ponen el acento en cambio en la reflexión sobre el lenguaje y la literatura en sí mismos. Esto sucede porque en la concepción del lenguaje de Pound como objeto eminentemente social, suscrita por los objetivistas, esta diferenciación entre literatura y “vida” se vería anulada. En otras palabras, trabajar sobre el lenguaje sería de por sí una forma de operar con lo social e incluso lo político. Así, en un poema de Prieto llamado "Poesía y política” donde el sujeto contempla a una pareja tomando sol en una playa se dice en los versos finales que "La política/ que pareciera estar afuera del cuadro/ es la misma que lo sostiene” (Prieto: 1995, 22).

Pero a diferencia de otras poéticas sesentistas, la figura que Joaquín Giannuzzi construye para sí mismo a lo largo de sus libros, y que los objetivistas retoman, agrega otro matiz porque sugiere la idea de un hombre común que está separado de la sociedad, a la que contempla desde cierta distancia. Al mismo tiempo, se trata de un "yo" que intenta pensarse en relación al mundo contemporáneo. ${ }^{111}$ Ese aislamiento está condensado en un motivo que se repite a lo largo de la obra de Giannuzzi y que los objetivistas de los noventa recuperan: el de aquel que mira el mundo desde el otro lado de un vidrio. El motivo aparece en el poema "Fábula”, que abre el libro Las condiciones de la época (1967). Allí Giannuzzi se separa claramente de una generación politizada y se construye como aquel que elabora un nuevo lenguaje en soledad. El lugar del poeta es "detrás de los cristales/ a cubierto del viento social donde toda culpa/ entra en crisis

\footnotetext{
${ }^{111}$ De hecho, los títulos de los libros publicados por Giannuzzi entre 1958 y 1977 aluden a este lugar que el poeta imagina para sí mismo en relación al mundo y a la época: Nuestros días mortales (1958), Contemporáneo del mundo (1962), Las condiciones de la época (1967), Señales de una causa personal (1977). Pero hay una tensión fundamental en la relación entre el poeta y el mundo que se enuncia del siguiente modo: "Con trabajo, con cierto desequilibrio,/ compongo algunos versos en la calle./ Son frases, motivaciones mentales/ sin compromiso especial con el mundo./ A pesar de todo/ me importa mucho el mundo" (74), dice un poema de Contemporáneo del mundo (1962). Joaquín Giannuzzi, Obra poética, Buenos Aires, Emecé, 2000. Todas las citas que figuran a continuación están tomadas de esta misma edición.
} 
con sus razones podridas”. ${ }^{112}$ Es en ese ámbito individual y privado donde el poeta decide que el cambio está cifrado en movimientos tan mínimos como "el giro de la cuchara en la taza de té”, y que inventa un “nuevo lenguaje” para decir ese cambio. ${ }^{113}$

El motivo de mirar a través de la ventana o de unos anteojos como cifra de una distancia real y simbólica respecto de la sociedad se reitera en los libros de Giannuzzi, que casi siempre se representa a solas en los poemas. ${ }^{114}$ Martín Prieto hace del motivo de mirar a través de la ventana el título de un poema, "Desde la ventana”: "El mundo es esta estación de trenes, casi invisible por la lluvia./ Hay, entre las vías, un resto:/ una naranja brillante apoyada contra el riel./ El hombre tiende la mesa/ y cree cambiar en algo las cosas.”"115 La variante que introduce Prieto en la escena es que el “yo”, presente

${ }^{112}$ En relación a esto, algunos de los poemas más significativos de fines de la década del cincuenta y comienzos de los sesenta, contemporáneos de Giannuzzi, se sitúan en la calle o en la ciudad, en el espacio público, como sucede con Argentino hasta la muerte de César Fernández Moreno y con Las patas en las fuentes de Leónidas Lamborghini. Este cambio de lugar señala la posición diferente de Giannuzzi en cuanto a sus contemporáneos y habilita, junto con otros rasgos, la recuperación de los objetivistas. Ver César Fernández Moreno, “Argentino hasta la muerte” (1954), en César Fernández Moreno, Sentimientos Completos, Buenos Aires, Ediciones de la Flor, 1981, y Leónidas Lamborghini, Las patas en las fuentes, Buenos Aires, Sudestada, 1968.

${ }^{113}$ El poema completo, perteneciente a Las condiciones de la época (1967), dice: “Abrumado por el tabaco y la cultura/ y convertido en un engaño por su propia clase/ estaba esperando la revolución/ por la desnuda, terrible acción de los otros en la calle./ Pero detrás de los cristales/ a cubierto del viento social donde toda culpa/ entra en crisis con sus razones podridas,/ resolvió que el cambio acontecía en las pequeñas mutaciones/ permanentes del cielo y el polvo,/ en el giro de la cuchara en la taza de té,/ en las decepciones periódicas del hígado,/ en la muerte de papá y de las moscas./ Inventó un poema con todo esto/ y el resultado es una estafa a la vieja forma,/ una lejanía cada vez más vergonzante/ de un nuevo lenguaje que puede estallar en cualquier momento” Joaquín Giannuzzi, Obra poética, Buenos Aires, Emecé, 2000 (83).

114 Otros ejemplos aparecen en "Evasiones”, de Señales de una causa personal (1977): “Hace un año comía/ junto a la ventana de un bar/ y miraba pasar la calle, la vida/ tan desnuda y decisiva" (159); en "Historia personal", del mismo libro: "Los hechos fueron considerados a través del vidrio de la ventana" (163), dice el primer verso, después se agrega que "Las razones sociales estallaban allá afuera". Sobre el final de ese poema se cambia la ventana por los anteojos: "Ahora he abierto la ventana pero uso anteojos". También en "Paisaje urbano" de Señales de una causa personal se dice "desde la ventana del bar contemplo esta furiosa esquina” (173). Esa distancia, como se ve, es constitutiva del armado de la ciudad como paisaje que el poeta contempla pero en el que no interviene.

${ }^{115}$ Martín Prieto, Verde y Blanco, Buenos Aires, Libros de Tierra Firme, 1988 (21). 
en los poemas de Giannuzzi y también en Casas, está desplazado, en un intento por hacer del centro del poema la emergencia de la materia en esa "naranja brillante”. ${ }^{116}$

A su vez, en Giannuzzi ese poeta que contempla al mundo en soledad también se ve a sí mismo como ser común e incluso como un objeto más entre otros. En "Cada mañana en el espejo” de Señales de una causa personal (1977) Giannuzzi se refiere al ritual cotidiano de afeitarse y se dirige a sí mismo en tercera persona: "Suelo mirarte, antiguo compañero,/ cada mañana de esta tierra al afeitarme/ y me sucede a veces/ que no te identifico a fondo” (Giannuzzi: 2000, 190). Este motivo se hace más explícito aún en el poema titulado “El cuerpo objeto”, del mismo libro de Giannuzzi, que Casas reescribe. El poeta contemplativo se vuelve en este caso objeto de su propia contemplación mientras está desnudo, es decir, en cierto modo despojado de la identidad social y la cultura y convertido en una cosa más: "Largamente he observado mi cuerpo desnudo/ tan especulativo debajo de su cáscara peluda/ que pareció cruzado de ráfagas mentales” (Gianuzzi: 2000, 144). ${ }^{117}$ Ese lugar que Giannuzzi recorta para sí mismo en relación al mundo exterior y a su propio cuerpo, condensado en los motivos de mirar a través de la ventana y de mirarse al espejo, es recuperado de diversos modos por Prieto, Casas y García Helder.

En Fabián Casas el motivo de mirarse al espejo aparece como reescritura directa en el siguiente poema de Tuca: "Recién salido de la ducha,/ me paro a ver mi cuerpo en el espejo./ Nada especial, me digo, es un objeto más en el mundo./ Fabián Casas, sin

\footnotetext{
${ }^{116}$ Sin embargo, como analizaremos en el apartado siguiente, ese desplazamiento del sujeto es sólo aparente porque lo que se pone en escena es en realidad la mirada, es decir, la relación dialéctica entre sujeto y objeto.

${ }^{117}$ El poema completo dice: "Largamente he observado mi cuerpo desnudo/ tan especulativo debajo de su cáscara peluda/ que pareció cruzado de ráfagas mentales./ De modo que éste es el famoso templo según la metáfora divina/ o si ustedes prefieren la porción más decisiva de la conciencia./ Mi cuerpo he observado largamente, palpando/ aquí y allá su insomne conocimiento propio,/ el mecanismo social de su comportamiento./ Pero toda contemplación acaba vaciando el cerebro/ así que fue un desierto cadáver entre objetos manufacturados” (Giannuzzi: 2000, 144).
} 
anteojos,/ cargando una estructura que comprende”. ${ }^{118}$ De nuevo, el sintagma "Nada especial” remite a una operación de desmitificación del poeta que no es más que un cuerpo entre otros cuerpos. Daniel García Helder recupera el motivo en el poema “Philishave”, donde el sujeto dice frente al espejo: “ese soy yo, esos dientes son míos,/ la lengua una sardina amarga, esos pocos/ pelos de ángel en vías de extinción”, y después imagina que podría morir por una descarga eléctrica de la afeitadora. ${ }^{119}$

Lo que comparten Prieto, Casas y García Helder, y que puede leerse como continuación de lo planteado por Giannuzzi, es la construcción de una figura de poeta como hombre común (una figura generalizada en el sesenta pero a la que Giannuzi agrega este matiz de aislamiento, que funciona también en los objetivistas) ${ }^{120}$ que se representa siempre en actos cotidianas como afeitarse, salir de la ducha o mirar una estación de trenes a través de una ventana. La desnudez y la decadencia física son también modos de postular al poeta como un hombre que tiene un cuerpo material y que vive en el mundo concreto, sujeto al cambio y al paso del tiempo. Según esta figura

${ }^{118}$ Fabián Casas, Tuca, Buenos Aires, Libros de Tierra Firme, 1990 (21). Todas las citas posteriores están tomadas de esta misma edición.

${ }^{119}$ El poema completo dice: "Hace un rato, descalzo, en ayunas,/ cumpliendo con un rito que hasta hoy/ no inspiró una sola idea positiva a nadie/ sino más bien la náusea y la fobia tempranas/ que llevan a decir frente a un espejo/ "ese soy yo, esos dientes son míos,/ la lengua una sardina amarga, esos pocos/ pelos de ángel en vías de extinción”,/ me sorprendí pensando que la afeitadora/ podría darme una descarga, que la descarga/ bien podría ser fatal, y me vi en el piso,/ seco, negro como una tostada, y el cuerpo/ todo se me estremeció de algo así como/ apego a la vida / aprensión a la muerte,/ por lo que intuyo que hay o debe haber/ en la raíz de esa planta negativa/ que abre sus flores negras a la mañana,/ tierra y abono de la misma,/ un ciego impulso vital”. Daniel García Helder, "Philishave”, en El guadal, Buenos Aires, Libros de Tierra Firme, 1994 (50).

${ }^{120}$ Sin embargo, como aclaramos, la modulación que agregan los objetivistas a este aislamiento relativo consiste en la no separación entre poesía y contexto político, desde el momento en que su imbricación mutua está dada en el lenguaje. O para decirlo de otro modo, el hecho de que el poeta se represente en el espacio público no sería de por sí una indicación de su relación ética con un lenguaje que es social, ni sería el aislamiento un obstáculo para que la poesía se vincule con la "época”, siempre mediante el lenguaje. 
desmitificada de poeta ellos son, también, “un par de tipos”, como decía Prieto a propósito de Rafael Bielsa y Daniel García Helder. ${ }^{121}$

En este sentido, la de Giannuzzi aparece como una figura altamente recuperable entre finales de los ochenta y principios de los noventa por el lugar de enunciación que recorta para sí mismo y que lo distingue de la poesía política del sesenta, una enunciación individual pero que al mismo tiempo intenta procesar conflictivamente su relación con el mundo. ${ }^{122}$ Por eso no estamos de acuerdo con Edgardo Dobry, que en el artículo ya citado señala que la subjetividad del poeta objetivista "se diluye en el paisaje o en la masa. Contra el arresto aristocrático del poeta simbolista, siempre cuidadoso de poner distancia entre él y la multitud, el poeta objetivista quiere fundirse, usar el lenguaje de la calle o poner voz a una emoción colectiva o generacional” (Dobry: 2006, 122). Hay cierta imprecisión en las afirmaciones de Dobry, porque si bien la actitud aristocrática no es propia del objetivismo -aunque aparece esporádicamente, como veremos- no se puede decir que aquí se trate de "fundirse” con la multitud.

Al contrario, la sociedad es contemplada a distancia, como vimos, por un poeta que reflexiona y mira en soledad. Si hay una vinculación posible con los otros está dada exclusivamente por el lenguaje y sus posibilidades de verbalizar una experiencia común, lo cual no es lo mismo que construir una voz "colectiva o generacional” que tome la palabra en nombre de los otros. Lejos de eso, la enunciación de los poetas objetivistas es individual; no hay, aquí, la confianza en la posibilidad de hablar en nombre de un “nosotros” que aparece en algunas poéticas del sesenta. La excepción la constituye Fabián Casas, que de hecho comienza su primer libro con una frase que no podría

\footnotetext{
${ }^{121}$ Martín Prieto, “Giannuzzi, Cantón, Girri, y los otros”, en Diario de poesía No 30, Invierno de 1994 (19).

${ }^{122}$ La figura de Lamborghini en cambio, si bien es también la de un lector y la del hombre común que estamos considerando, surge en ocasiones como representante de un colectivo (la clase trabajadora, el oprimido) que participa en un espacio público, y ésta es una figura que no se retoma en los noventa.
} 
encontrarse jamás en Prieto o en García Helder: “También tuvimos una guerra./ Ahora somos parte de Hollywood." (Casas: 1990, 11). Como se ve, el "nosotros” de Casas alude a la generación que es joven al principio de los noventa. En otra oportunidad reaparece el nosotros para decir que “todavía somos jóvenes, pero eso/ se pierde enseguida./ No tenemos nada” (Casas: 1996, 30). ${ }^{123}$

Esta enunciación colectiva es de todas maneras excepcional en la poesía del propio Casas, que generalmente da cuenta de la experiencia privada e individual en primera persona del singular. Porque los poetas objetivistas miran el espacio público desde cierta distancia, lo cartografían, lo nombran, pero cuestionan seriamente la posibilidad de intervenir en él como no sea en tanto poetas y a través de operaciones sobre el lenguaje. En este punto retoman más bien a Pound, para quien la función del poeta en la sociedad se construye estrictamente a partir del trabajo con la lengua, como vimos.

Pero esta lengua presenta características particulares porque construirse como "un par de tipos” tiene su correlato en un modo de usar el lenguaje. Por eso a la precisión y exactitud referencial que reclamaba Pound se suma lo que Giannuzzi denomina en un poema “objetivos avances de palabras”. ${ }^{124}$ Este modo de nombrar que intenta despojar al poema de cierta retórica romántica o de los lugares comunes de la lírica y su repertorio metafórico (y que se relaciona, como veremos, con la “preponderancia de la imagen sobre la metáfora” de la que hablaba Pound en El ABC de

\footnotetext{
${ }^{123}$ El poema de Casas se titula "Mientras me lavo la cara" y es una reescritura de "Con usura" de Ezra Pound, en la que el "nosotros" incluye a "Daniel” y "Darío" que probablemente aludan a Darío Rojo y Daniel Durand, compañeros de Casas en la revista 18 whiskies que son nombrados al comienzo del poema, con lo cual se estaría hablando en realidad de los poetas jóvenes.

${ }^{124}$ El poema, “Este mundo, muchachos...” de Contemporáneo del mundo (1962), termina con unos versos que en la lectura de Martín Prieto, como vimos, fundaban el objetivismo como problema que no se resolvería en la obra del propio Giannuzzi: "La estética/ desde adentro hacia afuera/ triste, podrida, incierta, tambalea/ y en dirección contraria/ vive ardiendo y camina la cuestión/ el gran problema” (Giannuzzi: 2000, 60).
} 
la lectura) está cifrado en Giannuzzi en el poema “Proyecto de apocalipsis” de Señales de una causa personal (1977), donde se dice que "La luna no había sido otra cosa que un abominable cascote gris” (Giannuzzi: 2000, 210).

Casas presenta su propia variante de esta idea, que es toda una declaración de principios en cuanto al uso del lenguaje, en el poema que dice “Ahora mirás al mar, pero no decís nada./ Ya se han dicho muchas cosas/ sobre ese montón de agua” (Casas: 1996, 9). Y Prieto ofrece su versión en el prólogo a La fragancia de una planta de maíz, su tercer libro, en el que intenta exponer la poética de sus libros anteriores. El texto se llama “Una teoría: Para mí la luna es un lugar”, y habla de una "voluntad de un uso literal de la lengua poética” y de una “objetivación de la subjetividad”, que descarta o pone en un segundo plano el sentido figurado de los objetos. ${ }^{125}$

El intento de acercarse a los objetos en su literalidad, que construye tradición porque separa al objetivismo sobre todo del neobarroco, pero también del surrealismo, de la poesía lírica del cuarenta y más en general, de cualquier poética basada en el uso metafórico o simbólico de la lengua, remite entonces a una decisión de valerse de las palabras para nombrar lo concreto, y concuerda con la idea del poeta que vive en el mundo material y que a partir de él construye su poética. Por eso Giannuzzi cambia “luna” por “abominable cascote gris”, Casas describe al mar como un “montón de agua” y Prieto señala a su vez a la luna como un lugar antes que un soporte para toda clase de metáforas.

Pero se trata ante todo de una decisión que concierne al modo de designar a los objetos, cifrado especialmente en el trabajo sobre el registro verbal y en la elección de los sustantivos. Esta decisión (que encierra como dijimos toda una ideología sobre la poesía y su manera de relacionarse con el mundo) está tensada sin embargo con usos

\footnotetext{
${ }^{125}$ Martín Prieto, La fragancia de una planta de maíz, Buenos Aires, Libros de Tierra Firme, $1999(7,8)$.
} 
sintácticos que tienden a desnaturalizar el lenguaje, que aquí no puede confundirse de ningún modo con la ilusión coloquialista de reproducir el habla. Al contrario, si bien los materiales muchas veces son "bajos” y el modo de referirse a ellos es directo, el trabajo con la sintaxis presiona sobre esos materiales y motivos desde un uso que destaca a la escritura como artificio.

Así, cuando Prieto hace ingresar una cita de la oralidad en el poema, el uso de las comas parte la frase para imponerle un ritmo que no es oral sino inconfundiblemente poético: "Daniel pasa, peinándose, los dedos entre sus pelos finos./ Te vas, le digo, a quedar pelado.” (Prieto: 1988, 17). Incluso el uso de cursivas señala ese fragmento de habla como una incrustación en el poema, que diferencia desde la tipografía la escritura de la oralidad, además de someter esta última al procedimiento que mencionamos. Pero no sólo cuando se trata de citar el habla aparece esta torsión de la sintaxis; en "Desde la ventana” el verso que dice "Hay, entre las vías, un resto”, subvierte como se ve las reglas de la sintaxis tradicional (que indicaría más bien la expresión "Hay un resto entre las vías”) porque dispone sus materiales de acuerdo al diseño del verso, de modo que la palabra “resto”, central en el poema, ocupe el final de la línea (Prieto: 1988, 21).

Sólo en un par de ocasiones Prieto ensaya fugazmente un tipo de escritura que desarrollarán después otros poetas del noventa, más cercana a la oralidad, cuando dice “Como si el río, al retraerse, al amanecer/ se fuera de mambo, cruzara los límites habituales” (Prieto: 1995, 25). Pero incluso con la frase coloquial “se fuera de mambo”, que disuena en el contexto, el poema no deja de presentar una característica de Prieto que es el uso abundante de las comas, a veces innecesario desde el punto de vista del sentido literal pero que tiene ante todo una función rítmica (y construye por lo tanto sentido en el conjunto del poema). 
En García Helder, del mismo modo, pueden aparecer versos que suenan decididamente anacrónicos cuando se trata de un poema que reescribe un fragmento de Cristóbal de Castillejo que dice “Aquí no hay/ sino ver y desear,/ aquí no veo/ sino morir con deseo”. ${ }^{126}$ El comienzo del poema de García Helder dice: “No hay, acá no veo, un pedazo de madera/ nunca va a enceguecer, ojos de carne/ y cáscaras de huevo -acá no veo-;/ el viento se basta con el dolor de las hojas/ y la puerta del altillo que golpea/ mal cerrada; acá no hay/ sino ver y desear, no veo/ sino morir con deseo” (García Helder: 1994, 10). Como se ve, el uso de las rimas y las repeticiones, que son recursos inexistentes en este poeta, delata la presencia del texto previo y plantea esta primera estrofa como un verdadero “montaje de tiempos heterogéneos”, como señala Didi-Huberman, ${ }^{127}$ en el que conviven -pero no sin contrastar- la dicción del poeta renacentista español con expresiones contemporáneas como "la puerta del altillo que golpea/ mal cerrada”.

Pero incluso cuando no se trata de reescrituras, los poemas de García Helder pueden presentar anacronismos a nivel del léxico, como en aquel que comienza con el verso “Sed, lembranza y vaciedad, el espectro del invierno” (García Helder: 1994, 12). Al término "lembranza” que es un cultismo por "recuerdo" se suman luego “añicos” y "ramas buidas" que denotan un repertorio verbal amplio que proviene tanto del habla contemporánea como de diversas lecturas. Y en García Helder, el uso continuado de comas y encabalgamientos que cortan el flujo sintáctico da cuenta, como en Prieto, de

\footnotetext{
${ }^{126}$ El fragmento está citado en las "Notas" que figuran al final de El guadal y que explicitan de qué textos previos se han tomado las citas que se incrustan en el poema o se reescriben. Estos materiales, sin embargo, no conforman tradición, desde el momento en que se trata de selecciones aleatorias y microscópicas que dan cuenta de lecturas que funcionan como disparadoras de escritura, pero que no hacen a la ideología poética que subyace en los textos (García Helder: 1994, 67).

${ }^{127}$ Didi-Huberman sostiene que el anacronismo sería en realidad propio de toda obra artística; en efecto, todo objeto artístico es temporalmente impuro y supone un montaje de tiempos heterogéneos con el cual "todo el abanico del tiempo se abre ampliamente". Ver Georges DidiHuberman, Ante el tiempo, Buenos Aires, Adriana Hidalgo, 2006 (19).
} 
una disposición de la materia verbal en el poema fundada en el aprovechamiento de recursos estrictamente poéticos, como el diseño de la estrofa y el verso. Cuando se dice "La vida que nos separa/ de lo inerte, y que nos separa/ del resto de los animales" (Helder: 1990, 13) se hace evidente, una vez más, la intención de ubicar el término “separa” al final del verso para potenciar el sentido de la palabra con el corte y la pausa rítmica que propone, además del espacio en blanco de la página.

Incluso en Casas, que presenta una sintaxis simplificada en relación a la de Giannuzzi, cuyos poemas muchas veces reescribe, aparece la noción del diseño del poema como artificio. En un poema dedicado a Joaquín Giannuzzi, “Para J. O. G. con amor”, se dice: “Siempre que pienso en usted/ lo imagino tomando su café crónico/ o hurgándose las uñas/ parado frente a una ventana/ a través de la cual mira pasar/ grandes catástrofes, terremotos financieros/ o paros cardíacos” (Casas: 1990, 25). La palabra “catástrofes” es recurrente en Giannuzzi en poemas como "Hogar” de Señales de una causa personal (1977), donde se dice que los desastres que pueden suceder en el ámbito de una casa de familia son “un síncope en el pecho de papá,/ una catástrofe sobre el olor del guiso” (Giannuzzi: 2000, 151). En el poema de Giannuzzi aparecen, como se ve, los motivos del infarto y de la pequeña catástrofe que citaba Casas, y que irrumpen en una vida cotidiana que se revela como frágil.

Casas recupera el término “catástrofe” en el último poema de Tuca, sin embargo, desde la noción de artificio. Ese poema llamado "Final” dice que "No todo es tan duro, ya lo sé;/ pero convengamos que esta falsedad/ de tensar los poemas con una catástrofe/ se ha convertido ahora en mi segunda naturaleza” (Casas: 1990, 39). ${ }^{128}$ Aquí Casas

\footnotetext{
${ }^{128}$ El poema completo dice: "Este es el patio donde fui chico./ Las baldosas se han gastado un poco y las plantas/ han crecido por las rendijas de las paredes./ En esta soledad de la casa deshabitada/ tengo la terrible certeza de estar parado sobre una equivocación./ No todo es tan duro, ya lo sé;/ pero convengamos que esta falsedad/ de tensar los poemas con una catástrofe/ se ha convertido ahora en mi segunda naturaleza./ Cuando veo a la gente besándose en las plazas/
} 
pone de relieve la idea de "catástrofe” como procedimiento compositivo para armar el poema -que consistiría en tensar una situación cotidiana y banal con el recuerdo o la posibilidad de una tragedia-, tomado de su modo particular de leer a Giannuzzi. El hecho de que la operación conforme ahora una "segunda naturaleza” para el poeta no quita que presente un cierto grado de “falsedad”, como dice el texto citado.

De modo que en la manera de armar el poema, tanto como en los usos sintácticos, el manejo de recursos poéticos como el corte de verso y el encabalgamiento y las elecciones verbales, estos poetas exhiben un trabajo sobre la lengua y la composición global del poema que desnaturaliza lo que pueda haber de común y cotidiano en las percepciones y experiencias que se cifran muchas veces en una lengua “prosaica”, como llamaba García Helder al lenguaje de Giannuzzi, y alejada de la lírica. Por eso, una vez más, no acordamos con Edgardo Dobry cuando dice que la poesía de los noventa -en la que él incluye al objetivismo- puede pensarse a partir de la metáfora de "filmar" como modo de registrar lo que se ve en el que "falta el montaje, el experto que corta y pega”, y que sería parte de una voluntad que "se dirige a dar la apariencia de una suma que se ha hecho por sí misma, sin intervención de la mano del artista” (Dobry: 2006, 119).

La "mano del artista”, por el contrario, se hace visible en los procedimientos que señalamos, e incluso esa conciencia del propio trabajo sobre la lengua adopta por momentos la forma de una altivez que recuerda a Pound, quien decía en "Causa": "Reúno estas palabras para cuatro personas,/ algunos otros pueden oírlas por casualidad;/ oh mundo, lo siento por ti,/ no conoces a estas cuatro personas.” (Pound:

no puedo dejar de creer en un futuro/ donde los únicos vestigios del amor/ serán videos/ pornográficos” (Casas: 1990, 39). 
2003, 178, 179). ${ }^{129}$ Prieto, en “Poesía y sociedad”, reformula este gesto en un poema que dice:

Una melodía de Mozart en la voz de una mujer de la que hablaba Desnos en un poema cortado con cuchillo de plata.

Pero estos bárbaros que me rodean no saben el valor de mi compra, nomás están ahí, cacareando como gallinas rojas que se toman fotos en una calle de Montevideo.

A veces pienso que en su ignorancia se encuentra la base de mi prestigio. (Prieto: 1995, 21).

En este caso Prieto, que sigue a Pound, se refiere aristocráticamente a un poema “cortado con cuchillo de plata”, mientras que las personas que no pueden apreciar a Mozart son "bárbaros” que “cacarean”. 130

En García Helder esta ambigüedad se traduce en una mirada naturalista sobre los otros en un poema donde se describe a una familia pobre en un rancho; el padre se despierta y los mira “como víctimas/ de una masacre de la cual, en estado de ebriedad/ él pudo haber sido el agente; pero no se acuerda/ de nada y el flequillo sobre los ojos/ le da una aspecto de pony tardíamente alfabetizado” (Helder 1994: 17). El “analfabetismo” que tanto Prieto como García Helder atribuyen aquí a los otros produce una tensión entre la representación del poeta como hombre común o standard y el lugar social distinto que imagina para sí a partir del trabajo de pulido que realiza con el lenguaje, e incluso de su saber cultural. Estas nociones de "barbarie” y “analfabetismo” dan lugar, significativamente, a las figuras que hemos seleccionado para leer ciertas poéticas posteriores de los noventa que se abordarán en el tercer capítulo. Porque mientras que en Prieto y García Helder el "bárbaro” y el “analfabeto” son modos de nombrar lo otro

\footnotetext{
${ }^{129}$ En esta misma edición figura la versión original en inglés del poema, que dice: "I join these words for four people,/ Some others may overhear them,/ O World, I am sorry for you,/ You do not know these four people."

${ }^{130} \mathrm{El}$ título del poema parece plantear aquí una toma de distancia con respecto a, precisamente, este modo aristocrático de plantear la relación entre poesía y sociedad, pero de todos modos no hay otras marcas en el texto que permitan leerlo como gesto irónico.
} 
desde una posición que se sustenta en la familiaridad con la cultura, y de recortar imaginariamente el espacio que estas poéticas asumen para sí, otros poetas como Desiderio, Durand y Gambarotta se apropiarán de estas figuraciones para hacer el ejercicio de escribir desde ese lugar y desde el "no saber", en un gesto que representa a la vez un cuestionamiento de la idea de cultura inscripta en estos poemas objetivistas.

Porque Prieto, García Helder y Casas se construyen también como poetaslectores en sus textos, que escriben porque han visto pero además y sobre todo porque han leído, y que dialogan en sus textos con otros escritores y artistas plásticos. Así, Daniel García Helder dedica las distintas secciones de su primer libro El faro de Guereño (1990) a los poetas Oscar Taborda y Martín Prieto (ambos rosarinos) y a Daniel Samoilovich. Los epígrafes que introducen las secciones corresponden al dramaturgo alemán Georg Büchner (contemporáneo de Schiller y Goethe y autor de Woyzeck) y a Theodor Adorno. El guadal (1994) no tiene epígrafes pero si un apéndice de Notas en el que se explicita de dónde provienen muchas de las citas que se incorporan en los poemas. El gesto supone una voluntad de democratización del saber sobre poesía pero se sigue circunscribiendo a la cultura "letrada"; las citas incluyen a Horacio, Pound, Cristóbal de Castillejo, el libro de Job y el de los Salmos, Heidegger, Francis Bacon, Macedonio Fernández, Gottfried Benn, William Blake, San Juan de la Cruz, Virgilio, el Cancionero de Baena, Georg Trakl, Lucio V. Mansilla, Quevedo y Raúl González Tuñón, entre otros.

En su primer libro, Martín Prieto dialoga con algunos de los escritores de la genealogía objetivista que se construyó en el Diario de poesía, como Giannuzzi y Saer. ${ }^{131}$ Las dedicatorias de los textos delimitan un círculo de amigos poetas y pintores

\footnotetext{
${ }^{131}$ La poética de Osvaldo Aguirre, no trabajada en esta tesis en forma extensiva, puede pensarse en relación con la poesía de Daniel García Helder y Martín Prieto. Ellos, de hecho, incluyen a Aguirre (Colón, 1964) entre los poetas del 90 en su ““"Boceto $\mathrm{N}^{\circ} 2$ para un...de la poesía
} 
(Daniel García Helder, Rafael Bielsa, Juan José Saer, y los artistas plásticos Juan Pablo

Renzi, que participó también del Diario de poesía, y Daniel Scheimberg) que al mismo tiempo representan poéticas con respecto a las cuales se sitúa la de Prieto.

Entonces, la posición de Prieto y García Helder puede situarse en lo que se conoce como “cultura letrada”, mientras que en sus poemas y textos críticos la cultura de masas no se hace presente. Se trata también de un modo de concebir la cultura propio de la modernidad, que se constituye precisamente en la separación de las esferas de la actividad humana. No sólo porque se aísla la modernización social, política y económica de la modernidad cultural, como apunta Marshall Berman, ${ }^{132}$ sino también porque la producción intelectual y artística se representa en el imaginario moderno como separada de otras instancias de la totalidad de la vida, y como una tarea especializada llevada a cabo por unos pocos individuos (cuyos productos se oponen sobre todo a los valores degradados que determina la actividad económica) que tienden a revestirse de cierta “aureola” (Berman: 1989, 112-115), en ocasiones sacralizada. En este caso, no puede decirse que los objetivistas construyan figuraciones sacralizadas de la tarea del poeta, sino todo lo contrario, pero sí está presente la percepción del saber, un

argentina actual”. La diferencia, que despunta allí casi de una manera incómoda, estaría en el ingreso de la naturaleza al poema, del "paisaje semirural”. Sin embargo, destacan que el uso del lenguaje es seco (vaciado de lirismo) y dicen que "Aguirre consiente que algo brille, pero lo pone al ras del suelo y sin contenido (...)” (García Helder-Prieto: 1998, 17). El paisaje semirural o de campo es el centro de la poesía de Osvaldo Aguirre desde sus primeros libros, Las vueltas del camino, Buenos Aires, Libros de Tierra Firme, 1992 y Al fuego, Buenos Aires, Libros de Tierra Firme, 1994. La vista allí se detiene en los objetos y se modula de dos maneras: como captación instantánea de los objetos pero también con cierta morosidad en el señalamiento, la fijación de los mismos. En este sentido, la poética de Osvaldo Aguirre entra en relación con la prosa de Juan José Saer, es heredera de eso objetivismo (si recordamos que Saer también entraba en el armado de tradición del Diario de poesía, ocupando un lugar similar al que Flaubert ocupaba para Pound en cuanto al uso preciso del lenguaje en prosa). El movimiento de la percepción es similar, la mirada se delecta en la naturaleza o los objetos y el poema da cuenta de esta delectación en la marcación de un recorrido (no en el desborde descriptivo): "Pegada al moho/ que verdea bajo/ una baldosa bruñida/ por el rocío y rota,/ en el caminito/ que ondula/ entre las gigantescas/ rosas chinas,/ inmóvil, la babosa.” (Aguirre: 1994, 25). Ver al respecto Ana Porrúa, “Capítulo 3. Paisajes”, Caligrafía tonal, Buenos Aires, Entropía, 2011 (113 y ss).

132 Ver Marshall Berman, Todo lo sólido se desvanece en el aire. La experiencia de la modernidad., Buenos Aires, Siglo XXI, 1989 (2, 10, 11). 
saber que se refiere siempre a la literatura entendida en un sentido tradicional, como aquello que otorga prestigio y hasta cierta superioridad sobre los otros. Si bien los objetivistas insisten sobre la idea del poeta como "hombre común” que se vincularía con la sociedad mediante el uso de un lenguaje que es social de por sí, esa representación está tensada como vemos con una idea de cultura que se construye por fuera de los medios de comunicación, la cultura de masas y lo popular, y que confiere al que escribe cierta "aureola” de prestigio, idea que la mayoría de los poetas del noventa pondrán en cuestión cuando los materiales provenientes de esos ámbitos ingresen masivamente en el poema.

En este sentido Casas construye un lugar diferente, y abre toda una línea de escrituras de los noventa que incorporan a la cultura de masas y al mundo del consumo de manera desjerarquizada en el poema, porque en un texto dice por ejemplo que "no puedo dejar de creer en un futuro/ donde los únicos vestigios del amor/ serán videos/ pornográficos” (Casas: 1990, 39). En otro poema de Tuca aparece “una heladera roja de Coca Cola” (Casas: 1990, 27); el mismo poema dice que esa heladera está en un baldío “donde nos reuníamos a fumar y mirar/ revistas pornográficas”, y en El salmón se habla de "gente que desea ser amada/ y gasta su tiempo en los flippers” (Casas: 1996, 19). El último poema citado se llama "Hegel” (el libro además tienen un epígrafe de Spinoza), y unas páginas más adelante el título de otro poema es “Comics”, así como en otro texto del mismo libro se alude tanto a los Beatles como, de nuevo, a una heladera de Coca Cola (Casas: 1996, 29). En “Pound’s station” (Casas: 1996, 41) se reescribe "En una estación del metro", ${ }^{133}$ de Ezra Pound, y en "El calor” el poeta dice "Leo a Robert Lowell en inglés/ y comparo las versiones de Girri” (Casas: 1996, 27).

\footnotetext{
${ }^{133}$ Este es el poema de Pound llamado "In a station of the metro": "The apparition of these faces in the crowd;/ Petals on a wet, black bough". La versión en español: "La aparición de esos rostros en la multitud; pétalos sobre una rama negra, húmeda”. En Ezra Pound, Personae. Los poemas breves., Madrid, Hiperión, 2003 (222, 223).
} 
De esta manera, Casas exhibe consumos culturales que provienen tanto de la literatura (Girri, Lowell, Pound, Giannuzzi, Spinoza, Hegel) como de la cultura de masas (las revistas pornográficas, los Beatles, los comics). En sus libros, lo que se lee ya no es sólo la literatura, sino también las revistas pornográficas y los comics, si bien se trata de materiales que ingresan al poema y no se constituyen en tradición. De todos modos Casas propone una idea de cultura ampliada que no se restringe únicamente a la literatura y las artes plásticas, y que no aparece en García Helder y Prieto pero sí en un segundo grupo de poetas de los noventa que publicarían en los años siguientes, como Marcelo Díaz y Martín Gambarotta.

\section{4- LA FORMA OBJETIVISTA: DE LO CONCRETO A LO ABSTRACTO Y DE LO DESCRIPTIVO A LO ESPECULATIVO. UNA MIRADA DIALÉCTICA SOBRE LOS OBJETOS.}

El uso del lenguaje que hemos analizado en el apartado anterior, tendiente a eliminar de las palabras que nombran los objetos su doblez metafórico para privilegiar el aspecto denotativo y referencial, tiene como objetivo, además de las connotaciones ideológicas que hemos señalado en cuanto al uso de un lenguaje que es social y que funciona como instrumento de comunicación, la construcción de imágenes nítidas. Porque la imagen está en el centro del modo objetivista de concebir la poesía; de hecho, en el "Dossier Pound” que mencionamos al comienzo de este capítulo, uno de los rasgos de la poética de Pound a los que se daba relevancia en el texto de Fondebrider era la “Preponderancia de la imagen sobre la metáfora”. 134

\footnotetext{
134 “Dossier Pound”, Diario de poesía No 3, Verano de 1986, (13).
} 
Este modo particular de tratamiento de la imagen que Pound desplegó también en $E l A B C$ de la lectura estaba ya presente en su breve paso por el movimiento imagista formado en Londres alrededor de 1910, que compartió con William Carlos Williams y otros poetas como T. S. Eliot. El Imagismo, que se oponía a la tradición simbolista y a la poesía romántica victoriana, postulaba a la imagen como el medio perfecto para condensar la mayor cantidad de información y sensaciones, a condición de que fuera tallada y precisa. ${ }^{135}$ Tanto los pensamientos como las emociones debían objetivarse en la imagen. Pound desarrollaría después esta idea al hablar del carácter ideogramático de la poesía, que consiste en presentar lo abstracto a partir de la conjunción de elementos concretos (Pound: 1968, 18-22), y William Carlos Williams lo haría postulando como lema recurrente para su poética la frase “No ideas salvo en las cosas”. 136

En el objetivismo argentino, a este tratamiento de la imagen que se toma del modernismo anglosajón se agrega sin embargo una instancia especulativa que para Pound y William Carlos Williams debía hacerse presente en el ejercicio de lectura pero no en el poema. Así, Prieto encuentra que en Giannuzzi se anuncia muy tempranamente un "yo" que posa la mirada sobre un objeto y hace una descripción flaubertiana de dicho objeto que, a su vez, dispara una serie de reflexiones especulativas. ${ }^{137}$ Se trata de

\footnotetext{
135 Algunos preceptos imagistas tenían que ver con hacer un tratamiento directo del objeto y sobre todo no usar palabras que no contribuyeran a la presentación, como señala Pound. Ver Ezra Pound, "A retrospect" (1918), en James Scully (ed.), Modern poets on modern poetry, Fontana / Collins, London, 1973 (30). Pound recuperaría después estos preceptos en Ezra Pound, El arte de la poesía, México, Joaquín Mortiz, 1970 [1954] (7).

136 "No ideas but in things", en idioma original. En William Carlos Williams, The collected earlier poems, New York, New Editions, 1966 (233-235).

${ }^{137}$ Martín Prieto, “Giannuzzi, Cantón, Girri, y los otros”, en “Dossier Giannuzzi”, Diario de poesía $\mathrm{N}^{\circ}$ 30, Invierno de 1994 (17).
} 
poemas que, en palabras de Giannuzzi entrevistado por Fondebrider, "parten de una situación objetiva” para concluir en lo especulativo. ${ }^{138}$

Pero el reemplazo de la imagen por la metáfora es fundamental -aun cuando esa

imagen funcione como disparadora de reflexiones- por la visión del mundo que supone

la elección de uno u otro recurso, visión que los objetivistas comparten con el

${ }^{138}$ Citado en Martín Prieto, op. cit., (17). Pero el elemento especulativo se haría presente en una forma objetivada. En 1962, en un poema de Contemporáneo del mundo, ya citado, Giannuzzi había enunciado que la complejidad del mundo contemporáneo sólo podría ser revelada a través de "objetivos avances de palabras" (La frase pertenece al poema "Este mundo, muchachos...", en Joaquín Giannuzzi, Obra poética, Buenos Aires, Emecé, 2000, p. 60). Prieto parafrasea a Giannuzzi cuando dice que esa complejidad se cifraría en "hechos poéticos autónomos que al interpretar el mundo, lo modifican, porque se le agregan” (17). Esta idea aparece también en Francis Ponge cuando afirma que los poemas no pueden imitar a los objetos del mundo (es decir que la literatura no establecería con el mundo una relación especular) pero sí tener el mismo grado de realidad y la misma evidencia que esos objetos, en tanto el texto se piense y se trabaje como un objeto más. Ver Francis Ponge, "La práctica de la literatura”, en Métodos, Buenos Aires, Adriana Hidalgo Editora, 2000 (279). Traducción de Silvio Mattoni.

La ideología poética de Ponge, que consiste en considerar a los objetos por sí mismos y no a partir de lo que significan para el hombre, reclama que las palabras "imiten" la vida de los objetos del mundo exterior, pero esa imitación no se piensa desde la idea de reflejo. "Imitar" consiste para Ponge en tener "una complejidad y una presencia iguales" (Ponge: 2000, 279). Para eso el texto debe alcanzar la realidad en el mundo de los textos, es decir, ser "un complejo de cualidades tan real como el que presenta el objeto" (Ponge: 2000, 280). Ponge considera que el mundo de las palabras y el mundo de los objetos son dos instancias bien diferenciadas, cada una con su propia materialidad, y no hay posibilidades de efectuar el pasaje entre una y otra. Dice Ponge: "Me parece muy importante que los artistas se den cuenta de esto. Si creen que pueden pasar muy fácilmente de un mundo al otro, entonces en ese momento dicen: "¡Ah, amo los caballos! ¡Ah, cuánto quisiera entrar en la manzana!” y todo eso. No es ésa la cuestión. La cuestión es hacer un texto que se asemeje a una manzana, es decir que tenga tanta realidad como una manzana. Pero en su género. Es un texto hecho con palabras. Y no es porque diga "amo la manzana” que daré cuenta de la manzana” (280). Esta poética de Ponge funciona como doble toma de posición, en contra de la lírica y en contra de una poesía metafísica o “de ideas”. Pero, como vemos, es en parte una poesía de ideas lo que defienden los redactores del Diario, que retienen de Ponge la importancia dada a la especificidad del trabajo con la palabra y restan importancia al hecho de que los objetos deben valer en tanto objetos y no a partir de una mirada humana.

Esta misma idea de la relación no especular entre el objeto y el poema trama la concepción de Daniel Samoilovich sobre el objetivismo cuando lo describe del siguiente modo, en una entrevista citada en la nota de Prieto: "Objetivismo no se refiere a la presunción de traducir directamente los objetos a palabras -tarea químicamente inverosímil-, sino al intento de crear con palabras, artefactos que tengan la evidencia y la disponibilidad de los objetos” (20). Por eso el objetivismo tal como es construido por los poetas de Diario de poesía remite a dos aspectos: se trata de una poética basada en lo concreto, que toma los objetos del mundo cotidiano como base para la especulación -pero nunca al revés- y que considera a su vez al poema como un objeto en sí mismo -de ahí que, como hemos visto, se ponga el acento en la especificidad del trabajo sobre la palabra y se trabaje una sintaxis que lo pone de relieve como construcción artificial. 
modernismo norteamericano y con los poetas argentinos que recortan como tradición -incluso con Leónidas Lamborghini, que si bien se diferencia en el tratamiento verbal insiste en la importancia de una poesía que priorice lo bajo y lo corporal-. Esa concepción del mundo condiciona el desplazamiento de la metáfora, en tanto figura que toma al mundo material como ilustración de ideas abstractas preexistentes o jerárquicamente superiores, a favor de la imagen, que invierte la dirección del proceso y otorga a los objetos un valor en sí mismos, al mismo tiempo que reconoce que las ideas y emociones surgen a partir del contacto con ellos.

Los objetos materiales, cuya percepción se construye como imagen, pueden dar lugar entonces a reflexiones y, en definitiva, lecturas, pero siempre desde la conciencia de que "las cosas no son signos" que funcionen como manifestación sensible de un orden superior, como afirma Laura Wittner en un poema que es clave para pensar las poéticas objetivistas. ${ }^{139}$ No ver a las cosas como signos supone desnaturalizar la mirada sobre los objetos para efectuar en cambio una operación conciente de lectura, que no niega ni anula el espesor del mundo material en sí. Como señala Jorge Monteleone, la mirada sobre las cosas “constituye una fuente del sentido del mundo" toda vez que establece un vínculo productivo "con una de las operaciones eminentes de toda lectura, reunidas ambas en la actividad imaginaria: ver/leer”. ${ }^{140}$ Pero a su vez, este proceso no es unidireccional sino dialéctico, en la medida en que está mediado por una mirada tramada por diversas lecturas.

Por eso si bien las poéticas objetivistas pretendían, como vimos al considerar la construcción del dispositivo objetivista en el Diario de poesía, hacer un acercamiento a

\footnotetext{
139 "No es que leamos mal los signos./ Es que las cosas no son signos.”, dice Wittner en un poema llamado "Mis padres bailan jazz en el Café Orion”, El pasillo del tren, Buenos Aires, Trompa de Falopo, 1996.

${ }^{140}$ Jorge Monteleone, “Mirada e imaginario poético”, en La poética de la mirada, Madrid, Visor, 2004 (29, 32).
} 
las cosas sin preconceptos y tomar en cuenta los objetos por sí mismos, lo que aparece es más bien una dialéctica entre sujeto y objeto que pone en las cosas lo que en realidad es propio de un “yo” especulativo, pero que a la vez es construido en relación a lo que mira.

Esto sucede porque como señala Didi-Huberman, el acto de ver sólo vale por lo que a su vez nos mira cuando vemos. ${ }^{141}$ En su estudio sobre la mirada, Didi-Huberman destaca una escisión que separa en nosotros lo que vemos de lo que nos mira, y que hace que el acto de ver se abra en dos. El acto de ver despliega en nosotros un vacío que nos mira y que nos constituye, una hendidura que tiene que ver con la pérdida. La tesis central de Didi-Huberman es que la mirada desnuda es imposible porque siempre hay una experiencia del ver que puede atribuirse al carácter fenomenológico -el carácter de experiencia subjetiva- que engendra la contemplación de los objetos. El acto de ver, entonces, no es “el acto de una máquina de percibir lo real en tanto que compuesto por evidencias tautológicas”, sino que “ver es siempre una operación de sujeto, por lo tanto una operación hendida, inquieta, agitada, abierta. Todo ojo lleva consigo su mancha, además de las informaciones de las que en un momento podría creerse el poseedor” (Didi-Huberman: 1997, 46).

En consonancia con esta idea, la paradoja de la mirada objetivista es que el acercamiento despojado a los objetos está siempre mediado por la experiencia (en el doble sentido de vivencia y de saberes adquiridos; Jay: 2009, 27, 28) de un "yo" que se hace preguntas frente a las cosas o que pone de manifiesto la propia mirada cuando intenta acercarse a lo real. Esta mirada, como vimos, está armada por experiencias y lecturas previas, de manera que plantea un movimiento dialéctico entre sujeto y objeto más que un tratamiento del objeto en sí.

${ }^{141}$ Georges Didi-Huberman, Lo que vemos, lo que nos mira, Buenos Aires, Manantial, 1997 (13). 
Por eso los poemas objetivistas pueden agruparse bajo dos formas mayores que presentan variantes particulares en el caso de cada poeta. La primera de ellas tiene que ver con armar el poema como movimiento que va de lo descriptivo a lo especulativo (ya hemos analizado cómo el antecedente principal de esta construcción se encuentra en la poética de Joaquín Giannuzzi). ${ }^{142}$ A este respecto, en los dos libros de Daniel García Helder publicados hasta el momento se hace presente una pregunta básica que fue enunciada por Daniel Freidemberg: “qué tienen las cosas para decirnos, qué nos dicen” (Freidemberg 1988: 36), aunque sería más preciso decir que la versión de García Helder para esta pregunta es “¿Qué podemos leer en las cosas?”. Porque en sus textos hay un sujeto que se posiciona frente a la realidad y no sólo la registra desde la percepción sino que también se pregunta por su sentido.

Esta pregunta, que siempre tiene como respuesta en García Helder la palabra “nada”, toma por eso en varios de sus poemas una forma asertiva. Así, uno de los poemas de El faro de Guereño se titula “Intrascendencia” (García Helder: 1990, 19), como para marcar desde el principio que la escena que se va a presentar no tiene un significado exterior a sí misma, y en el poema "Una ninfa”, en el que se contempla a una chica que toma sol a la orilla del río, se dice que "De todos modos, en lo que concierne a los dos/ proximidad y simultaneidad/ no significan nada” (García Helder: 1990, 18). En “La reparación” se dice también que los actos y conversaciones de un grupo de personas que conviven en una casa “como en una pecera giran en torno a nada” (García Helder: 1990, 21).

\footnotetext{
${ }^{142}$ Como señala Monteleone en el artículo ya citado, "Los objetos lo obsesionan (a Giannuzzi) por las cualidades que poseen y sobre todo por su permanencia, su inmovilidad e incapacidad de cambio, al ser considerados como entidades autónomas. De ese modo, la mirada en Giannuzzi obra como una fenomenología de la percepción, que corresponde al dominio de lo visible. Articula una de las preocupaciones centrales de la poesía de Giannuzzi: el antagonismo entre cambio y permanencia” (Monteleone: 2004, 35). El encuentro con los objetos, entonces, despliega una dimensión subjetiva en la medida en que pone al poeta frente a su propia mortalidad.
} 
La constatación de la intrascendencia tiene su complemento en la negación a interpretar porque en realidad, si hubo alguna vez un sentido, éste se encuentra en el pasado, como se señala en "El plazo”: "La vida que nos separa/ de lo inerte, y que nos separa/ del resto de los animales,/ tal vez no sea del todo un percance/ y recupere, en esta hora apacible,/ algo de su viejo sentido” (García Helder: 1990, 14). Ese “viejo sentido” (que bien podría pensarse tanto desde un punto de vista personal como desde uno histórico) no sólo no se encuentra, sino que hay incluso una resistencia en encontrarlo porque, frente a un mostrador con pescados que se pudren en la costa, se afirma: “no me conviene interpretar mensajes en nada”. Este verso pertenece al poema “Sobre la corrupción” (García Helder: 1990, 43), que como señalamos es una revisión del simbolismo de Baudelaire y su teoría de las correspondencias, pero lo importante en este caso no es tanto que se rechace un sistema interpretativo de carácter simbólico sino que se lo haga porque “no conviene” descifrar nada frente a esa escena de corrupción.

Como puede verse, el movimiento del poema va de lo descriptivo -una instancia donde se arma perceptivamente una escena- a lo especulativo. Pero el contenido de esa especulación es generalmente rechazado para decir que la interpretación no es posible. La no conveniencia de hacer una lectura sobre las cosas puede deberse al tipo de paisajes a los que se enfrenta García Helder, generalmente de decadencia, en los que sería difícil descifrar otra cosa que fugacidad y muerte, pero constituye al mismo tiempo un señalamiento de que las disquisiciones de orden metafísico parecen poco apropiadas para interrogar un presente que se impone sobre todo en su contundencia material.

A pesar de eso, el paso que va de El faro de Guereño a El guadal consiste por un lado en la desaparición gradual de las preguntas metafísicas y la concentración cada vez mayor en los objetos por sí mismos. Pero incluso en El faro de Guereño, a las preguntas por el sentido de las cosas que tienen por sola respuesta a la nada se le opone una poesía 
fuertemente centrada en lo material, en la que la decepción por la falta de un sentido metafísico tiene como contracara una afirmación resuelta de lo que existe. Esa afirmación puede pensarse bajo la figura del inventario, porque muchos poemas consisten en una enumeración de objetos que conforman un paisaje percibido.

En "Interior”, donde se describe una escena del despertar, se dice que las cosas

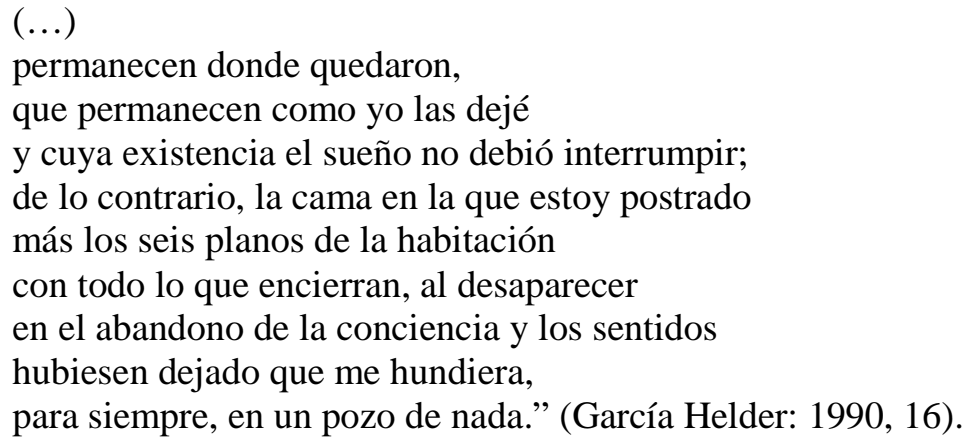

Lo que se afirma en este caso es la existencia independiente de las cosas con respecto a la conciencia del sujeto; son ellas las que no le permiten hundirse en la nada. Las cosas están ahí, aunque no tengan sentido, pero su importancia reside en que permiten al sujeto situarse en relación al mundo y funcionan a modo de "guía”, como se declara en los versos finales del poema "Perdidos":

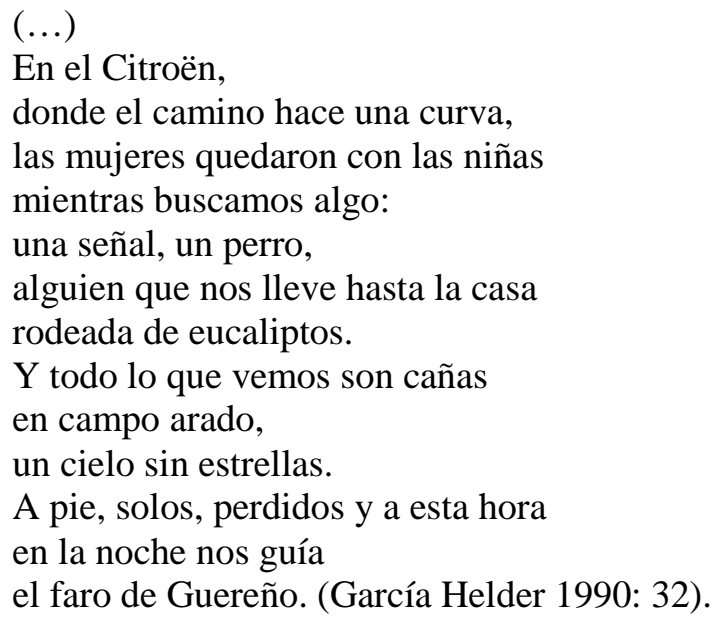

Fabián Casas presenta algunas variantes de los motivos que hemos analizado en García Helder, como el de la constatación de la propia existencia a partir de los objetos ("El olor a bronceador,/ las moscas/ y el ruido de botellas vacías/ conforman el peso/ de 
nuestra presencia en la costa”, dice un poema de Tuca $)^{143}$ y el de la indiferencia de éstos frente a los hombres: “A las cosas no les importan los mortales” (Casas: 1990, 13); “Está culminando un verano que no nos contempló” (Casas: 1990, 23). También aparece la negación a comentar lo que se ve, en un poema que Martín Prieto leyó en el “Dossier Giannuzzi” del Diario de poesía como emblemático del objetivismo, ${ }^{144}$ "Paso a nivel en Chacarita”: "Los chicos ponen monedas en las vías,/ miran pasar el tren que lleva gente/ hacia algún lado./ Entonces corren y sacan las monedas/ alisadas por las ruedas y el acero;/ se ríen, ponen más/ sobre las mismas vías/ y esperan el paso del próximo tren./ Bueno, eso es todo.” (Casas 1990: 17).

Si bien el último verso parece enunciar una poética basada en la presentación de lo real sin agregarle ningún tipo de interpretación o comentario, en Casas no está ausente el momento especulativo que recupera una escena desde el sentido, muchas veces metafísico, como en Giannuzzi. En realidad es más representativo de la poética de Casas un poema como "Sin llaves y a oscuras" donde se recorta una escena cotidiana, la de salir al pasillo de un edificio de departamentos a tirar la basura, y se la reformula a partir de una analogía sobre el final cuando azarosamente la puerta se cierra por el viento: "Quedé sin llaves y a oscuras/ sintiendo las voces de mis vecinos/ a través de sus puertas./ Es transitorio, me dije;/ pero así también podría ser la muerte:/ un pasillo oscuro,/ una puerta cerrada con la llave adentro/ la basura en la mano” (Casas: 1996, 8).

En este caso la lectura posible de una escena se conjuga en potencial, a partir del verbo "podría”. Lo que se ve puede recuperarse como sentido pero se trata de una capa que se superpone a la concreta presencia de los objetos y las situaciones, y que consiste en un ejercicio de interpretación posible. Pero también, en una actitud compartida de

\footnotetext{
${ }^{143}$ Fabián Casas, Tuca, Buenos Aires, Libros de Tierra Firme, 1990 (19).

${ }^{144}$ Martín Prieto, “Giannuzzi, Cantón, Girri, y los otros”, en "Dossier Giannuzzi”, Diario de poesía $\mathrm{N}^{\circ}$ 30, Invierno de 1994 (20).
} 
indagación frente a las cosas, porque Casas también se pregunta, en “Alarma”, si hay algún tipo de diálogo posible con el mundo: "Durante la noche/ suena la alarma de una fábrica/ cercana a mi casa./ Mientras fumo,/ me pregunto si será un error,/ un robo/ o algo exclusivo para mí” (Casas 1996: 11).

Como se ve, las preguntas a partir de las cosas siguen estando en los textos de Casas, pero permanecen como preguntas. Las únicas certezas, en cambio, no tienen que ver con lo intelectual sino con lo afectivo y con el contacto físico, porque el poeta cuenta que cuando extraña a la madre se mete en el ropero de ella, entre sus vestidos, y que "Parece absurdo: pero a oscuras y con ese olor/ tengo la certeza de que nada nos separa” (Casas: 1996, 17). Si bien las preguntas son metafísicas, entonces, las certezas son solamente físicas y se resuelven en el afecto y la memoria más que en el orden de lo racional. Así como García Helder tensaba las preguntas metafísicas con el inventario de las cosas concretas, Casas tensa las situaciones cotidianas de sus poemas con “catástrofes”, como lo enunciaba el último poema de Tuca, en las que lo único cierto es el afecto en tiempo presente.

En Martín Prieto la indagación de carácter metafísico es menor y la instancia especulativa de los poemas se centra en cambio en las preguntas sobre la percepción y la mirada. En "Barranca David Peña”, escrito en prosa, se retrata a un grupo de personas que miran el río. La composición de la escena es fotográfica: “Sentados sobre el pasto, recortados contra la luz de la tarde, como si allí abajo se sucediera un espectáculo deportivo, miran el río” (Prieto: 1998, 29). El poema arma una escena que no se centra en los objetos sino en el acto de la percepción, porque se dice que "Ellas dos miran en esa dirección y después, con la mirada, buscan otras cosas para señalarle a él”. Lo que se capta entonces es el acto del ver, y también sus resultados, porque aparece una vez más la oscilación entre lo que hay y lo que la percepción registra: “un bote atado contra 
una isla, un banco de arena brillante, plateado por la luz de la tarde, que emerge de entre las aguas como si se tratara de otra isla” (Prieto: 1998, 29).

En este caso el "como" tiene el mismo valor que los verbos conjugados en potencial de Casas y de García Helder, porque se trata del lenguaje plegando en sí mismo lo que hay y lo que podría haber, o el pestañeo entre la realidad y lo que en ella superpone la mirada. El paisaje aparece entonces como una construcción perceptual, constituida por escenas e imágenes "volátiles” que pueden mutar o diluirse según cómo se los mire, frente a las cuales no son posibles las certezas. En estos poemas, el motivo es menos el objeto que el acto problemático de la percepción, y la pregunta mayor tiene que ver con la mirada, que puede como se dice en un poema ya citado diluir los contornos de las cosas y "hacer de la percepción un instrumento del deseo/ y no de la verdad”.

La segunda variante de la forma objetivista, que adopta asimismo distintas modulaciones, consiste en plantear al poema como escena (que puede aparecer en ocasiones bajo las figuras del cuadro, la foto, el paisaje o la postal). Esta modalidad da cuenta de un acceso a la realidad tramado por lecturas y consumos culturales diversos, y que lejos de naturalizar el entorno lo recorta como objeto de contemplación y de un cierto diseño.

Este modo dialéctico de la mirada produce en los textos una temporalidad especial, que vincula distintos tiempos (sobre todo pasado y presente, o más precisamente lo que se hace presente del pasado, aquello a lo que Didi-Huberman aludía al hablar de la pérdida) para anudarlos en una determinada escena. Esta temporalidad es importante ya que supone una experiencia del tiempo que es fundamental para el modo de pensar la tradición de los poetas objetivistas. 
Porque los matices que se abren a partir del acto de ver no se atribuyen solamente a un vidrio opacado por el polvo o a una basurita en el ojo, como en "Una alegoría” y “Cerámica Verbano y alrededores” de García Helder, ya citados, o a una impresión generada por el deseo como en Prieto, sino también a la memoria. En el poema llamado precisamente “Una música en la memoria” Prieto pone de relieve cómo lo que se recuerda puede modificar completamente el entorno: "De zapatillas y pantalones negros,/ con el torso desnudo,/ lleno de yerba una calabaza marrón./ El paisaje es el de todos los días,/ salvo por una música que no silbo/ y sin embargo sé” (Prieto: 1998, 29). La música recordada, que no se vuelve materia sonora porque no se la silba, alcanza sin embargo para constituir una excepción (“salvo”) en el paisaje cotidiano.

Este dato permite leer un conjunto de poemas en los que se registran, como en capas superpuestas, las diferentes dimensiones del tiempo. Se trata de poemas que recortan una escena desde la composición visual, en la que funciona simultáneamente una pluralidad de tiempos. El primer poema de Verde y blanco de hecho ya presenta esta forma, que consiste en una constatación de la diferencia en la similitud, o de aquello que se mueve en un contexto aparentemente estático. El texto se llama "Contra Parménides” y dice: “La misma mesa ovalada/ con los mismos individuales rojos./ Los mismos vasos verdes/ llenos de vino tinto.”. La enumeración de lo que permanece idéntico continúa, pero sobre el final se dice que "Hace un año,/ sin embargo,/ los comensales eran otros” (Prieto: 1988, 13). La incógnita cifrada en la imprecisión de ese “otros” abre en el poema otra dimensión posible que tiene que ver con la ausencia, una ausencia que sin embargo se registra únicamente a partir de la presencia de lo que sigue igual. 
Este motivo se encuentra también en García Helder y en Casas, y representa esta segunda modalidad de la forma objetivista en la que la problematización de la percepción incluye a la memoria y por lo tanto se abre en el tiempo. En "Una heladera en la noche”, Casas organiza el poema en tres partes encabezadas por los términos “primero”, “después” y “ahora”: “Primero fue un terreno baldío./ Después vinieron los obreros/ y en dos días armaron la piecita,/ pavimentaron todo, pintaron las paredes/ (...) Ahora le pusieron entre medio de los coches/ una heladera roja de Coca Cola”. ${ }^{145}$ Significativamente, sobre este terreno vacío que se sitúa como pasado pero en el que la memoria pone una escena, la de unos chicos que fuman y miran revistas pornográficas (ver poema completo en nota al pie), se instala en el presente una heladera de Coca Cola que ilumina por la noche. Hay otros chicos, “ahora”, que ponen monedas en la heladera como los que ponían monedas sobre las vías en "Paso a nivel en Chacarita”.

El modo de mirar un lugar, en este caso, superpone las capas de una temporalidad que está abierta, porque el presente es continuamente modificado por la memoria y porque el pasado no lo es sino en la medida en que se constata su desaparición a partir de las huellas, de las transformaciones. El poema surge además como testimonio de una época distinta a partir de un solo objeto, la heladera de Coca Cola. Porque a diferencia de Prieto y García Helder, la ciudad de Casas está iluminada por carteles publicitarios, como lo estará la de Martín Gambarotta. En consonancia con esto, el primer poema de Tuca, ya mencionado, que también registra un cambio que se juega entre un antes y un después, comienza por decir “También tuvimos una guerra./ Ahora somos parte de Hollywood.” (Casas: 1990, 11).

\footnotetext{
${ }^{145}$ El poema completo dice: "Primero fue un terreno baldío./ Después vinieron los obreros/ y en dos días armaron la piecita,/ pavimentaron todo, pintaron las paredes./ (Pero antes era un terreno baldío/ donde nos reuníamos a fumar y mirar/ revistas pornográficas.)/ Ahora le pusieron entre medio de los coches/ una heladera roja de Coca Cola/ que tiene luz propia durante la noche./ (Durante la noche la oscuridad resplandece/ contra la heladera roja de Coca Cola./ A veces algún chico le pone una moneda/ y espera su botella prometida.)” (Casas 1990: 27).
} 
Los diferentes tiempos que se anudan en los poemas de Casas son los de la autobiografía (los chicos que se juntaban a fumar y mirar revistas, o aquellos de los que se dice que "tuvimos una guerra", incluidos en esa primera persona del plural que señala a una generación) pero también los de la cultura, porque los emblemas del presente son “Hollywood” y “Coca Cola”.

En García Helder, lo que se registra como presente del pasado son las ruinas urbanas -a veces vinculadas a proyectos políticos o económicos fallidos--, ${ }^{146}$ la permanencia de formas de trabajo artesanal que resultan extrañas ("La familia y la red de pescar”; García Helder; 1990, 38, 39), la decadencia del mundo industrial en los suburbios de una ciudad como Rosario: “Las torres de la usina, grúas de los diques que apuntalan/ en ruinas un ángulo del cielo, entre barracas de ladrillo/ y calles que convergen sin bulla hacia el riacho” (García Helder: 1994, 12), y la marginalidad, que después aparecerá como tema en Santiago Llach, Washington Cucurto y Martín Gambarotta: "Yo qué sé,/ en todas las ciudades hay, todavía,/ junto a las vías del tren y desde muy/ temprano, llamas de fuego real temblando/ debajo de ollas quemadas” (García Helder: 1994, 13).

Los poemas recortan un paisaje que como se ve pertenece a los bordes de la vida urbana: la orilla del río, las vías del tren, donde la supervivencia de formas de

\footnotetext{
${ }^{146}$ Ver por ejemplo el poema "A unas obras junto al Río Paraná” donde se dice con ironía: "Por que tengamos ruinas y la ciudad/ pueda mostrarse más antigua y venerable/ se emprendió años atrás la construcción/ de un magno y apócrifo colegio que,/ salvo en maqueta, ni nuestros hijos/ van a ver terminado. Columnas/ de proporciones colosales, galerías,/ rampas y escalinatas, el piso de los baños,/ paredes sin revocar de aulas inciertas,/ arcadas y balcones, allá las gradas vacías/ de un anfiteatro, la biblioteca y demás/ dependencias que hoy, a 3 días de julio/ de 1990, luego que uno de esos temporales/ de agua y tierra lo emporcaran todo, lucen/ junto al río y bajo un cielo de borra/ como estragos que por envidia las estrellas/ demandaron al tiempo" (García Helder: 1994, 30). Como se ve, si bien no se consigna qué gobierno comenzó estas obras, sí aparece la fecha en que el sujeto las contempla. Es que fechar el momento de la contemplación es un gesto que se repite en los poemas de García Helder; de hecho el poema siguiente de El guadal, "In memory of Jane”, tiene un epígrafe que dice "Cementerio de Disidentes/ Rosario, enero de 1994". Este gesto aparece como modo de fechar la mirada, pero también de precisar un estado de las cosas en el momento en que se las mira, con la conciencia de que se trata de paisajes sujetos al cambio.
} 
organización social y económica del pasado (cifradas en la palabra "todavía” del último poema citado) horada la imagen del presente. En estos poemas, que trabajan más con la figura del inventario que mencionamos antes, se suspende la interpretación como si el gesto de registrar lo que se está viendo fuera suficiente. Lo que sucede entonces es que la mirada da testimonio de un estado de cosas en un momento determinado, que se encuentra sujeto al cambio. Pero a la vez, el ojo hace foco sobre las ruinas, la basura, como en el poema "Una vida antigua y dispersa": "Te quiero decir, por Santa Magdalena llegué a este puente/ que pide PRECAUCION/ VELOC. MAX. 5 KM. para ver, bajo su arco/ delicadamente ensamblado, en el atardecer,/ dónde la mugre alcanza su apoteosis” (García Helder: 1994, 14).

Lo que hay debajo de ese puente se consigna por enumeración y es, “el engrudo de esa orilla/ amasado con limo y jabón, brea, cromo,/ cenizas de plástico y piedra carbonizada”. Pero si el paisaje vale algo para el sujeto es porque se lo ha recorrido en el pasado y entonces en él se puede "sentir que una vida antigua y dispersa/ se recoge en un haz y vuelve a tocarme”. Esa vida entonces, no está reunida en el sujeto sino que está fragmentada y dispersa, depositada en las cosas concretas.

En Prieto el término clave para leer esta misma operación es "resto", que aparece en el poema "Desde la ventana" que ya hemos analizado: "El mundo es esta estación de trenes, casi invisible por la lluvia./ Hay, entre las vías, un resto:/ una naranja brillante apoyada contra el riel./ El hombre tiende la mesa/ y cree cambiar en algo las cosas” (Prieto: 1988, 21). ${ }^{147}$ Aquí, la percepción del objeto como resto lo cambia todo

\footnotetext{
${ }^{147}$ La idea de "resto" puede plantearse como central al menos en los dos primeros libros de Prieto puesto que el primer poema de su segundo libro La música antes se titula, precisamente, "Un resto": "Por las hendijas de la persiana/ entra la luz del amanecer para destacar/ en la penumbra sensible, sobre la mesa,/ un par de tazas que usamos anoche/ y quedaron sin lavar./ Echo, en una, un chorro de café/ y no sé nada, no pienso nada, sigo dormido,/ hasta que apoyo la boca/ en el borde de la porcelana/ y reconozco ahí un resto de saliva/ seco ya y todavía perfumado/ que concentra, sobre mi cabeza,/ toda la presión del universo" (Prieto 1995: 13). Primero, las tazas aparecen como recuerdo intelectual de la noche pasada, pero ese recuerdo
} 
puesto que abre, una vez más, la escena a la intromisión de otros tiempos. Porque ese objeto que se percibe en presente se reconoce sin embargo como algo que permanece de un pasado desconocido o que, mejor, constituye por sí mismo ese pasado. Sin embargo la naranja es "brillante” y se destaca frente a un mundo presente "casi invisible por la lluvia”, y de hecho modifica la escena mucho más que el gesto del hombre que “cree cambiar en algo las cosas”.

El objeto funciona entonces como núcleo del poema en tanto reúne percepción y memoria, al mismo tiempo que pone de manifiesto la dialéctica entre la mirada -que nunca es un puro “ver”, como señalaba Didi-Huberman- y el pasado como construcción imaginaria a partir del momento presente. Los poemas objetivistas trabajan con la percepción, pero esa percepción nunca se despoja de lo que no pertenezca al momento presente de la contemplación, sino que por el contrario está mediada por experiencias y lecturas previas, es decir, por la memoria.

El mismo principio que funciona en la mirada sobre la realidad funciona cuando se trata de leer la literatura, y así como García Helder encuentra una vida dispersa entre ruinas, Prieto un resto que brilla con vivacidad, y Casas una heladera de Coca Cola que repone todo un pasado por defecto, cuando se trata de armar tradición los poetas objetivistas recuperan desde las lecturas (es decir, desde la producción) aquello que se hace presente del pasado. Y de la misma manera “leen” la realidad desde una mirada tramada por lecturas, y la literatura desde el deseo de dar cuenta de esa realidad en el presente, en un movimiento en que una y otra, tanto como el presente y el pasado, se reenvían permanentemente.

sólo funciona en tanto dato. El resto, sin embargo, se caracteriza por su potencia de concentración (que es también afectiva, y en este caso se debe como señalábamos en Casas a un contacto físico) de "toda la presión del universo". 


\section{CAPITULO II}

\section{DEL ARCHIVO A LOS REPERTORIOS: CONFIGURACIONES DE LA BIBLIOTECA OBJETIVISTA}

\section{1- Planteo inicial}

Este capítulo está dedicado a analizar una serie de poéticas que se vinculan con el objetivismo, ya sea porque retoman las problemáticas analizadas en el capítulo anterior con respecto a la mirada, el lenguaje y la relación de ambos con la realidad, o porque se vinculan con la tradición construida por los objetivistas a partir del uso. En efecto, el Diario de poesía, como hemos visto, pone en escena una serie de cuestiones que se convierten de algún modo en la agenda de problemas a discutir y procesar en la segunda mitad de la década del noventa en relación a la poesía, ${ }^{148}$ al mismo tiempo que habilita una biblioteca que los poetas que pondremos a consideración procesan de diversos modos.

En ese sentido es productiva la conceptualización de Gonzalo Aguilar, quien en su estudio sobre poesía concreta brasileña distingue entre “archivo” y “repertorios”. 149 Según Aguilar, al indagar en los usos de la tradición, es útil distinguir entre “archivos”, que designarían todos los textos disponibles en un momento dado, sobre los cuales los poetas ejercen una serie de selecciones, ampliaciones y jerarquizaciones, y “repertorio”,

\footnotetext{
${ }^{148} \mathrm{Al}$ menos, esto sucede hasta que la emergencia de poéticas pop, que abordaremos en los capítulos cuarto y quinto, no desplace la discusión hacia otras temáticas.

${ }^{149}$ Gonzalo Aguilar, Poesía concreta brasileña: las vanguardias en la encrucijada modernista., Buenos Aires, Beatriz Viterbo, 2003 (18).
} 
que alude a la selección particular que cada poeta hace de entre esos archivos. Como señala Aguilar, "La diferencia entre archivo y repertorio establece el pasaje entre la cantidad de información y prácticas que están a disposición de los actores culturales y la selección que estos hacen y que les sirve para posicionarse” (Aguilar: 2003, 18).

El término “archivo" tiene en Derrida un sentido que lo vincula a la memoria, porque se trata de actos de preservación ejercidos desde un poder que "establece, funda, fija, guarda al mismo tiempo que excluye, demora, retarda o descarta, básicamente porque elige”. ${ }^{150}$ La noción de “archivo” se vincula entonces a la idea de “exhumación” como “rescate de géneros o textos rechazados, ocultos, desvalorizados” (Gerbaudo: 2010). En este sentido puede articularse con la definición de tradición que trabajamos, porque aquí también se trata de un proceso de “exhumación”, no ya de la obra de un solo autor sino de segmentos heterogéneos de diversas tradiciones que constituyen un archivo.

La pertinencia de hablar aquí de “archivo” y “repertorios” para indagar en usos más puntuales de la tradición está dada por el hecho de que, mientras que el Diario de poesía construye como colectivo una tradición -que siempre, al margen de los usos particulares que se hagan de ella, debe ser colectiva según el modo en que la piensa

\footnotetext{
${ }^{150}$ Ver Derrida, Jacques. Mal de archivo. Una impresión freudiana. En "Derrida en castellano”, http://www.jacquesderrida.com.ar/textos/. Traducción de Paco Vidarte 1997; también la lectura de Analía Gerbaudo, “Archivos, literatura y políticas de la exhumación”, en Graciela Goldchluk y Monica Pené (comp.), Palabras de archivo, La Plata, UNLP (en prensa); "Por una nueva teoría del archivo (literario)”, en P. Arán (comp.), Interpelaciones. Hacia una teoría crítica de las escrituras sobre dictadura y memoria, Córdoba, Ferreira Editor, 2010 (135-159). Gerbaudo aclara que "archivo" también designa a la totalidad de escritos que constituyen la obra de un autor, con la consecuente pregunta acerca de los límites de ese archivo (dónde empieza y termina, si incluye a sus cartas, textos inéditos, proyectos inconclusos, etc., como problema metodológico para la crítica literaria).
} 
Williams- los poetas que aquí consideramos retoman ese armado pero lo varían en usos desviados, que el concepto de “repertorio” nos permite leer. ${ }^{151}$

La tradición construida por el Diario de poesía, junto con los libros publicados por los poetas de esta línea -que para la segunda mitad de los noventa pasan a formar parte también de esa tradición- funciona entonces como archivo, no sólo de "textos disponibles” como señala Gonzalo Aguilar sino también en tanto lee, interpreta esos textos, ya sean poéticos o críticos. El armado de una biblioteca, en este sentido, tiene que ver con una selección de la literatura argentina, latinoamericana, norteamericana y europea, y con el ejercicio siempre crítico de lectura que supone el armado de una tradición en la que se jerarquizarán segmentos que comienzan a reponer ciertas constelaciones o, con mayor claridad en el Diario de poesía, a generar nuevas constelaciones como ya se ha visto. Porque el archivo, como señala Analía Gerbaudo, no está dado solamente por procesos de selección sino también de interpretación (Gerbaudo: 2010), que en este caso establecen una agenda tanto como delimitan lo pensable y hasta los límites de lo percibido como “poético”.

Por eso las apropiaciones llevadas a cabo por las poéticas que aborda este capítulo trazan líneas de continuidad con el objetivismo, en la medida en que hacen uso del archivo habilitado por el Diario de poesía, pero a la vez, sin ser objetivistas, construyen una serie de posiciones adyacentes a esa formación que establecen tanto puntos de contacto como de divergencia. Nuestro análisis se centra entonces en los modos en que cada uno de ellos se apropia de esa tradición para elaborar un repertorio propio en el que esos "textos disponibles" se cruzan con el procesamiento de otras poéticas. Se trata, incluso, de un trabajo con el valor de determinadas partes de ese

${ }^{151}$ En efecto, si alguna objeción puede hacerse al concepto de tradición tal como lo piensa Williams es que siempre está a punto de soslayar los usos individuales en favor de un constructo mayor, y por eso mismo no es tan flexible como para dar cuenta de la relación entre una tradición y sus diversos usos y apropiaciones, que sí está contemplada en la conceptualización propuesta por Gonzalo Aguilar. 
archivo, que serán desplazadas (sacadas de contexto) a partir de lecturas que varían su signo ideológico.

En primer lugar, se pondrá a consideración una poética que incluye los libros de Carlos Battilana y José Villa, bajo la premisa de que comparten con el objetivismo una pregunta central en relación a la mirada, a la que se suma en este caso puntual el procesamiento del simbolismo y una concepción del lenguaje poético como huella de la experiencia.

En segundo lugar, y como deriva del gesto que ya hemos analizado en los poemas de Daniel García Helder de poner a prueba diversas tradiciones en relación a lo local, se analizarán los primeros libros de Alejandro Rubio, Marcelo Díaz, Mario Ortiz y Sergio Raimondi. En este caso se trata de textos que operan lecturas donde la tradición se tensa con modos de hacer que son propios de la vida cotidiana y con una “inventividad” de carácter popular, que serán leídos a partir de las conceptualizaciones de Michel de Certeau en La invención de lo cotidiano. ${ }^{152}$ Esta voluntad de cruzar la tradición literaria con lo popular constituye una toma de posición política en relación a tradiciones cuyo carácter culturalmente dominante se revisa en el plano local, a partir de lecturas situadas (al menos en el caso de los poetas bahienses, donde la propia poesía se construye en disputa con una tradición institucional fuerte que es la académica).

Por último se analizarán las poéticas de Laura Wittner y Walter Cassara como reformulaciones del modernismo norteamericano recuperado por el Diario de poesía. Más específicamente, se pondrá a consideración la apropiación de la idea de poesía ideogramática de Pound en el caso de Wittner, donde el sentido se halla disperso entre elementos concretos, y el modo en que Cassara retoma en Juegos apolíneos (1998) la

152 Michel de Certeau, La invención de lo cotidiano I. Artes de hacer, México, Universidad Iberoamericana, 2000. 
construcción de diversas “máscaras” enunciativas que ensaya Pound, como ejercicio de construcción de una subjetividad a partir de la tradición clásica.

\title{
2- LA PUESTA A PRUEBA DE LOS OBJETOS: CARLOS BATTILANA Y JOSÉ VILLA
}

\author{
Sobre un centro \\ de magnolias arruinadas \\ la mirada de las moscas \\ ejerce \\ su presión \\ Hay edificios \\ y también \\ un conjunto \\ de maneras \\ tiesas. \\ Carlos Battilana ${ }^{153}$ \\ La fruta aún desconoce \\ su nombre. Sabe entre otras cosas \\ que es media tarde. Que \\ alguien la mira posada en la frutera \\ y que una gota que cae, \\ lenta la abre con luz por la mitad. \\ José Villa ${ }^{154}$
}

En la poesía de Carlos Battilana y José Villa podría leerse -y de hecho así se ha hecho- una configuración de la poética objetivista, en la medida en que en ellas se presentan también los objetos, las escenas que estos objetos arman (incluso el motivo de

\footnotetext{
${ }^{153}$ Carlos Battilana, “Lotes”, Unos días, Buenos Aires, Libros del Sicomoro, 1992 (15). Todas las citas posteriores están tomadas de la misma edición.

154 José Villa, ocho poemas, Buenos Aires, Ediciones Deldiego, 1998 (sin números de página). Todas las citas posteriores están tomadas de la misma edición.
} 
la naturaleza muerta, o alguna de sus variaciones) y la relación que se establece entre estos y el sujeto, como relato de la percepción. Los dos poemas que abren como epígrafes este apartado podrían servir para corroborar lo acertado de la inclusión. Porque de hecho en "Lotes” de Battilana, un objeto se designa explícitamente como “centro” del poema. Al mismo tiempo, así como Martín Prieto se refería a la naranja brillante como “resto” en el poema “Desde la ventana” y García Helder hacía foco una y otra vez sobre las ruinas, acá se trata de “magnolias arruinadas”. La mirada, por otra parte, no está a cargo del sujeto que enuncia el poema solamente sino que también se habla de "la mirada de las moscas", que puede leerse como reminiscencia de la poesía de Giannuzzi. ${ }^{155}$ Por su parte, "naturaleza”, el poema citado de José Villa, también inscribe como eje un objeto, un fruto, y en este caso se produce un desplazamiento llamativo porque la mirada es la de la fruta y lo que "sabe” la fruta de sí misma es idéntico a lo que ve el poeta, en todo caso. De este modo, los poemas ponen en escena una mirada que más que del sujeto (ineludible en la poesía objetivista) es la del objeto.

La poesía objetivista abordada en el primer capítulo despliega la preocupación por pensar la relación entre poesía y realidad, entre poesía y experiencia, y supone una cierta vinculación entre la poesía y el mundo exterior que si bien no se resuelve de modo mimético da cuenta de una confianza en las posibilidades del poema para nombrar las cosas, asociada, como hemos visto, a un lenguaje despojado. Los textos de Battilana y Villa en cambio ponen en crisis estos dos presupuestos, en tanto aquello que se mira no puede ser nombrado directamente; de hecho, no se sabe casi nada sobre el

\footnotetext{
${ }^{155}$ Las moscas (y otros insectos, como pulgas y cucarachas) aparecen una y otra vez en Giannuzzi, muchas veces asociadas a la descomposición y la muerte, como en el poema de Battilana. Así, en "Fábula” de Las condiciones de la época (1967), citado en el capítulo anterior, se habla de "la muerte de papá y de las moscas" (83) y en "Mosca de velorio" de Señales de una causa personal (1977) (152) se trata de una mosca que ronda un ataúd. Ver Joaquín Giannuzzi, Obra poética, Buenos Aires, Emecé, 2000. Para un lector asiduo de Giannuzzi, la resonancia sería muy evidente, no sólo por las moscas sino por la escena de decadencia cifrada en un objeto.
} 
fruto del poema de Villa, ni siquiera su nombre. En un gesto similar, en la segunda mitad de "Lotes" de Battilana, los referentes concretos se diluyen para dar paso a frases más abstractas, que ya no proponen imágenes visuales (figuras que, como vimos, organizaban el poema objetivista). Del mismo modo, en los versos finales de otro poema del mismo libro se dice que "no pude rayar un círculo/ ni nombrar/ un cierto estado de promesa/ más bien borrosa” (Battilana: 1992, 12). Ese “no pude” da cuenta de una concepción deceptiva del poema según la cual el texto existe a pesar de que designa siempre otra cosa que la que se intentaba nombrar. Por otra parte, eso que quería nombrarse era un objeto de por sí “borroso” y, además, el uso de los adjetivos y adverbios en el poema (“un cierto”, “más bien”) tiende a quitar peso y precisión a los sustantivos.

Esto sucede porque Battilana retoma de los objetivistas la pregunta por las posibilidades de la poesía para nombrar la realidad pero la procesa como imposibilidad del lenguaje poético para tocar lo concreto, que retrocede todo el tiempo. La de Battilana no es una poética de los objetos, como las de Prieto y García Helder, sino de sensaciones y pensamientos siempre fragmentarios y evanescentes. En ese sentido, el poema "Estaciones” podría leerse como cifra de esta manera de pensar y practicar la poesía:

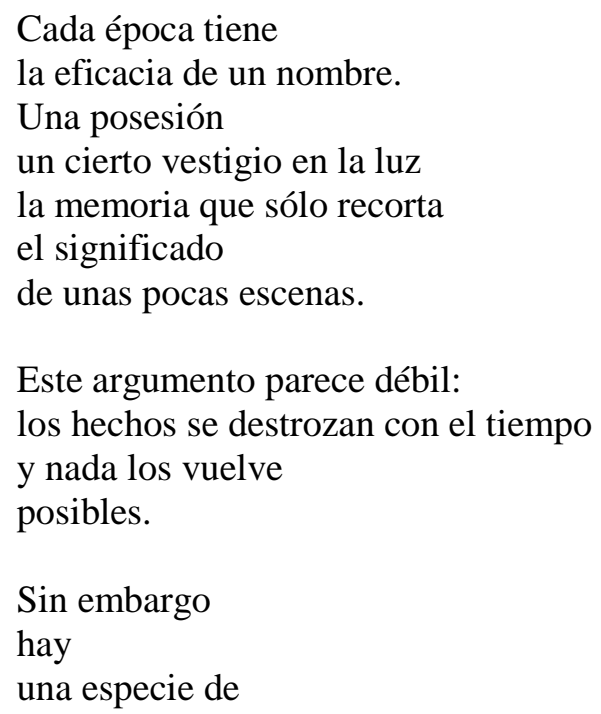


música en la memoria

que resiste en su bruma.

El agua

se escucha

correr.

Los días se agrupan en alguna parte. ${ }^{156}$

Aquí, como en la mayoría de los poemas de Battilana, no hay referentes identificables sino que lo concreto está velado y el trabajo con el lenguaje tiende a volver difusos los sustantivos en lugar de precisarlos (“un cierto vestigio”, “una especie de música”, “alguna parte”).

Otro punto importante en el último poema citado es que la percepción, que era central en los objetivistas, cede lugar a la memoria como si no pudiera nombrarse más que lo que ya ha sido, y esa memoria además recorta siempre, no las escenas sino su “significado” (lo que equivale a decir que el acceso a la realidad siempre está mediado por la interpretación de la experiencia). Asimismo, la imposibilidad de retener una totalidad se señala en el sintagma “unas pocas escenas”. La poesía, entonces, parece ser aquel discurso que trabaja todo el tiempo sobre la pérdida y que rescata, con dificultad, algunos vestigios de entre la "bruma".

Por eso, si bien el acto de mirar está tematizado en los poemas, no resulta central; antes bien, hay una insuficiencia de la mirada que hace que lo que importe sea finalmente el pensamiento. Entonces, Battilana toma elementos del archivo objetivista pero esta insuficiencia de la mirada podría leerse como trabajo con otro repertorio, discutido, como ya vimos, por Daniel García Helder y ausente tanto en la poesía de Prieto como en la de Casas: se trata del simbolismo francés, que incluso puede pensarse como lectura mediada por Rubén Darío. Dos elementos del simbolismo aparecen de manera peculiar en estos poemas de Battilana: la idea de insuficiencia del lenguaje para

\footnotetext{
${ }^{156}$ Carlos Battilana, El fin del verano, Buenos Aires, Siesta, 1999 (16, 17), Todas las citas
} posteriores están tomadas de esta misma edición. 
nombrar y la posibilidad (de ahí el peso del pensamiento) de leer los objetos, en realidad estos vestigios o fragmentos de objetos, como signos. El simbolismo plantea la relación entre sujeto y objeto desde la evocación y la sugerencia, dado que nombrar al objeto sería equivalente a suprimirlo, ${ }^{157}$ tal como se lee en una de las enunciados poéticos más conocidos de Mallarmé, refiriéndose a los parnasianos: "Nombrar un objeto significa suprimir las tres cuartas partes del goce de una poesía, que consiste en el placer de adivinar poco a poco. Sugerir, he aquí el sueño”. ${ }^{158}$ Entonces, el simbolismo propone evocar gradualmente al objeto para extraer de él un estado de ánimo mediante una serie de desciframientos. O, en palabras de Käte Hamburger, "Símbolo no significa así otra cosa sino aprehensión del objeto por parte de un yo lírico, o metamorfosis de aquel en estado de ánimo que lo convierte en simbólico para el yo” (Hamburger: 2005, 172; las cursivas son de la autora). Algo de este “estado de ánimo” está presente en los poemas analizados de Battilana, como sustracción permanente del objeto que se vuelve difuso y pareciera inaprensible, aunque no podríamos decir que el objeto se transforme en simbólico. Más bien su poesía pone en escena este doblez, de imposibilidad de nombrar los objetos y, simultáneamente, de incertidumbre sobre su conversión simbólica.

Por eso el tratamiento del objeto difiere de las poéticas de Prieto, Casas y García Helder; es más, ya como inversión de la postura objetivista (que según vimos estaba presente en el primer libro de Battilana) cifrada en el desplazamiento que se opera sobre la centralidad de la mirada, el último poema de El fin del verano enuncia el propósito de "Mirar lo que sucede/ pero/ sin precisión.” (Battilana: 1999, 63). Esto se debe a que la realidad se percibe como proliferación de signos también inciertos, imprecisos, a veces

\footnotetext{
${ }^{157}$ Käte Hamburger, La lógica de la literatura, Madrid, Visor, 1995 (172). Para una visión de época del simbolismo ver Gustave Kahn, Symbolistes et decadents, Genéve, Slatkine Reprints, 1977 [1909]. Sobre las resoluciones simbolistas de la poesía de Rubén Darío ver Ángel Rama, "Prólogo" a Rubén Darío, Poesías, Caracas, Biblioteca Ayacucho, 1977 (IX-LII).

158 Mallarmé, Encuesta sobre la evolución literaria. Citado en Manuel Álvarez Ortega, "Prólogo" a Poesía simbolista francesa, Madrid, Editora Nacional, 1975 (11).
} 
imposibles de leer. Así, un poema dice que “Al costado/ el humo de la quemazón/ describe un signo/ confuso" (Battilana: 1999, 21), mientras que en otro "Las eles del muro/ se tornan signos/ apenas visibles” (Battilana: 1999, 29).

Incluso la memoria aparece representada "Política del silencio" como una “catedral”, es decir, también un conjunto de signos que imprime al poema un matiz de religiosidad laica que ya estaba presente en Mallarmé:

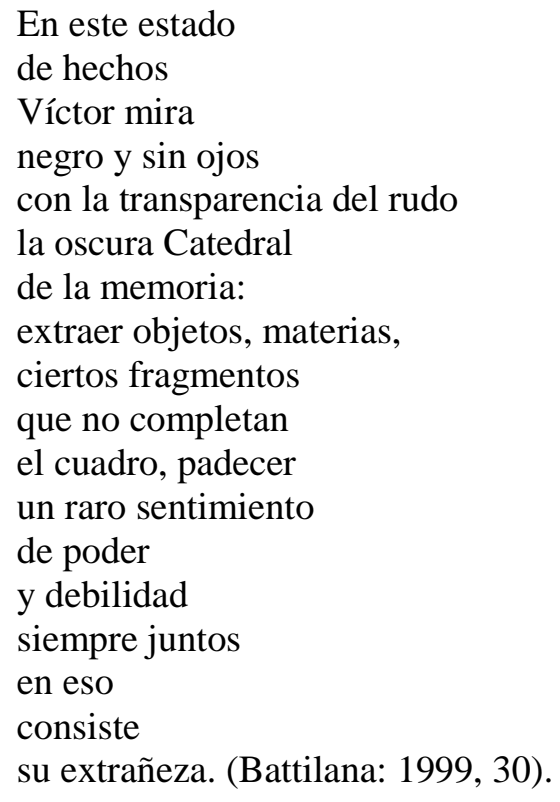

Como se ve, la mirada no se posa sobre la realidad sino que aquí se mira "sin ojos” hacia adentro de la memoria misma, que remeda una gran estructura de signos a descifrar. Pero, de nuevo, todo lo que de allí puede extraerse son "fragmentos”, y aparece nuevamente la imposibilidad de “completar el cuadro”, como si el poema, igual que el recuerdo, fuera siempre un fragmento de algo mucho mayor que resulta inaccesible. Por eso se repite varias veces en el libro la idea de que se recogió poco (“y no pude más que recoger/ la presencia del viento”; Battilana: 1999, 32; “Has recogido poco”; Battilana: 1999, 33). ${ }^{159}$

\footnotetext{
${ }^{159}$ Es interesante anotar que la concepción de la poesía que hemos rastreado en los poemas de Battilana coincide con su modo de leer críticamente la obra de Juan Manuel Inchauspe en un texto crítico que figura en la edición de sus obras completas, donde Battilana dice que Inchauspe concibe al lenguaje "como una entidad fantasmática, casi inasible, de la que se recoge, sin
} 
Y si en el último poema de Battilana citado se mira "sin ojos" "la oscura Catedral de la memoria”, en “naturaleza” de José Villa son las cosas las que miran, al igual que en "Correspondencias" de Baudelaire. Este traslado de la mirada es central para rastrear el procesamiento del simbolismo que se lleva a cabo, aludido en otro poema del mismo libro desde un título que plantea una estilización, "mallarmeana”: "Pone la cebolla en la sartén/ demasiado segura de que es invierno/ demasiado temerosa del olor que se lleva su pelo/ de la consagración que humildemente/ la perfuma. Sabe y no/ que cocina/ que los círculos blancos de la cebolla/ pronto estarán dorados” (Villa: 1998). En este caso, la estilización supone un desvío porque es obvio que “mallarmeana” no imita la escritura de Mallarmé sino que más bien evoca, a partir de una escena cotidiana y de elementos muy concretos, esa sugerencia de un estado, en tanto la mujer que cocina “sabe y no” sabe lo que está haciendo. En ese no saber o saber a medias, que también estaba explicitado en "naturaleza", los objetos y las escenas parecen no poder ser nombradas directamente. ${ }^{160}$

No podríamos decir, sin embargo, que esta relación entre poesía y misterio adopte en la producción de Battilana o Villa un sesgo idéntico al que tenía en el simbolismo. Sin embargo, sí podríamos pensar que el "misterio" no es lo que explícitamente se elude en sus poemas. Si retomamos la lectura que Daniel García Helder hace de “Coloquio de los Centauros” de Rubén Darío, la diferencia se torna más clara. Porque en “Sobre la corrupción”, tal como lo analizamos en el capítulo anterior,

embargo, un eco lejano en el plano de su materialidad ("Lo que quiero decir/ casi siempre me es escamoteado”)”. Ver Carlos Battilana, “Juan Manuel Inchauspe: la oscura atención”, en Juan Manuel Inchauspe, Trabajo nocturno. Poemas completos., Santa Fe, Universidad del Litorial, 2010 (257).

160 Dice Mallarmé en “A Léo d’Orfer. 27 de junio de 1884”, Cartas para la Poesía, Caracas, Fundación Editorial el perro y la rana, 2008. Selección, traducción, prólogo y notas de Rodolfo Alonso: "La Poesía es la expresión, por el lenguaje humano llevado a su ritmo esencial, del sentido misterioso de los aspectos de la existencia: ella dota así de autenticidad a nuestra permanencia y constituye la única tarea espiritual” (105). 
aparecen, nítidos, los objetos, los pescados en los mostradores del puerto, pudriéndose al sol, y el sujeto dice "no me conviene interpretar mensajes en nada” (García Helder: 1990, 43). En los poemas de Battilana, en cambio, los objetos pierden nitidez, aparecen a partir de fragmentos y además, lo que se lee como un leitmotiv es la imposibilidad del sujeto de interpretar y no la decisión o la inconveniencia de hacerlo. El cruce de objetivismo y simbolismo en Battilana se lee como resolución distinta del problema de la percepción y, en este sentido, como puesta en suspenso de aquello que funciona como certeza en la poesía de Prieto y García Helder: que la sola presencia de los objetos basta en el poema.

Por su parte, en el libro anterior a ocho poemas de Villa, Cornucopia, ${ }^{161}$ el conocimiento de los objetos (que son todos frutos) integra de otra manera la tradición simbolista, mediante la expansión de imágenes que rodean a cada uno de los frutos hablando más que del objeto en sí, de un estado, o un campo sensorial en expansión permanente. La operación no puede ser más distinta a la de los objetivistas, que buscan un lenguaje ajustado a la percepción y sintético (idea que también comparte la poesía de Battilana, como hemos visto). Así, la nominación en Cornucopia se limita al título de cada uno de los poemas: "Peras”, "Moras”, "Higos”, "Melones”, etc. Lo que sigue a la nominación es más bien el exceso del lenguaje, como puede verificarse en "Sandías":

Sobre la madera que se hincha, yacen, blancas, veteadas, marrones, las semillas, junto a los restos del glaciar-esponjosos trechos-. Tus dedos suelen tocar la perfección, querer, absorber la pequeña concavidad, completa, real. Y se enfrían las partes tajeadas, o reposan en un inquebrantable atardecer, casi impresente, construcciones de arena, hilos que hacen tic tac. Pero, insinuaciones, muchas nubes pasan sobre ellas (las sandías, no leer). Hojas tenues les hacen grabados en sombra. Se ven oleadas grafías en la cáscara. (Villa: 1996).

${ }^{161}$ José Villa, Cornucopia, Buenos Aires, Trompa de Falopo, 1996. La edición no tiene números de página. Todas las citas posteriores están tomadas de la misma edición. 
El objeto, la sandía, aparece rodeado de adjetivos que van rodeando también sus cualidades. Así, abre el poema e inmediatamente, como si la proliferación de atributos no fuese suficiente, aparece la imagen: la sandía, ya cortada, se asimila a los restos de un glaciar y enseguida esta analogía se desdobla en otra imagen que ya depende de la primera, “esponjosos trechos”. En realidad, el poema no trabaja desde la comparación: no se trata tanto de decir que la sandía parece un glaciar como de sugerir que la imagen es el modo elegido para nombrarla o para dar cuenta de la imposibilidad de nominación. ${ }^{162}$ Este poema es ejemplar en ese sentido, porque hay un paréntesis, en el noveno verso, que “prohíbe” de algún modo la nominación “(la sandía, no leer)”. La frase puede pensarse como una indicación al lector que reenvía a la escritura de Villa y que podría traducirse como el mandato simbolista: sugerir mediante el lenguaje, insinuar, como lo hacen las nubes en el verso octavo.

Cornucopia es, como dijimos, un libro en el que cada poema tiene como centro un objeto, un fruto, pero el armado de la imagen pareciera indicar el borramiento de ese objeto o, para decirlo de otro modo, la preeminencia del lenguaje sobre el mismo. Así, la sandía será nombrada como “la perfección” o “la pequeña concavidad” y se dice que esto es "real". El ejercicio de hacer foco en el objeto puede ser extremo (cuando se alude a las semillas, la tajada de sandía, su cáscara), pero suele estar mediado por la luz (o por imágenes visuales que extrañan el objeto): “Hojas/ tenues les hacen grabados en sombra. Se ven oleadas/ grafías en la cáscara.”. Lo que se ve, como en la poesía de Battilana, tiene la forma de un signo, un grabado, una grafía. ${ }^{163}$ Pero la poesía de Villa detiene directamente la posibilidad de nombrar (de hecho, en "naturaleza" se trataba de

\footnotetext{
${ }^{162}$ Cuando se usa en Cornucopia la comparación directa, suele plantearse como condición y no como necesidad, tal como se ve en "Duraznos": "El cielo, si tuviéramos que/ comparar, lo haríamos con un fuego envolvente cuya/ sustancia sería ligera y cortante.”

${ }^{163}$ En este mismo sentido podría leerse "Uvas”, también de Cornucopia: “Las uvas aparecen,/ altas, y el hombre las mira con intervalos abruptos, como/ desviándose de su ruta: unas líneas de hilo rojo,/ con números, tachaduras, signos que los modifican.”
} 
una fruta que no sabía su nombre),y además omite la interpretación inclinándose sin lugar a dudas por la apertura de campos sensoriales que mezclan los objetos con la experiencia de los sujetos. Si en “mallarmeana” no podríamos decir a quién corresponde el adjetivo que puede referirse tanto al poema como a la mujer que cocina o a la cebolla misma, en "Sandías” no podemos decir con claridad si las “construcciones de arena” y los "hilos que hacen/ tic tac" son imágenes de la fruta o del atardecer porque todo aparece bajo la forma de un paisaje de la percepción.

Por eso la importancia de la luz en la poesía de Villa, que da cuenta de un impresionismo que interesaba también a los poetas simbolistas, tal como lo explica Ballakian $^{164}$ (ver nota al pie): “Todo el éter/ Nos atraviesa por la galería/ En la oscuridad encendemos/ Un fósforo/ Vemos/ Un éxodo infinito” (Villa: 1992, “éter”); "El jugo de la savia cristalina irriga las/ hojas, se inyecta en la fruta y le da esa clara intensidad” (Villa: 1996, “Duraznos”). Los objetos suelen verse a través de ciertos velos, sombras como en este caso, o brumas. La luz y los objetos incluso aparecen asociados, como en una misma red: "Y el balanceo caliente de una hojas. Mientras,/ más pesados, espectros estallantes, resplandecían/ las partículas más claras -los limones- y se cifraba el paisaje/ en un código secreto.” (Villa: 1996, “Limones”).

Así como las sandías se describían a modo de extraños paisajes, aquí se habla de los limones como parte de un paisaje cifrado, secreto. Entonces, no se trata de objetos nítidos (aún cuando pueden ser nombrados, mencionados) sino justamente de objetos que se abren en campos de imágenes que los rodean (todas ellas asociadas a los sentidos) y de una relación peculiar entre el sujeto y el objeto, ya que unos se funden o confunden con otros. La idea de "misterio" se plantea con mayor claridad en la poesía

\footnotetext{
${ }^{164}$ Ver Anna Balakian, El movimiento simbolista, Madrid, Guadarrama, 1969. Allí la autora comenta que fue Mallarmé el primero en interesarse en la pintura impresionista y aborda la relación entre ésta y el simbolismo (sobre todo el simbolismo belga).
} 
de Villa que en la de Battilana, porque efectivamente en ella hay un secreto, algo que los objetos cifran. Pero si la Battilana elige decir todo el tiempo que hay algo inasible y eso surge en el poema como falta, como incompletud permanente del objeto y también de la mirada, Villa propone otra solución (que es la marca de su separación con el objetivismo), la de la sugerencia del lenguaje como único modo de descrifrar ese secreto o de adentrarse en ese “misterio”. Este tratamiento del lenguaje en la poesía de José Villa es lo que llevó a Prieto y García Helder a calificarlo como "lírico”. ${ }^{165}$ Sin embargo, la clasificación parece poco clara; lo que sucede más bien es que los textos de Villa (como los de Battilana) ejercen un cruce casi inédito en la década entre objetivismo y simbolismo, que funciona como lectura crítica del primero y sobre todo de su apuesta por la capacidad del lenguaje para nombrar los objetos.

\section{3- Procesamientos de la tradición en Relación a lo LOCAL Y COTIDIANO: RUBIO, ORTIZ, DÍAZ, RAIMONDI}

En una operación inversa a la que acabamos de analizar, en la que los referentes se desdibujaban al quitarles precisión mediante recursos verbales que tienden a difuminar los sustantivos, otro grupo de poéticas da un paso más allá en la búsqueda de precisión referencial que retoma del objetivismo. Porque si Martín Prieto, Fabián Casas

\footnotetext{
${ }^{165}$ Daniel García Helder y Martín Prieto hablan de poesía lírica en relación a Villa y a Osvaldo Aguirre; ver "Boceto $\mathrm{N}^{\circ} 2$ para un... de la poesía argentina actual”, Punto de Vista, $\mathrm{N}^{\circ}$ 60, abril 1998 (17). Por su parte, Ana Porrúa dice: “Aunque parezca una contradicción, la poesía de José Villa podría definirse como un objetivismo simbolista o esteticista. La naturaleza, las cosas, abren campos sensoriales que sugieren estados de la experiencia, modos de la temporalidad y la memoria y cada poema está trabajado como si se tratase de una joya: el escritor es un orfebre de las sensaciones (...)”. Ver “Campos de prueba”, en Caligrafía tonal, Buenos Aires, Entropía (216).
} 
y Daniel García Helder trabajaban un lenguaje referencial al tiempo que intentaban, como vimos, dejar constancia de las coordenadas espacio-temporales en que se situaban los poemas, Alejandro Rubio, Mario Ortiz, Marcelo Díaz y Sergio Raimondi toman esta misma actitud de los objetivistas: la de hacer una poesía no abstracta ni “universal” sino situada en relación a una cultura y, como dijimos, a una época y un lugar geográfico, no solamente a partir de la lengua sino de un uso de la referencialidad que diseña un espacio preciso.

Pero en ellos, y muy especialmente en Ortiz, Díaz y Raimondi, nacidos y residentes en la ciudad de Bahía Blanca, se agrega un interés especial por diversas modalidades de lo que llamaremos "lo popular" tal como lo entiende Michel De Certeau, antes de hacer especificaciones en cuanto al significado que el término adquiere en el caso de cada poeta. Para De Certeau, lo popular no está dado tanto por sectores sociales dominados que produzcan sus propias manifestaciones culturales (relatos, leyendas, canciones, bailes y comidas, etc., es decir, todo aquello que se designa generalmente como "folclore”) ni mucho menos por aquellos productos del mercado cultural que puedan estar dirigidos a un público que se homologue con el “pueblo". ${ }^{166}$ Antes bien, la cultura popular se define sobre todo a partir del uso y se formula esencialmente en "artes de hacer" esto o aquello a nivel cotidiano, "es decir, en consumos combinatorios y utilitarios. Estas prácticas ponen en juego una ratio 'popular’, una manera de pensar investida de una manera de actuar, un arte de combinar indisociable de un arte de utilizar. ${ }^{167}$

\footnotetext{
${ }^{166}$ Para un seguimiento de la cuestión de la "cultura popular” y muy especialmente del populismo en la literatura argentina desde Tuñón hasta Puig, ver Miguel Dalmaroni, "La injuria 'populista' (episodios literarios de un combate político)”, en La palabra justa. Literatura, crítica y memoria en la Argentina. 1960-2002, Mar del Plata, Editorial Melusina, 2004 (13-48).

${ }^{167}$ Michel de Certeau, La invención de lo cotidiano I. Artes de hacer., México, Universidad Iberoamericana, 2000 (XLV).
} 
Este interés por la noción de “uso" vale tanto para las representaciones que figuran en los poemas como para el modo en que estos poetas se vinculan con la tradición. Porque el acento en lo popular está acompañado por un gesto que es la contracara de la misma actitud: el de pensar la tradición como un objeto que no existe en abstracto, en el plano ideal, sino que se define como tal a través de apropiaciones y usos que son siempre situados. Se trata de un gesto que retoman de Leónidas Lamborghini, en primer lugar, y de su poética como máquina de procesar tradiciones siempre desde una lectura desviada que Daniel Freidemberg definía, a partir de Franz Fanon, como un modo de trabajar con lo dado desde la cultura dominante para transformarlo. ${ }^{168}$ Pero también de García Helder, quien como vimos ponía en escena, tanto en sus poemas como en los artículos críticos del Diario de poesía, un modo de leer la tradición contrastándola siempre con un estado actual de la cultura y de la lengua.

Además se trata, en todos los casos, de abrir el discurso poético para cruzarlo con otros discursos, ámbitos del saber y prácticas de vida cotidiana, como son los medios de comunicación en Alejandro Rubio, el discurso periodístico y las prácticas artesanales populares en Marcelo Díaz, la teoría y la historia literarias en Mario Ortiz, y la historia, la economía y el trabajo artesanal en la poesía de Sergio Raimondi. Así, mientras otras poéticas de los noventa, y sobre todo las que analizaremos en los capítulos IV y V, construyen una temporalidad que se define como "puro presente", en el caso de Rubio, Ortiz, Díaz y Raimondi el poema se constituye verdaderamente como “montaje de tiempos heterogéneos”, para decirlo con Didi-Huberman, ${ }^{169}$ porque las citas de la tradición se combinan en el poema con usos verbales que provienen del

\footnotetext{
${ }^{168}$ Ver Daniel Freidemberg, “Leónidas Lamborghini”, en Dossier Lamborghini, Diario de poesía $\mathrm{N}^{\circ}$ 38, Invierno de 1996 (14).

${ }^{169}$ Georges Didi-Huberman, Ante el tiempo, Buenos Aires, Adriana Hidalgo, 2006 (26).
} 
lenguaje oral, y también con representaciones del presente más inmediato y cotidiano que incluyen a la cultura popular.

Este modo de construir el poema como espacio donde el presente convive con fragmentos escamoteados a la historia literaria, desde figuras y motivos como el cisne modernista y el ruiseñor de la poesía romántica hasta usos verbales característicos de un estilo, ya sea el lenguaje neobarroco o el registro lírico, lo plantea verdaderamente como un "objeto de tiempo complejo, de tiempo impuro: un extraordinario montaje de tiempos heterogéneos que forman anacronismos” (Didi-Huberman: 2006, 19). Con este montaje, “todo el abanico del tiempo se abre ampliamente” (Didi-Huberman: 2006, 22), y es allí precisamente donde se debe hacer foco para leer el modo en que cada uno de estos poetas se posiciona con respecto a la tradición, siempre a partir del uso.

El modo de García Helder de evaluar críticamente la tradición en los propios poemas también funciona en estas poéticas, por eso Alejandro Rubio abre Música mala, su primer libro (prologado por García Helder), con un poema llamado "La canción de Bedoya”, que constituye una parodia del neobarroco. El poema comparte algunos rasgos con la lectura que García Helder efectuaba en "El neobarroco en Argentina”, y en cierto punto puede leerse como la realización satírica de algunos de los postulados de García Helder. En este caso, la sátira está dada por el hecho de que se extrema la carnalidad verbal del neobarroco al mezclarlo con motivos pornográficos: “Composición tema, La Obra: hilillos nada más,/ hilillos de la lengua, blanquitos, como vetas/ del texto que al develar/ defenestran: a los cuerpos. Llenos,/ vacíos, llenos /vacíos, llenos/ y vacíos, se los enjuaga, a ellos,/ en la corriente, lodosa, de la/ lengua.” ${ }^{170} \mathrm{El}$ comienzo del poema remeda como se ve una composición escolar, poniendo de relieve la artificialidad de escribir sobre “La Obra” con mayúsculas, y haciendo del uso lúdico del lenguaje propio

\footnotetext{
${ }^{170}$ Alejandro Rubio, Música mala, Bahía Blanca, Vox, 1997 (9). Todas las citas posteriores están tomadas de la misma edición.
} 
del neobarroco un ejercicio que tendría la misma esterilidad y el carácter rutinario de las composiciones de un alumno de primaria.

Para ponerlo en otros términos, desde el comienzo del poema se señala al neobarroco como una retórica ya cristalizada que permite ensayar una versión donde se imite ese estilo a conciencia, versión que deviene parodia cuando el fluir barroco se describe un poco más adelante como “carnicería general/ de la lengua” (Rubio: 1997, 9), y sobre todo cuando se lo interrumpe para hacer ingresar versos de este tipo: “Bedoya, cantan afuera los niños,/ nimios: chupame la polla. Y yo/ aquí.../ entre alcanfores. Truena el trueno sobre el trono,/ trota en el potro la Tota, los baguales y alazanes,/ en efecto, corvan la corva” (Rubio: 1997, 9, 10).

Aquí, al hacer explícito lo que el neobarroco velaba todo el tiempo y convertir el erotismo en pornografía (“chupame la polla”), y mediante el uso degradado de la rima ("Bedoya” se hace rimar con "polla”), se trata de desmontar al neobarroco reponiendo de modo brutal el cuerpo (nótese que al principio del poema se sugería que el develamiento de los cuerpos efectuado por este movimiento en realidad lo “defenestraba”). El texto pasa entonces a evidenciar que la voz que habla corresponde a una travesti, en estos versos que contienen una alusión directa a los poemas de Néstor Perlongher y resonancias más directas del lenguaje empleado en "El fiord” de Osvaldo Lamborghini: ${ }^{171}$ “¿Quién es? La Tota. ¿Qué Tota? La Tota que te parió./ Ah, el traba. Pasá, traba. Vos que te relamés/ el labio lábil, con el lápiz lapislázuli/ reponés lo consumido, entrás vestida de nada/ y enseñando un seno entonás: Bedoya, ah,/ Bedoya, Bedoya, Bedoya, Bedoya,/ Bedoya: chupame la. No. Sí. No. La Tota,/ abierta, toma entres sus manos las pelotas,/ puerca, con su lengüita de hilillos moja/ y mama. (Rubio: 1997, 10).

${ }^{171}$ Osvaldo Lamborghini, “El fiord”, en Novelas y cuentos I, Buenos Aires, Sudamericana, 2003. 
Lo que Perlongher designaba como “neobarroso” refiriéndose a una variante rioplatense del barroco que "enfrenta una tradición literaria hostil, anclada en la pretensión de un realismo de profundidad que suele acabar chapoteando en las aguas lodosas del río”, ${ }^{172}$ aquí se pone de manifiesto como preciosista en contraste con el lenguaje obsceno (“chupame la”), el uso de un sobrenombre popular como “Tota”, y una operación que tiende a reemplazar el cuerpo "textual” con el que trabaja el neobarroco, para el que "lengua" se refiere sobre todo al lenguaje, por un cuerpo explícito y sexuado cuya lengua es efectivamente el órgano con el que practica sexo oral (“puerca, con su lengüita de hilillos moja/ y mama”).

El poema puede leerse como resolución poética de lo planteado por García Helder en su artículo sobre el neobarroco del Diario de poesía, ${ }^{173}$ que analizamos en el capítulo anterior, pero la variante de Rubio opera de modo directo sobre el discurso poético de Perlongher desde un uso desviado que funciona como otra modalidad de la crítica. Porque si Roberto Echavarren describe la producción de Perlongher, en el prólogo a sus Poemas completos, como "una investigación desenfrenada de las posibilidades de gozar con las palabras" que sustenta una "poética del enchastre”, ${ }^{174}$ en Rubio ese goce con el lenguaje se convierte en goce del cuerpo y el "enchastre” es directamente la saliva sobre un miembro sexual en el que la travesti "Mama y leche”, como se dice poco después (Rubio: 1997, 10).

Al mismo tiempo, sobre este estilo en el que, también en palabras de Echavarren, "la sobreabundancia es compatible con el doble o triple sentido" (Echavarren: 1997, 7), Rubio efectúa una reducción que precisa el sentido de manera

\footnotetext{
172 Néstor Perlongher, “Neobarroco y neobarroso”, Prólogo a Medusario, Muestra de poesía latinoamericana., Buenos Aires, Mansalva, 2010 (22).

${ }^{173}$ Daniel García Helder, “El neobarroco en Argentina”, Diario de poesía No 4, Otoño de 1987 $(24,25)$.

${ }^{174}$ Roberto Echavarren, "Prólogo", en Néstor Perlongher, Poemas completos, Buenos Aires, Seix Barral, 1997 (7, 8).
} 
inequívoca, como puede verse en la frase “chupame la polla”, empleada tal como se lo hace en el lenguaje oral. A la multiplicidad de sentido se opone en este caso un sentido único porque así es como funciona el lenguaje obsceno, incluso cuando es eufemístico, y este dato puede explicar la elección de combinar al neobarroco con lo sexualmente explícito. Además, el poema trabaja con el diccionario neobarroco (cuando usa palabras como “lapislázuli” o “ánade”) ${ }^{175}$ también para señalarlo como un modo de nombrar ya perimido, en los versos que dicen "en días claros se ve nadar todavía/ al ánade, ya casi pato, habiendo echado ya/ los bofes el bagual” (Rubio: 1997, 10). El término “ánade”, que aparece reiteradamente en Perlongher al punto de que tiene en su poesía una tipicidad equivalente a la del cisne modernista, ${ }^{176}$ se usa aquí de modo referencial para decir que ese "ánade” se convierte gradualmente en "pato”, mientras que el "todavía” sitúa a ese “ánade” como un remanente del pasado.

El “neobarroso” de Perlongher suponía ya una “degradación” (en ese “enchastre” al que se refería Echavarren) del lenguaje metafórico, que se usaba en su aspecto material, y muchas veces trabajaba con elementos "bajos", como cuando al cisne, motivo por antonomasia del modernismo, se lo pone a hervir en una olla: "el halo de una olla, donde hierve/ cisne de entrañas escarbadas y heces/ dispersas en un mazo”, dice el poema de Perlongher “Anade, caracoles” (Perlongher: 1997, 98). Aquí se repone una corporalidad al cisne al nombrar sus “entrañas” y sus "heces”, pero desde la

\footnotetext{
${ }^{175}$ También en "Frenesí": "Campanuela de telgopor y el frunce de la "imitación seda”, tildaban lentejuelas los breteles, esmirna, pirca de lapislázuli, carmelo, cortióla rompiamor el encaracolado calacrí”, etc. En Néstor Perlongher, op. cit., (105). Del “diccionario” neobarroco de Perlongher Rubio recorta, como es evidente, dos de los términos más infrecuentes en español y por lo tanto "exóticos", sobre todo al ser contrastados con los términos coloquiales que aparecen en Música mala.

176 "Anade” figura por ejemplo en el poema titulado "Anade, caracoles”, cuyos versos finales trabajan exclusivamente con la sonoridad del término al rimarlo con "jade": "Anade/ Jade", y en "Frenesí”, donde un fragmento dice "ganglio del ánade (no es metáfora)" (Perlongher: 1997, 99 y 105 respectivamente). Si bien el texto de Perlongher postula un uso no metafórico del término, la proliferación verbal diluye toda posibilidad de referencialidad realista.
} 
perspectiva de Rubio éstas no serían más que formas de seguir sin nombrar al objeto, porque no es difícil imaginar que donde Perlongher dice "heces” Rubio hubiera dicho, sin más, "mierda” (de hecho su segundo libro, Metal pesado, comienza con el siguiente verso: “Me recontra cago en la rechota democracia”). ${ }^{177}$

Además, sobre el final del poema, así como el "ánade” deviene "pato”, "La Obra” que figuraba al principio como modo de hacer alusión a la producción escrita de un autor-creador (con la idea de sacralidad que ello implica, puesta de relieve aquí por el uso de mayúsculas) cambia de sentido, también, cuando se dice: “llegó la hora, llegó el material,/ llegó la factura, llegaron/ a hacer pata los obreros, llegó./ La Obra” (Rubio: 1997, 10). En este texto, la palabra “Obra” se resignifica para designar una obra en construcción que involucra "materiales” y sobre todo trabajo a cargo de obreros que llegan a "hacer pata”, un lunfardismo que equivale aproximadamente a “acompañar”, con lo cual el discurso poético neobarroco es llevado sobre el final del poema a una alusión que puede leerse como peronista en la medida en que ese "hacer pata” comporta también resonancias del “las patas en la fuente” (el peronismo y lo popular son centrales en la poética de Rubio y también en su modo de procesar la tradición, como veremos).

Este primer poema de Música mala que desmonta el discurso neobarroco reponiendo cuerpos allí donde se trataba ante todo de “cuerpos” textuales debe leerse en relación al segundo poema del mismo libro, porque la sintaxis que propone el ordenamiento de los textos es elocuente con respecto a las razones parciales que motivan la impugnación del neobarroco. El poema se llama "La información”, y representa a una familia que mira televisión: "Martes cuatro, la ley nueva/ todavía se discute, 99 por ciento/ de humedad. El depto huele a coliflor,/ en cientoveinticuatro planchas la grasa/ crepita, las familias se desplazan hacia la mesa/ y juegan con el

\footnotetext{
${ }^{177}$ Alejandro Rubio, Metal pesado, Buenos Aires, Siesta, 1999 (9). Todas las citas posteriores están tomadas de la misma edición.
} 
cuchillo, el tenedor, el vaso, la cuchara./ Estoy liquidado. Mi hijo también” (Rubio: 1997, 11).

La materialidad neobarroca y puramente lingüística del primer poema (aunque presente desde un uso paródico que la señala como anacrónica) deja lugar abruptamente a una escena que presenta una materialidad de una clase muy distinta en un paisaje de decadencia: la humedad, los olores desagradables de la comida, la pasividad frente al televisor. Más adelante, el poema dice “yo mismo edifiqué/ un bunker en el living; sentados atrás/ de la metra soviética miramos todo el día/ televisión por cable” (Rubio: 1997, 11). La representación de la familia encerrada en un departamento en el que no hace más que mirar televisión y quedarse “mordiendo comida fría” como dice el último verso del poema, es parte de una imagen desencantada del presente que surge de los libros de Rubio. Pero lo importante es que semejante representación -puede pensarse si se contrapone este poema con "La canción de Bedoya"- es imposible de elaborar a partir de los procedimientos y el discurso neobarroco.

Por el contrario, Rubio construye en los poemas escenas y personajes de extracción popular, e incluso figuras de poeta, que apelan a diversos segmentos de tradiciones que se resignifican en el presente. En Rubio, como en García Helder, la ciudad es una paisaje en ruinas: "La capital del Suroccidente es ahora una grande y hermosa/ ruina; entre pilares/ de monumentos fachosoviéticos se pasean filigranas/ humosas, turistas, periodistas, carteristas,/ animales de una y tres patas” (Rubio: 1997, 13). Este poema se titula irónicamente "La vida y el canto” y señala que el lugar de la poesía entendida como "rapsodia”, con sus connotaciones proféticas, es también entre las ruinas: "Los rapsodas ciegos/ se recuestan en vergeles virtuales y chuponean cigarrillos/ virtuales, es así, el viento tañe solo entre las hojas./ Está el ritmo, las letras, 
partes sueltas/ de melodías, arreglos mil, pero ante el público/ se les traba la lengua, callan, dicen no saber,/ no poder, no querer” (Rubio: 1997, 13).

Como se ve, lo que permanece de la tradición son "partes sueltas” que de poco sirven en el presente para que esos poetas que se representan como "rapsodas ciegos" construyan un saber. La mención a los “rapsodas” también es un anacronismo porque cita una figura de la tradición griega asociada al don de la profecía y el canto, sólo que aquí son “ciegos”. Y esas “partes sueltas” figuran en el poema como fragmentos de la lírica que son, lo mismo que la ciudad, ruinas. Porque en el paisaje de decadencia que retrata, el poema dice que "el viento tañe solo entre las hojas" y se habla de "filigranas" y “vergeles” (Rubio: 1997, 13), con lo cual se pone en escena un lenguaje “elevado” que poco se condice con la representación de la ciudad, y que contrastado con otros usos verbales como "monumentos fachosoviéticos” y “chuponean cigarrillos” se revela como desfasado temporalmente.

El poema funciona entonces como espacio en el que se ponen a prueba los lenguajes y figuras de la tradición, y los anacronismos adoptan un tono satírico porque resaltan la pobreza de un presente de ruinas que es todo menos "vergeles". Por otra parte, la figura de los poetas como "rapsodas” los construye como contemporáneos y al mismo tiempo remanentes de un pasado que es de poca utilidad en el presente, ante el que estos poetas “callan” y “dicen no saber,/ no poder, no querer”. La poesía entendida como "rapsodia”, entonces, se señala como imposibilitada para construir un discurso que funcione en la actualidad, que pueda decir algo de valor sobre el presente.

Incluso en un poema de Metal pesado llamado significativamente "Crisol” (como modo eufemístico y tradicional de aludir en Argentina a una cultura híbrida e inmigratoria) donde hay turistas brasileros, inmigrantes paraguayas y dominicanas y el 
poeta habla desde una "pocilga posmo", ${ }^{178}$ se sugiere la pobreza de una tradición de la que sólo quedan descartes: "De las cenizas rescaté/ magras figuras: un gaucho,/ Perón sobre un caballo pinto,/ una negra barriendo la vereda/ con los ojos de gato abiertos/ al sol decadente” (Rubio: 1999, 58). No sólo las imágenes son “magras” sino que además se rescatan de las cenizas, como si se estuviera viviendo después de una destrucción, lo que indica tanto la pobreza del país como la de una tradición resumida en unos pocos estereotipos.

Y sin embargo, es con esas “partes sueltas” que Rubio construye sus poemas. De hecho en este último poema citado se alude a la gauchesca, al peronismo y a la figura del inmigrante, todos elementos que traman su poesía. En "Romance”, por ejemplo, "La refalosa” de Hilario Ascasubi se usa para armar una escena de bailanta en Tropicana: "se trenzan, caen, se levantan, caen, patinan, pisan/ pedazos de bazo, segmentos sueltos/ de intestino; pierden, hacen ochos,/ sietes y nueves, se reviran y refalan/ en la sangre” (Rubio: 1997, 17). Pero mientras que el texto de Ascasubi le daba voz a la violencia política en el mazorquero federal que enuncia el poema, ${ }^{179}$ en este caso el texto se hace cargo de una mirada que muestra a las clases bajas como "salvajes", responsables de una pelea y de un "enchastre” muy distinto al neobarroco, que después “viene la patrulla y limpia,/ viene la ambulancia y limpia” (Rubio: 1997, 17). Esa misma mirada se caracteriza como “amarillista” en el poema cuando el que habla se llama a sí mismo en tercera persona “el cronista de Crónica”. De esta manera, lejos del “realismo” al que alude el principio del poema, ${ }^{180}$ el texto se hace cargo de la artificialidad de una mirada que pone el acento en la decadencia, la suciedad y hasta la "barbarie". Lo que hay,

\footnotetext{
${ }^{178}$ Alejandro Rubio, Metal pesado, Buenos Aires, Siesta, 1999 (55). Todas las citas posteriores están tomadas de la misma edición.

179 “La refalosa”, en Hilario Ascasubi, Paulino Lucero, Buenos Aires, Estrada, 1945.

180 "porque el realismo social nos cagó,/ nos trató como a tarados, y para realismo/ mágico, bueno, en fin, mejor/ el de Tropicana: es mejor, más real,/ visceral” (Rubio: 1998, 17).
} 
entonces, es una amplificación de las imágenes de decadencia que ya estaban en García Helder, pero que acá pasan a ocupar la totalidad de los poemas.

Así aparece también el repertorio de imágenes del peronismo, en otro texto que retrata a una familia que desciende de un "tano picapedrero" y se dice que "vimos el futuro donde el piso es de parqué/ y rompemos el parqué pa que se dore más lindo/ la pielcita de la vaca que nos vamos a lastrar” (Rubio: 1997, 20). Como se ve, Rubio trabaja sobre figuras que forman parte de la mitología popular, en este caso como devolución del lugar común antiperonista, porque esa imagen en el poema forma parte de un "futuro", con lo cual se carga trágicamente de sentido utópico a un motivo que proviene de un pasado, y sobre todo un presente, de fracaso (la versión del peronismo que es contemporánea a la escritura del poema es por supuesto el menemismo). De hecho este repertorio también se actualiza con imágenes del presente, en especial porque el centro alrededor del cual se mueven estos personajes signados por la “infrahumanidad”, como señala García Helder (Rubio: 1997, 28), y como vimos en el poema “La información”, es la televisión como basura:

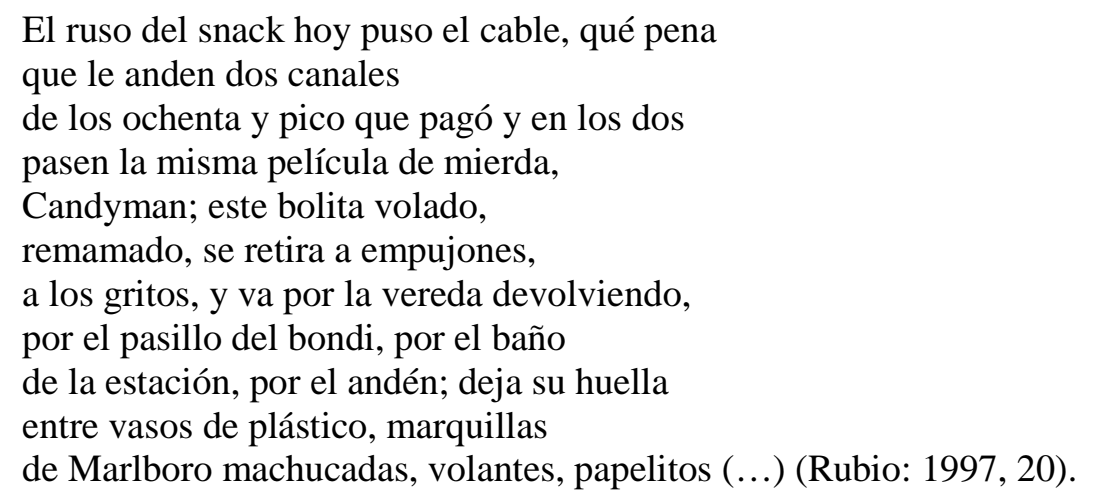

El ámbito donde se sitúa el fragmento es característico de los noventa: se trata de un snack bar, esos locales icónicos de la década menemista que reúnen el quiosco y el bar bajo grandes vidrieras y luces de neón y que muchas veces funcionan durante las veinticuatro horas, por lo que se convierten en refugio de los que están de paso y en ocasiones, como el boliviano de este poema, borrachos. Aquí, el desprecio, tanto por la 
televisión (“película de mierda”) como por el inmigrante (“bolita”), está cifrado en usos coloquiales despectivos que son comunes a otros poetas de los noventa como Santiago Llach y Martín Gambarotta, como veremos en el capítulo siguiente, y en la representación de un personaje que se mueve entre basura.

Pero el discurso además se hace eco de una mirada antiprogresista que estereotipa al otro cuando se pide en el mismo texto que los niños "sean como los coreanitos, respetuosos,/ estudiosos, que toman su caramelo/ en lo oscuro del rincón y dicen gracia/ y no se quejan ni escupen: tal es/ la angurria de la plebe inmigratoria” (Rubio: 1997, 21, 22). Como se ve, se trata de recuperar una tradición de representaciones del conflicto social y político que va desde Hilario Ascasubi y la guachesca, pasando por los poemas de Nicolás Olivari hasta el "las patas en las fuentes” de Leónidas Lamborghini y el lenguaje sexualmente violento y explícito de Osvaldo Lamborghini en "El fiord” y "El niño proletario". A estas lecturas puede agregarse como antecedente más cercano la poesía de Daniel García Helder en textos como “Cuerpos de todos los tamaños por donde corre la misma sangre”, ${ }^{181}$ donde se aludía a un padre de familia marginal como un "pony tardíamente alfabetizado".

Pero la particularidad de Rubio es que estas representaciones se construyen desde un discurso que yuxtapone un lenguaje socialmente violento y denigrante con fragmentos (de nuevo, en ruinas) de la lírica. De esta manera, como en "La vida y el canto" se decía que "el viento tañe solo entre las hojas” y se hablaba de "filigranas” y "vergeles" (Rubio: 1997, 13), en otro poema se retrata a una chica que se revienta un grano frente al espejo: "Nena de la casa en su tualé entre gárgolas,/ a cada lado de la nariz, frente al espejo empañado,/ los índices presionan hasta que sale un puntito/ blanco, eyectado, y se estrella y resbala,/ por un hilo de sangre, hasta el lavabo” (Rubio:

\footnotetext{
${ }^{181}$ Daniel García Helder, El guadal, Buenos Aires, Libros de Tierra Firme, 1994 (17).
} 
1997, 15). El comienzo falsamente elegante emplea el término “toilette” tal como se lo pronuncia en español rioplatense (“tualé”) como eufemismo por "baño”, y alude a un mal uso pretencioso del francés que hace juego con el uso posterior del término "lavabo", contrastados ambos con el "mal gusto” de toda la escena. Más adelante, la chica se cosifica al fundirse con un ambiente igualmente sucio: "La línea de cochambre que sube/ desde atrás del horno hasta el cielo raso/ y da una vuelta para bajar, en zigzag,/ hasta su sandalia frutada, debe partir, dice ella,/ de la raya de su pelo” (Rubio: 1997, 15).

El lenguaje de Rubio mezcla “vergeles” y “gárgolas” con “chuponean” y “cochambre”, de modo que la lírica, como señala García Helder en el "Ensayo de lectura de Música mala" que figura al final del libro, "se revela así como lo que históricamente es: algo codificado, degradado, y que por su prestigio hace honor a la parodia” (Rubio: 1997, 27). Por otra parte, lejos de replicar la pobreza que se retrata en la forma del poema, Rubio compone una imagen sofisticada en este último fragmento donde la sintaxis y el corte de verso construyen visualmente el movimiento espacial que describe el poema, en una tensión entre materiales bajos y formas muy elaboradas similar a la que analizamos en los objetivistas.

El poema funciona entonces, como dijimos, a modo de espacio en el que se ponen a prueba los lenguajes, en una filiación evidente con la obra de García Helder (que para la segunda mitad de los noventa ya forma parte del archivo, sobre todo en Rubio y en Raimondi), tanto en el gesto de evaluar los usos idiomáticos en relación al presente como en la construcción de imágenes por momentos cercanas al naturalismo, con la diferencia de que en Rubio los anacronismos adoptan un tono satírico. Porque Rubio, que asume por un lado cierta vinculación con la escritura de Leónidas Barletta, Elías Castelnuovo y Nicolás Olivari en el tipo de imágenes que propone y cuando 
afirma al principio de un poema que “el realismo social nos cagó” (Rubio: 1997, 17) (donde puede leerse una alusión al movimiento que fue conocido en nuestro país como “boedismo”), toma a la vez de Olivari el procedimiento que consiste en tensar formas poéticas con motivos plebeyos y de usar la lírica satíricamente.

Pero si esta decisión formal (que en Olivari se cifraba por ejemplo en el uso de sonetos y cuartetas endecasílabas y en Rubio en un registro verbal "elevado" que proviene de la lírica) tenía en los boedistas, como señala Martín Prieto, la función de posibilitar "un acercamiento político al público popular de Evaristo Carriego o del tango", ${ }^{182}$ en Rubio toma la forma de un elitismo que descree de toda posible conexión con los sujetos que retrata. Por el contrario, si Olivari podía decir en "La dactilógrafa tuberculosa” (a quien también denominaba “pobre yegua flaca”), “esta pobre invertebrada, tiene que trabajar”, ${ }^{183}$ en Rubio no hay lugar para la compasión cuando se trata de aquella "nena de la casa" que se arrastra entre la suciedad y que termina por fundirse con un entorno igualmente decadente (Rubio: 1997, 15). De hecho el uso de la lírica en Rubio tiende sobre todo a poner de relieve lo grotesco de un registro verbal engolado en un presente cuya imagen se le opone.

Y tampoco hay salvación para el poeta, cuya figura, decididamente anacrónica, se sitúa como vimos en la "pocilga posmo" donde el saber no sirve y no parece haber otra opción más que el fracaso. Por eso al final de Música mala se dice que “A partir de ahí no quiso escuchar más nada:/ se guardó, cortó las líneas, se dedicó a regar las plantas/ y, en la sombra su cara de entendido, a leer la revista/ del cable” (Rubio: 1997, 23). Así como en otro poema los que estaban en la sombra eran "los coreanitos" (Rubio: 1997, 21), en este caso se trata del mismo poeta, que de este modo resulta ser también

\footnotetext{
${ }^{182}$ Ver Martín Prieto, Breve historia de la literatura argentina, Buenos Aires, Taurus, 2006 (261).

${ }^{183}$ Nicolás Olivari, La musa de la mala pata, Buenos Aires, Editorial Deucalión, 1956 (29).
} 
un marginal y que opta por el encierro mientras “continuaban afuera/ con la emisión de noticias”, como señala el texto. Por eso en Rubio la escritura y el valor que se le da a la técnica, así como el gesto de recuperar todo el potencial violento y disruptivo de una tradición -popular pero sobre todo, peronista- parecen estar dirigidas no tanto a un público posible, como en Olivari, sino a oponer figuras exasperadas a ese televisor que recorre todo el libro con su ruido constante y que funciona en Rubio como signo de una época. El montaje de tiempos, en Rubio, está dado por contrastar en el espacio del poema la lírica y el neobarroco con el televisor para dejar planteada cuanto menos la inutilidad de esos lenguajes en un presente que es, como el de Leónidas Lamborghini, de derrota política.

Si lo popular se construye en Rubio desde una tradición que pone el acento en la miseria y la violencia, en Marcelo Díaz adopta un signo totalmente opuesto. En principio porque Díaz pone su poética bajo el signo de lo "berreta”, ${ }^{184}$ como lo indica el nombre de su primer libro, pero ese "berreta" se recupera positivamente como parte de una poética que pone el foco en la cultura popular entendida como modos de hacer que operan sobre lo dado para transformarlo (mientras que en Rubio, como vimos, había una pasividad inherente a los personajes representados que rozaba la inercia).

Díaz, que se construye como lector pero se retrata al mismo tiempo en la tapa de Berreta en una cancha de fútbol barrial vistiendo la camiseta del club Villa Mitre de Bahía Blanca, establece claras vinculaciones con el objetivismo, como Rubio, pero desde un recorte que conforma un repertorio distintivo. Porque en este caso se replica el gesto de García Helder (García Helder: 1994, 67-69) de especificar en las “Notas” al final del libro de dónde provienen los materiales que se trabajan (Wallace Stevens, Darío y Baudelaire, entre otros) (Díaz: 1998, 55). Sin embargo habría que marcar una

${ }^{184}$ Marcelo Díaz, Berreta, Buenos Aires, Libros de Tierra Firme, 1998. Todas las citas posteriores están tomadas de la misma edición. 
diferencia, ya que en los objetivistas el paratexto remitía únicamente a la literatura y las artes plásticas, y ahora se incorporan materiales de la cultura de masas que ya se estaban anticipados en Casas. De hecho Berreta comienza con un epígrafe que es un diálogo del programa Yo me quiero casar, ¿y usted? conducido por Roberto Galán (Díaz: 1998, 9); la segunda parte del libro se abre a su vez con un epígrafe del poeta español Leopoldo María Panero en el que se invoca al Capitán Marvel, un superhéroe de comics (Díaz: 1998, 31).

También se recuperan la dicción y la enunciación casi “elevada” de los poemas de Martín Prieto, sobre todo en la primera serie titulada “Once maneras de contemplar un cisne” que es una reescritura de las “Trece maneras de mirar un mirlo” del poeta norteamericano Wallace Stevens. Allí, la brevedad y el modo de organizar la serie proceden de Stevens pero la sintaxis es claramente deudora del objetivismo argentino: "No es improbable/ que una mano fugaz les restituya/ su dudoso esplendor, para ubicarlos/ en un lugar poco visible” (Díaz: 1998, 19), dice un poema que trabaja las comas y el corte de verso de modo similar a Prieto para elaborar una sintaxis que se aleje del coloquialismo (Stevens en cambio no usa comas dentro de un mismo verso ni encabalgamientos, y en general el corte de verso coincide con el del sintagma). ${ }^{185}$

La elección de Stevens, que representa un gesto de apropiación de la cultura dominante, replica a la vez el modo de acceso a la poesía norteamericana del objetivismo, porque procede seguramente de la versión de Raúl Gustavo Aguirre que figura en la antología El movimiento poesía Buenos Aires (1950-1960) en la que se compilan textos de la poesía argentina y “universal”, como señala el índice de esta

\footnotetext{
${ }^{185}$ Ver Wallace Stevens, “Thirteen ways of looking at a blackbird”, en The collected poems of Wallace Stevens, Random House, 1954.
} 
publicación invencionista. ${ }^{186}$ Pero en ese primer conjunto de poemas se establece a la vez una posición respecto de lo popular que plantea una divergencia clara con el objetivismo, donde había por momentos una postura aristocrática, en Prieto, o un cierto desprecio por los sectores bajos, en García Helder. Porque lo que se toma de Stevens es el modo de rodear un objeto en poemas breves que lo enfocan desde distintas perspectivas. Pero si Stevens elegía, para oponerlo a los ruiseñores y alondras de la tradición romántica, un simple mirlo (y en su serie la multiplicidad de perspectivas representaba ya un desplazamiento con respecto a una poesía romántica centrada en un “yo” que no admitía semejante multiplicidad desde el momento en que se pensaba en términos de “verdad”), ${ }^{187}$ Díaz va un paso más allá y propone como objeto el cisne de cemento.

Así, a la carga de sentido que supone pensar la serie como reescritura de Stevens se suma la elección de un objeto que es parte también de una tradición, pero no literaria sino cultural, asociada a una práctica doméstica de clase media y baja que consiste en decorar los patios con un artefacto que puede pensarse como kitsch: una maceta con forma de cisne que simula ser una escultura, y sin embargo utiliza un material degradado, netamente práctico, el cemento, que la sustrae del ámbito artístico para revelarla como parte de una producción en serie de corte industrial. Pero la serie no consiste en un ejercicio pop, por más que la copia se ponga de manifiesto en el título que calca el de Stevens (aunque el reemplazo de "trece maneras” por “once maneras” hace pensar en una pobreza asumida que remite nuevamente a lo "berreta”), porque lo

\footnotetext{
${ }^{186}$ Ver Wallace Stevens, “Trece maneras de mirar un mirlo” (versión de Raúl Gustavo Aguirre), en Raúl Gustavo Aguirre (comp.), El movimiento Poesía Buenos Aires (1950-1960), Buenos Aires, Editorial Fraterna, 1979 (304-306).

187 "Un poema es la imagen total de la vida expresada en su eterna verdad", dice Percy Shelley en su Defensa de la poesía, publicada por primera vez en 1840, en una concepción que evidentemente no contempla la multiplicidad de perspectivas. Ver Percy Shelley, Defensa de la poesía, Buenos Aires, Ediciones Siglo Veinte, 1978 (28).
} 
que se destaca es la intervención artesanal sobre el objeto que se pinta en ocasiones con los colores del equipo favorito (“brutalmente pintados/ de azul y oro”, Díaz: 1998, 15).

Además, la diferencia con las poéticas analizadas en el capítulo anterior es que en este caso el trabajo con el objeto contempla diversos abordajes, que van desde la reescritura del último verso de "El albatros” de Baudelaire ${ }^{188}$ ("Sus alas de cemento le impiden caminar”, Díaz: 1998, 16), la puesta en imagen desde una composición visual similar a la objetivista, en versos que se construyen sobre la base del endecasílabo (“Gruesas hojas de acelga, bajo esta luz,/ y geranios blancos en el lomo del cisne/ y geranios rojos en el cantero, bajo el tendal/ que ahora, ya cercano al mediodía exhibe/ sábanas blancas y sábanas azules”, Díaz: 1998, 15), y el ensayo de contemplación que requiere ajustar la mirada para cambiar el sentido: “Que se vea en él, en ocasiones/ nada más que hierro, piedra y cemento.// Que se vea en él, aunque no siempre,/ cifrada la memoria familiar” (Díaz: 1998, 22).

Por eso el intento de acercarse al objeto por sí mismo no excluye la posibilidad de "leer" en él una memoria que se despliega en otro poema, cuando se habla en “Genealógica” de las fotografías familiares que dan testimonio del paso del tiempo entre generaciones pero a la vez tienen como punto en común "la silueta, borrosa, del cisne de cemento” (Díaz: 1998, 23). En otro poema llamado “Cisne \& sociedad” se lo piensa en relación a otros monumentos de "Rivadavia, Sarmiento o Roca” que "se desdibujan/ en el corazón de una ciudad vencida,/ coloreados con mierda de paloma/ y aerosol azul” (Díaz: 1998, 24) mientras que el cisne de cemento, "Único sobreviviente/ de un país difícil/ en un tiempo difícil”, está pintado “con los oros del campeón” (Díaz: 1998, 24).

\footnotetext{
${ }^{188}$ El último verso de "El albatros" de Baudelaire dice en cambio, refiriéndose al ave, que "sus alas de gigante le impiden caminar". En Charles Baudelaire, Las flores del mal, Madrid, La Nación, 2000 (11).
} 
A diferencia del cisne modernista que podía pensarse como símbolo de pureza y que daba cuenta de una poesía abstraída del mundo cotidiano, el cisne de Díaz condensa en sí mismo ese mundo cotidiano porque pertenece a un ámbito doméstico de extracción popular, y porque en él pueden leerse los modos de apropiación de un objeto que caracterizan las “artes de hacer” de las que hablaba De Certeau:

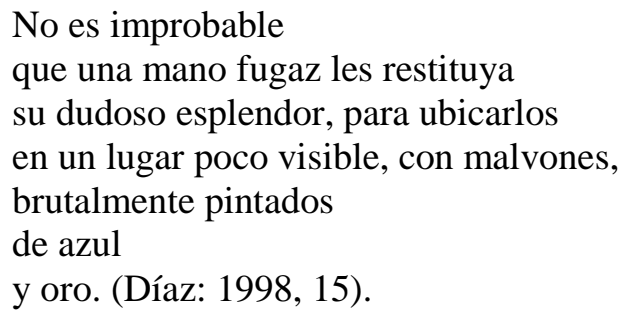

En un ademán similar al del poeta, que se apropia de un motivo de la tradición para hacerlo suyo en la reescritura, esa "mano fugaz" pone en escena una práctica artesanal sobre el objeto que le provee una identidad, en este caso la del club de fútbol ("azul y oro” es el modo popular de designar los colores de la camiseta de Boca).

De esta manera el cisne de Díaz reúne pasado y presente, tradición literaria y tradición popular, y anuda en sí a la poesía norteamericana con el modernismo latinoamericano y hasta con fragmentos del simbolismo francés. Se trata de un objeto atravesado por tiempos “impuros”, pero esa impureza es incluso deliberada en la elección del cisne de cemento porque se contrapone abiertamente a la "pureza" del cisne de la tradición prestigiosa y sacralizada:

Un cisne de cemento nunca es blanco.

Se advierte, al acercarse, impureza en su textura, piedras que el tiempo ha dejado a la vista, grumos de arena, ademanes torpes en su hipotético andar. (Díaz: 1998, 15).

Como señala el poema, el cisne en tanto objeto real está sujeto al paso del tiempo, a diferencia de un motivo literario que sería, en principio, atemporal (pero justamente los poemas están tratando de cuestionar esa “atemporalidad” al poner de relieve el carácter anacrónico del cisne como motivo poético en el patio de una casa de la ciudad de Bahía 
Blanca en la década del noventa). Por otra parte, el modo de mirar el objeto lo constituye de por sí en un montaje de tiempos heterogéneos porque hace oscilar el pasado y el presente cuando apela a la memoria, como vimos en el poema donde el presente se superpone con la "memoria familiar".

Así, el movimiento de los poemas va desde lo mínimo, desde la observación como con lupa (la "impureza en su textura” que se advierte al acercarse al cisne; Díaz: 1998, 15) a lo más general, cuando el cisne se confronta tanto con el modo de usar los monumentos en una ciudad como con lugares hipotéticos en los que no podría encontrarse jamás un cisne de cemento: en Washington D.C., Oxford, Harvard, en la Capilla Sixtina, en “una clasificación ornitológica seria” (Díaz: 1998, 21). De esta manera la elección del objeto delimita también un territorio, porque la lista sugiere que el cisne “no pertenece” al ámbito sagrado, ya sea de la religión o del saber, ni al poder, ni a una tradición literaria elevada y prestigiosa. De hecho el objeto desordena el archivo verbal e imaginario de esa tradición, ya que los cisnes de cemento "No cantan cuando mueren” (Díaz: 1998, 18), y “No hay lago cristalino/ capaz de soportar/ el doméstico bogar/ de un cisne de cemento” (Díaz: 1998, 18).

El ejercicio de "mirar” al objeto de diversas maneras en esta primera serie, que tiene como centro el patio de la casa familiar, funciona entonces como desplazamiento y ampliación de la mirada objetivista porque en él puede leerse tanto una memoria privada como una colectiva, cuando se compara el cisne como "monumento" familiar con otros monumentos cívicos presentes en la ciudad y entregados al olvido o a nuevos usos como el graffiti sugerido en ese "aerosol azul". Y es en ese mismo patio donde se sitúa a la tradición literaria, entre el “yuyaje” y la “chatarra/ que el óxido corroe” (Díaz: 1998, 25), que no tienen en este caso el signo negativo de las ruinas en la poesía de Rubio y García Helder. Por el contrario, la segunda parte del libro se titula precisamente 
“Las ruinas de Disneylandia” y contiene la serie “Once postales del Hospital Penna” (Díaz: 1998, 38-44) que se centra en una experiencia de la infancia, jugar al fútbol con los amigos del barrio. Aquí aparece, de nuevo, la inventividad de transformar un espacio para el juego cuando se dice que "Los campitos de la morgue/ siempre fueron los más aptos/ para la práctica entusiasta/ del fútbol infantil” (Díaz: 1998, 38). Se trata, en este caso, de apropiarse de un espacio a través del uso, en esa práctica popular que ve posibilidades de improvisar una cancha y un arco en los lugares más inesperados.

Del mismo modo, el poema "Las ruinas de Disneylandia” insiste sobre la idea de trabajar con lo que se encuentra disponible, con "lo que hay", ${ }^{189}$ cuando el relato generacional que pasa revista a un grupo de chicos ya convertidos en adultos se convierte en un poema que replica el modo de ponerse al día de amigos que no se ven hace tiempo: "Miguel está pelado, pero es buen tipo.// Norma, Laura y Marcela/ son maestras, y todas/ tienen más de un hijo.// El Cabezón embarazó a la novia y se cagó la vida./ El Topo se volvió abogado y si te ve, no te saluda” (Díaz: 1998, 50). El poema trabaja los lugares comunes de una práctica habitual -el reencuentro con viejos amigos para hablar del pasado-, en frases como "se cagó la vida” o "si te ve, no te saluda”, que constituyen un repertorio de formas fijas con que circulan oralmente las noticias. Pero al final del texto el mismo poeta se representa también como alguien instalado en "lo que hay”, y que construye poesía a partir de eso, cuando dice: "Yo en la misma que supiste:/ un tipo cuidadoso/ de no joder/ el sueño de nadie./ Wan Yan Kein caminando/ sobre papel de arroz.” (Díaz: 1998, 52).

En este caso, "lo que hay” es la figura televisiva que deviene figura poética en el uso porque sirve para dar cuerpo a un modo de definirse, y por eso se la apropia el

\footnotetext{
189 "Es lo que hay" es, de hecho, el nombre de las obras completas de Marcelo Díaz, de reciente aparición, cuyo título pone de relieve esa astucia popular de producir a partir de lo dado. Ver Marcelo Díaz, Es lo que hay, Bahía Blanca, 17grises Editora, 2010.
} 
poeta. Se trata del personaje de David Carradine en la serie televisiva de los setentas Kung $\mathrm{Fu}$ (en realidad el nombre del personaje es Wan Chan Kein, que en este caso deviene "Wan Yan Kein" probablemente por el modo de pronunciarlo de alguien que vio la serie siendo niño en esa década), que acá se activa desde la producción.

Como explicitamos, los poemas de Díaz están compuestos en buena medida por materiales que circulan masivamente, y el poeta es el que da forma a esa materia previa usando la tradición literaria tanto como modificándola por el ingreso de un objeto que le es ajeno. La operación se extrema en Diesel 6002, ${ }^{190}$ que consiste en la "puesta en estilo barrroco”, ${ }^{191}$ como señala Ana Porrúa, de una noticia periodística sobre una loca que se escapó del hospital Moyano y se robó una locomotora para ir a visitar a su novio a Temperley. El libro se abre con epígrafes de Apollinaire (Díaz: 2001, 9), Franciso de Rioja (Díaz: 2001, 13), el Diario Popular y el diario Clarín (Díaz: 2001, 11), a los que se suman después Nino Bravo (Díaz: 2001, 29), Osvaldo Lamborghini (Díaz: 2001, 37) y Góngora (Díaz: 2001, 47).

El ejercicio de selección de estos elementos es microscópico y sirve como marco a una serie de textos que combinan materiales del discurso periodístico con las formas y la dicción del barroco español. Pero como señala Ana Porrúa, los materiales se trabajan desde un “equilibrio sintáctico” que pone de relieve la construcción a partir de materias en principio dispares:
Aquí se trata, por medio de una rigurosa construcción, de mantener ambos registros en el mismo nivel, ya que si bien el "estilo barroco" presiona sobre el discurso periodístico, éste también ejerce una tensión que es imposible dejar de lado en la lectura. Casi podría decirse que cada uno resalta la diferencia del otro. La propuesta no es de mezcla; no se trata de pasar de uno a otro registro $-\mathrm{u}$ otro orden- sino de mantenerlos separados. Lo que permite el contrapunto entre uno y otro es la intensidad del acontecimiento que puede leerse como drama policial o

\footnotetext{
${ }^{190}$ Marcelo Díaz, Diesel 6002, Bahía Blanca, Vox, 2001. Todas las citas posteriores están tomadas de la misma edición.

191 Ver Ana Porrúa, "Volver al pasado: una nueva lectura de los clásicos", en Revista del CELEHIS, Mar del Plata, Buenos Aires, UNMdP, Nro. 15 (2003-2004); 157-170.
} 
como canto del dolor amoroso. Hay una lógica común que los une, la de la grandilocuencia, la hipérbole y el “puro gasto”. (Porrúa: 2003-2004, 160).

Lo que se destaca entonces es la escritura poética a partir de un modo de leer que se vuelve productivo, ya que se trata de detectar una "lógica común” entre dos tipos de discurso que no tendrían en principio nada que los acerque. De esta manera la poética de Díaz pone en escena “un arreglo hecho con los `medios a su disposición’”, como señala De Certeau citando a su vez a Lévi-Strauss (De Certeau: 2000, 187). ${ }^{192}$

Porque la figura que surge de estos dos libros es la del poeta como hombre común, casi podríamos decir “popular” (si atendemos también a la imagen del autor que comentamos en la tapa del libro) que trabaja con lo dado y se homologa en este punto a las figuras que se representan en los poemas: el poeta, tanto como esa "mano fugaz" que pinta el cisne de cemento en el fondo de una casa, "arregla”, para usar el término de De Certeau, una serie de materiales dispersos que se sustraen a un uso previsible que se reconocería como forma de reproducción de la cultura dominante. Por el contrario, el acatamiento de los discursos se subvierte porque ni se lee la noticia periodística como sola información, ni se reconoce a la tradición literaria la reverencia que la institución demanda. El poeta-lector es aquí el que "inventa en los textos algo distinto de lo que era

\footnotetext{
${ }^{192}$ A continuación reproducimos uno de los poemas de Diesel 6002 a modo de ejemplo, titulado "Diera voces amor (canción):
}

Lo que de riel en fuga/ partiera por un hilo/ y a la maniobra inversa/ voces inversas diera,/ que cruces son testigos/ de brazos que no trepan,/ ni grasas de cabina,/ ni piedras en la boca/ repletas de gasoil,/ en vías por el ido/ diera voces Amor./ Que aquellas voces diera:/ "estoy loca de amor"/ con rumbo Temperley/ "el Indio vive ahí,/ estoy loca de amor"/ y en fuga de la ley,/ en marcha enloquecida,/ piñas y amores diera,/ diera su voz de muero,/ dijera: Ten, per lei. (Díaz: 2001, 25).

Aquí, el registro verbal del barroco se yuxtapone con "grasas de cabina" o "gasoil”, que se destacan como ajenas a ese repertorio pero sin embargo ingresan eufónicamente en él por el trabajo de construcción del verso. Ciertamente, como señala Porrúa, la separación entre los discursos se mantiene porque pueden detectarse perfectamente los materiales de diversa procedencia, y porque las citas textuales de la mujer se consignan entre comillas, como inscripciones de otra voz en el poema. 
su intención. Los separa de su origen (perdido o accesorio). Combina sus fragmentos y crea algo que desconoce” (De Certeau: 2000, 182).

Pero en Díaz esta actividad no se atribuye únicamente a la escritura literaria sino también a aquellos que disponen el patio de cierto modo, o a los chicos que se apropian de un terreno para convertirlo en una cancha de fútbol. Así, el poeta también es un “usuario” que transforma el espacio a partir de procedimientos específicos sobre el lenguaje, pero es al mismo tiempo partícipe de una cultura que incluye otros modos de hacer que se valoran en el texto. Por eso en su poesía la técnica adquiere valor táctico, en la medida en que provee modos de operar en ese espacio del otro que sería la tradición consagrada. En efecto, para De Certeau la táctica es “un cálculo que no puede contar con un lugar propio (...). La táctica no tiene lugar más que el del otro” (De Certeau: 2000, L). Por eso las tácticas del consumo, en este caso de la literatura, constituyen “ingeniosidades del débil para sacar ventaja del fuerte”. En este caso entonces, el trabajo con la forma poética supone un modo de habitar la tradición para hacer ingresar furtivamente en ella un cisne de cemento o una noticia del periódico pero no implica, en cambio, un asentimiento a la norma. Por el contrario, la poética de Díaz puede pensarse como combativa en este sentido porque entiende la tradición como objeto de disputa.

Mario Ortiz construye una figura similar en sus Cuadernos de Lengua y Literatura, en los que el título ya pone de manifiesto a la poesía como un ejercicio de aprendizaje que se homologa al escolar: se trata de asimilar lo impuesto en la enseñanza o heredado por la tradición pero desde un uso desviado. Es importante aclarar que tanto Díaz como Ortiz y Sergio Raimondi, cuya poesía analizaremos después, son "sujetos 
educados por el Estado”, ${ }^{193}$ como dice el mismo Raimondi en una entrevista, porque en sus libros se ponen en cuestión críticamente los contenidos de la enseñanza académica. Raimondi señala a este dato como motivación parcial para el trabajo con la tradición en su poesía:

Escribir Poesía civil coincidió con una reconsideración más o menos radical (...) acerca de qué herramientas me había dado la Universidad para mirar otras ciudades dentro de la ciudad metafísica, (...) lo que yo trataba de escribir estaba inevitablemente cruzado, entre otras perspectivas, por mis aprendizajes de estudiante, y consideraba que era, además de honesto, estratégico que ese testimonio apareciera. ¿Quién habla ahí? Desde un nivel institucional neto, un sujeto educado por el Estado (Raimondi: 2006, 5).

Atendiendo a las declaraciones de Raimondi, la cita puede ampliarse para incluir a Díaz y Ortiz, sobre todo porque en ellos se trata de "mirar otras ciudades" dentro de esa ciudad metafísica e ideal que aquí se menciona. Es decir, de medir y sopesar cómo se lee una tradición desde una ciudad que presenta características propias, como lo hace Marcelo Díaz con su “cisne”, que no deja de ser un motivo modernista, trasladado en sus textos al cisne de cemento de una familia de barrio.

En Mario Ortiz, el gesto de nombrar todos sus libros con el título Cuadernos de Lengua y Literatura ${ }^{194}$ no deja de aludir a la literatura como asignatura escolar, pero en este caso escribir poéticamente en esos cuadernos supone construir una lectura divergente de la prevista por la enseñanza institucionalizada y llevada a cabo, nuevamente, desde el uso. De esta manera, este modo de aprendizaje que suele pensarse en términos de recepción pasiva y hasta de "consumo" (no por supuesto en las

\footnotetext{
${ }^{193}$ Ver "Sergio Raimondi: 'No hay mundo de un lado y versos del otro'”. Entrevista de Osvaldo Aguirre, en Diario de poesía No 72, Mayo a Agosto de 2006 (5). Mario Ortiz es Profesor en Letras y Sergio Raimondi es Licenciado en Letras, ambos por la Universidad Nacional del Sur, donde actualmente comparten las cátedras Literatura Contemporánea I y II como docentes. Marcelo Díaz cursó la mayor parte de la carrera en la misma institución, que se caracteriza por cierta tendencia conservadora en cuanto al valor de la literatura clásica (que ocupó hasta hace algunos años casi la mitad del plan de estudios).

194 Todos los libros publicados por Ortiz hasta el momento llevan el nombre Cuadernos de Lengua y Literatura, y se diferencian por el número de volumen y los subtítulos. En este caso trabajaremos con Cuadernos de Lengua y Literatura Vol. 1, Bahía Blanca, Vox, 2000. Todas las citas posteriores están tomadas de esta edición.
} 
pedagogías más recientes), deviene en un hacer que "no se señala con productos propios sino en las maneras de emplear los productos impuestos por el orden económico dominante” (De Certeau: 2000, XLIII), aunque en este caso debería reemplazarse “orden económico dominante” por “cultura dominante” y “enseñanza estatal”.

La variante de Ortiz es que en sus textos la referencialidad objetivista se suspende parcialmente porque siempre se pone de relieve que se trata de "textos". Uno de los poemas de Cuadernos de Lengua y Literatura Vol. 1 comienza por decir: "este es un texto donde/ definitivamente interviene martínez, el amigo mar/ tínez/ y todo el centro del mar,/ por un juego tonto de palabras, se congrega en una columna/ vertical en el centro de la ciudad del amigo martínez” (Ortiz: 2000, 23). En Ortiz, la percepción del lenguaje y del texto como tales es fundamental porque funciona como base de un procedimiento. En este caso, la partícula “mar” de "Martínez” se lee en su literalidad y desencadena una serie de asociaciones lúdicas que expanden el poema y lo hacen funcionar en dos planos superpuestos: el del lenguaje y el repertorio imaginario y verbal de la tradición, y el de lo cotidiano.

Así, el hecho de que la mujer llame al personaje para que lave la ropa -que se imagina como “fieras enjauladas” y luego se asocia con "peces”, en una conversión gradual- se vincula con el "mar" del apellido y entonces "el mar que ha congregado martínez y el lenguaje/ también lo busca para un juego tonto:/ volver la ropa al agua,/ el hombre a su estado de ninfa/ y los pejerreyes a transitar olvidados paisajes” (Ortiz: 2000, 23) (nótese como el supuesto "habla” de la mujer aparece entre comillas, como si se tratara de una cita, pero en realidad ostenta un registro lírico que lo convierte en el fragmento más artificioso del poema, precedido en cambio por la frase "viene y le dice” que es la verdadera incrustación de la oralidad; de nuevo, ambos órdenes se trastocan y se vuelven indiscernibles). El juego instaura su propia lógica y permite decir al final, 
estableciendo un paralelismo que termina por parecer evidente aunque represente un desvío notorio del sentido común y la normalidad de la vida cotidiana, que "lo busca el mar/ a martínez/ a su ropa,/ los peces” (Ortiz: 2000, 23).

La segunda parte de este poema trabaja una imagen que sirve como figura de la operación que realiza el texto y a la vez remite, de nuevo, a una práctica tan cotidiana como lavar la ropa: la del juego de arrojar piedras en el agua (Ortiz: 2000, 24). La reverberación que producen las ondas del agua se percibe como "flores” (superposición que condensa la puesta lírica de lo cotidiano que atraviesa toda la poesía de Ortiz, tensada con el dato de que las ondas también "llevan frutas podridas/ de la verdulería”, Ortiz: 2000, 25) que son producidas, otra vez, por el juego de los chicos. Una vez establecida esta imagen, la tercera y la última parte del poema pueden recuperarla como síntesis final para decir: "la floreada camisa como pez/ los pibes como peces que se vuelven flores/ martínez y el juego tonto/ de arrojar palabras como piedritas// los límites frutales de una tarde con ninfas” (Ortiz: 2000, 25). De este modo, todos los elementos desplegados en el texto se recuperan desde una sintaxis que los vincula desafiando al sentido común pero respetando a rajatabla, al mismo tiempo, el sentido interno del poema, que puede dar una vuelta sobre sí mismo (e incluir en ese movimiento a la tradición bajo una serie de transformaciones que remiten a las Metamorfosis de Ovidio, en un poema que parte de lo cotidiano) para decir "los pibes como peces que se vuelven flores” y “los límites frutales de una tarde con ninfas” porque todos los términos estaban enunciados previamente, de manera que su homologación y su copresencia es esperable: hasta tal punto el poema construye una lógica nueva, que es textual.

Pero el texto no sólo vuelve sobre sí mismo por la repetición de sus elementos sino también porque propone una figura, la del “juego tonto/ de arrojar palabras como piedritas” (Ortiz: 2000, 25), que condensa el modo en que opera la relación entre 
lenguaje y sentido en la poesía de Ortiz. Como hemos visto, al ingreso de un sustantivo que dispara una serie de asociaciones que expanden el texto se suma luego otro que procede de la misma forma, y así sucesivamente. ${ }^{195}$

Otro poema presenta una variante con respecto a este procedimiento porque se trata de un viaje en colectivo en el que se imagina que el colectivo es una "barcaza" y en este caso el arroyo Napostá, ya mencionado, debe cruzarse como si se tratara del Hades, el río de los muertos de la mitología griega y luego latina que Eneas debe cruzar durmiendo al Can Cerbero con tortas de miel que contienen droga. ${ }^{196}$ El poema de Ortiz dice: “el colectivo en subida/ bondi: barcaza/ me lleva?/ no me lleva?/ ¿tendré que dormirte con tortas?/ amado cráneo sumergido/ entre pelos de serpiente/ cálmate,/ esto es miel para que me cruces el Napostá/ voy a casa” (Ortiz: 2000, 19). Aquí se superpone

195 Muchas veces los poemas parten de una manera lúdica de experimentar el lenguaje, que abre el juego. Como en el caso de "martínez", en otro poema se trata de reflexionar sobre las esencias filosóficas (luego de un poema donde se nombra a Aristóteles y Deleuze; Ortiz: 2000, 13), pero en este caso se propone "la esencia del jeep”: “el jeep/ el tema/ es que podríamos más adelante,/ más tarde,/ preguntarnos por la esencia del jeep” (Ortiz: 2000, 14).

Este "jeep”, que quiere escribirse tal como se pronuncia oralmente en español rioplatense, "ý́,", suscita toda una construcción a su alrededor, de nuevo por procedimiento asociativo, porque la operación de Ortiz de literalizarlo todo hace que incluso una "esencia” necesite un camino sobre el cual transitar: "y también podríamos delinear otro espacio/ atravesable en un rojo jeep (...)/ hagamos entonces una ciudad/ inventando el Napostá/ y hagámoslo de un modo lento/ para que el agua se entrelace en hojas de eucalipto/ con sus frutos, en imagen de arroyo que se duerme" (Ortiz: 2000, 14). Otro poema parte de una manera también cotidiana de expresar la furia que consiste en la frase "a (tal) hay que matarlo". Ortiz destaca la cita de la oralidad porque es la única frase que aparece íntegramente en mayúsculas en el poema: "AL GORDO HAY QUE MATARLO” (Ortiz: 2000, 18). Por eso, tomada la frase en su literalidad y puesto el poeta a imaginar las maneras de matar al "gordo", empieza por decir que "para eso leemos a Chandler" (Ortiz: 2000, 18), como modo de usar la literatura policial para planear el crimen. Cuando se cae en la cuenta, después, de que habrá una "presencia muy real” del cadáver, se opta por llevárselo "al flaco que traduce Estacio", cuyo conocimiento de la literatura clásica lo haría un experto en el tema (Ortiz: 2000, 18). Pero lo importante es que, de nuevo, todo el poema parte de tomar una frase que funciona metafóricamente en el uso cotidiano y empezar a hacer asociaciones a partir de una lectura literal de la misma.

196 Virgilio, Eneida, Barcelona, Gredos, 2008. Traducción de Javier de Echave-Sustaeta.

Ese "Napostá" es un arroyo que atraviesa la ciudad de Bahía Blanca, parte del cual está entubado, pero otros tramos tienen diversos puentes que deben cruzarse diariamente para pasar de una parte de la ciudad a la otra. El arroyo funciona como centro de varios de los poemas en Cuadernos de Lengua y Literatura, con lo cual se introduce una nota característica de lo local y más difícilmente recuperable para un lector que proceda de otro lugar (para los bahienses, el lugar común es hacer bromas en cuanto a la pobreza de la ciudad que tiene como único "río" a un vulgar arroyo, en algunas partes muy poco profundo y estancado). 
el mito clásico con un viaje en colectivo o "bondi” (el uso del modo popular de designar al transporte es clave) al volver a casa por la noche, y se diseña un itinerario reconocible para un habitante de Bahía Blanca porque el colectivo va por "Rodríguez/ y 12 de octubre/ el parque” (Ortiz: 2000, 19), aparte de que como dijimos cruza el arroyo Napostá.

Los poemas parten muchas veces de un modo “zumbón” de leer el lenguaje, ya sea el de la vida cotidiana ("al gordo hay que matarlo”, “martínez”), la filosofía ("la esencia del jeep”, ver Nota al pie $n^{\circ}$ 195) o la literatura, por ejemplo la Eneida en el texto que acabamos de mencionar. Otro poema trabaja con referencias a Romeo y Julieta de Shakespeare pero de nuevo la geografía remite a lo local, en este caso al puerto de Ingeniero White devenido “Guaite”, tal como se pronuncia en la zona: “voy a ver si me sumerjo/ para navegar/ al fondo de Shakespeare/ entre las valvas de la ostra/ la perla de Julieta/ el balcón en el río de los versos” (Ortiz: 2000, 28). Hasta tal punto el texto se apropia de Shakespeare que más adelante se lo escribe "Shecspir" según la (mala) pronunciación argentina, con la misma familiaridad con que el jeep devenía “yí” y el colectivo, "bondi”. Pero lo más importante es que ese "sumergirse inicial”, que parece plantear al texto como un río imaginario, el "río de los versos" al que se alude, termina por ser el agua de la Ría de Bahía Blanca: “cuanto más se levanta el mar/ las vírgenes pulpas de los peces/ más suben al muelle de Guaite” (Ortiz: 2000, 28).

Esto sucede, de nuevo, porque el lenguaje permite articular órdenes diversos. Así, el metafórico y textual "río de los versos” se desplaza hasta desembocar en el muelle de "Guaite”. De esta manera Ortiz hace de la tradición un espacio habitable porque la superpone con el mundo cotidiano en los textos. La relación de Ortiz con la tradición es de convivencia, y los poemas establecen una continuidad entre el 
imaginario apropiado de las diversas lecturas y el espacio cotidiano. ${ }^{197}$ En un poema, por ejemplo, alguien hace gárgaras y el gesto de levantar la cabeza motivado por esta práctica trivial lo remite al Antiguo Testamento: “al final terminás haciendo gorgoritos/ con los ojos mirando al cielo como Isaías en busca de revelaciones” (Ortiz: 2000, 21). Además, como se está levantando la cabeza y se mira al techo, se piensa que "una leve sacudida en el techo/ haría bajar las arañas que tejen el rapto de Europa/ en labrados rebordes de filigrana descascarada” (Ortiz: 2000, 21).

A partir de gestos y elementos mínimos de la vida cotidiana se establecen analogías con un archivo que está presente todo el tiempo; hay una relación de

${ }^{197}$ Ver por ejemplo este fragmento de un poema donde se "dice recrear" la Oda 58 de Anacreonte, y que ilustra a la perfección el movimiento que va, en este caso, de la tradición a lo local, cuando la diosa griega Afrodita llega a la costa de Monte Hermoso (localidad balnearia cercana a Bahía Blanca). En este caso sin embargo, el desplazamiento de la Oda hacia lo local no está dado solamente al final del poema por el referente "Monte Hermoso", sino que comienza a efectuarse en la reescritura por el registro oral, como cuando se dice "¿la viste, pero?”, con esa cita de la oralidad que usa el "pero" al final de la frase, propia de la ciudad de Bahía Blanca:

el verde mar / el undoso mar

¿la viste?

bailando entre las olas

Afrodita la blanca

espuma sobre su carne cubriendo lo virgen

¿la viste, pero? rodeada

por delfines y amores en carro

de cuatro alazanes

alguien la ha pintado

Afrodita la virgen

cintura entre algas, y tetitas

ocultas bajo líquenes (...)

al emerger el faro

es lo primero que se ve (...)

el faro

en Monte Hermoso

y avanza hacia nosotros (Ortiz: 2000, 43, 44). 
continuidad entre tradición y cotidianeidad. Como señala Ana Porrúa, Ortiz "puede ir del espacio de la cultura al de lo cotidiano, sin que exista una frontera entre uno y otro (ambos se leen de la misma forma)” (Porrúa: 2003-2004, 163). De hecho, al final del poema recién mencionado se imagina que alguien come un bife y el humo asciende a los dioses, aludiendo al modo en que se practicaban los sacrificios en la mitología griega, “y un dios le da rosca/ al repasar los jugos de la carne/ con el pan, miguitas sobre el plato” (Ortiz: 2000, 22). Pero aquí lo central es el modo que estos materiales ingresan al poema, porque es precisamente lo que caracteriza la manera de Ortiz de pensar la tradición.

En este sentido, otro texto propone la figura del caleidoscopio para la escritura. Allí el poeta se representa sentado frente a la máquina de escribir donde "le da al tecleo/ al boludeo/ que es su laburo” (Ortiz: 2000, 32), y de nuevo, el poema va desplegando elementos (el gordo, el poeta, los cristales) que se reúnen cerca del final: "la escena continúa/ y puede revertirse/ con sus trozos de cristales:/ otras flores se forman/ y el gordo vuelve lenguaje al poeta/ que se caga de frío en la calle/ y los dedos invisibles invierten los rostros/ en otras flores ya vistas/ al extremo del caleidoscopio” (Ortiz: 2000, 33, 34). El modo de funcionamiento del caleidoscopio es útil para describir la poesía de Ortiz, porque si se piensa en cómo está construido el objeto, se trata de un receptáculo donde unos pocos elementos sueltos giran y gracias a un juego de espejos cambian de figura. De modo similar, los poemas de Ortiz están compuestos como vimos de elementos que funcionan como matriz y que se van combinando entre sí para variar el sentido.

Pero si se tiene en cuenta que esos elementos están tomados tanto de la vida cotidiana y de la cultura popular según la definimos a partir de De Certeau (el acto de lavar la ropa o de arrojar piedras en un charco, la frase "al gordo hay que matarlo”, el 
regreso al hogar en colectivo, la costumbre de mojar el pan en el jugo de la carne) como de la tradición (Shakespeare, la mitología clásica, el Can Cerbero, el rapto de Europa, el Antiguo Testamento, la filosofía de Aristóteles y Deleuze), pensar los fragmentos tomados de estos órdenes como elementos mínimos dentro de un caleidoscopio supone que no hay diferenciación entre una y otra: tradición y vida cotidiana conviven en el mismo espacio y se combinan de maneras siempre nuevas. La analogía implica también que todo el espectro de la temporalidad está abierto en la poesía de Ortiz, en la que el anacronismo funciona como modo de sustraer la tradición a la "historia literaria” y a la biblioteca; para este poeta, la tradición no aparece confinada al pasado ni es algo que deba disputarse o que se apropie de modo combativo como en Marcelo Díaz, sino que simplemente está ahí, disponible para el uso y para un tipo de lectura “juguetona, impugnadora, fugitiva” (De Certeau: 2000, 188).

Por otra parte, si esa convivencia es posible es porque Ortiz concibe a la poesía ante todo como "texto" según vimos en el primer poema analizado. Porque al procesamiento del objetivismo, que está presente en el modo de construir una figura de poeta-lector y en el trabajo a partir de segmentos del archivo habilitado por el Diario de poesía -sobre todo Leónidas Lamborghini- y muy especialmente en el modo de evaluar las tradiciones en los poemas que vimos en García Helder y que acá se desarrolla en clave lúdica, se suma en el repertorio de Ortiz otra figura contrastante como es la de Arturo Carrera. Así como Marcelo Díaz encontraba un punto de confluencia entre el barroco y el discurso periodístico, si algo tienen en común Lamborghini y Carrera en la lectura de Ortiz es que se toma de estas poéticas tan heterogéneas un modo de procesar las lecturas en los textos y también una puesta en evidencia del texto como tal.

En Carrera, como señala Reinaldo Laddaga, puede encontrarse “el despliegue de una manera que asociara a Mallarmé y a Góngora, a Lautréamont y Lezama Lima, 
leídos todos desde la familiaridad con la teoría estructuralista o postestructuralista y la obra de Sarduy y Pizarnik”. ${ }^{198}$ Pero esto proviene de un modo de leer y activar poéticamente la teoría que también destaca Ana Porrúa a propósito de la relación de Carrera con Barthes y Deleuze: "lo que importa en Carrera son las formaciones que una idea proveniente de la teoría produce en el texto” (Porrúa: 2006, 29). De modo similar, en Ortiz muchas veces la teoría tomada en su literalidad, en tanto texto, da lugar a nuevos textos. A esta concepción del lenguaje parece aludir Daniel García Helder cuando señala en el prólogo a Cuadernos de Lengua y Literatura que Ortiz ubica tanto los tópicos universales de la literatura como la lengua nacional "en una perspectiva plana de un milímetro de espesor donde todos los elementos parecen de la misma época” (Ortiz: 2000, 5, 6) porque la tradición se actualiza, como vimos, al estar absolutamente inmersa en la vida cotidiana.

Sergio Raimondi, como Díaz y Ortiz, también piensa la poesía en relación a modos de hacer propios de la vida cotidiana que en su caso se fundan en la figura del poeta-artesano. Pero en Raimondi esta figura articula, por un lado, el procesamiento del objetivismo y de Ezra Pound, y por el otro el gesto de pensar la poesía en relación a otras producciones de carácter artesanal que pueden englobarse también en lo que De Certeau denomina “cultura popular”. La alusión a Pound como artesano está dada en la dedicatoria con que T. S. Eliot encabeza su poema “La tierra baldía”: “For Ezra Pound, il miglior fabbro" ${ }^{199}$ La frase, que puede traducirse como “el mejor artesano”, es en realidad una cita del modo en que Dante se refirió al poeta provenzal Arnaut Daniel, y comporta una idea de poesía como modo de trabajo que se asimila al manual sobre la

\footnotetext{
${ }^{198}$ Reinaldo Laddaga, "Una poesía fotográfica. Sobre Arturo Carrera", en Nancy Fernández y Juan Duchesne Winter (ed.), La poesía de Arturo Carrera. Antología de la obra y la crítica, Pittsburh, PA, Instituto Internacional de Literatura Iberoamericana, 2010 (289-302).

${ }^{199}$ Ver T. S. Eliot, "The Waste Land", en T. S. Eliot, The Complete Poems and Plays, 19091950, New York, Harcourt Brace \& Company, 1995 (37-55).
} 
materialidad de las palabras que en el caso de los modernistas Eliot y Pound adquirió un valor opositivo con respecto a la creencia en un tipo de creación espiritualizada, condensada en la figura de la poesía como “canto”, de los poetas románticos y simbolistas (de hecho como veremos, esta idea de poesía se discute explícitamente en Poesía civil). ${ }^{200}$

En Raimondi entonces, la concepción de la poesía como trabajo artesanal remite al procesamiento del archivo objetivista pero no incluye solamente a la figura de Pound, que como vimos estaba en la base de todo el armado ideológico del objetivismo en el Diario de poesía, sino también a la de otros poetas objetivistas como Martín Prieto y muy especialmente Daniel García Helder. De hecho la dicción de Poesía Civil ${ }^{201}$ está construida en buena medida a partir de la de García Helder, de cuyos libros se toma también el gesto de vincular la poesía a un lugar específico que para García Helder es Rosario y para Raimondi será Bahía Blanca y su zona portuaria de Ingeniero White. Como señala el mismo Raimondi en una entrevista,
Si tuviera que elegir entre alguna idea de ciudad que, desde la poesía, haya sentido más próxima o que haya actuado como motivación para el proyecto de Poesía civil, señalaría en todo caso la dicción de los poemas de Rosario (otro puerto cerealero y descentrado) de Prieto, Helder y Taborda: La música antes, 40 Watt y sobre todo El guadal, un libro muy importante para mí; ahí hay cientos de escenas urbanas, pero más que nada un grado de resolución que...O sea, El guadal obliga a considerar la transmutación que "sufren" los motivos por la fuerza operativa, y fijate que ahí no se puede mencionar sólo la histórica pretensión de adecuación entre “forma” y "contenido" porque hay en general una no adecuación, una no correspondencia, un tono, por ejemplo, de oda augusta para "cantar" (digamos cantar) una construcción a medias junto al Paraná, o inclusive un lujo verbal cuasi modernista para dar

\footnotetext{
${ }^{200}$ Percy Shelley señala en Defensa de la poesía que "Un poeta es un ruiseñor, que permanece en la oscuridad y canta para alegrar su propia soledad con dulces sones”. En este texto Shelley activa una serie de analogías que tienden a desmaterializar el ejercicio poético asimilándolo al espontáneo "canto" de un pájaro, a la vez que sugieren, como en la frase citada, una figura de poeta aislado de la sociedad. Estos valores, que en los románticos ingleses tuvieron un carácter opositivo con respecto a los nuevos valores propuestos por la modernización económica, se volvieron conservadores en su permanencia a lo largo de las décadas, y son puestos a prueba en Poesía civil, como analizaremos luego. Ver Percy Shelley, Defensa de la poesía, Buenos Aires, Ediciones Siglo Veinte, 1978 (30).

${ }^{201}$ Sergio Raimondi, Poesía Civil, Bahía Blanca, Vox, 2001. Todas las citas posteriores están tomadas de la misma edición.
} 
cuenta no ya de un palacio de ensueño francés o japonés sino de una escena de perros y fogata al borde de las vías; mirá este alejandrino: "perros lengua afuera de cirujas que tumbados”. Yo leí esos poemas admirado de su exceso casi anacrónico, tratando de aprender y reconsiderar. ${ }^{202}$

El procesamiento del objetivismo, y más específicamente el de los poetas rosarinos, que Raimondi recupera en términos de analogías políticas y económicas entre Rosario y Bahía Blanca, está dado como se ve a partir de una lectura crítica detallada (que recuerda por otra parte al modo microscópico de leer de Ezra Pound en El ABC de la lectura) capaz de ir del nivel de la composición del verso a un marco mucho más general para pensar cómo funcionan determinadas formas en relación a su objeto.

Raimondi, además de "sujeto educado por el Estado" como consignaba el fragmento de esta misma entrevista citado anteriormente (Raimondi: 2006, 5), se construye como lector y como crítico, no solamente en esta entrevista sino también en los textos de Poesía Civil. Este modo de usar los poemas para hacer crítica, que ya analizamos en García Helder y Alejandro Rubio, aquí se amplía cuantitativamente para incluir casi todos los poemas del libro, pero esa ampliación también atañe a los ámbitos del saber que intentan abarcarse porque la crítica no es solamente de la tradición literaria sino de la historia (“Qué hay tras un boletín de campaña (a)”; Raimondi: 2001, 115), la economía local y su relación con el orden global (“Proyecto Mega”; Raimondi: 2001, 35-37), las noticias periodísticas (“W”; Raimondi: 2001, 25), los proyectos estatales (“Ficología y legislación flexible y fiscal”; Raimondi: 2001, 31) y los modos de hacer de la vida cotidiana ("Para hacer una torta sin leche”; Raimondi: 2001, 66). Otro desplazamiento con respecto a la poética de García Helder está dado por el hecho de que si en éste las preguntas sobre los objetos y escenas construidas en los poemas eran de orden metafísico (García Helder se preguntaba como vimos por el sentido de lo

202 "Sergio Raimondi: “No hay mundo de un lado y versos del otro"”. Entrevista de Osvaldo Aguirre, en Diario de poesía No 72, Mayo a Agosto de 2006 (3, 4). 
que se percibía), en Raimondi se pasa de la pregunta por el significado de las cosas a la pregunta por las relaciones entre las cosas.

De hecho, si recordamos el poema de García Helder "Una alegoría” (García Helder: 1990, 42) en el que una escena de trabajo observada desde la ventanilla de un tren se imaginaba en contraste con la alegoría de la caverna de Platón -pero la relación, que funcionaba como puesta a prueba de las teorías idealistas, se circunscribía a la contraposición de la escena con la tradición literario-filosófica-, la variante de Raimondi pone el acento en lo que tales cosmovisiones suelen omitir para constituirse. Porque en un poema que resume en su primera estrofa la Defense of poetry de Shelley con su concepción de la poesía como perteneciente al ámbito de lo que "verdadero es, eterno, único,/ imperio sobre el universo todo” (Raimondi: 2001, 11) se dirige al poeta romántico para decir que "no fuiste ignorado en absoluto,/ es sólo que fuiste considerado/ tal como exigías: se te dio el reino/ preferido, el invariable, intangible/ y perfectamente ideal;/ el otro quedó para tus lectores,/ dueños y destinados a regir/ territorios más concretos del planeta” (Raimondi: 2001, 11).

Raimondi le repone al lugar "ideal” reclamado por Shelley el contexto de la expansión imperialista británica, no sólo en el último verso donde se habla de “territorios más concretos del planeta” sino también porque lo que se está leyendo, según especifica el título del poema, es “Ante un ejemplar de Defense of poetry con el sello “Pacific Railway Library, B. Bca., nº 815 (to be returned within 14 days)”. Es decir que la reflexión, a diferencia de García Helder, surge de un objeto concreto que da testimonio material de la presencia de las empresas británicas en Bahía Blanca a fines del siglo XIX como inversoras y ejecutoras en la construcción del ferrocarril. Para decirlo de otro modo, allí donde García Helder veía una inadecuación entre la alegoría platónica y los trabajadores manuales al costado de las vías que se constataba sólo como 
diferencia, Raimondi encuentra una relación porque sitúa a la literatura, en este caso la Defense of poetry de Shelley -no sólo la ideología que comporta sino también el libro en tanto objeto- en el marco de la revolución industrial y el crecimiento capitalista cuyos valores pretendía rechazar (“Escrito está en tus páginas/ que poesía y principio de propiedad/ dos fuerzas son que se repelen”, dice el comienzo el poema).

Pero, para volver a la figura del poeta-artesano, esta no sólo remite a Pound y al objetivismo sino que vincula en Poesía civil el trabajo del poeta con el de otros artesanos en una operación que destaca los modos y las astucias del trabajo manual en un sector del país donde este tipo de actividades conviven con los modos de producción del capitalismo avanzado y global. De hecho “Los artesanos” es el título de una de las secciones del libro, y la idea aparece también cuando el poeta se contrapone con un jardinero, en un poema que se presenta como "Glosa a 'Ode to a nightingale' de John Keats” (Raimondi: 2001, 17). Aquí se construye una escena donde el poeta se levanta para encontrar que el jardín, ese en el que canta el ruiseñor de Keats “por los siglos para todos” ha sido arreglado por un jardinero. De nuevo, el poema repone lo que el texto de Keats dejaba afuera porque el pájaro canta "Bueno, no para todos. El jardinero duerme./ (...) Dejó la naturaleza parecida a un poema/ y se cansó, claro” (Raimondi: 2001, 17). Lo que sugiere esta “glosa” a Keats es que el canto nocturno del ruiseñor podría ser escuchado por los que a esa hora están despiertos, pero no por los que hacen un trabajo manual que de noche les reclama descanso y que son, además, los encargados de hacer que el jardín en el que Keats no veía otra cosa que naturaleza se parezca “a un poema”.

Tanto en este texto como en el que comentaba Defense of poetry de Shelley, las poéticas románticas se evalúan críticamente reponiendo lo que dejan afuera: en el primer caso, el orden económico global; en el segundo, el trabajo manual que pasa desapercibido para estos poetas. Los poemas funcionan como puesta a prueba de 
diversos segmentos de la tradición, porque en otros casos se tratan la poesía del anarquista Alberto Ghiraldo, que se piensa en su filiación con la de Darío (“A solas con Ghiraldo"; Raimondi: 2001, 15), las ideas poéticas de Wordsworth ("Poética y revolución industrial”; Raimondi: 2001, 13), la alegoría de la caverna de Platón (“De la caverna como imagen de la biblioteca”; Raimondi: 2001, 43), el artificio referencial del realismo (“A los reales seguidores del realismo”; Raimondi: 2001, 52), la poesía de Dante pensada en relación con sus costumbres alimenticias ("La dieta de Dante”; Raimondi: 2001, 49), un fragmento de Cicerón traducido por el profesor Antonio Camarero de la Universidad Nacional del Sur (“Ciuitas y humanitas”; Raimondi: 2001, 72), un discurso de Ezequiel Martínez Estrada ("De un discurso de E. M. E. en la Universidad Nacional del Sur con motivo del vigésimoquinto aniversario de la publicación de Radiografía de la Pampa, 1958”; Raimondi: 2001, 76, 77), y la lista continúa.

Es así como los textos ponen en escena un ejercicio de lectura crítica que pasa revista a parte de la formación académica a la que el propio Raimondi aludía, pero también a otros segmentos de la tradición. Lo que organiza estas lecturas es sin embargo una idea de Bertolt Brecht que aparece enunciada en un poema del que aquí citamos la primera parte:

Se trata de poner en tela de juicio la literatura con criterios no creados por ella; o sea: de tensar los versos ante la acción del fuego y de calificarlos no con el lápiz sino con el cuchillo, por ejemplo, o una sierra cariada o el carozo de un durazno. Poesía y ferretería, destornillador y vocal, metonimia a 220, en morsa la metáfora a ser por el toc ajustada del martillo.

Las herramientas no están terminadas aún.

(“La literatura será sometida a investigación (Brecht, 1939)”) (Raimondi: 2001, 55). 
Si la literatura puede "ponerse en tela de juicio" con criterios que le son ajenos es porque Raimondi recupera, como se pone de manifiesto en la mención a Brecht en el título de este poema, una tradición marxista para la cual la vinculación entre poesía, cultura, economía y sociedad no estaría dada tanto por las representaciones de estos diversos órdenes en los textos sino por el hecho de que la literatura puede y debe analizarse en los términos de la producción material y en la confluencia de esos diversos órdenes, de la que daría cuenta más por la técnica y la forma que por el contenido.

En efecto, lo que subyace al modo de concebir el lenguaje en Poesía civil es una idea marxista que supone un desplazamiento con respecto al modo objetivista de concebir el lenguaje, porque la referencialidad está presente en Raimondi y a la vez abordada críticamente a partir de la propuesta de Raymond Williams de poner en cuestión “La distinción fundamental entre 'lenguaje' y 'realidad', como entre 'conciencia' y 'mundo material', correspondiente a las verdaderas divisiones entre actividad 'mental' y 'física”” (Williams: 1997, 33) así como “la separación idealista entre 'lenguaje’ y 'realidad'” (Williams: 1997, 42), que se hace presente cuando Raimondi termina el poema “A los reales seguidores del realismo” con estos versos: "Suyo el artificio, en fin, de que el verso/ existe porque en algún lado se vivió,/ no de que el verso es la vida y lo intolerable” (Raimondi: 2001, 52). Este fragmento formula poéticamente la idea de que el lenguaje, antes que “reflejar” una realidad previa, es parte constitutiva de esa realidad, en concordancia con la perspectiva según la cual Williams propone reemplazar los pares binarios que aíslan al lenguaje en el ámbito de lo inmaterial y espiritualizado por la consideración que hace Marx del lenguaje como actividad práctica y constitutiva (Williams: 1997, 41).

Williams, además, sostiene “que el propio signo se convierte en una parte del mundo físico y material (socialmente creado)”, y que "La significación, la creación 
social de significados mediante el uso de signos formales, es entonces una actividad material práctica; en verdad es, literalmente, un medio de producción. Es una forma específica de la conciencia práctica que resulta inseparable de toda la actividad material social” (Williams: 1997, 51). Esta concepción de la lengua como producción material se activa en Raimondi en una serie de poemas que trabajan el discurso -no solamente poético- en analogía con los objetos materiales, como se sugería en el fragmento ya citado al hablar de "Poesía y ferretería, destornillador/ y vocal, metonimia a 220, en morsa la metáfora/ a ser por el toc ajustada del martillo.” (Raimondi: 2001, 55). Así, en “Pierto Gori \& Cicerón \& Percy Shelley, Ingeniero White, 1901” se describe un discurso anarquista como un "dispositivo detonante/ que mezcla retórica (55\%), inspiración romántica (20\%) y perspicacia crítica anarquista (25\%)” (24), y en “Poética y revolución industrial” se piensa la poética de Wordsworth en relación a la máquina de vapor de Watt para señalar que los versos también funcionan como una máquina que produce energía: “Wordsworth presentó a su lector/ ideas asociadas en estado de excitación en nombre/ de un mecanismo preciso que recupera la emoción/ en estado de tranquilidad hasta que la tranquilidad/ desaparece y la emoción se renueva. Y yo digo: eso/ es energía del vapor de agua que se expande expande/ y vuelve a enfriar para explotar y producir, más.” (Raimondi: 2001, 13, 14).

Así como la espiritualizada poesía romántica se tensa con la máquina de vapor que le es contemporánea y, más en general, la literatura se evalúa con herramientas del orden de la producción económica que en principio le son ajenas a partir de la idea también marxista de “totalidad” ${ }^{203}$ que desafía las oposiciones convencionales -y

\footnotetext{
${ }^{203}$ El teórico marxista Marshall Berman trabaja por ejemplo una idea similar a la que pone en práctica Poesía civil al leer la modernidad cultural en relación a la modernización económica y social desde la idea marxista de totalidad, que en su caso intenta "recuperar y reconstruir la visión de Marx de la vida moderna como un todo" (82) al reponer las relaciones entre diversos órdenes que la especialización pierde de vista. Sobre todo, en la evaluación que hace Raimondi de la poesía romántica cuya ideología tiende a borrar el trabajo material envuelto en la
} 
funcionales al sistema capitalista- entre las áreas del saber, en Raimondi también funciona la actitud crítica de Brecht enunciada en el poema "Preguntas de un obrero ante un libro", donde se trata de cuestionar la historia en estos mismos términos: “Tebas, la de las Siete Puertas, ¿quién la construyó?/ En los libros figuras los nombres de los reyes./ ¿Arrastraron los reyes los grandes bloques de piedra?”. ${ }^{204}$

Como si todo el libro fuera en parte un intento de dar respuesta a este tipo de preguntas desde una figura de poeta que se establece también como estudiante, en Poesía civil este principio crítico y didáctico da lugar a una serie de poemas que ponen el acento en aquello de la producción que no se ve, o que se oculta. Así, en "Paisaje de

producción literaria, y en su modo de revisar la tradición, se lee el mismo impulso que llevó a Marx a "arrancar las aureolas" de las cabezas de los intelectuales para poner de manifiesto sus relaciones con el mundo burgués cuyos valores rechazaban. "Los intelectuales", dice Marshall Berman”, deben reconocer las profundidades de su propia dependencia -dependencia tanto económica como espiritual- del mundo burgués que desprecian” (117). Es esta interdependencia lo que se explora en Poesía civil al poner la literatura en relación a otros ámbitos como el político y el económico, del que por lo general intenta separarse. Ver Marshall Berman, Todo lo sólido se desvanece en el aire. La experiencia de la modernidad., Buenos Aires, Siglo XXI, 1989 (82, 117).

${ }^{204}$ A continuación transcribimos otros fragmentos del poema, para que pueda leerse el tipo de operación que estamos considerando:

Tebas, la de las Siete Puertas, ¿quién la construyó?

En los libros figuran los nombres de los reyes.

¿Arrastraron los reyes los grandes bloques de piedra?

Y Babilonia, destruida tantas veces, ¿quién la volvió a construir otras tantas? ¿En qué casas

de la dorada Lima vivían los obreros que la construyeron?

La noche en que fue terminada la Muralla china,

¿adónde fueron los albañiles? Roma la Grande

está llena de arcos de triunfo. ¿Quién los erigió?

(...) El joven Alejandro conquistó la India.

¿El sólo?

César venció a los galos.

¿No llevaba consigo ni siquiera un cocinero?

(...) Una victoria en cada página.

¿Quién cocinaba los banquetes de la victoria?

Un gran hombre cada diez años.

¿Quién pagaba sus gastos?

Una pregunta por cada historia.

Bertolt Brecht, Poemas y canciones, Madrid, Alianza Editorial, 2005 (91, 92). Traducción de Jesús López Pacheco. 
Induclor con uno o dos operarios” (Raimondi: 2001, 23) se describe a dos hombres que trabajan con máscaras ("No se le ve la cara”, se dice de uno de ellos), en "Firma de electrodos en los caños del gasoducto” (Raimondi: 2001, 26, 27) se habla de cómo las marcas individuales de cada soldador para sellar unos caños por los que luego pasará el gas y que “testimonian el estilo/ serán hundidos luego tres metros bajo tierra.”, mientras que "Sueño y reparación” (Raimondi: 2001, 32, 33) trata sobre la dieta de los operarios seleccionada por la empresa en función de hacerlos rendir más con el mismo criterio de racionalidad que se impone a las máquinas.

Por eso la poesía constituye para Raimondi un modo de conocimiento que apuesta a la inespecificidad como modo de subvertir la separación propia del capitalismo y de la división moderna del trabajo entre diversos ámbitos de la vida práctica y del saber. Esta visión reúne la tradición marxista con aquello que ya detectábamos en el objetivismo, pero a diferencia de aquel, que suponía un conocimiento basado en la percepción, aquí se trata de uno de orden sensorial y al mismo tiempo intelectual (la escisión entre esas instancias sería, para Raimondi, imposible). Así, la investigación, o incluso el "estudio", como decíamos, se pone en escena en poemas que contienen sobre todo información, y para destacar la diferencia con el objetivismo es útil recordar cómo Fabián Casas se refería al mar como "ese montón de agua” (Casas: 1996, 9), en tanto Raimondi construye su poema titulado “Qué es el mar” (Raimondi: 2001, 28) como definición de una palabra recurrente para la poesía en términos de la actividad económica. ${ }^{205}$

\footnotetext{
${ }^{205}$ El poema completo dice: "El barrido de una red de arrastre a lo largo del lecho,/ mallas de apertura máxima, en el tanque setecientos mil/ litros de gas-oil, en la bodega bolsas de papa y cebolla,/ jornada de treina y cinco horas, sueño de cuatro, café,/ acuerdos pactados en oficinas de Bruselas, crecimiento/ del calamar illex en relación a la temperatura del agua/ y las firmas de aprobación de la Corte Suprema, circuito/ de canales de acero inoxidable por donde el pescado cae,/ abadejo, hubbsi, transferencias de permiso amparadas/ por la Secretaría de Agricultura, Ganadería y Pesca; ahí:/ atraviesa el fresquero la línea imaginaria del paralelo, va/ tras una mancha en la pantalla del equipo de detección,/ ignorante el cardumen de la noción de millas o
} 
Mientras el gesto de Casas suponía una poética que intentaba nombrar las cosas “a secas” y sin agregarles sentido, el de Raimondi implica una apertura de la palabra “mar”, no hacia el plano metafórico sino a dominios que en principio se piensan como separados de la poesía. Entonces el mar se define como "lugar" (tal como lo quería Prieto cuando decía que "Para mí la luna es un lugar”), pero uno en el que se lleva a cabo el trabajo de la pesca y luego el intercambio (ambos regulados por el Estado) que distribuye la mercadería a nivel internacional y somete la naturaleza a los parámetros del mercado, por el cual esas “toneladas de pota muerta” se vuelven inútiles, basura, ante la aparición del mejor cotizado langostino. La definición de “mar” en que consiste el poema no tiene que ver, como sucedía en los objetivistas, con despojar al lenguaje de sus connotaciones metafóricas para privilegiar la percepción como instrumento del conocimiento. Porque aquí la información que provee el poema -no perceptible a través de los sentidos más que en algunas de sus instancias, pero seguramente no en su totalidad- habla más bien de una concepción de la poesía como investigación que intenta reponer, por un proceso intelectual, las relaciones entre diversos órdenes de cosas a partir del procesamiento de lecturas marxistas. ${ }^{206}$

charteo,/ de las estadísticas irreales del INIDEP o el desfasaje/ entre jornal y costo de vida desde el año mil novecientos/ noventa y dos, filet de merluza de cola, SOMU y pez rata,/ cartas de crédito adulteradas, lámparas y asiático pabellón,/ irrupción de brotes de aftosa en rodeos británicos, hoki,/ retorno a lo más hondo de toneladas de pota muerta/ ante la aparición de langostino (valor cinco veces mayor),/ infraestructura de almacenamiento y frío, caladero, eso.” (Raimondi: 2001, 28).

${ }^{206}$ Ana Porrúa trabaja el modo de la visibilidad en la poesía de Raimondi como parte de un dispositivo objetivista -que define sobre todo a partir del ejercicio de la mirada- para decir que en Poesía Civil, hay una instancia que excede el régimen de visibilidad aparente que propone el libro desde el momento en que "ver" supone siempre "saber", "Porque lo que se sobreimprime a la visión es algo que no pertenece a su órbita en términos literales, una discursividad que apela a los materiales científicos, informativos, al discurso económico y político.” (Porrúa: 2001, 73, 74). Porrúa señala entonces que los poemas no se limitan a decir lo que se ve sino que despliegan un discurso interpretativo basado en analogías que se presentan como modos de ver, pero constituyen en realidad modos de interpretar. Ana Porrúa, Caligrafía tonal, Buenos Aires, Entropía, 2011 (129-135). En nuestro caso, la divergencia con respecto a esta perspectiva consiste en que no otorgamos al acto de ver un papel central en la poética de Raimondi, que en 
Raimondi se instala entonces en la tradición objetivista pero la desplaza por el procesamiento de estas lecturas, por eso en sus poemas la técnica, que se tomaba como vimos sobre todo de García Helder, adopta un valor específico vinculado con esa tradición que es el de poner de relieve el carácter material del lenguaje y del verso, al mismo tiempo que se evidencia su factura artesanal. La sofisticación y el retorcimiento de la frase tienen que ver aquí con esta idea tanto como con trabajar una técnica que permita reunir en la frase a través de usos sintácticos los órdenes del saber -y por ende, del lenguaje- que muchas veces funcionan aislados en la sociedad. Y es esa misma tradición marxista, con su énfasis en la producción material, la que sustenta la idea de poesía como artesanado y la atención a las “artes de hacer” de los otros en Poesía civil. Porque el poeta se homologa a otros artesanos que dan nombre como dijimos a una sección del libro que contiene el poema "Para hacer una torta sin leche”, cuyos versos finales dicen: "El resto se sabe: enmantecar un molde, enharinarlo/ y horno. Titi Trujillo le echa un chorrito de vino/ oporto. Titina Lancioni a veces licor de café o esencia/ de vainilla. Otros le ponen trozos de manzana,/ pasas de uva, chocolate o ciruela. Eso va en gustos,/ en las ganas de inventar, en lo que se tenga a mano.” (Raimondi: 2001, 66). ${ }^{207}$

nuestra opinión está basada, a diferencia del objetivismo de García Helder y de Prieto, en operaciones intelectuales.

${ }^{207}$ A continuación transcribimos el poema completo, que es al mismo tiempo una receta de cocina: La cocción tendrá que ver con el tipo de horno,/ como todo: se recomienda un fuego mínimo, lento/ de entre cuarenta y cuarenta y cinco minutos,/ pero cada cocina, como cada molde, es particular/ y es inútil establecer una medida exacta para todos./ Yo digo: una taza de té con leche de aceite de maíz/ (no mezcla), una y media (casi dos) de azúcar, bol/ y batir, batir: ladeado el recipiente y paleta el brazo/ o la máquina en su punto máximo. Ah, dos huevos/ además, y todo bien batido hasta espesar la mezcla./ Entonces se agregan dos tazas de agua hirviendo./ Se levantará una espuma. Se deja reposar un rato./ Mientras, se mezclan aparte tres tazas de harina/ (pasadas por el cernidor) con una cucharada/ de Royal y otra de bicarbonato (puede ser menos,/ más, se ve). Sumar todo y batir. Muy suavemente:/ hay que lograr que la masa pierda consistencia./ El resto se sabe: enmantecar un molde, enharinarlo/ y horno. Titi Trujillo le echa un chorrito de vino/ oporto. Titina Lancioni a veces licor de café o esencia/ de vainilla. Otros le ponen trozos de manzana,/ pasas de uva, chocolate o ciruela. Eso va en gustos,/ en las ganas de inventar, en lo que se tenga a mano. (Raimondi: 2001, 66). 
En las cocineras y artesanas Titi Trujillo y Titina Lancioni, que se mencionan en el poema por sus nombres (lo que recuerda a la pregunta de Brecht por los cocineros del César), se rescata aquello que también estaba en Díaz y en Ortiz, y que el poema destaca en los modos de hacer populares al tiempo que lo pone en práctica en cuanto a la tradición literaria: el gesto de trabajar con “lo que se tenga a mano”. En la poesía de Raimondi, tanto como en Díaz y en Ortiz, esto alude por un lado a lo más próximo -las prácticas cotidianas, las costumbres y los modos de la cultura local- pero también a una tradición adquirida de modo institucional y usada como herramienta para ocupar tácticamente los espacios del otro, en Díaz; para construir el texto como continuidad entre el archivo literario y la vida cotidiana, en Ortiz; y para armar el poema como espacio de tensión y relaciones entre distintos órdenes del saber y de la actividad práctica a partir de la idea de totalidad, en Raimondi.

En general, los poetas que hemos analizado construyen el texto de manera deliberada como “montaje de tiempos heterogéneos” porque trabajan explícitamente con la tradición, que reescriben y evalúan con sentido crítico. El anacronismo se convierte en estos casos en una figura productiva capaz de poner a prueba tanto las retóricas del pasado (el repertorio lírico en Rubio y el barroco en Díaz, los usos metafóricos de la poesía romántica en Raimondi) como los discursos y modos de hacer del presente (desde el habla cotidiana hasta el discurso periodístico). Si esto es posible es porque todos ellos hacen una lectura "histórica” de aquellos segmentos de la tradición que eligen y procesan, ya sean formas, motivos o textos puntuales. Para decirlo de otro modo, se trata de poetas que presentan un grado de autoconciencia fuerte sobre la pertenencia cultural y la diferencia temporal de los textos de la tradición que se trabajan. 
Esa conciencia habilita por un lado modos de contrastar las representaciones y lenguajes de la tradición con las escenas del presente, ya sea para poner de relieve la decadencia y el anacronismo de la poesía entendida como discurso profético y bello en Rubio, como para construir una poeticidad de la vida cotidiana que permita apropiarse de la tradición e instalarla en ese mismo mundo, en Ortiz. En Díaz y Raimondi, a su vez, el gesto de asociar la tradición a los modos de hacer artesanales de la cultura popular y el trabajo manual supone una lectura política donde la tradición se piensa en el marco de la cultura dominante que impone determinados valores (concernientes sobre todo a la poesía, y la cultura en general, como ámbitos separados del mundo material y cotidiano), y esto es precisamente lo que intenta subvertirse en el texto.

Pero lo más importante quizás es que en todos ellos hay también una voluntad de construir representaciones del presente que contemplen la existencia de anacronismos, es decir, de proponer visiones heterogéneas y alternativas que no permiten englobarse como “modernidad” o “posmodernidad”, porque hablan de un presente que incluye en sí mismo muchas otras temporalidades que merecen leerse.

\section{4- DOS VARIACIONES SOBRE POUND: LA ESCRITURA IDEOGRAMÁTICA DE LAURA WITTNER Y LAS RECUPERACIONES CLASICISTAS DE WALTER CASSARA}

El archivo vuelto disponible por el Diario de poesía, y la misma producción de los objetivistas que analizamos en el primer capítulo, habilita entonces diversos recortes y selecciones que dan lugar a poéticas por demás variadas, que incluyen desde reescrituras barrocas como en Diesel 6002 de Díaz, hasta reversiones de los mitos 
clásicos en la poesía de Mario Ortiz. Esto sucede en parte porque, si se tiene en cuenta que la una de las figuras que sirve como punto de partida a algunos modos de leer y pensar la poesía es la de Pound, como hemos intentado demostrar, su obra presenta variantes que van desde poemas breves e imagistas hasta reelaboraciones de Propercio en Homage to Sextus Propertius y del poeta chino Li Po en un libro como Cathay. ${ }^{208}$

Así, la obra de Pound funciona como archivo del que los poetas de los noventa pueden tomar, ya sea una ideología y una ética sobre el lenguaje, como en Daniel García Helder, un principio constructivo como la preponderancia de la imagen que destacaba Fondebrider ${ }^{209}$ o, como es el caso de los poetas que analizaremos, un ejercicio de reescritura de la tradición que se activa en las recuperaciones clasicistas de Juegos apolíneos (1998) de Walter Cassara, y un modo de composición ideogramático que Pound expone en El $A B C$ de la lectura y practica en sus poemas, y que Laura Wittner procesa en Las últimas mudanzas (2001) en un repertorio que cruza los postulados de Pound con ideas similares de William Carlos Williams.

Homage to Sextus Propertius ${ }^{210}$ (1917) es un libro en el que Pound reversiona elegías del poeta latino Propercio. Los textos consisten menos en una traducción que en una apropiación, porque el gesto es el de un poeta moderno usando como medio a un autor clásico para dar forma a su propia poética y, al mismo tiempo, reponer cierta

\footnotetext{
${ }^{208}$ El libro completo, que se basa en una serie de traducciones de Ernest Fenollosa reelaboradas libremente por Pound, fue publicado originalmente en 1915 y está incluido en Ezra Pound, Personae. Los poemas breves., Madrid, Hiperión, 2003 (257-291).

${ }^{209}$ Dossier Pound, Diario de poesía No 3, Verano de 1986, (13).

${ }^{210}$ En Ezra Pound, Selected poems of Ezra Pound, New York, New Directions, 1957 (78-95); Ezra Pound, Personae: the collected poems of Ezra Pound, including Ripostes, Lustra, Homage to Sextus Propertius, H. S. Mauberley, New York, New Directions, 1946. Existe una traducción libre reciente en español; ver Ronald Kay, Propercio, Pound, Santiago de Chile, La Calabaza del Diablo, 2005.
} 
actualidad en textos que la mayoría de las traducciones volvían “arcaicos”. ${ }^{211}$ De modo similar, en Cathay (1915) Pound simula traducir una serie de poemas chinos anotados por Ernest Fenollosa pero en realidad altera los textos, omite secciones y amplifica otras, porque el interés que lo guía es el de desarrollar el verso en lengua inglesa. Así, como señala Hugh Kenner, ${ }^{212}$ los poemas se vuelven reversiones de los textos chinos que activan los principios de la poética imagista en el interior de una tradición de la que Pound se apropia, antes que desde el uso de su propia lengua. Lo mismo puede decirse de muchas secciones de los Cantos, donde fragmentos de la tradición como El cantar del Mio Cid o La Odisea se incluyen en otro contexto, y sobre todo en otra lengua, que inevitablemente los modifican y ponen en evidencia ante todo, más que una traducción, un modo de leer esos textos (dado que la traducción es tan “selectiva” como la tradición, parafraseando la definición de Raymond Williams, desde el momento en que acota y dirige el sentido). ${ }^{213}$

Pero en Homage to Sextus Propertius y en Cathay, además, la construcción de diversas voces mediante el ejercicio de traducción libre altera las bases de la lírica porque se trata de poemas enunciados por diversas “personae” o “máscaras”. El término

\footnotetext{
${ }^{211}$ Según J. P. Sullivan, el modo de traducción libre de Pound tiene que ver con que para el poeta, "if a dead poet is to become a living poet, if a dead tradition is to become part of a living poetic tradition, it must first have something vital to offer and it must tempt someone who sees that something to re-create it in living terms by whatever method is appropriate. As living poetry the classics can only exist in translation.”. Ver J. P. Sullivan, Ezra Pound and Sextus Propertius. Austin, University of Texas Press, 1964 (22).

${ }^{212}$ Kenner señala, con respecto al ejercicio de "traducción” de Pound, que si bien se basó en notas de Ernest Fenollosa a los poemas chinos, sus versiones contienen divergencias con respecto a las originales que fueron percibidas como propias de una mala traducción. Pero el interés de Pound en alterar el contenido se debe en realidad a una voluntad de elaborar un texto mejor en lengua inglesa, por eso muchas veces cambia detalles o directamente omite partes del poema original. Así, más que una reproducción en otra lengua y cultura (que de todas maneras sería imposible) el ejercicio de Pound tiene que ver con una apropiación de una tradición y un trabajo de recorte y variación sobre materiales previos. Hugh Kenner, The Pound Era, Berkeley, University of California Press, 1971 (192-222).
}

${ }^{213}$ Ezra Pound, The Cantos of Ezra Pound, New York, New Directions, 1989. 
procede del latín y es el equivalente del griego “prósopon”, ${ }^{214}$ que significa literalmente “máscara” y designaba las que se usaban en el teatro griego y luego, por extensión, a los personajes de una obra. Estas “personae” enunciativas (Pound ya había usado el término como título de su libro Personae, de 1909) quiebran la base de la lírica porque no pueden identificarse con la figura del autor, ${ }^{215}$ como en "La esposa del mercader del río: una carta” de Cathay, donde la que habla es una mujer. ${ }^{216}$ Este ejercicio no es propio de la modernidad sino que remite a la literatura clásica -un ejemplo claro es el de la traducción recreativa que Catulo hace de un famoso poema de Safo- ${ }^{217}$ y subvierte la idea de “expresión” a la vez que supone que la emotividad procede en realidad de la composición y de un uso intensificado de la lengua antes que del pacto de lectura que atribuye el contenido del poema a la subjetividad de un autor.

Juegos apolíneos de Walter Cassara se presenta también como un ejercicio de construcción de "máscaras” que reelabora los mitos y motivos clásicos sin tomar un

\footnotetext{
${ }^{214}$ Ver Diccionario Griego-Español Vox, Barcelona, Bibliograf, 1997 (1967) y Diccionario Latino-Español Vox, Barcelona, Bibliograf, 1998.
}

${ }^{215}$ Käte Hamburger define la lírica como aquel modo de la enunciación en que el "yo" que enuncia el poema establece una relación de identidad con el "yo" del escritor; ver Kate Hamburger, “El género lírico”, en La lógica de la literatura, Madrid, Visor, 1995 (158).

${ }^{216}$ A continuación reproducimos un fragmento de este poema, a modo de ejemplo: "While my hair was still cut straight across my forehead/ I played about the front gate, pulling flowers./ You came by on bamboo stilts, playing horse,/ You walked about my seat, playing with blue plums./ And we went on living in the village of Chokan:/ Two small people, without dislike or suspicion.// At fourteen I married My Lord you./ I never laughed, being bashful./ Lowering my head, I looked on the wall./ Called to, a thousand times, I never looked back.// At fifteen I stopped scowling,/ I desired my dust to be mingled with yours/ Forever and forever and forever./ Why sould I climb to look out?”. Ezra Pound, “The River Merchant's Wife: A Letter" ("La esposa del mercader del río: una carta”), en Ezra Pound, Personae. Los poemas breves., Madrid, Hiperión, 2003 (266, 267). Como se ve, se trata de una mujer cuyo esposo está de viaje y que, al mismo tiempo que expresa su nostalgia por él, le pide que le avise de su regreso para salirle al encuentro, en los últimos versos.

${ }^{217}$ Se trata del Poema LI de Catulo que comienza con los versos "Ille mi par esse deo videtur,/ ille, si fas est, superare divos,/ qui sedens adversus identidem te/ spectat et audit", y que es una versión de un poema de Safo. Ver G. P. Goold (Ed.), Catullus, Tibullus, Pervigilium Veneris, Harvard University Press, 1995 (58-61). 
texto específico como base. ${ }^{218}$ Así por ejemplo, quien habla en “Artemis” (Cassara: 1998, 33) es la propia diosa, que cuenta su historia ("Hefesto me construyó un arco/ de oro, con flechas de oro/ y un carcaj también dorado”). Los textos seleccionan fragmentos centrales de la tradición como la muerte de Orfeo (Cassara: 1998, 19), la transformación de Ofiuco (Asclepio) por Zeus en una constelación a modo de castigo (Cassara: 1998, 20), el triunfo de Baco en Roma (Cassara: 1998, 24), o amplifican motivos secundarios como en una escena donde un mancebo toma agua de una fuente después de ejercitarse en el gimnasio (Cassara: 1998, 21) y una descripción detallada del taller de Hefesto (Cassara: 1998, 25). Además, el repertorio trabaja tanto mitos como motivos y estilos poéticos; así, en "Escancia con vino tus pulmones” (Cassara: 1998, 26) se versiona el motivo de la invitación a beber y de la brevedad de la vida (“Escancia con vino tus pulmones,/ otra vez no brillará el mediodía/ para nosotros, ni el laurel durará otro verano”), y en “De poesía bucólica” (Cassara: 1998, 47) se pasa revista a las figuras de la tradición que se dedicaron al canto y la poesía como Hermes, Apolo, Artemis, Orfeo, Pan y Dafnis.

Los desvíos en el modo de contar el mito son mínimos pero presentan un énfasis especial en detalles puntuales. De Sócrates se rescata, por ejemplo, no su filosofía sino que "Una corrosión, una lozanía/ de viejo sátiro es lo que amamos, no sus discursos./ Ni siquiera el gusto por los mancebos, sino/ el hedonismo despectivo, el gesto diáfano/ de elegir eso, no otra cosa/ única fuente de sabiduría” (Cassara: 1998, 49). A su vez, cuando se comenta el mito de Leda y el cisne se pone de relieve el aspecto erótico: “Primero el coito, después qué importa/ la alegoría. Leda se arrulla al calor del ave./ Dormida/ es un ascua que vuelve a encenderse.” (Cassara: 1998, 52). De modo similar, en “El taller de Hefesto” se intenta una descripción detallada del taller y del sudor de los

\footnotetext{
${ }^{218}$ Walter Cassara, Juegos apolíneos, Buenos Aires, Siesta, 1998. Todas las citas posteriores están tomadas de la misma edición.
} 
que allí trabajan: "las herramientas mejor afiladas de toda Lípari,/ varias fundiciones y martillos/ y ayudantes esponjando el sudor” (Cassara: 1998, 25). El "hedonismo” del que se hablaba a propósito de Sócrates se hace presente también en otro poema que elabora el motivo clásico de que “Los amados por los dioses mueren jóvenes”, como indica el título (Cassara: 1998, 31).

No solamente se amplifica lo sensual y hedonista, sino que también se pone el acento en el potencial homoerótico que contienen los mitos. Así, en “Ofiuco” se habla de dos hermanos cuyos “culitos blancos se rindieron al gran culo/ negro de Heracles” (Cassara: 1998, 20), o en "Se abreva el mancebo en la fuente" se destaca la delicadeza del joven que termina de hacer ejercicios "Porque también sabe el héroe dar gracias/ e inclinarse como una flor en la fuente” (Cassara: 1998, 21). ${ }^{219}$ Lo que parece construirse de ese modo es un relato del deseo masculino por otros hombres: "Comienzo a pensar seriamente/ que él y yo somos como Cástor y Pólux,/ gemelos por la gracia de los dioses. El y yo/ nos compenetramos hasta abolir toda diferencia./ Si él se repliega hacia la selva en ondulaciones linfáticas/ yo me despliego hacia las lujurias del desierto” (Cassara: 1998, 41). Como se ve, el lenguaje del poema “erotiza” a una pareja de hombres que se piensan como gemelos por analogía con el mito. El último poema del libro, de hecho, concluye con la idea de que "el rostro del bello muchacho", que “sobresale de la multitud”, terminará por apagarse y perder tanto la vida como la belleza, pero “mis ojos cansados/ seguirán buscándolo” (Cassara: 1998, 55).

De esta manera, al amplificar y poner en primer plano algunos detalles secundarios y seleccionar sobre todo aquellos segmentos de la literatura y la mitología clásicas que habilitan una lectura en clave amorosa y erótica de las relaciones entre

\footnotetext{
${ }^{219}$ De Patroclo se dice que si lo cobijaron en la tienda de Apolo como a un príncipe "fue por tu belleza inusitada" (Cassara: 1998, 32), y otro texto pone de manifiesto la amistad entre hombres como amor pasional al decir: "Aquiles y Patroclo, Jasón/ y Hércules lo sabían. Felicidad es/ caer en el campo de batalla/ y que nuestras cenizas se confundan.” (Cassara: 1998, 44).
} 
hombres -que indudablemente no funcionaban del mismo modo en el mundo clásico, donde eran admitidas socialmente, que en nuestra cultura donde normalmente son, o fueron hasta no hace mucho tiempo, "velados"-, Cassara como lector selectivo “escamotea” segmentos de la tradición clásica para construir una poesía homoerótica en el presente. Pero la apropiación no está dada solamente por el recorte de fragmentos de mitos y el uso de motivos, sino también por la inscripción de la lengua coloquial dentro de la tradición que se trabaja.

El ejercicio no es, sin embargo, el de “traducción” de materiales clásicos a la lengua coloquial; se trata más bien de incrustaciones mínimas que sin embargo delatan la apropiación de materiales desde otra cultura, al mismo tiempo que plantean una familiaridad con la tradición y una figura de poeta contemporáneo que se oculta detrás de “máscaras” para revelar un modo del deseo. Por ejemplo, se dice que Orfeo “dominó al cerbero y durmió/ a los tres jueces con una tonadita ligera” (Cassara: 1998, 19). Otro poema llamado “Lamento por Heracles” comienza con los versos “Pobrecito Heracles, haber pasado/ tantos trabajos y quedar abolido/ en mitad de la apoteosis”, y dice más adelante “Qué nostalgia, dios mío, haberse quedado/ en semidiós para mirar por la ventana/ el encumbrado banquete” (Cassara: 1998, 38). Y de Mirtilo, muerto en una carrera de carros que el poema describe, se declara que "zinchando a la yunta, revolucionando/ como una hoja encaró la recta final” (Cassara: 1998, 39). De modo que las ocurrencias del registro oral se combinan en una misma oración con otro tipo de dicción que bien podría pensarse como una falsa traducción de textos clásicos.

Habría que aclarar, sin embargo, que estos usos no tienen por función, como en la poesía de Mario Ortiz, instalar la tradición en el mundo inmediato y cotidiano, que de hecho está borrado en los textos de Cassara a excepción de su manifestación verbal en los ejemplos citados. El libro de Cassara da la impresión, de este modo, de que "Cada 
poema (...) debe haber sido construido, sopesado en el más extremo silencio, como en una cámara cerrada que no parece deberle nada a este mundo” (Cassara: 1998, 9), como señala Osvaldo Bossi en el "Preludio”. El correlato de esta actitud está cifrado de hecho en el poema “Que se amontonen por miles" donde, a tono con ese "hedonismo despectivo” que se atribuía a Sócrates, se reformula el motivo del desprecio por el vulgo (que estaba en Pound, y también como vimos en Prieto) para decir: "Que se amontonen por miles/ tras el vano de la puerta estrecha;/ (...) Nada de esto debe importarnos,/ siempre la majada se apretuja contra el cerco/ cuando no hay sitio en el corral;/ y son pocos los uncidos al carro,/ los que expurga y reglamenta/ la mayoría.” (Cassara: 1998, 35). Por eso, si bien Cassara comparte algunas lecturas y selecciones con el repertorio conformado por Ortiz, Díaz y Raimondi, las resoluciones son distintas porque aquí se trata de construir poemas donde la apropiación de una tradición constituye una forma de rechazo parcial de la cultura popular que analizábamos en aquellos, y del mundo cotidiano. ${ }^{220}$

En este punto, es útil comparar este trabajo con lo clásico con el de Sergio Raimondi, que también reescribe segmentos de la tradición clásica en una serie de textos inéditos de los que sólo aparecieron fragmentos en la antología Monstruos y en un suelto incluido en la revista Vox. Allí, Raimondi construye una serie de poemas en estrofas de cuatro versos que funcionan a modo de diálogo entre Alexis y Corydón, pastores que aparecen en las Églogas de Virgilio. Pero la operación es distinta porque en este caso se toma de las Églogas la estructura dialógica para poner en escena un registro que mezcla el habla coloquial con una sintaxis más elaborada, en versos libres armados sobre la base del octosílabo y el endecasílabo y en un discurrir que se detiene sobre lo cotidiano: “Corydón: En el campo las estrellas vi una vez/ entre cardos al ras y

\footnotetext{
${ }^{220}$ En Arturo Carrera (selección y prólogo), Monstruos. Antología de la joven poesía argentina, Buenos Aires, Fondo de Cultura Económica, 2001 (149-153).
} 
rosetas volando/ más veloces la verdad que no sé qué/ Yo quería una para llevarme a casa/ (...) Alexis: En alta mar el partrón relojea a Vito/ que zarandea sin ganas la pesca/ y deja dos o tres rayas entre los langostinos./ “¿Qué anda pasando, Vito?”, pregunta.” (Carrera: 2001, 151). El poema funciona de este modo como síntesis que reúne la estructura virgiliana con el tipo de cuartetos propios del soneto y versos que van del dolce stil nuovo y el renacimiento español al modernismo latinoamericano y que se usan, por ejemplo, para citar el habla de un pescador artesanal, al tiempo que el primer verso citado reformula los versos populares "En el cielo las estrellas, en el campo las espinas”. Pero lo importante de esta operación compleja es que se trata de poner en escena la vida y el habla cotidianas a partir de la apropiación de formas tradicionales, que en el ejercicio de traducción cultural revelan su actualidad. ${ }^{221}$

El gesto de Cassara en cambio se asemeja más al de Pound, que recupera la tradición con el doble propósito de probar los alcances poéticos de la propia lengua, y a la vez usarla como “máscara” para plantear una sensibilidad que se opone a los valores vigentes en la época. En Cassara también, la figura de poeta “enmascarado” en la tradición funciona como construcción de una voz simultáneamente clásica y

${ }^{221}$ En su segundo libro, El bizantino (Córdoba, Alción: 1994), Silvio Mattoni también recupera la tradición clásica grecolatina en una serie de textos que llevan por nombre el de algún poeta o personaje clásico: "Lucrecio", "Propercio”, “Catulo”, "Cleis”, "Ligurino”, “Ovidio”, y así sucesivamente. En ciertas ocasiones son estos personajes los que enuncian en el poema, y en otras el "yo" se dirige a ellos en segunda persona. Sin embargo, no nos detenemos en esta tesis en las reescrituras de Mattoni por considerar que en su caso no hay un ejercicio crítico que actualice la tradición clásica, como los usos coloquiales de Cassara y Raimondi, y ni siquiera que subvierta su sentido mediante lecturas desviadas. Se trata, más bien, de una repetición realizada en un lenguaje diferencial que mantiene el estatuto culto de la tradición clásica como puede verse en el siguiente poema llamado "Catulo" donde por contraste, la cita del poeta latino "suena" mucho más actual que los versos de Mattoni: "Muerto el gorrión de Lesbia, trabaja el poeta/ sin terminar, teme las hábiles palabras, busca/ exactitud, belleza y claridad en la sombra/ de la cámara, donde ella se acera y lo llama./ No vayas todavía, veronés, ya salen esos versos:/ "Está muerto el gorrión de mi nena,/ ese gorrión, delicia de mi nena,/ que ella más que a sus ojos amaba."/ Lesbia se acuesta, ansiosa, se distrae/ acariciando el cuerpo del eunuco, escanciador de vino/ burlándose, sin risa, de las frases que el amo se repite.” (Mattoni: 1994). De todos modos la idea de enunciación a través de diversas voces, que despliega Cassara, también está presente aquí, tanto como su siguiente libro titulado, precisamente, Tres poemas dramáticos (Córdoba, Alción: 1995). 
contemporánea, que permite contrastar dos épocas y sus modos de experimentar la diversidad sexual. Porque el trabajo sobre materiales “arcaicos” y su reversión en un registro por momentos oral que los actualiza hace que por contraste, la censura sobre la diferencia sexual aparezca como lo verdaderamente “arcaico”.

Laura Wittner por su parte retoma la ideología poética de Pound que se basa en su propia interpretación de la escritura ideogramática, explicitada en $E l A B C$ de la lectura. Se trata, por supuesto, del modo como Pound lee y entiende la escritura china (muchas veces se ha cuestionado su precisión científica, pero ése no es el caso porque lo importante es que la lectura de Pound, aunque desviada, le sirve para formular su propia poética) donde el sentido proviene de la yuxtaposición de elementos que siempre son concretos. Así, la definición de “rojo” provendría de la unión entre los términos “rosa”, “hierro oxidado”, “cereza” y “flamenco” (Pound: 1968, 19). ${ }^{222}$ Pound piensa en este texto, ante todo, en una poética fuertemente basada en lo concreto, donde los significados más abstractos se construyan siempre a partir de lo sensorial. Y también en un tipo de poema descriptivo que antes que comentar un objeto o una escena la presente al lector y la construya de tal manera que le permita sacar sus propias conclusiones en un tipo de lectura que se concibe como actividad. Por eso aísla tres principios constructivos: la “fanopoeia” (representar el objeto ante la imaginación visual), la “melopoeia” (sugerir correlaciones emocionales por el ritmo y el sonido) y la “logopoeia” (descrita también como "la danza del intelecto entre las palabras”, porque tiene que ver con sugerir relaciones intelectuales o emocionales por la disposición de las palabras en el texto) (Pound: 1968, 51).

\footnotetext{
${ }^{222}$ Es importante destacar el trabajo sobre la escritura china que Pound hace al concluir el texto del sinólogo Ernst Fenollosa. Ver Pound, Ezra y Fenollosa, Ernest. El carácter de la escritura china como medio poético, Madrid, Visor, 1977 [1936]. Traducción de Mariano Antolín Rato.
} 
En "El lamento de la escalera de gemas", que es uno de los poemas del libro Cathay, citado anteriormente, Pound agrega una nota donde se ilustra el modo en que concibe estos procedimientos compositivos que rastrea no sólo en la escritura sino también en la poesía china. El poema, de sólo cuatro versos, dice: "Los peldaños de gemas están ya casi blancos de rocío,/ tan tarde es que el rocío humedece la gasa de mis medias,/ y dejo caer la cortina de cuentas de vidrio/ y a través del límpido otoño contemplo la luna.” (Pound: 2000, 271). ${ }^{223}$ La nota que figura a continuación pone en escena el modo en que Pound deriva ideas y nociones más abstractas de los elementos concretos presentes en el poema:

Escalera de gemas, es decir, un palacio. Lamento, es decir, algo de lo que quejarse. La gasa de mis medias, es decir, es una dama de la corte y no una criada la que se lamenta. Límpido otoño, es decir, él no puede excusarse a cuenta del tiempo. También ella ha llegado temprano, porque el rocío no sólo ha blanqueado los peldaños, sino que ha humedecido sus medias. El poema es especialmente apreciado porque ella no profiere ningún reproche de modo directo. (Pound: 2000, 271).

A este modo de condensar información en unos pocos elementos y de plantear lo abstracto (el "reproche” del que habla Pound) en frases que "presentan" el objeto ante los sentidos y permiten una actividad del lector que infiera su significado se refiere también William Carlos Williams en los versos del poema "Paterson” que se toman como representativos de su poética: "No ideas salvo en las cosas”. ${ }^{224}$

Estas formulaciones se activan en la poesía de Laura Wittner, que trabaja una escritura fuertemente centrada en lo material. Lo ideogramático se hace presente en la medida en que lo abstracto se construye siempre a partir de elementos concretos y cotidianos, como sucede en este caso con la idea de "pureza" que se vierte como

\footnotetext{
${ }^{223}$ La versión en inglés, titulada “The jewel stairs' grievance”, es: “The jewelled steps are already quite white with dew,/ It is so late that the dew soaks my gauze stockings,/ And I let down the crystal curtain/ And match the moon through the clear autumn.” (Pound: 2000, 270).

224 “No ideas but in things", en idioma original. En William Carlos Williams, The collected earlier poems, New York, New Editions, 1966 (233-235).
} 
“imagen”: "tratando de invocar/ una imagen de pureza,/ una bañera reluciente recién/ pasada por el ódex”. ${ }^{225}$ La operación, que revela el procesamiento de las lecturas que acabamos de exponer, es tan autoconciente que la materia se nombra una y otra vez como tal, y no solamente en objetos concretos. El poema final de Las últimas mudanzas se llama "Siempre más o menos el mismo material”, y lo que lleva adelante el desarrollo del texto es el deslizamiento de la percepción y el intelecto entre los objetos. ${ }^{226} \mathrm{Al}$ comienzo del poema hay una "despedida” que no tiene como efecto desatar emociones de forma lírica sino que se concentra, como en el “Lamento de la escalera de gemas”, en un objeto: una piedra que los que se van a despedir encontraron juntos. En un ejercicio autorreflexivo, el poema describe un gesto como “teatral”, porque se pone de manifiesto que el movimiento puede ser leído, es decir, puede constituirse en signo.

Pero el texto nunca se detiene en un hecho sino que pasa rápidamente a otro; no hay, como en los objetivistas, un procedimiento compositivo que haga foco en un objeto particular, sino una dispersión entre diversos elementos. Al mismo tiempo el poema pone en escena su modo de construir sentido cuando la que habla deriva información a partir de un objeto como las rosas amarillas: “““Se las regaló un hombre”, pensaste”, con lo cual da lugar a un modo de interpretación similar para el próximo verso, “Tenés una

\footnotetext{
${ }^{225}$ Laura Wittner, Las últimas mudanzas, Bahía Blanca, Ediciones Vox, 2001 (20). Todas las citas posteriores están tomadas de la misma edición.

${ }^{226}$ A continuación reproducimos parte del poema para ilustrar la operación a la que nos referimos: "Tenés la remera manchada con mermelada del desayuno./ En un minuto partirá el tren, hacia el centro/ de un continente, y nunca más se verán. Suena el silbato:/ él se lleva la mano al pecho, y en un gesto teatral/ muestra sobre su palma la piedra que encontraron juntos,/ ayer en la playa./ Tenés las uñas repintadas una y otra vez. Capas de esmalte./ Salís de la fiesta al frío de la noche, te metés en tu auto/ y conducís. En el semáforo desierto volvés a delinearte/ los ojos con una raya negra desprolija./ Hojitas secas sobre el parqué junto a la puerta del patio./ Lo primero que viste al entrar a su casa fue una docena/ de rosas amarillas atadas con una cinta verde abandonadas/ sobre la mesa. "Se las regaló un hombre”, pensaste.” Tenés una estrellita dibujada entre teta y teta./ Conducías por la nieve como si estuvieras acostumbrada,/ y el reflejo del sol rebotaba por todas partes./ La primera señal de la ciudad fue un granero rojo/ en medio de la nada./ Querías mejillones y aquí están: el mozo trae más,/ deja una pila de conchas vacías, decís esta fuente/ ya se puede retirar./ Se mezcló el subtitulado. Las letritas/ corresponden a otra serie./ Horas, días y años de lavar la taza del desayuno./ (...).” (Wittner: 2001, 45).
} 
estrellita dibujada entre teta y teta” (Wittner: 2001, 45). Es decir que así como la voz que enuncia el poema se fija sobre un objeto para hacer conjeturas, la yuxtaposición de este fragmento con el verso recién citado sugiere una operación similar al lector que levante la pregunta sobre quién habrá pintado esa “estrellita”. El funcionamiento del sentido en relación al modo de presentar los objetos remite entonces a lo que Pound llamaba “logopeia” y “fanopeia”, porque aquí vale tanto “mostrar” o hacer perceptible un objeto como el lugar que se le da en la cadena significante que es el poema, y que construye sentido.

Hay que destacar además que en el poema el propio lenguaje deviene materia en la medida en que se percibe como "subtitulado", es decir, como letras que se superponen a lo visual en tanto imagen. Esta concepción del lenguaje que organiza el diseño estrófico de algunos textos de Wittner aparece también en otro texto que tematiza el ejercicio descriptivo, en el que se trata de dar cuenta del vapor que surge de los platos recién lavados. En este caso se dice que "esta fuente de calor/ admite un único encuadre-/ el que la necesita como núcleo/ de una dura sintaxis” (Wittner: 2001, 22). Al describir algo tan evanescente como la temperatura, un estado que se manifiesta en el vapor que exhalan la porcelana y el vidrio - es decir, una materia que se desprende literalmente de los objetos- se apela a una “dura sintaxis” que sería lo opuesto al objeto descrito (por otra parte, la idea de “encuadre” parece introducir una concepción fotográfica pero esta posibilidad enseguida se desvía hacia los usos sintácticos, con lo cual se pone en primer plano el artificio verbal). De esta manera se establece una tensión, antes que una relación mimética, entre la cualidad material del lenguaje y la propia materia, a la vez que se pone de manifiesto cómo el trabajo de composición de la frase puede hacer "palpable” un objeto que de otro modo no tiene forma propia. 
De modo similar, en "Me cuenta mi padre..." se menciona un llamado telefónico durante el cual alguien habla de la ciudad de Toronto: "si fuera por vos/ no existiría población en Canadá,/ tan a trasmano de un clima razonable” (Wittner: 2001, 42). Esta idea se reformula con el sintagma “desbaratás Toronto”, que pone de relieve el hecho de que en el texto, la ciudad es de lenguaje, y como tal, puede deshacerse y dar lugar a esta idea: "Me quedo un largo rato sentada/ frente al escritorio, pensando/ en un material que pueda/ ser modelado con los dedos/ pero que también, con la presión/ y la insistencia/ se empiece a deshacer en migajas/ para devolverse al vacío.” (Wittner: 2001, 42). Eso es entonces para Wittner lo que hacen las personas al hablar, al usar el lenguaje: forman materia, y también la “desbaratan”. Y es, al mismo tiempo, la operación que efectúan los poemas. Este punto constituye una diferencia importante con los objetivistas, porque si bien en ellos funciona también la premisa de lograr precisión en el uso del lenguaje postulada por Pound, la precisión está vinculada, como vimos, a la referencialidad y a la voluntad de buscar una palabra "justa” para designar al objeto. ${ }^{227}$ Para decirlo de otro modo, en el objetivismo, según García Helder, se haría presente una confianza en la posibilidad del lenguaje para designar un objeto, desde el momento en que "conseguir el sustantivo más adecuado” es un objetivo posible (García Helder: 1987, 25).

Wittner plantea en cambio cierta desconfianza en cuanto al lenguaje y sobre todo los sustantivos, especialmente los que designan conceptos tan abstractos como ese vapor que se desprende de la vajilla recién lavada, como sucede con el término “amor”: "lo inexplicable/ es cómo un concepto tan difuso/ se las arregló para/ ser representado

\footnotetext{
${ }^{227} \mathrm{Al}$ respecto, dice García Helder en su artículo "El neobarroco en Argentina” citado en el capítulo anterior, postulando un uso del lenguaje que se oponga al uso "fraudulento" del neobarroco: "todavía nos preocupa imaginar una poesía sin heroísmos de lenguaje, pero arriesgada en su tarea de lograr algún tipo de belleza mediante la precisión, lo breve -o bien lo necesariamente extenso-, la fácil o difícil claridad (...). Que la palabra justa, ese sueño de Flaubert y de tantos otros, sea una ilusión de prosistas con la que los poetas a menudo no quieran transar, no invalida el esfuerzo de nadie por conseguir el sustantivo más adecuado y el adjetivo menos accesorio para lo que intenta decir”. Daniel García Helder (García Helder: 1987, 25).
} 
por algún sonido/ en tantos idiomas/ sino en todos” (Wittner: 2001, 12). Se trata entonces de una poética que sospecha de las ideas y los conceptos, de ahí el énfasis puesto sobre la materia (de la cual, insistimos, el lenguaje forma parte). Antes que buscar la palabra que designe con precisión un concepto u objeto, la operación de Wittner es más bien la de trabajar una “dura sintaxis” que se oponga a lo difuso de las ideas y los significados y que ponga en cuestión toda posible transparencia del lenguaje.

Por eso, y como recorte distintivo sobre el archivo objetivista, en Wittner el principio de construcción ideogramática de Pound está cruzado con un tratamiento de los objetos que remite al procesamiento de los poemas extensos de William Carlos Williams, donde la presentación de las cosas materiales siempre es parcial y fragmentaria (en oposición a esta modalidad de Williams, podría decirse que los poemas objetivistas centrados en un objeto producen en ciertos casos la ilusión de estar presentándolo a la percepción por medio del lenguaje). De hecho y como adelantamos, aquí los textos no hacen centro en nada, no enfocan, y proponen en cambio descripciones precisas pero fragmentadas. En este sentido, el "Paterson” funciona como modelo de poema extenso en el que Williams Carlos Williams ensayó una “épica monumental (un poema que, como dice Pound, incluye la historia)”, según Allen Ginsberg, de una ciudad pequeña “con una historia propia desde la revolución norteamericana”. ${ }^{228}$ Sólo que Wittner deja de lado el aspecto histórico (que sí elabora

\footnotetext{
${ }^{228}$ Ver Allen Ginsberg, "La práctica poética de William Carlos Williams”, en Ginsberg, Levertov, Rexroth, Stevens, William Carlos Williams. Poemas, textos, entrevistas., México, Universidad Autónoma de Puebla, 1987 (129). A continuación transcribimos, a modo de ejemplo, un fragmento del poema "Paterson" que figura en esta edición: "Antes de que salga la hierba sale la gente/ y desnudas ramas azotan el viento/ cuando no hay nada, en la pausa entre/ la nieve y la hierba en los parques y esquinas/ -Dilo, no ideas salvo en las cosas-/ nada salvo las pálidas caras de las casas/ y cilíndricos árboles/ doblegados, hendidos por preconcepción y accidente/ rajados, surcados, acanalados, moteados, manchados/ secretos -en el cuerpo de la luz-/ (...) Desde arriba, más alto que las agujas, más alto/ aún que las torres de oficinas, desde cenagosos campos/ abandonados a grises lechos de hierba muerta/ negro zumanque, marchita profusión de tallos/ lodo y matorrales atascados de hojas muertas/ viene el río volcándose sobre la ciudad/ y estalla en el filo de la barranca/ en una explosión de espuma y brumas luminosas/ -
} 
Martín Gambarotta en Punctum, como veremos en el capítulo siguiente) y toma en cambio el modo de composición de un poema que, en lugar de concentrarse en una escena u objeto como los de Prieto, Casas y García Helder, propone una deriva perceptual entre distintos objetos, de apariencia aleatoria. La variación de Wittner, y también de Gambarotta, con respecto a los objetivistas, es que en su caso el acceso a la poesía del modernismo norteamericano es directo, es decir, sin la mediación de poéticas como la de Giannuzzi, y por lo tanto la instancia especulativa que Prieto, Casas y García Helder tomaban de Giannuzzi está prácticamente ausente, a excepción de algunos fragmentos como los que hemos citado donde se corta el flujo perceptual para enunciar una reflexión fragmentaria sobre el texto, tal como Williams interrumpe la descripción en el “Paterson” para decir “No ideas salvo en las cosas”. ${ }^{229}$

Este tratamiento del objeto también puede rastrearse en Wittner en relación a las emociones, como cuando se interrumpe la oración en un poema donde se está describiendo una lámpara para apuntar: "Llorar en verano: con calor y con tiempo” (Wittner: 2001, 28). En este caso, el llanto conjugado en infinitivo, que lo despersonaliza, funciona como cifra del modo de plantear una subjetividad “enmascarada” en la materia y lenguaje, así como en Cassara la figura de poeta estaba enmascarada en el mito, y puede leerse como una manera de activar la idea de T. S. Eliot de que el poeta no tiene tanto una personalidad que expresar como un medio sobre

Dilo, no ideas salvo en las cosas-/ y de su potencia cristalizaron las fábricas/ como hielos de rocío sobre las piedras de la chimenea/ (...)” $(129,130)$.

${ }^{229}$ Sin embargo en este libro aparece de modo esporádico una línea de escritura que remite de modo lateral al objetivismo argentino, donde se pone en escena como en Casas y Prieto el hecho de mirar un lugar -ya sea Nueva York (Wittner: 2001, 11) o una playa (Wittner: 2001, 25)- en el que se perciben "capas” temporales superpuestas. Como Casas miraba un baldío convertido en estacionamiento en Tuca (Casas 1990: 27), en "El error" de Wittner se plantea una escena donde la que enuncia el poema está en una playa con la madre y señala que "En este mismo escenario, en esta arena/ tuvo algunos capítulos/ el tiempo pasado. De entonces/ sólo ella y yo fuimos extraídas.” (Wittner: 2001, 25). Este gesto de detectar lo que permanece igual en un contexto modificado es un motivo que analizamos en los objetivistas. 
el cual opera. ${ }^{230}$ Según Eliot, la experiencia sentimental y emocional se funde en el ejercicio de escritura con la tradición sobre la cual se trabaja, por lo tanto el poeta más original no será aquel que invente algo “nuevo” sino el que pueda hacer funcionar "el momento presente del pasado” (Eliot: 1944, 29), es decir, aquello de la poesía del pasado que todavía está vivo, en el interior de la propia poética. En Wittner, esta premisa se pone en funcionamiento desde la apropiación de ciertos principios compositivos del modernismo norteamericano, que se llevan a cabo con los objetos, y el lenguaje percibido también como un objeto, propios de otra situación cultural.

Como puede verse, el modo de armar tradición es distinto en Wittner y Cassara porque se trata de poéticas donde el procesamiento de lecturas previas -en este caso el archivo habilitado por el Diario de poesía, y especialmente el segmento que corresponde al modernismo norteamericano- se activa en la práctica pero no se plantean, como en Rubio, Díaz, Ortiz y Raimondi (y en los objetivistas) figuraciones de la tradición en el interior de los textos. Lo mismo puede decirse de Battilana y Villa, en los que la problemática de la mirada se trabaja desde una idea de poema como huella de una percepción, a la vez que el lenguaje se revela como insuficiente para nombrar al objeto. La posición es diferente porque, tanto en los objetivistas como en los poetas que hemos leído en este capítulo y que cruzan los modos de hacer de la cultura popular con la tradición literaria, la poesía se concibe, como explicita Raimondi al comienzo de un poema, como “materia de disputa” (Raimondi: 2001, 13). Se trata de poéticas que se construyen en oposición abierta a otras poéticas y sobre todo a otras ideologías sobre la literatura, y que usan el poema como espacio donde ejercer la crítica.

Así, Rubio, Ortiz, Díaz y Raimondi no sólo trabajan con el archivo objetivista sino que también comparten con esta formación el gesto de pensar la tradición como un

${ }^{230}$ T. S. Eliot, "La tradición y el talento individual", en Los poetas metafísicos y otros ensayos sobre teatro y religión, Buenos Aires, Emecé, 1944, Tomo I (24). 
objeto cuyas apropiaciones definen tomas de posición ideológicas. En ellos, las lecturas de la tradición no suponen un modo de relacionarse con los textos de manera individual y a través de reelaboraciones directas sino que se piensan en el marco de una cultura donde la tradición ya está cargada de valor, un valor que debe discutirse y hasta subvertirse. Esta idea habilita la construcción de figuras de poeta y de representaciones de la tradición en el interior de los textos, que hemos intentado rastrear, y que permiten leer un grado de autoconciencia sobre un objeto que en otras poéticas no se problematiza. Por eso es pertinente que García Helder y Prieto se refieran a estos poetas como “goliardos” (García Helder y Prieto: 1998) que entablan una relación orgánica con la tradición (en la que nosotros incluimos no solamente a los poetas bahienses, sino también a Rubio). En consonancia con esta idea, Michel De Certeau se refiere a los poetas medievales como lectores cuyos "procedimientos refinados infiltran mil diferencias en la escritura autorizada que les sirve de marco, pero sin que su juego obedezca a la coerción de su ley” (De Certeau: 2000, 188).

Sin embargo esta idea también puede recuperarse en el modo de usar la tradición en Cassara para poner en escena una subjetividad “enmascarada” que resulta de los mínimos desvíos en el modo de reelaborar los mitos y en el ingreso de la oralidad, y en el caso de Wittner, porque su poética no supone simplemente una repetición de los principios del modernismo norteamericano sino un modo de hacerlos operar en otra cultura, sobre todo para poner a prueba el propio lenguaje y su manera de construir sentido. Por eso esta conciencia crítica sobre la tradición como "escrituras autorizadas" que instauran una "ley" con la que debe trabajarse en el texto motiva algunas de las recuperaciones que hemos trabajado en este capítulo, y establece a su vez un punto de contacto con las poéticas del capítulo siguiente, cuya variante plantea la lectura no sólo como subversión, sino como impugnación directa de esa “ley”. 


\section{CAPITULO III}

\section{POÉTICAS DE RUPTURA: FIGURACIONES DEL BÁRBARO Y DEL ANALFABETO}

\section{1- Planteo inicial}

Este capítulo se organiza alrededor de una parte de la producción poética de los noventa que permite ser agrupada por una posición de ruptura con respecto a otras líneas poéticas contemporáneas -y, más en general, con respecto a una idea tradicional de literatura que construyen los mismos textos-, o a la propia literatura como institución, tal como la entiende Peter Bürger: “En el concepto institución arte deberían incluirse el aparato productor y distribuidor de arte como también las ideas dominantes sobre el arte de una época dada, las cuales definen esencialmente la recepción de las obras”. 231

No se trata de textos que asuman explícitamente un linaje literario determinado. En todo caso, los usos de la tradición deben leerse en algunas reescrituras puntuales y en las ideologías poéticas que procesan, mientras que los gestos más visibles que se construyen en los poemas tienden a plantear posiciones de ruptura cuya variante extrema es el ejercicio de la tabula rasa.

En este sentido, los primeros libros de Juan Desiderio, Daniel Durand, Martín Gambarotta y Santiago Llach $^{232}$ suponen la emergencia (Williams: 1997) de lo que se conoció como poesía de los noventa en un sentido restringido, que alude menos a una

\footnotetext{
${ }^{231}$ Peter Bürger, Teoría de la vanguardia, Buenos Aires, Las cuarenta, 2010 (31).

${ }^{232}$ Zelarayán de Washington Cucurto podría incluirse en este grupo pero será trabajado en otro capítulo dado que su manera de usar los signos se acerca más al pop, a diferencia de los textos aquí considerados.
} 
periodización histórica que al surgimiento de nuevos valores entre los cuales se incluye el cuestionamiento de la tradición literaria. En efecto, si bien la denominación “poesía de los noventa” llegó a incluir la producción objetivista en un recorte que coincide aproximadamente con el de la década 1990-2000, en su momento fue acuñada para designar esta otra zona de escrituras que se percibían como disruptivas y que se vinculaban, como apuntamos en la Introducción, con la situación cultural del menemismo.

Así, el rótulo “poesía de los noventa” incluyó por extensión a los poetas nucleados alrededor del Diario de Poesía (especialmente Martín Prieto y Daniel García Helder) y a otras poéticas que son una derivación de esa línea objetivista, como las de Fabián Casas, Alejandro Rubio y Sergio Raimondi, pero que en realidad deben pensarse como continuidad de poéticas previas, como analizamos en otro capítulo. En cambio las poéticas aquí analizadas se construyen en buena medida por oposición a la ideología poética sostenida por los objetivistas, que puede considerarse como dominante dentro del campo poético restringido en que funcionó el Diario de poesía, especialmente en vistas de que esa publicación, y la formación (Williams: 1997, 139) que nucleó, funcionaron como instancia legitimadora o excluyente para los nuevos poetas.

Lo que separa a estas poéticas y las constituye en emergentes respecto a las líneas de escritura hasta aquí consideradas es, en primer lugar, una serie de gestos puntuales de ruptura, rechazo o impugnación, en algunos casos de textos y poéticas concretos y en otros de la literatura percibida como una institución con un conjunto de códigos preestablecidos y con instancias propias de legitimación y de prestigio.

Sin embargo, mientras que algunos textos trabajan a partir de la impugnación de tradiciones, figuras y poéticas previas, y del rechazo de una idea de literatura como alta cultura, otros se constituyen alrededor de la idea de tabula rasa, lo que equivale a decir 
que hacen el gesto, siempre paradójico, de escribir como si la literatura y la poesía previas no existieran, de hacer poesía a partir de lo que no es, o todavía no es, poesía.

Se trata, además, de poéticas que trabajan con el habla como material para la escritura. Hay que precisar en este caso el sentido de la palabra "ruptura”, porque si por un lado, al optar por el habla como material, los poemas parecen estar haciendo el ejercicio de tabula rasa, por otra parte ese uso del habla ya constituye de por sí un modo de recortar una tradición, que tiene sus antecedentes inmediatos en la literatura argentina en las figuras de Ricardo Zelarayán y Leónidas Lamborghini, de los que también proviene la idea de ampliar los márgenes de lo que es aceptado como literario, como veremos.

A diferencia del objetivismo, los poetas que aquí consideramos se niegan a otorgar a la tradición un valor a priori y a pensarla en términos orgánicos; por el contrario, “tradición”, "poesía” y "literatura” comportan valores que deben ser discutidos. Tanto el uso del habla como los gestos anti-tradición y de tabula rasa se condensan en una figura a partir de la cual, según constataba hace unos años Ana Porrúa, pueden leerse varios de los textos inaugurales de los noventa: la figura del bárbaro. La idea de barbarie, tomada de Benjamin, surgía de la repetición de un gesto particular en varios de estos textos. Dice Porrúa: "El que escribe parte, o simula partir, de un lugar que no es el de la literatura consagrada, el de los clásicos. Los personajes de Punctum miran televisión, series como Kojak, El Gran Chaparral o Las calles de San Francisco y también escuchan rock, heavy metal, punk. ¿Se trata del ejercicio de la tabula rasa, aquél que Benjamin define a partir de "un concepto nuevo, positivo de barbarie?”. 233

\footnotetext{
233 Ana Porrúa, "Volver al pasado: una nueva lectura de los clásicos”, en Revista del CELEHIS, Mar del Plata, Buenos Aires, UNMdP, Nro. 15 (2003-2004), (157-170). En el mismo artículo, Porrúa señala que "Obviamente, la idea de experiencia que aparece en este artículo de Benjamin
} 
En el texto de Benjamin que acá se cita, la experiencia traumática de la guerra, y sobre todo la imposibilidad de dar cuenta de esa experiencia a través de la palabra, dan lugar a ese nuevo modo de barbarie que él hace el ejercicio de leer en términos positivos cuando se pregunta: “¿Adónde le lleva al bárbaro la pobreza de experiencia? Le lleva a comenzar desde el principio; a empezar de nuevo; a pasárselas con poco; a construir desde poquísimo y sin mirar ni a diestra ni a siniestra.” ${ }^{234}$ Esta idea de barbarie que propone Benjamin es productiva en la medida en que da densidad a nociones de otro modo negativas como las de "pobreza” y “falta”, a la vez que permite articular una experiencia histórica con un estado de la cultura, y en ese sentido será tomada en cuenta para pensar este conjunto de textos que de diversos modos señalan una situación histórica particular, la de la postdictadura y el menemismo. ${ }^{235}$

Sin embargo tomaremos en cuenta también la dimensión original del término "bárbaro” tal como fue acuñado en la cultura griega para designar al extranjero, es decir a aquel que no domina el propio idioma y que por lo tanto está fuera de la civilización y

es distinta, porque está asociada a la transmisión oral de historias; sin embargo, si uno piensa la experiencia en términos de escritura, la reflexión funciona para los `90. El poeta, en estos textos, no escribe a partir de sus lecturas. La poesía entonces se inicia con lo dado (los productos de los medios masivos, por ejemplo) y no como reescritura u homenaje; la poesía no explicita sus deudas literarias.” El resto del artículo, por otra parte, se dedica a leer las diversas figuras de lectores que se construyen en otra serie de textos de Marcelo Díaz, Mario Ortiz y Sergio Raimondi, que analizamos en el capítulo anterior.

${ }^{234}$ Walter Benjamin, “Experiencia y pobreza”, en Discursos interrumpidos I, Madrid: Taurus, 1982 (169).

${ }^{235}$ Nicolás Rosa se pregunta por los modos de representar la pobreza en la narrativa, y entiende sobre todo que sólo puede haber "idealizaciones ennoblecedoras de la miseria" porque la pobreza es lo irrepresentable, rechaza la retórica que funda toda escritura y resiste la distribución figurativa. Desde el punto de vista semiótico, la pobreza sería lo inenarrable, puesto que no habría palabras para contarla. Por eso es significativo que en este caso -si bien lo que se pone en juego es una "pobreza" de carácter cultural y no tanto económico- estas figuraciones de barbarie cultural y de analfabetismo estén vinculadas a poéticas que trabajan con el habla, como modo de escapar precisamente a las "retóricas" desde un "empobrecimiento" del discurso poético. Ver Nicolás Rosa, La lengua del ausente, Buenos Aires, Biblos, 1997. 
de la ley. En este caso, "bárbaro” adopta también connotaciones que lo vinculan a “incivil”, “rudo”, “salvaje” y “grosero”. ${ }^{236}$

Además, y como variante de esta figura del bárbaro, algunos textos construyen figuraciones del analfabeto que se definen a partir de la falta, ya sea real o simulada, de capital cultural específico y “de un dominio práctico o teórico de la herencia que está inscrita en la estructura misma del campo” (Bourdieu: 1997, 361). No sólo se afirma una falta de conocimiento exhaustivo de la literatura y de los códigos específicos del campo, sino que hay además un rechazo a concederle algún valor implícito a la tradición más allá del uso que de ella pueda hacerse. Esta figura del analfabeto se articula con otro rasgo central de estas poéticas: se trata de un uso abundante de materiales provenientes de la cultura de masas y de lo popular entendido como modos de hacer a partir de la cultura dominante, lo que incluye a la lengua (Michel de Certeau: 2000, 31, 32), que remiten a una manera nueva y ampliada de concebir la tradición y la cultura.

Los rasgos hasta aquí señalados (gestos puntuales de adhesión o rechazo a poéticas previas, gestos de tabula rasa, uso del habla y figuraciones del bárbaro y del analfabeto) funcionan como modo de recortar el propio lugar dentro del campo poético. Son, en términos de Bourdieu, tomas de posición, en la medida en que permiten a los poetas definir sus posiciones relativas en esa red de relaciones objetivas que es el campo literario. Las tomas de posición pueden ser “obras literarias o artísticas evidentemente, pero también actos y discursos políticos, manifiestos o polémicas” (Bourdieu: 1997, 343), y muchas veces adquieren un grado de violencia en su voluntad opositiva que es precisamente lo que les otorga cierta visibilidad, puesto que "la revolución tiende a

\footnotetext{
${ }^{236}$ Diccionario Griego-Español Vox, Barcelona, Bibliograf, 1997 (1967).
} 
imponerse como el modelo del acceso a la existencia en el campo” (Bourdieu: 1997, 191).

Además, esta serie de gestos da lugar a un cambio dentro del campo poético, en consonancia con la idea de Pierre Bourdieu sobre la "institucionalización de la revolución permanente como modo de transformación legítima de los campos de producción cultural” (Bourdieu: 1997, 325). Según Bourdieu, un campo que ha alcanzado un grado relativamente alto de autonomía "está habitado por una tradición de ruptura permanente con la tradición estética” (Bourdieu: 1997, 362).

Pero al mismo tiempo, esta serie de rupturas supone una revisión crítica de la tradición a partir de criterios específicos que iremos desglosando. Es entonces en estos dos aspectos -como toma de posición al interior del campo y como perspectiva crítica sobre la tradición, leída desde el presente- que dichos gestos serán puestos a consideración para indagar en la condición histórica de estos textos.

A partir de estos parámetros se ordenará la lectura de los siguientes libros: $L a$ zanjita de Juan Desiderio (Revista Trompa de Falopo: 1992, Ediciones Trompa de Falopo: 1996), Segovia de Daniel Durand (18 Whiskys Nrs 3-4, Marzo de 1993, Ediciones Amadeo Mandarino: 2001, Mansalva: 2006) Punctum de Martín Gambarotta (Libros de Tierra Firme: 1996, Mansalva: 2011) y La raza de Santiago Llach (Siesta: 1998). Se trata de libros que inauguran esta zona de la poesía de los noventa donde literatura y cultura de masas se nivelan definitivamente, y en la que posteriormente se inscriben Zelarayán de Washington Cucurto (Buenos Aires, Ediciones Deldiego, 1998), Redondel de Romina Freschi (Buenos Aires, Siesta, 1998), Coming attractions (Siesta: 1997) y $X X X$ de Marina Mariasch (Siesta: 2001) y toda la producción, editada en plaquetas por Belleza y Felicidad, de Fernanda Laguna y Cecilia Pavón, que serán analizados en los capítulos siguientes. 
El capítulo se ordena entonces en la articulación entre la construcción de diversas figuraciones del bárbaro -que se pondrán en tensión a su vez con las figuras de poeta-, la construcción de personajes, la idea de tabula rasa y el uso del habla como material para la poesía.

\section{1- EL USO DEL HABLA Y LA CONSTRUCCIÓN DE PERSONAJES EN RICARDO ZELARAYÁN Y LEÓNIDAS LAMBORGHINI}

Como dijimos, tanto La zanjita como Segovia y Punctum procesan una ideología poética que hasta el momento era marginal en el sistema literario argentino, y que se condensa en las figuras de Ricardo Zelarayán y Leónidas Lamborghini.

Zelarayán estuvo vinculado en la década del setenta a la revista Literal, una publicación que trabajó a partir de una combinación, como señala Martín Prieto, del psicoanálisis lacaniano, la lingüística postsaussuriana y el posestructuralismo. ${ }^{237}$ Muy cercana al programa de Literal, que sostiene la preeminencia del lenguaje por sí mismo y no como representación de la realidad, la poética de Zelarayán se recorta, según Prieto, por oposición a una línea centrada en “la ilusión referencial del gelmanismo y de la poética sesentista en general”, es decir, a la línea de poesía política que fue dominante en los sesenta (Prieto: 2006, 429). Para Zelarayán, el lenguaje es la única realidad, tal

\footnotetext{
${ }^{237}$ Ver Martín Prieto, Breve historia de la literatura argentina, Buenos Aires, Taurus, 2006 (429). Si bien acordamos con la ilusión referencial en que se basan parte de las poéticas sesentistas, es muy cuestionable que esa característica pueda hacerse extensiva a la obra de Gelman, que trabaja más bien, como señala Miguel Dalmaroni, "una forma de oralización del género inseparable de una intervención experimental sobre el lenguaje" que se acerca por momentos al modo de construcción de la imagen surrealista. Ver Miguel Dalmaroni, La palabra justa. Literatura, crítica y memoria en la Argentina. 1960-2002., Mar del Plata, Editorial Melusina, 2004 (62).
} 
como lo explicita en el "Posfacio con deudas" que aparece al final de su libro La obsesión del espacio: “si la realidad está en alguna parte, está en el lenguaje”. ${ }^{238}$

A partir de esta premisa, Zelarayán trabaja una poesía centrada en la captación del habla cuya forma más característica es el poema largo, construido como un flujo de imágenes desarticulado que permite ingresar desde imágenes visuales, recuerdos y fantasías hasta frases oídas al pasar y reflexiones sobre la propia escritura. El modelo de este tipo de texto es el poema más conocido de Zelarayán, “La gran salina”, en el que la discontinuidad y la interrupción ponen de relieve el hecho de que el movimiento del poema no está dado por la “imitación” de la realidad ni por el pensamiento lógico sino justamente por el encadenamiento rítmico de las frases, especialmente de las frases de la oralidad. $^{239}$ Lo literario, entonces, no se define a partir de convenciones institucionalizadas sino que debe ser captado en el lenguaje. A su vez, el escritor no es aquel que crea a partir de la originalidad sino el que está atento y puede detectar esas irrupciones de lo literario en las conversaciones cotidianas o en cualquier tipo de manifestación lingüística.

A partir de esta idea sobre el lenguaje se deriva la concepción de literatura que funciona como eje de Literal, y que puede pensarse también para la poética de Zelarayán. Se trata, como señala Prieto, de "ampliar las fronteras de la literatura, desestabilizando aquello que de antemano esté convenido como literario (incluidos los géneros) y también la misma idea de la literatura como propiedad privada del escritor” (Prieto: 2006, 431).

\footnotetext{
${ }^{238}$ Ricardo Zelarayán, La obsesión del espacio, Buenos Aires, Atuel, 1997 (83-87).

${ }^{239}$ Este modo de concebir y usar el habla se diferencia por eso del coloquialismo de los sesenta, con su intención de "reproducir supuestos registros de realidad dialectal" como señala Miguel Dalmaroni, desde una voluntad mimética. Si el coloquialismo intentaba producir una ilusión referencial, aquí el habla aparece siempre mediada por el artificio, sobre todo porque se la contrasta con otros usos tradicionales del lenguaje poético. Respecto al uso del lenguaje coloquial en los sesenta, ver Miguel Dalmaroni, La palabra justa. Literatura, crítica y memoria en la Argentina. 1960-2002., Mar del Plata, Editorial Melusina, 2004 (62).
} 
Esta ideología poética, desprendida de la vinculación con la teoría postestructuralista sostenida por Literal y de la disputa con la línea de poesía política sesentista, es retomada por algunos de los poetas de los noventa, como señala Martín Gambarotta en el artículo "El habla como materia prima”. ${ }^{240}$ En ese texto, Gambarotta construye un relato de sus comienzos como escritor a partir del rechazo de la obra de Saer, que si bien le resultaba deslumbrante en cuanto a maestría técnica le parecía al mismo tiempo "lejana”, con una estructura (aquí se refiere a la novela Glosa) “demasiado artificial”. Gambarotta parte de la premisa de "querer entablar un diálogo con lo contemporáneo”, pero en ese movimiento se reconoce como no contemporáneo de Saer.

La escritura de Juan José Saer, que Sandra Contreras sitúa en el campo literario argentino a partir de valores como la negatividad adorniana y el pulido extremo de la frase, resulta lejana y artificial. ${ }^{241}$ En oposición a esto, Gambarotta descubre, en una lectura de poesía llevada a cabo en Liber/arte, un texto que le llega a partir de la escucha, y en el que cree encontrar "la voz de una tribu": se trata de La zanjita de Juan Desiderio (Gambarotta: 2006, 239). El texto de Gambarotta insiste sobre el diálogo con lo contemporáneo como valor, cuando describe de este modo la sensación que le produjo la escucha de ese texto: "En todo caso, démosle al texto de Desiderio la

${ }^{240}$ Ver Martín Gambarotta, "El habla como materia prima”, en Jorge Fondebrider (compilador), Tres décadas de poesía argentina. 1976-2006, Buenos Aires, Libros del Rojas, 2006 (235-242).

${ }^{241}$ Sandra Contreras caracteriza a la escritura de Saer a partir de una ética y una estética de la negatividad, que se ha convertido en el valor canónico del sistema literario argentino contemporáneo (y a la que también se opone la obra de César Aira). Esta negatividad, que "se expresa en la tensión de la forma y en la que el arte cifra toda su fuerza de resistencia a las formas estatuidas, al asedio de las ideologías y de la industria cultural”, se opone para Contreras a la "sensibilidad posmoderna", la atracción por los materiales y las formas de la cultura masiva y los linajes de "baja” procedencia, por la estética de la mezcla y los estilos híbridos. Esta idea de Contreras puede iluminar el relativo rechazo que aquí expresa Martín Gambarotta por la obra de Saer, en tanto representante de una línea poética que incorpora precisamente estos materiales que según Contreras la estética de la negatividad rechaza. Ver Sandra Contreras, Las vueltas de César Aira, Rosario, Beatriz Viterbo, 2002 (27,28). 
cualidad de funcionar como la voz de una tribu y la cualidad, que yo sentí en ese momento, de que el autor me estaba hablando a mí. Esto suena un poco cursi, pero lo que yo detectaba era que Desiderio tenía la capacidad de hablarles a sus contemporáneos de una manera que yo no encontraba en Glosa” (Gambarotta: 2006, 239).

Gambarotta sitúa, como antecedentes de esta cualidad de poder "hablar” a los contemporáneos, dos textos que funcionan también como modelos para otros poetas de los noventa: La tierra baldía de T.S. Eliot y, como mencionamos anteriormente, el libro La obsesión del espacio de Ricardo Zelarayán, del que rescata en particular el posfacio. El rasgo común que permite constituir en tradición tanto a los poemas de Eliot como a los de Zelarayán, por otra parte tan disímiles, es para Gambarotta el hecho de que el habla no aparece entre comillas (porque las comillas funcionarían como una marca de separación entre el lenguaje “poético” y el oral) ni se le da un contexto a las voces que hablan.

En la lectura que hace Gambarotta del “Posfacio con deudas” de La obsesión del espacio, ese lenguaje que constituye la única realidad es decididamente el habla, pero aquí, como ya se ha dicho, ese modo particular de usar el habla se diferencia del uso que hace el coloquialismo: "Pero no el habla para hacer una poesía coloquial, sino el habla como materia prima para construir una máquina verbal que no necesariamente es coloquial” (Gambarotta: 2006, 242). Y también se destaca, de esta especie de manifiesto de Ricardo Zelarayán, la idea de que no existen los poetas sino "los hablados por la poesía”. Dice Gambarotta: “Que haya un texto que diga que no existen los poetas, es para mí un alivio” (Gambarotta: 2006, 242).

Entre estas coordenadas -oposición a una literatura que se recorta por su valor de negatividad con respecto al mundo, interés por establecer un diálogo con lo 
contemporáneo, uso del habla como material para hacer una poesía no coloquial, voluntad de "no ser poeta”- Gambarotta sitúa el surgimiento de su primer libro, Punctum (1996). El artículo es interesante también en la medida en que propone la idea de que, a causa de la velocidad de circulación de estos primeros textos de los noventa a través de lecturas de poesía, publicaciones rápidas y revistas, los propios contemporáneos pasan a constituirse en parte de la tradición que los poetas construyen en sus textos. La tradición que en este caso Gambarotta construye para Punctum cruza a T. S. Eliot con Zelarayán y con un contemporáneo como Desiderio, a partir del trabajo con el habla.

A modo de resumen, los valores que Gambarotta sostiene para la poesía son, por un lado, la posibilidad de constituirse en "la voz de una tribu" a partir del uso del habla como material, y por el otro la capacidad de establecer un diálogo con lo contemporáneo, que debe leerse en su doble vertiente: lo contemporáneo es el presente, con sus experiencias y sus modos del habla históricamente situados, pero también son los poetas jóvenes que están escribiendo al mismo tiempo. Estos dos aspectos funcionarán entonces como criterios de selección al momento de construir una tradición propia por medio de operaciones de apropiación y recorte sobre distintas tradiciones, en este caso la poesía argentina de los setenta y la poesía modernista norteamericana.

La otra figura que opera en estos textos es la de Leónidas Lamborghini, que no se hace presente desde el ejercicio de reescritura pero sí en dos aspectos que son fundamentales: el uso de distintas voces y máscaras para hablar en el poema, y una concepción que toma partido contra la poesía entendida sobre todo como discurso "bello”. ${ }^{242}$

\footnotetext{
242 "Nada que ver con la belleza” es la frase de Lamborghini que se toma en el dossier correspondiente del Diario de poesía como característica de su poética. Ver Daniel García Helder, "Nada que ver con la belleza". Entrevista a Leónidas Lamborghini, en "Dossier Lamborghini”, Diario de poesía No 38, Invierno de 1996. Lamborghini se refiere con esta
} 
Lamborghini comenzó a desarrollar en la década del cincuenta una obra que se diferenciaba en buena medida de las líneas poéticas contemporáneas, invencionismo y surrealismo, si bien su primera publicación fue en la revista de los invencionistas, Poesía Buenos Aires. ${ }^{243}$ De hecho, puede pensárselo, como lo hace Martín Prieto, como uno de los representantes, junto a Nicanor Parra y César Fernández Moreno, de la tendencia conocida como “antipoesía” (Prieto: 2006 381). Pero la particularidad de Lamborghini reside en que, como señala Prieto, “a diferencia de los antipoetas que mantienen, como Fernández Moreno, un pie en la convención de la lírica, con esa primera persona que organiza la estructura del poema, da un paso más hacia fuera y construye un poema con argumento (...), ambientación (...) y personajes” (Prieto: 2006, 384). ${ }^{244}$ Lo narrativo y lo teatral, junto con la construcción de personajes como modo de

expresión a su modo de oponerse a la generación romántica del cuarenta, en contraste con la cual su poesía disonaba como "feísmo".

${ }^{243}$ Bajo el sello editorial de Poesía Buenos Aires publicó Lamborghini, de hecho, su segundo libro, Al público, de 1967, además de que formaba parte del grupo de poetas que intervenía en la revista ocasionalmente.

Poesía Buenos Aires es una revista que sacó treinta números entre 1950 y 1960, bajo la dirección de Raúl Gustavo Aguirre, acompañado ocasionalmente por otros poetas como Nicolás Espiro y Edgar Bayley. La revista publicó textos programático variados, y en uno de ellos, llamado "Realidad interna y función de la poesía”, Edgar Bayley cuestiona el predominio de lo referencial en la poesía contemporánea y propone, siguiendo a Huidobro, que el poema debe presentar un hecho nuevo, independiente del mundo externo, desligado de toda otra realidad que él mismo, porque "la poesía no debe imitar los aspectos de las cosas, sino seguir las leyes constructivas que constituyen su esencia y que les confiere la independencia de todo lo que es". Por esta ideología, que se condensa en lo que Martín Prieto llama "giro retórico" -el reemplazo de la metáfora, que es siempre referencial, por la imagen autosuficiente-, Prieto señala a esta publicación invencionista como un antecedente importante para la poética de Leónidas Lamborghini (Prieto: 2006, 371-375).

${ }^{244}$ Prieto se refiere al poema El saboteador arrepentido, de 1955, a partir del cual sitúa también a Lamborghini como un caso paradójico de un poeta "peronista y, sin embargo, no popular" (Prieto: 2006, 386). El uso de materiales populares para la elaboración de una poesía no populista es también un rasgo común que vincula a Lamborghini con los poetas que analizaremos a continuación. El populismo, después de los sesenta, aparece como un límite que los poetas rechazan de manera sistemática. 
constitución de una poesía anti-lírica, están prefigurados entonces en los libros de Lamborghini, desde El saboteador arrepentido a El solicitante descolocado. ${ }^{245}$

Los poetas de los noventa separan el signo político de la producción de Lamborghini -que se funda sobre la derrota del peronismo en el '55-y retoman en cambio otros componentes que configuran, como dijimos, una poesía anti-lírica. En primer lugar, la enunciación a partir de distintas voces, que Lamborghini atribuye a una tradición de lecturas que incluye al Martín Fierro de José Hernández y, significativamente, al ensayo "Poesía y drama” de T. S. Eliot. ${ }^{246}$ Las características que Ana Porrúa señala para la poesía de Lamborghini, provenientes de un modo particular de leer los textos que recorta como tradición, son el abandono del “yo” lírico y del tono elegíaco que caracterizaba a la poesía argentina contemporánea (Porrúa: 2001, 19).

La figura de poeta de Lamborghini es la del que, a falta de una voz propia (y de la ideología de la originalidad que esa voz personal sustentaría), “escucha otras voces y 'estudia’ en ellas el canto; el poeta es el que no tiene voz (en una ficción que desmitifica las concepciones románticas del origen) y le da forma mediante las voces de otros” (Porrúa: 2001, 21). Además, la escritura de Lamborghini, según Porrúa, también atenta, como la de Ricardo Zelarayán, contra la especificidad de lo poético en la medida en que ingresan en ella “otros discursos -los de la literatura, pero básicamente las consignas, la publicidad, los relatos periodísticos” (Porrúa: 2001, 23). ${ }^{247}$

\footnotetext{
${ }^{245}$ Ver Leónidas Lamborghini, El saboteador arrepentido, Buenos Aires, El peligro amarillo, 1955, y El solicitante descolocado, Buenos Aires, Ediciones de la Flor, 1971, reeditado por Libros de Tierra Firme, 1989.

${ }^{246}$ Ver Ana Porrúa, Variaciones vanguardistas, Rosario, Beatriz Viterbo, 2001 (18, 19).

${ }^{247}$ En el análisis que hace Porrúa de la obra de Lamborghini aparece una vez más la necesidad de diferenciar el uso de las voces de la oralidad que hace el poeta del coloquialismo de los sesenta, con su voluntad de realismo: "La voz poética se construye dialógicamente (e incluso polifónicamente) y exhibe su carácter ficcional: no es una voz real sino una voz construida en términos poéticos. No se propone como una voz directa (tal como lo hace la mayor parte de los poemas sesentistas), sino indirecta, bajo la pauta del artificio” (Porrúa: 2001, 31).
} 
Es a partir de ese ingreso de otros discursos como Lamborghini construye una poesía que es política pero no desde lo referencial, sino en tanto se constituye al texto en un espacio donde se cruzan los modos de decir, las consignas y debates en torno a lo político de la época, es decir, en tanto lo político se hace presente en el lenguaje desde las operaciones de corte y composición sobre otros discursos. Esto puede leerse en una serie de versos que funcionan también a modo de poética: “En la casa llena de ruidos/ el libro comienza/ en cualquier/ parte/ termina en cualquier parte// el lenguaje/ narrándose a sí mismo/ protagonista de sí mismo/ embrollándose a sí mismo/ lleno de ruidos”. ${ }^{248}$

Esta conciencia con respecto al lenguaje como el lugar donde se captan los signos del presente (en el caso de Lamborghini, lo político en el presente) es un elemento que los poetas de los noventa recortan en el ejercicio de lectura que efectúan sobre las poéticas que estamos considerando. Esta idea aparece en el poema bajo la figura del poeta que se representa a sí mismo en medio de una casa "Ilena de ruidos”, y es a partir de esos ruidos que escribe.

La escucha de los lenguajes del presente es entonces lo que vincula al poeta (que ya no se piensa como aquel que crea aislado y en soledad) con la sociedad. Como señala Ana Porrúa, este fragmento enuncia la conformación de la poética de Lamborghini como oposición a otros imaginarios modernos que vinculan a la poesía con el silencio, la soledad, el misterio, y la diferencialidad del lenguaje poético. Lamborghini opta en cambio por el "ruido” y construye, junto con otras poéticas sesentistas, un discurso poético que se caracteriza por la permeabilidad, un rasgo que es general a la mayoría de las poéticas de los noventa (aunque en menor medida al objetivismo). ${ }^{249}$

\footnotetext{
${ }^{248}$ Leónidas Lamborghini, “Diez escenas del paciente”, en El solicitante descolocado, Buenos Aires, Libros de Tierra Firme, 1989 (120).

${ }^{249}$ Dice al respecto Ana Porrúa: "El ruido se asocia, por supuesto, a una larga tradición de la poesía moderna que se juega a rodear la idea de imposibilidad de la escritura y está siempre
} 
Esta idea de Lamborghini de romper las fronteras de lo poético para que irrumpa -de manera violenta, si es necesario- la experiencia, se lee en versos como los que siguen: "habla/ di tu palabra/ y si eres poeta/ "eso"/ será poesía// que tu palabra/ sea irrupción/ de lo espontáneo/ que lo que digas/ diga tu existencia/ antes/ que tu “poesía”// que tu ritmo/ sea/ pulso de la vida/ antes que un elemento/ de la música”. ${ }^{250}$ Aquí, el poema construye una oposición entre la “poesía” -las formas retóricas, convencionales y gastadas, que se revelan como incapaces de dar cuenta de la vida- y una palabra, que se enuncia en el habla, capaz de decir la “existencia”. Entre la poesía y la existencia, el poeta debe optar por la segunda, y trabajar el texto de manera que la vida pueda irrumpir (la violencia de esa irrupción está contemplada en este poema en el que, como dijimos, la voz que enuncia esta poética habla desde una barricada) porque el "pulso de la vida”, dice el texto, importa más que la "música”. ${ }^{251}$

permeado por cierta connotación sacra (aunque laica); el ruido, en cambio, es lo que siempre estuvo fuera del círculo del género, al menos de sus constituciones más literarias” (Porrúa: 2001, 27).

${ }^{250}$ Leónidas Lamborghini, El solicitante descolocado, Buenos Aires, Libros de Tierra Firme, $1989(26,27)$.

${ }^{251}$ Giannuzzi se refiere en cambio al poema como composición musical, en la entrevista del Diario de poesía ya citada, sin "notas disonantes ni nada que altere la armonía del conjunto" (así parafrasea Freidemberg una entrevista anterior realizada a Giannuzzi por La danza del ratón). El poeta agrega: "Me gusta que el poema tenga una construcción armónica, fluida, coherente, que "cierre". Que no haya cabos sueltos, que uno tenga la sensación de que no hay palabras de más. Ezra Pound reclamaba no usar dos palabras cuando solamente se necesita una”. Ver Daniel Freidemberg, “Un poeta standard”, en “Dossier Giannuzzi”, Diario de poesía No 30, Invierno de 1994 (15). Aquí surge un rasgo fundamental en el modo de armar tradición de los objetivistas, que ponen en el centro de un conjunto que reenvía al modernismo norteamericano y otras poéticas, a Giannuzzi. Esta postura contrasta con la que trabajamos en este capítulo (no sin matices, claro), que prioriza a Lamborghini y Zelarayán. Así, mientras que los objetivistas dan primacía a la composición y al poema concebido como objeto "armónico", según establece Giannuzzi, aquí el énfasis está puesto en los materiales, e incluso en su presentación "en crudo", más que en la forma (lejos de sugerir que no hay trabajo con la forma en Zelarayán y Lamborghini, nos referimos al hecho de que el objetivismo construye un objeto verbal que en su composición se señala a sí mismo como artificio, mientras que estos poetas operan a veces sobre discursos previos y el artificio está cifrado sobre todo en el corte más que en la dicción o las selecciones verbales; el ejemplo más extremo de esta modalidad es "Eva Perón en la hoguera” de Lamborghini; ver "Eva Perón en la hoguera” en Partitas, Buenos Aires, Corregidor, 1972). 
El contexto histórico que Lamborghini construye para su poema es el de "un país/ podrido por la injusticia” (Lamborghini: 1989, 28) después del derrocamiento de Perón en el año '55. Por eso, la toma de posición en contra de la belleza y a favor de lo vital tiene valor ideológico: se trata de dar cuenta de una experiencia de derrota política. En los noventa, esta ideología funciona en algunos poetas -como Daniel Durand y Alejandro Rubio- ligada a su origen peronista, mientras que en otros, como Martín Gambarotta, se resignifica en el contexto del menemismo y la postdictadura. En todo caso, lo que se toma como criterio de selección es el hecho de que los materiales constituidos en tradición puedan ser operativos para establecer un diálogo, como decía Martín Gambarotta, con lo contemporáneo, y para dar cuenta del presente (la recuperación de Lamborghini y su “actualidad” en los noventa, como veremos, pueden pensarse en relación al hecho de que tanto Gambarotta como Llach ponen en escena un presente donde lo que se perciben son las ruinas de todo proyecto político, incluso de la democracia).

Por eso, las figuras marginales de Ricardo Zelarayán y Leónidas Lamborghini pasan a estar en los noventa en el centro del sistema poético a partir de las prácticas de lectura, reediciones, publicación (en revistas como 18 Whiskies y Diario de poesía) y reescritura, pero aparecen cruzadas en el armado particular de la tradición que hace cada poeta, con otras poéticas previas, tales como la de T. S. Eliot, Ezra Pound y William Carlos Williams, como analizaremos en cada caso. 


\title{
2- EL POEMA COMO LABORATORIO: MEZCLA DE ORALIDAD Y REGISTRO POÉTICO EN LA ZANJITA. LA PUESTA AL DÍA DE LA TRADICIÓN EN SEGOVIA
}

\author{
"Esto es un laboratorio \\ bienvenidos" 252 \\ "La poesía todavía no existe \\ Nunca va a haber literatura." 253
}

La zanjita, publicado muy tempranamente en la década y presentado al público en una lectura de poesía realizada en Liber/arte que Martín Gambarotta, como vimos, marcaba como fundacional, presenta ya algunos de los rasgos que serán retomados poco después por textos como Segovia. El primero de ellos es un nuevo uso de la oralidad que no puede pensarse a partir del coloquialismo de los sesenta, ${ }^{254}$ por el cual se intentaba reproducir un habla sin mayores marcas de clase o pertenencia social. El uso del habla como material para la poesía en Desiderio remite en cambio a un modo de la barbarie (en su acepción de "salvajismo", en este caso cultural), desde el momento en que la escritura sugiere casi una trascripción fonética de la variedad lingüística de

\footnotetext{
252 Juan Desiderio, La zanjita, Buenos Aires, Trompa de Falopo, 1992, poema II (este libro no fue publicado con números de páginas, por lo tanto consignaremos el número de poema). Todas las citas posteriores están tomadas de la misma edición.

253 Daniel Durand, Segovia, Buenos Aires, Selecciones de Amadeo Mandarino, 2001 (21). Todas las citas posteriores están tomadas de la misma edición, que es la primera publicación completa de Segovia en formato libro. Antes habían aparecido fragmentos en la revista 18 Whiskies $\mathrm{N}^{0} 3$ / 4, marzco de 1993, y una versión completa en formato electrónico en Poesía.com $\mathrm{N}^{\mathrm{o}} 8$ (sin fecha).

${ }^{254}$ Ver Damián Selci y Violeta Kesselman, “Juan Desiderio: delirios de juventud cultural”, publicado en la revista virtual Planta $\mathrm{n}^{\circ}$ 3, febrero del 2008.

(http://plantarevista.com.ar/anteriores/desiderio.html).
} 
algunos sectores marginales (la geografía que se señala en el poema mismo es la del barrio Bajo Flores, más específicamente):

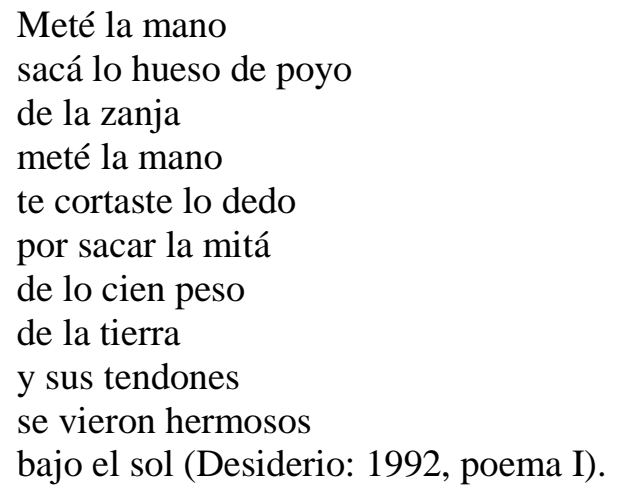

Como se ve, la caída de las `s` al final de palabras en plural tales como "lo hueso” y “lo dedo”, y de la `d’ en “mitá”, así como el cambio de 'll’ por 'y' en “poyo”, tienden a construir un lenguaje que no está legitimado en ninguna tradición literaria, y que tampoco pretende "normalizar" o "corregir" el uso oral para adecuarlo a la normativa del lenguaje escrito (y en esto, también, se cifra la diferencia entre este uso particular de la oralidad y el coloquialismo al que aludimos), aspecto en el que Desiderio es incluso más radical que Zelarayán y Lamborghini.

Las elecciones lingüísticas de La zanjita están más cerca en este punto de libros como La crencha engrasada de Carlos de la Púa y La musa de la mala pata de Nicolás Olivari, como señalan Prieto y García Helder, que trabajan la cruza de formas tradicionales con variedades lingüísticas como el lunfardo. ${ }^{255}$ Pero el gesto es diferente, porque tanto De la Púa como Olivari hacen ingresar el lunfardo como material en formas previamente marcadas como poéticas tales como los versos con metro y rima (octosílabos, endecasílabos, alejandrinos), las estrofas de cuatro versos, etc. En este

${ }^{255}$ Ver "Boceto No 2 para un...de la poesía argentina actual”, en Punto de Vista, No 60, abril 1998, p. 18. Prieto y García Helder hablan aquí de una línea de poesía argentina "rantifusa” que incluye desde Baldomero y César Fernández Moreno, el grupo Boedo, el tango, el lunfardo, el rock nacional y la épica orillera de Borges hasta Ricardo Zelarayán, Leónidas Lamborghini y buena parte de la poesía reciente, y que ellos denominan "la red antipoética satírica urbana antilírica y coloquial”. Sin embargo, en razón de su amplitud, este modo de agrupar poéticas diversas elude sus particularidades históricas. 
sentido, puede decirse que parten de la poesía para ir hacia el habla, o dicho de otro modo, que se trata de otorgar un carácter poético al habla popular al someterla a formas que son poéticas a priori. ${ }^{256}$

En este sentido, el uso que hace Desiderio del habla es similar al de De la Púa y Olivari, especialmente en cuanto a la grafía “oral” de De la Púa, que reproduce la dicción del lunfardo, pero se diferencia por la ideología poética que supone. ${ }^{257}$ Porque la operación, desde Zelarayán y Lamborghini en adelante, es la inversa: se trata de partir del habla para encontrar en ella "lo poético" y darle forma en el poema, pero en todo caso los límites canónicos de la literatura se dejan de lado o se los pone al servicio del habla. Esta nueva conciencia, moderna, con respecto a las limitaciones institucionales de la literatura y la necesidad de transgredirlas, es algo que los poetas de los noventa comparten con los de los sesenta en adelante, junto con el rechazo hacia el carácter representativo de la lengua (“Si la realidad está en alguna parte, está en el lenguaje”, decía Zelarayán en el "Posfacio con deudas”). Por eso, el diálogo de La zanjita con la poesía de Olivari y De la Púa debe leerse mediado por el procesamiento de las poéticas de Zelarayán y Lamborghini.

Sin embargo, retomando La zanjita, el registro oral no es homogéneo a lo largo de la serie, como puede leerse en los tres últimos versos del poema citado, sino que aparece mezclado con un registro más fácilmente identificable como “poético”. En este

\footnotetext{
${ }^{256}$ Es significativo, en este punto, que Carlos de la Púa haya subtitulado La crencha engrasada con una frase que en la época debía constituir casi un oxímoron: "Poemas bajos". El sintagma, que sugiere una tensión entre lo aceptado en el momento como "poético" y los materiales populares que trabaja De la Púa, pone de manifiesto a la vez la conciencia de la existencia de dos esferas separadas, lo "poético" y lo "bajo", que es precisamente lo que no aparece en La zanjita. Ver Carlos de la Púa, La crencha engrasada, Buenos Aires, Editorial Porteña, 1954.

${ }^{257}$ Además, el modo de vinculación entre las poéticas de De la Púa y Olivari con el tango y con lo popular -en cuyo fondo está presente la pregunta por lo nacional- no es recuperado de ningún modo en los noventa, y ya había sido impugnado tanto por Lamborghini como por Zelarayán ("No tengo nada que ver con el populismo ni con la filosofía derrotista del tango", dice este último en el ya citado “Posfacio con deudas”, Zelarayán: 1997, 85).
} 
caso, en los tres últimos versos se abandona el recurso de elisión de letras, se incluyen palabras con un linaje poético establecido, tales como "hermosos” y “sol”, y se pasa de la segunda a la tercera persona. Lo que hay, entonces, es la alternancia entre una voz que habla en un registro oral, y un "narrador” que comenta la escena, en tercera persona.

Esta diferenciación entre la voz de un narrador que opera en un registro poético y un personaje que maneja un registro puramente oral no se mantiene sin embargo a lo largo de la serie. Por el contrario, ambas instancias se mezclan, por ejemplo, en un poema que dice:

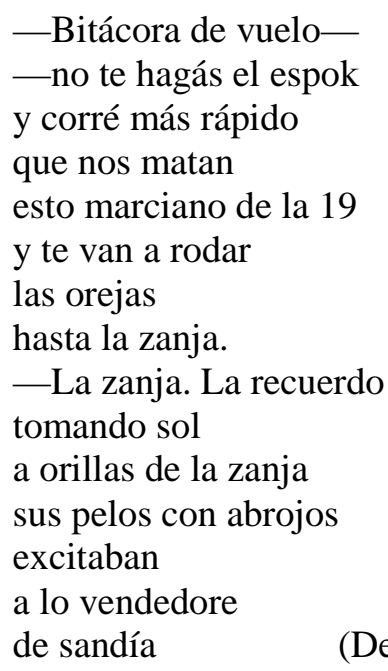

En este caso, la voz que interviene para decir "La zanja. La recuerdo” parece introducir un personaje que maneja un registro elevado, pero a continuación de ese tono que resulta artificial vuelve al registro oral para decir "lo vendedore”. Por eso, antes que la construcción verosímil de personajes a partir de modos diferenciados del habla (lo que sería propio de una voluntad realista) lo que hay es un discurso que mezcla oralidad y tono poético y en el que por lo tanto no es del todo posible distinguir al poeta-narrador de sus personajes. El lenguaje de La zanjita es un híbrido que funde oralidad y registro poético sin jerarquizarlos. ${ }^{258}$

\footnotetext{
${ }^{258}$ En realidad es problemático afirmar que exista una separación neta entre la oralidad y lo poético, dado que existe, y no sólo en la literatura argentina, una larga tradición de mezcla de ambos registros, y de poetización de lo oral, que se remonta en nuestro país a la década del '20
} 
El efecto que produce la yuxtaposición de registros es doble: por un lado, el registro reconocible como "poético" se extraña, se revela como artificio, y por el otro se descubre un lirismo inédito -una cualidad poética- en los giros del habla.

El gesto de La zanjita puede pensarse como un ejercicio de tabula rasa en dos sentidos. Primero, porque no hay en la serie componentes atribuibles a una tradición particular, excepto la recuperación del procedimiento de De La Púa y Olivari con los matices que hemos señalado. Desiderio apela por momentos a un registro que puede definirse de modo difuso como "poético", pero al mismo tiempo el poema se centra en el uso como material de un lenguaje que no tiene linaje poético. Y en segundo lugar, porque tanto en el habla que recorta como en el tipo de personajes que construye -con los consecuentes consumos culturales que se ponen en escena- el poema toma partido por lo popular entendido como modos de hacer a partir de la cultura dominante, en este caso, un uso específico y situado de la lengua (Michel de Certeau: 2000, 31, 32).

con los poemas lunfardos de Carlos de la Púa, que mencionamos anteriormente, y en la poesía norteamericana, a T. S. Eliot. Sin embargo, hasta los noventa la vertiente nacional de esa tradición se mantiene como marginal, de ahí que el tono elevado y el concepto de belleza sigan funcionando como sinónimo de poesía.

Aquí también se leen las marcas de la poética lamborghiniana, que en "El solicitante descolocado" puede yuxtaponer una estrofa que dice "Crack crack crack/ pasa el carro alegórico/ del fútbol corrompido/ ¿Dónde está el gran Martino?” con otra que dice "Cómo se pianta la vida/ cómo rezongan los años/ cómo se viene la muerte/ tan callando”, estrofa que es una reescritura en clave lunfarda de un fragmento de las Coplas por la muerte de su padre de Jorge Manrique ("Recuerde el alma dormida,/ avive el seso y despierte/ contemplando/ cómo se pasa la vida/ cómo se viene la muerte/ tan callando", ver Jorge Manrique, Coplas por la muerte de su padre, Buenos Aires, Losada, 1998). Esta operación, que mezcla lo oral y lo poético, pero versionado en este caso a través del lunfardo, es similar al ejercicio de mezcla de registros que hace en este caso Desiderio y también, como veremos, Daniel Durand. Ver Leónidas Lamborghini, El solicitante descolocado, Buenos Aires, Libros de Tierra Firme, 1989 (14).

Eduardo Romano remonta esta tradición y este tipo de operaciones al tango y a la gauchesca, que en determinados períodos son apropiados desde la poesía (Ver Eduardo Romano, Sobre poesía popular argentina, Buenos Aires, CEAL, 1983). Pero la idea de "literatura popular", que tiene peso en la poesía del sesenta justamente a partir de la recuperación de estas tradiciones, no aparece en cambio en los noventa, cuando sí se hacen ingresar al poema elementos de la cultura popular (tal como la define De Certeau) a partir del habla o de los objetos y prácticas que se retoman, como vimos en el capítulo anterior. Lo que no hay, en las poéticas que trabajamos, es esa idea de "literatura popular" que era central en los sesenta, como si se hubiera perdido esa diferenciación, del mismo modo en que se pierde la partición entre alta cultura y cultura de masas. 
Pero a la vez, no puede decirse que en este caso la tabula rasa -que acá se cifra en la elección de un material que se encuentra en los márgenes, no sólo de la literatura sino de la cultura- suponga un ataque contra la poesía como institución, desde el momento en que hay una voluntad de hacer poesía con esos materiales. Porque si bien en los textos se construyen voces que pueden atribuirse a figuras del bárbaro, hay al mismo tiempo, en el paratexto, un gesto de señalamiento que puede resumirse en la frase "Esto es poesía”, como puede leerse en los títulos de algunos poemas: "Postales de la zanja (uno)”, “Postales de la zanja (dos)” y “Poema de amor desde la cárcel” (el resto de los textos no tiene títulos sino números).

En la línea de Ricardo Zelarayán, la operación de La zanjita consiste en descubrir lo que hay de poético en el habla, en este caso de un habla marcada culturalmente como marginal y situada en un barrio periférico de la Capital argentina. Esto se articula de modo directo con los materiales de la cultura masiva y popular que figuran en el texto, y que construyen el mundo de La zanjita como un todo coherente.

La raza de Santiago Llach se inserta en esta misma línea porque se abre con un poema que da título al libro y que funciona como poética, además de que pone de manifiesto una conciencia del habla inseparablemente ligada a una situación cultural que ya estaba presente en La zanjita. Porque en "La raza”, el poema, se contrasta un modo del festejo popular, el de Alemania cuando gana la Eurocopa, que llega como imagen televisiva, con otra escena hipotética: “¿Te imaginás a toda/ la negrada en el obelisco gritando/ prolijamente “we are the champions,/ we are the champions"? ${ }^{259}$ La pregunta es retórica, pero lo absurdo de la situación conjeturada deja en claro la imposibilidad de traducir culturalmente la escena sin modificarla. Acá y ahora, hay una realidad -la “negrada”, junto con la desprolijidad que se le atribuye implícitamente- que

\footnotetext{
${ }^{259}$ Santiago Llach, La raza, Buenos Aires, Siesta, 1998 (9). Todas las citas posteriores están tomadas de esta misma edición.
} 
opone resistencia a ese modo supuestamente civilizado y europeo del festejo. Además, el uso del inglés, lengua extranjera que los alemanes se apropian espontáneamente para expresar la emoción del triunfo, se plantea como algo imposible para esta “negrada”, con lo cual se sugiere una correspondencia entre determinadas realidades y el lenguaje con que éstas se dicen.

El poema funciona entonces como toma de posición geopolítica: se escribe desde un "acá” donde el pueblo es "la negrada”, y el poema se hace cargo de ese modo de denominar cargado de violencia y de connotaciones históricas que circula socialmente, lo hace propio. En este texto, como el resto de los poemas de La raza, la voz que enuncia los poemas no toma distancia de lo que se dice por medio de comillas o del uso de discurso indirecto, ni tampoco hay (excepto en "Los mickey”), según analizaremos en el caso de Durand y Gambarotta, ningún tipo de construcción de personajes que ponga en cuestión la posibilidad de atribuir lo enunciado a un enunciador que se podría identificar con el poeta. En ambos casos, se trata de textos cuyo gesto de ruptura consiste en instalarse en el habla como lugar de la poesía y alejarse, en el mismo movimiento, de los parámetros de lo establecido como literario, sin realizar un gesto de impugnación explícito al respecto.

En este sentido el gesto de Segovia, ${ }^{260}$ el primer libro publicado por Daniel Durand, es diferente porque aquí se trata de poner en escena de modo asistemático

\footnotetext{
${ }^{260}$ Durand mismo sitúa la escritura en el año '90, con lo cual lo constituye en un antecedente muy temprano de la poesía de los noventa y contemporáneo de La zanjita. Además, como aclaramos, algunos fragmentos del poema se publicaron en la revista 18 Whiskies en el año 1993.

En una entrevista realizada por Pedro Mairal, Durand arma la siguiente cronología para sus textos: "El estado y él se amaron” es una recopilación y un recorte de mi poesía. "Segovia” lo empecé a escribir en el 90, el resto de los textos son posteriores, "Durán deberías...” por ejemplo lo empecé en el 92, el libro respeta bastante un orden cronológico, a "Salto Grande" lo tenía escrito en prosa desde el 98 más o menos, pero recién lo versifiqué en 2006, de manera que hay textos muy viejos de hace mas de 15 años, textos intermedios como "Marquina" del 98 o "Nueces mojadas...” del 2003 y textos más recientes que escribí o definí entre 2005 y 2006 para
} 
distintos segmentos de la tradición para impugnarlos. Los versos que figuran en el epígrafe dan cuenta de uno de los movimientos de Segovia que justifican ese carácter fundacional: la voluntad de situarse por fuera de la poesía, y por extensión de la literatura, para escribir aquello que todavía no ha sido dicho. En este gesto resuena, una vez más, la idea que comparten Zelarayán y Lamborghini de forzar los límites de lo que se acepta como literario. Pero en Durand esa operación supone, necesariamente, no ser poeta, negar todo linaje posible dentro de la institución literaria y toda vinculación más o menos orgánica con la tradición.

Sin embargo, y de manera paradójica, esta poesía que se postula a sí misma como no-todavía-poesía y como no-literatura está tramada por diversos usos y lecturas explícitas de la tradición que funcionan como puesta a prueba de la biblioteca y que no están presentes en Desiderio, Llach y Gambarotta. Segovia se constituye de este modo en otro tipo de "laboratorio" donde la experimentación supone no sólo el ingreso del habla sino también la revisión y traducción de zonas de la literatura en función de una situación cultural específica.

Segovia se presenta como un libro hecho de fragmentos, que exhibe la fragmentación desde los mismos títulos de los poemas: "Las rocas marrones. (Parte dos)” (Durand: 2001, 13) (pero no hay una Parte uno), “La luz de las piedras que están bajo las aguas. (Frag.)” (Durand: 2001, 20), “Salmos de cisne de tanque australiano (Lamento $\mathrm{N}^{\circ}$ 88)” (Durand: 2001, 22), pero tampoco en este caso hay otros textos que pertenezcan a la misma serie. Los fragmentos remiten en todo caso a una biblioteca inexistente de la que Segovia funcionaría como compendio, y pueden pensarse como los restos de una obra ficticia que pone en cuestión de modo simultáneo las nociones de “obra”, “autor” y “estilo”.

ensamblar el libro". En http://elseniordeabajo.blogspot.com/2006/08/entrevista-danieldurand.html. 
Porque no hay un estilo que unifique los textos ni una voz única que pueda identificarse con un autor, sino más bien lo contrario; el repertorio de voces y estilos usados es amplísimo. Entre ellos se encuentran un caligrama que imita en el diseño visual a los poemas de Apollinaire pero que desde su mismo título, "Yuquerí”, propone una mezcla entre la tradición europea y la geografía del litoral. ${ }^{261}$ El poema habla de un horno en el que se cuecen los ladrillos con los que se construirá una casa y anuncia que "Es bueno para el asma el calor y el tufo/ a bosta quemada que sale de adentro del boquete” (Durand: 2001, 9). Tanto el motivo y la forma de bloque que el texto reproduce visualmente como el registro empleado remiten a un gesto por el cual la tradición es convocada pero sólo a condición de ser modificada en función de una situación cultural diferente, que pone en escena un saber de origen popular. ${ }^{262}$

\footnotetext{
${ }^{261}$ Yuquerí es el nombre de una localidad de Entre Ríos, provincia en la que nació Durand y a la que sus textos, como el poema "Salto grande", incluido también en El estado y él se amaron, remiten permanentemente.

A este respecto, Durand afirma en la misma entrevista que citamos anteriormente: "Me siento muy cerca de algunos escritores del litoral, me siento uno de ellos, aunque no viva ahí, participo de encuentros regionales y estoy comunicado con muchos de ellos, y está bueno porque ese ámbito no se toca mucho con la actividad de capital, es un circuito menor, zonal, y hay poetas y escritores por todos lados, que surgen todo el tiempo. Ahora me han puesto en una página web que se llama autoresdeconcordia.com.ar ahí estoy con otros poetas y escritores de la ciudad de donde provengo. En muchos aspectos mi actividad está centrada hacia abajo, y no tanto hacia arriba, es decir que me fijo más en los poetas que recién empiezan, y no tanto en los dioses del olimpo fluvial, ya transité esa franja, reconozco su importancia y sus logros y es lo que recomiendo para la formación de un lector o un escritor, pero no le doy ya tanta bola a Saer o a Juanele, a Mastronardi menos, tengo más presente a Calveyra o Zelarrayán, que son más parecidos a mí, es decir que no viven en el litoral pero tienen al litoral como espacio o zona donde se ubica su escritura (...)”.

${ }^{262}$ En la misma línea, en "Salmos de cisne de tanque australiano (Lamento $\mathrm{N}^{\circ}$ 88)" se recurre a la figura emblemática del modernismo latinoamericano para repetir, con variaciones mínimas, la frase "carne es dinero" (Durand: 2001, 22). El propósito de disputar la definición de lo que es y no es poesía se resume en el verso "cisne no es poesía”, y aparece también en ese título que saca al cisne de un espacio preciosista -en una operación sobre el motivo similar a la efectuada por Marcelo Díaz, como vimos- para ubicarlo en el típico tanque australiano del campo argentino. El título de otro de los poemas es "Caballitos de Troya", y en este caso la referencia clásica aparece miniaturizada por el diminutivo, tachada, y usada para narrar las primeras experiencias sexuales de un grupo de jóvenes de un barrio de provincia. En este caso, el "caballo de Troya" alude a los chicos que van a la casa de una vecina llevando un regalo para terminar violándola (Durand: 2001, 16-19).
} 
Otros poemas proponen desde el título un juego de palabras entre el nombre del autor del libro, Daniel Durand, y el trovador provenzal Arnaut Daniel, que da como resultado a los autores ficcionales Miel Danieles y Daniel Mieles (Durand: 2001, 10, 12). En este caso, una vez más, y casi como autoparodia, el poema "Miel Danieles" aparece con una indicación bajo el título que dice “Trozo”, como forma pretenciosa y excesivamente estilizada de aludir al fragmento (Durand: 2001, 10).

La operación en estos textos consiste en trabajar con referencias puntuales a ciertos autores prestigiosos de la tradición -especialmente de la literatura europeacomo Mallarmé, Apollinaire, Arnaut Daniel y Homero, para mezclarlas con materiales bajos y culturalmente marginales que remiten a espacios como el barrio y la provincia, y sobre todo para someterlas a un registro lingüístico coloquial y plebeyo. ${ }^{263}$

Tanto la cita de textos y autores puntuales y el uso de procedimientos eminentemente poéticos como la mezcla de esos materiales con motivos y registros orales y bajos constituyen uno de los modos posibles de diálogo con la tradición. Sin embargo, en este caso se trata de autores y procedimientos que ya no son operativos dentro del sistema poético al momento de la escritura de Segovia, y que por lo tanto funcionan de modo difuso como metáfora de la poesía entendida en el sentido más

\footnotetext{
${ }^{263}$ En otros casos, la operación consiste en usar en clave plebeya ciertos procedimientos y formas prestigiosas que tantas veces funcionan como metonimia de "poesía", tales como el soneto, la rima y la metáfora. "Isar" es un poema que toma la estructura estrófica del soneto para hablar de un camping a orillas del río: "Desde 500 metros se escuchaba/ el ruido del caudal contra las piedras,/ laberintos de arroyos y cascadas:/ el oradar constante de una sierra" (Durand: 2001, 14). Aquí, el segundo término de la comparación para hablar de la naturaleza es el ruido de una sierra, así como en "Mariposas non salutant" se construye una imagen que convierte a un cable en una rosa blanca que es absorbida y triturada por las aspas de un ventilador Yelmo (Durand: 2001, 33). A su vez, el uso profano -y en este caso sí, claramente destructivo- de la rima da lugar a algunos de los versos más célebres de la poesía de los noventa: "Por el ojo del choto/ yo lo veo todo roto" (Durand: 2001, 10), en los que resuena el “Escuche mi General, vea:.../ -Yo no veo, meo.” de Ricardo Zelarayán, que es el comienzo del poema "La razón pura o el sueño de la lógica implacable" de La obsesión del espacio, Buenos Aires, Atuel, 1997 (45).
} 
tradicional, como discurso bello y prestigioso y con signos que permitan reconocerlo como tal -rimas, metáforas, estrofas, etc.

Pero hay otra serie de textos que discuten explícitamente con figuras que sí funcionan dentro del sistema poético contemporáneo a Segovia y que remiten tanto al neobarroco como a la biblioteca construida por el Diario de poesía. En primer lugar, la alusión al neobarroco se condensa en un verso que pertenece al poema ya citado "Miel Danieles”: “La paja es una barroca mucho más” (Durand: 2001, 10). ${ }^{264}$ En este poema se construye la figura del que escribe con el sexo, y el ejercicio de escritura se homologa a la masturbación, como una forma de parodiar el repertorio corporal y erótico del neobarroco mediante la explicitación de lo que en esta línea poética aparecía velado -en una operación similar a la de Alejandro Rubio-, y con una escritura “con trazo grueso”. 265

En consonancia con esto, en el poema hay una toma de posición explícita respecto al hecho de ostentar un linaje literario. Contra los que "intentan un texto/ para quedar adentro aunque sea/ en el último puesto/ puesto que tienen metida a toda su familia/ dentro de la biblioteca” se esgrime un linaje popular: “mamá es maestra/ papá

\footnotetext{
${ }^{264}$ De nuevo, el verso puede leerse como reescritura del "Pero, ¿qué piensa el pasajero?/ Que el porvenir es pasajero como él/ o que el pasado es pajero?/ La paja no es como el trigo/ y el trigo no es como el burro/ que va adelante para que no se espante (Zelarayán: 1997, 18). Tanto el uso irreverente y hasta absurdo de la rima, como el trabajo escatológico con la corporalidad en el poema antes mencionado, "La razón pura o el sueño de la lógica implacable", vinculan estos poemas de Segovia con Zelarayán y permiten leerlos como reescrituras microscópicas de ciertos fragmentos de La obsesión del espacio.

${ }^{265}$ El fragmento del poema “Miel Danieles” (Durand: 2001, 10, 11) al que nos referimos dice:

primero, a arremangarme

el cuero que me sobra cuando la tengo muerta, y expuesta la cabeza a esta brisa de Febrero

la voy a introducir en la boca del tintero.

Azul entonces la sopeso con la palma, la miro; con trazo grueso van estas magnolias rosadas por debajo pero duras.

$$
\text { (...) }
$$

y a la rima no la pulo no me importa metétela en el culo.
} 
trabaja en el correo/ Pablo es taxista/ Susana es panadera/ mi abuelo tiene una fábrica de ladrillos/ mi prima Norma es puta”, (Durand: 2001, 11). Los nombres propios funcionan de por sí como referencias que sitúan a los poemas socialmente. En este caso aparecen “Norma”, “Susana”, “mi tía Tota”, así como en el ya mencionado “Caballitos de Troya” se enumeran los sobrenombres de los chicos del barrio: El Pando, El Paty, Mela, El Vaca, El Negro Beltrán (Durand: 2001, 16).

La biblioteca, entonces, aparece como aquello que se opone al origen social del que habla en los poemas e incluso al mundo que estos construyen a través de las referencias. Sin embargo, el reconocimiento y el ajuste de cuentas con ese linaje también estructuran a Segovia, aunque sea como modo de construir el propio lugar de escritura a partir de la oposición.

En "Hielo seco" (Durand: 2001, 24, 25) la figura que aparece puesta en entredicho es la de Walt Whitman, pero en realidad el texto es una reescritura de un poema de Pound, “Un pacto”. Allí Pound reconoce en Whitman a una figura a la que se había opuesto en sus comienzos como escritor pero con la que ahora puede reconciliarse, después de haber trabajado una escritura propia que se le opone formalmente (así como Durand se refería a su propia escritura como de "trazo grueso”, Pound describe el estilo de Whitman como más rústico, hecho de "hachazos" sobre la madera, mientras que define al propio como una escritura de "tallado") porque pertenecen, después de todo, a una misma tradición (“Tenemos igual savia y la misma raíz”). ${ }^{266}$

\footnotetext{
${ }^{266}$ El poema completo dice:

I make a pact with you, Walt WhitmanI have detested you long enough. I come to you as a grown child Who has had a pig-headed father; I am old enough now to make friends. It was you that broke the new wood,
} 
El poema de Durand dice en cambio:

Estaba escribiendo todo esto cuando me tocó el timbre.

Era Walt Whitman, y le dije:

Tomátela de acá, vieja, no quiero hacer pactos con vos y no me importa toda la leña que cortaste. No me sirve. No me importa que te hayas metido en un supermercado delante de tus emputecidos alumnos.

En este Abasto no hay lugar para las alabanzas.

Volvé a la tumba padre! (Durand: 2001, 25).

Mientras que Pound, en un poema de madurez, se declara listo para hacer un pacto con aquel antecesor con el que en un momento se enfrentó, y la idea funciona como conciliación con una tradición orgánica de la que se reconoce como parte (sobre todo al señalar que Whitman cortó los troncos que Pound tallaría, con lo cual se piensa a la poesía como un trabajo colectivo que se continúa en el tiempo), Durand envía al "padre” de vuelta a la tumba como forma de revertir el gesto de Pound, afirmando que no hay ni debe haber linajes, y lo que esgrime contra la tradición es una expresión coloquial por demás irreverente: “Tomátela de acá”.

En "Belleza me canso y te bardeo" que también dialoga con la tradición anglosajona, la escena es la de la traducción; el poema comienza con un fragmento de

Now it is a time for carving.

We have one sap and one root-

Let there be commerce between us.

Hago un pacto contigo, Walt Whitman:

te he destestado ya lo suficiente.

Vengo a ti como un niño crecido

que tuvo un padre cabezota;

ahora ya tengo edad de hacer amigos.

Fuiste tú quien cortó los nuevos troncos

y ahora es el momento de tallarlos.

Tenemos igual savia y la misma raíz, vamos a hacer un trato entre nosotros.

En Ezra Pound, Personae, Madrid, Hiperión, 2000 (181). 
poesía inglesa, pero de pronto esta poesía traducida -y fundida con el texto propio- se interrumpe de manera brusca para decir:

\author{
poesía inglesa es todo esto \\ mierda \\ basura quieta \\ pureza inmóvil \\ y qué? \\ No hay nada detrás de la belleza \\ no hay nada detrás de la poesía \\ inglesa. \\ Can can! cancancan! can! kan can! \\ la leche que da la vaca \\ que se la tome el lechero \\ nosotro tomamo vino \\ tomamo vino resero” (Durand: 2001, 29).
}

El rechazo de una poesía "bella”, escrita en un lenguaje “elevado”, se cifra en este caso en dos operaciones: la introducción de onomatopeyas, ruidos, que bien podrían ser los acordes de una guitarra eléctrica, y la inserción de un estribillo popular que ensalza el alcohol y cuya adscripción social puede leerse tanto en la caída de la "s" al final de palabras como “nosotro” y “tomamo”, como en la presencia de la marca del vino.

Lo popular, que en La zanjita y La raza aparece sin una contraparte "culta” que se le oponga, como en Segovia, se esgrime entonces como aquello que puede socavar, mediante la violencia ejercida por el ruido, a esa poesía inglesa que se caracteriza como “quieta” e “inmóvil”, y que puede reponer en el poema cierto dinamismo. De esta manera Segovia construye, para oponérsele, una idea de poesía que tiene que ver con conceptos como la pureza, lo bello, lo elevado, la mesura, y el diálogo no disruptivo sino conciliatorio con la tradición. ${ }^{267}$ A esta ideología poética se le opone un ejercicio

\footnotetext{
${ }^{267}$ En esta misma línea debe ubicarse otro poema de Segovia que enuncia una poética mediante la construcción de una escena de juego de la infancia, "Mariposas” (Durand: 2001, 34). La voz que habla en este texto corresponde a un niño que enuncia en presente, pero el tiempo verbal gira por momentos al pasado -con lo que se plantea una indefinición entre el niño que vive la experiencia y el adulto que la recuerda-, y describe un juego por el cual, junto con una amiga, ataban un pedacito de telgopor a las mariposas que pasaban por el jardín para que murieran enredadas en las plantas. El poema concluye: "A la siesta todos duermen y sólo en el jardín/ Segoviano/ hay un castigo liviano/ para todo lo que es hermoso", lo que recuerda a la consigna ya citada de Leónidas Lamborghini que apareció como título de una entrevista que se le realizó
} 
de escritura asistemático, múltiple y fragmentario que toma partido por la desmesura, el ruido, la disonancia.

Pero el debate no es solamente con una tradición anglosajona o norteamericana sino que se dirige antes que nada al interior del campo poético contemporáneo. Porque los poemas aluden de manera indirecta a toda una línea poética nucleada alrededor del Diario de poesía que construyó su biblioteca fundamentalmente a partir de algunos de los poetas que aquí se impugnan y muy especialmente de Ezra Pound, como vimos en el primer capítulo.

En la lectura de Durand, tanto Pound como los poetas del Diario de poesía especialmente Martín Prieto y Daniel García Helder- aparecen como los impulsores de un principio de pulido y corrección en la escritura, de búsqueda de precisión (ese “tallado” que figuraba en el poema "Un pacto”) del que Durand se desmarca para construir, por su parte, una poética de la “irrestricción” (tal como él mismo la llama) que postula como fundacional de la poesía de los noventa (de la que excluye, claro, al objetivismo).

En una entrevista, Durand realiza una demarcación política del campo poético para situar al Diario de poesía como "la expresión moderada de la izquierda progresista intelectual sosa que tanto detestábamos”, y que se caracterizaría por una impronta “solemne y políticamente correcta”. ${ }^{268}$ De esta manera efectúa, por un lado, un

desde el Diario de poesía: “Nada que ver con la belleza”. Ver Daniel García Helder (reportaje), en “Dossier Leónidas Lamborghini”, Diario de poesía N 38, invierno de 1996 (13-24).

${ }^{268}$ En la misma entrevista mencionada anteriormente, a cargo de Pedro Mairal, Durand sitúa su propia poética en oposición al Diario de poesía: "Bueno, acá una vez vino un español coleccionista a comprarme libritos de Deldiego y se los llevó para su colección privada y me dijo una cosa que me quedó grabada: "el Diario de Poesía es la enciclopedia hispanoamericana de la poesía...”. Pero a nosotros, si bien nos interesaba la información del Diario, no nos gustaban mucho los poetas argentinos que publicaban, ni la impronta solemne y políticamente correcta que tenía la publicación, el Diario era la expresión moderada de la izquierda progresista intelectual sosa que tanto detestábamos. Yo estaba del lado del bardo, del descontrol, del lado de las actitudes iconoclastas, en contra de la academia, de la institución y 
cuestionamiento ideológico del Diario de poesía, al mismo tiempo que manifiesta su rechazo por esta formación ya consagrada.

Como hemos visto, las operaciones sobre la tradición le sirven a Durand tanto para situarse con respecto a las líneas poéticas contemporáneas -neobarrocos, y objetivistas del Diario de poesía - como para impugnar una idea institucionalizada y prestigiosa de literatura que se asocia con la figura de la biblioteca y que en Segovia se construye imaginariamente alrededor de la idea de linaje.

Pero los ejercicios de reescritura de la tradición tienen que ver sobre todo con dos operaciones: la de desacralización, al mezclar textos y poéticas prestigiosos con materiales bajos y con un registro lingüístico coloquial y plebeyo, y la de traducción. En este caso el gesto es común a Llach y Desiderio, en la medida en que las formas y procedimientos ya consagrados como poéticos se cruzan con un sistema de referencias geográficas y sociales que remite a lo local y a lo popular. El material más resistente a la asimilación canónica parece ser en este caso el habla, que funciona como centro de estas poéticas, en versos como “Meté la mano/ sacá lo hueso de poyo” (Desiderio), “¿Te imaginás a toda/ la negrada en el obelisco gritando?” (Llach) o “Tomátela de acá, vieja”

del monopolio que el Diario había alcanzado, en poco tiempo, pulverizando el valor de pequeñas publicaciones como la revista Último Reino, Xul o La danza del Ratón. Había que hacerle frente a ese monopolio, y lo hicimos desde la 18 Wiskys (sic). Creamos una opción irrestricta frente al principio de restricción que decían haber impuesto ellos, un principio de restricción respecto del lirismo neorromántico o del desborde barroco. Nosotros creamos el antídoto inmediato, a las restricciones del modelo objetivista impusimos un principio de irrestricción, y ahí surge ese modelo que hoy se designa como poesía de los noventa. Yo me oponía férreamente a que mis amigos publicaran en el Diario, por un montón de motivos. Por ejemplo, nosotros nos juntábamos, estábamos charlando y decíamos "Vamos a hacer una revista”. “¿Y qué publicamos?” "Yo tengo tal poema”, "yo tengo tal nota”, pero resulta que ya estaba todo publicado en el Diario. El Diario nos quitaba material para llevar a cabo nuestros propios proyectos. Yo me di cuenta rápidamente de eso, y entonces les decía a mis amigos que escribieran pero no publicaran ahí, que esperasen a que hiciéramos algo. Yo podría haber publicado Segovia en el Diario, porque Daniel García Helder me lo pidió varias veces, pero preferí no dárselo para publicar en otras revistas. Me parece que con ediciones Deldiego y con la Wiskys rompimos con el monopolio y ayudamos a crear las bases para toda la andanada de ediciones independientes que vendría después, cuando decayó el predominio del Diario". 
(Durand), que tienden a hacer del poema una tabula rasa donde se inscriben las formas de la oralidad en su versión más cruda.

\section{LITERATURA, CULTURA DE MASAS Y USOS POPULARES: UNA IDEA DE CULTURA AMPLIADA}

En La zanjita, Punctum y La raza se da una operación de mezcla en el plano del lenguaje sin que el poema jerarquice los diversos registros. Pero además hay una operación similar en cuanto a las imágenes y referencias culturales presentes en los textos, que no sólo trabajan con el habla sino con materiales provenientes de la cultura popular y la cultura de masas.

En La zanjita los personajes hablan por ejemplo de Spock, que deviene “espok” en el modo de Desiderio de transcribir fonéticamente el habla (“—no te hagás el espok/ y corré más rápido/ que nos matan / esto marciano de la 19”, Desiderio: 1992, poema III). Se trata del protagonista de la serie televisiva estadounidense de culto Star Trek de los años sesenta. El modo de pronunciar el nombre da cuenta de una apropiación por parte de los que hablan que se hace extensiva al personaje televisivo. En efecto, la presencia de Spock, hijo de una humana y un extraterrestre, se vuelve significativa porque el personaje funciona como una figura híbrida en la que pueden leerse las operaciones de hibridación lingüística y cultural que traman el poema. ${ }^{269}$ Este tipo de

\footnotetext{
${ }^{269}$ Néstor García Canclini define "hibridación” como una serie de procesos socioculturales por los cuales prácticas discretas, que existían de forma separada, se combinan para generar nuevas estructuras, objetos y prácticas. Ver Néstor García Canclini, Culturas híbridas. Estrategias para entrar y salir de la modernidad., Buenos Aires, Paidós, 2001. Como señala el autor, Bajtin usó el concepto para caracterizar la coexistencia de lenguajes cultos y populares en los textos, y es en ese sentido que puede planteárselo aquí, pero también en relación a la apropiación de objetos culturales heterogéneos que se modifican por el uso que se hace de ellos, y con los que se
} 
personajes híbridos tomados de la televisión (en realidad, de un conjunto de series televisivas de culto estadounidenses que pueden considerarse como parte de una cultura trash que procesa materiales marginales del pasado) aparecen también en Punctum de Martín Gambarotta, como veremos, y permiten ser pensados en relación a las figuraciones de poeta que construyen los textos, porque así como Spock pertenece a dos órdenes distintos el poeta es aquí el que participa de dos mundos culturales diferentes que articula en el texto, en ocasiones de modo conflictivo.

Por otra parte, junto a la figura de Spock aparecen también San Jorge y Santa Rita en sus versiones populares y profanas, porque la santa se separa de su origen sagrado al funcionar como segundo término de una comparación referida a una chica que tomaba sol a la orilla de la zanja (“y aparecía como/ santa rita envuelta/ en una nube”, Desiderio: 1992, poema III), a la vez que se habla de un “viejo/ que creía ser san jorge/ y yevaba al matungo/ a tomar agua/ a la zanja” (Desiderio: 1992, poema III). Ambas figuras religiosas aparecen aquí desde la apropiación, que desvía las significaciones y usos autorizados: la santa se percibe como mujer al homologarla con la belleza de una chica, a la vez que el viejo que “creía ser san jorge” usurpa una identidad al margen de la religión institucionalizada.

Al mismo tiempo, si hay algo que asimila las imágenes televisivas a las religiosas es que se trata en ambos casos de representaciones de las que los hablantes se apropian para construir, de modo plebeyo, una mitología del barrio. La esfera religiosa y la del consumo cultural se vinculan a partir del uso y de la posibilidad de convertirse en parte de un relato mítico colectivo.

$\mathrm{Al}$ mismo tiempo, la esfera del consumo se sacraliza mientras que la esfera de lo sagrado es destinada para usos que la profanan. Porque como afirma De Certeau, "Un

establecen relaciones intensas y esporádicas, como en el caso de las figuras televisivas que estamos analizando. 
uso (“popular”) de la religión modifica el funcionamiento de ésta. Una cierta manera de hablar este lenguaje recibido lo transforma en un canto de resistencia”, lo cual se aplica en este caso tanto a lo religioso como a la televisión y las mercancías. Así, se dice que "todos los yiros/ besaron al pelahueso/ lavaron sus pies besaron/ sus ojos acostaron/ al pelahueso rezaron y fumaron” (Desiderio: 1992, poema IV), y también que "Los hevys con sus pelos/ quemados y ojos de arsénico como tocaban/ esos chicos la pared a cada rato/ rituaban con eso de romper la puntita lo/ divertido de romper la cajita del/ tetra” (Desiderio: 1992, poema VII). Las prostitutas ejecutan rituales de carácter religioso sobre el cuerpo de un marginal, a la vez que los jóvenes constituyen en rito el modo de consumo de un vino barato. El poema aparece entonces como un espacio en el que se realiza la mezcla de lo oral y lo poético, pero también de lo religioso devenido profano y la esfera del consumo sacralizada.

De ese "laboratorio" poético que es La zanjita surgen entonces los rasgos que se van a continuar en otros textos posteriores: no sólo el uso del habla como lo específico de la poesía, sino también la presencia del consumo de los jóvenes como modo de situar culturalmente el habla y en tanto fuente de imágenes que producen sentido, y el barrio como espacio diferenciado. La figura del laboratorio es útil para pensar el modo en que La zanjita funciona como puesta a prueba del discurso poético, y como modo de procesar una tradición que mezcla componentes de la poesía nacional con la apropiación de figuras televisivas de origen norteamericano, en un espacio simbólico caracterizado por la hibridez.

Como señalaban Selci y Kesselman en el artículo ya citado, “La zanjita articula un mundo a partir de la cultura joven y sienta en el mismo movimiento una premisa: el habla no es modelo, sino objeto eminente, y en esa medida condición objetiva de todo acceso a la contemporaneidad. O bien: el habla es para la poesía la objetividad del 
presente. De este modo, quedan establecidas las bases evolutivas de la poesía de los 90.” Por otra parte, la figura de poeta que surge de estos textos es, como señalamos, la del que opera el paso entre uno y otro registro. Porque el gesto de La zanjita supone que no hay materiales específicamente poéticos sino que por el contrario, tanto los diálogos entre jóvenes a propósito de la televisión como las pequeñas leyendas barriales son pasibles de ser poesía en la medida en que son, precisamente, lenguaje. De este modo los principios enunciados en las poéticas de Zelarayán y Lamborghini se actualizan en el ingreso de los materiales de la cultura de masas y del barrio como espacio de la diégesis - un espacio cargado de los signos de la situación cultural del menemismo. ${ }^{270}$

De modo similar, en Punctum el sistema de referencias culturales más visible no proviene de la literatura sino del rock y la televisión porque los personajes del poema se identifican en parte según sus consumos culturales. Una figura que recorre varios de los textos es la de Sid Vicious, que se vincula con los personajes del libro en el hecho de que se cambia el nombre y de que se presenta como un muerto en vida: "Sid Vicious, decía el titular, is dead”. ${ }^{271}$ También está Luca Prodan, el cantante de Sumo, cuando el Guasuncho dice "loco, yo era amigo de Luca” (Gambarotta: 1996, 10) mientras escuchan Blondie. Alguien tiene un tatuaje que dice "KISS" (Gambarotta: 1996, 22), y más adelante Hielo le dirá a otro "sacá (...) esa basura/ clásica de la radio/ y poné heavy/ metal” (Gambarotta: 1996, 38). ${ }^{272}$

\footnotetext{
${ }^{270}$ De hecho, el libro anterior de Desiderio tiene un título que alude al barrio. Ver Juan Desiderio, Barrio trucho, Buenos Aires, Ediciones Trompa de Falopo, 1990.

${ }^{271}$ Martín Gambarotta, Punctum, Buenos Aires, Libros de Tierra Firme, 1996 (17). Todas las citas posteriores están tomadas de la misma edición.

${ }^{272}$ A propósito de este "heavy metal”, Metal pesado es justamente el título de uno de los libros de Alejandro Rubio que trabajamos en otro capítulo y que al igual que Punctum propone una vinculación entre poesía y rock.
} 
Además los personajes de Punctum miran televisión, pero no la programación de los canales abiertos de la década del noventa en Argentina sino una serie norteamericana de los sesenta, El gran chaparral (Gambarotta: 1996, 14). La serie está ambientada en el desierto de Sonora (la actual Arizona), en un territorio de frontera, y los protagonistas son familias norteamericanas y mexicanas, por eso en ocasiones los personajes pasan del inglés al español. ${ }^{273} \mathrm{La}$ otra serie a la que se alude, también norteamericana pero esta vez de la década del setenta, es Kojak (Gambarotta: 1996, 23), en la que Telly Savallas interpreta a un policía neoyorquino de origen griego. En ambos casos se trata, como en Desiderio, de figuras fronterizas, que valen a su vez como representantes de la posición del texto entre la cultura de masas y la literatura. Y el televisor prendido, incluso cuando nadie lo está mirando, reducido por el corte de la programación a una pantalla vacía pero que sin embargo da entidad a las cosas en la medida en que las ilumina, es un motivo constante en el libro (Gambarotta: 1996, 8).

Las dos series mencionadas pueden pensarse como parte de un consumo cultural trash que opta por los materiales degradados de la cultura de masas, especialmente de los sesentas y setentas. ${ }^{274}$ El narrador de Punctum se hace cargo de esta marca cultural cuando dice, en el poema que sigue a aquel que menciona a Kojak: "Trash es la hojarasca, broza, paja, escombros/ basura, bagazo, desecho/ de este mundo o/ un cualquiera, trashery y trashiness/ quieren decir lo mismo,/ trashy es un despreciable, un inútil” (Gambarotta: 1996, 24).

\footnotetext{
${ }^{273}$ Esto se relaciona con el uso de las lenguas en Punctum, como veremos más adelante.

${ }^{274}$ El culto de lo trash, relacionado con lo "mal hecho" supone la celebración del error, de la irregularidad y, en ese sentido, se convierte en una forma de trasgresión, de distorsión de las estéticas establecidas. "El arte trash libra su peculiar batalla contra lo preceptivo -la belleza, los cánones estéticos, entre otras cosas- (...). Construirse un paladar basura puede ser, asimismo, un acto político: en nuestro mundo sin ideologías, seguimos viviendo bajo el yugo de las dictaduras del gusto, y la única manera de combatirlas consiste en articular una personal guerra de guerrillas en las cloacas de la estética". En Jordi Costa, Mundo Bulldog: un viaje al universo basura, Madrid, Editorial Temas de Hoy, 1999.
} 
El modo en que aparecen estos productos de la cultura de masas es relevante porque no hay una separación nítida entre las percepciones de los objetos y el entorno y las imágenes de la televisión o la publicidad. Por el contrario, todo se mezcla en la mente de los personajes, como puede verse en el poema 5 (Gambarotta: 1996, 13, 14). Allí se arma una serie que comienza con la figura de Sid Vicious, pasa a algunas frases enunciadas por Manolo, uno de los personajes de El gran chaparral, luego a un aviso publicitario de yogur que se ve en un cartel luminoso a través de la ventana, que a su vez se mezcla con el personaje Manolo (“y Manolo pide un yogur”), y finalmente se dice que toda la escena, imaginada por el personaje, "parece/ estar rodándose en la banquina de la ruta 2”. El personaje Manolo sale de la escena -de la ficción, pero sólo para pasar a otra ficción- para firmar autógrafos y el poema culmina con la voz de un grupo de fans que le dice "Manolo es verdá que te la movés a Greta,/ joya, Manolito, y otros/ andan con pancartas que dicen Manolo/ come with your Navajos a vivir to Ciudad Evita” (Gambarotta: 1996, 14). ${ }^{275}$

Como se ve, en este caso el límite entre la ficción televisiva, la imaginación del personaje y la “realidad” del poema se anula por completo, poniendo de manifiesto el carácter artificial y extrañado por igual de todos estos ámbitos. Porque el modo de consumo de estos materiales moldea la manera de percibir la realidad, que es vista por momentos como una escena o escenografía ("la escena ansiosa de desarrolla sin tiempo verbal”, Gambarotta: 1996, 82; “Enfocando una linterna desde el margen izquierdo/ se obtienen sombras transversales en la escenografía”, Gambarotta: 1996, 83), al punto que en el último poema se dice que todo lo que el personaje ve desaparece "de la pantalla

\footnotetext{
${ }^{275}$ Aquí, el verso "Manolo es verdá que te la movés a Greta”, en el que la caída de la `d’ al final de la palabra "verdad" recuerda a la grafía de $L a$ zanjita, supone un modo de la barbarie que aparece también en el poema "La Lejandra" de Segovia $(45,46)$ y señala, una vez más, al hecho de que estos poetas son lectores de sus contemporáneos, como puede constatarse en el uso común de determinados procedimientos.
} 
nevada de su mente” (Gambarotta: 1996, 87). Esa misma “pantalla nevada” que iluminaba un pasillo al comienzo del libro (Gambarotta: 1996, 8) termina por fundirse con la conciencia del personaje. ${ }^{276}$

Por otra parte y a diferencia de La zanjita, además de las referencias explícitas a programas televisivos, en dos oportunidades se ponen en escena los modos de yuxtaposición caótica y des-jerarquizada de las imágenes que habilita la televisión. En la primera de ellas se trata de la práctica del zapping. En este caso, el poema reproduce verso a verso la cadena de imágenes aleatorias que se sucede velozmente al cambiar de canal y habilita la hipótesis de que el flujo inconexo de imágenes que hay en el libro remite en parte a ese modo, novedoso en los años noventa gracias a la aparición de la programación por cable, de consumir televisión. ${ }^{277}$

En la segunda, un niño recuerda cómo vio, sin comprenderla, la transmisión del velorio del General Perón, justo a continuación de los dibujos animados que se interrumpieran. ${ }^{278} \mathrm{El}$ corte televisivo, que interrumpe unas imágenes para imponer otras y las coloca al mismo nivel, se constituye también en el procedimiento del poema, un procedimiento cuyo origen literario o televisivo es en este caso indecidible. Por eso, las referencias explícitas a la cultura de los medios masivos no son el único modo de

${ }^{276}$ En otros poemas se vuelve sobre la misma idea: “A veces no sabíamos si dormíamos/ o si mirábamos televisión,/ a veces pensábamos/ que lo que mirábamos por televisión/ lo estábamos soñando/ en colores luminosos” (Gambarotta: 1996, 58).

${ }^{277} \mathrm{El}$ poema al que nos referimos reproduce la yuxtaposición rápida de imágenes que caracteriza al zapping, del siguiente modo: “Antes del corte de la programación estuvo/ el vuelo de una polilla en la pantalla/ a contrapunto de la banda de sonido del Gran Chaparral,/ una japonesa que se tiraba a la pileta,/ los subtítulos en verde decían:/ "acaso no eres tú la de los ojos azules”,/ en otro canal, el documental sobre cáncer de piel/ y en otro un delfín saltando aros de fuego/ y de nuevo la japonesa secándose la nuca/ con la toalla, mirando la cámara/ cambia y otro dice "sólo se escribe/ acerca de la muerte por dinero" (Gambarotta: 1996, 8,9). Se trata de un modo caótico de consumir imágenes en el que de vez en cuando, como ese punctum barthesiano que da título al libro trasladado a la televisión, aparece una imagen aleatoria que produce sentido.

${ }^{278}$ Dice el poema: “todo se mezcla, qué personajes hablan/ con las rayitas coloradas de la remera del Cadáver,/ el día en que la televisión cortó los dibujitos/ para mostrar un edificio de piedra en la lluvia,/ un general viejo metido en un cajón,/ gente haciendo cola para verlo muerto" (Gambarotta: 1996, 45). 
constituirlos en parte de una tradición: también deben tenerse en cuenta las modificaciones que suponen a nivel formal (en el modo de organización de las imágenes dentro del poema) y perceptual.

Por otra parte, ese narrador que reflexionaba sobre lo "trash" -con una distancia crítica que supone la pertenencia a la esfera intelectual- es el mismo que sostiene una serie de referencias indirectas a la literatura, especialmente a William Carlos Williams, como hemos visto, y a Ezra Pound: "Por la ventana, un/ relámpago dibuja el/ ideograma 人 en el cielo” (Gambarotta: 1996, 18). Unos versos más adelante en el mismo poema se vuelve sobre la frase de Williams con esta variante más literal y fragmentada esta vez por el corte de verso: “No hay/ ideas”. En contraste con esto, la única escena de lectura en Punctum, a cargo del personaje Confuncio, se refiere al "horóscopo que viene con el chicle bazooka” (Gambarotta: 1996, 25).

Esta diferencia entre narrador y personajes señala a Punctum como un libro que se pretende escrito, al mismo tiempo, por un letrado que se apropia de la biblioteca del Diario de poesía que Durand impugnaba, al punto de incluirla por medio de la reescritura en su propio discurso, y por un bárbaro que rechaza al Quijote: “Nunca leí el Quijote./ En todo caso sueño con Alien/ escupiendo los huesos de Don Q. en el basural./ Las tripas de Sancho Panza/ vaciadas en la mandíbula de Alien./ Veo capítulos repetidos de Kojak/ durante el invierno sin chica” (Gambarotta: 1996, 56). Como se ve, el gesto de barbarie no se refiere a la biblioteca -es decir, por extensión a la literatura- como un todo, sino que en este caso apela a una obra, la de Cervantes, que funciona como sinécdoque de un modo de "ser culto" sostenido por ciertos sectores conservadores de instituciones relacionadas con la educación secundaria y universitaria, para los cuales el libro de Cervantes es el origen mismo de la literatura moderna en occidente. 
En La raza de Santiago Llach los materiales que ingresan al poema son tanto el habla y los productos de la cultura de masas como los signos del presente y los textos de los poetas contemporáneos. El consumo adopta en este caso carácter de adicción en el poema que dice: "En tu cabeza rapada tallaría poemas de Gambarotta,/ una adicción moderada a los márgenes de la cultura oficial/ recitada por señores de pelo largo en el suplemento literatura/ de los dueños de la pelota” (Llach: 1998, 49). Aquí, no sólo es importante la mención de Gambarotta (porque La raza dialoga claramente con Punctum), sino el hecho de que se lo sitúe en los márgenes de la cultura oficial, poniendo en duda al mismo tiempo la posibilidad de que algo como eso exista cuando lo marginal o alternativo es rápidamente asimilado por el poder ("los dueños de la pelota”).

En este caso la palabra “adicción” se usa para referirse al consumo, y la serie de objetos que se consumen en este segmento del poema y el que sigue pone de manifiesto qué tipo de productos culturales se asimilan como tradición: "Una adicción moderada al cancionero popular/ tocado por bandas de rock chabón en los canales de cable/ de la dueña de la pelota./ Una adicción moderada a la programación satelital.” (Llach: 1998, 50). La serie reúne a un poeta contemporáneo como es Martín Gambarotta con la música popular -que llega mediante la televisión- y la programación televisiva. Como en Gambarotta, estamos frente a un sujeto que se define como lector y al mismo tiempo como consumidor de los productos de los medios de comunicación masivos que aquí, además, se identifican como controlados por el poder.

Lo que se consume, entonces, proviene de la poesía contemporánea tanto como de los medios de comunicación masivos, que en la serie conformada en el poema ocupan lugares similares. Esto es importante porque modifica el lugar de la literatura, 
que ya no es de privilegio sino que aparece como uno más entre los distintos productos y fenómenos sociales que ingresan como materiales al texto.

Llach, que en esto se acerca a Gambarotta, también se le asemeja al poner en evidencia el hecho de que los diversos productos culturales están situados social y políticamente. Porque así como Gambarotta marca en Punctum ciertas correspondencias entre cultura y política (“Que los fasci de combattimenti/ se queden con la belleza/ que los demócratas se queden/ con la narrativa actual”, Gambarotta: 1996, 55), en La raza Llach asume una tradición que está controlada por el poder y que en todo caso puede modificarse por el modo particular de recepción -crítico- y por el uso que se hace de esos materiales. Entonces, al tiempo que retoma, como Gambarotta, las ideas sobre el habla que enunciamos en el capítulo anterior a partir de Ricardo Zelarayán, Llach construye en La raza una tradición que mezcla esas lecturas con la de Punctum (que también retomaba, a su modo, a Zelarayán), y con el consumo de los medios de comunicación masivos. ${ }^{279}$

Si al abordar el objetivismo era posible leer el armado de tradición a partir de operaciones de selección y recorte sobre distintas poéticas, aquí se pone en evidencia que el ejercicio de selección que hacen Desiderio, Gambarotta y Llach sobre el presente se caracteriza por la inespecificidad. Lo que se lee y constituye en tradición no es sólo la literatura sino todo aquello que es propio del presente, en un doble sentido: los signos del presente, la calle, el espacio público, la televisión y el rock, y también los poetas

${ }^{279}$ Como Ricardo Zelarayán, Llach enuncia una posición en la que la poesía no se define por convenciones que provengan de la literatura: "Poesía es lo que habla la comunidad. Hoy en la parrilla de enfrente, una parrilla de puertas abiertas, dos personas con uniformes de basureros tomaban cerveza y hablaban del aguinaldo. A uno le sonó el celular con un tema de los Redondos. Eso es poesía. Lo que hay. Después está la impostura cultista de los guardianes del templo. Contra ellos (que a veces somos nosotros mismos) se dirigen nuestras lanzas.”

Esta declaración es parte de una entrevista realizada en el 2008 por Valeria Tentoni, en Bahía Blanca, periódico Nexo, diciembre del 2008. La versión web puede leerse en:

http://4.bp.blogspot.com/_wp1 bAQ5l7M/SXKUyVU1wI/AAAAAAAAAUI/WtvF26h9DtY/s1600-h/LLACH1.bmp. 
contemporáneos. Entonces, la tradición no se arma desde la especificidad de lo literario sino en la articulación de diversos textos con la lectura de los signos del presente, lo que incluye al habla, los grafitti, los medios de comunicación y todo aquello que puede registrarse en el espacio público, en la ciudad. Pero este modo de plantear una idea de cultura en la que ingresan tanto la literatura como la cultura de masas y lo popular no está desprovisto de tensiones y conflictos, como veremos al analizar las figuras de bárbaros/analfabetos en relación a las figuras de poeta.

\section{VARIACIONES DE LA FIGURA DEL BÁRBARO Y DEL ANALFABETO: DURAND, GAMBAROTTA, LLACH}

El uso del habla y el ingreso de materiales provenientes de la cultura popular y de masas está estrechamente vinculado en los poemas a la construcción de personajes -que algunas veces funcionan como alter ego del poeta- que son variantes de la figura del bárbaro y el analfabeto. Al mismo tiempo, los personajes ponen en cuestión la idea de “autor” y la identificación del poeta con la voz que habla en los textos que es propia de la lírica. Así como en Leónidas Lamborghini la falta de una voz propia daba forma a una poesía construida a partir de las voces de otros, en este caso los poemas se construyen como puesta en escena de distintas voces cuya situación cultural no es homogénea.

En Segovia, como adelantamos, no hay un solo estilo ${ }^{280}$ sino muchos, y ninguno puede considerarse como “propio” del autor Daniel Durand. ${ }^{281}$ Así, junto al poeta-lector

${ }^{280}$ La idea de estilo, ligada a la autonomización de la literatura en la modernidad, a la concepción burguesa del individuo y a la idea romántica del genio que crea a partir de un acto 
que convoca distintas zonas de la tradición para impugnarlas (en ocasiones enmascarado como los poetas ficticios Miel Danieles y Daniel Mieles) aparecen otros personajes que no son poetas. Se trata de Segovia, el personaje que da nombre al libro, y de un niño que se construye a partir de una voz infantil. Estos dos personajes, cuya falta de capital cultural está indudablemente construida, deben pensarse también como variantes de una toma de posición, en el sentido que consignamos al comienzo de este capítulo a partir de Bourdieu (Bourdieu: 1997, 343), con respecto a la literatura y a la poéticas ya consagradas en el campo.

Segovia aparece desde los primeros versos: "Y si viene Segovia y termina con el arte y con la muerte?” (Durand: 2001, 5). En el mismo poema, un poco más adelante, figura una variación de este mismo verso: "Pero si llega Segovia con su risa y termina con el arte/ y con la suerte?”. En este caso se construye una red de sentido que asimila “el arte” con "la muerte”. A este arte no vital, cuyo fin se desea, se le opone la risa de Segovia. El personaje se retoma sólo en tres ocasiones; la primera de ellas, en un poema que concluye con los versos “(No supo qué decir Segovia/ cuando le preguntaron por sus ideas)” (Durand: 2001, 12). En “Bardemas”, compuesto de varios poemas breves, se dice que "Segovia anduvo/ entre las margaritas/ con el olor a pata” (Durand: 2001, 26) y también se le advierte “-Segovia!/ nadie te va a dar/ bola/ si vos le das/ la mano a

original y que vierte su subjetividad en lo creado, es discutida por Jacques Rancière, cuando analiza la obra de Flaubert. Para Flaubert, dice Rancière, el estilo no es una marca individual (como se lo leyó después) sino como "una manera absoluta de ver las cosas", es decir, la exacta identidad entre una mirada y una escritura. Ver Jacques Rancière, La palabra muda. Ensayo sobre las contradicciones de la literatura., Bueno Aires, Eterna Cadencia, 2009, (138-140). De todas formas, esta definición de estilo tampoco puede aplicarse a Segovia, por cuanto lo que hay en el libro no es estrictamente una mirada sobre el mundo, sino distintas visiones parciales y fragmentadas sobre el mundo y la literatura.

${ }^{281}$ Sin embargo, en el caso de Durand esa "falta" no debería pensarse en sentido negativo, sino como una elección deliberada. Porque en Segovia, lejos de la idea de que una carencia de habilidad o cultura impedirían "escribir poesía”, Durand ensaya diversas formas y demuestra que si bien puede dominarlas, elige no hacerlo. Esta postura se diferencia de la construcción que hace Washington Cucurto, de una figura de poeta que se basa precisamente en la imposibilidad de acceso a la cultura a causa de un origen iletrado, como veremos en el capítulo final. 
Mendes-” (Durand: 2001, 27). En otro fragmento del mismo poema, Segovia pasa a ser “un segovia clase 1964”, en minúscula, que cuando muere y llega al paraíso solamente pide “un 17 de octubre de 1945/ como primer gozo,/ fulgor”. Aquí se revela entonces la identidad política del personaje, que comparte además el año de nacimiento con Durand, lo que habilita la lectura en clave biográfica.

El personaje Segovia, que puede pensarse como un alter ego de Durand a partir de la fecha de nacimiento, se sitúa entonces entre las siguientes coordenadas: es peronista, de Boca, y profana las margaritas con el “olor a pata” -sintagma en el que resuena veladamente, el "las patas en las fuentes” de Leónidas Lamborghini, y que funciona como variante de esa imagen profanatoria-. Pero, con más precisión, el peronismo que acá aparece como una representación del paraíso es el primer peronismo, condensado en esa fecha mítica del 17 de octubre. En cambio, el gobierno justicialista de turno, que es el de Carlos Menem, es aludido a partir del seudónimo “Mendes” y se lo reconoce como algo de lo que es necesario separarse.

Este Segovia, que también es “un segovia” (como si se dijera “un fulano”), es el que puede venir a destruir el arte con su risa. ${ }^{282}$ La representación que surge de los fragmentos citados está muy cerca de la figura de poeta de Leónidas Lamborghini, y casi parece construida a partir de la diseminación y variación de frases del propio Lamborghini. ${ }^{283}$ Esa red de sentido permite pensar a Segovia como un bárbaro por la

\footnotetext{
${ }^{282}$ Por otra parte, el personaje Segovia es el que da nombre a lo que Durand denomina "el ciclo segoviano", y que incluye, a grandes rasgos, toda su producción poética a excepción de El cielo de Boedo. Dice Durand en la entrevista ya citada: "Por lo tanto el ciclo segoviano es eso, Segovia y los textos satelitarios. Pero yo me animo a agregar que el ciclo segoviano tiene que ver mucho con la poesía de los 90, con el tono que tratamos de crear en esa época y con la literatura que tratamos de valorar. También tiene que ver con el descontrol y con una manera un poco maldita, desprejuiciada y antiliteraria de relacionarse con la poesía y su entorno. Son los años de iniciación sexual y literaria, de alcohol, drogas y bardo... todo eso es el ciclo segoviano, pero es un poco impreciso este "ciclo segoviano" porque hay excepciones a lo que lo define en casi todas las páginas.”
} 
asociación que se establece con el pueblo peronista del '45. La destrucción del arte que Segovia vendría a efectuar, entonces, no se realiza a través de determinados procedimientos sobre la tradición sino por esa “risa” lamborghiniana y por la irrupción de lo analfabeto y popular en el terreno sacralizado del arte y la poesía. ${ }^{284}$

El otro analfabeto que aparece en Segovia es un niño, y esto es importante porque inaugura una línea que tendrá un extenso desarrollo dentro de la poesía de Durand en textos como "Salto grande” y "Vieja del agua”. ${ }^{285}$ El niño es el que narra las experiencias de un grupo de chicos de barrio en “Caballitos de Troya” (Durand: 2001, 16-19). Esas experiencias, salvajes, consisten en la iniciación sexual violenta de una chica (“Después fueron a la bañera/ y el Negro se lo rompió”, “pero el Negro le dice:/ “no te preocupés Carla que para los quince/ lo vas a tener sano de nuevo”, p.16), el primer aprendizaje de la masturbación (“Carlitos Blescher nos mostró/ los otros días/ en la quinta del abuelo de Darío/ cómo se hace una paja”, p. 18) y la violación de un chico llevada a cabo por otro como una travesura y festejada por el grupo, que observa la escena (“El puto Larba ya es puto de verdad!/ salimos todos gritando”, p. 18). ${ }^{286}$

${ }^{283}$ Como señalamos, la poética de Lamborghini, diseminada en los mismos poemas y en entrevistas, incluye frases como "golpea/ golpea/ en la llaga/ libre de la "belleza"/ libre de "lo poético”” (en El solicitante descolocado, Buenos Aires, Libros de Tierra Firme, 1989, p. 28) y "Nada que ver con la belleza", que da título al reportaje realizado por Daniel García Helder en el “Dossier Leónidas Lamborghini” del Diario de poesía, antes citado.

${ }^{284}$ La risa es un elemento que Lamborghini lee como central tanto en la gauchesca como en el tango: "Cuando digo que la gauchesca sin la risa no es tal, entonces van por los contenidos...Y no..., el alma, el alma de ese género, es esa risa maliciosa, esa risa paisana. (...) Porque Discépolo cifró lo que uno quiere decir. Dice: “Tanto dolor que hace reír”. ¿Cómo batís eso? (...) El yo lírico no admite la risa”. Sergio Raimondi, "Como leés, escribís. Entrevista a Leónidas Lamborghini”, en Cuadernos del Sur. Letras No 34, Bahía Blanca, Departamento de Humanidades, UNS, 2004 (223, 224).

285 "Vieja del agua” fue publicado como libro por Ediciones Deldiego en el año 2000 y apareció después en El estado y él se amaron (Mansalva: 2006), junto con "Salto grande”.

${ }^{286}$ Pero también se presenta a un grupo de personajes a partir de sobrenombres y de datos simples, que construyen un mundo particular, situable social y económicamente, y que recuerda al poema "Las ruinas de Disneylandia" de Marcelo Díaz, publicado en 1998, con lo cual puede pensarse en una lectura y un diálogo rápido e inmediato de los poetas de la década entre sí. Ver Marcelo Díaz, Berreta, Buenos Aires, Libros de Tierra Firme, 1998 (50-52). 
La voz que habla en el poema mantiene de todos modos cierta ingenuidad, aunque se presente como testigo o escucha de las experiencias de los otros, y concluye diciendo:

\author{
Yo escribí una cosa que se llama poema \\ para Élida, porque me enamoré de ella, \\ y lo escondí arriba del ropero; \\ después me fui en la bicicleta y lo tiré \\ por el ferrocarril, para que nadie se entere \\ que me gusta \\ la poesía \\ y Élida. (Durand: 2001, 19)
}

La figura del niño, entonces -un niño que “habla” con un registro coloquial y en principio no poético- es la que permite el ejercicio de escribir por fuera de la poesía, en un texto que hace ingresar al sistema poético materiales que estaban presentes sólo en la narrativa (específicamente, en textos como “El fiord” y “El niño proletario” de Osvaldo Lamborghini).

Por otra parte, la escena que cierra el poema es la del descubrimiento de la poesía llevado a cabo de manera espontánea por un niño de barrio junto con el primer aprendizaje amoroso. Todos los elementos que hemos distinguido hasta aquí como característicos de la obra de Durand se encuentran condensados en esta escena que prefigura el deseo de escribir a partir de la inocencia, con materiales bajos, y sobre todo por primera vez y desde afuera de la institución literaria, exterioridad que se cifra en ese modo analfabeto de referirse a la poesía como "una cosa que se llama poema”.

Tanto el personaje Segovia como el personaje-niño (que también habilita la lectura en clave autobiográfica en razón de las referencias particulares al lugar de procedencia del autor, especialmente en los ya mencionados "Vieja del agua" y "Salto grande”) son figuraciones del bárbaro y del analfabeto que funcionan de modos 
diferentes: Segovia está escrito en tercera persona, funciona como alter ego del autor y es un personaje fluctuante que permite enunciar de manera indirecta una utopía poética en la que se reúnen lo político y lo vanguardista: la destrucción del arte, no a cargo de un artista sino de un bárbaro de origen popular. El niño en cambio -aquel que no sabe lo que es un poema y lo descubre por primera vez- permite borrar las marcas de pertenencia al campo cultural y hacer el gesto de escribir únicamente desde la experiencia. Ambas figuras apuntan al ejercicio de la tabula rasa como horizonte deseado, y ambas deben ponerse en tensión, a su vez, con la figura de poeta analizada previamente.

Porque el deseo por lo salvaje y por un nuevo comienzo para la poesía condensa en Durand el proyecto de construir un lenguaje que pueda dar cuenta de la experiencia. A este respecto es pertinente retomar dos textos posteriores a Segovia que figuran en $E l$ estado y él se amaron. ${ }^{287}$ El primero de ellos, “Durán, deberías estar escribiendo...”, 288 es una serie breve de textos que trabajan a partir de una variedad de procedimientos imposible de unificar en un programa. Los poemas 1 y 3, por ejemplo, se construyen a partir de la anáfora: la mayoría de los versos empiezan con “que...” como respondiendo a la consigna del título (“Durán, deberías estar escribiendo...”). Sin embargo, ese “deberías” postula que en realidad no se está escribiendo, sino más bien ejecutando un procedimiento de modo absolutamente provisorio y contingente (“que tu máquina puede borrar esto que escribes”, Durand: 2006, 53). En consonancia con esta idea, en el poema 3 uno de los versos dice "que nunca vas a escribir esto que escribes” (Durand: 2006, $55)$.

\footnotetext{
${ }^{287}$ Recordemos que Durand sitúa el inicio de la escritura de "Durán deberías...” en el año 1992, y la de "Salto Grande", en prosa, a 1998.

${ }^{288}$ En Daniel Durand, El estado y él se amaron, Buenos Aires, Mansalva, 2006 (53-58).
} 
Otro fragmento, en cambio, trabaja a partir de la enumeración caótica (“que hubo una manifestación de microbios, una nube de tábanos, una floración de mamíferos, una cola de gusanos, una fiesta de fósforos, una bolsa llena de diskettes, veinte kilos de mate, un toco de coquitas”, etc.) y anota sobre el final, como refiriéndose al que registra todos esos elementos diversos, "Bruto, baba, bestia” (Durand: 2006, 53). El único criterio de unificación que ordena estos poemas es el uso del procesador de texto Word, que también determina el diseño centrado en la página de los poemas de Segovia. La idea es la de que cualquier cosa puede ingresar en ese ejercicio de escritura que consiste en la acumulación desordenada de frases en el Word. Por otra parte, en esta serie se señala una y otra vez que ese flujo de escritura no pretende ser poesía.

Se trata de una escritura "salvaje" que no se piensa "escritura" en un sentido convencionalizado y legitimado, y que decididamente no parte del intento de ser poesía. Por eso, al final de la serie y cuando ya se está terminando de escribir ese no-poema, se dice “que ahora empiezo” (Durand: 2006, 58), como si todo lo anterior no fuera otra cosa que una manera de retrasar ese comienzo. Todos estos elementos indican que el texto se construye imaginariamente como lo que está más acá, o antes, de la poesía.

Por todo esto, la escena de escritura que termina construyendo este texto es por demás significativa. Lejos del conocido motivo del poeta ante la página en blanco, aquí se trata de alguien que acumula frases en el procesador de texto Word, como una puesta al día de ese motivo devenido espurio, mediada por las posibilidades de la tecnología actual en la que todo puede borrarse, y donde los cortes de verso están dados por el uso de la tecla Enter al final de cada frase. Así, el poema termina diciendo "que cuando bajo y pienso que me hundo, son los renglones que suben:/ así son los procesadores de palabras./ que mañana me muero. pero mejor morite vos primero./ que filoso, vacío, mejor me voy del word a un juego" (Durand: 2006, 58). 
“Durán, deberías estar escribiendo...” apuesta de este modo a no ser poesía ni literatura, y al mismo tiempo pone esa escritura aparentemente caótica al mismo nivel que un juego de computadoras. Escribir es algo que se hace por un rato, antes de pasar a un juego. El gesto de desacralización, entonces, vale también en Durand para la propia escritura (y para el nombre del autor, que en este caso se desacraliza en la caída de la “d” final, como una versión bárbara del apellido).

En otro texto que figura en la sección "Marquina” de El estado y él se amaron se narra brevemente un aborto casero en estos términos: “mi madrina Rosalía se murió, a los 43 quedó preñada y una vecina le metió un ramo de perejil adentro de la argolla para que se le pudra el niño, pero se pudrió todo, el perejil, el niño y mi madrina” (Durand: 2006, 102). A continuación de la anécdota, contada con un grado de crudeza que pretende dar la dimensión del espanto de esa muerte, figura este fragmento que puede funcionar a modo de poética: “esto, sucedió hace mucho cuando yo recién leía a benedetti, y no había manera de contar lo que pasaba, menos mal que ahora, gracias a nosotros mismos, podemos contarlo”. 289

Lo que surge de este último texto es una conciencia muy fuerte (e histórica) de las posibilidades y limitaciones que suponen determinados lenguajes al momento de dar

\footnotetext{
${ }^{289}$ En este texto aparece una vez más la toma de posición con respecto al objetivismo que ya hemos analizado, encarnada en este caso en la figura de Martín Prieto, que en el poema aparece nombrado como Porto. El fragmento dice "Porto escribía "úsalo al mar al bien”, en Rosario" (Durand: 2006, 102). Durand revela, al comentar este texto en una entrevista, que se trata de una alusión a Prieto: "Me parece que hay toda una literatura de protesta y de denuncia que lo único que hace es ocultar un montón de cosas. Y lo que digo ahí es que mi tía quedó embarazada y se hizo un aborto casero y se murió en un hospital de Rosario. Con los presupuestos teóricos de Benedetti no era posible ese tipo de relato, y con el principio de restricción de Prieto y compañía tampoco, porque el Porto de ese texto no es, obviamente, otro que Prieto, con una frase muy estilizada de un viejo poema suyo." En: http://www.revistaotraparte.com/n\%C2\%BA-14oto\%C3\%B10-2008/daniel-durand-cielos-personas-flash

Si bien esta consideración retrospectiva de Durand con respecto al objetivismo no deja de ser un modo de construir su propio lugar en el campo a partir del gesto opositivo, sí puede decirse, en vista del trabajo con el habla y la experiencia que venimos analizando en este capítulo, que estas poéticas representan un momento de apertura del discurso poético en relación al registro verbal y la precisión y mesura establecidas como valor por los objetivistas.
} 
cuenta de ciertas experiencias. Mientras que el modo de escritura de Benedetti hacía imposible que ingresaran a la literatura este tipo de historias, años después, y luego de ese trabajo de extender los límites de lo poético que hemos analizado, contar esa experiencia se vuelve posible "gracias a nosotros mismos". Ese "nosotros mismos" alude claramente al trabajo de escritura del propio Durand (centrado en ese principio de irrestricción que él mismo enunciaba) y de sus contemporáneos.

La idea de que el presente no puede enunciarse a partir de ciertos lenguajes (poesía inglesa, Eliot, Pound, Benedetti, y más en general, del principio de restricción postulado por el Diario de poesía) aparece una y otra vez, junto con la vinculación indisoluble entre lenguaje y experiencia. El criterio que rige entonces el ejercicio de selección y recorte que efectúa Durand sobre la tradición, así como la necesidad de violentar los límites institucionalizados de la literatura, es el de dar cuenta de la propia experiencia sin falsearla -es decir, sin amortiguarla en su violencia-.

El uso del habla y la construcción de diversos personajes también son procedimientos centrales en los libros publicados hasta el momento por Martín Gambarotta. En Punctum la voz que abre el libro y funciona como marco en muchos de los poemas corresponde a un narrador que habla de los distintos personajes en tercera persona. ${ }^{290}$ La figura del narrador puede diferenciarse claramente de los personajes, que por momentos toman la palabra en primera persona, desde el principio del libro: "La bruma se traslada a su mente/ vacía, no sabe quién es y el primer/ pensamiento "un perro que se da cuenta que es perro/ deja de serlo” vuelve a formar parte/ del sueño pero

${ }^{290}$ El uso de personajes también es un recurso que aparece en Seudo (Vox, 2000) y Relapso+Angola (Vox, 2005), los siguientes libros de Martín Gambarotta. Sin embargo, en este caso nos centraremos en Punctum, cuya particularidad reside en la presencia de esa voz del narrador que trabajaremos a continuación. Lo que desaparece en los libros siguientes es justamente esa figura del narrador, si bien se mantiene la construcción de personajes. Por otra parte, Punctum comparte con Segovia ese carácter fundacional de los noventa que reside, entre otras cosas, en la figura del bárbaro. En cambio en Seudo y en Relapso+Angola, si bien se reescribe la poesía norteamericana, el gesto disruptivo que inaugura aquí una posición diferente y colectiva con respecto a la tradición está ausente. 
aparece, difusa/ la maceta" (Gambarotta: 1996, 7). En este caso el "narrador omnisciente” se diferencia de su personaje en el hecho de que, mientras que la mente del personaje está vacía, en un estado difuso entre la vigilia y el sueño en esta escena del despertar, el narrador registra todo.

Sin embargo, a partir del segundo poema ese mismo personaje asume el lugar de enunciación en primera persona y se presenta como aquel que escribe el poema: “Cómo se llama eso que cuelga de la pared,/ cómo se llama eso que cubre la lámpara./ Rodeado de cosas sin nombre a mí también/ me hubiera gustado empezar esto/ con: de noche junto al fuego" (Gambarotta: 1998, 8). En el mismo texto, y en varias oportunidades a lo largo del libro, esta voz se dirige en segunda persona al resto de los personajes (Gamboa, el Guasuncho, Cadáver), pero también alterna su lugar de enunciación con el del narrador dentro del mismo poema (que pasa de un "vos” a un “él”): “Cadáver, esto ya no es rock,/ algunos roban estéreos, otros roban esposas/ pero todos robamos./ Discriminando entre el dolor y la apertura siciliana/ va hasta la pieza y en una hoja escribe/ la jugada de una partida por correspondencia” (Gambarotta: 1996, 9).

Hay un "nosotros”, entonces, inscripto en ese "todos robamos”, que engloba al grupo de personajes y los separa del narrador que a continuación toma la palabra. De todas formas, la indecidibilidad entre narrador y personaje vuelve dudoso el estatuto “exterior” de ese narrador omnisciente, y permite pensarlo más bien como un desdoblamiento de la misma persona ficcional. Lo que hay, decididamente, es uno -o varios- sujetos escindidos, una voz que se fragmenta en dos o más voces. ${ }^{291}$ Esta escisión está puesta en evidencia en un poema que dice a propósito de Confuncio, otro de los personajes: "ve irse a una parte de su persona, Kwan-fu-tzu,/ por una calle

\footnotetext{
${ }^{291}$ Para un análisis detallado de este uso de personajes en Punctum, ver Ana Porrúa, "Punctum: sombras negras sobre una pantalla", en Boletín del Centro de Estudios de teoría y crítica literaria; Centro de Teoría y Crítica Literarias, Fac. de Humanidades y Artes, UNR, Rosario, octubre de 2000; 102-111.
} 
mientras la otra, una fracción/ a la vez de sus mil partes/ hasta ese momento indivisibles,/ se queda parada” (Gambarotta: 1996, 30).

Por último, hay también textos en los que desaparece cualquier tipo de voz o personaje y sólo queda la escritura, en una serie de frases imposibles de atribuir dentro del sistema de enunciación construido por el libro: “Una máscara real, la máscara/ de un arquero de jockey/ sobre hielo, el hombre de la máscara/ de hierro, una máscara de oxígeno,/ una máscara de anestesia, una máscara/de esgrima, el barbijo de enfermero,/ una máscara de gas (...)” (Gambarotta: 1996, 33).

Para resumir, las voces de Punctum traman un sistema de enunciación múltiple y heterogéneo que remite a uno o más sujetos escindidos: un narrador, que es intercambiable con uno de los personajes al que podríamos llamar protagonista, varios personajes que se construyen a partir de un nombre y de una mínima historia, y una serie de textos, por último, en los que las frases parecen sostenerse por sí mismas sin remitir a ningún tipo de enunciador y que se presentan como pura escritura, que ya no sugiere una puesta en escena del habla sino variaciones verbales y sintácticas sobre una estructura. $^{292}$

Es necesario indagar en la caracterización y el estatuto de esos personajes para comprender la figura de poeta y las figuraciones del analfabeto que propone Punctum porque es una de esas voces la que dice, en esos mismos versos que señalaba Ana Porrúa en el artículo citado al comienzo de este capítulo: “Nunca leí el Quijote./ En todo caso sueño con Alien/ escupiendo los huesos de Don Q. en el basural./ Las tripas de

\footnotetext{
${ }^{292}$ Este sistema de enunciación no se mantiene en los libros posteriores de Gambarotta, Seudo y Relapso+Angola. Básicamente, la diferencia en estos libros es que se elimina la instancia del narrador, así como el elemento narrativo que detectamos en Punctum. En estos libros, los textos que parecen ser enunciados por un personaje se resuelven bajo la forma de aquellos que aquí describimos como "pura escritura", lo que señala a una realización más cabal de la idea de Gambarotta de construir una escritura a partir del habla que no se confunda de ningún modo con una poesía coloquial.
} 
Sancho Panza/ vaciadas en la mandíbula de Alien./ Veo capítulos repetidos de Kojak/ durante el invierno sin chica” (Gambarotta: 1996, 56).

Este fragmento, que podría hacer pensar en un libro escrito por un analfabeto que desconoce los códigos de la literatura (cuya postura puede parafrasearse como "me gusta más ver televisión, no me gusta leer”), debe situarse dentro de ese sistema de voces y personajes contradictorios y ponerse en tensión con el hecho de que en el segundo poema del libro aparezca un verso que contradice el analfabetismo y el estricto consumo de televisión. El verso es una variación de una frase de Williams Carlos Williams: "ninguna emoción salvo en las cosas” (Gambarotta: 1996, 8), y sugiere una diferencia cultural entre el narrador y sus personajes que deberá explorarse. ${ }^{293}$

Los personajes de Punctum están construidos además a partir de coordenadas más o menos precisas que remiten a la militancia política de los setenta. En el Cadáver resuena el título del poema de Perlongher “Cadáveres” (donde la figura que da nombre al texto remite a los desaparecidos durante la última dictadura militar), como señala Tamara Kamenszain. ${ }^{294}$ El narrador dialoga en varias ocasiones con este Cadáver: "Si hubieras sobrevivido/ verías esto" (Gambarotta: 1996, 69), "si volvieras a aparecer desaparecido/ serías un mono rehabilitado/ repudiado por los partidos de la tarde/ en las solicitadas pagas de los diarios” (Gambarotta: 1996, 70), con lo cual constituye en

${ }^{293}$ Esta frase de Williams ya citada, que pertenece a "A sort of a song” del poema extenso Paterson, es "no ideas but in things" y generalmente se la lee como fórmula de la poética de Williams, como dijimos. En William Carlos Williams, The collected earlier poems, New York, New Editions, 1966.

${ }^{294}$ Ver Tamara Kamenszain, La boca del testimonio, Buenos Aires, Norma, 2007 (146-148). No acordamos, sin embargo, con la lectura de Kamenszain respecto a la poesía de Gambarotta, que parte de la división lacaniana entre lo real, lo simbólico y lo imaginario para decir, con Hal Foster, que "hay cierto arte que en vez de pacificar la mirada, de unir imaginario y simbólico contra lo real, es como si quisiera que la mirada brillara, el objeto se erigiera, lo real existiera" (140). La cita pertenece a Hal Foster, El retorno de lo real, Madrid, Akal, 2001 (144). En el caso de Gambarotta nos parece más pertinente, sin embargo, hablar de "material" y no de "real" (que es lo indecible), puesto que su concepción está más cerca de la idea de Raymond Williams de que el lenguaje debe concebirse como parte de la producción material que de la conceptualización lacaniana. Ver Raymond Williams, Marxismo y literatura, Barcelona, Ediciones Península, 2000 (51). 
interlocutor a ese desaparecido. Se trata, en parte, de mostrar un estado de cosas a aquel que ya no está para verlo.

El resto de los personajes son el Guasuncho, Confuncio, Hielo y Gamboa. De el Guasuncho se dice que "hace años fundó/ una pseudo célula clandestina y después se puso/ a vender biblias para el Ministerio/ de Ondas de amor y paz” (Gambarotta: 1996, 10), y en otro poema, que "fumaba Oxi Bithué/ después de haber roto/ su ficha de afiliación” (Gambarotta: 1996, 46). En el paisaje en que se mueven los personajes también se leen los signos del pasado político reciente, como cuando el Cadáver y Confuncio preparan un asado cerca del río y al fondo se ve “el brillo/ espeso, de unos focos iluminando/ el puente hecho por los militares” (Gambarotta: 1996, 47).

Confuncio, a su vez, se presenta como "Un expulsado del paraíso,/ la vez que todos los pibes de la agrupación arrugaron/ (...) Cuando lo traicionaron/ los de la 7 de mayo/ que le habían prometido un par de cargos” (Gambarotta: 1996, 21). Hielo “era de la banda/ que le daba a los de la orga para que tengan pero/ después de un par de lecturas se abrió de la derecha/ y se pasó a la 7 de mayo” (Gambarotta: 1996, 39); también se dice que tiene una remera de la UOM, gastada, con la palabra "lealtad", que ahora usa algunas noches para dormir (Gambarotta: 1996, 39).

Por último, Gamboa es “un ex-capitán de la regional Norte,/ que en Entre Ríos se transformó en profesor de inglés/ y se mantiene gracias al kiosco y la huerta de su mujer” (Gambarotta: 1996, 62). El personaje se define a sí mismo como "Una reliquia en vida/ del museo de la subversión -un tipo/ que pasó a la clandestinidad y después zafó/ tan fácil que todos en la orga, salvo vos y/ Confuncio, pensaron que había batido” (Gambarotta: 1996, 63). Se trata de un ex combatiente que detenta un modo particular de relacionarse con el pasado porque "La guerra termina pero sigue/ en la cabeza del combatiente (Gambarotta: 1996, 66). 
Los personajes, entonces, no son intelectuales sino ex militantes de la lucha armada de los setenta inmersos en un presente en el que la reflexión sobre política ha sido reemplazada por otro modo, peronista, de la barbarie, que puede leerse en la transición de un tipo de discurso a otro en los siguientes versos:

\author{
Gamboa anota: \\ La violencia organizada \\ es superior porque permite \\ perpetrar reiterados hechos de violencia \\ contra el sistema. Para derrotar al sistema \\ hay que lograr una organización superior \\ al sistema, golpearlo varias veces hasta \\ desorganizarlo. Que la inteligencia revolucionaria \\ supere la inteligencia de la reacción. Pero bueno, \\ acá los negros saben que no queda otra, \\ quieren quemar la Gobernación y salir \\ con la cabeza del gobernador al que votaron \\ clavada en una tacuara, gritando \\ patria o muerte (Gambarotta: 1996, 64).
}

Las reflexiones de Gamboa, propias de un discurso de izquierda radical, son interrumpidas por el "Pero bueno", que cifra al mismo tiempo la oposición entre ese discurso y los hechos políticos del presente, y la resignación por un tiempo en el que la única alternativa política parece ser ese "no queda otra”. 295

Como puede verse, las figuras de bárbaros y analfabetos en Punctum no son versiones de una figura de poeta. A diferencia del personaje Segovia de Durand -un bárbaro que se propone terminar con la institución arte- en este caso el estado de barbarie remite en esta serie de personajes a un momento histórico particular que se caracteriza aquí por un vaciamiento de la política, y a un pasado de derrota. Estos ex militantes son los mismos que miran televisión en lugar de leer y que poseen, al menos a partir de la cita que acabamos de considerar, un saber que ya no cumple ninguna

\footnotetext{
${ }^{295}$ La cronología de Punctum es compleja y no lineal, porque los personajes, que son jóvenes en los noventa (más específicamente durante el menemismo) no pueden haber sido militantes de los setenta. Por eso, como señala Ana Porrúa (Porrúa: 2000), el libro construye un continuo temporal que rompe con la posibilidad de una cronología, en la medida en que el "pasado" se hace presente en un texto que se construye como espacio de coexistencia, ante todo, de temporalidades heterogéneas.
} 
función en el presente, y aquí cobra sentido la elección de programas de una época particular (los sesentas y setentas). No sólo porque estos programas serían contemporáneos a la juventud y a la actuación política de los personajes, sino también porque El gran chaparral remite al western y Kojak al policial, dos géneros que funcionan como espacios de identificación para estos ex protagonistas de la lucha armada. $^{296}$

El personaje que constituye una excepción, además del narrador, es Gamboa (compresión del apellido Gambarotta), que reflexiona en este último poema sobre la violencia organizada y sobre la organización en general, e incluso sobre las mismas palabras “orden” y “organización” presentes en el poema. ${ }^{297}$ A diferencia de los personajes-analfabetos, Gamboa y el narrador son los que ponen de manifiesto una conciencia crítica sobre la lengua a partir de una sensibilidad exacerbada que en el texto se plantea como patología, como veremos en el apartado siguiente. Frente a la sensación de fracaso y la desorientación histórica de los personajes, estas figuras son las que permiten establecer las conexiones entre una experiencia histórica y un estado del presente que es también un estado de la lengua. Entonces, en Punctum funciona un conjunto de voces que pueden agruparse en principio a partir de dos órdenes. Los

\footnotetext{
${ }^{296}$ Esto se explicita en un poema donde Kojak aparece como un derrotado, y esa figura se confunde con el derrotado político en la transición que se plantea inmediatamente a el Cadáver: "Kojak vendió su coche en llanta/ a los chacales, entregó el escudo y arma/ al Capitán Griego, los negros amagan/ con quemar un kiosko y no lo queman;/ no va a haber, Cadáver, mañanas/ reales de color tierra/ para usar el gatillo, un gatillo difícil,/ tenso, que se resiste a ser gatillado/ contra algún objetivo enemigo" (Gambarotta: 1996, 23). Hay que señalar también cómo, al tiempo que se le anuncia al desaparecido que ya no habrá oportunidad de usar las armas, se vuelve sobre la idea de que los negros -que en el poema que trabajamos anteriormente representaban al peronismo- no terminan de concretar una acción y se alude, por último, a la que se sugiere como única lucha armada posible en los noventa -la de la policía contra los manifestantes en esa frase "gatillo difícil” que alude por contraste al "gatillo fácil”-.

297 Pero este tema, que podría parecer abstracto, en seguida se aplica a la materia, específicamente a la falta de organización de los restos del desayuno en la mesa (Gambarotta: 1996, 65). O dicho de otro modo: en Gambarotta el pensamiento se cifra en un lenguaje que se concibe como material. De esta concepción nos ocuparemos en el apartado final de este capítulo.
} 
personajes (Cadáver, el Guasuncho, Hielo, Gamboa) suponen figuraciones del bárbaro y del analfabeto en más de un sentido. Por un lado, pertenecen a un medio cultural que se define por el consumo de rock y televisión, y construyen su experiencia a partir de una mezcla de percepciones e imágenes donde la música y los medios de comunicación masivos (las series, la televisión, la pantalla, la publicidad) se funden por completo con la conciencia del que habla.

Por otro lado, participan de un presente de barbarie en el que la política está confinada entre la violencia espontánea y la falta de proyectos. Se trata de alguna manera de muertos en vida, sobrevivientes fracasados y anacrónicos de un proyecto político que se interrumpió. Las figuras y objetos que los identifican pertenecen también al pasado, desde Sid Vicious y las series de televisión hasta la remera de la UOM y el tatuaje de Kiss, como elementos de una cultura trash que está hecha de restos tanto culturales como políticos.

En contraste con estos personajes, la figura del narrador es la de un lector que usa un conjunto de textos previos, especialmente de la tradición modernista norteamericana, para tramar su discurso. Así, la cita de William Carlos Williams que mencionamos antes le sirve para enunciar una poética: se trata de construir una poesía sin ideas, fuertemente basada en lo material y despersonalizada ("Ninguna emoción salvo en las cosas”). ${ }^{298}$ A su vez, la referencia al trabajo de Pound con la escritura ideogramática condensa el programa de plantear las relaciones entre las cosas, no a partir de ideas abstractas sino de elementos concretos. ${ }^{299}$

\footnotetext{
${ }^{298}$ En Punctum no hay un sujeto que se diferencie de los objetos y que de cuenta de sus impresiones ante ellos, sino que es todo lo contrario. Ese tipo de subjetividad se disuelve en la medida en que se derrama sobre todas las cosas y en que se reconoce construida por el lenguaje. Más que un sujeto, hay una circuito que va de la materia a la conciencia y al lenguaje percibido también como materia.

${ }^{299}$ Las ideas de Pound sobre la escritura ideogramática china parten de una interpretación suya de la obra Essay on the written chinese caracter, de Ernest Fenollosa. Dice Pound: "El
} 
Este lector se vale de los personajes, en tanto figuraciones del bárbaro, para construir un espacio de escritura que se imagina utópicamente a partir del ejercicio de la tabula rasa, como se lee en el siguiente poema:

Ese negro, su buzo adidas, su actitud de mierda, sus pantalones bombilla y los espasmos en la dentadura. La cultura no quiere cortarle los huevos al negro. Disco no es cultura, tu cultura filtrada para quedar bien. Disco no es cultura, tu cultura la cultura de tus caricaturas. Que los fasci de combattimenti se queden con la belleza, que los demócratas se queden con la narrativa actual. (...) Así, en vez de hacerte el artista buscate un oficio noble que te gaste las manos. (...) Y después de trabajar, por la nochecita me gusta mirar televisión, me gusta mirar mucha televisión” (Gambarotta: 1996, 55).

El poema es elocuente por el modo en que yuxtapone los fragmentos para sugerir que en el paisaje de los noventa, representado por el consumismo menemista de los "negros" con buzos “adidas”, existe todavía un modo de pensar la cultura, "filtrada para/ quedar bien” que ya no sirve para dar cuenta de ese mismo presente.

Lo que hace el texto, entonces, es prescindir de ese "filtro" -que podría pensarse, también, en la homologación, extremadamente limitada, entre “cultura” y “Don Quijote” que analizamos antes- para que ingresen todo tipo de materiales, a la vez que recorta un espacio que no pertenece a la literatura, sino a la televisión, en un campo literario donde la belleza se atribuye a la derecha y la narrativa contemporánea a los “demócratas”. La incorrección política y la barbarie tienden en este caso a abrir un espacio nuevo, como en Durand, donde no se pueda ser -ni hacerse- el artista (al mismo

ideograma chino no quiere ser el diseño de un sonido, o ser un signo escrito que recuerde a un sonido, sino que el ideograma sigue siendo el dibujo de una cosa; de una cosa en una posición o relación dada, o de una combinación de cosas” (Pound: 1968, 18). En los libros de Gambarotta, el modo de procesar a Pound se hace presente también en esta idea de concebir a la escritura en su dimensión gráfica, de "dibujo", a partir de una patología del lenguaje como es la dislexia, según se analizará en el próximo apartado. 
tiempo, la cita propone reemplazar la figura de artista por la idea de oficio manual, separándose así de una concepción espiritualizada del arte).

En este espacio de una escritura que simula empezar desde cero, los personajes permiten incorporar toda una situación histórica a partir de la experiencia, cifrada en el habla de esos mismos personajes, a la vez que el libro como conjunto, en la medida en que hay una figura de poeta-lector que alterna en la enunciación con las figuras de bárbaros, construye una tradición que fusiona la literatura, los medios masivos y la política, a partir del lenguaje.

\section{1. LA RAZA Y PUNCTUM: EL PRESENTE COMO PATOLOGÍA DEL LENGUAJE}

Como afirmaban Prieto y García Helder en su artículo de Punto de vista, una característica mayor de cierta zona de la poesía de los noventa tiene que ver con la captación del Zeitgeist, el “espíritu de la época” (García Helder y Prieto: 1998, 15) que como vimos se cifra ante todo en el trabajo con el habla y en la incorporación de materiales provenientes no sólo de la tradición literaria. Pero si hay un diagnóstico sobre el presente que pueda derivarse de la lectura de Punctum y La raza, éste debe buscarse esencialmente en el modo de pensar la lengua que plantea cada uno de estos libros y que en ambos se postula como variación de una idea: la imposibilidad de articular pensamiento en el lenguaje, ya sea a nivel de la letra (Gambarotta) o de la sintaxis (Llach). Mientras que en Gambarotta esa imposibilidad adopta la forma de patologías del lenguaje como la afasia y la dislexia, en Llach se presenta como 
“adicción” en tanto incapacidad literal para decir y como fragmentación que no permite construir un relato mayor a partir de los datos perceptuales.

En este punto también, se trata de poéticas que retoman a Leónidas Lamborghini, quien se refería, a través de la lectura de Franz Fanon, a las patologías del lenguaje (pensadas en clave política) como características del oprimido: "Lo que decía Fanon: el opresor deja sin lenguaje al oprimido. Y el oprimido, esas cosas que parecen dislexias, ese habla balbuceante, no es una enfermedad, en todo caso es una resultante de esa opresión que se ejerce sobre él. Se queda sin palabras o con la mitad de las palabras”. ${ }^{300}$ Miguel Dalmaroni analiza esta idea a propósito de Partitas, donde Lamborghini “juega con el tema de la desnutrición infantil en las villas miseria, y en la enumeración de los efectos de esa calamidad insiste una y otra vez en algunas palabras: ‘distrofia', ‘afasia', ‘dislexia’”. ${ }^{301}$ Según el mismo Dalmaroni, “en Partitas la sintaxis es objeto de una fractura sobre el orden visible de la lengua” que podría leerse en términos políticos en tanto da cuenta de un orden social y sus efectos sobre el habla de los sujetos.

En Punctum (donde se reúne la noción williamsiana de la lengua como producción material con la concepción ideogramática de Pound) esta idea se pone en escena como dificultad de los personajes para manejar las palabras: "Kwan-fu-tzu trasca que cuando lee/ la letra A se le aparece representada/ al revés o acostada/ tres líneas que se entrecruzan en un punto definido/ pero que no representan nada y pronuncia perro/ como prero" (Gambarotta: 1996, 30, 31). Como se ve, la dislexia es una de las modalidades que adopta la afección vinculada al lenguaje, que en su punto extremo

\footnotetext{
${ }^{300}$ Ver Sergio Raimondi, “Como leés, escribís. Entrevista a Leónidas Lamborghini”, en Cuadernos del Sur. Letras No 34, Bahía Blanca, Departamento de Humanidades, UNS, 2004 (223).

${ }^{301}$ Miguel Dalmaroni, La palabra justa. Literatura, crítica y memoria en la Argentina. 19602002, Santiago de Chile, RIL/ Melusina, 2004 (71, 72).
} 
impide hasta leer: "Las palabras en el libro no significan nada,/ al leerlas están cargadas de electricidad, saltan de la hoja/ pero no quieren decir nada” (Gambarotta: 1996, 40).

Esta limitación supone, necesariamente, la imposibilidad de orientarse para Kwan-fu-tzu, también llamado Confuncio (nombre en el que resuena claramente “confusión” y se trabaja la alteración patológica en este mismo sentido), que se queda paralizado en una estación de ómnibus: “No lee, Confuncio,/ en el tablero que anuncia/ la partida de los servicios/ Diamante sino Daimante,/no Bahía Blanca sino Bhaía Bancla” (Gambarotta: 1996, 34). Al no poder representarse tampoco el tiempo que media entre la salida de uno y otro micro anunciada por el tablero, el personaje simplemente opta por no moverse. A su vez la indecisión sobre los modos de nombrar -que no llega a ser, como en Lamborghini, un balbuceo- está presente también en el poema ya citado donde se reflexionaba sobre la palabra “organización”. Para Sergio Raimondi,

\begin{abstract}
"Son varias las escenas de Punctum en las que la frase se vuelve sobre quien la escribe, extrañada (...). Esa extrañeza no siempre coincide con la imposibilidad de hallar la articulación buscada. Por ejemplo: "en la mesa de la cocina / siempre ordenada, mejor, organizada / por Gamboa” (66). La diferencia que se instala en la aparente zona de sinonimia es fundante. En ella es posible reconocer una ubicación temporal para la conciencia previa de la lengua: porque si son numerosas las reminiscencias políticas y discursivas que operan en torno tanto a "orden" como a “organización”, en principio cabría detectar que, en la distancia marcada entre esos términos, están presentes los vestigios de la experiencia de la lucha armada de los años '60 y '70 en la Argentina. Distinguir ese pasado de la lengua (y de la conciencia) es sin duda pertinente, pero por lo pronto menos que distinguir cómo esa experiencia es extendida mucho más allá de una esfera recortada y específica: concebir, desde el sentido táctico de una ORGA, la disposición de una mesa no es trasladar sino identificar una experiencia política con todos los niveles de la vida; es atravesar de sentido político cualquier conducta y reponer una totalidad que incluye, por supuesto, modos de ingerir el té o usos singulares de la lengua.”. ${ }^{302}$
\end{abstract}

Como señala Raimondi, las elecciones verbales comportan para Gambarotta connotaciones y posicionamientos que son políticos en la medida en que la lengua lleva inscripta la historia de sus muchos usos. Aquí, “organización” remitiría a la lucha

\footnotetext{
${ }^{302}$ Sergio Raimondi, "El sistema afecta la lengua (sobre la poesía de Martín Gambarotta)", en Margens/Márgenes, Universidade Federal de Minais Gerais-Universidad de Buenos Aires, Belo Horizonte-Buenos Aires, nº 9/10, jan.-jun. 2007, (50-59).
} 
armada de los setenta experimentada desde la izquierda mientras que “orden” tiene asociaciones que la vinculan a la derecha y al discurso de los militares. Incluso cuando se trata de usos cotidianos y aparentemente banales, las experiencias políticas y las disputas por el sentido se hacen presentes en la escritura porque la lengua articula diversos órdenes, desde el uso denotativo más inmediato hasta lo político, lo histórico y lo social.

Pero esta articulación de órdenes heterogéneos a partir de la lengua, a la que también alude Raimondi, es una operación que está tratada en Punctum desde la dificultad: a diferencia del lenguaje-marco del libro que correspondería al narrador, y que pretende constituirse en un espacio donde puedan leerse las relaciones entre esos distintos órdenes, el lenguaje oficial, al que se encuentran sometidos los personajes (de ahí la patología) está endurecido y lo que hace es más ocultar que poner de manifiesto esas vinculaciones, de ahí que se lo defina como un “idioma sin vértebras” (Gambarotta: 1996, 85), es decir, un lenguaje que no permite la articulación.

El título del libro debe pensarse a partir de esta articulación de diversos órdenes en un elemento microscópico de la lengua. Porque la operación de Gambarotta consiste en apropiarse del concepto de “punctum”, que Barthes elabora para pensar la fotografía, y trasladarlo al lenguaje. Para Barthes, el término designa aquel elemento de la imagen fotográfica que "sale de la escena como una flecha y viene a punzarme (...) pues punctum es también: pinchazo, agujerito, pequeña mancha, pequeño corte, y también casualidad. El punctum de una foto es ese azar que en ella me despunta (pero que también me lastima, me punza)”. ${ }^{303}$ Hay cierta idea de “afección” en Barthes que en Gambarotta funciona en sus dos acepciones: la que remite a la sensibilidad y la patológica. Otra característica del "punctum” tiene que ver con su potencial expansivo,

\footnotetext{
${ }^{303}$ Roland Barthes, La cámara lúcida, México, Siglo XXI, Buenos Aires, Paidós, 2005 (58, 59).
} 
así como Gambarotta decía que las palabras estaban “cargadas de electricidad” (Gambarotta: 1996, 40): "Por fulgurante que sea, el punctum tiene, más o menos virtualmente, una fuerza de expansión. Esta fuerza es a menudo metonímica” (Barthes: 2005, 83). Para Barthes, entonces, el concepto remite a ese elemento de la fotografía que captura desde la afección y que permite reponer o construir una historia, una situación mayor, a partir de un detalle.

Ese es exactamente el modo en que el lenguaje funciona para Gambarotta; por eso, cuando se dice “organización”, toda una experiencia política es convocada por el uso del término, que vincula una acción cotidiana con el pasado (efectivamente, si acá hay una memoria es una memoria de la lengua). Pero a diferencia de Barthes, que podía reponer una afección o una historia a partir del detalle, en los personajes de Gambarotta que detentan patologías el lenguaje está roto y el punctum hiere pero no significa. Y en este dato se cifra, nuevamente, la diferencia entre el narrador-lector (con una conciencia crítica sobre la lengua) y los personajes analfabetos: el narrador es aquel que intenta señalar y reponer aquellas conexiones que los personajes, sujetos de un lenguaje dislocado, no pueden ver. A partir de este trabajo nuclear sobre la lengua, la toma de posición ideológica que supone el intento de articulación entre distintos órdenes es fundamental para comprender toda la producción de Gambarotta. Porque si puede hacerse, en términos teóricos, una separación entre la esfera de la literatura y las esferas del consumo, los medios masivos y la historia política, esta separación intenta superarse en Punctum gracias a esa alternancia entre un poeta-lector y una serie de personajesbárbaros.

En el poema “Abajo del agua”, de La raza -que es, como vimos, un texto que incluye a Punctum como parte de su tradición- la idea de “articulación” también está presente porque la dificultad con el lenguaje aparece bajo la forma de una incapacidad 
para hilar las frases. El poema se propone como una serie de percepciones y reflexiones inconexas a cargo de un sujeto que hace un recorrido por la ciudad. Desde el comienzo se pone el acento fuertemente en lo referencial, y aparece un "yo" que da cuenta de lo que ve de manera casi impersonal, reforzada en este caso por el uso de la tercera persona: "Se detiene pero finalmente/ se impone sobre el tendido/ transversal de las vías y avanza./ M.R. Trelles dos mil ochocientos./ Pared pintada especial, blanco y/ grandes letras entre comillas,/ PAVÉ y a un lado, más chicas,/ sin comillas,/ LADRÓN.” (Llach: 1998, 19, 20).

Como se ve, los versos iniciales presentan uno de los rasgos centrales del poema: el registro perceptual de un entorno determinado, intervenido a su vez por ciertas operaciones formales que tienden a interrumpir, destacar, y por lo tanto extrañar, lo que se ve. En este caso, se trata del corte de verso, que separa la frase "Pavé ladrón” del graffiti; al mismo tiempo se llama la atención sobre el modo particular de esa escritura callejera (en este caso un modo "bárbaro" de usar las comillas donde no corresponde). En otra parte del poema, una operación similar se ejerce sobre una frase oída al pasar: "Del conductor al conductor/ de un camión de nafta Shell:/ "Todo tranqui, no te veo/ más por allá”.” (Llach: 1998, 21).

Este ejercicio de registro resulta en la captación de los signos de una época, en primer lugar, en las modulaciones del habla y en los modos específicos e históricamente caracterizados de nombrar ("la negrada”, “tranqui”, etc.), así como en el uso de las imágenes de los medios de comunicación masivos como referente, tal como habíamos visto en Punctum: "una chica con cara de animadora de televisión/ (...) otro con la voz de cucharita de Joe Pesci” (Llach: 1998, 20). En el orden de lo visual, también aparecen en ese recorrido marcas comerciales, nombres de empresas, pintadas callejeras y espacios urbanos, como el shopping, que delimitan desde lo referencial las coordenadas 
de los noventa: “tres bolsas de nylon con logotipos/ de Ipako” (Llach: 1998, 20, 21); “El hotel Regent/ -enfrente de la EG3/ donde a la noche paran los taxis”, (Llach: 1998, 29); "los tipos cuyas hijas/ se compran botitas negras en el shopping de Salguero" (Llach: 1998, 29).

En “Joda y espiral”, la composición del siguiente fragmento da cuenta de esta voluntad de representar la época casi de manera fotográfica, y sugiere a la vez, tanto por el graffiti que se consigna como por el hecho de que la imagen está explícitamente fechada, una lectura que ponga en relación lo que se ve con todo un orden social y político: "Despierto a las 9, en la calle un cabeza come chorizo, tropiezo/ con el cordón de la zapatilla. Aprieto el walkman contra la oreja,/ el negro se ríe, come chorizo recostado contra una pared que dice: / Menem gobierna. Catorce de mayo de mil novecientos noventa/ y cinco: dos meses que no cojo” (Llach: 1998, 73-74). ${ }^{304}$

Sin embargo, esta operación de registro de los signos del presente se caracteriza por la fragmentariedad y la falta de conexión entre los datos, que se ofrecen a la percepción de modo aleatorio:

Un tipo con cara de rana en el bar Las Vegas de Santa Fe y Agüero rodeado por una chica con cara de animadora de televisión y por otro con la voz de cucharita de Joe Pesci.

Carro metálico del botellero para que un hombre parecido a Jorge Born (cuando estaba secuestrado) lo arrastre vacío, inclinado hacia atrás.

Una heladera apenas reconocible, tres bolsas de nylon con logotipos de Ipako llenas de un cable tensor, cañamazo de miles de líneas de alambre, líneas de puntos.

Del conductor al conductor de un camión de nafta Shell: "Todo tranqui, no te veo más por allá”. (Llach: 1998, 20, 21).

\footnotetext{
${ }^{304}$ Aquí, el uso del walkman, anacrónico en los noventa por la aparición de los CDs, y los discman, representa un modo de resistencia sutil, a través de los productos culturales del pasado, frente a la situación del menemismo, tal como habíamos visto en el consumo televisivo que hacen los personajes de Punctum de Martín Gambarotta.
} 
Como puede verse, la captación de los signos es asistemática y la lógica es acumulativa, al punto de que por momentos el texto adopta la forma de la enumeración, y no hay elementos en común que vinculen lo que se ve, aparte de la pertenencia a una época. El poema, como sucedía con la alternancia entre voces de distintos personajes en Punctum, incluye tiradas de versos en cursivas que cortan el flujo perceptual (a continuación de este fragmento dice, por ejemplo, "Se bebe para apagar la sed./ Se bebe/ para apagar la sed.”). De este modo el movimiento perceptivo del texto, orientado hacia el exterior, alterna con otra instancia reflexiva donde la variación de una misma frase con distintos cortes de verso da lugar a un detenimiento en procedimientos específicos sobre el lenguaje, en este caso el uso de la sintaxis.

Pero la misma lógica acumulativa que rige la percepción funciona para el lenguaje, es decir, el pensamiento. El texto pone el acento en el hecho de que la unidad con que se dice y se piensa es la frase: "Frases: la guerra es continua,/ la belleza interna equilibra la belleza de afuera,/ la representación debe salir del cuadro./ Más frases: Carolina, la puta de las tropas./ Todas las tardes mi viejo tomaba fernet con coca./ La coca es empalagosa” (Llach: 1998, 32). Aquí, el procedimiento acumulativo está puesto de relieve en el sintagma "Más frases", al mismo tiempo que el poema explicita su forma, que consiste en la yuxtaposición de enunciados de modo casi aleatorio y disgresivo. Lo importante, en este caso, es que no hay conexión entre las frases y por momentos no hay sentido posible, cuando a "Todas las tardes mi viejo tomaba fernet con coca”, que parece sugerir una caracterización del padre en el recuerdo mediante ese consumo, le sigue una frase como "La coca es empalagosa”, que obtura la significación.

Además en La raza la imposibilidad de decir surge como diagnóstico de la experiencia del sujeto en el presente: “Con una especie de adolescencia íntegra, supuesta,/ una chica dijo/ adicto significa no dicho” (Llach: 1998, 29). Poco después se 
retoma esta idea, casi para rechazarla: "Hay que hacer gala absoluta del principio de inocencia/ porque la moral no tiene sangre, por dios:/ la adicción es un problema de este tiempo./ Mandan fruta.” (Llach: 1998, 33). Aquí, la expresión “mandar fruta” como modo popular de aludir a un habla inflada, engañosa, que no se corresponde con la realidad y en la que la profusión verbal oculta la falta de sentido, se contrapone con la noción misma de adicción - dificultad para verbalizar-, como si fueran las dos caras de una misma moneda. El hecho de atribuir la reflexión sobre un término (“adicto significa no dicho”) a una tercera persona permite poner en escena una perspectiva sobre el estado del lenguaje en el presente pero sin teorizar, y desde la "inocencia” como dice el poema. La operación es similar a la de Gambarotta y reclama también la alternancia entre distintas voces, porque se trata de dar cuenta del presente en tanto sujetos inmersos en él y afectados por las mismas patologías que caracterizan a la época.

Sin embargo en La raza la escritura está planteada como modo de enfrentarse a la patología que consistiría en no poder decir (a-dicción). Porque una de las voces del poema reflexiona sobre la fragmentariedad en estos términos: "La fragmentación hace cagadas,/ estoy contento porque acabo de inventar/ la máquina que producirá otro poema” (39). La fluidez se opone en el texto a la fragmentación bajo la figura del agua: “El agua líquida como el tipo perfecto/ del cuerpo fluido,/ fluido” (Llach: 1998, 26); “La sed de los tejidos. La sed./ La sed de los tejidos” (Llach: 1998, 28). El agua, que se enuncia en otro pasaje como “la base misma de la vida” (Llach: 1998, 19), aparece como el principio que puede dar vitalidad al texto, representado en el fragmento citado más arriba por “los tejidos”, si tenemos en cuenta que "tejido” es el significado literal de la palabra "texto". Aunque no pueda construirse un relato mayor sobre la época, el movimiento -el paso de una frase a la otra- es el modo que encuentra el poema de hacer frente a la patología, a la dificultad para decir, porque de lo contrario puede caerse en el 
estado que se anota como: "Estasis: detención o estancamiento/ de un líquido que circula por el cuerpo” (Llach: 1998, 31). Por eso, incluso cuando se trate de moverse siempre en la superficie (la de la percepción) lo que importa es seguir adelante, como sugieren los versos finales del libro: “Todo es paisaje: no hay 'frito'. No hay freno. No hay fracaso" (Llach: 1998, 84).

Como se ve, tanto Llach como Gambarotta proponen modelos de escritura que constituyen distintos modos de superar una dificultad asociada al lenguaje y a la capacidad de articular conceptos en el habla. Pero a la vez, estas soluciones se concentran en niveles distintos. Mientras que Gambarotta en Punctum hablaba del presente desde las ruinas - del lenguaje, de la dictadura, de las experiencias políticas de los setenta-, y se concentraba en la posibilidad de leer en el lenguaje las vinculaciones entre una experiencia histórica y un estado de cosas actual (como manera de oponerse a ese “lenguaje sin vértebras” que no permitía articular conceptos), en Llach el problema es el del paso de una frase a la otra. Lo que aparece en este caso es una figura del presente que reproduce, en su fragmentación, lo que sería el “espíritu de la época”, el Zeitgeist, y que a la vez enuncia una poética que lo reproduce, que no intenta oponérsele sino superar esa adicción mediante el movimiento. Porque en efecto, si el signo de la época es la imposibilidad de decir, lo que se hace es inventar una máquina, un procedimiento, que permita seguir diciendo. 


\section{CAPITULO IV}

\section{POÉTICAS PERFORMÁTICAS, POÉTICAS POP}

\section{1- Planteo inicial}

La segunda mitad de la década del noventa es el momento de emergencia de una serie de poéticas que ponen en escena el problema de “lo femenino” más como pregunta y como gesto disruptivo que como categoría que se de por sentada o, menos todavía, se esencialice. En efecto, los primeros libros de Marina Mariasch, Roberta Iannamico, Romina Freschi, Karina Macció, Ana Wajszczuk, Verónica Viola Fisher y Vanna Andreini y el segundo de Anahí Mallol, que analizaremos en este capítulo, son textos firmados por mujeres pero eso no constituye una razón suficiente para considerarlos “escrituras femeninas” como si hubiera en ellos elementos -ya sea los recursos poéticos empleados o el tipo de voces que construyen- que permitan por sí solos pensar estas escrituras ante todo a partir del género. Para decirlo de otro modo, la coincidencia genérica entre el sujeto de enunciación textual y la persona biográfica de la autora no basta, en nuestra opinión, para hablar de “escrituras femeninas”, como si lo “femenino” pretendiera definirse a partir del sexo.

De hecho, en este caso se trata de poéticas heterogéneas que abarcan desde escrituras de la intimidad cuyo modo de enunciación puede considerarse lírico a partir de la definición propuesta por Käte Hamburger, que aquí trabajaremos (Hamburger: 1995), hasta escrituras de superficie con rasgos pop que se enuncian a través de 
personajes, a la vez que trabajan con materiales hipersaturados de la cultura de masas (Masotta: 2004). Lo que permite leerlas como conjunto es que trabajan críticamente con lo definido en la cultura como femenino, a partir de figuraciones que se construyen en los textos y de la apropiación de otros discursos. Por eso en este capítulo no se incluyen las recuperaciones simbolistas de Anahí Mallol en su primer libro, Postdata, ni la escritura ideogramática con filiaciones objetivistas de Laura Wittner, que se abordaron en el segundo capítulo, dado que en ninguno de estos casos lo femenino aparece planteado como tema o representado de manera explícita en los textos.

En cambio la zona de escritura que delimita este capítulo puede ser agrupada a partir de una puesta en escena provocadora -tanto como lo son las figuraciones de analfabetos respecto a la tradición literaria en su versión sacralizada- de lo que la cultura dominante, reproducida en el espacio privado, impone a las mujeres como pauta para la definición del género. En otras palabras, si hubiera que plantear una tradición sobre la cual operan estas poetas habría que decir que no es la de determinada línea poética sino una tradición de representaciones de lo femenino que circulan socialmente y que exceden los límites de lo literario para incluir, por ejemplo, el tipo de juegos que se propone a las niñas desde la infancia, en Mariasch, los productos que el mercado destina al consumo de las mujeres, en Mallol, y hasta el discurso paterno autoritario que se define a partir de la exclusión de lo femenino, en Viola Fisher. Este dato se articula además con una apertura decidida de la idea de “tradición”, que en este caso ya no se circunscribe a la tradición literaria sino que incorpora, como acabamos de mencionar, los discursos y representaciones sociales, y también los productos de la cultura de masas, que sólo en estas poéticas ingresan como una instancia que se pone al mismo nivel que la literatura. Por eso no es casual que algunos de estos textos presenten rasgos que los acercan al arte pop en tanto modo de “representar lo representado” y de abordar 
los objetos (que incluirían aquí las definiciones de género) no desde un pretendido “realismo” sino como materiales atravesados por los lenguajes y códigos sociales. ${ }^{305}$

La pregunta por el modo de abordar críticamente la producción poética de las mujeres, que intentamos abrir en este capítulo aunque el centro de nuestro análisis siga siendo siempre la idea de tradición, puede remontarse en nuestro país a la década del ochenta, cuando se la plantea frente a la consolidación de una serie de escrituras que en esa década terminan de conformar, según Martín Prieto, una “enunciación femenina”. 306 En efecto, hasta la década del ochenta la presencia de las mujeres en el campo poético fue siempre esporádica, desde casos aislados como el de Alfonsina Storni, Silvina Ocampo y Norah Lange hasta Alejandra Pizarnik, Susana Thénon y Juana Bignozzi en la década del sesenta. La heterogeneidad de estas poéticas vuelve imposible -si es que tal cosa fuera deseable- agruparlas como "poesía femenina” desde criterios estrictamente literarios, ya que no hay prácticamente rasgos en común entre el modernismo de Storni, el surrealismo de Pizarnik y la poesía política de Juana Bignozzi.

En cambio, como señala Prieto, hay un punto de clivaje en la década del ochenta porque se multiplican los libros escritos por mujeres (con una extensa lista que incluye a Mirta Rosenberg, Tamara Kamenszain, Diana Bellessi, Irene Gruss, Marilyn Contardi, Alicia Genovese y María Negroni entre sus representantes más destacadas). Además estas poetas, más allá de su “adscripción estética de base -neobarroca, ideogramática, objetivista, neorromántica, según el caso- obligan, para su comprensión, a la incorporación de nuevos textos a la bibliografía”, dice Prieto, porque vuelven a leer a Olga Orozco y a Silvina Ocampo, entre otras, y porque algunas de ellas traducen a

\footnotetext{
${ }^{305}$ Oscar Masotta, "El pop-art”, en Revolución en el arte. Pop-art, happenings y arte de los medios en la década del sesenta., Buenos Aires, Edhasa, 2004 (158).

${ }^{306}$ Ver "Lo femenino como enunciación”, en Martín Prieto, Breve historia de la literatura argentina, Buenos Aires, Taurus, 2006 (454-455).
} 
poetas norteamericanas como Marianne Moore y Denise Levertov e incorporan también a la uruguaya Marosa Di Giorgio (Prieto: 2006, 455).

Prieto también sostiene, junto con Jorge Monteleone, que a partir de esta década podría hablarse de una "enunciación femenina” caracterizada por "asuntos, puntos de vista, elecciones léxicas, tonos”, continuada en escrituras de los noventa como las de Marina Mariasch y Anahí Mallol, que verían su producción condicionada por poetas como Kamenszain, Irene Gruss, Rosenberg y Bellessi. En consonancia con esta idea, Jorge Monteleone afirma que “En la poesía argentina escrita por mujeres se plantearía la cuestión de una voz femenina, lo cual deriva en la búsqueda de un sujeto poético nuevo. Es decir, al representar el yo imaginario del poema, lo femenino se conforma como enunciación. Otra forma de la visión, otro deseo soberano y otra historia donde todo recomienza”. ${ }^{307}$ Pero si esto sucede es también porque en los ochenta surge un campo de reflexión específica sobre las escrituras femeninas que las vincula con lo político, del que forma parte el análisis de Monteleone. Para poner otro ejemplo, la misma Diana Bellessi declara en un ensayo publicado en el Diario de poesía que la escritura de las mujeres se enfrenta al desafío de trabajar “con un discurso prestado: el del productor”, y habilita de ese modo la idea de que estas escrituras harían un uso político de la lengua dominante. ${ }^{308}$

Anahí Mallol, como Prieto, también traza una línea en los ensayos de El poema y su doble entre las obras de Alejandra Pizarnik, Diana Bellessi, Mirta Rosenberg, Tamara Kamenszain y Susana Thénon, entre otras, a partir de la figura del poema como jardín, en la que intenta luego incluir a algunas poetas de los noventa como Marina

\footnotetext{
307 Jorge Monteleone, "La utopía del habla” (Estudio preliminar), en Diana Bellessi, Colibrí, ¡lanza relámpagos!, Buenos Aires, Libros de Tierra Firme, 1996 (22).

${ }^{308}$ Diana Bellessi, “La diferencia viva”, en Diario de poesía No 9, Buenos Aires, Invierno de 1988 (9).
} 
Mariasch, Roberta Iannamico y Ana Wajszczuk. ${ }^{309}$ Pero el armado parece endeble porque, en primer lugar, omite las diferencias -poéticas e ideológicas- entre estas producciones para forzar el ejercicio de lectura bajo una misma figura, y también porque no contempla los modos diversos de construir voces que cambian de los ochenta a los noventa (aunque es cierto que Mallol detecta y reconoce la presencia del artificio y la ironía en la escritura de las poetas más recientes) (Mallol: 2003, 201, 202).

Si bien resulta posible establecer una continuidad entre diversos textos firmados por mujeres como lo hacen Prieto y Mallol y pensarlos a partir de una "enunciación femenina”, la operación tiende a ocultar las diferentes modalidades que adopta esa enunciación en cada caso. Por eso no estamos del todo de acuerdo con la idea de Prieto de que las escrituras de algunas poetas que empiezan a publicar en los noventa estén “condicionadas” por poetas como Kamenszain, Irene Gruss, Rosenberg y Bellessi, o en todo caso habría que reformular el planteo para enfatizar tanto los puntos de continuidad como los de divergencia. De otro modo la afirmación de Prieto parece más bien un modo de forzar una serie de producciones heterogéneas para adaptarlas a una categoría preexistente, que sería la de una “enunciación femenina”, basándose ante todo en el dato de que se trata de libros firmados por mujeres y sin tomar en cuenta el hecho de que si esa enunciación se construía en las poéticas de los ochenta desde una voz lírica, en los noventa $-\mathrm{y}$ esto supone una diferencia fundamental- se produce un desplazamiento porque esa voz se plantea como artificio, al punto de que hablar y escribir "como las mujeres”, según dice un verso de Mariasch (Mariasch: 2001, 37), se revela como una construcción cultural.

En este sentido, Käte Hamburger define el “yo lírico” como sujeto enunciativo que se diferencia de la narración en tanto "producción de sujetos ficticios” a cargo de un

\footnotetext{
${ }^{309}$ Anahí Mallol, El poema y su doble, Buenos Aires, Ediciones Simurg, 2003.
} 
narrador o dramaturgo. ${ }^{310} \mathrm{Si}$ bien la distinción que establece Hamburger entre “realidad” (que sería propia de la enunciación poética) y “ficción” es cuestionable, desde el momento en que todo sujeto enunciativo es una construcción y por lo tanto en alguna medida ficcional, puede decirse que convencionalmente, como afirma la autora,

Vivimos la enunciación lírica como enunciación de realidad de un auténtico sujeto enunciativo que no puede ser referida sino a él mismo. (...) No vivimos los enunciados de un poema lírico como apariencia, ficción o ilusión. (...) Pues siempre nos hayamos ante él de forma inmediata lo mismo que ante la expresión de algún otro real, de un tú que habla a mi yo. (Hamburger: 1995, 182).

Este efecto de “realidad” de la enunciación lírica se vincula con la cuestión de la “identidad del yo lírico con el yo del escritor” (Hamburger: 1995, 183). Dado que el poema es un tipo de enunciación, se experimenta en la lectura como “campo vivencial del sujeto enunciativo, que nos lo hace accesible en forma de enunciación de realidad”. Y esto implica que, aunque más no sea como pacto de lectura, el yo lírico "es idéntico del escritor” en un sentido lógico (Hamburger: 1995, 185), desde el momento en que no media la construcción de personajes que pongan en cuestión esa identidad.

Estas afirmaciones resultan válidas para pensar las escrituras femeninas de los ochenta, como puede verse en los siguientes fragmentos de dos poemas distintos de Diana Bellessi:

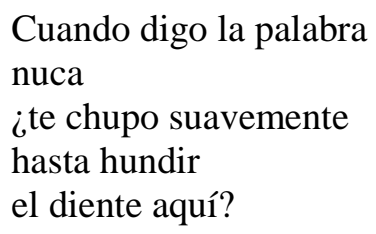

He construido un jardín como quien hace los gestos correctos en el lugar errado. Errado, no de error, sino de lugar otro, Como hablar con el reflejo del espejo

\footnotetext{
${ }^{310}$ Käte Hamburger, “El género lírico”, en La lógica de la literatura, Madrid, Visor, 1995 (158).

${ }^{311}$ Diana Bellessi, “Cuando digo la palabra nuca...”, Eroica, Buenos Aires, Libros de Tierra Firme/ Último Reino, 1988 (114).
} 
Y no con quien se mira en él.

He construido un jardín para dialogar

allí, codo a codo en la belleza, con la siempre

muda pero activa muerte trabajando el corazón. ${ }^{312}$

En el primer caso, como el poema plantea una situación de enunciación en la que un “yo” se dirige a un “vos” al que más adelante llama "mi amada”, el estatuto del yo lírico como sujeto de enunciación es claro. Pero incluso cuando ese interlocutor no está explicitado, como en el segundo fragmento, el efecto de apelación a un otro -que puede coincidir con el que habla- hace leer el poema como presentación de una subjetividad y experimentarlo, como señala Hamburger, en tanto vivencia posible de un sujeto que puede tanto "expresar” su interioridad como constituirla a través del lenguaje, según la ideología poética que se suscriba.

Pero algo cambia cuando Marina Mariasch comienza un texto de Coming attractions de este modo:

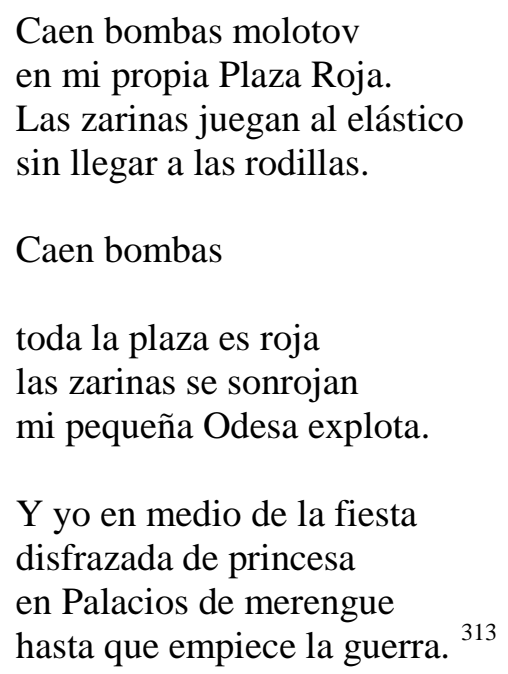

Aquí el poema, si bien está a cargo de un sujeto enunciativo que entra dentro de los parámetros de lo que definimos como lírica, plantea desde el comienzo un espacio ficcional, una "Plaza Roja” miniaturizada, devenida espacio de juegos infantiles y

\footnotetext{
${ }^{312}$ Diana Bellessi, “He construido un jardín...”, El jardín, Rosario, Bajo la Luna Nueva, 1992 (21).

313 Marina Mariasch, Coming attractions, Buenos Aires, Siesta, 1997 (29). Todas las citas posteriores están tomadas de la misma edición.
} 
habitada por personajes que pueden ser tanto niñas como muñecas, porque se alude a “palacios de merengue”. Además, el “yo” que enuncia el poema puede encuadrarse como “yo lírico” pero significativamente afirma que está “disfrazada”, con lo cual pone en suspenso la identificación posible entre el “yo” del texto y el del escritor, a los que Hamburger hacía coincidir.

Si bien la idea de hablar a través de máscaras (o “disfrazada”, como en Mariasch) ya estaba presente en Bellessi -de hecho uno de sus libros de llama Danzante de doble máscara- y hasta en Alejandra Pizarnik, en ambos casos bajo una forma de enunciación que puede considerarse lírica, ${ }^{314}$ en el poema de Mariasch el estatuto de la que habla es diferente porque el texto se plantea como espacio ficcional que permite el ingreso de lo fantástico, tanto cuando se hace mención a la ciudad de Odessa como en el caso de “mi propia Plaza Roja”, que si bien por el uso de las mayúsculas podría remitir a la histórica plaza de Moscú, al estar caracterizada como “mi propia” indica un referente que es desde el principio una invención. De modo que el “yo lírico” puede ser en este caso una muñeca o una niña que fabula, aunque el poema no se proponga explícitamente como ficción ni mucho menos como construcción teatral de personajes. Esto sucede porque en las escrituras femeninas de los noventa se realiza una síntesis entre dos líneas definidas por distintas modalidades de enunciación que pueden remontarse a la obra de Alejandra Pizarnik, pero que allí se encontraban separadas.

En efecto, como se sabe, la producción de Pizarnik se divide no sin matices en dos tipos de textos que pueden pensarse, a partir de los criterios establecidos por Hamburger, como ficcionales y líricos. Miguel Dalmaroni también hace una distinción en la obra de Pizarnik, entre una voz "del puro yo" y una voz en la que ingresan otros

${ }^{314}$ Ver Diana Bellessi, Danzante de doble máscara, Buenos Aires, Ultimo Reino, 1985. Pizarnik, por su parte, tiene un poema llamado precisamente "La máscara y el poema" donde la sintaxis -que equipara ambos términos- habilita a pensar en el poema mismo como máscara. Ver El infierno musical (1971) en Alejandra Pizarnik, Obras completas, Buenos Aires, Corregidor, 1994 (165). Todas las citas posteriores están tomadas de la misma edición. 
discursos. ${ }^{315}$ La diferenciación entre poesía en verso y textos en prosa (que también está en Mariasch y en Freschi, como veremos) es secundaria, porque los poemas en prosa comparten el modo de enunciación lírico de los poemas en verso mientras que algunos relatos breves, y muy especialmente Los poseídos entre lilas y La bucanera de Pernambuco o Hilda la polígrafa, se presentan como piezas teatrales y otras formas experimentales, pero en todo caso no líricas. Sin embargo uno de los rasgos comunes a estas dos líneas de escritura es que en ambas aparecen figuras como la muñeca y la niña (en ocasiones coinciden), que las poetas de los noventa recuperan con diversas variantes. Estas figuras funcionan en los poemas líricos como miniaturización del yo que enuncia el poema, y en otros casos como personajes teatrales que tienen a su cargo la enunciación.

En algunos textos de Los trabajos y las noches (1965) la muñeca y la niña pueden ser un personaje de cuentos infantiles, como la Alicia de Lewis Carrol en un poema cuyos últimos versos dicen que “alguien entra a la muerte/ con los ojos abiertos/ como Alicia en el país de lo ya visto” (Pizarnik: 1994, 100), o una “Dama pequeñísima/ moradora en el corazón de un pájaro” que "sale al alba a pronunciar una sílaba/ NO” (Pizarnik: 1994, 102). Se trata de diversas “máscaras” con las cuales se representa un yo que resulta de esta manera móvil, inestable, pasible de transformarse en todo un repertorio de figuras como sucede en el poema "Formas" que consiste en una acumulación disyuntiva de modos posibles de definirse: un pájaro, una amazona, un

\footnotetext{
${ }^{315}$ Dalmaroni en efecto observa algún tipo de diferenciación entre los poemas que Pizarnik publicó en vida y su obra en prosa, cuando propone que estos últimos textos introducen una transformación considerable en la obra de Pizarnik, debido al "paso que le hacen dar desde la voz única y pura del puro yo que se perseguía en libros como Árbol de Diana (1962) o Los trabajos y las noches (1965), hacia la incontinencia de una voz desbocada que despurifica todos sus enunciados” (Dalmaroni: 2004, 81). Esta diferenciación es importante porque como veremos, el vínculo entre la obra póstuma de Pizarnik y las poetas que estamos considerando reside en parte en que se trabaja un lenguaje donde se cruzan los materiales y las consignas, y sobre todo, en el caso de las poetas de los noventa, los mandatos culturales respecto a las mujeres.
} 
juglar o una “princesa en la torre más alta”, según concluye el poema (Pizarnik: 1994, 110).

En los textos en prosa de Extracción de la piedra de locura (1968) esta figura se despliega en un espectro que va desde la ingenuidad a lo siniestro, porque hay una "niña loba” que llora aunque nadie la oye y en otro caso el sujeto dice "sonríe y yo soy una minúscula marioneta rosa con un paraguas celeste yo entro por su sonrisa yo hago mi casita en su lengua” (Pizarnik: 1994, 136, 137). También aparece como una figura que es pura superficie cuando se dice "Muñequita de papel, yo la recorté en papel celeste, verde, rojo y se quedó en el suelo, en el máximo de la carencia de relieves y de dimensiones” (Pizarnik: 1994, 144). En este caso se pone de manifiesto que la muñeca funciona como objeto en el que se desdobla el yo, porque un poco antes el texto dice: “El cortejo de muñecas de corazones de espejo con mis ojos azul-verdes reflejados en cada uno de sus corazones” (Pizarnik: 1994, 143).

En otras piezas en prosa de El infierno musical (1971) la distinción entre el yo y el objeto se desdibuja porque se habla de "Las muñecas desventradas por mis antiguas maños de muñeca, la desilusión al encontrar pura estopa", y también se dice que "Yo quería que mis dedos de muñeca penetraran en las teclas” (Pizarnik: 1994, 153). De modo similar, en otro texto las niñas devienen muñecas de papel cuando se pasa de la frase “el súbito desbandarse de las niñas que fui” a “Caen niñas de papel de variados colores” (Pizarnik: 1994, 156). El desplazamiento de las "niñas que fui” en tanto memoria de la infancia a las "niñas de papel”, y en general a las muñecas que aparecen en los fragmentos citados, es significativo porque como lo señalan los mismos textos, la muñeca se caracteriza por ser un objeto sin interioridad (cuando se alude a la “desilusión de encontrar pura estopa”) que es solamente superficie, según el texto que constata su "carencia de relieves y de dimensiones", pero que al mismo tiempo puede 
vincularse con el yo como reflejo (no por supuesto en tanto reflejo "realista” sino como superficie espejada donde se mira el yo que habla en el poema).

Sin embargo, en todos los ejemplos citados se trata de una figura presentada desde la voz del sujeto que enuncia el poema. En cambio en otros textos como "A tiempo y no" (de Textos de sombra y últimos poemas, 1982), ${ }^{316}$ un breve ejercicio de sinsentido carrolliano en el que tres personajes -la niña, la muerte y la reina locaconversan mientras toman el té, la muñeca pasa a ser un personaje más que observa la escena sorprendida ante algunas frases y termina por exclamar “Qé bida!”, porque todavía no sabe hablar "sin faltas de ortografía” (Pizarnik: 1994, 199-201). En Los poseídos entre lilas y La bucanera de Pernambuco o Hilda la polígrafa la muñeca también deviene personaje que tiene a su cargo la enunciación. El escenario de Los poseídos entre lilas (inédito en vida de la autora y fechado entre 1971 y 1972) se describe al comienzo del texto como "Una habitación con muebles infantiles de vivos colores. Luz como una agonía, como cenizas. Pero también a veces, como una fiesta en un libro para niños” (Pizarnik: 1994, 259).

El decorado incluye corazones, objetos rosados, flores y juguetes pero también inodoros y féretros. Los personajes principales de esta pieza son Segismunda y Carol (que bien puede ser una alusión a Lewis Carroll), y sólo se revela que son muñecos cuando otro de los personajes, Macho, dice "Recordá cuando los tres camiones

\footnotetext{
${ }^{316}$ Con respecto a este texto señala Miguel Dalmaroni: "El volumen titulado Textos de sombra y últimos poemas de Alejandra Pizarnik fue publicado por primera vez en 1982, casi diez años después de la muerte de la poeta. La última sección del libro, “1971-1972”, incluye dos grupos de textos bien diferenciados: treinta y nueve piezas breves, por una parte, y "Los poseídos entre lilas" junto a "La bucanera de Pernambuco o Hilda la polígrafa”, por otra. (...) En el primer grupo están los "Textos de sombra" (...). Lo que parece narrar el conjunto de los "Textos de sombra” no es otra cosa que la misma evolución de la escritura de Pizarnik”. Miguel Dalmaroni, “Alejandra Pizarnik: “el último fondo del desenfreno"”, en La palabra justa. Literatura, crítica y memoria en la Argentina. 1960-2002, Mar del Plata, Editorial Melusina, 2004 (79). La última observación de Dalmaroni es pertinente para nuestro análisis porque, como veremos, los textos que se pondrán a consideración también incluyen una instancia autorreflexiva sobre la escritura de Pizarnik.
} 
embistieron nuestros triciclos. Perdimos brazos y piernas. Segismunda nos compró brazos pero no quiso comprarnos piernas, solamente estos zancos ganchudos para empujar los pedales” (Pizarnik: 1994, 266). De todas formas el estatuto de los personajes es imposible de fijar porque si bien habitan un mundo infantil y por momentos hablan como niños (“Macho (mostrando el chupetín): ¿Querés un cachito?. Futerina: No, ¿Un cachito de qué?. Macho: De chupetín. Te guardé más de la mitad y además el palito. (Mira el chupetín con ternura). ¿№ lo querés?”, p. 266), también conversan sobre tangos y psicoanálisis (Pizarnik: 1994, 261, 262), repiten fragmentos de otros poemas y relatos de Pizarnik y hablan de sexo (Pizarnik: 1994, 268).

Pizarnik incluye en estos textos reflexiones sobre la figura de la muñeca y su vinculación con el yo cuando en Los poseídos entre lilas Carol y Segismunda mantienen esta conversación a propósito de una muñeca que se llama Lytwin:

SEG: Dámela. (Car se la entrega. Seg la abraza.) Enigmático personajito tan pequeño, ¿quién sos?

LYTWIN: No soy tan pequeña; sos vos quien es demasiado grande.

SEG: Pero, ¿quién sos?

LYTWIN: Soy un yo, y esto, que parece poco, es más que suficiente para una muñeca.

SEG: ¿No pensás que Lytwin es adorable y siniestra a la vez? (Pizarnik: 1994, 282). ${ }^{317}$

La muñeca funciona en los textos de Pizarnik como figura que permite alternar entre la voz de los poemas líricos y otros discursos que ingresan al texto tales como el tango, el psicoanálisis y la pedagogía infantil, como se ve en un fragmento de Los poseídos entre lilas donde un personaje dice a otro "Voy a contarte lo que nos decía mi maestra de

\footnotetext{
${ }^{317}$ El último texto de La bucanero de Pernambuco o Hilda la polígrafa vuelve sobre este punto y de hecho reescribe esta conversación, ahora entre el yo lírico y la muñeca:

“-Al alba dormiré con mi muñeca en mis brazos, mi muñeca la de ojos azul oro, la de la lengua tan maravillosa como un poema a tu sombra. Muñeca, personajito pequeño, ¿quién sos?

-No soy tan pequeña. Sos vos quien es demasiado grande.

-¿Qué sos?

-Soy un yo, y esto, que parece poco, es suficiente para una muñeca. (...)” (Pizarnik: 1994, 364). Es interesante observar cómo Pizarnik había avanzado en estos últimos escritos en una reflexión crítica sobre su propio uso de la muñeca en tanto figura que funciona como un "yo", según los textos aclaran una y otra vez, es decir, como miniaturización de sí misma en tanto sujeto.
} 
primero inferior”, y a continuación la cita: “Acostumbre a su niño desde un principio a adoptar una postura conveniente (...) aconsejada por la higiene escolar” (Pizarnik: 1994, 267). De este modo el texto se abre a los discursos que pretenden normalizar los cuerpos y los sujetos imponiéndoles modos de hablar, sentir y comportarse que aquí se subvierten desde la risa.

En tanto juguete que se impone a las niñas como modo de incorporar las pautas culturales que definen lo femenino, la muñeca convoca todo un universo infantil que remite a cuentos, relatos y juegos cuyos significados aquí se trastocan por un uso desviado y porque el texto opera, como señala Miguel Dalmaroni,

sobre dos conjuntos de materiales privilegiados: el campo discursivo de lo corporal, casi siempre en sus registros más bajos y procaces; y una selección de múltiples citas y tópicos culturales y literarios (...). Y es por la obsesión festiva y despiadada, humorística y violenta con que el texto trabaja estos materiales que la irresponsabilidad lúdica e infantil de sus estrategias se vuelve intensamente política (o si se quiere, anti-ideológica y anarquizante). Pues no es un lenguaje puro ni destilado de sus contextos el que se exhibe y se usa como objeto del juego, sino materiales discursivos con una identidad saturada (Dalmaroni: 2004, 83).

Pizarnik aisló este tipo de escritura de la otra vertiente más conocida de su obra, conformada por una poesía “puramente negativa, gratuita, absolutamente autónoma, que es una variante poética del mito inalcanzable de le mot juste” (Dalmaroni: 2004, 80) (una ideología poética que es residual en los noventa), y se valió de personajes para poner en escena el tipo de experimentación que describe Dalmaroni, que le permitieron hacer el paso desde "la voz única y del puro yo" de los poemas líricos hasta "la incontinencia de una voz desbocada que despurifica todos sus enunciados” (Dalmaroni: 2004, 81).

La escritura lírica de Pizarnik tuvo su continuidad en los ochenta, sobre todo en la producción de Diana Bellessi que retoma exclusivamente su obra en verso. En cambio los textos en prosa que hemos analizado no se procesan sino hasta los noventa, cuando las poetas que mencionamos al comienzo del capítulo llevan a cabo un ejercicio 
similar con materiales culturalmente saturados, en ocasiones desde textos que en la definición de Hamburger podrían considerarse como líricos. Sólo que algo sucede con este yo lírico, porque como apunta Tamara Kamenszain, en los noventa

El yo lírico parece a punto de soltar su función de custodio de la experiencia o, para decirlo de otro modo, los poemas parecen haber abandonado aquella pretensión de intimismo que fue un secreto compartido entre lector y poeta a través de toda la historia de la poesía. (...) Hoy, de vuelta de la conciencia enunciativa, el poema se instala en un universo que, en el polo opuesto de la intimidad, deja entrar a los otros en su acontecer. No hay un relato abortado por escansiones ni tampoco una invasión del poema sobre el campo de la prosa como sucedía con aquel híbrido, tan de moda en los setenta, denominado prosa poética, cuyo discurso transcurría sin escansiones ni encabalgamientos pero pasando a depender de la experiencia de un yo lírico. Aquí sucede todo lo contrario: en medio de las escansiones, sin prosa alguna, un yo acentuado por los otros se funde y se confunde en un ir y venir de personas que quedan a medio camino -barradas, escandidas- en su vocación de devenir personajes. ${ }^{318}$

Las poéticas que analizaremos a continuación cubren un espectro que va desde el yo lírico entendido como sujeto de la experiencia que se enuncia en el poema hasta el yo devenido personaje, como anota Kamenszain, pero incluso en el primer caso la “pretensión de intimismo” a la que alude el artículo citado se pone en cuestión porque los textos plantean la construcción de una subjetividad femenina como artificio.

En este sentido, y como desplazamiento con respecto a la posibilidad de postular esa “enunciación femenina” a la que aludía Jorge Monteleone, el trabajo con la muñeca permite leer en estos textos la construcción de género como gesto performativo que se vuelve crítico en la medida en que desnaturaliza lo impuesto por la cultura. La presencia de esta figura permite articular dos cuestiones mayores que organizan este capítulo, dado que pone en escena la construcción del género a partir de un objeto vinculado a lo lúdico que constituye una versión miniaturizada y artificial de lo femenino. Por eso la perspectiva que hemos elegido para pensar el género es la de Judith Butler en El género

\footnotetext{
${ }^{318}$ Tamara Kamenszain, “Testimoniar sin metáfora, narrar sin prosa, escribir sin libro. La joven poesía argentina de los noventa”, en Jorge Fondebrider (compilador), Tres décadas de poesía argentina. 1976-2006, Buenos Aires, Libros del Rojas, 2006 (226, 227). En la parte final de su libro de ensayos La boca del testimonio, la autora desarrolla esta idea en la lectura crítica de Washington Cucurto, Martín Gambarotta y Roberta Iannamico. Ver Tamara Kamenszain, La boca del testimonio, Buenos Aires, Norma, 2007 (117-162).
} 
en disputa. ${ }^{319}$ Según Butler todas las identidades de género pueden pensarse como performativas en el sentido de que "la esencia o la identidad que pretenden afirmar son invenciones fabricadas y preservadas mediante signos corpóreos y otros medios discursivos” (Butler: 2007, 266). El trabajo con la figura de la muñeca, que tiene su correlato en la representación de lo femenino como "disfraz" asociado con la exageración y la teatralidad, supone entonces la apropiación de un objeto que tiene la función cultural, como señala Butler, de “fabricar y preservar” una identidad femenina impuesta como naturaleza que en los textos se cuestiona.

Pero además, y esta es una cuestión que se abordará en la segunda parte de este capítulo, la muñeca funciona como objeto pop en tanto es pura exterioridad, pura superficie (como se pone de relieve en la elección de la mamushka, tanto en Mariasch como en Iannamico, es decir, un objeto que está conformado únicamente por una sucesión de capas sin “centro”). Y es, además, un objeto que aparece en el texto mediatizado por otros discursos sociales en torno a la condición de la mujer, y que como tal condensa un ejercicio de escritura donde la presencia del yo como sujeto real que organiza la experiencia da lugar a un nuevo modo de constitución de las subjetividades vinculado al pop. Además la relación con el arte pop también está dada como veremos, por el ingreso sin precedentes de materiales de la cultura de masas al poema, que no sólo funcionan como “citas” sino que modifican la manera de plantear la poesía en relación a la propia tradición literaria y a la cultura de masas.

Por todo lo expuesto, el modo de construir tradición varía con respecto a las poéticas consideradas hasta aquí. Las poetas que analizaremos a continuación no construyen exclusivamente una tradición de “poesía femenina” que delimite un corpus de libros escritos por mujeres como si semejante filiación fuera "natural”, sino una

\footnotetext{
${ }^{319}$ Judith Butler, El género en disputa. El feminismo y la subversión de la identidad, Barcelona,
} Paidós, 2007. 
tradición de representaciones del cuerpo de la mujer y de distintos modos de poner en escena lo definido culturalmente como femenino que provienen sólo parcialmente de la literatura. ${ }^{320}$ De hecho los criterios que rigen el ejercicio de selección sobre la tradición literaria, como las operaciones de recorte practicadas sobre la obra de Pizarnik, se rigen por esta voluntad de trabajar críticamente con lo femenino.

El armado de la tradición es distinto porque si en los objetivistas se trataba de conformar un corpus orgánico de poéticas que se leían a partir de criterios ideológicos sobre el lenguaje, y en las poéticas abordadas desde las figuras del bárbaro el gesto era el de poner a prueba la tradición consagrada y los valores asociados con ella, en este caso puede pensarse en "tradición” en un sentido amplio, que excede los límites del campo literario para adentrarse decididamente en la cultura, lo cual está en estrecha relación con el uso del pop que hemos adelantado.

\section{2- “COMO UNA FIESTA EN UN LIBRO PARA NIÑOS”}

Para constatar el modo en que operan estas poéticas sobre lo que Prieto y Monteleone llamaban “enunciación femenina”, ya convertida en tradición para las poetas de los noventa, basta con pensar en los títulos de los dos libros más representativos de la poesía escrita por mujeres de los ochenta: Eroica de Diana Bellessi y Madam de Mirta Rosenberg, porque en ambos se alude a una variante exaltada de lo

\footnotetext{
${ }^{320}$ Por eso, para dar algunos ejemplos, la obra de Laura Wittner y el primer libro de Anahí Mallol no se incluyen en este análisis y sí en el Capítulo II, como ya hemos mencionado, así como tampoco aparecen Fernanda Laguna, Gabriela Bejerman y Cecilia Pavón, que serán abordadas en el próximo capítulo como parte de la formación Belleza y Felicidad, dado que en este capítulo no estamos trabajando simplemente con "poesía escrita por mujeres" (en ese caso, todas estas autoras que acabamos de nombrar deberían haber sido incluidas) sino de textos donde lo femenino se pone en escena como problema, cosa que no sucede en otras poetas.
} 
femenino, desde el componente épico implícito en el término fraguado por Bellessi (incluso si esa épica lo es del amor y del cuerpo, como sugiere la otra palabra contenida en el título, “erótica”) hasta la actitud de reverencia que supone dirigirse a alguien como “señora” y hacerlo en francés. ${ }^{321}$ Estas poetas construyen un discurso afirmativo sobre lo femenino donde incluso la reelaboración de tópicos amorosos puede leerse como modo de exponer una subjetividad en clave combativa y presentar una perspectiva sobre el tema que hasta el momento era secundaria en la poesía. Así, cuando Diana Bellessi se dirige en el poema citado al principio a una mujer que es el destinatario explícito del poema, da estatuto poético a un modo del deseo que no estaba presente en la poesía argentina y reclama para la subjetividad femenina -y en este caso lésbica- un lugar que no es solamente discursivo sino también social, cuando el poema repite como un estribillo “No me mandes al rincón” (Bellessi: 1996, 110).

En los noventa en cambio, como si se tratara de asumir esa posición relegada que implica el "rincón” en tanto lugar donde se manda a los niños cuando desobedecen a los mayores, podría pensarse que las poetas escriben desde ese “rincón”, un lugar del que se apropian para politizarlo y subvertirlo. Este desplazamiento supone construir un espacio de enunciación que coincide parcialmente con el descrito por Pizarnik en Los poseídos entre lilas cuando sitúa la escena en un decorado que se presenta "como una

\footnotetext{
${ }^{321}$ Ver Diana Bellessi, Eroica, Buenos Aires, Ediciones Ultimo Reino/ Libros de Tierra Firme, 1988, y Mirta Rosenberg, Madam, Buenos Aires, Libros de Tierra Firme, 1988.

Rosenberg consigna otro sentido posible para el título de su libro en una entrevista, cuando propone "madam" como término legible del mismo modo de izquierda a derecha que al revés, y postula que reúne los géneros masculino y femenino: "El libro se llama "Madam" porque procede de un palíndromo en inglés, que es el momento en que Adán se le presenta Eva. Es decir, el momento del origen, según la Biblia, de la estirpe humana. Entonces no había nadie que los presentara. Obviamente porque dios no se preocupó por presentar a sus creaciones, entonces se acercó a Eva y le dijo: "Madam, I'm Adam". Y lo curioso es que, obviamente -según la Biblia la mujer está hecha de la costilla del hombre-, esto se lee de izquierda a derecha, y de derecha a izquierda, exactamente igual. Son dos mitades de una misma cosa. Y por eso el libro se llama "Madam" -en inglés, no en francés-. Por este palíndromo, que es como el palíndromo originario." En:

http://www.buenosaires.gob.ar/areas/com_social/audiovideoteca/literatura/rosenberg_texto_en.p hp
} 
fiesta en un libro para niños” (Pizarnik: 1994, 259). Por eso la intervención sobre la tradición se resume en un gesto inaugural que abre esta línea de escrituras desde una toma de posición en el campo (Bourdieu: 1997, 343) que delimita un espacio de enunciación en común a través del uso de un "nosotras” (opuesto a un "ustedes" masculino, y que devuelve los mecanismos de exclusión social hacia las mujeres en un movimiento de exclusión inicial dirigido a los varones), sólo que esas “nosotras” ya no son “eroica” ni “madam” sino niñas y muñecas.

El primer libro de Marina Mariasch, Coming attractions (que condensa en el título la idea de adelanto de aquello que está por venir, planteado en términos que se toman prestados a la industria cinematográfica) comienza con un poema que declara:

Es una era púrpura.

Cualquiera de nosotras sería una mascota perfecta.

Y todo lo que hacemos es atrapar panaderos y pedir tres deseos:

Estar en una fiesta de té, en otro lugar, un planeta miniatura lleno de baby cactus que nosotras cuidaríamos.

Darnos besos en la nariz, besos esquimales.

Bailar lento, random drivers en la casa.

Sacamos fotos del mar y llenamos las paredes, respiramos bajo el agua.

Los peces son la mamá.

Nos contamos las pestañas, los pocitos: las pupilas dilatadas shifty-eyes / por el agua agridulce.

Nos mandamos caramelos en papel celofán -uno por día- así nadie se

Sentadas, las rodillas abrazadas, queremos correr.

/ olvida.

El techo de la casa vuela.

Creo que estamos en $\mathrm{Oz}$.

(Mariasch: 1997, 9).

Ese "nosotras" que aparece en el segundo verso puede incluir, a falta de precisiones posteriores, tanto a las mujeres en general como a las mujeres que escriben; en todo caso lo importante es que la posibilidad de que cualquiera sea una "mascota perfecta" habla desde el principio de una posición subordinada en relación a otro que sería el “amo” (de hecho una mascota sólo se define como tal cuando lo es de alguien). Pero enseguida el poema pasa a plantear una situación hipotética, producto del deseo, que 
representa una huida con respecto a esta primera declaración: la de estar “en una fiesta de té, en otro lugar” que se describe como un "planeta miniatura”.

Ana Wajszczuk retoma el "nosotras” de Mariasch en un poema titulado "Las chicas que escribimos” del libro Trópico trip, donde construye una imagen de las mujeres poetas a partir de la amplificación de lugares comunes tales como la homologación de la escritura a labores domésticas, entre ellas el tejido:

A las chicas que escribimos alguna vez nos llamaron al festín, al convite a nosotras que escribimos todos los deseos con cada pulso

y allí nos fuimos

y allí nos perdimos apenas un piecito cruzó el espejo

¡todas las palabras se abrieron capullos dentro nuestro!

las chicas que escribimos vivimos entretejidas en sueños estridentes como todo secreto Yo en el verdor, ella con los cactus bebé niñas atragantadas que llevamos dentro llevamos pequeñas Alicias pornostar danzando en tacos aguja de cristal ceniciento

¡ah el deseo que nos ahoga!

¡ah, si la sed no nos resecara más que los labios frutilla! (...)

princesas húmedas en love-trip

nosotras aullamos

mientras nuestra piel miente la seda

luego nos queda el consuelo de descoser las palabras amorosas hilarlas en nuestras ruecas

con el paso de las horas oscuras

luego salir a lo verde

somos ninfas de un bosque del cual ustedes sólo pueden entrever el follaje (...). ${ }^{322}$

En Wajszczuk la escritura femenina se sitúa en un espacio fantástico similar al Oz del último verso citado de Mariasch (Mariasch: 1997, 9), que en este caso se representa como el Wonderland carrolliano en el verso que dice "y allí nos perdimos apenas un piecito cruzó el espejo”. El texto de Wajszczuk pasa revista a los tópicos

${ }^{322}$ Ana Wajszczuk, Trópico trip, Buenos Aires, Ediciones Deldiego, 1999; sin número de página. 
previsibles sobre lo femenino porque aparece la mención a las palabras como capullos que florecen, las plantas, los cuentos de hadas como La Cenicienta, las princesas, y finalmente la escritura como hilado, que remite a la figura mítica de Penélope tejiendo y destejiendo cada noche una mortaja para burlar con astucia a sus pretendientes, ${ }^{323}$ y también a las Parcas, figuras femeninas de la mitología romana que limitan a voluntad la vida de los hombres porque gobiernan el nacimiento, el matrimonio y la muerte (Grimal: 1993, 408). El anacronismo de aludir en este caso a la dimensión mítica de la escritura como tejido funciona puesta en metáfora desde la ironía, sobre todo porque el poema se dirige a un "ustedes” masculino, como lo muestran los últimos versos, que supuestamente no tendría acceso a ese espacio asociado al misterio. Pero la trampa reside en que el acceso a ese "bosque" que los versos permitirían entrever se construye como devolución de una imagen estereotipada que en realidad no revela nada, y también como exageración del gesto de asociar la escritura femenina con el deseo -que tiene su contrapartida en la visión de lo masculino vinculado con lo intelectual- cuando se exclama de modo anacrónico “¡ah el deseo que nos ahoga!”.

Como el bosque habitado por ninfas de Wajszczuk, el planeta miniatura de Mariasch claramente está habitado sólo por mujeres, como lo muestran el resto de los poemas de Coming attractions, porque los hombres están aludidos pero no presentes: “Camino y algunos hombres/ con bebés en la mano/ me dicen piropos”, dice el segundo poema (Mariasch: 1997, 11); en el tercero, llamado precisamente “en una fiesta”, se relata un sueño en estos términos: "Soñé con una nursery./ Que te esperaba toda la noche en una fiesta/ atada al teléfono/ dándole besos a todos los chicos que no eran vos.// Yo vivo en una casa de chicas de piel/ de látex gastado, irrompible, mojado” (Mariasch: 1997, 13). En Pupilas estrelladas de Karina Macció se repite esta idea de

\footnotetext{
${ }^{323}$ Pierre Grimal, Diccionario de mitología griega y romana, Barcelona, Paidós, 1993 (419).
} 
una casa como espacio del que los varones quedan excluidos: "Un aire gélido/ agarra la casa,/ y los chicos se calientan/ jugando/ en el jardín”. ${ }^{324}$ Y en Polaroid de Anahí Mallol la toma de posición con respecto a lo masculino, que en su caso incluye a las poéticas de los varones, presenta una variante que toma la forma de la amenaza frente al discurso masculino que señala a la mujer como "niña”: "mis labios/ mis dientes/ se posan/ voraces/ sobre cualquiera que me diga/ niña/ y ahí vuelan/ en la mejilla/ de un anciano sonrosado/ en el brazo/ de un saludable/ joven poeta”. ${ }^{325}$

Otro poema de Mariasch pone de manifiesto que la construcción de una voz de niña funciona como adopción del lugar asignado por el discurso dominante, cuando exclama: “Me llaman la chica/ ¡Socorro! ¡Ámame!” (Mariasch: 1997, 27). El “me llaman” señala una condición de la mujer (perpetuada en la infancia por ese "la chica”, con sus connotaciones de minoría de edad que hasta pueden pensarse como dependencia legal de un adulto) que existe en tanto es nombrada por otros, que la marcan como “desvalida” y necesitada de afecto. Por eso el poema se enuncia desde ese lugar pero a la vez revela el artificio en el uso del “tú” como segunda persona cuando dice “ámame”, sugiriendo que "la que habla" es en realidad una mujer que es socialmente "hablada". Pero además de ironía hay una violencia latente en esta construcción de lo infantil, explícita en el fragmento de Mallol donde se representa mordiendo al que le diga “niña”, que también se encuentra en el motivo de la destrucción inminente que rodea la figura de la casa como espacio de refugio, cuando Mariasch anota que "el techo de la casa vuela” (Mariasch: 1997, 9) y agrega en otro poema que "Un tornado arrasa/ la casa de las Barbies” (Mariasch: 1997, 22) y Macció señala que “un aire gélido/ agarra la casa” (Macció: 1998, 52).

\footnotetext{
${ }^{324}$ Karina Macció, Pupilas estrelladas, Buenos Aires, Siesta, 1998 (52). Todas las citas posteriores están tomadas de la misma edición.

${ }^{325}$ Anahí Mallol, Polaroid, Buenos Aires, Siesta, 2001 (91). Todas las citas posteriores están tomadas de la misma edición.
} 
Esa violencia también se revierte sobre el cuerpo porque en el poema de Wajszczuk se dice que las chicas llevan niñas “atragantadas” (Wajszczuk: 1999), así como el texto de Mariasch donde dice que vive en una casa de chicas “de piel de látex gastado” apunta después: “Se me notaba de lejos/ la estirpe de garganta cerrada” (Mariasch: 1997, 14). Estas alusiones, que pueden pensarse como reelaboraciones del tópico de tener o no tener una voz, ya presente en Pizarnik, comportan además en este contexto un sentido social en la medida en que forman parte de una situación colectiva que los poemas ponen en escena: la de las mujeres que, eternamente asociadas a las niñas, no tendrían voz ni posibilidad de hablar como no sea a través de máscaras infantilizadas.

Karina Macció resume esta concepción de lo femenino en el personaje de Sara Key (en realidad Sarah Kay), una figura muy popular que circuló en la década del ochenta en álbumes de figuritas, posters, papeles de carta y objetos escolares. La serie incluía niñas en distintos juegos y actividades domésticas, siempre en actitudes dulces y sumisas. Por esto este poema de Macció funciona casi como manifiesto en contra de esas representaciones de lo femenino de las que sería necesario deshacerse:

Dejo mi figurita Sara Key para siempre.

Con sus moños ondulados su cabello claro floreado sus vestidos apuntillados sus tiernos ojos volados dan ganas de pegarle una patada y decirle ¡Basta de bondades! ¡Andá a seducir a otra! (...)

Dejo mi figurita Sara Key pero no dejo de verla pero me embaraza tenerla

Y si la rompo se reproduce en la tele en la escuela en la novia en la tienda en la casa en la cama Y si la rompo 


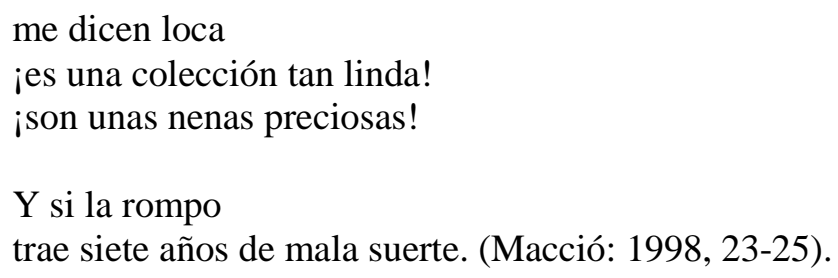

Pero como muestra el poema, "romper” la figura no es suficiente porque su carácter ubicuo hace que aparezca por todas partes, tanto en los espacios públicos y los medios masivos (la televisión, la escuela) como en la vida privada. Macció retoma la valoración de los otros sobre la mujer cuando señala "si la rompo/ me dicen loca”, además de que esta modalidad de lo femenino vinculada a las flores, los vestidos con puntillas y la ternura aparece como maldición según indica el final del poema, homologando el gesto de romper la figurita con la superstición popular según la cual romper un espejo trae siete años de mala suerte.

Vanna Andreini presenta una variante de esta idea en un poema de bruciate / quemadas donde la muñeca deviene directamente un dictador:

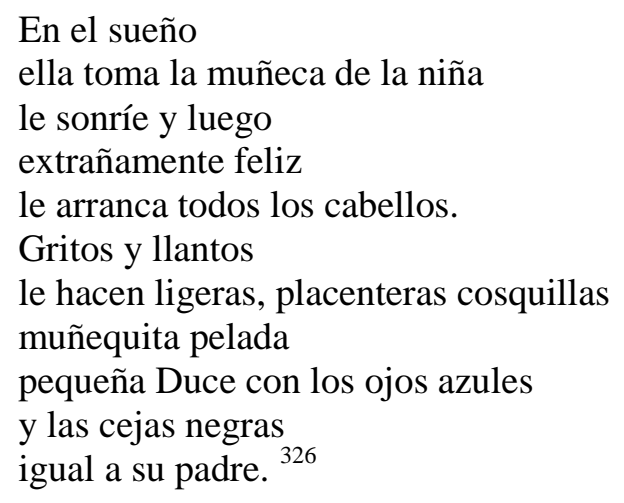

El texto establece un juego de espejos entre una “ella” que sueña, una niña y una muñeca. Pero la cadena de identificaciones entre mujeres se rompe porque cuando se le arrancan los cabellos a la muñeca, lo que se descubre debajo de la apariencia femenina es la figura del padre, con lo cual la muñeca se convierte en una especie de caballo de

\footnotetext{
${ }^{326}$ Vanna Andreini, bruciate / quemadas, Siesta, 1998 (39). Todas las citas posteriores están tomadas de la misma edición.
} 
Troya dentro del que se oculta para infiltrarse, revestida de ingenuidad, la autoridad masculina y paterna.

Así, la figura de la muñeca encierra un grado de violencia que también se encuentra en los poemas aniñados de Mariasch, y por eso sus textos no intentan "romper” la figura sino habitarla para subvertirla, poniendo de relieve lo que hay de terrorífico en ella. A mitad de camino entre la muñeca y el monstruo, sus personajes que en algunos casos enuncian los poemas- son zarinas-niñas (Mariasch: 1997, 29), en el primer poema de Coming attractions que citamos, y muñecas que se llaman Plurabelle (Mariasch: 1997, 39), Frankenstein (Mariasch: 1997, 21), o Paraíso (Mariasch: 1997, 17). Una de las funciones de las muñecas es la de convertir el espacio doméstico, identificado socialmente como el lugar de lo femenino, en un espacio fantástico (“creo que estamos en Oz”, decía el primer poema de Coming attractions; Mariasch: 1997, 9) que coincide con la práctica infantil de "jugar a la casita”. La conversión de la casa -que aquí no se presenta en clave "realista"- en una casa de juegos más cercana al universo de los cuentos de hadas tiene por objeto poner de relieve lo que hay de potencialmente siniestro en un "hogar”, que deviene en el desplazamiento a lo fantástico un espacio cargado de peligro.

En ese sentido es significativa la serie que da título al libro porque el primer poema introduce a una niña llamada sugestivamente Paraíso: "Paraíso había salido Princesa Fotogénica en un certamen de belleza. Serpentinas, papel picado, brillantina cayeron sobre su cabeza.// Paraíso es una nena con olor a mandarinas de las tres. Teje macramé, come cenas de TV, tose a veces, cuenta gotas (...)” (Mariasch: 1997, 17). El segundo consiste en una enumeración de objetos cotidianos que conforman la normalidad de la vida doméstica, pero con agregados cuya intromisión en la secuencia altera esa normalidad: “descubrir los almidones, la ropa de blanco, ropa de cama./ los 
camisones, las sábanas, salto de cama./ (...) escarabajos, cartas, sellos./ la estantería, ropa de cama, salto de rana./ garabatos, escuadrones, sellos, cartas./ tenedores, corazones, cucharitas./ servilletas./ estampillas, escorpiones, sábanas” (Mariasch: 1997, 18).

El tercer poema de la serie pone en escena la miniatura como modo de desnaturalizar lo doméstico y femenino, que sustrae los objetos al uso regular y los destina a un tipo de uso diferente, lúdico:

Planchaba camisas en miniatura y las guardaba en cofres con candado.

(children know something they can't tell).

“Tengo frío y una estufa eléctrica”.

Tomaban té de a una, ella y Paraíso.

Una mañana, dio vuelta un souvenir de San Francisco y la nieve cubrió sus trinos.

"-Siento deseos de huir hacia un país más hospitalario y, al mismo tiempo, busco bajo mis ropas un puñal.” (Mariasch: 1997, 19).

La disposición de los textos en la serie es elocuente porque desde el principio se plantea un escenario infantil habitado por una niña que realiza actividades domésticas como si fueran juegos - una situación similar a las de las “figuritas Sara Key” con que trabaja Macció- y cuyo nombre, Paraíso, instala la idea de la vida doméstica como lugar de aislamiento idealizado, que puede pensarse también desde la figura de la bola de nieve presente en el poema recién citado. Sin embargo en ese lugar también hay, entre las sábanas y las tazas, “escorpiones” y “escuadrones”, como lo enuncia el segundo poema. Quizás por eso en este último texto la cita de Los poseídos entre lilas del final (Pizarnik: 1994, 264) plantea un deseo de huida que ya estaba presente en el primer poema de Coming attractions; al mismo tiempo, la frase escamoteada de Pizarnik "busco bajo mis ropas un puñal” pone de manifiesto al segundo poema de la serie como modo de desplegar en el espacio doméstico esta idea de violencia agazapada bajo una superficie, 
que en Pizarnik es la ropa y en Mariasch los objetos más triviales que componen una casa.

De esta manera, las poetas de los noventa traman colectivamente un discurso infantilizado que funciona como respuesta a esos hombres que les dicen "niña”, como se pone de manifiesto en el poema de Mallol. El gesto es el de apropiarse de esa posición subordinada que implica una relación de poder, cifrada en esta idea de ser hijas o incluso, como dice Mariasch, “mascotas”.

Hacer sapito de Verónica Viola Fisher es un libro donde esta articulación es central, ya que la que habla se posiciona como hija pero también reproduce la voz del padre y en esa voz, el mandato de estar en silencio: “con mierda hay que limpiarles/ la boca/ antes de hablar/ de mí porque soy yo/ el único/ que supo conseguir, los laureles/ y las hará jugar/ con gloria/ conglomerado de conchas/ vos, tu madre, tu abuela/ mi futura nieta seguir/ calladas”. ${ }^{327}$ En este poema, la voz del padre se confunde con la voz del estado representada por el Himno Nacional para enunciar una violencia sobre el cuerpo de la mujer que supone anularle la voz. Pero el mandato no se acata en Hacer sapito sino que por el contrario, la voz de la hija es la que hace visible tanto la violencia de la autoridad paterna como el carácter apariencial de la “casa” que aquí, a diferencia de Mariasch, cobra el doble sentido de hogar y de institución: "Mi casa es una entera/ casca/ miento porque al quebrarse/ estaba llena de jugo/ podrido y casca/ es hollejo/ solamente corteza/ de las uvas se hace/ el vino de mi casa/ es sangre” (Viola Fisher: 1995, 15).

La operación es distinta porque si en Mariasch y Macció las figuraciones de lo femenino, la familia y el hogar se construyen desde el artificio de una casa en miniatura o de una figurita, tanto en Andreini como en Viola Fisher es una voz lírica la que

\footnotetext{
${ }^{327}$ Verónica Viola Fisher, Hacer sapito, Buenos Aires, Nusud, 1995 (13). Todas las citas posteriores están tomadas de la misma edición.
} 
enuncia sin la mediación de personajes una determinada perspectiva sobre lo femenino, aunque en el último caso el discurso poético se haga permeable al discurso paterno. En Viola Fisher hay incluso un trabajo de corte sobre la lengua que funciona como modo de potenciar una violencia que se atribuye a la institución familiar, como cuando en el poema recién citado se reemplaza “casamiento” por “casca/ miento”. Además, los cortes sobre la lengua tienen su correlato en otro tipo de cortes simbólicos que el discurso dominante masculino ejerce sobre el cuerpo de la mujer: "Es mujer/ es gorda/ rosadita tiene/ en la muñeca/ de trapo/ guarda/ aceite de ballena/ qué pena/ sin pene/ nació” (Viola Fisher: 1995, 25). ${ }^{328}$

328 Si bien no trabajamos en esta tesis de manera extensiva la poesía de Martín Rodríguez, podrían pensarse sus textos, sobre todo los de sus dos primeros libros, Agua negra (Siesta: 1998) y Natatorio (Siesta: 2001), en esta línea de escrituras de la intimidad que ponen en escena las relaciones familiares, en ocasiones desde voces aniñadas. Rodríguez, como Viola Fisher, trabaja sobre la politización del espacio doméstico y el modo de disputar el poder entre padres e hijos (“estoy marcado a fuego/ por la guerra familiar”, dice en un poema: Rodríguez: 2001, 71), construyendo en este caso una voz que es simultáneamente de niño y adulto porque la infancia se cuenta en presente pero se analiza críticamente desde otro lugar; en sus libros también se representa la figura paterna alternativamente agigantada o encogida ("con los brazos caídos, papá/ parecés una bolsa de papas o un toro/ ¿vos construiste edificios?/ ¿la corteza dura de las casas/ piedra sobre piedra? no llego a vos/ estás alto, la armadura reluce/ como una estrella fría”; Rodríguez: 1998, 22), y se condensa en ella el cruce entre lo público y lo privado: "dormido papá es un auto viejo/ la gran industria la política la familia/ rompió y soldó lo roto dentro suyo" (Rodríguez: 1998, 23). Por lo tanto, en su poesía, la idea de sujetos e individuos que se constituyen al margen de lo político se pone en cuestión, como en Viola Fisher. Pero además se incorpora a la madre, que en Hacer sapito aparecía desplazada por la voz hegemónica del padre: "mientras mamá toma sol/ apoyada en un árbol, yo junto huesos/ tirados por ahí: de perro, de vaca o cabra/ y los pongo en una bolsa./ huesos pelados/ alrededor de mamá o del sol/ que toma/ la forma de su cara/ y su cuerpo,/ si la mirás fijo/ te cegás, si le hablás/ te saca la voz./ huesos alrededor del sol/ que usa su cuerpo/ te quema/ o te separa en partes/ disecadas, tiradas en el pasto./ animales que llegaron hasta/ el borde y pusieron la pata en ella/ y se quemaron vivos, cayeron,/ después de tocarla/ aprendí a mirarla de lejos/ mientras toma sol o le da/ al sol su forma/ le quita el poder” (Rodríguez: 1998, 42). Este poema es útil para leer el procedimiento compositivo en los poemas de Rodríguez, porque aquí se trata del plegado metafórico de las imágenes unas en las otras: el poema parece partir de una situación cotidiana, o del recuerdo presentificado de la infancia puesto en la voz de un niño, pero enseguida el verso "mamá o el sol” superpone las dos figuras en una y les otorga un carácter simbólico, de modo que el poder de la madre se pone en los términos de la fuerza solar; a su vez, esos "huesos" que recogía el niño pasan a ser las partes de su propio cuerpo desmembrado por el poder, mítico, de la madre (que además se compara con una figura como el sol, tradicionalmente masculina).

En relación a esto, como en Viola Fisher se asimila la voz autoritaria del padre a la voz del estado, en Rodríguez se vuelve insistentemente sobre la idea de que el lenguaje que construyen los textos para dar cuenta de la intimidad es siempre público, "civil” incluso, como dice un 
Como se ve, la figura de la muñeca también está presente en Hacer sapito y en

otro poema se llama Barbie:

\author{
Le dije la quería Barbie \\ y ella \\ estúpidamente \\ se dejó crecer \\ la barba \\ Como vos papito \\ me chilló \\ Le dije que la quería \\ menos \\ que antes \\ yo jugaba con Barbies \\ cuando era pibe \\ pero ella \\ no entiende \\ estúpidamente juega \\ a la pelota qué \\ mal la puse
}

poema ("en este ambiente cuadrado y en esta/ dimensión civil en la que hablamos/ un lenguaje directo/ y frío y lento"; Rodríguez: 1998, 54). Pero la escritura de Rodríguez recupera una obra casi totalmente omitida en el armado de tradición de los noventa como es la de Juan Gelman; de hecho, ciertos poemas de Agua negra pueden leerse como reescritura de Carta a mi madre de Gelman (1989) donde el diálogo con la madre, puntuado por preguntas, funciona como modo de reflexionar también sobre la institución familiar y la propia escritura. Así, como Gelman se pregunta en este poema, o pregunta a la madre muerta, “¿por eso escribo versos? / ¿para volver// al vientre donde toda palabra va a nacer? / ¿por// hilo tenue? / la poesía ¿es simulacro de vos? / ¿tus// penas y tus goces? / te destruís conmigo como// palabra en la palabra? / ¿por eso escribo versos? // ¿te destruyo así pues? / ¿nunca me nacerás? / ¿las// palabras son estas cenizas de adunarnos?”. En Juan Gelman, Carta a mi madre, Buenos Aires, Libros de Tierra Firme, 1989 (22), Rodríguez arma el poema como diálogo con los padres, que adquieren una dimensión mítica (“ya no tengo culpa ni compasión/ ¿está bien? ¿hice bien en decirlo/ mamá?”; Rodríguez; 1998, 47; "cuerpos entre piezas de una casa/ cuando se cierra el sentido, así siempre:/ girar en el principio, ¿¿sí? ¿es así/ mamá?”; Rodríguez: 1998, 56). Pero esta dimensión habilitada por el lenguaje no sólo los agiganta o empequeñece, los hace maleables, como en el poema antes mencionado, sino que permite subvertir la autoridad cuando se dice irónicamente al padre, asimilado tanto a un "animal” como la familia a un ejército: "padre, desde acá se escucha cómo/ le das a ese animal/ su aullido su chirrido: se sudan/ las paredes por vos, padre/ que sos máquina de bombear/ a mi animal preferido/ te torea la hembra te embiste/ pero vos le metés/ y le das así se te queda/ en los brazos, a tus brazos sale/ rendida y todos los hijos varones/ en fila marcial aplaudimos/ cómo domesticás/ te llevás el título” (Rodríguez: 2001, 36).

La recuperación de Gelman en Rodríguez, y lo que se recorta de esta obra, es importante también para pensar un nuevo modo de plantear lo político en los noventa, que está tanto en Rodríguez como en Viola Fisher y otras poetas abordadas en este capítulo. Porque ya no se trata, por supuesto, de pensarlo en términos referenciales o en la remisión a un proyecto colectivo -que de hecho articula la poesía política de Gelman y ya en los noventa es inexistente- sino de hacer foco sobre el modo en que las relaciones de poder se construyen en el espacio privado y se distribuyen en el lenguaje. Para otra lectura sobre las figuraciones de lo político en Martín Rodríguez, ver Marcelo Díaz, "Estoy completo, sé lo que me falta. Notas sobre la poesía de Martín Rodríguez, de Agua Negra a Maternidad Sardá”, en Revista Otra Parte $\mathrm{N}^{\mathrm{o}}$ 24, primavera 2011. 


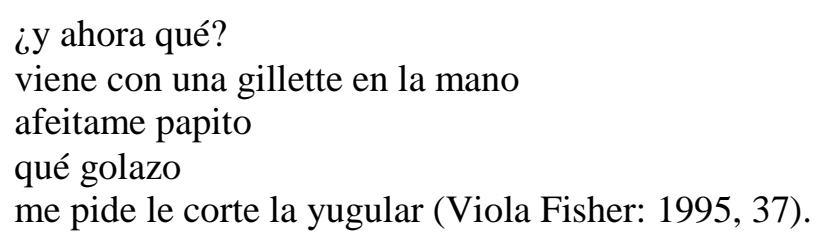

En este caso, jugar a las muñecas y jugar a la pelota aparecen como simplificación extrema de los roles atribuidos socialmente a los niños y las niñas, y el poema señala que el varón -que en Viola Fisher siempre es el padre, y en este caso el que enuncia el poema- puede apropiarse de ambos tipos de juego ("yo jugaba con Barbies/ cuando era pibe”) pero a la mujer no se le permite hacer lo mismo (“estúpidamente juega/ a la pelota”). En cierta forma lo que se plantea en el texto es que ser mujer es imposible, porque el mandato del padre le indica que debe parecerse a él (“qué pena/ sin pene/ nació”, señalaba el poema anterior) pero a la vez aquí la hija, que se deja crecer la barba, merece la condena del padre por malinterpretar la orden implícita cuando el padre dice "Barbie".

Lo que los textos ponen en escena de diversos modos es el entramado discursivo que construye el lugar de la mujer como género que no se define de manera esencialista sino a través de relaciones de poder tanto públicas como privadas. En esta estela crítica, en El género en disputa Judith Butler se pregunta si hay una especificidad de lo femenino que exista al margen de la oposición binaria masculino/femenino y que sea universal (Butler: 2007, 50). Y lo que encuentra es que son las estructuras jurídicas del lenguaje y de la política las que crean el campo de poder dentro del cual lo femenino se define (Butler: 2007, 52). Las poetas de los noventa intervienen precisamente en ese campo de poder en la medida en que evalúan críticamente las diversas implicaciones de la categoría “mujer” en sus variantes de “chica”, "hija”, “madre” y "niña” como términos que anudan relaciones institucionales, legales, familiares y jurídicas. Por eso, más que la construcción de subjetividades femeninas, lo que se lee en este corpus de textos es una operación sobre el género como experiencia “discursivamente 
determinada", para decirlo en los términos de Butler, “cuyos límites siempre se establecen dentro de los términos de un discurso cultural hegemónico basado en estructuras binarias que se manifiestan como el lenguaje de la racionalidad universal” (Butler: 2007, 59).

Pero mientras que Viola Fisher y Andreini trabajan sobre los estereotipos femeninos desde un imaginario que incluye a lo masculino como parte de la oposición binaria planteada por Butler, y donde la voz y la figura del padre están presentes -lo que puede relacionarse con el hecho de que trabajen a partir de voces líricas y de sujetos “reales”, como señalaba Hamburger, que ponen en escena una experiencia, aunque se valgan de objetos que tienen valor metafórico- Mariasch plantea una huida hacia un espacio fantástico en el cual "Los peces son la mamá”, como declara el primer poema de Coming attractions (Mariasch: 1997, 9), y también hacia una voz que se propone como artificio. La operación es conciente y se repite en "zarina”, donde se dice que "En los cuentos infantiles/ todas las niñas son huérfanas” (Mariasch: 1997, 31). La diferencia puede verse también en el modo en que Macció trabaja con la "figurita Sara Key” en tanto objeto, que tiene evidentemente una carga simbólica pero que supone una distancia con respecto al sujeto que en Mariasch se anula, porque la muñeca no sólo se contempla y manipula sino que se la habita y se le da una voz.

De todas formas, ambos tipos de voces comparten la apelación a la muñeca como figura que permite abordar lo femenino desde el artificio. Pero en poéticas como las de Mariasch en Coming attractions y Mallol en Polaroid, donde la enunciación está muchas veces a cargo de personajes, el estatuto de lo femenino como identidad fluctuante y a veces incluso vacía se extrema en la multiplicación de las figuras que se usan para representarse, como parte de una estrategia que incluye a su vez reescrituras de Pizarnik y en particular del poema "Formas", ya mencionado: "no sé si pájaro o 
jaula/ mano asesina/ o joven muerta entre cirios/ o amazona jadeando en la gran garganta oscura/ o silenciosa/ pero tal vez oral como una fuente/ tal vez juglar/ o princesa en la torre más alta” (Pizarnik: 1994, 110). Mariasch retoma estas figuras provenientes de una voz lírica en dos poemas: en “zarinas”, donde la niña que habla dice que "ya no soy ni payaso, ni amazona” (Mariasch: 1997, 30), y en otro texto protagonizado por una muñeca llamada Frankenstein que dice en un momento "Soy sirena o soldado/ alternativamente” (Mariasch: 1997, 22). Mallol por su parte, en "Wonder Woman or Suicide Blonde”, dedicado a Mariasch, reelabora los versos de Pizarnik en un texto que comienza, de nuevo, con la reproducción de una mirada masculina ("Me dicen/ la chica/ Para Ti”) y que plantea lo femenino como identidades móviles que se resumen en el "maquillaje”: “Oral/ Juglar/ Animal/ cubro/ necesidades vitales mínimas:/ (...) Mi cuerpo es/ una auténtica/ arma de guerra/ (puedo ser/ la que tú quieras, mi amor,/ sólo necesito/ algo de plata/ algo de tiempo/ pour faire le maquillage)” (Mallol: 2001, 77-79).

Lo que en el texto de Pizarnik aparecía claramente como una serie de figuras, de “formas” como señala el título, entre las cuales el sujeto de la enunciación parecía creerse compelido a optar (porque hablaba desde un no saber, ese "no sé” manifestado en el primer verso), en Mariasch y Mallol no se consigna desde la incertidumbre sino, en un sentido positivo, como posibilidad. En estas poetas de hecho no parece haber nada que "saber”, sino que más bien se trata de entregarse al juego de ser o parecer (que en los poemas es exactamente lo mismo) una y otra cosa alternativamente, incluso cuando se le dice al hombre, en este último poema de Mallol, "puedo ser/ la que tú quieras”. Porque lo femenino aparece en los noventa como disfraz y maquillaje, así como la mujer -o el sujeto que está debajo de aquello que se define culturalmente como “mujer” - se caracteriza por el ocultamiento. 
Esta concepción de lo femenino habilita el recorte de una variante de la muñeca que Mariasch comparte con Roberta Iannamico: la de la mamushka, esa serie de muñecas rusas huecas que se encajan una dentro de la otra. Dice Mariasch: "Si me escondo en una muñeca,/ dentro de otra, y así,/ seré una matriushka/ y me uniré al circo que recorre el mundo” (Mariasch: 1997, 30). En Mariasch, la posibilidad de devenir una muñeca escondida en otras está asociada con la perspectiva de huir para "recorrer el mundo" (la alternativa entre quedarse quieta o fugarse es recurrente en sus poemas, como hemos visto). Iannamico por su parte construye sus mamushkas como superposición de capas donde ninguna puede considerarse "Madre” con mayúsculas, como modo de anular la autoridad que en Mariasch se realizaba en una serie de muñecas y de niñas "huérfanas":

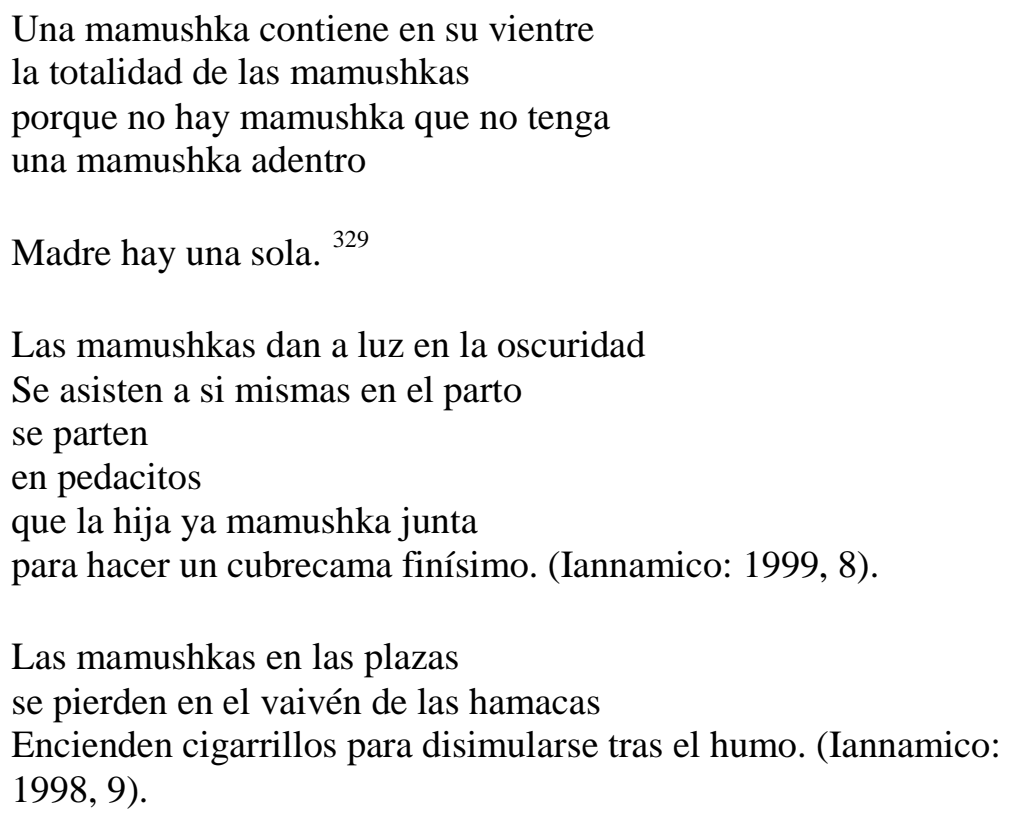

Si “Madre hay una sola”, como dice el refrán que acá se cita, Iannamico la desvía al elegir una figura que es múltiple, fragmentaria, y que desmiente la posibilidad de que exista un modelo único y estable. Como señala Tamara Kamenszain al leer este poema en La boca del testimonio, "La especie mamushka, entonces, puede ser entendida como

${ }^{329}$ Roberta Iannamico, Mamushkas, Bahía Blanca, Ediciones Vox, 1999 (7). Todas las citas posteriores están tomadas de la misma edición. 
lo que en la madre se resiste a quedar congelado en el estereotipo Madre. Esa condición subversiva es la que las mamushkas esconden cuando circulan en público" (Kamenszain: 2007, 156).

La mamushkas en tanto objeto vacío y múltiple formado por muchas muñecas que son pura superficie dan lugar a acciones posibles como partirlas y armar con los fragmentos “un cubrecama finísimo”, y también “disimularse tras el humo”. Iannamico vuelve una y otra vez sobre el tópico de lo femenino como simulacro, por ejemplo en un poema de El collar de fideos donde se mira al espejo vistiendo "una polera negra/ y un saco de lana/ violeta/ encima de todo/ como una capa/ como un gran pétalo/ como si yo fuera/ una flor nocturna/ que resplandece/ a la luz de la luna/ y disimula/ a la luz del sol”. ${ }^{330}$ La imagen no es además otra cosa que un reflejo sobre una superficie espejada que permite imaginar una modalidad "nocturna" de lo femenino que se sustrae a la vida doméstica y diurna, donde se “disimula”. En otro poema del mismo libro donde se adopta una voz de niña, la que habla expresa el deseo de “dar un portazo” y salir corriendo para llorar en público:

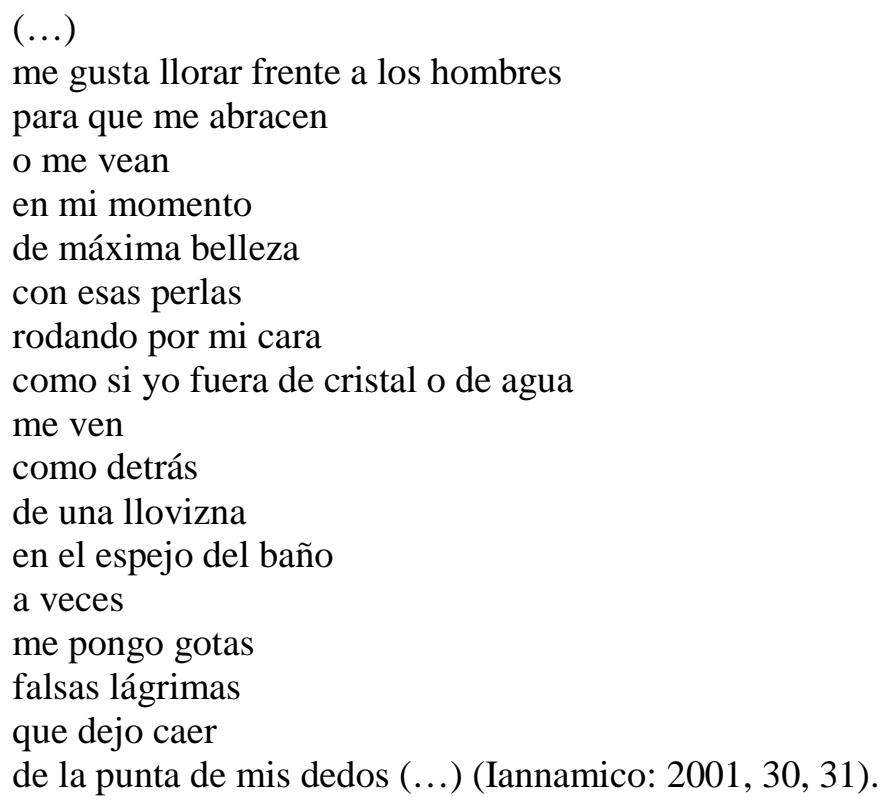

\footnotetext{
${ }^{330}$ Roberta Iannamico, El collar de fideos, Bahía Blanca, Ediciones Vox, 2001. Todas las citas posteriores están tomadas de la misma edición.
} 
El llanto aparece aquí no tanto como emoción sino como estrategia casi teatral que aspira a conseguir la atención de los hombres cuya mirada sobre la mujer permanece velada en el poema (“me ven/ como detrás/ de una llovizna”), además de que se alude a “falsas lágrimas”. De esta manera el poema subvierte la idea de “expresión” de una interioridad porque de lo que se trata es de una puesta en escena artificial, destinada a los otros.

No hay, en este poema de Iannamico, un gesto de hacer visible una interioridad como podría esperarse en una poética pensada como lírica, sino que el texto se concentra únicamente en lo visible como superficie cuya exhibición puede tener un determinado efecto. Además la exhibición aparece ligada al ocultamiento, porque las lágrimas se muestran pero al mismo tiempo ocultan a la que llora; a su vez, las "falsas lágrimas” frente -una vez más- al espejo, sugieren una figura de la mujer como actriz que aquí no tiene las connotaciones negativas que comporta la frase popular "lágrimas de cocodrilo" (siempre referida a las mujeres) sino que funciona más bien como modo de manipular y sabotear un estereotipo femenino vinculado siempre con las emociones, que aparecía también en la exaltación del “deseo” que ahogaba a las chicas en el poema de Wajszczuk (Wajszczuk: 1999) y en el suplicante pero impostado “¡Ámame!” de Mariasch (Mariasch: 1997, 27).

El maquillaje, lo teatral y hasta lo cinematográfico son entonces la segunda modalidad en que se representa lo femenino, que en ocasiones se articula con la primera modalidad miniaturizada que hemos analizado, centrada en la figura de la muñeca. La operación crítica más radical sobre el género consiste en este sentido en ponerlo de manifiesto como una identidad "instaurada en un espacio exterior mediante una reiteración estilizada de actos” (Butler: 2007, 273) por la cual ser mujer podría no ser otra cosa que actuar como tal (en el doble sentido de “acción” y de “actuación”). Lo 
que se establece de modo definitivo es que no hay una "esencia” naturalizada de lo femenino sino que más bien, como señala Butler, el género se constituye en actos orientados hacia el exterior:

Dichos actos, gestos y realizaciones -por lo general- son performativos en el sentido de que la esencia o la identidad que pretenden afirmar son invenciones fabricadas y preservadas mediante signos corpóreos y otros medios discursivos. El hecho de que el cuerpo con género sea performativo muestra que no tiene una posición ontológica distinta de los diversos actos que conforman su realidad. Esto también indica que si dicha realidad se inventa como una esencia interior, esa misma interioridad es un efecto y una función de un discurso decididamente público y social, la regulación pública de la fantasía mediante la política de superficie del cuerpo, el control fronterizo del género que distingue lo interno de lo externo, e instaura de esta forma la «integridad» del sujeto. En efecto, los actos y los gestos, los deseos organizados y realizados, crean la ilusión de un núcleo de género interior y organizador, ilusión preservada mediante el discurso con el propósito de regular la sexualidad dentro del marco obligatorio de la heterosexualidad reproductiva (Butler: 2007, 266).

Por eso en estas poéticas no hay “expresión” de una interioridad que, como señala Butler, no sería más que una construcción ilusoria producida por actos visibles; en realidad, esta idea se invierte porque lo femenino se desnaturaliza al presentarlo como una serie de gestos performáticos, y en el mismo movimiento lo que sería propio de una intimidad constituida de forma privada se politiza al plantearse como producto de una construcción “pública y social”, como señala el fragmento recién citado.

Esta construcción también es una tradición en el sentido planteado por Raymond Williams (Williams: 1997), porque se constituye en el ejercicio de selección y recorte sobre diversos modos de figurar y significar lo femenino llevado a cabo por instituciones como la escuela y la familia, formaciones culturales, medios de comunicación, medios discursivos y legales, cuyo funcionamiento como “máquina selectiva” tiende a legitimar ciertos significados al mismo tiempo que se excluyen otros. La intervención mayor de las poetas de los noventa en los textos que hemos analizado es justamente sobre esta tradición, que en el trabajo con los estereotipos se revela como ideológica. 
Desde esta perspectiva, y teniendo en cuenta lo señalado por Butler a propósito de la "interioridad" entendida como efecto de lo social, cobra sentido también el paso de la poesía concebida como lírica a una poesía que se presenta como artificio, un artificio que se tematiza, como dijimos, bajo la forma del maquillaje. Porque "parecer” una mujer, que quizás es todo lo que hay, es algo que se aprende y se incorpora de diversos modos, como se señala en "zarina” de Mariasch: "todas las niñas aprenden/ la ciencia de usar vestidos:/ ellas saben algo/ que no pueden revelar” (Mariasch: 1997, 29, 30). El mismo poema señala más adelante que "Nos maquillamos tanto tiempo/ para ver llegar los trenes” (Mariasch: 1997, 30, 31). Y Karina Macció vuelve sobre la idea cuando postula al cuerpo femenino como reproducción seriada que se vincula al mundo del consumo:

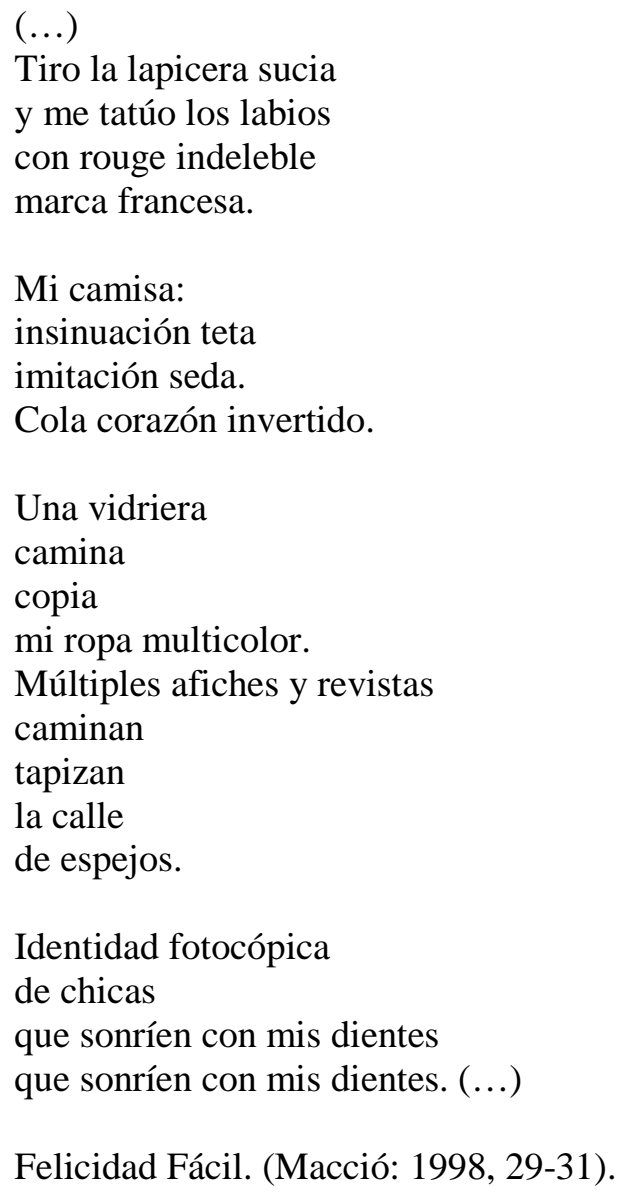

Felicidad Fácil. (Macció: 1998, 29-31).

Como muestra el poema, ser mujer puede ser tatuarse los labios como variante del maquillaje que marcaría al cuerpo como femenino de modo permanente, pero la 
identidad sigue siendo un asunto de “imitación” e "insinuación” que se plasma en superficies reflejantes, ya sea la vidriera o las revistas que reproducen hasta el infinito un estereotipo femenino que se vuelve modélico en su ubicuidad.

Por eso Mallol, en consonancia con esta idea del género como performatividad sobre una superficie, propone la figura de la travesti o la drag queen en tanto cuerpo que extrema la divergencia entre interioridad y exterioridad: "Pestañas/ postizas/ de azul metalizado./ En los labios/ brillitos de chivré/ al tono./ Y plumas,/ muchas plumas./ Hombre/ vestido de azul/ oculto/ por el taco aguja/ de sandalia/ (cherchez la femme) (...)” (Mallol: 2001, 33). En este caso la última expresión en francés, típica del género pulp fiction norteamericano como modo de indicar que siempre que un hombre está en problemas habría una mujer involucrada (la famosa "femme fatale" del policial negro), sugiere que si se trata de "buscar a la mujer” habrá que hacerlo en las pestañas postizas y los brillos bajo los cuales hay un cuerpo que desmiente de modo definitivo la concordancia entre sexo y género. La presencia de la figura de la travesti en el espectro de representaciones femeninas que abren estas poéticas es significativa porque como señala Judith Butler, “Al imitar el género, la travestida manifiesta de forma implícita la estructura imitativa del género en sí, así como su contingencia.” (Butler: 2007, 269).

Entonces, si lo femenino se construye como superficie y a través de gestos performáticos, la posibilidad de que haya algo así como una “enunciación femenina” de la que hablaban Prieto y Monteleone en las citas al principio de este capítulo se pone en cuestión de modo radical. Por eso la operación de las poetas de los noventa consiste en habitar y manipular los estereotipos hasta hacerlos estallar, con lo que se liquida la posibilidad de que se constituyan escrituras "femeninas", o al menos que lo hagan sin tomar en cuenta la desnaturalización definitiva del término y sus significaciones sociales que se lleva a cabo en estos textos. Lo que hay, antes que una "enunciación 
femenina”, es una puesta en escena crítica de lo femenino como categoría, en escrituras que en realidad se fugan de la posibilidad de ser encasilladas como poesía de género porque llevan la categoría, mediante la exasperación de lo artificial, a un extremo que termina por anularla. De hecho en su segundo libro Marina Mariasch, como reconociendo la clausura del gesto inicial que hemos analizado, declara: “¿Hay algo que pueda hacer callar/ a esa chica? Detesto/ oír hablar a las chicas.”, ${ }^{331}$ y agrega en otro poema: “¿quién iba a querer/ ser mujer y escribir/ como las mujeres?” (Mariasch: 2001, 37).

Y Vanna Andreini, como si se tratara de un ritual que cierra toda una modalidad discursiva sobre lo femenino asociada a la muñeca y el simulacro que aquí hemos desplegado y que tenía su antecedente, como vimos, sobre todo en la prosa de Alejandra Pizarnik, recupera la dicción de esta poeta en un texto que comienza "He hecho algo contra el miedo/ he terminado su muerte”, y en el que se describe luego cómo alguien maquilla a una muñeca, le pone "base tostado/ rubor/ gris metalizado/ pestañas postizas", le pinta los labios y termina por decirle: "he terminado/ estás preciosa,/ ya podés irte.” (Andreini: 1998, 21-23).

\section{4- MUÑECAS POP}

El trabajo con el género como una serie de actos y gestos performáticos que se plasman en una superficie da cuenta de un desplazamiento con respecto a los modos de pensar la subjetividad, como adelantamos al diferenciar entre voz lírica -con sus

\footnotetext{
${ }^{331}$ Marina Mariasch, $X X X$, Buenos Aires, Siesta, 2001 (14). Todas las citas posteriores están tomadas de la misma edición.
} 
implicaciones de "interioridad” y “exterioridad”, que tienen su correlato en el par de términos “profundidad” y “superficie”- y el uso de máscaras y personajes para enunciar el poema. En efecto, aquí está prácticamente ausente la idea de un sujeto que se construye de modo secreto, invisible, y cuya interioridad se hace visible en el texto. Este modo de pensar la conformación de la subjetividad es propio de la modernidad, como señala Paula Sibilia, y tiene su manifestación literaria en las narrativas del “yo” que conciben la producción del sujeto a partir del ejercicio de introspección. ${ }^{332}$ Esta idea de individuos que escribirían para sumergirse en "los misterios más insondables de sus almas” (Sibilia: 2008, 76) halla su correlato en la separación entre la vida pública y la esfera de lo privado, también moderna, que planteaba al hogar como "el territorio de la autenticidad y de la verdad: un refugio donde el yo se sentía resguardado, donde estaba permitido ser uno mismo” (Sibilia: 2008, 74). Pero al proponer representaciones miniaturizadas de la vida doméstica y familiar que se oponen drásticamente a esta idea de "refugio" y a su vez tienden lazos entre lo público y lo privado, las poéticas que analizamos ponen en cuestión las nociones de autenticidad vinculadas al espacio íntimo y privado, especialmente porque operan sobre objetos y significantes ya socialmente connotados como la niña, la muñeca y los diversos modos de nombrar y situar a las mujeres en un campo de relaciones de poder.

En este sentido se trata de poéticas que forman parte del "gran desplazamiento histórico del eje de la subjetividad” del que se ocupa Sibilia en La intimidad como

\footnotetext{
${ }^{332}$ Paula Sibilia, La intimidad como espectáculo, Buenos Aires, Fondo de Cultura Económica, 2008 (76, 77). Fredric Jameson también se ocupa de esta mutación en el modo de concebir la subjetividad en El posmodernismo o la lógica cultural del capitalismo avanzado, Barcelona, Paidós, 1991 (30-32). Allí Jameson distingue entre la concepción moderna de la subjetividad como envoltura monádica en cuyo interior se sienten las cosas y desde donde se expresan proyectándose al exterior, y el sujeto descentrado y fragmentado que caracterizaría a la posmodernidad, con la consecuente despersonalización de los sentimientos. Sin embargo, no acordamos del todo con esta idea de "despersonalización" puesto que implica un análisis de las nuevas subjetividades referido todavía al concepto moderno de "persona" que el mismo Jameson describe.
} 
espectáculo. Para la autora, el corte en la historia que supone el paso del régimen de poder propio de la modernidad y el capitalismo industrial a otro proyecto político, sociocultural y económico que Deleuze denomina “sociedades de control”, apoyado en las tecnologías electrónicas y digitales, donde rigen el consumo, el marketing y la publicidad (Sibilia: 2008, 21), da lugar a una mutación en las subjetividades que las orienta hacia el exterior y las estimula a construirse de manera visible en nuevos medios como los blogs, las redes sociales y otros soportes tecnológicos más o menos novedosos. Al mismo tiempo, se pone de manifiesto como nunca antes el hecho de que la subjetividad no es algo vagamente inmaterial que reside “dentro” del individuo sino que está tanto embodied, encarnada en un cuerpo, como embedded, es decir, “embebida en una cultura intersubjetiva” (Sibilia: 2008, 20).

En consonancia con esto, las poetas de los noventa piensan la subjetividad e identidad en términos de capas y superficies (como lo muestra la figura de la mamushka y la alusión recurrente a los espejos y vidrieras) pero que no ocultan nada en su interior como "secreto" sino que más bien, constituyen por sí mismas el espacio en que se inscribe el sujeto. A su vez, como apelan a significantes que ya están socialmente marcados, no hay en sus textos (al menos en el recorte que aquí realizamos) una voluntad de vincular a la poesía de modo más o menos directo con la realidad -como sucedía con los objetivistas- sino que aquí se pone de relieve que se trabaja siempre sobre la mediación de códigos y objetos igualmente codificados. En este sentido (con la excepción de Roberta Iannamico, Verónica Viola Fisher y Vanna Andreini, quienes construyen voces que pueden considerarse "líricas" en el sentido explicitado por Käte Hamburger) se trata de poéticas que presentan rasgos asociados al pop, incluso en el tratamiento del género que hemos analizado. 
Porque así como el arte pop pone en escena el problema de la relación entre el original y la copia, para Judith Butler la noción performativa del género no presupone que haya un original imitado por una serie de identidades paródicas sino que más bien se da un cuestionamiento radical de la noción de “originalidad”. El género concebido como parodia del género supone que la identidad primaria sobre la que se apoya cualquier tipo de construcción es una "imitación sin un origen”. O, también en términos de Butler, es una producción que "se presenta como una imitación” (Butler: 2007, 269). Butler recupera positivamente esta idea de inexistencia de un original porque, lejos de toda nostalgia por un origen o de cualquier visión negativa sobre las nociones de “imitación” y “copia”, encuentra un potencial liberador en este modo de conformación del género -que puede pensarse también para las subjetividades- cuando señala que “Este desplazamiento permanente conforma una fluidez de identidades que propone abrirse a la resignificación y la recontextualización; la multiplicación paródica impide a la cultura hegemónica y a su crítica confirmar la existencia de identidades de género esencialistas o naturalizadas.” (Butler: 2007, 269).

Este planteo en torno a la relación entre la copia y el original, así como también la cuestión de la pura superficie como alternativa al par binario profundidad/superficie que sería propio de un modo de pensar la subjetividad cuyos correlatos literarios abarcan desde el diario íntimo hasta la poesía lírica, vincula las escrituras que estamos analizando con ciertos rasgos del arte pop, como dijimos. No solamente porque en las poetas de los noventa las identidades femeninas se plantean como copias de copias reproducidas culturalmente, y la subjetividad puede encontrarse en los reflejos de una superficie vinculada al mundo del consumo como es una vidriera, sino también porque el pop, como se sabe, da por finalizada de modo drástico la separación entre alta cultura y cultura de masas que organiza la modernidad. En efecto, como señala Andreas 
Huyssen, si el arte moderno se constituyó a partir de la exclusión de la cultura de masas como una instancia consumista y opresiva con la que debía mantenerse una distancia crítica, el paradigma posmoderno supone una reformulación de las relaciones entre arte elevado y cultura de masas. ${ }^{333}$ A partir del pop, y sobre todo de las obras de Andy Warhol, Roy Liechtenstein, Tom Wesselmann y otros artistas plásticos de fines de la década del cincuenta y principios de los sesenta que abordaron el mundo del consumo y la reproducción de imágenes seriada, “el arte se hizo profano, concreto y adecuado para la recepción masiva” (Huyssen: 2002, 249).

Para Fredric Jameson, que describe la posmodernidad a partir de elementos que encuentra en parte en el arte pop, la disolución de los límites entre alta cultura y cultura de masas se manifiesta entre otras cosas en el hecho de que los productos de esta última ya no se citan sino que se incorporan a la esencia de la obra. ${ }^{334}$ Delfina Muschietti llamó la atención tempranamente sobre la presencia de este cambio en la poesía de los noventa cuando señaló:

No hay división entre la cultura alta y la cultura de masas en el trabajo del poema; pierden su diferencia, su partición. Esto sucede porque los jóvenes de los noventa tienen una relación con la cultura de masas muy diferente a la que se tenía en los setenta. Entonces se podía trabajar con la cultura de masas, pero con una distancia operacional, con un esfuerzo por incorporarla. En cambio, en el texto de un joven de los noventa, puede aparecer, naturalmente, una cita de Joyce junto a la figura del Betty Boop. ${ }^{335}$

Sin embargo esta afirmación no puede hacerse extensiva a la poesía de los noventa en su conjunto porque como hemos visto, en los objetivistas la cultura de masas está ausente a excepción de Fabián Casas, que prefigura su ingreso en alusiones

333 Andreas Huyssen, Después de la gran división. Modernismo, cultura de masas, posmodernismo., Buenos Aires, Adriana Hidalgo, 2002 (5-10).

${ }^{334}$ Fredric Jameson, El giro cultural. Escritos seleccionados sobre el posmodernismo, Buenos Aires, Manantial, $2002(16,17)$.

335 Delfina Muschietti, “Tecnorama: la poesía de los 90”, en Radar Libros, 18 de octubre de 1998. 
ocasionales a los comics (Casas: 1996, 23) o a objetos como una heladera de Coca Cola (Casas: 1990, 27) sin que estos materiales incidan en la organización del poema. En Rubio, Díaz, Ortiz y Raimondi se trata más bien de operaciones sobre la cultura popular (además de la visión negativa sobre los medios de comunicación que ofrecían los textos de Rubio), y en Martín Gambarotta, como analizamos en el capítulo anterior, el rock y la televisión se instalaban junto con una figura de poeta que experimentaba la relación entre literatura y cultura de masas como conflicto, al tiempo que incluía a esta última. En cambio en algunas poetas que abordamos en este capítulo, y sobre todo en Mariasch, Mallol y Freschi (más específicamente en su primer libro, Redondel) ${ }^{336}$ tiene lugar un ingreso masivo de estos materiales que ya no son solamente citas ocasionales sino que modifican la concepción de la poesía y su modo de pensarse en relación a una tradición. Sobre todo porque, como señala Mercedes Bunz a propósito del pop, lo que cambia es la ideología sobre la producción, que se separa definitivamente de cualquier idea romántica de creación “original” pero también de las figuras de poeta artesano y hasta del poeta que reelabora poéticamente su experiencia que hemos visto en capítulos anteriores. En el pop en cambio,

La reelaboración de material preexistente sustituye la antigua producción original de este. Los "escombros de la cultura" constituyen, por así decirlo, el futuro cercano de la producción. Porque, como casi siempre, la repetición de lo que ya existe es mucho más que una simple repetición. La repetición equivale aquí a un desplazamiento; consiste en una redistribución de los medios de producción. ${ }^{337}$

Si bien no puede decirse que las poéticas aquí consideradas se circunscriban a "repetir" materiales preexistentes, acordamos con Bunz en cuanto al hecho de que el uso de elementos provenientes de la cultura de masas no sólo representa un desplazamiento en cuanto a las "fuentes" (si antes se reelaboraba la literatura, ahora se reelabora la cultura

\footnotetext{
${ }^{336}$ Romina Freschi, Redondel, Buenos Aires, Siesta, 1998. Todas las citas posteriores están tomadas de la misma edición.

337 Mercedes Bunz, La utopía de la copia. El pop como irritación, Buenos Aires, Interzona, 2007 (38, 39).
} 
masiva) sino que también modifica las concepciones de poeta y de escritura que hemos consignado a lo largo de este trabajo, como veremos. En primer lugar, porque cambia la valoración tanto de la literatura como de su “otro” en la ideología moderna, la cultura de masas.

Efectivamente, en Coming attractions los poemas trabajan y ponen al mismo nivel elementos tomados de la tradición literaria, como la cita de Pizarnik que mencionamos en el apartado anterior, y películas icónicas del cine de Hollywood (por ejemplo Mars attacks de Tim Burton, en el poema titulado precisamente "Marte ataca"; El mago de $\mathrm{Oz}$ de Victor Fleming, en el primer poema que concluye “creo que estamos en Oz", y cuando se dice en "Microscópica”: “No soy ninguna bruja del Oeste”) ${ }^{338}$. El siguiente libro de Mariasch, $X X X$, hace uso abundante de las letras de canciones pop como "La música que escuchan todos” de El otro yo, "You never give me your money” de Los Beatles, “Skin” de Madonna y "Eiti leda” de Seru Giran, ${ }^{339}$ que en ningún caso están explicitadas como citas y aparecen, por el contrario, como apropiaciones fragmentarias a cargo de la voz que enuncia el poema.

En Polaroid de Anahí Mallol los objetos culturales proliferan todavía más y conforman un repertorio heterogéneo que incluye un epígrafe del cantante Manu Chao, Alicia en el país de las maravillas, marcas como Kodak, los pantalones Levi’s, el lápiz labial Lancome, medios masivos como la revista Para Ti y el Discovery Channel, personajes de ficción como Gatúbela y Ana Karenina, escritores y artistas como Lewis Carroll, Jack Kerouac y su novela En el camino, Gore Vidal, Novalis, Tom Waits, Sartre, una canción de The Doors (“Moonlight Drive”), Sting, los beatniks, Stan Kenton (un músico de jazz norteamericano), Marosa di Giorgio, Roger Belait (en él se basa el

\footnotetext{
${ }^{338}$ Ver Mariasch: 1997, 25, 9 y 21 respectivamente.

${ }^{339}$ Ver Mariasch: 2001, 27, 33 y 39 y 41 respectivamente.
} 
personaje Alan Eager de una novela de Kerouac), grupos y estilos musicales como La nueva luna, Tambó tambó, Los pibes chorros, el cumbiastón y la cumbia villera, Mick Jagger, Javito y Lía Crucet. También es elocuente la presencia de figuras devenidas marcas e imágenes icónicas como los anteojitos John Lennon y las fotos del Che, la lengua stone, y la puesta en relación de estilos musicales con estilos de vida que incluyen lo que se conoce actualmente como "tribus urbanas", vinculadas a formas de identificación tanto como a la diversificación del consumo.

Así aparecen por ejemplo los rollingas y la ropa que los caracteriza (flequillo, pañuelo, jeans y zapatillas Topper; Mallol: 2001, 99) y otras “tribus” definidas a partir de sus elecciones musicales ("quiero matar un Perico/ quiero matar un Ska”; Mallol: 2001, 102). Además, lo que es todavía más importante es que tanto en Polaroid como en $X X X$ de Mariasch la propia poética se piensa en los términos de estas identificaciones con bandas musicales. Porque en el poema "Lengua Stone” de Mallol, donde se visita una bailanta llamada Metrópolis para comprobar que "las chicas y los chicos/ que eran/ del rocanrrol/ bailan al ritmo/ de músicas fugaces/ la nueva luna/ y tambó tambó” (Mallol: 2001, 99), es decir que pasaron del rock a la cumbia, se dice en los últimos versos: "Cuando me voy/ saco la lengua/ la de Andy Warhol/ la cuelgo de la antena/ como una bandera/ como un isotipo/ de guerra.” (Mallol: 2001, 103). Cabe señalar que esta lengua, que apareció por primera vez en el álbum de The Rolling Stones Sticky Fingers de 1971 y se popularizó como un diseño de Warhol (quien en cambio diseñó la tapa) pertenece en realidad a John Pasche. Pero el texto, significativamente, opta por el mito popular que la atribuye a Warhol y que permite, valiéndose de una sola figura, señalar tanto al mundo del rock como al del arte pop. 
Mariasch por su parte reescribe los conocidos versos del "Poema XX" de Neruda, "Puedo escribir los versos más tristes esta noche", ${ }^{340}$ en un texto de $X X X$ que cuenta los vaivenes de una relación amorosa donde un chico y una chica comparten el gusto por la banda Counting Crows y termina diciendo “Quiero escribir los versos más bailables/ esta noche. Quiero verte bailar como un/ perro, entero” (Mariasch: 2001, 43). Y termina este libro con otro poema, “Querida Marina”, del que dice "Parece el título/ de una canción de Bon Jovi/ solista o de Leonard/ Cohen” (Mariasch: 2001, 45). Enseguida se menciona a Cortázar y Bioy Casares, y se afirma: "La parte afectadita/ literario-pop es la que menos/ me gusta. Me gusta/ la parte industrial, hit trolo/ es decir: femenino.” (Mariasch: 2001, 45). Aquí se vuelve imposible decidir si estos últimos versos aluden a la música, a la literatura o a ambas por igual, que es lo más probable. Lo relevante es que se hable de la poesía en términos tomados de la jerga del consumo y la crítica musicales, tales como "hit”, “pop” e "industrial”, así como en el poema anterior se declaraba la intención de escribir versos "bailables”. Por eso, como habíamos adelantado y como señalaba Jameson, para quien la cultura de masas ya no se alude sino que se incorpora a la "esencia” de la obra, la música no funciona en Mariasch y Mallol simplemente como cita: la propia poesía se piensa en los términos de un estilo musical, que representa a su vez una toma de posición en relación a otros estilos, y los poemas hasta se rigen por la premisa de ser bailables, en Mariasch. Es decir que el modelo con el que vincular la propia poética no se toma de la tradición literaria, que ya no es el lugar esperable del que extraer figuraciones sobre la escritura, sino de las canciones pop.

Redondel de Romina Freschi no sólo toma sus materiales de la música sino también de la televisión y los videojuegos; hay dos personajes que recorren todo el

\footnotetext{
${ }^{340}$ Ver Pablo Neruda, "Poema XX”, en Veinte poemas de amor y una canción desesperada, Buenos Aires, Losada, 1967 [1924].
} 
libro, Blanche y Luli, que pueden tanto ser muñecas como niñas y habitan un mundo que se asimila al de los juegos electrónicos:

BLANCHE Y LULI INVENTARON UNAS PISTOLAS LÁSER QUE VEMOS EN LA TELE. DE TRASNOCHE SÁBADO A LA MAÑANA LAS VIERON EN UN BOSTEZO DE ABURRIMIENTO TELEVISIÓN. Y SE ENCAPRICHARON. -LAS QUEREMOS!!! SIN DORMIR NUNCA MÁS ESA TRASNOCHE, TRABAJARON DÍA Y NOCHE CONSTRUYENDO LAS PISTOLAS. Y CUANDO LAS TERMINARON, PENSARON QUE QUERÍAN AFILIARSE A LA GUERRA. SE HICIERON TRAJES ESPACIALES DE TENIENTE Y CORONEL, Y ENTRENARON A UNA CENTENA DE CENTINELAS ENANOS DE VIDEOJUEGOS. AHORA PATRULLAN LAS CALLES, Y DISPARAN MANCHONES DE COLORES CON SUS PISTOLAS LÁSER DE TELEVISIÓN A TODOS LOS BERRUGOS MALOLIENTES, QUE YO NO SÉ QUIÉNES SON (...). (Freschi: 1998, 11). ${ }^{341}$

En el espacio referencial del libro se funde la televisión con los videojuegos, las bandas de rock y los consumos de la cultura de masas como las series televisivas, el cine clase B y los dibujos animados; también aparecen el cuento "La bella durmiente” y el personaje $\mathrm{K}$. de las novelas de Kafka, en un texto que se presenta como reescritura en clave infantil del relato "Preocupaciones de un padre de familia". ${ }^{442}$ Pero lo más importante es que la inestabilidad tipográfica y el uso de las mayúsculas en todo el libro aluden al modo de escritura que los jóvenes sobre todo emplean en los nuevos soportes tecnológicos como el chat, los mails, los fotologs y los mensajes de texto enviados por teléfonos celulares, con lo cual los materiales mencionados previamente aparecen en un

\footnotetext{
${ }^{341}$ Todos los poemas están escritos íntegramente en mayúsculas, tal como los reproducimos aquí.

${ }^{342}$ El texto dice: "K. ES MODELO STANDARD. CAMINA, HABLA, PIENSA, ETC. PERO K. ES UN TIPO SOLITARIO. QUIERE SER ERMITAÑO. UNA VEZ SINTIÓ MUCHO ODIO POR LA GENTE. Y DE LA NOCHE A LA MAÑANA QUEDÓ RECUBIERTO POR UNA ESPESA CAPA DE PELOS. LE MOLESTABA Y LE HACÍA PICAR, PERO AL MENOS NO PERMITÍA QUE SUS AMIGUITAS LO TOQUETEARAN Y LO CACHETEARAN, COMO SUELEN HACER. K. QUISO TENER MUCHO PELO ASÍ, SIEMPRE. PERO A LAS POCAS SEMANAS UN ROLLITO SE LE DESPRENDIÓ. QUEDÓ AL LADO DE Él HECHO PELOTITA Y EMPEZÓ A CRECER DESPACITO, AL RITMO DE UNA RESPIRACIÓN VACILANTE E INFANTIL. (...)” (Freschi: 1998, 43). El personaje Odradek, del cuento "Preocupaciones de un padre de familia", se describe como "una bobina de hilo, chata, con forma de estrella; y es que en realidad parece estar cubierto de hilos", tal como la "pelotita" de pelos del texto de Freschi. Ver Franz Kafka, Relatos completos Vol. 2, Buenos Aires, Losada, 2005 (55, 56).
} 
texto que pone en escena una modalidad novedosa de la escritura habilitada por la tecnología. ${ }^{343}$

Además, en Redondel la fusión entre tradición artística y cultura de masas se da no solamente porque coexisten en los textos y porque la segunda determina la modalidad de la escritura, sino por el uso que hacen de ellas los personajes. En efecto, algunos de ellos forman una banda de rock que se llama “ÑAM-ÑAM” porque siempre están mascando chicle: “DICEN QUE HACEN ARTE. Y CONTINÚAN HACIENDO GLOBOS CON FORMAS DE ESCULTURAS FAMOSAS, QUE EXPLOTAN CON EXPLOSIONES TUTTI-FRUTTI QUE SON LA BASE RÍTMICA DE LAS CANCIONES DE ÑAM ÑAM” (Freschi: 1998, 25).

Otro de los personajes, Nadia, está “obsesionada por la vanguardia”, por eso “ESCRIBE POEMAS DE GUERRILLERA. Y REVOLUCIONA LA COMPRENSIÓN INCRUSTANDO OBJETOS MINIATURA EN EL PAPEL, AHÍ DONDE VAN LOS SUSTANTIVOS COMUNES Y CONCRETOS. OBLIGA A TODO EL MUNDO A LEER, DICIENDO... -NO SE PARECE A PULP FICTION? (...)” (Freschi: 1998, 15). Tanto en los chicos que hacen globos “con formas de esculturas famosas” y usan ese ruido como base rítmica, como en la que en este último fragmento imita el procedimiento dadaísta de agregar objetos y papeles al cuadro para comparar el resultado final a “pulp fiction” (la película de Quentin Tarantino de 1994, que toma su nombre de un tipo de ficciones publicadas en revistas populares en Estados Unidos

\footnotetext{
${ }^{343}$ Cecilia Pavón hace un ejercicio similar en la serie de poemas "NO ME IMPORTA EL AMOR ME IMPORTA LA PLATA" de libro Caramelos de anís, escrito en conjunto con el poeta alemán Timo Berger. Varios de los poemas están escritos en mayúsculas en su totalidad y además emplean las abreviaturas propias de los medios que hemos mencionado, como cuando se dice “DESDE Q'VINISTE ME VOLVI RE PELEADOR C/ TODA LA GENTE” o "no pienses en la poesía/ pensá en escribir algo q` sea verdad”. Cecilia Pavón, Caramelos de anís, Buenos Aires, Ediciones Belleza y Felicidad, 2004 (17, 25). En este caso bien puede pensarse que los poemas forman parte de un intercambio de emails entre amigos, y tanto en el poema de Freschi que acabamos de citar como en estos textos de Pavón, el uso del lenguaje vincula la poesía a las nuevas formas de escritura que se practican en los nuevos soportes tecnológicos masivos.
} 
hasta la década del '50, aunque es más probable que el poema de Freschi se refiera a la película), aparece una idea de lo que se entendió en su momento como "arte elevado" (categoría que las vanguardias pretendieron derribar y de la que finalmente pasaron a formar parte) devenido ahora una serie de objetos icónicos y de procedimientos fácilmente reconocibles por la difusión que les dio, precisamente, la apropiación de que fueron parte desde la cultura de masas.

Huyssen señala a propósito de lo que se llamó “vanguardias históricas” que "No solamente es la vanguardia algo que pertenece al pasado, sino que además resulta inútil resucitarla, cualquiera sea la excusa para hacerlo. Sus invenciones y técnicas artísticas han sido absorbidas y capturadas por la cultura de masas occidental en todas sus formas (...)” (Huyssen: 2002, 39). ${ }^{344}$ Aunque el autor se refiere a las agrupaciones artísticas de las dos primeras décadas del siglo XX, algo similar puede decirse de la mención que hace Mallol a la vanguardia política representada en las fotos del Che y a la revolución simultáneamente artística y política que supuso la figura de Lennon, aludidas en estos versos: "Pero esas chicas,/ las de anteojitos/ a lo John Lennon,/ las chicas de mi barrio/ con los sobacos gastados/ por los libros de Sartre/ y las fotos del Che/ de blusas hindúes/ (...) nunca/ van a morder estos labios” (Mallol: 2001, 79, 80).

Lo que surge de estos poemas de Freschi y Mallol es una serie de objetos vinculados a las grandes revoluciones artísticas y políticas del siglo XX y convertidos, luego de ser absorbidos por la cultura de masas y desligados de su origen histórico, en estilos que pueden imitarse y usarse como modo de identificación por el alto grado de codificación cultural que comportan -tanto como la cumbia y el rock en los poemas de

\footnotetext{
${ }^{344}$ Para una perspectiva distinta sobre este punto ver Hal Foster, El retorno de lo real, Madrid, Akal, 2001 (3-36). Para Foster la propuesta de las vanguardias históricas no se vuelve realmente eficaz sino hasta ser releída por las neovanguardias norteamericanas y europeas de las décadas del 50 y 60, que retoman sus procedimientos para plantear un verdadero cuestionamiento a la institución artística como no se había hecho en las primeras décadas del siglo XX. Foster discute en este punto con Peter Bürger y su Teoría de la vanguardia (Bürger: 2010), por supuesto.
} 
Mallol ya citados, cuyo estatuto en este sentido no se diferencia del “arte”. Pero no sólo en estos objetos sino en la larga lista de marcas, escritores, películas y canciones que consignamos antes a propósito también de Mariasch, se trata siempre de objetos insertos en una trama de codificaciones culturales.

La operación no se asemeja en este punto a la que describe Fredric Jameson sobre los “Diamond dust shoes de Warhol”. Para Jameson el arte posmoderno (y el pop, en este caso) despoja al objeto de su carga simbólica, que permitiría reponer en un gesto hermenéutico el "mundo vital originario" al que pertenece (Jameson: 1991, 30). En cambio para Masotta, que concuerda sin embargo en que el pop descarta la construcción de metáforas, semejante despojamiento no sería del todo posible porque “el arte 'pop’ es un arte del objeto enmascarado, enmascarado por los lenguajes y los códigos” (Masotta: 2004, 158). Masotta propone que no habría “individuos” ni “cosas” propiamente dichas, ni tampoco algún tipo de "realismo” en el pop, “puesto que se trata de un arte en actitud de ruptura radical con la noción de un objeto sin lenguaje” (Masotta: 2004, 159), pero sus tesis habilitan la posibilidad de pensar los objetos pop en relación a la cultura de la que se toman en primer lugar, y aquí las adoptamos porque este es precisamente el modo en que funcionan los objetos culturales en este conjunto de textos de los noventa.

Esto supone un tratamiento del objeto absolutamente distinto al que analizamos en los objetivistas, que intentaban acercarse a los objetos desde la percepción y cuya pregunta por el sentido de las cosas, planteada en clave metafísica, no contemplaba la inmersión de los objetos en una cultura que los carga de información. O mejor dicho, esta "cultura” (pensada en ocasiones en clave local o nacional) podía situarse en una época y lugar específicos pero desde un recorte que excluía a la cultura de masas. Así, donde Prieto decía “De zapatillas y pantalones negros,/ con el torso desnudo,/ lleno de yerba una calabaza marrón./ El paisaje es el de todos los días,/ salvo por una música que 
no silbo/ y sin embargo sé” (Prieto: 1998, 29), porque el poema se centraba en la captación de lo diferente dentro de lo igual, estas poetas agregarían las marcas de las zapatillas y los pantalones e incluso cambiarían “una música” por el nombre de una canción conocida. De hecho Mallol, en "Blues de San Francisco” donde dice además que “no soy/ salvo una espía/ en el cuerpo/ de otra persona” y describe el ambiente como “una escenografía casi” declara la intención de escribir "unos versos tan reales/ como un par/ de pantalones Levis” (Mallol: 2001, 72, 73).

La idea de "realidad” se ve modificada entonces porque no sólo incluye lo percibido por un sujeto sino también la producción de realidad llevada a cabo por los medios de comunicación de masas y el mercado. Esto sucede porque, como señala también Masotta, el arte pop se ocupa de “representar lo representado”. Para Masotta los pintores pop reproducen “símbolos” y no “cosas” y demuestran en el mismo movimiento que no hay realidad que no haya sido previamente simbolizada (Masotta: 2004, 114). Por eso no se trata de “informar” sobre la realidad ni reproducirla, sino de informar sobre una información preexistente que no es otra que la de "los productos de las comunicaciones y de la cultura de masas” (Masotta: 2004, 116). Sin implicar que los poemas que aquí se ponen a consideración sean pop o que lo sean en su totalidad, la observación de Masotta es válida para pensar el modo en que el ingreso de los materiales de la cultura de masas modifica la concepción de la literatura en los textos.

En efecto, más relevante aún que la presencia de las citas -que importan no sólo como citas sino porque son indicios de un imaginario tomado de la cultura de masas que recorre los libros- es que algunos textos se constituyen del mismo modo que las superficies coloridas del arte pop, como sucede en "candytrip” de Mariasch (el uso abundante del inglés, presente en todos los títulos de los poemas de Polaroid, también da cuenta de apropiaciones de la cultura norteamericana): 
Abrí los ojos y divisé unas pestañas muy cerca del final de mis labios. Nos unía un collar de florcitas silvestres que no podría desatar hasta pasada la mediamañana. Pisé un cuadrado de sol cubierto de mostacillas. Eran las frutillas de los días las que llenaban el aire de olor a rojo. Las frutillas con azúcar y el sol.

No era más ese día luminoso cuando esquivé las piernas de esa chica que llevaba un collar de perro. Su novio también, y estaban atados por un par de Houdini's. Yo iba a la casa de Yoel, pero ¡ojito!, tuve muchas ganas de entrar a los jardines del museo. Las uvas siempre -casi- estaban verdes y los dedos me quedaban pegoteados con la savia de las hojas que juntaba para el herbario.

Me fui llegando tarde lo que más me gustaba de la sala era mirar por la ventana de marco azul los maceteros con flores fucsias y amarillo contra el cielo ahí todo es amarillo y naranja clarito (...).

Llegando a la esquina había un acuario, y en la vidriera unas peceras con tortuguitas acuáticas y de las otras. Las tortuguitas acuáticas tenían piedras de colores en sus peceras, eran fucsia, azul, amarillo fosforescente y más colores (verde). (Mariasch: 1997, 35, 36).

El fragmento forma parte de un relato breve donde la narradora dice que su hermana come "tortuguitas de chocolate", y al final, porque estas golosinas se confunden -involuntariamente o no- con las mascotas acuáticas que se mencionan más arriba, la encuentra con la cara llena de sangre y dice que "Cruel, impregnada de olor a chicle, ahí estaba tirada, durmiendo el festín” (Mariasch: 1997, 38).

Se trata una vez más de un texto donde la inocencia infantil y la crueldad se vuelven indecidibles, pero lo importante es que lejos de cualquier intento de descripción “realista”, lo que destaca son los colores brillantes y planos que se expanden para abarcar toda la superficie textual, como cuando se dice "Eran las frutillas de los días las que llenaban el aire de olor a rojo”. La mención a los colores y a la materialidad de los objetos constituye el texto como superficie satinada hecha de objetos que remiten al pop, como el chicle y las frutillas, en un procedimiento que se intensifica cuando en otro relato de Coming attractions se describe un encuentro erótico entre dos chicas valiéndose de marcas de golosinas:

Dedos que sólo las chicas saben meter aplastando Bubaloos y los últimos temores. Malva-vulva-viscos. Tocando marshmallows, pegoteando Moguls. Los ojos cerrados o pequeños glimpses del rosado brillante de gordura de bebé. Mordiscos a todos los Bazooka: sandía atómica, frutilla explosiva, banana loca, pomelo pop, 
naranja sport. Horas buceando en Lifesavers (sumergidas en el candy with the hole). Sugus al final, yo azules, ella rojos. (...) (Mariasch: 1997, 42).

Aquí el cuerpo no coincide con el de ese otro poema lésbico de Bellessi citado al comienzo del capítulo. Porque donde Bellessi ponía de relieve la diferencia insalvable entre lenguaje y realidad (“Cuando digo pezón/ ¿la mano roza/ las dilatadas rosas de los pechos tuyos?/ ¿te toco acaso?”, Bellessi: 1988, 114) manifestando a la vez la separación entre el poema y el objeto real, ese “áspero cuerpo de la amiga a quien deseo” (Bellessi: 1986, 115), en Mariasch esa partición se pierde y no hay referente para un cuerpo que está compuesto de mercancías (Bubaloos, Moguls y Bazooka), o en todo caso el referente pasa a ser la mercancía misma.

De modo similar, en Polaroid de Anahí Mallol hay poemas que se construyen tomando como base imágenes previas y hasta mitos culturales. En "Bad girl reading in a garden” se recupera una escena donde el personaje Lolita de la novela de Vladimir Nabokov (1955) lee tendida en el jardín mientras Humbert la observa, pero el poema parece combinar la descripción de Nabokov, que sólo se refiere a "gafas oscuras”, 345 con la imagen del afiche de la película de Stanley Kubrick (1962) donde hay una chica con anteojos de sol de marco rojo con forma de corazón, cuando dice: "tras las gafas estrelladas/ de plástico/ multicolor/ infantil/ toda ella” (Mallol: 2001, 25). Al mismo tiempo que el término "gafas” funciona como huella de la lectura de una traducción española (probablemente la de Anagrama que aquí se cita y que circuló durante la década del noventa), la descripción del objeto agrega información que no está en la novela pero sí en el afiche mencionado (y tampoco en la película, que es en blanco y negro; sin embargo, ese afiche es la imagen más icónica de Lolita que exista hasta la

\footnotetext{
${ }^{345}$ Vladimir Nabokov, Lolita, Barcelona, Anagrama, 1991 (48).
} 
actualidad ). ${ }^{346}$ El poema trabaja la escena para plantear una consideración sobre el deseo masculino, por eso dice al final del "padre” que mira a Lolita que "sólo es/ otro/ hombre celoso/ en el lugar/ equivocado” (Mallol: 2001, 28), pero lo importante es que no apela para esto a una experiencia sino a una imagen reconocible de la cultura de masas.

También, en "Sex and the City” se discuten los estereotipos femeninos a partir de una serie televisiva de fines de los noventa producida por la cadena HBO (Mallol: 2001, 105-107), en “Moonlight Drive” se describe a Jim Morrison, el cantante de The Doors, con pantalones de cuero y el pelo suelto tal como figura en sus fotos y filmaciones más difundidas (Mallol: 2001, 53-57), y “Breakfast in Tiffany's” reescribe la letra de la canción "Diamonds are a girl’s best friend” de la película Los caballeros las prefieren rubias de Howard Hawks (1953) cantada allí por Marilyn Monroe, aunque el título del poema alude a otra película de Blake Edwards, Desayuno en Tiffany's (1961), protagonizada por Audrey Hepburn. El texto mezcla al personaje Lorelei Lee interpretado por Monroe en Los caballeros las prefieren rubias con la figura mítica (porque ya no puede decirse “con la persona real”) de la actriz: "Lo digo yo que soy/ exigente y rubia y sensual/ como Lorelei Lee/ radiante como la Monroe” (Mallol: 2001, 115). De esta manera los textos se plantean como superposición de capas, siempre tramadas a partir de imágenes que se construyen como superficie (entre las cuales el mismo “yo" se encuentra “enmascarado”), y que provienen de los significados previos de los materiales con los que se trabaja, a la vez que el libro presenta un sujeto que no se busca en el ejercicio de introspección, como señalaba Paula Sibilia, sino en la superposición de imágenes hipercodificadas de la cultura de masas que arma el poema.

\footnotetext{
${ }^{346}$ Hay una versión más reciente y a color de Lolita de Adrian Lyne (1997), pero como observamos la imagen que selecciona Mallol remite a la versión anterior.
} 
La operación coincide parcialmente con lo apuntado por Masotta a propósito de los cuadros de Roy Liechtenstein, sobre todo con el más conocido, “Crying girl” (1963), una pintura que copia una viñeta de historietas. En este caso la reproducción exacta a cargo del artista pone de manifiesto que

los objetos a los que se refieren las imágenes de las historietas no son objetos reales. Que son objetos que no existen; que, exactamente, no son más que mitos sociales. El rostro de su "Mujer llorando" no tiene como correlato a ninguna mujer real sino al estereotipo social sostenido por las imágenes muy conocidas de las historietas. El objeto real, en Lichtenstein, mediatizado por los estereotipos y los mitos, envuelto en lenguaje de imágenes, no existe. O bien se podría decir: no es más que esas envolturas.” (Masotta: 2004, 171).

Hay un efecto similar en los textos de los noventa con respecto a los objetos de la cultura de masas y las mercancías, pero que alcanza por igual a la conformación del género y las subjetividades que, como apunta Masotta a propósito del objeto "real” que subyacería a las reproducciones, no son otra cosa que “envolturas”, superficies tramadas por lo social. Pero en los poemas, si bien el procedimiento tiene puntos de contacto con el pop, nunca hay una pura reproducción intervenida por distintas técnicas (la pintura, la serigrafía) como en los cuadros de Warhol y Lichtenstein donde se retratan objetos de la cultura de masas. Al contrario, en los textos analizados los objetos aparecen en función de plantear subjetividades que se buscan de modo lúdico en distintas máscaras y formas y se constituyen en el mismo movimiento, además de que en ocasiones se aborda críticamente la inscripción social y cultural de los elementos que se citan.

Si bien se coincide, entonces, en el repertorio de objetos representados y el trabajo con las superficies, hay una diferencia fundamental con el arte pop, ya que en las poetas de los noventa los objetos de la cultura de masas se presentan a partir del uso. Así, cuando Mariasch reescribe la canción de The Beatles "You never give me your money" en los primeros versos del poema "La plata”, lo que se lee es un modo de plantear las relaciones simultáneamente afectivas y económicas entre una mujer y un hombre que puede ser el padre o el marido mediante la apropiación de un objeto: 


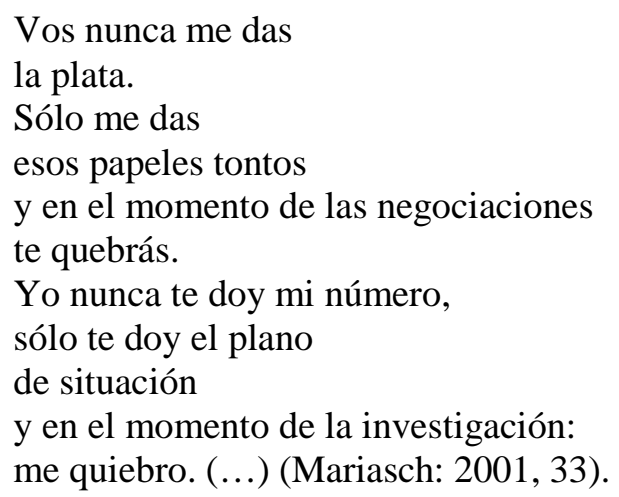

Estos primeros versos del poema reproducen literalmente la letra de la canción, pero hay un pequeño desvío, sobre todo porque al ser enunciada por una mujer, la frase "nunca me das la plata” adquiere otras resonancias en el contexto cultural en que se la emplea, en vistas de la dependencia económica de la mujer respecto al varón como proveedor del hogar, que sólo en las últimas décadas se ha ido modificando.

En "Desa” también se representa la vida familiar a partir de escenas donde la artificialidad da la pauta de que se trata de modelos observados en el cine y la televisión, a la que se alude al principio del poema:

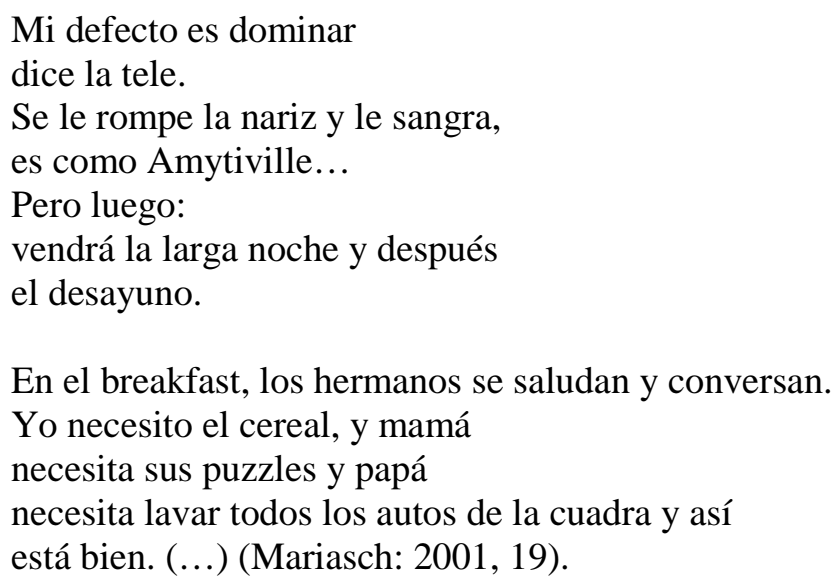

El texto pone de manifiesto, como se ve, que lo que se presenta es un modelo de familia proveniente del consumo televisivo cuyo carácter de pauta cultural hegemónica se revela como artificio al resaltar la ajenidad de una vida doméstica donde la familia no asiste al desayuno sino al "breakfast", come cereales y arma "puzzles”. De este modo el énfasis se desplaza de la presentación de los objetos culturales por sí mismos a lo que el 
consumidor cultural "fabrica” a partir del uso que hace de ellos. De nuevo, como en los poetas analizados desde sus apropiaciones de la cultura popular en el Capítulo II, aquí se trata de enfocar no tanto una cultura dominante pensada como una instancia omnipotente frente a la cual sólo resta la pasividad, sino más bien en lo que los sujetos producen con las imágenes, objetos y canciones de los que son receptores (De Certeau: 2000, XLII), como sucede en el tratamiento de las imágenes del cine y la televisión que hace Mallol en Polaroid.

Por eso en estos textos no tiene sentido la discusión a propósito del carácter celebratorio o crítico de la cultura de masas que haría el pop del que se encarga Huyssen en “La política cultural del pop” (Huyssen: 2002, 245-275). Aquí, como los objetos no se presentan des-simbolizados como señalaba Jameson sino envueltos en lenguajes sociales que los codifican (Masotta: 2004, 171), está claro que el gesto de apropiación supone una actitud crítica y, más importante aún, no simplemente reproductiva sino también productiva, como se puede observar en los últimos poemas de Mariasch citados, donde el foco está puesto en lo que el sujeto como consumidor hace con la cultura de masas, en un sentido creativo.

Pero si se piensa en esta apertura a los materiales de la cultura de masas desde la perspectiva del armado de una tradición, no puede decirse que estas apropiaciones fragmentarias conformen una tradición ni que la cultura de masas como un todo lo sea. Hay, sí, un ejercicio de selección que se vale tanto de segmentos de la literatura como de imágenes masivas, objetos, películas y canciones, pero esas selecciones son fragmentarias y microscópicas y en ningún momento conforman un corpus con cierto grado de organicidad en el que pueda leerse una ideología poética. No obstante, esta ideología sí se inscribe en las apropiaciones de materiales masivos en general, porque estas escrituras dan cuenta de un desplazamiento en el valor otorgado a la literatura, que 
ya no constituye el lugar "evidente" y prioritario al que ir a buscar referencias sino que ahora forma parte -no de manera privilegiada- de la cultura como un todo.

En efecto, hay un cambio en el modo de plantear las relaciones entre la literatura y otras prácticas, del que se ocupa Mercedes Bunz en La utopía de la copia. El pop como irritación. Para Bunz la ideología de la autonomía del arte es reemplazada por un nuevo tipo de porosidad en las fronteras entre distintas prácticas (Bunz: 2007, 85). En este caso, no sólo porque el discurso poético se abre al cine, la televisión y la música sino también porque se modifica el vínculo entre la literatura y lo que antes se imaginaba como su “exterior”. Esa idea de exterioridad suponía, como señala Bunz, una figura de artista que llevara a cabo la operación de importar y exportar elementos entre los distintos campos y que la señalara como "gesto” (Bunz: 2007, 85). En este sentido puede compararse el modo en que Marcelo Díaz incluía epígrafes de un programa televisivo como Yo me quiero casar, ¿y usted? o del cantante Nino Bravo en un aparato paratextual que marcaba su procedencia y en el que la yuxtaposición de estas citas con otras de la literatura delineaba precisamente un gesto, el de ponerlas al mismo nivel (Díaz: 1998; Díaz: 2001). Además, en Punctum de Martín Gambarotta aparecía también la televisión pero como parte de una oposición entre cultura de masas y literatura, cifrada en la alternativa entre "leer al Quijote" o "soñar con los huesos de Alien" (Gambarotta: 1996). En los textos analizados en este capítulo, ya no se aclara la procedencia de los materiales empleados, y mucho menos se hace un "esfuerzo" por incorporarlos, como señalaba Delfina Muschietti (Muschietti: 1998). Al contrario, en ellos no hay aclaraciones ni epígrafes, ni está presente el gesto de señalar de dónde están tomados los materiales que se reelaboran, como si se diera por sentado que esos materiales son de por sí una propiedad colectiva, casi anónima (aunque tengan la firma 
de Nabokov, de Kubrick o de John Lennon) desde el momento en que pasan a formar parte de la cultura masiva.

Este modo de vincularse con la tradición literaria y con la cultura en general da cuenta entonces de un desplazamiento en el modo de pensar el lugar de la literatura, como dijimos (Bunz: 2007, 96-101) (Jameson: 1992). ${ }^{347}$ Además, la modificación en las fronteras entre los campos artísticos está ligada a un cambio en la forma del poder, al que hicimos alusión anteriormente a partir de una cita de Paula Sibilia referida al concepto deleuziano de "sociedades de control" (Sibilia: 2008, 21). Sucede que si en la modernidad la función crítica del arte se basaba en situarlo en un “afuera” en relación al poder (exterioridad que estaba garantizada por la "autonomía artística”), ${ }^{348}$ frente al nuevo régimen de poder ya no hay posibilidad de evitar la apropiación, como efectivamente se constata que sucedió con el arte modernista (Huyssen: 2002), porque se trata de un modo de dominación caracterizado por su capacidad para asimilar todo tipo de resistencia. Entonces, frente a este poder que se apropia rápidamente de todas las formas de oposición y frente al cual ya no existe ningún “afuera”, lo que se conocía como “distancia crítica” (Jameson: 1991, 108) deja de tener sentido.

La alternativa de las poéticas que acabamos de considerar consiste, como señala Bunz, en “torcer desde adentro el régimen de productividad” (Bunz: 2007, 99), porque los objetos de la cultura de masas e incluso los significantes sociales que definen y controlan al sujeto y, en este caso, a los sujetos femeninos, se usan y reelaboran para

\footnotetext{
${ }^{347}$ Jameson, como se sabe, explica el cambio al que nos referimos a partir del reemplazo del paradigma moderno por el posmoderno. Sin embargo aquí no suscribimos a la categoría de "posmodernidad" por no considerarla del todo pertinente para el contexto cultural en el que se inscriben las poéticas analizadas, ya que está ligada a una situación económica y cultural signada por el capitalismo avanzado en las grandes metrópolis de Europa y los Estados Unidos.

${ }^{348}$ Puede pensarse que todavía hay resabios de esta idea de un "afuera” en el modo de Alejandro Rubio de presentar la televisión como un "otro” en relación a la poesía (Rubio: 1997), y quizás también en el modo de construir tradición de los objetivistas, si se piensa como significativa la completa omisión de la cultura de masas que tiene lugar en algunas producciones del objetivismo, tales como la poesía de Daniel García Helder y Martín Prieto.
} 
modificar críticamente su sentido. Pero se trata, también según Bunz, de "hacer surf con la apropiación” (Bunz: 2007, 100) con la conciencia de que lo producido será a su vez apropiado por el poder. Esta figura se articula perfectamente, en la idea de una superficialidad positiva, con el trabajo con las superficies de los textos analizados, tanto en su modo de construir subjetividades e identidades de género como de usar los productos de la cultura de masas, aspectos que representan un cambio de paradigma en el modo de pensar el sujeto, la poesía y su vinculación con la cultura respecto a las poéticas tratadas anteriormente.

Este nuevo tipo de superficialidad también concierne al modo de plantear la temporalidad en los poemas. Porque en los objetivistas el ejercicio de la mirada sobre un objeto iba inevitablemente unido al de la memoria, que desplegaba tiempos diversos en el acto de la visión. La memoria tenía también un papel preponderante en las concepciones simbolistas analizadas en el capítulo II y en aquellas, como las de Rubio, Díaz y Raimondi, que usaban el anacronismo como contraste en el que leer críticamente tanto la tradición como el presente. Incluso en las figuraciones de analfabetos abordadas en el capítulo III y su modo de impugnar parcialmente la tradición como un bagaje arcaico que se oponía a una actualidad cifrada en las hablas, como en Durand, y sobre todo en el modo de Gambarotta de percibir la lengua como el sitio donde leer la historia reciente, aparecía una noción de temporalidades diferenciales que constituye lo que solemos denominar "historia”.

Cabe preguntarse entonces qué sucede en las poéticas trabajadas en este capítulo con las nociones de historicidad y de temporalidades heterogéneas, porque como vimos, no parece haber en este caso una dimensión histórica en los objetos que se trabajan. Por el contrario, las apropiaciones siempre se realizan en tiempo presente y sobre objetos y discursos que tienen, sí, significaciones sociales pero no históricas. En consonancia con 
esto, en figuras como la mamushka y la vidriera y más en general, las superficies espejadas, hay distintas capas que se superponen sobre una superficie sin espesor, y sin que haya un "pasado" subyacente a ellas, ni siquiera uno que emerja y se construya como tal por contraste, como propone la noción de montaje de tiempos.

Estas figuras resultan útiles para leer el entramado de imágenes que proponen los poemas, porque en ellas "superposición” no implica "profundidad”, sino todo lo contrario: la superposición, como sucede en los espejos, es de imágenes que se conjugan siempre en tiempo presente. Ni siquiera en el tratamiento de la infancia hay una noción de historicidad, porque la infancia se presentifica en las voces niñas, es decir que no se percibe como pasado y mucho menos como pérdida. Tampoco hay, salvo excepciones puntuales, ${ }^{349}$ una historicidad en el paso entre generaciones, desde el momento en que el “yo” puede ocupar alternativa o simultáneamente el lugar de hija, madre, “chica”. Por eso consideramos que en estas poéticas ya no se puede hablar de "tradición”, dado que la tradición contempla siempre una percepción de la diferencia temporal, aunque se la construya desde un presente en el que el modo de leer los materiales puede constituirlos como pasado o, por el contrario, actualizarlos en el uso. Aquí en cambio, se trata más bien como dijimos de apropiaciones que tienen lugar en el presente, y operan sobre objetos que no están inmersos tampoco en otro tiempo que no sea el presente. El cambio de paradigma no concierne entonces sólo al modo de nivelar literatura y cultura de masas, sino que está intrínsecamente relacionado con un desplazamiento por el cual ya no hay tradición sino recortes, selecciones, repetición y apropiaciones sobre materiales

\footnotetext{
${ }^{349}$ Roberta Iannamico tiene dos poemas donde pone en escena la idea de "herencia", en un caso como repetición, cuando habla de gestos que se transmiten de madres a hijas (Iannamico: 2001, 26), y en otro como legado, cuando se alude a los camisones que se heredan de una abuela (Iannamico: 2001, 15). Pero se trata de ocurrencias ocasionales en una poética que por otra parte trabaja una voz fluctuante, que puede ser tanto de mujer como de niña, como vimos en el texto donde se proponía llorar frente a los hombres (Iannamico: 2001, 31).
} 
deshistorizados, a partir de operaciones de lectura y relectura que son siempre microscópicas y fragmentarias. 


\section{CAPITULO V}

\section{VERSIONES DE LA INGENUIDAD Y EL MALDITISMO: LA CONSTRUCCIÓN DE AUTORES-PERSONAJES EN WASHINGTON CUCURTO Y BELLEZA Y FELICIDAD}

\section{1- Planteo inicial}

La zona de la producción de los noventa que abordaremos en este capítulo tiene puntos de contacto con las que hemos analizado hasta aquí, porque en ella también se da la construcción de figuras de analfabetos que vimos en el Capítulo III, así como la enunciación a través de personajes, las vinculaciones con el pop, y los nuevos modos de construir subjetividades de los que nos ocupamos en el capítulo anterior. Sin embargo la razón para estudiarla por separado reside en ciertas características, especialmente en cuanto al modo de plantear las relaciones entre autor y personaje, que si bien podrían pasar a primera vista por nuevas modulaciones de lo mismo que no representarían más que una cuestión de grado, a nuestro juicio suponen cambios cualitativos en el modo de posicionarse respecto a la tradición y también en la construcción de figuras de poeta, pero sobre todo en la ideología sobre la literatura que subyace a esas construcciones.

Las poéticas de Washington Cucurto y de las artistas que formaron parte del grupo Belleza y Felicidad (sobre todo Fernanda Laguna y Cecilia Pavón) se diferencian en varios aspectos pero encuentran su punto de contacto en dos cuestiones fundamentales: primero, que todas ellas arman la propia escritura como pastiche de estilos previos, que en Cucurto tiene que ver con la apropiación del barroco 
latinoamericano pero también de los modos de representación del comic y la televisión, y en Belleza y Felicidad, con el trabajo sobre géneros menores como el diario íntimo, las cartas y los libros de autoayuda, además de los productos de la cultura de masas (en especial la música pop). Por eso apelaremos al concepto de pastiche tal como lo describe Fredric Jameson. El pastiche es "la rapiña aleatoria de todos los estilos del pasado, el juego de la alusión estilística al azar”, por el cual el pasado se convierte en una vasta colección de textos disponibles para el uso y la cita que los despoja de su carácter histórico (Jameson: 1991, 45), y según Jameson se distingue de la parodia porque en él está ausente el impulso satírico, la imitación de un modelo con el fin de ridiculizarlo, que es propia de este último recurso. ${ }^{350}$ Esta idea, como veremos, está en consonancia con la poética del plagio enunciada por el propio Cucurto, pero también se activa en los textos de Belleza y Felicidad a partir de la exageración de las marcas de lo que tradicionalmente se identifica como "poético".

En segundo lugar, y en estrecha relación con el procedimiento que acabamos de mencionar, estas producciones están vinculadas porque en ellas la construcción de personajes espectacularizados se aleja definitivamente de las figuras de poeta que hemos analizado hasta aquí, y representa sobre todo el abandono de la idea de poeta como aquel que realiza un trabajo específico (que en ocasiones se figura como artesanal) con la palabra. También se deja de lado la especificidad genérica, ${ }^{351}$ al mismo

\footnotetext{
${ }^{350}$ Fredric Jameson, El giro cultural. Escritos seleccionados sobre el posmodernismo., Buenos Aires, Manantial, 2002 (20).

${ }^{351}$ Washington Cucurto adquirió especial notoriedad al comenzar a publicar narrativa a partir de su novela Cosa de negros, Interzona, 2001. Luego publicó Las aventuras del Sr. Maíz, Interzona, 2005, El curandero del amor, Emecé, 2006 y 1810. La revolución de Mayo vivida por los negros, Emecé, 2008. Fernanda Laguna y Gabriela Bejerman, vinculadas a ByF, también produjeron novelas en el mismo período: Laguna publicó Me gustaría que gustes de mí, Mansalva, 2005, y Dame pelota, Mansalva, 2009, y Bejerman, Presente perfecto, Interzona, 2004, y Linaje, Mansalva, 2009. Cecilia Pavón por su parte incluye cuentos en su libro Caramelos de anís, Ediciones Belleza y Felicidad, 2004. Si bien esta producción excede el recorte de esta tesis, centrada en poesía, haremos alusiones ocasionales a algunas de estas obras
} 
tiempo que la construcción de autores-personajes (término del que nos valdremos para describir este entramado peculiar entre realidad biográfica y ficción que tiene lugar en la escritura) pasa a formar parte de la obra, al punto de que aquí el poeta no se define sólo por su producción sino también por lo que es.

En cuanto a esto, en estas poéticas el uso de personajes difiere notoriamente del de otros poetas como Daniel Durand, Martín Gambarotta o Marina Mariasch. Porque en ellos estaba claro que estos constructos se distinguían del “yo real” propio de la poesía lírica (Hamburger: 1995) y suponían el armado de voces ficcionales que sólo de modo ocasional podían identificarse con la figura de autor (cuando funcionaban como "alter ego” de la misma, como en Durand). Asimismo, en las poéticas abordadas en el Capítulo IV la enunciación a través de máscaras y personajes no se confundía con un tipo de enunciación lírica, y tendía a poner en cuestión los modos tradicionales de pensar el género y la subjetividad. En el caso de Cucurto y ByF, en cambio, tiene lugar una contaminación entre autor y personaje, entre realidad y ficción, y entre vida privada y literatura, que termina por volver estos términos indecidibles.

Al abordar estas poéticas, Cecilia Palmeiro apela al desplazamiento en el modo de construcción de las subjetividades estimulado por las nuevas tecnologías que vimos en el capítulo anterior, y señala que una de las consecuencias del nuevo tipo de subjetividades construidas hacia el exterior, como superficie visible, es que "se produce la vuelta del autor como un sujeto de superficie, como categoría de análisis y como un atractivo del mercado, a escala mainstream, pero también como una ética y una política del under" (Palmeiro: 2011, 167). ${ }^{352}$ Si bien por momentos no resulta del todo cuando sea necesario para iluminar la construcción de figuras de escritores que aborda este capítulo.

${ }^{352}$ Cecilia Palmeiro, Desbunde y felicidad. De la cartonera a Perlongher., Buenos Aires, Título, 2011 (167). 
pertinente, como veremos, hablar de "subjetividades" a propósito de estos poetas, esta vuelta del autor a la que alude Palmeiro es fundamental para pensar la producción de Cucurto y ByF porque en ellos, más que nunca, el discurso sobre la obra -del que forma parte la construcción de las figuras de autor-personaje- también es parte de esa obra, así como de su sentido y su valor (Bourdieu: 1997, 258). Por eso buena parte de este capítulo estará dedicada a indagar el armado de estas figuras, no sólo en los poemas sino también en entrevistas.

Además, la importancia otorgada a la construcción de figuras de poeta como parte de la producción cambia el sentido de la “obra”, porque en Cucurto y en Fernanda Laguna dicha obra está a punto de constituirse por la firma de su autor, y al mismo tiempo se realiza colectivamente, con lo cual se da una tensión entre "autoridad” de la firma y conformación de la propia identidad dentro de, y a cargo de, un grupo. En realidad, la operación vanguardista que supone la constitución de la obra de arte a partir del señalamiento del autor o la firma, no aparece como gesto puro sino que ingresa como parte del pastiche, en estas poéticas que apelan de modo ocasional a ciertos rasgos de la vanguardia concebida más como cantera de procedimientos que pueden resultar provocadores que como tradición de ruptura con la institución artística (Bourdieu: 1997). Así, Fernanda Laguna tiene un poema compuesto únicamente por números (“1724,78, 3241,20/ 201012 237”), ${ }^{353}$ y el autor-personaje Cucurto, a su vez, surge

\footnotetext{
${ }^{353}$ Fernanda Laguna, Triste, Buenos Aires, Belleza y Felicidad, 1998. La idea de vanguardia, tanto como la de "revolución” (como veremos al analizar los poemas de Fernanda Laguna) aparecen como parte del imaginario de Belleza y Felicidad y se trabajan desde la autoconciencia en textos que ponen en escena el campo artístico, como sucede en un cuento de Cecilia Pavón donde la práctica artística se metaforiza en el relato de una narradora que es dueña de una compañía discográfica a la que se refiere como "productora vanguardista”. Allí Pavón describe la música producida por el sello Discos Gato Gordo, y generada por computadoras, como "música sin estridencias, monótona, sin letras, sin cuerpo, sin rostros, y sin sexo -los videos están hechos sólo de animaciones con figuras geométricas de colores- pero es el futuro, aunque a algunos les cueste entenderlo”. Ver Cecilia Pavón, “Discos Gato Gordo o una nube con forma y color de moretón”, en Caramelos de anís, Buenos Aires, Belleza y Felicidad, 2004 (53-57). La descripción de Pavón, que puede vincularse con el modo de trabajar el lenguaje en sus
} 
como una invención colectiva de la que formaron parte tanto el mismo Santiago Vega (nombre real de Cucurto) como otros poetas contemporáneos. En todo caso, ambos representan el abandono de la ideología poundiana que analizamos en los dos primeros capítulos y que todavía era objeto de reconocimiento por parte de Daniel Durand, tal como establecimos en el Capítulo III, quien la valoraba en la medida en que la discutía -es decir, que debía oponérsele de algún modo, como vimos en el poema donde reescribía la reconciliación de Pound con Whitman-. Aquí en cambio el trabajo del poeta sobre el lenguaje ya no es un tema, en ninguna de sus variantes: ni en tanto modo de vinculación entre el poeta y la sociedad, como en los objetivistas, ni como cuestionamiento de los modos de nombrar que circulan socialmente, como en las escrituras "femeninas".

Sucede que en estas poéticas se desplaza el acento puesto sobre el producto y el trabajo implicado en su elaboración, y en cambio cobra una importancia fundamental la figura de artista, que según Palmeiro "no se define por lo que hace (como el artesano) sino por lo que es”. (Palmeiro: 2011, 168). Además, dice Palmeiro:

\begin{abstract}
Al retomar uno de los pilares de la poesía marginal, donde lo fundamental era la "vida de artista", el autor adquiere ese aura, y su subjetividad se vuelve la instancia creadora de valor. Ahora que las cifras indican una fuerte disminución del público lector de libros y un gran aumento de autores, el aura del artista no sólo vuelve sino que se distribuye más ampliamente, y por esto mismo acota a ciertos territorios (o nichos) su autoridad transformada. En términos de Ludmer, ficción y realidad se permean mutuamente, y lo hacen en función de dos instancias que, según Paula Sibilia, caracterizan las escrituras contemporáneas: la "sed de veracidad" (el interés en que todo sea "verídico") y la espectacularización de la realidad. (Palmeiro: 2011, 168).
\end{abstract}

propios poemas y los de Laguna, como veremos en la segunda mitad de este capítulo, se acerca a la noción de arte abstracto -de ahí que la música ocupe un lugar central en ese imaginario- y puede asociarse también con el hecho de que estas poetas son al mismo tiempo gestoras culturales, por lo que la reflexión sobre los modos de hacer en la poesía y el arte en general, incluso en el aspecto económico, aparece ocasionalmente en los textos. Pero esta reflexión, e incluso la idea de vanguardia como arte del futuro que surge de este relato de Pavón, adopta muchas veces una forma paródica, y está tensada además con las figuras de poetas que desconocen las reglas de funcionamiento y la historia del campo, sostenida sobre todo por Laguna. 
Como bien observa la autora, esta forma de postular autores-personajes que pueden pasar por sujetos reales, y construidos como veremos en base a datos verificables que funcionan como garantía de la base "real” de los textos, modifica el modo de concebir las vinculaciones entre realidad y ficción porque lo que puede haber de fantástico en los poemas tiene siempre un sustento verídico que vuelve difusos sus límites, al mismo tiempo que la "realidad” aparece construida bajo la lógica hiperbólica del espectáculo.

Esta operación es descrita también por Paula Sibilia, que no se refiere sólo a lo que tradicionalmente entendemos como "literatura” sino también a las nuevas textualidades del “yo” que circulan sobre todo en Internet, del siguiente modo:

Si la paradoja del realismo clásico consistía en inventar ficciones que pareciesen realidades, manipulando todos los recursos de verosimilitud imaginables, hoy asistimos a otra versión de ese aparente contrasentido: una voluntad de inventar realidades que parezcan ficciones. Espectacularizar el yo consiste precisamente en eso: transformar nuestras personalidades y vidas (no tan) privadas en realidades ficcionalizadas con recursos mediáticos. (Sibilia: 2008, 223)

Tanto Sibilia como Palmeiro prestan atención al problema de la "realidad” al estudiar las nuevas subjetividades, precisamente porque la distinción entre sujeto privado y “real” cuya vida íntima se puede distinguir con nitidez de un sujeto público que se piensa como ficción y personaje, en cierta medida inauténtico, es abolida por este nuevo tipo de escrituras. ${ }^{354}$

Con respecto a esto, Hal Foster propone dos grandes modelos de representación bajo los cuales puede englobarse el arte del siglo XX (que traman también los modos de construcción de subjetividades en la obra artística), y que implican “que las imágenes están atadas a referentes, a temas iconográficos o cosas reales del mundo, o bien, alternativamente, que lo que todas las imágenes pueden hacer es representar otras

\footnotetext{
${ }^{354}$ Podría decirse que esta diferenciación tampoco estaba presente en las voces caracterizadas como líricas, según vimos con Hamburger, pero lo que cambia en este caso es que efectivamente hay construcción de personajes y de voces que no pueden considerarse líricas sino a condición de aceptar que el sujeto autobiográfico que enuncia el poema coincide en todo punto con el personaje que construye en él.
} 
imágenes, que todas las formas de representación (incluido el realismo) son códigos autorreferenciales” (Foster: 2001, 130). Se trata por supuesto de modelos interpretativos, pero lo cierto es que la mayoría de las explicaciones sobre la relación entre arte y realidad se ubican entre uno u otro de estos extremos. De hecho a lo largo de este trabajo hemos visto cómo el objetivismo planteaba la relación con el objeto desde la referencialidad y como registro perceptual de un sujeto sobre una realidad exterior que tenía una existencia independiente; en el Capítulo III analizamos luego la idea de Ricardo Zelarayán del lenguaje como única realidad y su reelaboración en los noventa, y en el capítulo anterior vimos en cambio cómo Masotta define el pop como el arte de “representar lo representado” (Masotta: 2004, 114), en una propuesta que es útil para pensar el modo de trabajar los objetos de la cultura de masas en poéticas como las de Mariasch y Mallol. Foster sin embargo no se pliega a esta interpretación del pop -que nosotros encontramos válida para las poéticas del capítulo anterior, pero no para las de este- y propone su propia versión de un “realismo traumático”, como encuentro fallido con lo real, que no puede ser representado (Foster: 2001, 140).

Pero en nuestra opinión ninguno de estos modelos es pertinente para pensar la construcción de realidad que se efectúa en los textos de Cucurto y de ByF, porque en ellos hay una fuga a lo fantástico que tiene sin embargo una base realista fuertemente señalada en los textos -la garantía de esta “realidad” reside de hecho en la presentación del poema como experiencia de un yo real-. Por eso Palmeiro toma el concepto de “realidadficción” de Josefina Ludmer para pensar estas escrituras, con el que Ludmer se refiere a la producción de realidad que una serie de ficciones recientes comparten con la instancia abarcadora a la que denomina “imaginación pública” ${ }^{355}$ Para Ludmer hay un

\footnotetext{
355 Josefina Ludmer, “Literaturas posautónomas”, en Aquí América Latina. Una especulación., Buenos Aires, Eterna Cadencia, 2010 (153). En nuestro caso, y sin necesidad de recurrir a un neologismo como el "realidadficción" propuesto por Ludmer, consideramos que se trata de ficciones en la medida en que hay en ellas un proceso de construcción por demás evidente,
} 
nuevo tipo de escrituras que atraviesan las fronteras de la realidad y la ficción para

quedar “afuera-adentro” en ambas. Dice Ludmer:

Esto ocurre porque reformulan la categoría de realidad: no se las puede leer como mero realismo, en relaciones referenciales o verosimilizantes. Toman la forma del testimonio, la autobiografía, el reportaje periodístico, la crónica, el diario íntimo, y hasta de la etnografía (muchas veces con algún "género literario" injertado en su interior: policial o ciencia ficción, por ejemplo). Salen de la literatura y entran a "la realidad" y a lo cotidiano, a la realidad de lo cotidiano, y lo cotidiano es la TV y los medios, los blogs, el e-mail, Internet. La realidad cotidiana no es la realidad histórica referencial y verosímil del pensamiento realista y de su historia política y social (la realidad separada de la ficción), sino una realidad producida y construida por los medios, las tecnologías y las ciencias. Es una realidad que no quiere ser representada porque ya es pura representación: un tejido de palabras e imágenes de diferentes velocidades, grados y densidades, interiores-exteriores a un sujeto, que incluye el acontecimiento pero también lo virtual, lo potencial, lo mágico y lo fantasmático. (Ludmer: 2010, 151).

Aunque aquí no nos adentraremos en los debates actuales sobre la autonomía literaria de los que forma parte este texto de Ludmer, ${ }^{356}$ sí nos parece pertinente la reformulación de la "realidad" como categoría que la autora lleva a cabo, a partir de las múltiples combinaciones que realizan estos textos entre escrituras "no ficcionales" como la autobiografía y el diario íntimo, y géneros literarios como el policial, la ciencia ficción o incluso lo fantástico.

como intentaremos demostrar, pero cuya complejidad y carácter revulsivo están dados justamente por su capacidad para presentarse de modo persuasivo como realidades.

${ }^{356}$ Con respecto a este punto, hay una serie de artículos críticos recientes que discuten la idea de "posautonomía" y otras nociones propuestas por Ludmer. Alberto Giordano se pregunta por ejemplo si estos textos realmente indican como afirma Ludmer que estamos ante un cambio en el estatuto de la literatura. Acerca de los nuevos modos de combinar realidad y ficción, dice Giordano: “¿No sería más conveniente pensar que la ambigüedad de algunas prácticas del presente significa otro avatar, condicionado por el estado actual de la cultura posmoderna, de la tensión entre experiencia e institución que mueve a la literatura desde sus comienzos, antes que un síntoma (...) de la formación de un nuevo "imaginario de las artes verbales" heterogéneo al que se definió en la modernidad? Se sabe, al mismo tiempo que participó del proyecto civilizatorio del humanismo burgués, la literatura ha sido, desde sus orígenes románticos, una experiencia ininterrumpida de los límites de tal proyecto". Alberto Giordano, "Presentación”, en Alberto Giordano (ed.), Los límites de la literatura, Rosario, Centro de Estudios de Literatura Argentina, UNR, 2010 (11). Para otra perspectiva sobre el tema ver la reseña crítica de Miguel Dalmaroni al libro de Ludmer en Miguel Dalmaroni, “A propósito de un libro de Ludmer (y de otros tres)”, en BazarAmericano, Actualización octubre/noviembre de 2010.

http://bazaramericano.com/buscador.php?cod=19\&tabla=columnas\&que=miguel\%20dalmaroni 
Esta operación no tiene antecedentes en poesía pero sí en la obra narrativa de César Aira, que también se construye muchas veces como protagonista de sus propios relatos. Además, el gusto por las formas populares y masivas de la cultura forma parte también de una “tradición intelectual”, como señala Sandra Contreras, en la que se inserta el propio Aira (Contreras: 2002, 117). Por eso no puede decirse que los textos “salgan de la literatura” como anota Ludmer, sobre todo desde el momento en que en Cucurto, como veremos, el gesto es el de disputar insistentemente el derecho de entrada a la misma. Pero sí es cierto que, más todavía que las poéticas del capítulo anterior, aquí la escritura se rige por una lógica que proviene en buena medida de los modos de representación de los medios de comunicación y la cultura de masas y que además y en tensión con esto, a diferencia de las poéticas “pop” que se ponían en evidencia como reelaboraciones de consumos culturales, se construye con rasgos fuertemente “realistas”.

Por último, y dado que estas poéticas son las que más controversias suscitaron en el momento de su emergencia, cabe recordar que según Bourdieu, en el campo literario llegado a cierto punto de su desarrollo, el proyecto más vanguardista y revolucionario es también el que está más cargado de guiños que remiten a la historia específica del campo (que en estos poetas, y sobre todo en Cucurto, incluyen en ocasiones el recurso a la parodia) (Bourdieu: 1997, 242). ${ }^{357}$ Por eso la intervención mayor sobre la tradición que realizan estos textos reside no sólo en el uso del pastiche sino fundamentalmente en su construcción de autores-personajes y en sus modos de "producir realidades que parezcan ficciones”, como propone Sibilia, que por su sola

\footnotetext{
${ }^{357}$ No estamos dando a entender que se trate de escrituras de vanguardia, sino que a partir del concepto relacional y no esencialista de vanguardia que propone Bourdieu, si hubiera que identificar esta posición en el campo poético de los noventa habría que situar en ella a estas poéticas. El carácter "revolucionario" sí les corresponde, como veremos, y en especial a Cucurto por el escándalo suscitado por su primer libro.
} 
presencia ponen en cuestión de modo radical las otras variantes que coexisten en el campo, y a los que se dará atención especial en las páginas que siguen.

\section{2- ANALFABETO, MARGINAL Y MALDITO: LA CONSTRUCCIÓN DE WASHINGTON CUCURTO}

Zelarayán (Buenos Aires, Deldiego, 1998) es el primer libro publicado por Santiago Vega bajo el seudónimo de Washington Cucurto, que en un principio fue un personaje construido según el modelo de los heterónimos literarios usados, por ejemplo, por Juan Gelman o Fernando Pessoa para ensayar diversos estilos asociándolos a una figura de poeta determinada. En 1998, Vega ganó el II Concurso Hispanoamericano “Diario de Poesía” con este libro, premio que compartió con La raza de Santiago Llach. El texto, que contiene escenas de sexo y violencia que involucran a mujeres y diversos tipos de inmigrantes, hizo que el autor fuera tildado de misógino y racista y provocó cierto escándalo porque, al ser publicado con una subvención de la Secretaría de Cultura y de Medios de la Nación, la Conabip lo distribuyó a algunas bibliotecas populares de la provincia de Santa Fe. Zelarayán fue denunciado por el director de una biblioteca y destruido por considerárselo “deplorable” y “no apto para todo público”, en un caso en el que intervino el Ministerio de Educación de la provincia de Santa Fe. La segunda edición, que apareció en el 2001 a cargo de la revista chilena Matadero, incluye en la primera página el mail de una bibliotecaria que califica a Zelarayán de libro de “mal gusto” y aclara que los ejemplares donados a la biblioteca fueron quemados. ${ }^{358}$

\footnotetext{
${ }^{358}$ Washington Cucurto, Zelarayán, Revista Matadero, 2001 (en la edición no figuran más datos editoriales).
} 
El impacto simbólico de este ejercicio de censura provocó una reacción defensiva de parte de la comunidad artística, y al mismo tiempo otorgó a Cucurto (para ese entonces la identidad y el nombre de Santiago Vega ya habían sido absorbidos en el personaje) la posibilidad de asumir un estatus de malditismo a partir del cual él construyó, en buena medida, su figura de poeta. ${ }^{359}$ Bourdieu define al artista maldito como "víctima provisional de la reacción suscitada por la revolución simbólica que lleva a cabo" (Bourdieu: 1997, 102). ${ }^{360}$ En el caso de Cucurto, esta noción de malditismo se trabaja a conciencia como figura, dentro de una operación de pastiche que no sólo incluye textos sino también figuraciones previas. Y se lo hace, en parte, desde la exasperación de esta “revolución simbólica” inicial, podríamos decir, que consistió en

${ }^{359}$ En la página web del Proyecto Venus, de Roberto Jacoby, puede leerse una pequeña entrevista de Martín Prieto a Santiago Vega a propósito del caso, junto con un comunicado oficial del gobierno:

http://proyectov.org/venus2/index.php?option=com_content\&task=view\&id=259

En otra nota del mismo sitio web se vuelve sobre el caso, con el siguiente texto: "El libro Zelarayan del joven poeta (que recibe en su casa a quien quiera para abrirle su biblioteca de poesía latinoamericana) fue declarado "material para adultos" por su "xenofobia" y "pornografía" por el Director de la regional IV de Educación, señor Andrés Rattaro. La idiotez también corrió por cuenta de la secretaría de Cultura que envió el libro a las escuelas en lugar de hacerlo a las Bibliotecas Populares para las cuales estaba destinada la compra.”

En http://proyectov.org/venus2/index.php?option=com_content\&task=view\&id=193

${ }^{360}$ No estamos sugiriendo que deba pensarse a Cucurto bajo el mismo estatus de malditismo que Bourdieu usa para analizar la situación de Baudelaire en el campo literario francés de mediados del siglo XIX como “crítico del gusto burgués” (Bourdieu: 1997, 103). Antes bien, una vez que la oposición a los valores vigentes se convierte en el modo de acceso legítimo de los artistas al campo, esta figura puede recuperarse a conciencia, incluso como parte de una estrategia de promoción llevada a cabo por la prensa. Así, varias entrevistas al poeta comienzan por presentarlo como "escritor maldito" (Entrevista de Julia Mangolini, 8 de marzo de 2011, en http://www.niapalos.org/?p=3820; esta denominación es empleada también de modo acrítico en un artículo académico, ver Graciela Aletta de Sylvas, "El lenguaje de la marginalidad en Paraguayito de mi corazón de W. Cucurto”, en Políticas lingüísticas Año 2 Vol. 2, octubre de 2010, Córdoba, Facultad de Lenguas, Universidad Nacional de Córdoba, ISSN 1853-3256, p. 70). En otra entrevista se pone de relieve esta operación cuando se habla de la "parafernalia (modesta, pero parafernalia al fin) de marketing que lo señala ya como un escritor maldito". Ver Diego Erlan, "Washington Cucurto, el escritor del país que la literatura no mira" (entrevista), en http://occidentes.com.ar/noticias/literatura/285/washington_cucurto el escritor del_pais que_l a literatura no mira .htm.

Damián Selci y Claudio Iglesias analizan críticamente este estatus de malditismo en "Análisis de un malentendido", que pondremos a consideración más adelante. 
hacer ingresar al campo literario toda una serie de representaciones políticamente incorrectas de los inmigrantes y las clases bajas -protagonistas de todos sus textos-, que están estrechamente relacionadas con la construcción de sí mismo como “negro”.

Pero si Zelarayán se publicó con la firma de Santiago Vega, el segundo libro del poeta, La máquina de hacer paraguayitos, introduce a Washington Cucurto en la figura de un autor ficcional que se identifica en un texto al final del libro, que lleva su firma. Allí Cucurto se presenta como un escritor dominicano nacido en 1942 que se radica en Buenos Aires en la década del setenta, donde funda el "realismo atolondrado", una corriente literaria que se basa en el plagio. ${ }^{361}$ Esta especie de posfacio está firmado por Santiago Vega como “albacea” de Cucurto, quien declara que el autor dominicano le dejó todos sus manuscritos (Cucurto: 1999, 55). Hasta ese momento Vega se diferenciaba explícitamente de su personaje, pero en sus libros posteriores, todos firmados bajo el seudónimo de Washington Cucurto, esa doble identidad se perdió porque Vega adoptó definitivamente el nombre de Cucurto y comenzó a relatar sus orígenes como escritor desde esa identidad, a la vez que el relato ficcional sobre el autor dominicano quedó en el olvido.

Así, el poeta ha contado repetidas veces en entrevistas cómo el nombre “Cucurto” le fue impuesto por los poetas que hacían la revista 18 Whiskies (Durand, Villa, Desiderio, etc.), como se pone de manifiesto en una entrevista realizada por Timo Berger:

No lo construí, lo construyeron los demás. Me decían Cucurto. Yo lo adopté. Y empecé como la burla de volverla. Te gastan siempre cuando sos el más boludo del grupo, el más chico. Empezó con los del Diego, con la editorial de Daniel Durand. (...) Cuando sale Zelarayán, me ponen "Cucurto”. Yo voy a la casa de Durand, ya

\footnotetext{
${ }^{361}$ Washington Cucurto, La máquina de hacer paraguayitos, Buenos Aires, Siesta, 1999 (53,
} 54). Todas las citas posteriores están tomadas de la misma edición. 
está el libro hecho y dice "Cucurto". Así que a ellos agradezco también. Fueron los primeros que me dieron bola de alguna manera." 362

La anécdota se completa, en otro texto, con el detalle significativo de que el término “Cucurto” parte de un balbuceo en el lenguaje, causado por la timidez que le producían a Santiago Vega los otros poetas, mayores que él y relativamente consagrados: "Casas le presenta a Desiderio, Durand, Villa, Rojo y demás poetas de la 18 Whiskys.. (...) Una noche, cuando se está despidiendo para volver a su casa, le quiere decir a los Whiskys “Yo curto el 36”, pero le sale “yo cucurto el 36”, ya que todavía no maneja el léxico juvenil y se trabuca”. Este relato figura en un pliego, publicado en papel y subido a la página web de la editorial Interzona, que describe en clave cómica la evolución de Cucurto desde la infancia hasta la adultez, y en el que él mismo remeda, en una serie de fotos, los gráficos que ilustran el modelo de la evolución darwiniana. ${ }^{363}$

El mismo relato es recuperado por Cucurto en su novela Las aventuras del Señor Maíz, en la que cuenta cómo, con la llegada de Gelman a Argentina a fines de los ochenta, conoció a los que poco después serían llamados “poetas de los noventa”: "Me daban miedo. Bromeaban mucho con los putos y los negros. Yo era un negro. Cuando volvimos caminando me invitaron a otro bar. Yo dije claramente, “No, no, yo cu, curto el 39”. Y se empezaron a reír, a señalarme y a decirme “iCucurto, Cucurto, Cucurto!”. ${ }^{364}$ Como muestran los ejemplos citados, en el entramado de la figura de Cucurto se da un desplazamiento desde el uso relativamente sofisticado de un

\footnotetext{
${ }^{362}$ En Timo Berger, "Yo actualmente soy el mejor escritor dominicano sin duda" (entrevista a Washington Cucurto), en la página web del Proyecto Patrimonio, Chile, 2010. En: http://letras.s5.com/tb060710.html

${ }^{363}$ En: http://www.interzonaeditora.com/titulos/getAttachment.php?a=8\&f=5

${ }^{364}$ En Washington Cucurto, Las aventuras del Señor Maíz, Buenos Aires, Interzona, 2005 (48).
} 
heterónimo literario, a este relato donde el narrador se separa de "los poetas" mediante la frase “yo era un negro”, que insiste sobre su no pertenencia al campo literario. ${ }^{365}$

Esta afirmación sobre la propia identidad social cobra una importancia fundamental porque se convierte en el sustento de la verosimilitud del mundo representado en la obra de Cucurto, y también de su derecho a representarlo. Además definirse como "negro" supone asumir una identidad que en otros textos de los noventa, como Punctum de Martín Gambarotta y La raza de Santiago Llach, aparece como "lo otro”. En Punctum, el negro se presenta como estereotipo desde la voz de uno de los personajes que reproduce los lugares comunes que definen socialmente al otro, cargados de prejuicios: “Así que no te hagás el negro,/ el negro de mierda muere viajando de polizón/ y baila a lo grasa en el Super Verdi Tropical,/ duerme en una pieza sin enchufes” (Gambarotta: 1996, 50), y también “Los negros con buzos de gimnasia adidas/ comen en los puestos de panchos” (Gambarotta: 1996, 51). En La raza, uno de los integrantes de Los Mickey, descrita como "una banda de hijos de ricos,/ conchetos y católicos” (Llach: 1998, 14) cuenta que "Esa noche salimos a cazar negros/ cerca de la villa del Bajo.” (Llach: 1998, 12). Ninguno de estos “negros”, por supuesto, tiene una voz en los poemas, aparte de que son representados siempre desde la perspectiva de otro que los cosifica bajo el mote generalizador de “el negro”, como se lee en Punctum, y los convierte en objeto de violencia física o verbal.

Por eso en los libros de Cucurto el origen “negro” del autor (dominicano en La máquina de hacer paraguayitos, pero que después mutará hacia el uso popular y

\footnotetext{
${ }^{365}$ Cucurto se propone, de esta manera, como una figura construida por el campo, y más específicamente por el grupo vinculado a la revista 18 whiskies al que Durand planteaba, según vimos, como alternativa a la hegemonía del Diario de poesía, a pesar de que muchos de estos poetas alcanzan la consagración gracias a la publicación de inéditos en este medio y a la instancia legitimadora representada por el Concurso Hispanoamericano "Diario de Poesía". Después, efectivamente, este grupo se separa del Diario a medida que se va tramando alrededor de sus textos y figuras de poetas una zona que se opone al objetivismo ideológicamente, y que construye sus propias instancias de legitimación.
} 
despectivo de “negro” como el marginal o el “otro” para las clases medias y altas argentinas de origen europeo) representa el verdadero gesto por el cual el poeta se desvía de esa tradición, en la medida en que por primera vez en la poesía argentina, el “negro” tiene una voz y tiene un nombre, aunque en sus textos esa figura sirva también para amalgamar un repertorio de identidades heterogéneas, como veremos. Y al mismo tiempo cumple la función de hacer ingresar a los textos un mundo que tiene una base real: se trata de los barrios de Once y Constitución, especialmente, con sus bailantas y sus conventillos, sus prostitutas dominicanas y todo un sector social que representa a las nuevas corrientes inmigratorias que llegaron al país desde Paraguay, Perú, Bolivia y otros países latinoamericanos durante las últimas décadas.

Con respecto a esto, en el armado desde lo referencial del mundo que representa Cucurto se inscribe en la tendencia reciente que Graciela Speranza caracteriza a partir de cierto "espíritu etnográfico", por el cual los escritores "parecen haberse abierto a lo que se ve y se oye en las calles de Boedo, la bailanta o el chat, aquilatado en el protagonismo de lúmpenes o individualidades sobresalientes del barrio bajo”. ${ }^{366}$ Según Speranza, el peso simbólico que adquiere la figura del escritor en relación con el lugar geográfico que recorta en sus textos tiene consecuencias fundamentales en el modo de representación del otro, porque "garantizado por la extracción social del que escribe o la inmersión vocacional en la impureza, el pasaje al otro lado -y por extensión el paralelismo entre el lenguaje y lo real- se alcanza con sorprendente facilidad.” (Speranza: 2005, 17). El origen social o el lugar en que se vive aparecen entonces como garantía, ya sea de verosimilitud, ya sea de la legitimidad de las representaciones,

\footnotetext{
${ }^{366}$ Graciela Speranza, "Por un realismo idiota”, en el Boletín del Centro de Estudios de Teoría y Crítica literaria, Rosario, Facultad de Humanidades y Artes, Universidad Nacional de Rosario, diciembre del 2005 (17). Si bien Speranza trabaja en el artículo citado con la narrativa, puede pensarse a otros poetas de los noventa, como Fabián Casas y Daniel Durand en relación al barrio de Boedo, o Desiderio con el Bajo Flores, como figuras que se proponen, con diverso énfasis, como etnógrafos del lugar en que viven.
} 
realistas o no, de un mundo que muchas veces el escritor señala como "otro” cuando lo traduce para el campo literario. ${ }^{367}$

En consonancia con esto, los principales argumentos de Cucurto para justificar su derecho a representar en sus textos a ciertos sectores sociales, como los inmigrantes bolivianos y paraguayos, apelaron desde un principio a la autobiografía y configuraron el perfil de escritor que mantuvo en todos sus libros:

Mi viejo era vendedor ambulante y andábamos toda la vida en la calle, y él tenía esa cosa alegre que tienen los pobres (que tenían perdón, porque ahora la perdieron completamente), de andar por la vida, de sacarle pecho a la vida, de alegrar a la gente para que le compre una chuchería. Muchos dicen que mi poesía es misógina, están equivocados, mi poesía tiene esa alegría, esa vitalidad de la gente con la que me crié... Bueno, esa alegría yo la encontré en los inmigrantes con los que me crié. El inmigrante es gente muy sufrida, siempre remándola de noche y de día, y sin embargo no pierden nunca la alegría de bailar, de singar... Mi viejo tiene una relación muy fuerte con todos ellos, pues le vendía medias, repasadores, a paraguayos, peruanos, bolivianos, yo tengo un poco de boliviano y paraguayo. ${ }^{368}$

Como se ve, Cucurto, al igual que Durand, exhibe un linaje que se construye por fuera de lo literario, y plantea una forma de populismo idealizador que consiste en destacar el vitalismo de las clases populares, especialmente los inmigrantes provenientes de países limítrofes. Cucurto destaca la cercanía del padre con estos sectores y la convierte en una

367 Porque esa figura, la del traductor, es precisamente la que Cucurto construye para sí en algunos de sus textos, y sobre todo en sus novelas. En el prólogo de Cosa de negros, por ejemplo, se dice a los lectores: "Señoras y señores, bienvenidos al fabuloso mundo de la cumbia. Están por ingresar con boleto preferencial (y en una Ferrari) al magnífico barrio de Constitución, cuna de la mejor cumbia del mundo, lugar donde todo es posible. (...) Pasen, vean, están ustedes invitados...”. En Washington Cucurto, Cosa de negros, Buenos Aires, Interzona, 2003 (64). En este fragmento es evidente cómo se está pensando en un lector que no pertenece al mundo representado, en el que puede ingresar como "invitado" de la mano del narrador, que sí tiene acceso a ese mundo.

Este es el gesto permanente en las novelas, especialmente: el de "explicar" el mundo de lo popular a la intelectualidad letrada, como se ve en otro fragmento de Cosa de negros donde se aclara qué son las tickis (nombre inventado por Cucurto para las chicas del Once y de Constitución): "Ellas no saben lo que es el negocio. No conocen a Freud e ignoran el psicoanálisis. Igual les pasa con el yoga, la comida vegetariana y la internet. De lo que son auténticas conocedoras es de letras de cumbia y capítulos de novelas televisivas. Pues su vida es una novela, y tienen una imaginación novelesca que a mí me encantaría tener” (Cucurto: 2003, $61)$.

${ }^{368}$ Paula Leitao, "El hombre de los mil nombres y un rostros" (sic), entrevista a Santiago Vega (alias Washington Cucurto), en Vox Virtual No 15, Vol. II, Bahía Blanca, Abril del 2003. En: http://proyectovox.org.ar/virtual_15-2.htm 
especie de herencia para terminar diciendo "yo tengo un poco de boliviano y paraguayo".

Esta variante del populismo representa una innovación dentro de la tradición literaria porque como señala Miguel Dalmaroni, el populismo en la poesía argentina suele estar asociado a representaciones pietistas, desde González Tuñón hasta la primera poesía de Gelman, y es una denominación de la que autores como Osvaldo y Leónidas Lamborghini intentaron separarse (Dalmaroni: 2004, 13-16). Sin embargo Dalmaroni cita una definición del término en tanto “aquellas fórmulas políticas por las cuales el pueblo, considerado como conjunto social homogéneo y como depositario exclusivo de valores positivos, específicos y permanentes, es fuente principal de inspiración y objeto constante de referencia”, ${ }^{369}$ que sirve para describir la relación que Cucurto establece con las clases bajas y los inmigrantes en sus textos y entrevistas. Sólo que aquí se modifican las valoraciones porque Cucurto, como vimos, destaca la alegría y la vitalidad de los “pobres”, como él mismo los llama en la entrevista recién citada, y es así como los representa en todos sus libros, además de que se incluye a sí mismo en este grupo.

De esta manera se invierten los valores que definen un perfil de escritor que se caracterizaría por su conocimiento exhaustivo de la literatura o por una formación literaria temprana y se los reemplaza, como analizamos a propósito de Segovia de Daniel Durand, por la exhibición de un linaje popular, extraliterario y peronista, al que Cucurto suma la relación estrecha con los inmigrantes. Como parte de esta operación, en la misma entrevista ya citada, cuando se le pregunta por el uso que hace de los heterónimos Cucurto no alude a la construcción de su personaje en La máquina de hacer paraguayitos sino que dice: “Está toda esa cuestión peronista donde todos nos

\footnotetext{
${ }^{369}$ La cita pertenece a Ludovico Incisa, “Populismo”, en Norberto Bobbio y otros, Diccionario de política, México, Siglo XXI, 1992 (1247); citado en Dalmaroni: 2004, 18.
} 
llamábamos ‘compañero’, fijate vos qué casualidad a Perón le decían Pocho y a Eva, simplemente Evita, ¿no es conmovedor eso?; sólo por eso soy peronista, porque el peronismo tiene esas cosas preciosas, esa alegría, es como decía Favio “el movimiento de la revolución de la alegría”. ${ }^{370}$

Como se ve, por un lado el poeta remite el uso de los heterónimos -o más precisamente “sobrenombres"- no a la literatura sino a una práctica popular que remonta hasta el peronismo (a la vez que omite el gesto "literario" inicial de haberse inventado un heterónimo). Y al mismo tiempo que se declara peronista, construye para el movimiento una imagen de la que apenas quedan el pragmatismo y la alegría popular. El peronismo de Cucurto es el mitificado movimiento de la década del '40 y está vaciado de contenido político, además de que se aplica no sólo al “pueblo” argentino sino que abarca también a los inmigrantes. Es por eso que en un verso del poema "La muerte viene vestida de mulata”, los peruanos y dominicanos, asimilados al pueblo peronista, se dirigen a la muerte y le dicen "que cómo vamos a morirnos un 17 de octubre”. 371

Se trata nuevamente de la construcción de una figura de analfabeto (como lo muestra en este caso la insistencia en no hablar de literatura en términos "literarios”), con énfasis en un origen social de sesgo popular. Ese origen sería lo que permite la introducción de un mundo que se supone desconocido para el campo literario. El autorpersonaje Cucurto se presenta como el traductor de este mundo, que en sus textos hace el gesto de volver visible frente a un ámbito literario del que lo piensa como separado completamente. ${ }^{372}$

\footnotetext{
${ }^{370}$ Paula Leitao, op. cit.

${ }^{371}$ Washington Cucurto, La máquina de hacer paraguayitos, Buenos Aires, Siesta, 1999 (50).

${ }^{372}$ En este sentido, puede pensarse que Cucurto, paradójicamente, no hace más que reafirmar la división entre alta cultura y cultura de masas. Así lo señalan Damián Selci y Claudio Iglesias en
} 
Pero la diferencia con las figuraciones de analfabetos que analizamos antes es que en el caso de Cucurto el personaje (que al poco tiempo se confundió con el autor) cobra una importancia fundamental, porque en su construcción participaron tanto otros poetas y editores contemporáneos como los medios de prensa. ${ }^{373} \mathrm{Al}$ mismo tiempo, los

su artículo “Análisis de un malentendido": “Como escritor-testigo del modo de vida de los inmigrantes peruanos Cucurto no ocupa el lugar verlaineano de la maldición, sino el más canónico de fundador. Cucurto sólo es maldito desde y para los intelectuales; adosarle ese mote es inscribirlo en un determinado campo de vectores, orientarlo hacia el ámbito profesional frente al cual su mensaje alcanza verdadero sentido: los profesores de letras y sus dolorosas polémicas. Desde este punto de vista, y aunque él mismo quizás no se haya percatado, Cucurto es principalmente (como trataremos de demostrar) un crítico literario escribiendo literatura: su referente más nítido no es ni de lejos Roberto Arlt, sino más cercanamente Silvia Molloy, cuyas inagotables novelas tratan sobre la deconstrucción, el devenir-menor, la circulación del poder y otros temas de esta suerte. La elocuencia con la cual Cucurto construye un mensaje y lo dirige a sus colegas no necesita ser críticamente establecida: alcanza con leer las primeras páginas de la novela para comprobarlo (Nota: se refieren a la entonces recién publicada El curandero del amor, Buenos Aires, Interzona, 2006). El problema es ver qué dice efectivamente Cucurto, siendo evidente ya a quién le habla.”

Este texto fue publicado por la revista virtual Éxito en el verano del 2007, y actualmente se encuentra disponible en el sitio www.notasexito.blogspot.com.

Estamos de acuerdo con Selci e Iglesias en este punto, puesto que todas las operaciones de Cucurto, desde la construcción del personaje hasta el diálogo permanente con los críticos y escritores contemporáneos en sus textos, representan guiños al interior del campo, y que sólo adquieren sentido en el marco de la historia específica del campo literario, como señalamos con Bourdieu. Sin embargo las polémicas en torno a la figura de Cucurto exceden el ámbito académico, además de que el término "maldito" se usó abundantemente en las notas de prensa, como consignamos. Por eso es productivo tomarlo en cuenta aunque sea en tanto artificio, como lo hacemos aquí, a fines de preguntar con respecto a qué valores se definiría ese hipotético malditismo, y sobre todo qué postura hacia la tradición señala.

${ }^{373}$ Es importante destacar que esta presencia en los medios de prensa se debe a que Cucurto pasó de la publicación de poesía en editoriales independientes como Deldiego y Vox a la escritura de novelas, que se publicaron primero en editoriales también independientes como Interzona, y luego en una editorial mayor como Emecé. Cucurto, junto con Fabián Casas, es el único de los poetas de los noventa que pasó de las editoriales independientes al circuito comercial, en ambos casos, de la mano de la narrativa, y fue el único poeta de los noventa que fue entrevistado en medios como las revistas Noticias y Los inrockuptibles, los diarios Perfil, Clarín, Página/12 y la revista Rolling Stone, por dar sólo algunos ejemplos. A continuación figuran algunas notas donde puede leerse también la construcción que estamos analizando:

Aquí, un texto y entrevista de Fernanda Nicolini para el sitio web de la Revista Noticias: http://www.revista-noticias.com.ar/comun/nota.php?art=137\&ed=1577

Un fragmento de la entrevista realizada por Matías Capelli que se publicó en la edición impresa de Los inrockuptibles, $\mathrm{N}^{\mathrm{o}}$ 110, Buenos Aires, diciembre del 2006:

http://www.losinrockuptibles.com/cucurto.htm

Una nota del diario Perfil a propósito de la publicación de El curandero del amor (Buenos Aires, Emecé, 2006): 
editores y los mismos poetas de los noventa, especialmente los vinculados a la revista 18 Whiskies, tuvieron un papel central en la promoción de Cucurto, al que propusieron como escritor "de culto" y de hecho bautizaron con ese nombre. ${ }^{374}$ Cucurto parece realizar para los pares, en este sentido, la utopía de no ser poeta que señalábamos en el capítulo tres, y que en Durand y Gambarotta estaba encarnada en diversos personajes ficcionales, diferenciados del “autor”. Efectivamente el analfabeto, que en libros como Punctum, Segovia y La raza era una construcción llevada a cabo por poetas "letrados”, o una figura externa que formaba parte del paisaje de la ciudad y que se contemplaba con desprecio o indiferencia, encuentra en Cucurto una realización que se presenta como “verdadera”, porque cuando Cucurto empezó a escribir poesía era un adolescente que trabajaba como repositor en un supermercado, y éste es un relato de origen que, de nuevo, se repite una y otra vez en sus textos y en entrevistas. ${ }^{375}$

http://www.perfil.com/contenidos/2006/11/22/noticia 0062.html

Nota del diario Página/12 sobre la misma novela: http://www.pagina12.com.ar/diario/suplementos/espectaculos/4-4988-2007-01-05.html

Y aquí, un par de notas de Clarín que sirven a modo de ejemplo de la cobertura más temprana que se le dio a Cucurto, desde el año 2002. La primera de ellas es la misma entrevista a cargo de Martín Prieto que aparece en el sitio web del Proyecto Venus: http://edant.clarin.com/suplementos/cultura/2002/03/30/u-00801.htm

Un pequeño texto del suplemento Sí! del Clarín a propósito de la quema de Zelarayán: http://edant.clarin.com/suplementos/si/2002/06/07/3-00204.htm

${ }^{374}$ Así se editorializa, en el sitio web de la Editorial Interzona, la aparición de la segunda edición de la novela Cosa de negros (Buenos Aires, Interzona, 2006): “La aparición de Cosa de negros convirtió a Cucurto en un autor de culto. Los dos relatos que integran el libro marcan el momento en el que el mundo de la cumbia, de la bailanta, de la música tropical se topa con la literatura, para desembocar en una escritura absolutamente nueva y original." Novedad, originalidad absoluta, y carácter "de culto" (que supone un modo de circulación restringido y marginal, que no se aplica en este caso) son los valores que aquí como en otros comentarios se atribuyen a la escritura de Cucurto.

En: http://www.interzonaeditora.com/titulos/titulo.php?idTitulo=7\&idAutor=8

${ }^{375}$ De hecho el enredo Cucurto-Vega fue representado en una serie de capítulos de la novela Las aventuras del Sr. Maíz en la que se cuentan los comienzos de la carrera literaria de Cucurto a partir del primer poema de Zelarayán, escrito mientras trabajaba como repositor en un supermercado:

“-No, señor. Usted se llama Santiago Vega. Tyson Grande es su apodo. 
Como vemos, el origen "literario" de Cucurto en tanto autor ficcional que funcionaba como heterónimo de Santiago Vega fue omitido y reemplazado por el relato de un origen popular y marginal para la figura de Washington Cucurto como autorpersonaje. Esta figura, que participa tanto del orden de lo real como de lo ficcional porque aparece como protagonista de todos los libros pero a la vez se identifica con la persona biográfica del autor, habilita las representaciones de los inmigrantes y marginales en los textos -incluso cuando son políticamente incorrectas-, el uso aleatorio de la tradición, y la presentación de un mundo -junto con las hablas que lo conforman- que Cucurto conocería de primera mano.

Montada sobre esta figura, la operación que recorre sus textos es la del saqueo de la tradición, porque el mundo al que nos referimos aparece construido a partir del pastiche de textos previos. De hecho La máquina de hacer paraguayitos es un libro que está compuesto íntegramente con este procedimiento que consignamos a partir de Jameson. Los usos y apropiaciones de textos previos son aleatorios, y muchas veces funcionan como alusiones que se incorporan para construir el propio texto, que no trabaja con las significaciones ideológicas previas del material citado. Así es como figuran menciones a la novela Los pichiciegos de Rodolfo Fogwill ("si no fuera porque

-Sí, Vega, a usted lo apodan Tyson Grande pero no es su nombre. Por cierto, un apodo bastante despreciativo.

Yo:

- ¡Yo me llamo como quiero!

-No, señor usted es Santiago Vega.

Yo:

-No, yo soy Washington Cucurto.

-No insista con lo mismo...

-Sí, dese cuenta de una buena vez...

-Cucurto es un personaje literario.”

Este fragmento está tomado de Las aventuras del Sr. Maíz, Buenos Aires, Interzona, 2005 (32, 33). El grado de autoconciencia con que se narran retrospectivamente estos inicios literarios aparece enunciado así: "Mientras espero el momento de mi consagración, repongo y garabateo en mi mente los poemas de Zelarayán. [...] Dentro de poco seré invencible. Mi vida y mi literatura son una ensalada con los ingredientes más desopilantes. ¡Contra eso no puede nadie!” (Cucurto: 2005, 36). 
me bates el pichiciego", Cucurto: 1999, 16), a Reinaldo Arenas (“te toca que te roben la cartera un tintel un rímel una novela de Arenas”, Cucurto: 1999, 17), Georges Perec (“A vos, ¿te gusta Perec, te gusta Perec, te gusta Perec?”, Cucurto: 1999, 18), y Ezra Pound (“con usura todo lujo es niñería, pues con usura jamás pintaremos un campo de girasoles”, Cucurto: 1999, 22), por dar sólo algunos ejemplos.

En otros casos los textos están tramados según modelos como los epigramas clásicos $^{376}$ (“y ahora licenciada, licenciosa,/ a fuerza de números te recibiste en letras/ y ya no le das bola a esos jactanciosos/ jugadores organizadores de jodas...”, Cucurto: 1999, 33), o de la poesía medieval española mediada por lo latinoamericano. En "La muerte viene vestida de mulata”, por ejemplo, está el motivo de la visita de la muerte, a la que sus posibles víctimas le objetan, como habíamos citado, “que cómo vamos a morirnos un 17 de octubre” (Cucurto: 1999, 50). De modo similar, un poema de Zelarayán funciona como reescritura parcial de un poema del chileno Gonzalo Rojas: “Afuera estaba parado Jesús, ¡el verdadero!/ Jesús, el plomo, acusándote de copión./ ¡No le copien a Jesús, no le copien/ al copión maravilloso de Jesús!”. ${ }^{377}$ En este caso, tampoco se trata de un gesto paródico hacia Gonzalo Rojas ni de un comentario sobre la poesía de Pound sino de poner en escena, mediante una vuelta de sentido, parte de la poética de Cucurto. Porque Gonzalo Rojas lee a Pound como un poeta que “copia” de la

\footnotetext{
${ }^{376}$ Los epigramas, que en un primer momento eran inscripciones realizadas en piedras, monumentos y tumbas como dedicatoria a un personaje en especial, se independizaron después de este origen como forma poética cultivada en el período helenístico cuya característica principal era una fuerte impronta deíctica que señalaba a una situación de enunciación, muchas veces de contenido erótico o satírico. Ver Peter Bing y Jon Steffen Bruss (editores), Brill's Companion to Hellenistic Epigram, Boston, Brill, 2007 (1-28). Esta forma fue recuperada en la poesía latinoamericana por Ernesto Cardenal en 1961 y muy probablemente de esta lectura la haya tomado Cucurto; ver Ernesto Cardenal, Epigramas, Buenos Aires, Ediciones Carlos Lohle, 1973.

377 “De lo que le pasó al Ricky al caer sobre una sinagoga”, en Washington Cucurto, Zelarayán, Buenos Aires, DelDiego, 1998. La edición no tiene páginas numeradas, por lo tanto se indicará en cada caso el título del poema.

El poema de Rojas, de 1977, comienza con estos versos, que son los que reescribe Cucurto: "No le copien a Pound, no le copien al copión maravilloso/ de Pound". Ver "No le copien a Pound”, en Gonzalo Rojas, Oscuro y otros textos, Santiago de Chile, Pehuén Editores, 1999.
} 
tradición y Cucurto a su vez le copia a Gonzalo Rojas para plantear un Jesús -que aquí podría pensarse como una figura que condensa a los posibles lectores, pero sobre todo a una crítica que haría de la originalidad un valor- que acusa al propio Cucurto de “copión”. 378

Esta manera de usar la tradición agrega un componente más a la figura de analfabeto que construye Cucurto. Porque se trata de un analfabeto omnívoro, que puede absorber y procesar, desde la ingenuidad que garantiza en principio su no pertenencia al campo, toda la literatura. Y estas apropiaciones se dan en el marco de una relación de irresponsabilidad que en este punto se diferencia de los usos de la tradición que hacen otros poetas de la época, especialmente los objetivistas. De hecho, Cucurto plantea al plagio y el "robo" como principios de su poética, pero no los piensa como un gesto político por el cual se saquea la literatura de los dominantes, sino desde la astucia en su vertiente popular y peronista:

Para qué nos vamos a matar pensando si después viene un gil y te chorea, siempre es mejor ser ese gil a ser el currado. Yo no afano, simplemente escribo `a la manera $\mathrm{de}^{\prime} ;(\ldots)$ en estos casos el plagio siempre es progresista y por consecuente productivo, al igual que el peronismo. El plagio es ante todo un acto de amor

\footnotetext{
${ }^{378}$ Tamara Kamenszain lee los usos de la tradición en Cucurto bajo el gesto de la profanación, idea que toma de Giorgio Agamben. Según la autora, "hoy estaríamos ante un nuevo tipo de religiosidad mucha más sutil, esa que él (Agamben) define como capitalista y que, en su fase extrema -la del "espectáculo"-, "apunta a la creación de un absolutamente Improfanable" (Kamenszain: 2007, 119). Desde esta premisa Kamenszain lee el primer poema de Zelarayán: "A las diez/ de la mañana recitando sus mejores/ poemas/ asustando a cajeras y viejas/ con su aullido/ Ricardo Zelarayán/ era arrastrado de los pelos/ por los guardias de seguridad/ por tirar las espinacas/ al piso,/ por destapar los yogures/ de litro./ (...) El monstruo/ fue desalojado/ del supermercado/ por tener malos hábitos/ y ser improductivo/ para la Sociedad/ para la Gran Empresa Nacional/ de los Mendes”. Para Kamenszain, la escena supone un ejercicio profanatorio de parte del poeta en el supermercado, y lo que se profana es precisamente esta nueva sacralidad del espectáculo y la mercancía que postulaba Agamben, junto con la sacralidad de una institución -la artística- "que suele dejar separada a la tradición literaria confinándola al museo de la cultura” (Kamenszain: 2007, 123). El problema con esta lectura, o al menos con su segunda parte, es que no parece pertinente atribuir ningún tipo de sacralidad a la figura marginal de Ricardo Zelarayán, quien difícilmente pueda funcionar como representante de "la poesía”, ni mucho menos pensarlo como parte del "museo de la cultura" (de hecho Zelarayán fue marginal hasta su recuperación por los poetas de los noventa). Tampoco parece que pueda profanarse a las figuras televisivas más de lo que la televisión misma las profana, y de hecho los poemas de Cucurto no se diferencian demasiado de la lógica de medios como Crónica Tv, por lo cual la relación es incluso más compleja que la que plantea Kamenszain a partir de Agamben.
} 
peronista...Perón le afanaba a Mussolini, Cortázar a Michaux, en fin...me parece muy bien que se afanen, ¿qué significa eso de ser auténtico? ¿Ustedes conocen a algún escritor original? (Cucurto: 1999, 54, 55).

En este caso, nuevamente se plantea un procedimiento literario en relación a la política, más específicamente al pragmatismo peronista y al modo de ser conocido como "viveza criolla”, sobre todo por el lenguaje, cargado de giros populares, con que se explicita esta poética, consecuente con aquella afirmación de “yo era un negro” con la que Cucurto se define en medio de otros poetas (en este caso, la no pertenencia al ámbito literario está dada por el lenguaje empleado para hablar de literatura, que no proviene del discurso crítico -ni siquiera del de divulgación, como el del Diario de poesía- sino del ámbito popular).

Estos usos de la tradición, antes que representar lecturas críticas o posiciones con respecto a la literatura -más allá de la teoría del plagio que, como dijimos, concibe toda la literatura como fuente siempre disponible de formas, motivos y procedimientosse mezclan en una construcción de lo latinoamericano que no es estrictamente realista, a pesar de que Cucurto defina su estilo como “realismo atolondrado” (Cucurto: 1999, 53). Esto da como resultado la condición híbrida de La máquina de hacer paraguayitos y de Zelarayán, que reúnen la precisión referencial del objetivismo y las citas de las hablas populares con escenas que son manifiestamente reelaboraciones de motivos literarios o con situaciones cotidianas y verosímiles que derivan en lo fantástico.

Zelarayán consiste en una serie de poemas sin continuidad entre sí, que presentan en clave cómica distintas aventuras protagonizadas por un inmigrante salteño, por el propio Cucurto y su padre, y por el poeta Ricardo Zelarayán, entre otros personajes. Los espacios privilegiados para la acción son los barrio de Once y Constitución, el centro porteño, un supermercado y una librería, todos lugares que configuran muy tempranamente la geografía que va a reiterarse en los libros posteriores de Cucurto. Tanto los espacios mencionados en los poemas como los personajes 
elegidos - especialmente los inmigrantes paraguayos, y el salteño que llega a la Capital desde el interior- conforman, como señalamos, una escena de los noventa que podría remitir al realismo, si no fuera por el modo en que son trabajados esos referentes. Porque además, estos personajes aparecen junto a una serie de personalidades mediáticas, como Carlitos Menem Junior, Zulemita Menem, los jugadores de fútbol Enzo Francescoli y Diego Maradona, Susana Giménez y Lía Crucet, que interactúan en los poemas con poetas como Juanele Ortiz y Ricardo Zelarayán, Laura Wittner, Rodolfo Edwards y Martín Gambarotta.

La mezcla supone entonces la construcción de un espacio ficcional basado fuertemente en las referencias a personas biográficas, lo que genera un efecto de “realidad” cuanto menos ambiguo, en el que se combinan la tradición literaria, los poetas contemporáneos, los inmigrantes y las figuras televisivas que en los noventa cobraron protagonismo como "los famosos", y que confiere un estatuto igualmente ilusorio a toda la galería de personajes. La operación es similar a la señalada por Martín Kohan a propósito de las novelas de César Aira, en las que se da una "acentuación destellante de la referencialidad" cuyo resultado es "la liquidación implacable de cualquier verosímil realista”. ${ }^{379}$ Según Kohan, el uso que hace César Aira de sus personajes (que muchas veces son escritores como Carlos Fuentes, Alberto Giordano o el propio Aira, o políticos como Domingo Cavallo) y de lugares de la ciudad como el barrio de Flores o la villa del Bajo Flores en la novela La villa, no está en función de "llevar al realismo a sus extremos, sino para volatilizarlo con golpes certeros de absoluta irrealidad” (Kohan: 2005, 33).

\footnotetext{
${ }^{379}$ Martín Kohan, "Significación actual del realismo críptico", en el Boletín del Centro de Estudios de Teoría y Crítica literaria, Rosario, Facultad de Humanidades y Artes, Universidad Nacional de Rosario, diciembre del 2005 (24-35), p. 33.
} 
Efectivamente, en la escritura de Cucurto hay un nuevo tipo de superficialidad que no tiene antecedentes en la poesía pero sí en la narrativa y otras formas de la cultura de masas como los comics, en la medida en que se trabaja con personajes planos y que todas las escenas de violencia se resuelven con la ligereza de la comedia. En el poema “De cómo están hechos los arcoiris y por qué se van”, por ejemplo, hay un salteño que, luego de ser despedido en una fábrica de caucho en Constitución, consigue trabajo en un taller textil del Once que pertenece a un coreano. Cuando el coreano se niega a pagarle el sueldo, al terminar el día de trabajo, el salteño golpea al patrón y luego viola a la hija:

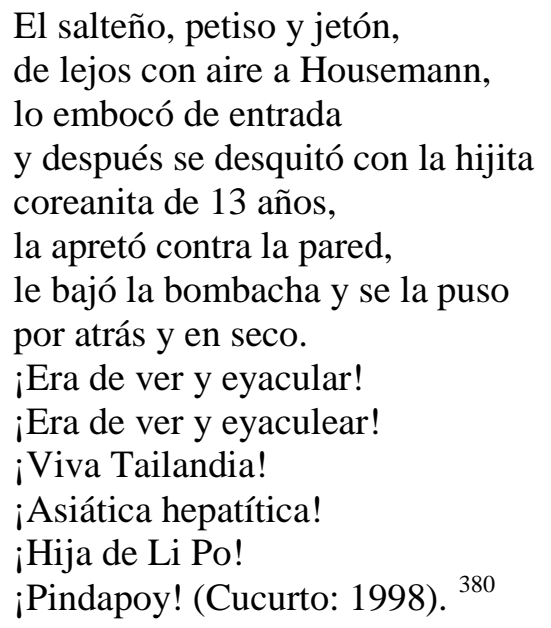

${ }^{380}$ La tradición de violencia sexual vinculada a la violencia política que retoman los textos de Zelarayán podrían remontarse a Osvaldo Lamborghini, y en particular a dos relatos que publicó el escritor en 1969 y 1973 respectivamente: "El fiord” y "El niño proletario", pero sobre todo para contrastarlas. Martín Prieto describe el asunto de estos primeros libros de Lamborghini como "la violencia política argentina puesta en acto a través de la violencia sexual”, en un estilo fragmentado, hecho de secuencias abigarradas y desprovistas de solución de continuidad (aquí Prieto cita a Sergio Chejfec). Ver Martín Prieto, Breve historia de la literatura argentina, Buenos Aires, Taurus, 2006 (433). Es importante señalar que Lamborghini construye un texto político pero, como dice Prieto, no en tanto "representación realista" sino haciendo del relato una expresión "del aquelarre simbólico de la época” y especialmente "a partir de la emergencia, en la novela, de una voz coral simultáneamente popular y política, que es el novedoso análogo de la popularización de la acción política de fines de los sesenta y principios de los setenta" (Prieto: 2006, 434, 435). En "El niño proletario" en cambio lo que se pone en escena es la violencia de clase, en la forma de tres chicos burgueses que violan y matan a un chico proletario. Pero a la vez, Lamborghini construye un sujeto que goza con la violencia, y que en esa misma violencia ejercida sobre el otro termina por encontrar la anticipación de su propia muerte: "Pero también vendrá por mí. Mi muerte será otro parto solitario del que ni sé siquiera si conservo memoria". El narrador se involucra, de esta manera, en el acto de violencia que lleva a cabo, y que le devuelve su propia condición como en espejo. Por eso dice, sobre el final del relato: "La exasperación no me abandonó nunca y mi estilo lo confirma letra por letra" (Lamborghini: 2003, 62). En Zelarayán, en cambio, la diferencia fundamental está en el procedimiento con que se construyen las escenas violentas, si bien comparte con Lamborghini 
En el fragmento la figura del salteño está construida desde la caricatura, cuando se lo describe en un par de trazos como "petiso y jetón” y se lo compara con el jugador de fútbol Rene Houseman, y en consonancia con esto, la violación da lugar a una serie de juegos verbales destinados a provocar la risa. Por otra parte, no es posible leer una posición del enunciador con respecto a los hechos más allá del señalamiento enfático, cifrado en los signos de exclamación, que propone la escena como divertida.

Esto sucede porque si bien el texto está lleno de referencias, éstas se desdibujan al representar a los personajes con recursos no realistas, como cuando se le hace decir a la chica violada “-¡Yamanochuqui ando!/ -¡Yamanochuqui ando! -decía./ ¡Me están culeando!” (además, nótese que el recurso poético a la rima se emplea de modo paródico para generar un efecto humorístico). Aquí, los chistes que antes hacía el enunciador del poema se ponen en boca de la coreana, que claramente no es más que un soporte para hacer, una vez más, un juego de palabras que cita el nombre del poeta ficticio “Yamanokuchi Ando”, heterónimo de Gelman en Cólera Buey. ${ }^{381}$ Lo que podría ser representación de una tensión social entre dos tipos diferentes de inmigrantes

las representaciones políticamente incorrectas. Pero Cucurto mezcla todo un material referencial que aparece como "realista", con el procesamiento de las ficciones televisivas y del comic, como señalamos, y con un tono ligero y festivo. De hecho en el poema que acabamos de citar hay un momento "poético" sobre el final, cuando se dice que los bomberos llegan y manguerean el taller del coreano: "El vapor se elevaba hasta el cielo/ y formaba un bello arco iris./ ¡Que llueva, que llueva, los pajaritos/ cantan los ponjas se levantan!/ Le titilaba el culo a la ponja/ y en cada titilar le salía un poquito/ de leche salteño-boliviana.../ ¡Era de ver y no creer!/ ¡Era de ver y eyacular!”. Ese arcoiris, señalado como "bello” agrega una nota de ironía a la escena, a la vez que la convierte en un dibujo animado. Además, no se establece ningún contraste porque en este caso no hay dolor, y de nuevo los comentarios de la voz que habla en el poema rematan el texto como chiste. De esa manera Cucurto elabora una serie de viñetas cómicas en las que se lleva a cabo una operación similar a la de las novelas de César Aira, que según Graciela Speranza, trituran los fragmentos de realidad "en su ya ejercitada máquina voraz que, con movimiento centrífugo y entrópico, destruye el verosímil y el sentido, y los aplana en una superficie colorida de cuento de hadas desquiciado". Graciela Speranza, "Por un realismo idiota”, en el Boletín del Centro de Estudios de Teoría y Crítica literaria, Rosario, Facultad de Humanidades y Artes, Universidad Nacional de Rosario, diciembre del 2005 (18).

381 Juan Gelman, “Traducciones II. Los poemas de Yamanocuchi Ando”, Cólera buey, Buenos Aires, Seix Barral, 1994. 
-salteños y coreanos- y de violencia entre los dominados, se resume en una escena violenta puesta en clave cómica que desacraliza al mismo tiempo la literatura (en el uso de la alusión a Gelman y la rima) y el discurso políticamente correcto.

El carácter irreal de los poemas, entonces, disuelve las posibles significaciones sociales de las escenas de violencia y de aventuras, que están construidas como historietas, como puede leerse en el siguiente pasaje, perteneciente a un poema en el que se rescata al poeta Ricardo Zelarayán de la cárcel. A la persecución que tiene lugar a continuación se suma Carlitos Menem Junior, acompañado de una sirvienta paraguaya:

El Junior vio el volante y se transformó.

Salimos embalados por Coronel Díaz.

¡Ese es mi pollo de Aniyaco!

Agarramos Soler y después doblamos por la curva de Agüero a todo lo que da ¡Esa Zulemita!

¡Carlitos iba por Agüero concentrado como si fuera por las sierras de Córdoba.

¡Carlitos corría el Rally Agüero!

¡Hiupi!

Cruzamos Córdoba a toda velocidad ¡con toda la prefectura atrás!

¡Y siete, siete patrulleros de la 21!

¡Los patrulleros despertaron al barrio!

¡Hiupi! ¡El colmo del afano!

¡Qué superbanda! (“Apocalíptico rescate de Zelarayán”, en Cucurto: 1998).

Aquí, el estatuto de los personajes -el poeta Zelarayán, Carlitos Menem, y la inmigrante paraguaya- es igualmente irreal; todos funcionan como caricaturas de un comic hiperbólico. En todo caso, la escena constituye un desfile carnavalesco que trabaja los signos desprendiéndolos de sus referentes, o para decirlo con Graciela Speranza, que alude a la narrativa de Sergio Bizzio, “el pastiche posmoderno se depura en una alegoría plana, si cabe la paradoja” (Speranza: 2000, 20). Una vez que la mimesis realista se ha demostrado como imposible, y más como una serie de convenciones culturales de representación que un registro “puro” de algún aspecto del mundo, “El efecto de lo real hoy (...) sólo es posible con la mediación televisiva.” (Speranza: 2005, 20). 
Si como señala Hal Foster, a quien citamos al comienzo de este capítulo, los dos grandes modelos básicos de representación se dividen entre "imágenes atadas a referentes, a temas iconográficos o cosas reales del mundo”, e imágenes que sólo pueden representar otras imágenes, la poética de Cucurto en Zelarayán se ubica decididamente en el segundo grupo (Foster: 2001, 130). Porque todas las representaciones de los poemas, si bien están cargadas de referencialidad, se construyen a través de la mediación, no sólo de la literatura, sino de las imágenes televisivas y del comic, es decir, del imaginario conformado por los medios de comunicación masivos, que en este caso no se toma sólo como material, como habíamos visto en La raza y en Punctum, sino como modelo de representación para la construcción de los poemas. De hecho, el propio Cucurto señala esto en una entrevista en la que se revela como un lector agudo de sus propios textos: “Zelarayán es un libro que está en el borde, es inclasificable, ¿qué es? Televisión y cómic, están los mismos elementos de la televisión, el ruido, con las onomatopeyas y el griterío, la violencia, y la imagen, el cómic, con lo inverosímil de las peripecias que se van generando (...)”. 382

De modo similar, en La máquina de hacer paraguayitos las representaciones de los poemas, antes que en la realidad, se apoyan más bien en clisés sobre lo centroamericano como el colorido, la alegría, la exuberancia, la disposición para el amor y el sexo de las mujeres latinas, junto con otros motivos como el carácter maternal y la sabiduría para la vida de las prostitutas:

Idalina, Justina y Miguelina, tus tres primas, suben las escaleras del yotibenco, como una bandada de mariposas embrujadas o un oleaje de aguas carbonizadas, dando zancadillas y elevando oropéndolas en llamas, aprendizas de un parto de

\footnotetext{
${ }^{382}$ Paula Leitao, "El hombre de los mil nombres y un rostros" (sic), entrevista a Santiago Vega (alias Washington Cucurto), en Vox Virtual No 15, Vol. II, Bahía Blanca, Abril del 2003. En: http://proyectovox.org.ar/virtual_15-2.htm

Esto no significa, en nuestra opinión, que no pueda hacerse una lectura de Zelarayán que vincule los poemas con la sociedad de la que surgen los signos que se trabajan en el libro, pero esta lectura debe tener en cuenta la mediación de esas imágenes que impiden una vinculación directa de los textos con los referentes que éstos toman de la realidad.
} 
serpientes, un tacto y un contacto de abejorros, un diablerío en el revoltijo de los mestizajes, escupen y mojan las prendas íntimas expuestas, ipuercas!, iguaracheras!, golpean las puertas de las piezas, retuercen el blanco de las sábanas, lascivas vuelan las sábanas sexuales, irrumpen en el claro sueño de un peruano y este caballero piensa en una premonición del infinito... (Cucurto: 1999, 23).

Aquí, sobre el fondo referencial que conforma el conventillo en el que viven inmigrantes de diversa procedencia, se construye, con un lenguaje barroco, una representación de las mujeres mediada por el procesamiento de otros escritores centroamericanos como José Lezama Lima, y en la que prima el vitalismo (es importante aclarar que el barroco que procesa Cucurto no es el de Perlongher sino el de Lezama Lima, Severo Sarduy y otros poetas y narradores centroamericanos tales como Reinaldo Arenas, como lo muestran en parte sus recuperaciones de la poesía española, y sobre todo porque aquí no se trata de un juego lúdico y puramente material con la proliferación de sentido entre los significantes al modo de Perlongher; en Cucurto nunca se pierde de vista lo referencial, como vemos). ${ }^{383}$

Otros pasajes trabajan representaciones similares pero con una cruza entre la dicción barroca y la porteña: “óyelas cómo van: luciendo su lengua colorada de dominicana ardiente, con verdadero fervor boquense: por las piezas del yoti yirean las mulatas, tus tres primas libidinosas, Idalina, Justina, Miguelina” (Cucurto: 1999, 19).

\footnotetext{
${ }^{383}$ Sobre el barroco de Lezama Lima y Sarduy, ver Edgardo Dobry, "Barroco y modernidad: de Maravall a Lezama Lima”, en Orbis Tertius, UNLP, 2009, XIV (15); también Severo Sarduy, "El Barroco y el Neobarroco", en César Fernández Moreno (ed.). América Latina en su literatura, México, Siglo XXI, 1972 (167-184). La recuperación del neobarroco de Perlongher aparece en cambio en Estremezcales de Romina Freschi (tsé=tsé, 2000), que aquí no trabajamos porque no representa ninguna reelaboración sino más bien una repetición tardía del estilo de Perlongher. Por otra parte, no nos extendemos en las apropiaciones del barroco de Cucurto porque éstas representan un momento de su producción centrado en el libro La máquina de hacer paraguayitos, o en menor medida en sus novelas, y no caracterizan la totalidad de su obra. Para una construcción de personajes similar a la que hace Cucurto en Zelarayán, ver Reinaldo Arenas, El mundo alucinante, Barcelona, Tusquets, 1997. Se trata de una novela de aventuras que se inscribe en la tradición del barroco cubano pero que permaneció ignorada debido a la marginación de su autor, que volvió a reeditarse en los últimos años. Significativamente, no sólo en ese aspecto la obra de Arenas es excepcional sino porque también -y esto puede vincularse con la recuperación que hace Cucurto- algunos personajes y situaciones están tramados a partir de rasgos que remiten al comic y al pop, además de que las escenas violentas suelen ser caricaturizadas (ver a modo de ejemplo el naufragio que se narra en las pp. 213-214).
} 
Las inflexiones del habla coloquial porteña aparecen una y otra vez, como cuando se dice "La muy turra” (Cucurto: 1999, 52), “Te la pasas de joda/ con estudiantes de marketing/ de universidad palermitana” (Cucurto: 1999, 31), o "a fuerza de números te recibiste en letras/ y ya no le das bola a esos jactanciosos/ jugadores organizadores de jodas...” (Cucurto: 1999, 33).

En este punto, la escritura de Cucurto se acerca al trabajo con las hablas que hay en Llach, Durand y Gambarotta, pero aquí, a la mezcla entre lengua coloquial y recursos manifiestamente poéticos se suman además las inflexiones de las hablas centroamericanas. Como el neobarroco de los ochentas, que fue según Martín Prieto el único movimiento poético argentino que estableció un diálogo sistemático y productivo con lo latinoamericano, Cucurto arma su obra a partir de la selección fragmentaria y aleatoria de diversos textos, sobre todo de autores latinoamericanos (una línea que, como hemos visto, no es recuperada por otros poetas de los noventa). ${ }^{384}$ Pero a

\footnotetext{
${ }^{384}$ Dice Martín Prieto, diferenciando a los neobarrocos del grupo de la revista Literal, del que formaban parte Ricardo Zelarayán y Osvaldo Lamborghini: "En el segundo lado en el que hay que buscar la novedad que el neobarroco importa en la literatura argentina tiene que ver, precisamente, con el carácter de su biblioteca que es, como vimos, eminentemente nacional y no mixturadamente nacional y europea o nacional y norteamericana, como fueron históricamente las bibliotecas argentinas de vanguardia. Pero esa biblioteca eminentemente nacional está, a su vez, abierta al diálogo y a la conversación y a la confrontación con una biblioteca latinoamericana".

Y más adelante en el mismo artículo, Prieto explicita cuál es esta biblioteca: "Los neobarrocos, en cambio, muy rápidamente establecen vínculo con la biblioteca latinoamericana: el chileno Enrique Lihn, en el libro de Kamenszain de 1983, el cubano Severo Sarduy, entusiasta prologuista de Ciudad del colibrí, una antología de Carrera publicada en España en 1982, la uruguaya Marosa di Giorgio, el brasileño Haroldo de Campos y, en todos, el cubano José Lezama Lima. Eso, hacia atrás. Y hacia los costados, los uruguayos Roberto Echavarren, Eduardo Milan, Eduardo Espina, el brasileño Wilson Bueno, autor de Mar paraguayo, escrito en portuñol-guaraní, el chileno Diego Maquieira, el cubano José Kozer que es quien, por otra parte, en un reportaje, instado por el entrevistador a dar el listado del who is who de la poesía neobarroca, no duda en armar un combinado latinoamericano, prescindiendo de la nacionalidad de cada uno de sus actores."

Ver Martín Prieto, "Neobarrocos, objetivistas, epifánicos y realistas: nuevos apuntes para la historia de la nueva poesía argentina”, en Delgado, S., y Premat, J., (eds.), Movimiento y nominación. Notas sobre la poesía argentina contemporánea, Cahiers de LI.RI.CO, $\mathrm{N}^{\circ} 3$, Université de Paris 8 - Université de Bretagne-Sud, Paris, 2007, pp. 23-44.

Disponible online en Vox Virtual No 23, julio de 2009. En:

http://www.proyectovox.org.ar/virtual_23.htm
} 
diferencia de los neobarrocos, Cucurto opera desde un sistema referencial que delimita un espacio a primera vista "realista”, urbano y lumpen. Y al mismo tiempo, como se trabaja tanto con los giros de las lenguas centroamericanas como con el “porteño” y el lunfardo, el resultado es un repertorio verbal caracterizado por la hibridez y por la mezcla.

Es este lenguaje múltiple el que trama todos los textos, cuyo espacio referencial es el centro de la ciudad de Buenos Aires. Por eso, más importante que el modo en que se reelaboran o citan puntualmente estos materiales de la tradición, la operación central en La máquina de hacer paraguayitos tanto como en Zelarayán (y en todos los libros posteriores de Cucurto) es que estos materiales se usan para construir una Buenos Aires negra y latinoamericana. Porque desde los motivos y el lenguaje se diseña un espacio donde se cruzan y coexisten, en una Buenos Aires cosmopolita y latina, los jamaiquinos, colombianos, argentinos, peruanos y paraguayos, en una convivencia que en los poemas de La máquina de hacer paraguayitos, a diferencia de Zelarayán, se da sin conflicto. ${ }^{385}$

Entonces, el impacto simbólico de Cucurto sobre la tradición de la poesía argentina -tanto del personaje como de la escritura, que como argumentamos, a duras

\footnotetext{
${ }^{385}$ De hecho, La máquina... es una serie de poemas de amor y de erotismo, donde hay un "yo” que declara su admiración por la sensualidad de las mujeres centroamericanas. En la segunda parte, son estos personajes femeninos los que toman la voz, una voz que repite en dos poemas el verso: "Yo que he contribuido al bienestar nacional" (Cucurto: 1999, 46, 48). Fuera de esa declaración, en $L a$ máquina..., de manera significativa, podría decirse que no hay nada propiamente "argentino". La operación del libro apuesta sobre todo a ensalzar la exhuberancia y la predisposición para el amor de las inmigrantes dominicanas. En este sentido, La máquina... da cuenta, si bien de forma idealizada, de un dato de la época. Durante la década del noventa, y estimulada por la paridad cambiaria (con la posibilidad de envío de remesas en dólares a sus países de origen), se incrementó la llegada de mujeres procedentes de la República Dominicana al país, y especialmente a Buenos Aires. Estas mujeres "comienzan a adquirir visibilidad como grupo específico -particularmente en la ciudad de Buenos Aires- hacia 1995”, según un informe de la CAREF (Comisión Argentina para los Refugiados). Muchas se insertan en el sector servicios (trabajo doméstico, cuidado de niños y ancianos, restaurantes, peluquerías, etc.), y algunas se dedican a la prostitución, en ocasiones forzadas por "reclutadores" que tramitan el viaje desde el país de origen. En Migración, prostitución y trata de mujeres dominicanas en Argentina, Buenos Aires, Organización Internacional para las Migraciones, 2003 (17-30).
} 
penas pueden separarse- es doble: por un lado, tiene que ver con ofrecer representaciones festivas que son novedosas dentro de esa tradición en la que el populismo siempre se hizo presente en clave pietista, así como una figura de escritor un negro- que también supone una innovación dentro de una tradición de escritores mayormente de origen inmigrante europeo. Y por otro lado, el gesto de Cucurto de hacer ingresar tanto las hablas como los estilos literarios centroamericanos en el marco referencial de lo argentino hace que, quizás por primera vez, la poesía argentina sea a la vez latinoamericana y negra. ${ }^{386}$

Por último, la indecidibilidad entre ficción y realidad y entre autor y personaje que recorre sus textos -algunos de ellos autobiográficos- es fundamental porque se vale del prestigio de lo real para que a la crítica, los escritores contemporáneos y otros agentes del campo no les sea posible descartar sus fabulaciones, incluso cuando se presentan manifiestamente bajo la lógica de los medios de comunicación de masas, con el pretexto de que después de todo, se trata de ficciones. De hecho, como vimos al principio de esta sección, la obra de Cucurto fue discutida desde el comienzo.

Paradójicamente la escritura de Cucurto, que podría ser altamente impersonal en función del uso predominante del pastiche, y de que está construida casi íntegramente por apropiación y re-montaje de textos previos, es, de todas las poéticas de los noventa, la que más se trama en vinculación estrecha con una figura de escritor que se apoya en la autobiografía. Pero el relato autobiográfico, a su vez, también tiende a la construcción de un mito que puede leerse como ficción literaria.

Entonces, la relación entre autor, personaje y obra, y entre la realidad y la lógica específica del campo literario, se ve modificada. La tradición puede saquearse y

\footnotetext{
${ }^{386}$ El vínculo con lo latinoamericano también estaba presente en el barroco de los ochentas, como señalamos junto con Martín Prieto, pero la diferencia es que se trataba de un movimiento altamente intelectualizado que en su versión argentina tomaba incluso rasgos de la teoría francesa, y en ese sentido estaba presente lo latino pero no lo popular.
} 
“robarse” para construir la propia obra, pero a condición de que esa operación sea acompañada de la construcción de sí mismo como negro y analfabeto, que reafirma su pretendida exterioridad respecto al campo. Por eso, la construcción del analfabetoomnívoro, que puede asimilar toda la tradición desde una posición “irresponsable”, debe leerse en este caso también como un modo de disputar el derecho de entrada al campo de un "negro", repositor de supermercado y peronista, cuya sola presencia es maldita porque supone para la tradición el ingreso de “lo otro”. ${ }^{387}$

\title{
3- BELLEZA Y FELICIDAD: ESCRITURAS INGENUAS Y LA POESÍA COMO ARTE DE LO EFÍMERO
}

\author{
Desde el 70 todo lo que pasa es irreal \\ dijo, un poco cansado porque venía de \\ una fiesta en la que habían bailado \\ mucho para despedir al mundo. ${ }^{388}$ \\ "Todo lo que hacen \\ ya fué hecho \\ ustedes son parte de un \\ experimento, \\ igualmente son muy capaces \\ y tenemos fe en ustedes" 389
}

\footnotetext{
${ }^{387}$ Damián Selci y Claudio Iglesias hacen una observación interesante sobre este punto cuando afirman que la contracara de esta construcción es que se trata de un proyecto de escritura nacional (pero a la vez latinoamericano) y popular, que sólo puede ser revulsivo y maldito en tanto discuta con la Academia y con la intelectualidad progresista. En esta relación y en la función del escritor como pretendido crítico se basa la hipótesis central de su artículo ya citado. Ver Damián Selci y Claudio Iglesias, “Análisis de un malentendido”, publicado en la revista virtual Éxito, verano del 2007. En www.notasexito.blogspot.com.

${ }^{388}$ Cecilia Pavón, El festival de las lágrimas, Buenos Aires, Belleza y Felicidad (sin fecha).

${ }^{389}$ Fernanda Laguna, Samanta, Buenos Aires, Belleza y Felicidad, 1999 (los errores ortográficos y tipográficos están en el original).
} 
Belleza y Felicidad designa al mismo tiempo un lugar de encuentro, una editorial y un grupo de escritoras, que se caracteriza por englobar distintas prácticas como la poesía, las artes plásticas y la performance. En este caso nos centraremos en la lectura crítica de la producción poética publicada en plaquetas por el grupo, pero haremos una breve descripción de otras actividades para iluminar el contexto de emergencia y circulación de estas poéticas. Entre los años 1999 y 2007, ByF funcionó como galería de arte independiente en un local del barrio de Almagro donde además había una tienda de libros y materiales para artistas plásticos, se realizaban performances y lecturas de poesía, y se editaban revistas y plaquetas. ${ }^{390}$ Las poetas que llevaron adelante el proyecto, Fernanda Laguna y Cecilia Pavón (acompañadas de cerca por Gabriela Bejerman), fueron reconocidas objetivamente como grupo literario -tal vez el único que verdaderamente fue percibido y pareció funcionar como tal en los noventa-. Por grupo literario entendemos, como señala Bourdieu, “un instrumento de acumulación y de concentración del capital simbólico (con la adopción de un nombre, la elaboración de manifiestos y de programas y la instauración de ritos de agregación, como los encuentros regulares)” (Bourdieu: 1997, 398).

\footnotetext{
390 A continuación reproducimos un fragmento de una entrevista en la que Laguna misma describe las actividades realizadas en ByF, y el origen del nombre:

"Realizamos encuentros de poesías (sic), muestras de arte, recitales de música; es un lugar de experimentación artística, vendemos libros de editoriales independientes, discos también independientes y obras de arte, materiales para artistas, pinturas, telas, etc. y también tenemos una editorial propia, llevamos más de veinticinco libros publicados. Se han realizado improvisaciones musicales con computadoras, fue un ciclo que se llamó "Juventud clandesina"* $\mathrm{y}$ fue un encuentro entre artistas alemanes y argentinos. Realizamos desfiles de modas y espectáculos teatrales. Se realizan dos exposiciones por mes con artistas, algunos conocidos y otros que hacen su primera muestra. En este momento se exhibe "La Crista", es una gran instalación hecha por un grupo de internas del penal de Ezeiza. Nos identificamos con lenguajes contemporáneos y con artistas que expresan su inquietud por los tiempos que nos toca vivir. P.C: ¿Y por qué el nombre?

F.L: Cuando comenzamos en 1999 éramos dos las que estábamos con este proyecto y se nos ocurrió "Belleza y felicidad" porque es en resumen lo que todo ser humano busca y desea y podían conseguirlo aquí adquiriendo las cosas que en ese entonces vendíamos.”

Revista El Abasto, n 50, octubre 2003, http://www.revistaelabasto.com.ar/50_Belleza_y_Felicidad.htm
} 
Es necesario señalar, sin embargo, que la denominación de "grupo literario" debería en este caso ampliarse, ya que Fernanda Laguna proviene del campo de las artes plásticas y Gabriela Bejerman (que no formó parte de la gestión del espacio pero sí del círculo delimitado en los poemas, como veremos), si bien es Profesora de Letras, incursionó también en las artes performáticas y la música electrónica. Este carácter multidisciplinario es relevante porque trama las poéticas que despliega el grupo, y modifica en algún punto la relación con la propia literatura. De acuerdo con lo señalado por Bourdieu, en el caso de Belleza y Felicidad -si bien no hay, como tampoco en el resto de las formaciones analizadas, manifiestos ni programas explicitados-, el nombre del espacio y la editorial, puesto en relación con las poéticas allí elaboradas, operó como una especie de consigna. De hecho, parte del reconocimiento externo como grupo se debió a la elección del nombre, que funcionó en buena medida como programa estético (y que fue relativamente polémico para otros productores del campo en el contexto de los noventa, especialmente con el resurgimiento de los debates sobre poesía y política que se dio a fines de la década y después de la crisis del 2001). ${ }^{391}$

\footnotetext{
${ }^{391}$ Sobre ByF y otros segmentos de la poesía y las artes plásticas de los noventa, se suscitaron debates en torno a la oposición arte político/arte banal, uno de cuyos ejemplos es la Mesa Redonda: Arte rosa light y arte Rosa Luxemburgo, realizada en el Malba el 12 de mayo de 2003 y en la que participaron Roberto Jacoby, Ana Longoni, Andrea Giunta y Magdalena Jitrik. Las ponencias que conformaron este encuentro pueden leerse en Ramona. Revista de artes visuales., Buenos Aires, julio/agosto, 2003 (52-91).

Disponible online en:

http://es.scribd.com/doc/48521316/ramona-33-Arte-Rosa-Light-Rosa-Luxemburgo
}

Para otro ejemplo sobre las acusaciones de que fue objeto ByF, ver la nota de Daniel Molina “Belleza y felicidad: festejo que terminó en velorio”, Revista Ñ, Clarín, 1/2/2003. Allí Molina comenta cómo con motivo de celebrar su quinto aniversario se organizó una muestra en el local de Byf a la que se invitó al crítico Ernesto Montequin, quien en lugar de elogiar el proyecto y contra lo esperado, lo cuestionó con dureza. Reproducimos un fragmento de esta nota para ilustrar el tipo de críticas que recibió el proyecto ByF, en parte por algunas características que analizaremos a continuación como el infantilismo y la subjetividad, además del carácter de "amateur" con que se construyen las artistas (y que nosotros hemos llamado "ingenuo"), que aquí se valoran negativamente. Dice Molina:

Montequin caracteriza "la estética ByF" como el reinado de la subjetividad. El artista ByF, sostiene, es: "un eterno principiante, obsesionado (y agobiado) por el espectáculo de su vida interior; es el amateur cuya sensibilidad desplazada o marginal y su heterodoxia estética bastan 
Estos datos explican la pertinencia de trabajar la producción de Fernanda Laguna y Cecilia Pavón (con menciones ocasionales a la de Gabriela Bejerman) como conjunto, si bien se incluyen algunas consideraciones aparte con respecto a las poéticas de cada una. Además, en ciertos casos haremos alusión a las novelas y cuentos publicados por estas mismas poetas, que si bien exceden los alcances del corpus de esta tesis, centrado en la poesía, permiten destacar ciertos aspectos relevantes de sus poéticas.

Sucede que en Belleza y Felicidad, tanto como en Cucurto, está puesta en entredicho la especificidad genérica. Así como hay poemas que comienzan en verso para adoptar después la forma de la narración en prosa (como Sueños y pesadillas de Fernanda Laguna) y poemas que se describen a sí mismos como cuentos (Salvador Bahía, ella y yo, de Fernanda Laguna), también las tres poetas que aquí trabajamos publicaron cuentos y novelas. ${ }^{392}$ Por lo tanto, limitarse al análisis de sus obras en verso significaría ignorar esta circulación entre distintos géneros y formas que ellas mismas proponen, como sucedía también en el caso de Cucurto. En efecto, las poéticas de ByF

para calificarlo como artista a la vez que lo inhabilitan para triunfar entre los profesionales del arte". Pero en verdad no son éstos los artistas que le interesa confrontar. Pero desperdicia lo mejor de su texto - una tibia crítica al infantilismo cultivado por algunos de los artistas que menciona-, al dispersarse en otros temas. Ese infantilismo, según Montequin, se caracteriza por producir obras en serie consistentes en pegar papel glacé sobre una cartulina, agregar una fotito - mejor si es del jardín de infantes- y concluir estampando frases escritas en cursiva: "no me beses, tenés fríos los labios" o "me gusta tu café con leche".

Y se abstiene de profundizar su crítica al infantilismo porque el centro de su escrito se regodea en un lugar común que se ha puesto de moda entre varios artistas en el último año: que el llamado arte de los 90 es el gran enemigo cultural. Y lo sería porque esa "corriente" es "la expresión cultural del menemismo". Montequin lo dice a su manera: "El apogeo de la sensibilidad sólo puede producirse con la bendición de un capitalismo cerril (como el que disfrutamos durante la década de 1990), y que las facilidades que éste le otorga no son sólo un recurso mendaz para desarticularla, sino que también acaban por convertirla en una forma del conformismo".

En: http://edant.clarin.com/suplementos/cultura/2003/02/01/u-00702.htm

Por último, Cecilia Palmeiro lee esta concentración de ByF en la banalidad de las minucias cotidianas como un modo transgresor de "prescindencia frente a la cosa pública" que se impuso como parte de la "problemática vigente" (Bourdieu: 1997, 361) del campo poético a fines de los noventa y principios del 2000 (Palmeiro: 2011, 181).

${ }^{392}$ Estas novelas están consignadas en nota al pie en la Introducción de este capítulo. 
se arman desde una ideología de la inespecificidad o de aquello que Reinaldo Laddaga llama "una cultura posdisciplinaria de las artes”, que vendría a reemplazar a la cultura moderna centrada en la noción de “obra” y en la creencia en la importancia de dicha obra en tanto soporte de una verdad. ${ }^{393}$

Si bien esto no podría aplicarse a la publicación posterior de novelas por parte de las poetas, las primeras plaquetas de $\mathrm{ByF}^{394}$ presentan algunos rasgos que Laddaga señala como propios de las “comunidades experimentales” posdisciplinarias, dado que se trataba de escribir y publicar casi simultáneamente y de ediciones efímeras que no condicen con las ideas tradicionales de “obra” y "biblioteca”. Los textos, entonces, funcionan dentro de estas modalidades de la práctica artística que los determinan formalmente, por lo cual el primer desplazamiento con respecto a la tradición está dado por este modo de publicar y hacer circular la poesía que acabamos de describir.

${ }^{393}$ Laddaga, Reinaldo, Estética de la emergencia, Buenos Aires, Adriana Hidalgo, 2006.

${ }^{394}$ Esta es la lista de las plaquetas con que trabajaremos a continuación, que representa una selección dentro de lo publicado por ByF (que de hecho sigue funcionando como editorial en la actualidad, aunque la galería de arte cerró sus puertas en el 2007). En ningún caso se especifica el número de página, puesto que las publicaciones no lo consignan.

Gabriela Bejerman, judía, Buenos Aires, Belleza y Felicidad, 2000.

Lirio Violetsky (seudónimo de Gabriela Bejerman), Concurso de tortas: Ganadora ¡Sonia!,

Fernanda Laguna, Samanta, Buenos Aires, ByF, 1999. Buenos Aires, ByF, 1999.

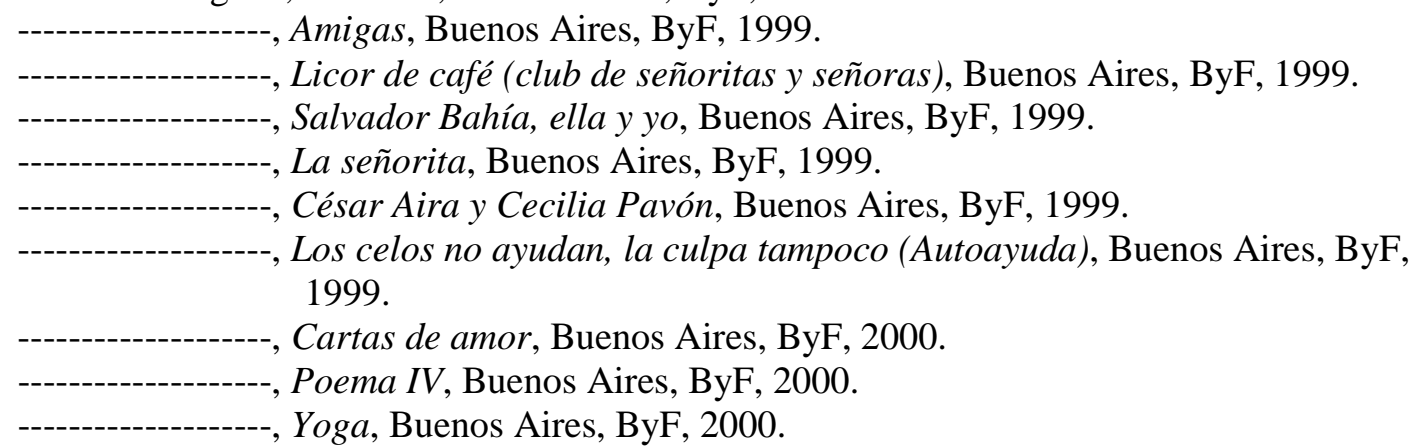

Dalia Rosetti (seudónimo de Fernanda Laguna), Sueños y pesadillas, Buenos Aires, ByF, 1999.

Cecilia Pavón, El festival de las lágrimas, Buenos Aires, ByF, sin fecha.

--------, Gabriela, los hombres y yo, Buenos Aires, ByF, sin fecha.

-----------, La euforia, Buenos Aires, ByF, 1999.

--------------, a fernanda, Buenos Aires, ByF, 2000.

------------, Primer beso, Buenos Aires, ByF, 2000. 
Las plaquetas realizadas por Belleza y Felicidad entre 1999 y el 2000 son publicaciones de pocas páginas, editadas en fotocopias sobre papel o cartón, con ilustraciones cuyos autores generalmente no se consignan. ${ }^{395}$ En la contratapa figura por lo general el número telefónico del local de Belleza y Felicidad, al que los lectores podían llamar para hacer pedidos. Esto supone una relación directa entre lector y autores que se diferencia del modo de distribución del resto de las editoriales independientes, cuyos libros podían y pueden encontrarse en librerías especializadas, festivales y lecturas de poesía. ${ }^{396}$ Otro dato relevante es que muchas veces las plaquetas presentan errores de tipeo y faltas ortográficas. El diseño es mínimo, y da toda la sensación de un objeto hecho de forma rápida y descuidada. Muchos de los dibujos están realizados a mano, con trazos desprolijos, o a veces con figuras muy simples hechas por computadora. Algunas plaquetas contienen un solo poema, aunque una parte menor consta de varios textos y constituye casi un pequeño libro. El uso ocasional de las cursivas en las tapas es también importante, porque por momentos la estética se acerca visualmente a la del cuaderno de un chico de primaria. ${ }^{397}$

\footnotetext{
${ }^{395}$ En este sentido, las publicaciones de Belleza y Felicidad se diferencian de otras editoriales como Vox o Siesta, que muchas veces ilustraban sus libros con obras de artistas plásticos contemporáneos, pero explicitaban el nombre del artista en la primera página. El gesto supone, en este caso, reconocer la colaboración entre artistas de distintas disciplinas y constituir a su vez el libro en objeto de diseño.
}

${ }^{396}$ Para otra perspectiva de análisis sobre ByF en el contexto de los proyectos editoriales autogestionados de los noventa, ver Cecilia Palmeiro, Desbunde y felicidad. De la cartonera a Perlongher, Buenos Aires, Título, 2011 (171-181), donde la autora atribuye este modo de editar y comercializar poesía al descubrimiento de la "literatura de cordel" durante un viaje a Salvador, Bahía, en Brasil, de las poetas de ByF.

397 Se trata de una estética que proviene de las artes plásticas, como puede verse en la presentación de una muestra realizada en el año 2009 en la que participó Fernanda Laguna. La selección de dibujos, pinturas, fotografías, videos, objetos e instalaciones presentes en la exposición pone de manifiesto la presencia de un catálogo de recursos formales propios de la escuela, que Ricardo Martín-Crosa define como una "retórica de la enseñanza primaria argentina". Las obras ponen en escena un imaginario vinculado al repertorio escolar y también "una tendencia a la manualidad; un armar perfecto, ajustado y pulcro; el gusto por pegar, recortar, plegar, hacer collages; una obsesión por la repetición y el uso de iconografías relacionadas con lo infantil, los juegos para chicos, los libros de cuentos, los manuales de 
Las plaquetas parecen estar hechas bajo el lema "Hacelo vos mismo", y son voluntariamente descuidadas, lo que las acerca a esa consigna que proviene del movimiento punk. La prioridad está puesta en el hacer y en la circulación rápida y eficaz de los poemas, por eso es que el diseño está más cerca de los fanzines del mundo del rock que de los libros de poesía. De hecho, se trata de un formato que presenta un carácter efímero, y que parece negar tanto la fetichización del libro como objeto como la posibilidad de conservación en una biblioteca. A este respecto, Ana Mazzoni y Damián Selci, en su artículo "Poesía actual y cualquierización”, señalan que los nuevos formatos de las publicaciones independientes de los noventa deben tomarse como una mediación imprescindible entre las poéticas y el crítico. En ese texto, los autores observan a propósito de las ediciones de ByF que "están hechas de fotocopia, de modo que lo más probable es que en diez años la impresión desaparezca y nos quede un libro en blanco. Los libros fueron hechos para conservar conocimiento, cultura o lo que fuere, pero estos libritos en cambio son más parecidos a preservativos -su fórmula no es “yo conservo", sino más bien "úselo y tírelo”. En cierto modo nos indican que son o serán basura”. 398

No parece que el planteo pueda aplicarse a todas las ediciones independientes de los noventa por igual, puesto que las publicaciones de editoriales como Siesta o Vox presentan, es cierto, un formato de libro miniaturizado, pero que se propone como objeto de diseño coleccionable (en parte porque se pone el acento en las colaboraciones entre artistas plásticos y escritores, como dijimos). Pero en el caso de las plaquetas de

lecturas escolares, los mapas, las figuritas; un misterio poético, cierta ternura y belleza, una tensión entre el individualismo y el apiñarse, estar solo y en muchedumbre, todos modos característicos de la escuela.” Ver Martín-Crosa, Ricardo, "Escuelismo (Modelos semióticos escolares en la pintura Argentina”, en Pacheco, Marcelo, Escuelismo, Arte argentino de los noventa, Buenos Aires, Malba-Fundación Constantini, 2009.

${ }^{398}$ En Jorge Fondebrider (comp.), Tres décadas de poesía argentina. 1976-2000, Buenos Aires, Libros del Rojas, 2006 (263). 
ByF es pertinente lo señalado por Selci y Mazzoni, no sólo por razones materiales como

el descuido en la edición, la falta de mención de los artistas que diseñan las tapas o las

fechas de publicación en algunos casos, sino porque ese carácter efímero del objeto

entra en consonancia con la temporalidad efímera que proponen los mismos poemas, como veremos. ${ }^{399}$

Además, si bien en la década del noventa se incrementó ampliamente la práctica de las lecturas públicas de poesía como modo de difusión de los textos, en el caso de ByF no se circunscribió a la simple puesta en voz de los textos sino que se acercó más a la performance y a la puesta en escena, como lo muestra el testimonio de un poeta y crítico literario que asistió a un espectáculo de este tipo:

En Bahía Blanca el año pasado se organizó un recital de Fernanda Laguna, Cecilia Pavón y Bejerman: la sala apagada, salen ellas vestidas con una especie de pijamas o camisones blancos, descalzas. Se sientan en un rincón lleno de almohadones y papeles afiche blancos desparramados en el piso; al rato encienden una gran cantidad de velitas que depositan sobre esos papeles. Una música muy suave e indefinida acompaña este clima espectral, y comienzan a leer. Mientras una lo hace, las otras dibujan sobre los papeles. Los poemas, más que textos aislados, parecen estar dialogando entre sí, respondiéndose unos a otros como en un encuentro de amigas. ${ }^{400}$

${ }^{399}$ Sin embargo, aunque resulta atendible la propuesta de Selci y Mazzoni de leer los nuevos soportes editoriales de los noventa en relación a las poéticas y a la crisis de la industria editorial que se da en la década, también resulta arbitrario dejar afuera otros aspectos importantes tales como las performances y los recitales de poesía, que constituyen el campo de los noventa tanto como los formatos editoriales, y muy especialmente en el caso que estamos analizando.

${ }^{400}$ Ver Mario Ortiz, “Hacia el fondo del escenario”, en Vox Virtual No 11/12, Bahía Blanca, julio del 2002 (disponible en http://elistas.egrupos.net/lista/voxvirtual/archivo/msg/15/). La dificultad de este poeta que no pertenece al ámbito porteño y más "moderno" para percibir y apreciar el espectáculo queda de manifiesto en la carencia de palabras precisas para describir, por ejemplo, la música empleada, que se caracteriza simplemente como "suave e indefinida". Mario Ortiz continúa su relato con la explicitación de ese desconcierto, cuando dice: "Este recital, debo confesarlo, durante los primeros días me dejó perplejo porque era algo que hasta ese momento no había visto en poesía, una sensación de distancia y hasta de desconfianza. Pero con el correr del tiempo empecé a hilvanar algunas cosas: algunos poemas que yo había leído en la revista Nunca nunca... y que, confieso nuevamente, me habían parecido banales o poco consistentes, en este contexto de espectáculo cobraban otra dimensión. La puesta en escena recreaba un clima y un ambiente que es el mismo que por momentos encuentro en Crin: algo evanescente, una comunidad de amigas que flotan en un trasmundo. No quiero decir que haya cambiado a partir de allí mi evaluación sobre esos poemas; quiero decir que posiblemente yo estaba haciendo una lectura in-pertinente, según el modelo tradicional de la lectura silenciosa en el gabinete, con la revista sobre el escritorio y bajo la luz de la lámpara.” Es interesante remarcar, sin embargo, la intuición de Ortiz de que estaba frente a un fenómeno que excedía el 
En este tipo de performance, donde el cuerpo usado como material para la obra se convierte en signo, ${ }^{401}$ la persona del poeta determina fuertemente la recepción de los textos, y la escena funciona, según expondremos, como representación de un modo de circulación particular de los textos poéticos dentro de un grupo definido. Por eso, como dijimos, si bien aquí nos centraremos en la producción poética, el estatuto de los textos debería pensarse a la luz de estas prácticas que se caracterizan por el cruce de lenguajes, y donde el cuerpo es “puro presente, realidad absoluta, presentación sin más”. 402

Estas prácticas que rodean y constituyen la producción de ByF modifican parcialmente el modo de concebir la poesía, que ya no puede pensarse sólo en relación al campo literario sino a los intercambios más amplios de una comunidad interdisciplinaria de artistas en la que el énfasis está puesto más en el "hacer” que en el producto final. Al mismo tiempo, la velocidad de producción, publicación y circulación ponen en entredicho, como adelantamos, la idea de poesía como trabajo artesanal sobre el lenguaje que demanda tiempo y corrección. Al contrario, como señalábamos junto con Laddaga, lo que se pone en cuestión es la noción de “obra”, o al menos se la amplía para incluir en ella tanto la producción textual como sus modos de circulación y presentación en público, a la vez que todas estas instancias adquieren un carácter efímero.

Este modo de presentar los poemas que enfatiza la vinculación entre los textos y el autor -aunque haya un grado de teatralidad implícita, en tanto en la performance el autor se presenta al mismo tiempo como personaje de una puesta en escena- se articula, modo tradicional de circulación y recepción de los textos poéticos, así como la pertenencia de los textos a una comunidad culturalmente definida, como analizaremos más adelante.

${ }^{401}$ Glusberg, Jorge, El arte de la performance, Buenos Aires, Ediciones de Arte Gaglianone, 1986.

${ }^{402}$ Rosenbaum, Alfredo, “Performance, cruce de lenguajes y provocación”, en Revista KEPES, Año 5 N . 4, enero-diciembre de 2008 (217-235). 
por otra parte, con la construcción de sí mismas como autoras-personajes que las poetas llevan a cabo en sus textos. En este sentido el uso de seudónimos es relevante porque, si bien dentro del ámbito de circulación de los textos era conocida la correspondencia entre los seudónimos y los autores (Dalia Rossetti corresponde a Fernanda Laguna, y Lirio Violetsky a Gabriela Bejerman), el gesto remite explícitamente a una construcción ficcional que establece una distancia entre el autor y la voz que habla en los poemas, como vimos en el caso de Segovia o Punctum. Pero de nuevo, esta distancia está puesta en cuestión en las poéticas de ByF, donde (como analizamos en el caso de Cucurto) la ficcionalización también es incompleta, porque todas estas poetas se refieren a sí mismas por sus nombres reales en los textos. Se trata de personajes "literarios” en cuya construcción se apela a la biografía de las autoras y a diversos datos de la realidad como la mención del propio local de Belleza y Felicidad-, elementos que dan lugar al mismo estatuto de indecibilidad entre personaje y autor que analizamos en Cucurto.

Además, la modalidad de publicación descrita está en consonancia con la construcción que estas poetas, sobre todo Laguna, realizan de sí mismas como artistas “ingenuas”. Según Bourdieu, en cada momento del campo hay una problemática vigente de la que los escritores se hacen cargo, ya sea para rechazarla o plegarse a ella, y que delimita el espacio de lo pensable (Bourdieu: 1997, 361). Pero hay artistas que ignoran (o simulan ignorar) la historia específica del campo y la lógica de su juego. Bourdieu se refiere a este grupo como "artistas ingenuos”, y señala que se caracterizan por una producción que intenta acatar las normas más convencionalizadas de lo que se entiende como "literario" dentro de ámbitos no especializados, e incluso aquellas que han sido 
abandonadas hace tiempo por otros artistas consagrados (Bourdieu: 1997, 363, nota al pie). ${ }^{403}$

Como señalamos en el caso de Cucurto y su apropiación de la figura de poeta maldito, en ByF esta noción del "artista ingenuo" se activa por la recuperación, no tanto de la tradición literaria sino de sus derivaciones más bien degradadas en la cultura de masas, y puede verse por ejemplo en el uso de un léxico desprestigiado en la poesía de los noventa pero que tiene su pervivencia en otras manifestaciones culturales tales como los posters, las tarjetas de celebración que se comercializan en los quioscos o los diálogos de las telenovelas. Además, en este caso emplearemos el término “ingenuos” sumándole otro sentido, puesto que aquí se construyen voces adolescente e infantiles que pueden caracterizarse de ese modo. Pero, como dijimos, esta idea de "artista ingenuo" debe pensarse como el armado de una figura que permite parodiar los valores consagrados en el campo, dado que las poetas de que nos ocupamos tenían cierto capital cultural específico (Pavón y Bejerman completaron la carrera de Letras en la UBA y

\footnotetext{
${ }^{403}$ Bourdieu se refiere con esta denominación a una figura como la del Aduanero Rousseau, “descubierta” por un campo del que ignoraba las reglas, pero también, por ejemplo, a la correspondencia amorosa de las clases populares y su empleo de una retórica ya considerada obsoleta en el campo literario. Es interesante que al definir al artista ingenuo, el autor plantee cierta vinculación con una idea tradicional de literatura propia de la escuela primaria (porque como hemos visto, la producción de ByF puede relacionarse también con la tendencia denominada "escuelismo" en plástica y su modo de trabajar sobre el imaginario y la retórica escolares). Dice Bourdieu: "la poesía sigue encarnando todavía en nuestros días la idea que de la literatura se forman los consumidores menos cultos (sin duda debido a la influencia de la escuela primaria, que tiende a identificar la iniciación literaria con el aprendizaje de poesías). Como cabe comprobar mediante el análisis de un diccionario de escritores (...) los miembros de las clases populares y de la pequeña burguesía que empiezan a escribir tienen (salvo excepciones) una idea demasiado elevada de la literatura para escribir novelas "realistas"; y, de hecho, su producción consiste esencialmente en poesías -muy convencionales formalmente(...)" (Bourdieu: 1997, 363, nota al pie). Entonces, dejando de lado la referencia a las "clases populares”, que no es pertinente aquí, sí podemos decir que el gesto de acceder a la literatura desde otro lugar articula en ByF esta idea "ingenua" de poesía que no está ni estaría presente de ningún modo en otros poetas de los noventa (sobre todo en aquellos que exhiben cierta conciencia histórica de los usos de la lengua en poesía) con el trabajo de pastiche sobre aquellas manifestaciones de esta misma idea ingenua de poesía que aparecen en los productos de la cultura de masas. Pero no está de más remarcar que estas operaciones constituyen un artificio, que se tensiona en ByF con la puesta en escena ocasional del imaginario vanguardista, como comentamos a propósito de un relato de Cecilia Pavón (Pavón: 2004).
} 
Laguna es Profesora Nacional de Dibujo y Pintura por la Escuela Nacional de Bellas Artes Prilidiano Pueyrredón). Esta idea de “ingenuos” también, por último, describe bien la posición ocupada por ByF como grupo centrado en la práctica pero en el que mayormente se eludía la reflexión crítica e incluso la tendencia a tomar las teorizaciones sobre la escritura propia y ajena como parte de la condición de poeta que en otros casos, y sobre todo en el Diario de poesía, se daba por sentada como un valor.

A partir de esta idea puede pensarse el armado de los poemas como pastiche de estilos que incluye escrituras menores como el diario íntimo, las cartas y las formas del discurso sentimental de la cultura de masas, además de recursos como el uso de rimas y del pretérito perfecto y de términos altamente estilizados que denotan el esfuerzo por “escribir correctamente”, mezclado con las faltas de ortografía que se conservan en la edición final, sobre todo en Laguna. De hecho en el poema Salvador de Bahía, ella y yo, Laguna comienza por decir: "Este es un cuento/ muy bonito/ y simple.// Es mi primer cuento/ es lo más largo/ que he escrito.// Mi proyecto ambicioso,/ mi consagración”. 404 Estos primeros versos, que resumen de manera absurda la carrera de un escritor -el primer cuento coincide con la consagración, dando lugar a un desfasaje humorístico similar al contraste entre "bonito" y "simple” y "proyecto ambicioso"-, pueden leerse como parodia del ingreso institucional a la literatura e incluso de la tradición pensada en términos de “canon”, sobre todo por la lista de "influencias” que se consignan a continuación: “He usado/ más palabras que nunca./ He imitado/ a grandes escritores/ como Bocaccio,/ César Aira,/ Clarice Lispector,/ Cecilia Pavón,/ Gabriela Bejerman/ y Paulo Coelho”.

La lista es aberrante con respecto a cualquier canon porque pone a un clásico como Bocaccio junto a César Aira, a una escritora de moda en los círculos

\footnotetext{
${ }^{404}$ Fernanda Laguna, Salvador Bahía, ella y yo, Buenos Aires, Belleza y Felicidad, 1999.
} 
especializados como Clarice Lispector, a las amigas de Fernanda Laguna (Pavón y Bejerman) y a un escritor de best sellers como Paulo Coelho, difícilmente tomado en cuenta tanto por la academia como por otros poetas de los noventa cuyas bravatas alcanzaban hasta atacar a Cervantes o a Ezra Pound. Más adelante en el mismo texto la autora se refiere al esfuerzo que tuvo que poner para escribir, bien distinto del "pulido" que funcionaba como valor que se atacaba o discutía en poéticas que van desde las de los miembros del Diario de poesía hasta la de Daniel Durand: "Fue difícil para mí/ mantener el hilo para que se entienda/ algo tan largo./ También me costó/ conjugar bien los verbos/ y encontrar los adjetivos apropiados”. Más que una dificultad en el trabajo con la escritura, aquí se trata de construir una figura del que tiene dificultades en el manejo más básico y escolar de la lengua, al punto de que le cuesta conjugar los verbos. En Laguna sobre todo, lo que se pone en escena es un yo infantilizado que parece estar accediendo a la escritura poética por primera vez, sin un manejo fluido de las reglas más elementales, como lo muestran aquí las faltas de ortografía: "Ella se ha ido a Uruguay/ a travez de la frontera con la Argentina./ (...) La casa es de dos hambientes chicos” (Cartas de amor).

Pero lo que podría pasar fácilmente por parodia encuentra su base "real” en el hecho de que Laguna efectivamente es una artista plástica que accede por primera vez a la poesía, por lo tanto su construcción como artista ingenua tiene un sustento que la vuelve por lo menos ambigua, además de que se complementa con su modo de presentarse en público en entrevistas y otras intervenciones, como lo muestra este fragmento de una entrevista a cargo de la también artista plástica Judith Villamayor:

$\mathrm{J}$ : como es tu rutina de trabajo?

Fernanda Laguna: no tengo una rutina. Pasan meses que no pinto. Luego hago lo que pinte. Escribir algún cuentecillo. algún poema, delirar en los flogs, salir a caminar y jugar a ser grande. Otras ... me encanta frotar el pincel por cualquier lado y hago cuadros porque así aprovecho la energía del frote metiendole un poco de color al pincel 
me da lo mismo pintar cualquier cosa no tengo ni idea de lo que voy a pintar por eso me repito mucho.

\section{J: de q hablás con tus amigos?}

Fernanda Laguna: bueno, depende con que amigos soy de hablar mucho de arte pero así como de chanfle de que dijo tal lo que va a hacer tal otro me cuantan proyectos y nos vamos por las ramas arte y amor, arte y platita, arte y trepasaon, amor, problemas socials pero lo que mas hago y hacemos es soñar e idear cosas y es tan hermoso porque de a varios todo es possible y viste después las cosas se realizan que difícil preguna!!! la más difícil! ${ }^{405}$

Como puede observarse en las respuestas de Laguna, la poesía se concibe como una práctica más entre otras, no profesionalizada (y de la que se habla "como de chanfle”), que se coloca en el mismo nivel que “delirar en los flogs” y "salir a caminar”. Además se hace presente una construcción de sí misma como sujeto infantilizado (cuando Laguna dice que le gusta "jugar a ser grande”) que tiene su continuidad en los poemas, con lo cual estamos nuevamente frente a un autor-personaje donde los límites entre el sujeto biográfico y el que enuncia el poema se desdibujan hasta volverse indecidibles.

Esta figura impregna buena parte de la producción de ByF. Los poemas publicados por Laguna, Pavón y Bejerman en este proyecto remiten en su mayoría a un mundo adolescente en el que un grupo de amigas cuentan sus aventuras, sobre todo sexuales y amorosas, y se dedican poemas unas a otras. ${ }^{406}$ Algunos textos de Fernanda

405 Disponible online en http://spaghettiabasto.com.ar/entrevistas/fernanda/index.html. Las cursivas y los errores ortográficos y tipográficos pertenecen a la publicación original.

406 Gabriela Bejerman y Cecilia Pavón en cambio presentan poéticas divergentes cuando publican en otras editoriales o en libros de poesía (y no plaquetas) más parecidos a la producción de los noventa que hemos analizado hasta aquí. Así, Bejerman por ejemplo procesa la escritura de Perlongher y de Marosa di Giorgio en un libro como Crin, donde el énfasis está puesto en la materialidad de la palabra en elaboraciones que detentan rasgos del neobarroco: "Cuando me seduzco en las melodías del piano de mi voz planeo sobre lagos turquesas y arena volcánica y pareciera entonces que nunca volveré a devorar carne, suelto alas, pájaros y adolescentes llorosos, todos se zambullen en el cielo aéreo o en el cielo acuático, y yo floto convertida en un puñado de plumas que se dispersan en la inmensidad”. En Gabriela Bejerman, Crin, Ediciones Belleza y Felicidad, 2001 (31). También hay poemas de este libro que tematizan el funcionamiento del sentido en relación a la escritura ("siento que viene el sentido/ como una ola/ apenas llega/ la marea baja/ no sé si queda alguno/ en mí/ sólo hay colores”, p. 18). Pero este tipo de escritura más autorreflexiva, impensable en Laguna como no sea bajo un 
Laguna contienen además una marca performática, porque remiten a una escena de lectura frente a un público: “-¡Hola!/ Mi nombre es Samanta y/ he venido a este planeta/ a contarles un cuento" (Samanta); "Este es un cuento/ muy bonito y muy simple" (Salvador Bahía, ella y yo); “Les voy a contar una anécdota triste” (Licor de cafê). ${ }^{407}$ En estos casos, los poemas parecen estar concebidos para ser presentados ante una audiencia y muchas veces, como sugieren estos versos, toman la forma de un cuento infantil leído ante un grupo de niños. ${ }^{408}$

La construcción del analfabeto adopta en este caso una modulación infantil que sustrae la poesía a las reglas de juego propias del campo en un momento dado, como señalaba Bourdieu (Bourdieu: 1997, 361). Mientras que en Cucurto el analfabetismo se fundaba en un origen social determinado, la variante que presenta Laguna y que se extiende parcialmente a otras publicaciones de ByF tiene que ver, también, con hacer el gesto de escribir por fuera del campo literario, pero desde una concepción ingenua y escolar de la poesía, y las faltas de ortografía ponen en escena la falta de capital cultural específico, que remite la escritura no al trabajo de un poeta que se concibe a sí mismo como tal, sino a los ejercicios escolares y la práctica de registro del diario íntimo.

gesto paródico o por lo menos ambiguo, ya estaba presente en algunos poemas de Bejerman publicados como plaquetas en ByF: "no hay más prosa que la sintaxis rítmica del verso" (Judía).

Sin embargo, en este caso optamos por trabajar únicamente la producción en plaquetas de ByF (con menciones ocasionales a otros libros) centrándonos en la figura de Fernanda Laguna puesto que su escritura y su construcción como poeta, en tanto constituyen la propuesta más radical de las nucleadas en ByF, condicionaron el modo en que el grupo fue percibido desde el exterior, como lo demuestran los artículos de prensa citados anteriormente donde se lo criticaba a partir de rasgos presentes sobre todo en la obra de Laguna.

${ }^{407}$ En el caso de las plaquetas no especificaremos el número de página de la cita puesto que casi ninguna de estas publicaciones tiene páginas numeradas.

${ }^{408}$ La voz de enunciación en los poemas de ByF puede ser alternativamente infantil o adolescente, sin que resulte posible fijar una "identidad", puesto que se trata, como vimos en el capítulo anterior, de construcciones performáticas que eluden la posibilidad de ser fijadas en una u otra categoría. En este sentido, se acercarían más bien a la noción de sujeto no-unitario y nómade porpuesta por Rosi Braidotti en Feminismo, diferencia sexual y subjetividad nómade, Barcelona, Gedisa, 2004. 
Efectivamente, muchos de los textos remedan el diario de una adolescente, por eso hay todo un campo semántico asociado a los sentimientos que se repite sin matices: “En casa tengo al osito-mono/ que me satisfacería bastante/ si no fuera tan parecido a un muñeco./ El amor se me revela de a pedacitos/ como un cristal facetado;/ un ojo, un brillo, una caricia, un cuerpo, un sonido,/ una sonrisa,/ etc.// Ay.../ El amor, el amor, el amor...” (Poema IV). Los gustos que manifiesta el “yo” que habla en los poemas, así como su modo de relacionarse con los amigos y con los productos culturales de su preferencia, se caracterizan asimismo por la ingenuidad: “¿cómo será Madonna?/ Será buena y simpática/ ¿existirá?/ A mi me gustan mis amigos/ que los puedo tocar,/ que me abrazan,/ me miran y yo siento/ su presencia en el corazón./ De Madonna me gusta “Like a virgen”/ “Open your Heart” y "Thief of hearts”/ y alguna de sus bailarinas” (La señorita). En consonancia con esto, en Fernanda Laguna, pero también en Bejerman y Pavón, la relación con las amigas toma la forma del enamoramiento.

Lo mismo puede decirse de las plaquetas de Cecilia Pavón. Una de ellas, sin ir más lejos, lleva por título a fernanda (por Laguna) y otra se llama Gabriela, los hombres y yo (por Bejerman). El festival de las lágrimas, La euforia y Primer beso son los títulos de otras publicaciones, que remiten una vez más a un mundo de emociones tan intensas como efímeras similar al de Laguna. Tanto el amor romántico y la alegría aunque sería más preciso hablar de euforia- como la tristeza y la angustia, se presentan “sin que (las obras) parezcan rendirse ante la emoción más que como un concepto abstracto”, según señala Marcos Livingstone a propósito de los cuadros pop de Roy Liechtenstein. ${ }^{409}$ Gabriela, los hombres y yo, por ejemplo, es un poema de Pavón dedicado a Bejerman en el que se cuentan las conversaciones telefónicas entre las amigas por la noche. El poema dice: “Sonrisas, sonrisas, sonrisas/ Gabriela, Gabriela,

\footnotetext{
${ }^{409}$ Marcos Livingstone, "Una tecnicultura gloriosa”, en Arte pop. Muestra del Museo Nacional Reina Sofía., Madrid, Electra, 1992 (19).
} 
Gabriela/ ¿sos consciente?: la naturaleza ha nacido/ para mostrársete y nada más/ Creo que el amor es un sueño que tienen/ tus animales”. De nuevo, junto a un vocabulario acotado en el que se repiten términos como “sonrisa”, “naturaleza”, “amor” y “sueño”, que formarían parte de un diccionario degradado y prácticamente ausente en el resto de las poéticas de los noventa, aquí aparece puesta de relieve la importancia de una operación que atraviesa estos poemas: la de nombrar, no sólo a las amigas poetas sino al grupo más amplio de novios, amigos y conocidos.

Esta operación de nombrar cobra en este caso otro sentido que el analizado en Llach y en Cucurto, porque aquí no se trata tanto de la mención de los contemporáneos en tanto poetas a los que se lee, sino sencillamente en tanto amigos (por eso Llach y Cucurto citaban a los poetas por nombre y apellido, mientras que aquí figura sólo el nombre). Si bien se trata de una comunidad de artistas, las representaciones del intercambio de poemas y dedicatorias que hacen estas poetas remiten más a la práctica común de enviarse cartas y tarjetas que realizan las adolescentes entre sí (una apreciación similar puede leerse en la descripción que Mario Ortiz hace de una performance de ByF que figura más arriba). Los poemas, por eso mismo, adoptan un carácter doble: son publicados y vendidos como literatura, pero a la vez hacen el gesto de ser cartas, páginas de diarios íntimos, pequeños cuentos para ser contados entre amigos (de ahí que estén plagados de guiños al interior del grupo). Desde esta perspectiva cobra sentido el diseño que, como dijimos, remite por momentos a la apariencia de los cuadernos escolares y las tarjetas que se regalan las adolescentes. Esta idea de la poesía como objeto de intercambio entre un grupo de amigas concuerda con las representaciones de un tipo de escritura no institucionalizada ni profesionalizada que estas poetas construyen en sus textos. 
Como puede verse, la producción de ByF representa un cambio de paradigma en relación a los valores vigentes en el campo poético en todos sus aspectos: en primer lugar, porque la figura de poeta ingenuo supone el abandono de la vinculación entre poesía y crítica (unida a la reflexión sobre el lenguaje) que vimos en los primeros capítulos de este trabajo, y de cierta idea de la poesía como objeto de disputa que es común a varios de los poetas analizados, y también porque aquí el gesto de tabula rasa con respecto a la tradición reside en el empleo de materiales degradados y desprestigiados, asociados fuertemente a lo infantil y adolescente, y a un culto de los sentimientos que proviene de sectores de la cultura de masas y de ningún modo de la tradición literaria. Además, la ideología de la inespecifidad que mencionamos al principio alcanza también al lenguaje, que ya no se concibe como instrumento de comunicación o como objeto sobre el que se trabaja, y ni siquiera como un elemento socialmente connotado.

Por el contrario, aquí el lenguaje se asimila más que nunca a las superficies de los objetos de la cultura tecnificada, y puede ser motivo de fascinación para un sujeto pero en todo caso no mantiene ningún vínculo referencial con lo que otros poetas señalaban como "realidad” en sus textos. Es por eso que Pavón, al contar un cuento con un vocabulario que remite por momentos a los cuentos de hadas (como sugiere el uso del término “personas malvadas”) puede decir:

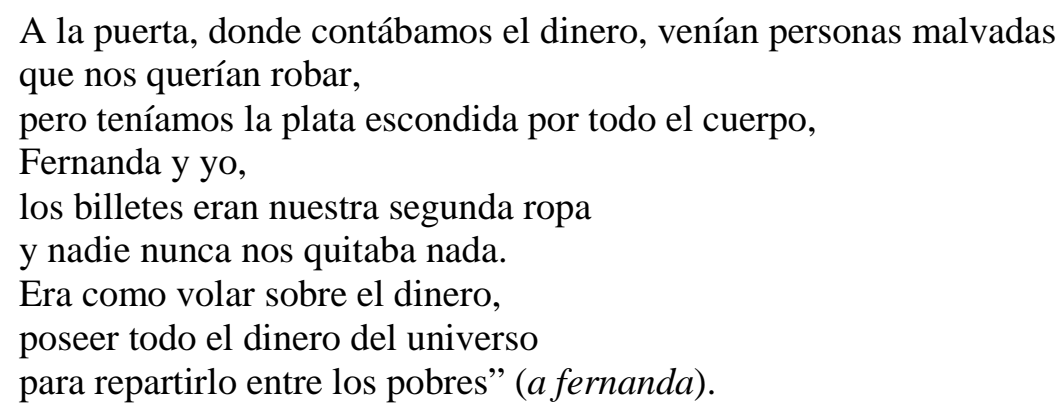

El texto pone en escena una fantasía, en la que términos como "los pobres" o "dinero" (en un uso por otra parte altamente artificial) ya no tienen correspondencias con un 
referente social sino que se convierten en pura superficie de un lenguaje que se lee como cita de discursos previos, ya sea el de los cuentos o las telenovelas. Así, a fuerza de repetición y de usar las palabras de una manera plana que las esencializa y las vuelve casi abstractas (“la tristeza”, “el amor”, “los pobres”) parecería alejárselas de la experiencia para convertirlas en puro significante vaciado de sentido, una operación que encuentra su figura en el momento en que las emociones y las palabras mismas se convierten en ondas, imágenes, pantallas.

Porque tanto la imaginación como las emociones adoptan formas tecnológicas en Laguna, que en La señorita sueña con organizar una revolución pero se pregunta, “Revolución ¿de qué?”, y acto seguido se imagina esta utopía difusa, desprovista de contenido (y por supuesto de toda connotación histórica) y en clave tecnificada: "Sí una revolución.../ Siento la presencia del deseo del amor/ y me entrego como en un video”. Más adelante en el mismo poema, lo que se pone en escena es la versión tecnificada también -pero no sofisticada, sino al contrario- de las emociones y hasta de la propia idea de "alma”:

La música es mi amiga

porque sus ondas

llegan a mi corazón

$(\ldots) /$

Las ondas existen

como la onda del amor

y es por eso que no puedo evitar

enamorarme

porque las ondas del amor son

como las de la música

y en el corazón no hay ninguna tapa

para evitar que entren.

¡Lo he descubierto!

Por eso me enamoro.

En el mundo todo son ondas

y somos cuerpos de ondas

porque si hablo con Cecilia por teléfono

llego hasta allí

a través del cable

y cuando me muera

seré otro tipo de onda.

Una onda negra. (Fernanda Laguna, La señorita). 
En este caso lo que se imagina es la desmaterialización de los cuerpos, y hasta el "yo" se asimila a las ondas eléctricas en su versión más simple y cotidiana, más banal (las ondas del teléfono).

En Poema IV, también de Laguna, la que habla dice que está enamorada de una foto: "Yo sé muy bien que esa foto no tiene vida/ (...) Pero en realidad/ creo que amo la foto en general./ Amo el papel brillante,/ esa suavidad rozando mis labios./ En la intimidad de la noche/ la ilumino con una vela/ y siento al verla vibraciones muy especiales”. El amor, en este caso, no reclama como objeto algo "vivo", como dice el propio texto, sino que se concentra en los brillos de la foto impresa, en la textura del papel, que se presenta incluso como objeto erótico, y no en la imagen que contiene el soporte. Dicho de otro modo, la foto no se percibe como representación sino como objeto real, y es eso lo que se ama. En Amigas, un cuento sobre cuatro mariposas que viven "En un jardín muy lindo”, aparece una computadora en medio de ese jardín nada natural “y era mentira/ que necesitaba electricidad/ y que dependía del hombre./ Ella era libre/ porque lo deseaba/ y la tierra era su alimento/ agua y abono”. También se dice que las mariposas “se reflejaban/ en la pantalla/ y ponían videos de Madonna”. En la pantalla de ese objeto tecnológico aberrante que tiene comportamiento vegetal se fusionan las mariposas con la figura del ícono pop, y esta imagen puede valer como figura del poema y de su operación con el lenguaje. En este caso, la palabra "mariposa” que deviene reflejo (no de la realidad, puesto que estos usos están lejos de la mimesis) como continuidad de la superficie verbal en la superficie brillante y tecnificada del monitor de una computadora. Al mismo tiempo que usan el lenguaje de modo no representativo, los poemas ponen en escena una fascinación por el objeto técnicamente reproducible y por las imágenes que adopta incluso matices religiosos, y que se suma a la fascinación por las propias emociones. 
Fredric Jameson se refiere a esta experiencia de los sujetos en relación a la tecnología como un nuevo "sublime tecnológico", donde la exaltación que en otros tiempos se daba frente a "lo otro" (es decir, lo irrepresentable) encarnado por la naturaleza, la divinidad o la propia tecnología de las máquinas de producción se desplaza ahora hacia las máquinas de reproducción, es decir, las computadoras y la televisión, que constituyen la parte experimentable de una red más amplia de poder y control imposible de imaginar (Jameson: 1991, 79-86). Por eso los textos de ByF, aunque podrían tildarse de “irreales” sin más, ponen en escena una nueva experiencia del sujeto en relación a la tecnología, que fusiona incluso las imágenes técnicamente reproducibles con las imágenes mentales. En efecto, en Los celos no ayudan, la culpa tampoco (Autoayuda) el brillo de las imágenes aparece asociado a la creencia: "Yo deseo ser feliz/ (...) Y al acostarme/ soñar imágenes preciosas/ con mucho brillo/ y desear creer en ellas”. Esta serie de sentido que se arma entre imágenes, felicidad y creencia habilita la idea de que hay un nuevo tipo de sublimidad e incluso de sacralidad en las imágenes -las mentales pero también las imágenes tecnificadas, que en ocasiones pueden ser intercambiables, así como en este poema el sueño adopta el carácter brillante que antes se atribuía a la foto.

En César Aira y Cecilia Pavón, Laguna describe un “momento de iluminación” en el subte -de nuevo, como en el caso del teléfono, una experiencia cotidiana que remite a la vida en una gran ciudad-. Se trata de un instante de "realidad extrema" que se describe en estos términos: "La situación en el subte/ ese momento de iluminación/ donde la inspiración/ o la realidad extrema/ se mete dentro de los pulmones/ y de allí va a la sangre.” En este caso, la realidad extrema y la irrealidad se confunden totalmente, especialmente porque la “iluminación” puede referirse tanto a un instante de lucidez mental o espiritual como a las luces artificiales del transporte público. Por eso la fusión 
entre espiritualidad y técnica, que produce un momento alucinatorio propio de la experiencia cotidiana de viajar en una metrópolis, es total. El poema sigue hablando de este estado, al que denomina "trance” y que hace decir al sujeto: “Adoro a todos,/ amo a todos,/ no me importa nada”.

Fredric Jameson se refiere a este tipo de estados cuando describe el punto de indecidibilidad entre realidad y fantasía que implica la "ruptura de la cadena significante” (término del que se vale el autor para describir las obras posmodernas). ${ }^{410}$ Esta ruptura deja librado al sujeto a "una experiencia puramente material de los significantes o, en otras palabras, a una serie de meros presentes carentes de toda relación en el tiempo”. Además, esto va a acompañado de sensaciones de irrealidad: “inmensidad sin límites, luz brillante, y la lisura y el lustre de las cosas materiales” (Jameson: 1991, 64, 65), que se aplican perfectamente al poema de Laguna que acabamos de citar. Sin afirmar de ningún modo que las poéticas analizadas deban pensarse a partir de la categoría de "posmodernidad", ${ }^{411}$ lo cierto es que lo descrito por Jameson coincide con las sensaciones que ponen en escena los poemas de ByF. Porque aquí hay un presente intensificado que, según Jameson, puede producir angustia y sensación de pérdida de realidad, pero también "puede imaginarse en términos positivos como la prominente intensidad intoxicadora o alucinatoria de la euforia” (Jameson: 1991, 66). En los poemas de ByF, éste es precisamente el signo que adopta la

\footnotetext{
${ }^{410}$ De hecho, Jameson toma esta noción de la descripción lacaniana de la esquizofrenia, pero en este caso no haremos alusión a este término por las connotaciones de normalidad/patología que supone.

${ }^{411}$ El término “posmodernidad” con el que Jameson intenta vincular un estado de la cultura con la situación del capitalismo avanzado en las grandes metrópolis nos parece poco apropiado para pensar las poéticas de ByF, si bien coinciden en muchos rasgos con lo descrito por este autor, puesto que se trata de un fenómeno cultural de una ciudad donde ciertos rasgos que podrían pensarse como posmodernos (sobre todo después de la implementación de las políticas neoliberales de la década del noventa) coexisten en un entramado particular con modos de hacer y condiciones culturales propias de los países no globalizados -no debe olvidarse, además, que las poéticas que aquí abordamos surgen en torno al derrumbe de la era neoliberal que supuso la crisis del 2001.
} 
experiencia del puro presente, experiencia que a su vez aparece ligada a la vida en la gran ciudad y a la interacción del sujeto con la tecnología.

Así, la "realidad” se menciona y redefine de modo recurrente en los poemas de Laguna y Pavón, que pueden tanto decir “la bella realidad” (Fernanda Laguna, Salvador Bahía, ella y yo, donde también se dice que es la Virgen quien hace a la que escribe “enamorarme,/ entregarme,/ escribir y ver/ la bella realidad”) como afirmar que semejante cosa no existe más. Tal es el caso en El festival de las lágrimas, un poema de Pavón en el que se imagina el fin del mundo con una mezcla de miedo y euforia:

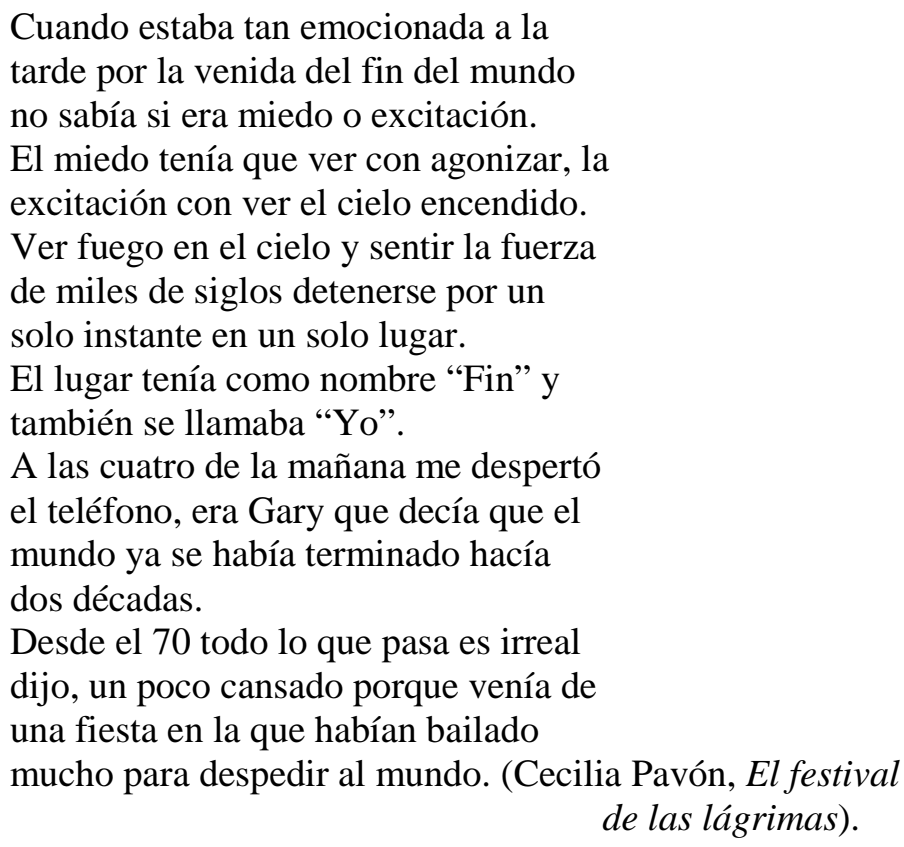

Aquí, el fin del mundo -y del tiempo- coincide con el fin del "Yo" (prefigurado en el grupo de amigas que intercambian poemas y que se nombran en ellos al punto de volverse casi intercambiables), ese "Yo" con mayúsculas que ha sido siempre el centro del discurso poético moderno como lugar de enunciación que organiza la subjetividad. La pérdida del yo como límite, temido y a la vez deseado, se hace presente también en las preguntas de Pavón en otro poema: “llegará la locura alguna vez? la convulsión? la epilepsia?” (Cecilia Pavón, a fernanda). 
Entonces, lo que se lee en los poemas de Laguna y Pavón publicados en el marco del proyecto ByF es la fascinación con el brillo de las imágenes que alcanza también al modo de experimentar el lenguaje como superficie. Ellas conforman una nueva realidad desrealizada (no exactamente la "realidadficción” de la que hablaba Ludmer) que tal vez no sea otra cosa que el lenguaje convertido en imágenes planas, que brillan pero nada reflejan. Por eso las emociones y las mismas palabras que las nombran, que también son objeto de adoración, se convierten a su vez en imágenes, reflejos en una pantalla o en la superficie de una foto, al punto de que en Amigas, el poema de Laguna antes citado, se dice que "Las pantallas/ también saben dar/ y recibir amor”. Lo importante es que debido a este modo de experimentar la tecnología, las imágenes y el lenguaje, la tensión entre alta cultura y cultura de masas que enunciaba la cita de Gambarotta en la figura de Alien devorando al Quijote definitivamente no existe en ByF, donde la fusión entre literatura y cultura de masas tecnificada es total.

Finalmente debemos agregar ciertas consideraciones con respecto a la temporalidad que se deriva de estos textos. Sucede que, como parte de ese cambio de paradigma al que aludimos anteriormente, lo que se modifica también, además de las concepciones sobre el lenguaje, la poesía y la figura del poeta (aunque como intentamos demostrar, todos estos cambios están relacionados) es el modo de experimentar el tiempo, y esta modificación pone en entredicho la posibilidad de hablar de una “tradición” a propósito de ByF. Porque como señalaba Jameson, la ruptura de la cadena significante supone que el sujeto se fragmenta y queda librado a "una serie de meros presentes carentes de toda relación en el tiempo”. Bajo esta condición, no hay posibilidad de construir una vinculación entre pasado, presente y futuro que unifique al sujeto y por lo tanto de continuidad a su experiencia a lo largo del tiempo (vinculación 
que es imprescindible, como vimos, para el armado de una tradición desde una perspectiva histórica). Así, Cecilia Pavón enuncia en un poema que

El pasado no es doloroso, el pasado es lindo cuando voy en el colectivo, ex novio, qué lindo es recordarte siento que navego por el mar de autos y que mis percepciones son

Si el amor es lo único que puede darle contenido a la vida, ligeras qué lindo es haber vivido y ahora estar liberada (...). ${ }^{412}$

Si el texto puede plantear un pasado sin dolor y desprovisto de conflicto, y hasta "lindo" (es decir, sin heterogeneidad y sin matices), es porque lo que surge aquí no es una memoria que presentifique una experiencia vivida, sino que se trata más bien de un recuerdo en alguna medida despersonalizado (de ahí que el poema contraste el "haber vivido" con el "ahora estar liberada”, como si nada hubiera quedado del pasado más que un recuerdo tan "ligero" y en alguna medida ajeno como las percepciones de la ciudad a las que se alude).

Esta desconexión entre pasado y presente en la mente del sujeto, de hecho, anula la posibilidad de que exista la historia, y este dato está estrechamente vinculado con el juicio sobre la realidad que se plantea en el poema de Pavón ya citado, El festival de las lágrimas: "Desde el 70 todo lo que pasa es irreal/ dijo, un poco cansado porque venía de/ una fiesta en la que habían bailado/ mucho para despedir al mundo”. Sin embargo aquí este comentario sobre el fin de la realidad -que constituye casi una reflexión teórica- está puesto en boca de otro personaje llamado Gary, mientras que la que enuncia el poema dice “No sé, le respondí, yo nací en el 73 no/ he vivido tanto tiempo”.

En Samanta de Fernanda Laguna se presenta una variante de esta idea que adopta la forma del déjà vu: "Todo lo que hacen/ ya fue hecho/ ustedes son parte de un/ experimento,/ igualmente son muy capaces/ y tenemos fe en ustedes”. Para Paolo Virno, el déjà vu se define como una repetición puramente ilusoria, aparente: se cree haber

\footnotetext{
${ }^{412}$ Cecilia Pavón, ¿Existe el amor a los animales?, Buenos Aires, Siesta, 2001 (39).
} 
vivido algo que en cambio está sucediendo por primera vez. ${ }^{413}$ Según el autor, este es un estado de ánimo extendido que caracteriza las formas de la vida contemporánea, ligado al tema filosófico del fin o la detención de la historia (que puede leerse en la afirmación de que “Desde el 70 todo lo que pasa es irreal” del texto de Pavón), y en este caso podemos ligarlo con el carácter ilusorio de la "realidad” que se construye en los poemas.

Virno recurre a Bergson para decir que en esta forma de experiencia prevalece la impresión de que el futuro está cerrado (Virno: 2003, 17), y esto se relaciona con la presencia recurrente del motivo del fin del mundo (vinculado en ocasiones con el motivo de la fiesta como, de nuevo, en El festival de las lágrimas de Cecilia Pavón) en los textos de ByF y en publicaciones posteriores de las mismas autoras. Así, en la novela Presente perfecto de Gabriela Bejerman, ${ }^{414}$ el relato se refiere a una fiesta en la casa de una baronesa. En un cuarto significativamente poblado de pantallas, la baronesa monitorea su propia fiesta por televisor, y está preocupada porque el fin de la fiesta será también el fin del mundo (Bejerman: 2004, 40). ${ }^{415}$ En un momento este mismo personaje, aburrido de la fiesta, quisiera poner la mente en blanco (volver a "la pantalla blanca”, dice en realidad el texto) para que las imágenes de la fiesta la impresionen y encanten por primera vez (Bejerman: 2004, 44). Ese adelgazamiento del tiempo tiene como consecuencia que el deseo de una vuelta al origen coincida con la experiencia del fin del mundo como una inminencia que asedia de modo recurrente, por más que al final de esta novela breve, que tiene lugar a la mañana siguiente de esa noche de fiesta, los

\footnotetext{
${ }^{413}$ Paolo Virno, El recuerdo del presente, Buenos Aires, Paidós, 2003 (15).

${ }^{414}$ Gabriela Bejerman, Presente perfecto, Buenos Aires, Interzona, 2004.

415 Es interesante observar, como variante de esta idea, que un relato de Fernanda Laguna publicado bajo el seudónimo de Dalia Rosetti donde se cuentan las desventuras de una chica neurótica e insegura que se siente fracasada, siempre en clave cómica, termina con el suicido de la protagonista, que en el momento de morir se siente feliz y satisfecha. Ver Dalia Rosetti, Me encantaría que gustes de mí, Buenos Aires, Mansalva, 2005 (44).
} 
invitados que quedaron desayunen juntos y se diga que "creaban el ambiente perfecto para presentir que todo puede siempre continuar” (Bejerman: 2004, 76).

Lo que ponen en escena estos textos es una experiencia del tiempo constituida por "puros presentes", para decirlo en términos de Jameson, o de un tiempo fragmentado que ya no se concibe como linealidad -incluso hecha de interrupciones y caídas como en la perspectiva dialéctica de Benjamin-, sino de bloques de sensaciones y estados autónomos que apenas guardan conexión entre sí. Esta percepción del tiempo se vincula con lo planteado por Virno, para quien el déjà vu, como fenómeno propio de la sociedad del espectáculo caracterizada por una inclinación a “mirarse vivir” (Virno: 2003, 63, 64), hace percibir el presente como repetición ilusoria de un pasado que nunca existió.

Por eso el espectro de temporalidades que abarca esta investigación, inaugurado por el Diario de poesía como formación cultural cuya concepción del tiempo y el carácter histórico del lenguaje habilitaban una idea de la tradición como armado consciente y selectivo donde el pasado se percibía como tal y en tanto diferente de, y construido al mismo tiempo desde, el presente, encuentra su extremo opuesto en Belleza y Felicidad, donde ya no puede hablarse de “tradición” en los términos de Raymond Williams (porque esa tradición implica por supuesto la historia). Y donde la poesía, además, no se vincula necesariamente a la literatura como institución, sino que forma parte de otro conjunto de prácticas constituidas a partir de apropiaciones siempre fragmentarias de la cultura de masas como un todo llevadas a cabo por un sector muy específico de jóvenes en una ciudad cosmopolita y en tanto consumidores-productores, que desjerarquiza el lugar de privilegio otorgado por otros poetas de los noventa a la literatura. 
Sin embargo, aunque acordamos con la descripción que hace Virno de la experiencia del tiempo, no puede decirse como lo hace este autor que este modo de experimentar el presente inhabilite al sujeto para la acción o lo confine a una actitud de indiferencia y apatía (Virno: 2003, 16) porque, como hemos intentado demostrar, ByF fue un proyecto que puso el énfasis en el hacer y que abrió todo un espectro de actividades y poéticas nuevas, como lo muestra su vinculación posterior con la editorial Eloísa Cartonera (Palmeiro 2011: 212) que, tanto como las modalidades de publicación de ByF, dio lugar a nuevos proyectos autogestionados que a esta altura se extienden a diversos países de Latinoamérica y Europa. 


\section{CONCLUSIONES}

La definición de tradición retomada, como se ha visto, es la de Raymond Williams entendida como proceso activo de selección y recorte sobre la literatura del pasado desde una voluntad de establecer una continuidad, es decir, valorando en el presente aquello que se considera o se desea todavía operativo (Williams: 1997, 137); el problema de lectura de la tradición, entonces, atiende un movimiento simultáneo que supone un gesto colectivo de definición ideológica dentro de una cultura, y a la vez una toma de posición dentro del campo literario (Bourdieu: 1997, 343). Según esta caracterización que fue el eje de nuestra tesis, se abordó el corpus seleccionado. Dentro del mismo, sólo una formación (Williams: 1997, 139), la de los poetas objetivistas que operan desde el Diario de poesía, lleva a cabo colectivamente y de modo programático, en los noventa, un armado de tradición que pueda pensarse en estos términos.

No se trata de que luego la tradición se abandone, o al menos no en todos los casos, sino que en ciertas poéticas que surgen después pasa a ser una instancia que se contrasta con otras, tales como la cultura popular o la cultura de masas. Para decirlo de otro modo, lo que cambia es el modo de percibirla, porque mientras los poetas objetivistas, y sobre todo Prieto y García Helder, operan sobre la tradición "desde adentro” de los límites, siempre permeables, de lo literario (mientras que en la poética de Casas puede leerse una mínima apertura hacia lo masivo, que prefigura ciertas operaciones de las poéticas que surgen en los años siguientes), el gesto que lo continúa es el de situar esta tradición literaria en un contexto ampliado que ya no es el de la literatura y menos aun el localizado de la “poesía argentina” sino el de la cultura; de ahí 
que esta apertura permita incluir los medios de comunicación de masas, el habla y la vida cotidianas.

Lo que cambia también es que en las poéticas de Rubio, Casas, Ortiz y Raimondi, la tradición no solamente se construye sino que se percibe como lo impuesto por la cultura y el sistema educativo, de ahí que se trabaje como una materia que puede subvertirse a través de relecturas, reescrituras y otras variantes críticas, en un gesto que ya estaba presente en García Helder. Ciertamente, este movimiento ya estaba prefigurado en el objetivismo, pero dentro de una formación que todavía escribe, y sobre todo lee, a partir de una idea moderna de literatura, a la que se le otorga un valor opositivo con respecto a los valores vigentes en la cultura y a la que se concibe como una esfera separada y especializada en el marco de la totalidad cultural (Berman: 1989). Uno de las características centrales de esta ideología poética es el trabajo específico con el lenguaje, sobre el cual se ejercen una serie de operaciones asimiladas al "pulido", la búsqueda de precisión y adecuación al objeto que se nombra (cuyo modelo estaba en Pound pero había sido prefigurado más tempranamente por Flaubert y conforma de por sí una tradición, moderna, de figuraciones sobre la escritura), que definen la actividad del poeta. Por eso también, la importancia otorgada al discurso crítico en la publicación que funcionó como medio de construcción y difusión de esta línea poética, el Diario de poesía.

En efecto, los redactores y poetas vinculados a la publicación explicitan siempre las recuperaciones efectuadas sobre otras poéticas o segmentos de tradición, no sólo en los ensayos críticos aparecidos en la revista sino también, en ocasiones, en sus propios poemas. Así, la figura que se construye fuertemente desde el Diario de poesía es la de poeta-crítico que, además, explica o permite entender cómo conciben el armado de tradición en tanto operación conciente que se da a conocer a partir de operaciones 
complejas: establecer una cronología y líneas de continuidad entre poéticas heterogéneas, como lo hace Martín Prieto para lo que por la misma época ya se designaba como objetivismo (Prieto: 1994), recuperar ciertos poetas que estaban olvidados, traducir y publicar textos que eran difícilmente disponibles pero sobre todo, explicitar la valoración que se efectúa sobre esos textos, y usar estos criterios para posicionarse en relación a otras líneas poéticas como el neobarroco (García Helder: 1987).

Así, resulta evidente que para Prieto, García Helder, Samoilovich, Freidemberg y Fondebrider, entre otros, la definición de la propia poética es inseparable del acto de dejar establecidas las propias filiaciones con poéticas previas; éstas se fijan siempre desde la lectura crítica, e implican una relación con un constructo mayor que a veces puede tomar la forma de la historia literaria o la "poesía argentina”. Porque como dijimos, la idea dar un panorama "global” de la poesía argentina (Fondebrider: 1994, 22) fue parte del programa de esta publicación.

Entonces, la tradición diseñada por el Diario es orgánica y articula poéticas heterogéneas a partir de una serie de criterios puntuales que se activan en la producción de los integrantes de la revista. Esta manera de construir una tradición abre un amplio repertorio de cuestiones porque supone, por un lado, una valoración sobre la literatura del pasado que puede parecer obvia tratándose de escritores pero que en el conjunto de la poesía de los noventa se revela como una posición más entre otras posibles, que tiene su contrapartida en la omisión casi completa de la cultura de masas. Al mismo tiempo, hay cierta idea moderna de la poesía como trabajo específico sobre la palabra, como mencionamos, asociada a la figura de poeta-artesano postulada por Pound, con una atención especial sobre modo en que funciona el idioma dentro de la propia cultura. Y este armado se basa también en una conciencia histórica sobre las poéticas y los 
lenguajes de la tradición que se recorta, conciencia que habilita el modo de contrastar críticamente ciertas ideologías poéticas con las representaciones y los usos lingüísticos del presente. Estos puntos delinean un paradigma, asociado a ciertas figuraciones de poeta y estrechamente vinculado al ejercicio crítico y al conocimiento de la historia literaria, que no se continúa en la década, al menos de modo programático y colectivo.

A partir de estas premisas los poetas del Diario dan forma a lo que hemos llamado “dispositivo objetivista”, compuesto por distintas líneas de reflexión crítica, lectura y escritura que presentan continuidades y también establecen distintos puntos de tensión. Como parte de este dispositivo, se enuncia el programa de construir una poesía basada en lo concreto, asociada con una voluntad de usar la lengua de modo literal y en la que la mayor o menor calidad de los poemas (porque como señalamos, también se establecen criterios de valor en ese armado) estaría dada por la adecuación del lenguaje al objeto que nombra. Lo referencial y lo verificable, entonces, cumplen un papel fundamental en una poesía que se concibe como conocimiento, tanto intelectual como perceptual, sobre una realidad exterior al poema.

Pero a la vez, desde el momento en que se trabaja con la mirada, e incluso con la memoria y lo especulativo, el énfasis se desplaza en los poemas de esa voluntad de dar cuenta de los objetos en sí mismos a una puesta en escena del acto problemático de la percepción y a la apertura del texto a diversas temporalidades superpuestas, y esa es una tensión constituyente al objetivismo. La preponderancia otorgada a los objetos y al uso de la lengua en su aspecto referencial interactúan entonces con la percepción y la memoria, de modo que el poema aparece más como puesta en escena de una relación, la del poeta como sujeto con aquello que mira, mediada siempre por el lenguaje y el trabajo con la sintaxis, que como aproximación directa a una realidad que se de por sentada como aprehensible. 
Esto sucede también porque la perspectiva sobre los objetos es histórica, en el sentido de que se experimenta como una actividad de la memoria (Benjamin: 1989) (al punto de que el despliegue de temporalidades superpuestas a partir de una escena o un objeto constituye, como vimos, prácticamente un motivo objetivista), que despliega un espectro de tiempos contrastantes en el que la desaparición y las ruinas, los restos, tienen un papel fundamental en la percepción del pasado como tal y en la definición simultánea del presente (Didi-Huberman: 2006). Esta modalidad de la mirada y la memoria es representativa del modo de concebir el tiempo que subyace a la idea de tradición sustentada por el Diario, porque el gesto de constituir ciertas poéticas previas en tradición supone que éstas se perciben como situadas históricamente, y atravesadas por una diferencia temporal en relación al que las lee y reelabora por la cual pueden actualizarse en el uso pero no dejan de dar testimonio, ya sea en las figuraciones, los usos verbales o los temas que abordan, de su propia heterogeneidad temporal con respecto al presente.

Por eso armar una tradición implica también situarse desde el presente para discernir aquello que en los textos es ya pasado, y sobre todo aquello que puede experimentarse como presente, aunque pertenezca a otro momento cronológico (así, esta idea organiza por ejemplo la evaluación del neobarroco y la recuperación, como contrapartida, de ciertas poéticas como la de Joaquín Giannuzzi). Es más: puede decirse que armar una tradición, si bien puede dar como resultado el establecimiento de una cronología (tan llena de discontinuidades e interrupciones como la que ensaya Prieto con respecto al objetivismo), no es otra cosa que discriminar, en una operación efectuada desde el ahora, aquello del pasado que todavía puede considerarse actual y productivo, como sucede en los noventa sobre todo con las poéticas de Ricardo Zelarayán, Joaquín Giannuzzi y Leónidas Lamborghini. 
Pero aunque esta concepción de la tradición y del tiempo histórico no haya tenido continuidad a lo largo de todas las poéticas de la década, lo cierto es que el impacto y la contundencia crítica de los principios levantados por el objetivismo, unidos al papel relevante que tuvo el Diario de poesía como espacio de consagración y difusión de los nuevos poetas, hicieron que la tradición delineada por esta formación cultural funcionara como un referente con respecto al cual otras poéticas se posicionaron, ya sea para establecer puntos de convergencia, o para impugnarla.

Así, como vimos en el segundo capítulo, otras líneas poéticas de los noventa trabajan sobre el archivo habilitado por el Diario de poesía, pero representan a la vez un movimiento de apertura y diversificación de los postulados del objetivismo. Porque por un lado, la problemática de la mirada y la percepción se recupera en Carlos Battilana y José Villa desde repertorios que la cruzan con el procesamiento de concepciones simbolistas, de modo que se revisa críticamente la ideología poética objetivista y su certeza en cuanto a la capacidad del lenguaje para nombrar los objetos. A su vez, otros poetas como Rubio, Ortiz, Díaz y Raimondi procesan también la biblioteca propuesta por el Diario y comparten con éste la idea de tradición como objeto de disputa y sobre todo, como objeto historizado, pero lo hacen desde el contraste o la continuidad de esta tradición con otra instancia, la de la cultura popular (De Certeau: 2000), también ausente en el objetivismo. Es por eso que nos referimos a esta línea poética como un momento de apertura, donde el ejercicio crítico ya no se circunscribe al espacio delimitado por el Diario de poesía, que se corresponde aproximadamente con lo que se denomina “alta cultura” (Huyssen: 2002), sino que se vale del anacronismo y del uso de textos, motivos y figuraciones tradicionales para ponerlos a prueba en relación a las imágenes y las manifestaciones verbales del presente. 
De todos modos, otra línea de continuidad que establecen estas poéticas con el objetivismo es el ingreso de figuraciones explícitas de la tradición en el interior de los textos, que da cuenta de una concepción del poema como espacio desde el cual ejercer la crítica. Y aunque esta se lleve a cabo, en todo caso, por medio de la actualización y las lecturas desviadas, subyace a estas operaciones una valoración sobre la tradición y la necesidad de apropiársela, aunque sea críticamente, que marca una filiación con los poetas del Diario de poesía. La posición de Cassara y Wittner es distinta en este punto, porque si bien conforman sus poéticas como variación sobre el archivo objetivista, la tradición se continúa o se subvierte sin necesidad de pasar por una instancia opositiva, como lo demuestran las recuperaciones clasicistas de Cassara, que se valen de la tradición clásica como “máscara” para plantear una sensibilidad determinada, o la activación no problemática de los principios del modernismo norteamericano en los poemas de Wittner.

Todas estas poéticas tienen en común, no obstante, el gesto de valorar la tradición literaria por medio del uso. Por eso las poéticas que analizamos bajo la figura del bárbaro y el analfabeto representan un punto de clivaje en la producción de los noventa, y un segundo momento de apertura del discurso poético a las modulaciones del habla y también a la cultura de masas, que en ellas, y sobre todo en los primeros libros de Gambarotta y Durand, se plantea de modo conflictivo. Así, los usos de la tradición, ya sea para reescribirla o impugnarla, aparecen tensados con figuraciones de un poeta que simula escribir a partir de la falta de capital cultural y hasta en contra de lo aceptado como literatura. El gesto, que es el de escribir desde los márgenes de lo literario, o incluso por fuera de ellos (no sólo en la apertura discursiva sino también en la fuerte recuperación de las obras marginales de Zelarayán y Lamborghini) y expandirlos en el mismo movimiento, fue tan efímero como contundente, y bastó para poner en cuestión 
ciertas premisas de la ideología sustentada por el Diario de poesía. En especial, la centralidad otorgada a la tradición literaria, la idea de "pulido" asociada a la escritura y la pretensión de articular en la lengua cotidiana una vinculación del poeta con la cultura, que en contraste con el uso del habla en Durand y Desiderio, sobre todo, se revela como producción de un lenguaje diferencial para la poesía.

Este corrimiento autoconciente de los márgenes, que sigue siendo de todos modos un gesto moderno (Giordano: 2010), muchas veces se juega en la tensión entre tradición y experiencia, dado que la primera se percibe como un sistema retórico ya cristalizado que no hace otra cosa que repetirse de modo anacrónico, al tiempo que impide el ingreso de nuevas modalidades de la sensibilidad y la experiencia en el poema, que necesitan de una renovación de los lenguajes admitidos como literarios para poder enunciarse (Dalmaroni: 2010). Por eso, en poéticas como las de Desiderio, Durand y Gambarotta se hace presente el ejercicio de escribir desde lo que denominamos "tabula rasa”, que señala precisamente al borramiento de las retóricas ya consagradas. Esta idea forma parte a la vez de una tradición de ruptura (Bourdieu: 1997, 362) que el Diario de poesía y las poéticas abordadas en el capítulo II que procesan el objetivismo no comparten porque en su caso, la relación es de continuidad antes que de quiebre o de desvío con respecto a las retóricas y las ideologías literarias que se seleccionan como tradición.

La pregunta que levantan estos textos sobre el valor concedido a la tradición literaria tiene carácter inaugural, de ahí el amplio desarrollo que le hemos dado y de ahí también el gesto de ubicarla en el capítulo central de esta tesis como momento de inflexión en las ideologías poéticas que recorren la década. Porque esta pregunta se lleva a cabo en la situación cultural del menemismo y durante el establecimiento definitivo en nuestro país de la hegemonía de los medios de comunicación de masas 
como formadores de pensamiento y de discurso. De ahí que la tensión que señalamos entre ser y no ser poeta (que se percibe como modo de reproducir figuraciones tradicionales del trabajo y la función del escritor), visible sobre todo en los primeros libros de Durand, Gambarotta y Llach, funcione como testimonio de esta situación histórica, y de cierto malestar en el presente con respecto a las limitaciones de la poesía entendida como discurso diferencial y como ámbito separado de la también hegemónica cultura de masas.

De todos modos la percepción histórica sobre los materiales que se trabajan -que se lee en el modo de impugnar la centralidad de determinadas tradiciones que ya no tendrían lugar en el presente- sigue funcionando en este conjunto de textos, tanto como la preponderancia otorgada al lenguaje, que en este caso es ante todo el habla, en el ejercicio poético. Pero el gesto de relativizar la importancia concedida a la tradición habilita el ingreso de materiales y figuraciones de la cultura de masas que no se encontraban hasta el momento en la poesía producida en nuestro país, aunque ese uso se experimente como conflicto, según apuntamos, en poetas que aparecen tensados entre la idea de apropiarse y reescribir la tradición, y la voluntad de impugnarla. Por eso la noción de “tradición selectiva” de Raymond Williams sigue siendo operativa para leer estos textos, y sobre todo el modo en que retoman la ideología poética de Ricardo Zelarayán y Leónidas Lamborghini, escritores que como se dijo eran marginales en el sistema poético hasta el reordenamiento llevado a cabo por el Diario de poesía.

Esta definición de Williams, sin embargo, ya no es suficiente para abordar las dos últimas zonas de escritura que hemos analizado, y que operan la nivelación definitiva entre literatura y cultura de masas en el marco de los noventa. Semejante nivelación, observada por autores como Huyssen (Huyssen: 2002) y Fredric Jameson (Jameson: 1991) sobre todo en el cine y las artes plásticas a partir de la década del 
cincuenta, no se realiza en la poesía escrita en nuestro país sino hasta la década que aquí trabajamos, y a ella se debe en parte el rechazo inicial que produjeron estas poéticas, con las consecuentes valoraciones negativas como "poesía marca Tinelli" o "banal” (Mallol: 2001), cuando no directamente con textos y comentarios que les negaban todo estatuto poético. Sin embargo, cabe aclarar que más que una nivelación (que connota un equiparamiento entre dos instancias que siguen existiendo independientemente la una de la otra), lo que tiene lugar es como observa Jameson una fusión en una cultura que en adelante se experimenta como una totalidad indiferenciada.

Esto se debe a que las poetas analizadas en el capítulo IV ya no sólo trabajan sobre una tradición específicamente literaria, sino que al abordar estos textos es necesario ampliar el concepto de "tradición” para incluir, no sólo la cultura de masas, sino también determinadas figuraciones sociales del rol de la mujer que se encuentran dispersas en un entramado que abarca los modos de nombrar lo femenino, los juegos infantiles, los estereotipos sobre la distribución y definición de los géneros y los productos de la cultura masiva. Los textos de Mariasch, Mallol, Wajzczcuk, Andreini, Iannamico, Freschi y Macció, en lugar instalarse sin más en lo que Prieto y Monteleone denominaban una “enunciación femenina” (Prieto: 2006; Monteleone: 1996), operan críticamente sobre estos modos de definir al género desde la exageración y la puesta en escena performática de lo femenino que dan como resultado, antes que una continuación de la producción poética de los ochenta escrita por mujeres, una subversión de algunos de sus postulados que incluye la desnaturalización del pacto de verosimilitud del modo enunciativo lírico, y que se efectúa en la concepción del poema (y también de las maneras de definir culturalmente lo femenino) como artificio.

Pero lo más importante -porque la poesía siempre se apropió, críticamente o no, de diversas figuraciones sociales- es que este movimiento se lleva a cabo en textos que 
al mismo tiempo desplazan las definiciones tradicionales de lo poético en la medida en que la poesía ya no se piensa como trabajo específico sobre el lenguaje, sino que se asimila a los objetos de la cultura pop en tanto superficie donde ingresan las imágenes de los medios masivos, los objetos de consumo, los discursos sociales de carácter público y privado, la música y hasta las prácticas de escritura asociadas a las nuevas tecnologías como Internet. El imaginario del que extraer figuraciones sobre el papel del poeta, entonces, ya no proviene de la literatura sino de estos ámbitos, y el texto se presenta también como superficie sobre la cual “representar lo representado” (Masotta: 2004), en la que reverbera todo el entramado cultural ya no como cita sino como material constituyente del poema.

Aquí, el abandono de las nociones modernas de literatura y crítica, así como de las figuraciones de poetas asociadas a éstas, es inescindible de un cambio en la percepción de la temporalidad, porque los objetos aparecen deshistorizados (aunque no desprovistos de significación ideológica y social) en la medida en que está ausente el contraste entre tiempos diferenciales. Lo que hay, más bien, es una manera de experimentarlos siempre en presente, haciendo foco alternativamente en su materialidad o su función cultural, pero sin que intervenga la memoria, ni siquiera en la conformación de subjetividades o cuando se trata de poner en escena la infancia. Esto no significa, sin embargo, que no haya en estas poéticas un ejercicio crítico, pero este se efectúa de otro modo porque la crítica ya no se piensa como valoración realizada desde un “afuera” (Jameson: 1992) sino en operaciones fragmentarias de apropiación y subversión “desde adentro” de las imágenes, los discursos y los estereotipos culturales.

Las poéticas de Cucurto, Laguna y Pavón tratadas en el último capítulo representan en este sentido una continuidad con este conjunto de escrituras, y plantean a la vez la exasperación de ciertos rasgos como la enunciación a través de personajes, con 
la diferencia de que aquí, éstos se fusionan con las figuras autorales, dando lugar a un nuevo modo de interpenetrar realidad y ficción. Porque en este caso, los modos de construir subjetividades espectacularizadas y orientadas hacia el exterior (Sibilia: 2008), distintas del modelo de sujeto moderno introspectivo, modifican el estatuto de la realidad. En efecto, así como no hay en este caso un ejercicio de la memoria, tampoco se puede hablar de "percepción”, dado que esta idea supone una distancia entre sujeto de la contemplación y objeto contemplado, que aquí se anula desde el momento en que la construcción del sujeto es inseparable de la construcción de realidad efectuada en el texto.

Pero mientras que Cucurto interviene sobre la tradición consagrada mediante la exacerbación de la figura de poeta analfabeto de origen popular, que en su caso no se plantea de manera explícita como construcción ficcional sino que se sustenta en la biografía, las poetas de Belleza y Felicidad acceden a la escritura desde un lugar diferente. Estas poéticas no hacen el gesto de disputar la legitimidad literaria ni el derecho de acceso al campo porque la poesía ya no se piensa en el marco de la institución literaria sino en el de una comunidad posdisciplinaria de las artes (Laddaga: 2006) que no se basa en la noción moderna de “obra”, sino que se caracteriza por la inespecificidad y el cruce entre distintas prácticas. Aún así, el recurso constante al pastiche, común a Cucurto, Laguna y Pavón, que apela de modo indiferenciado a la literatura, la televisión, los comics, la música pop y a géneros menores como el diario íntimo, las cartas y las versiones provistas por la cultura masiva del discurso confesional y amoroso, da cuenta de un modo de experimentar la totalidad de la cultura como cantera de materiales disponibles. Además, la idea de "historia” está ausente por completo, sobre todo en Belleza y Felicidad, porque se rompe decididamente toda posibilidad de establecer una continuidad temporal entre pasado, presente y futuro que 
organice la experiencia. Por el contrario, este rasgo estaba ligado como vimos a la percepción del tiempo como una serie de presentes desconectados entre sí (Jameson: 1992) que se plantean como repetición de un momento ya vivido (Virno: 2003), asociada a los motivos de la fiesta y el fin del mundo, que concluye para volver a comenzar incesantemente.

Por todo lo expuesto, puede observarse que a lo largo de la década tiene lugar un cambio de paradigma que atañe al modo de concebir la literatura en el contexto de la totalidad cultural, inseparablemente ligado a una modificación en el modo de experimentar el tiempo, que determina fuertemente las diversas posiciones con respecto a la tradición literaria. Pero este cambio no supone el abandono de ciertas ideologías sobre la poesía y su reemplazo por otras nuevas, sino que todas las poéticas y las posiciones que construyen respecto a la tradición o la apropiación de materiales de una cultura que se experimenta como un todo indiferenciado, que ya no coincide sin más con lo que se conoce como "literatura", coexisten hasta la actualidad y devuelven una imagen global del presente como “montaje de tiempos heterogéneos” (Didi-Huberman: 2006), eminentemente complejo, que no puede encuadrarse en lo que ciertos teóricos denominan “modernidad” o “posmodernidad” (Berman: 1989, Jameson: 1991) porque excede las periodizaciones y da cuenta de una situación cultural radicalmente múltiple y heterogénea en la que sí puede afirmarse, sin embargo, que se asiste a una ampliación y una mutación cualitativa de lo que hasta hoy seguimos refiriéndonos como "literatura”. 


\section{BIBLIOGRAFÍA}

\section{1- BIBLIOGRAFÍA GENERAL}

AA.VV., Michel Foucault, filósofo, Barcelona, Gedisa, 1990.

Adorno, Theodor, W. Teoría estética, Madrid, Taurus, 1971 [1970]. Traducción de Fernando Riaza.

Agamben, Giorgio, Infancia e historia, Buenos Aires, Adriana Hidalgo, 2001.

Aguilar, Gonzalo, Poesía concreta brasileña: las vanguardias en la encrucijada modernista., Buenos Aires, Beatriz Viterbo, 2003.

Anderson, Perry, Los orígenes de la posmodernidad, Barcelona, Anagrama, 2000.

Benjamin, Walter, “Tesis de filosofía de la historia”, en Discursos interrumpidos I, Buenos Aires, Taurus, 1989.

, “Experiencia y pobreza”, en Discursos interrumpidos I, Buenos Aires, Taurus, 1989 [1972].

Berman, Marshall, Todo lo sólido se desvanece en el aire. La experiencia de la modernidad., Buenos Aires, Siglo XXI, 1989.

Bourdieu, Pierre, “Campo intelectual, campo del poder y habitus de clase”, en Campo del poder y campo intelectual, Buenos Aires, Folios, 1983 [1971]. Traducción de Jorge Dotti.

----------------, “Campo intelectual y proyecto creador”, en AAVV. Problemas del estructuralismo, México, Siglo XXI, 1967 [1966].

-, Las reglas del arte. Génesis y estructura del campo literario, Barcelona, Anagrama, 1995 [1992]. Traducción de Thomas Kauf.

Braidotti, Rosi, Feminismo, diferencia sexual y subjetividad nómade, Barcelona, Gedisa, 2004.

Bunz, Mercedes, La utopía de la copia. El pop como irritación, Buenos Aires, Interzona, 2007.

Bürger, Peter, Teoría de la vanguardia, Buenos Aires, Las cuarenta, 2010.

Butler, Judith, El género en disputa. El feminismo y la subversión de la identidad, Barcelona, Paidós, 2007.

Cevasco, Maria Elisa, Para leer a Raymond Williams, Buenos Aires, Universidad Nacional de Quilmes, 2003. 
Contreras, Sandra, Las vueltas de César Aira, Rosario, Beatriz Viterbo, 2002.

Dalmaroni, Miguel, Juan Gelman. Contra las fabulaciones del mundo., Buenos Aires, Editorial Almagesto, 1993.

, La palabra justa. Literatura, crítica y memoria en la Argentina 1960-2002, Santiago de Chile, Melusina y Ril editores, 2004. , “A propósito de un libro de Ludmer (y de otros tres)", en

BazarAmericano, Actualización octubre/noviembre de 2010. http://bazaramericano.com/buscador.php?cod=19\&tabla=columnas\&que=miguel\%20da $\underline{\text { lmaroni }}$

De Certeau, Michel, La invención de lo cotidiano I. Artes de hacer., México, Universidad Iberoamericana, 2000.

Derrida, Jacques, Mal de archivo. Una impresión freudiana. En "Derrida en castellano”, http://www.jacquesderrida.com.ar/textos/.

Traducción de Paco Vidarte, 1997.

Didi-Huberman, George, Lo que vemos, lo que nos mira, Buenos Aires, Manantial, 1997.

Ante el tiempo, Buenos Aires, Adriana Hidalgo, 2006.

Diederichsen, Diedrich, Personas en loop. Ensayos sobre cultural pop., Buenos Aires, Interzona, 2005.

Ducrot, Oswald y Todorov, Tzvetan, "Poética", en Diccionario enciclopédico de las ciencias del lenguaje, México, Siglo XXI, 1986.

Eliot, T. S., “La tradición y el talento individual”, en Los poetas metafísicos y otros ensayos sobre teatro y religión, Buenos Aires, Emecé, 1944, Tomo I.

------------, Poesía y drama, Buenos Aires, Emecé, 1952.

Fernández, Nancy, Escrituras de lo real: César Aira y Arturo Carrera, (En línea). Tesis doctoral. UNLP, Facultad de Humanidades y Artes, 2005. Disponible online en http://www.fuentesmemoria.fahce.unlp.edu.ar/tesis/te.15/te.15.pdf.

Fernández Moreno, César, La realidad y los papeles. Panorama y muestra de la poesía argentina contemporánea., Madrid, Aguilar, 1967.

, Sentimientos Completos, Buenos Aires, Ediciones de la Flor, 1981.

Foster, Hal, El retorno de lo real, Madrid, Akal, 2001.

García Canclini, Néstor, Culturas híbridas. Estrategias para entrar y salir de la modernidad., Buenos Aires, Paidós, 2001.

Gerbaudo, Analía, “Por una nueva teoría del archivo (literario)”, en P. Arán (comp.), Interpelaciones. Hacia una teoría crítica de las escrituras sobre dictadura y memoria, Córdoba, Ferreira Editor, 2010. 
Gilman, Claudia, Entre la pluma y el fusil. Debates y dilemas del escritor revolucionario en América Latina., Buenos Aires, Siglo XXI, 2003.

Giordano, Alberto (ed.), Los límites de la literatura, Rosario, Centro de Estudios de Literatura Argentina, UNR, 2010.

Glusberg, Jorge, El arte de la performance, Buenos Aires, Ediciones de Arte Gaglianone, 1986.

Gramuglio, María Teresa, "La construcción de la imagen", en Héctor Tizón, Rodolfo Rabanal y María Teresa Gramuglio, La escritura argentina, Santa Fe, Universidad Nacional del Litoral, Ediciones de la Cortada, 1992.

Grimal, Pierre, Diccionario de mitología griega y romana, Barcelona, Paidós, 1993.

Hamburger, Käte, La lógica de la literatura, Madrid, Visor, 1995.

Huyssen, Andreas, Después de la gran división. Modernismo, cultura de masas, posmodernismo, Buenos Aires, Adriana Hidalgo Editora, 2002.

Jameson, Fredric, El giro cultural. Escritos seleccionados sobre el posmodernismo., Buenos Aires, Manantial, 2002.

El posmodernismo o la lógica cultural del capitalismo avanzado, Buenos Aires, Paidós, 1991.

Jay, Martin, Cantos de experiencia. Variaciones modernas sobre un tema universal, Buenos Aires, Paidós, 2009.

Kohan, Martín, “Significación actual del realismo críptico”, en el Boletín del Centro de Estudios de Teoría y Crítica literaria, Rosario, Facultad de Humanidades y Artes, Universidad Nacional de Rosario, diciembre del 2005.

Laddaga, Reinaldo, Estética de la emergencia, Buenos Aires, Adriana Hidalgo, 2006. , "Una poesía fotográfica. Sobre Arturo Carrera”, en Nancy

Fernández y Juan Duchesne Winter (ed.), La poesía de Arturo Carrera. Antología de la obra y la crítica, Pittsburh, PA, Instituto Internacional de Literatura Iberoamericana, 2010.

Disponible online en el sitio: http://www.gtcit.com/publicaciond.php?PublicacionId=12706\&lang=es

Livingstone, Marcos, “Una tecnicultura gloriosa”, en Arte pop. Muestra del Museo Nacional Reina Sofía., Madrid, Electra, 1992.

Ludmer, Josefina, Aquí América Latina. Una especulación., Buenos Aires, Eterna Cadencia, 2010.

Pacheco, Marcelo, Escuelismo, Arte argentino de los noventa, Buenos Aires, Malba- 
Fundación Constantini, 2009.

Masotta, Oscar, Revolución en el arte. Pop-art, happenings y arte de los medios en la década del sesenta., Buenos Aires, Edhasa, 2004.

Monteleone, Jorge, “Mirada e imaginario poético”, en La poética de la mirada, Madrid, Visor, 2004.

Jitrik, Noé, “Poesía argentina entre dos radicalismos”, en Ensayos y estudios de literatura argentina, Buenos Aires, Galerna, 1970.

Porrúa, Ana, Variaciones vanguardistas, Rosario, Beatriz Viterbo, 2001. , Caligrafía tonal, Buenos Aires, Entropía, 2011 (en prensa).

Prieto, Adolfo, “Los años sesenta”, en Revista Iberoamericana, № 125, octubrediciembre de 1983.

Prieto, Martín, Breve historia de la literatura argentina, Buenos Aires, Taurus, 2006.

Rancière, Jacques, La palabra muda. Ensayo sobre las contradicciones de la literatura., Bueno Aires, Eterna Cadencia, 2009.

Romano, Eduardo, Sobre poesía popular argentina, Buenos Aires, CEAL, 1983.

Rosa, Nicolás, La lengua del ausente, Buenos Aires, Biblos, 1997.

Rosenbaum, Alfredo, "Performance, cruce de lenguajes y provocación”, en Revista KEPES, Año 5 N 4, enero-diciembre de 2008.

Sibilia, Paula, La intimidad como espectáculo, Buenos Aires, Fondo de Cultura Económica, 2008.

Speranza, Graciela, “Por un realismo idiota”, en el Boletín del Centro de Estudios de Teoría y Crítica literaria, Rosario, Facultad de Humanidades y Artes, Universidad Nacional de Rosario, diciembre del 2005.

Urondo, Francisco, Veinte años de poesía argentina. 1940-1960., Buenos Aires, Galerna, 1968.

Virno, Paolo, El recuerdo del presente, Buenos Aires, Paidós, 2003.

Williams, Raymond, Palabras clave. Un vocabulario de la cultura y la sociedad, Bs.As., Nueva Visión, 2000 [1976]. Colección "Claves" dirigida por Hugo Vezzetti. Traducción de Horacio Pons.

La política del Modernismo. Contra los nuevos conformistas.

Bs.As., Manantial, 1997 [1989]. Selección e introducción de Tony Pinkney. Traducción de Horacio Pons. Marxismo y literatura, Barcelona, Ediciones Península, 1997 [1977]. Traducción de Pablo Di Masso.

------------------, Cultura. Sociología de la comunicación y del arte, Barcelona, 
Paidós Comunicación, 1982 [1981]. Traducción de Graziella Baravalle.

\section{2- BIBLIOGRAFÍA ESPECÍFICA}

Aguirre, Raúl Gustavo (comp.), El movimiento Poesía Buenos Aires (1950-1960), Buenos Aires, Editorial Fraterna, 1979.

Álvarez Ortega, Manuel, “Prólogo” a Poesía simbolista francesa, Madrid, Editora Nacional, 1975.

Arenas, Reinaldo, El mundo alucinante, Barcelona, Tusquets, 1997.

Ascasubi, Hilario, Paulino Lucero, Buenos Aires, Estrada, 1945.

Balakian, Anna, El movimiento simbolista, Madrid, Guadarrama, 1969.

Barthes, Roland, La cámara lúcida, México, Siglo XXI, Buenos Aires, Paidós, 2005.

Battilana, Carlos, “Diario de poesía: el gesto de la masividad”, en Celina Manzoni (compiladora), Violencia y silencio. Literatura latinoamericana contemporánea, Buenos Aires, Corregidor, 2005

"Formas de lo ilegible. En torno a la revista Xul”, en Celina Manzoni (compiladora), Errancia y escritura en la literatura latinoamericana contemporánea, Alcalá La Real, Alcalá Grupo Editorial, 2009.

Baudelaire, Charles, Las flores del mal, Buenos Aires, Coligue, 2006. Edición bilingüe. Traducción de Américo Cristófalo.

Bejerman, Gabriela, Presente perfecto, Interzona, 2004.

Bellesi, Diana, Danzante de doble máscara, Buenos Aires, Ultimo Reino, 1985.

---------------, Eroica, Buenos Aires, Ediciones Ultimo Reino/ Libros de Tierra Firme, 1988.

, “La diferencia viva”, en Diario de poesía No 9, Buenos Aires, Invierno de 1988.

, Colibrí, ¡lanza relámpagos! (antología), Buenos Aires, Libros de Tierra Firme, 1988.

Berger, Timo, "Yo actualmente soy el mejor escritor dominicano sin duda". Entrevista a Washington Cucurto., en la página web del Proyecto Patrimonio, Chile, 2010. En: http://letras.s5.com/tb060710.html 
Bielsa, Rafael García Helder, Daniel, Quince poemas, Rosario, El lagrimal trifurca, 1988.

Bing y Jon Steffen Bruss (editores), Brill's Companion to Hellenistic Epigram, Boston, Brill, 2007.

Borges, Jorge Luis, Ficciones, Buenos Aires, Emecé, 1989.

Brecht, Bertolt, Poemas y canciones, Madrid, Alianza Editorial, 2005.

Bustos, Emiliano, “Generación poética del '90, una aproximación”, en Hablar de poesía No 3, Año II, junio de 2000.

Carrera, Arturo, La partera canta, Buenos Aires, Sudamericana, 1982.

, Monstruos. Antología de la joven poesía argentina., Buenos Aires, FCE, 2001.

Casas, Fabián, “Como una aguja en la mesa de saldos”, en “Dossier Giannuzzi”, Diario de poesía $\mathrm{N}^{\circ}$ 30, Invierno de 1994.

Chejfec, Sergio, Sobre Giannuzzi, Buenos Aires, Bajo la luna, 2010.

Cófreces, Javier, “Diez años de poesía argentina”, en Mascaró, № 4, 1984.

Cucurto, Washington, Cosa de negros, Interzona, 2001.

----------------------, Las aventuras del Sr. Maíz, Interzona, 2005.

-, El curandero del amor, Emecé, 2006.

-, 1810. La revolución de Mayo vivida por los negros, Emecé, 2008.

De la Púa, Carlos, La crencha engrasada, Buenos Aires, Editorial Porteña, 1954.

Diario de poesía, “Dossier Pound”, Diario de poesía N 3, Verano de 1986.

, “Dossier Lamborghini”, Diario de poesía N 38, Invierno de 1996.

Díaz, Marcelo, "Estoy completo, sé lo que me falta. Notas sobre la poesía de Martín Rodríguez, de Agua Negra a Maternidad Sardá”, en Revista Otra Parte $\mathrm{N}^{\circ}$ 24, primavera 2011.

Dobry, Edgardo, “Poesía argentina actual: del neobarroco al objetivismo”, en Cuadernos Hispanoamericanos, $\mathrm{n}^{0}$ 588, junio de 1999.

-------------------, "Poesía argentina actual: del neo-barroco al objetivismo (y más allá), publicado en Jorge Fondebrider (compilador), Tres décadas de poesía argentina. 1976-2006, Buenos Aires, Libros del Rojas, 2006. , Dobry, "Barroco y modernidad: de Maravall a Lezama Lima", en

Orbis Tertius, UNLP, 2009, XIV.

Echavarren, Roberto, "Prólogo”, en Néstor Perlongher, Poemas completos, Buenos Aires, Seix Barral, 1997. 
Eliot, T. S., The Complete Poems and Plays, 1909-1950, New York, Harcourt Brace \& Company, 1995.

Fondebrider, Jorge, “Una causa personal”, en el Dossier Giannuzzi, Diario de poesía Nº 30, Invierno de 1994.

, “Treinta años de poesía argentina”, en Jorge Fondebrider (compilador), Tres décadas de poesía argentina. 1976-2006, Buenos Aires, Libros del Rojas, 2006. , Prólogo a Una antología de la poesía argentina (1970-2008), Santiago de Chile, Editorial LOM, 2008.

Freidemberg, Daniel, Freidemberg, "Para una situación de la poesía argentina”, La Danza del Ratón, № 6, diciembre 1984.

, “Un poeta standard”, en Dossier Giannuzzi, Diario de poesía N ${ }^{\circ}$ 30, Invierno de 1994.

, Prólogo a Poesía en la fisura, Buenos Aires, Ediciones del Dock, 1995.

“Leónidas Lamborghini”, en Dossier Lamborghini, Diario de poesía $\mathrm{N}^{0}$ 38, Invierno de 1996.

, "Escuchar decir nada (una vieja respuesta nunca enviada y después notas, notas de las notas y algo más)”, en Jorge Fondebrider (compilador), Tres décadas de poesía argentina. 1976-2006, Buenos Aires, Libros del Rojas, 2006.

Gambarotta, Martín, “El habla como materia prima”, en Jorge Fondebrider (compilador), Tres décadas de poesía argentina. 1976-2006, Buenos Aires, Libros del Rojas, 2006.

García Helder, Daniel, “El neobarroco en Argentina”, Diario de poesía N 4, Otoño de 1987.

, “Giannuzzi”, en Dossier Giannuzzi, Diario de poesía No 30, Invierno de 1994.

, “Nada que ver con la belleza”. Entrevista a Leónidas

Lamborghini, en Dossier Lamborghini, Diario de poesía $\mathrm{N}^{\circ}$ 38, Invierno de 1996.

“Juan L. Ortiz: un léxico, un sistema, una clave”, en Juan L.

Ortiz, Obra completa, Centro de Publicaciones, Universidad

Nacional del litoral, 1996.

Gelman, Juan, Carta a mi madre, Buenos Aires, Libros de Tierra Firme, 1989.

---------------, Cólera buey, Buenos Aires, Seix Barral, 1994.

Genovese, Alicia, "La escritura poética en los años ochenta y en los noventa: de la sobrecarga a la liquidez", en Jorge Fondebrider (compilador), Tres décadas de poesía argentina. 1976-2006, Buenos Aires, Libros del Rojas, 2006.

Giannuzzi, Joaquín, Obra poética, Buenos Aires, Emecé, 2000.

Ginsberg, Allen, “La práctica poética de William Carlos Williams”, en Ginsberg, 
Levertov, Rexroth, Stevens, William Carlos Williams. Poemas, textos, entrevistas., México, Universidad Autónoma de Puebla, 1987.

Goold, G. P., (Ed.), Catullus, Tibullus, Pervigilium Veneris, Harvard University Press, 1995.

Herrera, Ricardo, “Romanticismo, neorromanticismo”, en La hora epigonal, Buenos Aires, GEL, 1991.

Inchauspe, Juan Manuel, Trabajo nocturno. Poemas completos., Santa Fe, Universidad del Litorial, 2010.

Kafka, Franz, Relatos completos Vol. 2, Buenos Aires, Losada, 2005.

Kahn, Gustave, Symbolistes et decadents, Genéve, Slatkine Reprints, 1977 [1909].

Kamenszain, Tamara, “La nueva poesía argentina: de Lamborghini a Perlongher”, en AAVV, Literatura y crítica. Primer encuentro UNL, Santa Fe, Cuadernos de Extensión Universitaria, 1987.

----------------------, “Testimoniar sin metáfora, narrar sin prosa, escribir sin libro. La joven poesía argentina de los noventa.”, en Jorge Fondebrider (compilador), Tres décadas de poesía argentina. 1976-2006, Buenos Aires, Libros del Rojas, 2006.

, La boca del testimonio, Buenos Aires, Norma, 2007.

Kenner, Hugh, The poetry of Ezra Pound, University of Nebraska Press, Lincoln and London, 1985.

1971.

Lamborghini, Leónidas, El saboteador arrepentido, Buenos Aires, El peligro amarillo, 1955.

Las patas en las fuentes, Buenos Aires, Sudestada, 1968.

, El solicitante descolocado, Buenos Aires, Ediciones de la Flor, 1971, reeditado por Libros de Tierra Firme, 1989.

, Partitas, Buenos Aires, Corregidor, 1972.

Lamborghini, Osvaldo, “El fiord” y “El niño proletario”, en Novelas y cuentos I, Buenos Aires, Sudamericana, 2003.

Leitao, Paula, "El hombre de los mil nombres y un rostros" (sic), entrevista a Santiago Vega (alias Washington Cucurto), en Vox Virtual No 15, Vol. II, Bahía Blanca, Abril del 2003. En: http://proyectovox.org.ar/virtual_15-2.htm

Mallarmé, Stéphane, Cartas para la Poesía, Caracas, Fundación Editorial el perro y la rana, 2008.

Mallol, Anahí, "Muchachos futboleros, chicas pop y chicas que se hacen las malitas: la 'poesía joven de los 90' en la Argentina”, en Literatura argentina.

Perspectivas de fin de siglo., Buenos Aires, Eudeba, 2001. 
, El poema y su doble, Buenos Aires, Ediciones Simurg, 2003.

"Hacia una subjetividad pop: poesía, ficción y sujeto en algunas poetas argentinas”, en Cuadernos del Sur. Letras, № 34, Bahía Blanca, EdiUns, año 2004.

Manrique, Jorge, Coplas por la muerte de su padre, Buenos Aires, Losada, 1998.

Mazzoni, Ana y Selci, Damián, “Poesía actual y cualquierización”, en Jorge Fondebrider (compilador), Tres décadas de poesía argentina. 1976-2006, Buenos Aires, Libros del Rojas, 2006.

Monteleone, Jorge, “Una mirada corroída. Sobre la poesía argentina de los años 80”, en Roland Spiller (comp.). Culturas del Río de la Plata (1973-1995). Transgresión e intercambio, en Lateinamerika-Studien 29, Universidad Erlangen-Nürnberg.

"La utopía del habla” (Estudio preliminar), en Diana Bellesi, Colibrí, ¡lanza relámpagos!, Buenos Aires, Libros de Tierra Firme, 1996.

Muschietti, Delfina, “Tecnorama: la poesía de los 90”, en Radar Libros, 18 de octubre de 1998.

Nabokov, Vladimir, Lolita, Barcelona, Anagrama, 1991.

Neruda, Pablo, Veinte poemas de amor y una canción desesperada, Buenos Aires, Losada, 1967.

Olivari, Nicolás, La musa de la mala pata, Buenos Aires, Editorial Deucalión, 1956.

Ortiz, Mario, “Hacia el fondo del escenario”, en Vox Virtual No 11/12, Bahía Blanca, julio del 2002.

Disponible en http://elistas.egrupos.net/lista/voxvirtual/archivo/msg/15/).

“Entre la 'videncia' y el 'lumpenaje': sujeto(s) / objeto(s) en la poesía argentina del siglo XX (breve aproximación histórica)”, en Cuadernos del Sur. Letras, № 34, Bahía Blanca, EdiUns, año 2004.

Palmeiro, Cecilia, Desbunde y felicidad. De la cartonera a Perlongher., Buenos Aires, Título, 2011.

Perlongher, Néstor (recopilación y prólogo), Caribe trasplatino, San Pablo, Iluminuras, 1991.

, “Caribe transplatino”, en La caja, Nro. 1, septiembre-oct. 1992.

, "Neobarroso y el realismo alucinante", entrevista de Pablo M.

Dreizik, en Tiempo Argentino, Buenos Aires, domingo 3 de agosto de 1986.

, Poemas completos, Buenos Aires, Seix Barral, 1997.

"Neobarroco y neobarroso", Prólogo a Medusario, Muestra de poesía latinoamericana., Buenos Aires, Mansalva, 2010. 
Pizarnik, Alejandra, Obras completas, Buenos Aires, Corregidor, 1994.

Ponge, Francis, “La práctica de la literatura”, en Métodos, Buenos Aires, Adriana Hidalgo Editora, 2000. Traducción de Silvio Mattoni.

Porrúa, Ana, “Escenas de los `90: el ejercicio del ojo sobre las superficies” (inédito).

----------, “Punctum: sombras negras sobre una pantalla”, en Boletín del Centro de Estudios de teoría y crítica literaria; Centro de Teoría y Crítica Literarias, Fac. de Humanidades y Artes, UNR, Rosario, octubre de 2000.

-------------, “Notas sobre poesía argentina reciente y sus antologías”, en Punto de vista, $\mathrm{n}^{\circ}$ 72, Buenos Aires, abril de 2002.

, "Una polémica a media voz: objetivistas y neo-barrocos en el Diario de Poesía”, Boletín del Centro de Estudios de Teoría y Crítica Literaria, Facultad de Humanidades y Artes, Univ. Nac. De Rosario, Nro. 11, diciembre de 2003.

, “Subjetividad y mirada en la poesía argentina reciente”, en Cuadernos del Sur. Letras, N 34, Bahía Blanca, EdiUns, año 2004.

, “Una nueva lectura de los clásicos: poesía argentina del `90”, en Revista del CELEHIS, Mar del Plata, Buenos Aires, UNMdP, Nro. 13.

, "La novedad en las revistas de poesía: relatos de una tensión especular", en Orbis Tertius, año X, número 11, Universidad Nacional de La Plata, 2005.

Pound, Ezra, El ABC de la lectura, Buenos Aires, De la Flor, 1968.

, "Vorticism”, en Berry, T.E., Readings in American criticism, The Odyssey Press, 1970.

, Ezra Pound, El arte de la poesía, México, Joaquín Mortiz, 1970 [1954].

, The Cantos of Ezra Pound, New York, New Directions, 1989.

, Ensayos literarios, México, Cien del Mundo, 1993.

-------, Personae. Los poemas breves., Madrid, Hiperión, 2003. Traducción de Jesús Munárriz y Jenaro Talens.

Prieto, Martín y García Helder, Daniel, “Boceto n 2 para un...de la poesía argentina actual”, en Punto de vista ${ }^{\circ}$ 60, Buenos Aires, abril de 1998.

Prieto, Martín, “Giannuzzi, Cantón, Girri, y los otros”, en Dossier Giannuzzi, Diario de poesía No 30, Invierno de 1994.

" "Neobarrocos, objetivistas, epifánicos y realistas: nuevos apuntes para la historia de la nueva poesía argentina”, en Delgado, S., y Premat, J., (eds.), Movimiento y nominación. Notas sobre la poesía argentina contemporánea, Cahiers de LI.RI.CO, $\mathrm{n}^{\circ}$ 3, Université de Paris 8 Université de Bretagne-Sud, Paris, 2007.

Raimondi, Sergio, “Como lees, escribís. Entrevista a Leónidas Lamborghini, en Cuadernos del Sur. Letras, N 34, Bahía Blanca, EdiUns, 2004. "Sergio Raimondi: "No hay mundo de un lado y versos del otro". Entrevista de Osvaldo Aguirre, en Diario de poesía $\mathrm{N}^{\circ} 72$, Mayo a Agosto de 2006.

"El sistema afecta la lengua (sobre la poesía de Martín Gambarotta)", en Margens/Márgenes, Universidade Federal de 
Minais Gerais-Universidad de Buenos Aires, Belo HorizonteBuenos Aires, nº 9/10, jan.-jun. 2007.

Rama, Ángel, “Prólogo” a Rubén Darío, Poesías, Caracas, Biblioteca Ayacucho, 1977.

Ríos, Damián y Blatt, Mariano, “Daniel Durand. Cielos, personas, flash” (entrevista), en Revista Otra parte N $\mathrm{N}^{\mathrm{0}}$ 14, otoño del 2008.

Disponible online en http://www.revistaotraparte.com/n\%C2\%BA-14-oto\%C3\%B1o2008/daniel-durand-cielos-personas-flash

Rojas, Gonzalo, Oscuro y otros textos, Santiago de Chile, Pehuén Editores, 1999.

Rosenberg, Mirta, Madam, Buenos Aires, Libros de Tierra Firme, 1988.

Rosetti, Dalia (seud. de Fernanda Laguna), Me encantaría que gustes de mí, Buenos Aires, Mansalva, 2005.

Rubén Darío, Poesía, Madrid, La Nación, 2000.

Rojas, Gonzalo, Oscuro y otros textos, Santiago de Chile, Pehuén Editores, 1999.

Sarduy, Severo, Ensayos generales sobre el barroco, Buenos Aires, FCE, 1987. "El barroco y el neobarroco”, en César Fernández Moreno (comp.), América Latina en su literatura, México, Siglo XXI, 1984 (1972).

Scully, James (ed.), Modern poets on modern poetry, Fontana / Collins, London, 1973.

Selci, Damián, “El verano es para mostrar los dientes” (sobre Relapso+Angola de Martín Gambarotta), en www.hacemellegar.com.ar. "Martín Rodríguez, o por qué mantener a la familia”, en www.hacemellegar.com.ar.

Selci, Damián, Kesselman, y Mazzoni, Ana, “Por qué soy peronista” (sobre la poesía de Alejandro Rubio), en www.hacemellegar.com.ar. ----, "Conocimiento Civil” (sobre la poesía de Sergio Raimondi), en www.hacemellegar.com.ar.

Selci, Damián y Kesselman, Violeta, "Helder contra Helder”, en www.hacemellegar.com.ar. , "Juan Desiderio: delirios de juventud cultural”, en Revista virtual Planta n ${ }^{\circ}$ 3, febrero del 2008.

(http://plantarevista.com.ar/anteriores/desiderio.html).

Selci, Damián e Iglesias, Claudio, “Análisis de un malentendido”, en revista virtual Éxito, verano del 2007.

Disponible en el sitio www.notasexito.blogspot.com

Shelley, Percy, Defensa de la poesía, Buenos Aires, Ediciones Siglo Veinte, 1978.

Tentoni, Valeria, Entrevista a Santiago Llach, Bahía Blanca, periódico Nexo, diciembre 
del 2008. La versión web puede leerse en:

http://4.bp.blogspot.com/_wp1_bAQ517M/SXKUyVU1wI/AAAAAAAAAUI/WtvF26h9DtY/s1600-h/LLACH1.bmp.

Vignoli, Beatriz, “Poesía argentina de los noventa: breve bibliografía crítica” (inédito).

Virgilio, Eneida, Barcelona, Gredos, 2008. Traducción de Javier de Echave-Sustaeta.

Villamayor, Judith, “Entrevista a Fernanda Laguna”. Disponible online

en:http://spaghettiabasto.com.ar/entrevistas/fernanda/index.html.

Williams, William Carlos, The collected earlier poems, New York, New Editions, 1966.

-------------------------, Cien poemas, Madrid, Visor, 1988.

Zelarayán, Ricardo, La obsesión del espacio, Buenos Aires, Atuel, 1997. 